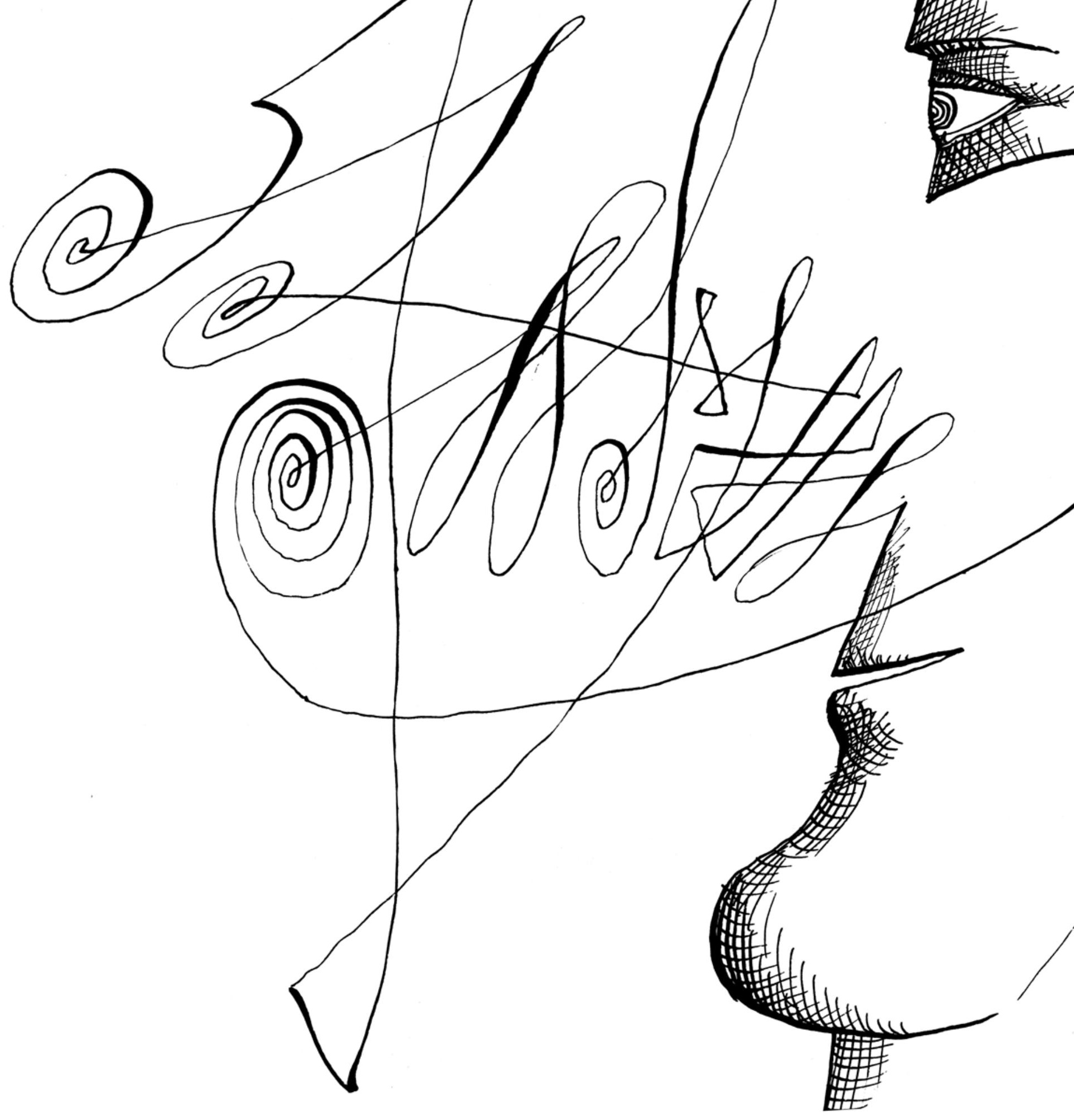

0 DESENHO MODERNO DE SAUL STEINBERG: OBRA E CONTEXTO

Daniel Oliveira Bueno

São Paulo, 2007 

Daniel Bueno

São Paulo, 2007

Dissertação de Mestrado

Orientador: Prof. Dr. Luiz Americo de Souza Munari

São Paulo, 2007

\section{O DESENHO MODERNO DE SAUL STEINBERG:} OBRA E CONTEXTO

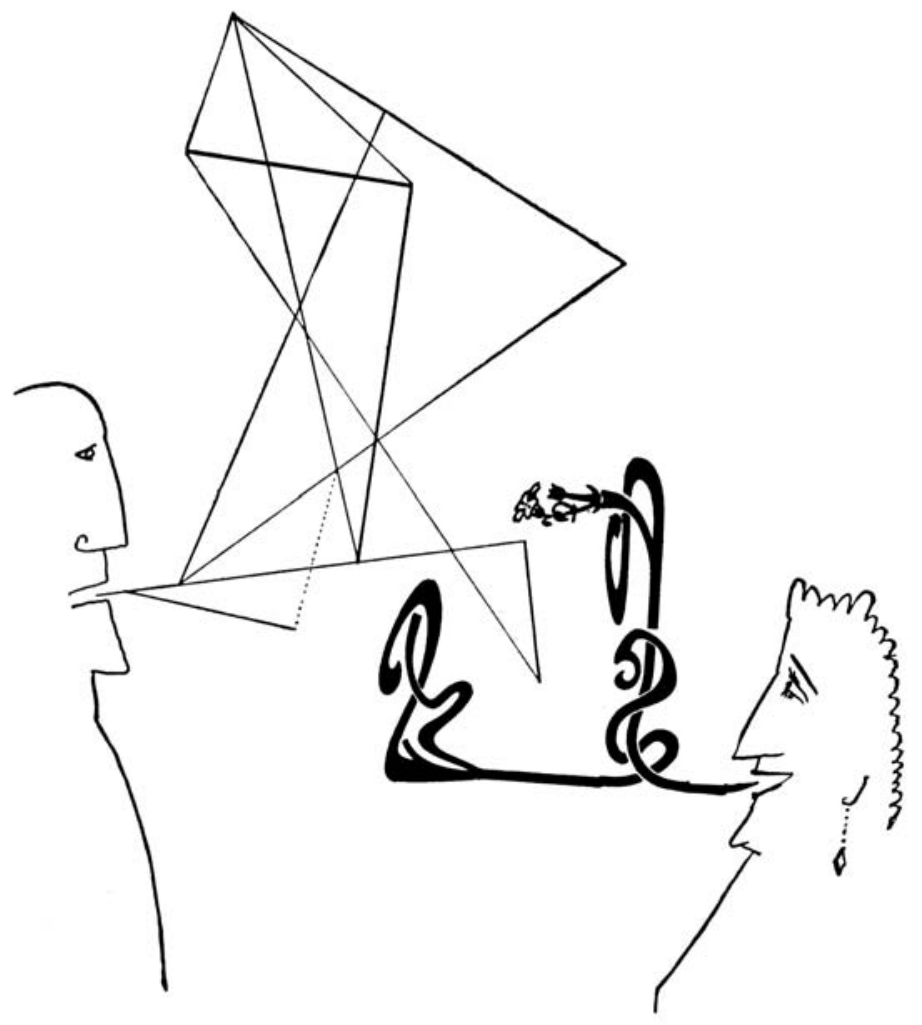

Universidade de São Paulo

Faculdade de Arquitetura e Urbanismo

Programa de Pós-Graduação: Mestrado

Área de Concentração: História e Fundamentos da Arquitetura e do Urbanismo 





\section{AGRADECIMENTOS}

Ao Prof. Dr. Luiz Americo de Souza Munari, por acolher e orientar esta pesquisa sobre Steinberg, norteando-a de modo decisivo.

À Sheila Schwartz e à Steinberg Foundation pelo grande apoio e troca de informações sobre Steinberg.

À Biblioteca do MASP e ao Instituto de Estudos Brasileiros pela atenção na disponibilização de material sobre Steinberg.

Agradecimentos especiais, por todo o apoio, dicas e incentivo, a José Lino Oliveira Bueno, Belmira Amélia de Barros Oliveira Bueno, Mariana Oliveira Bueno, Arthur Oliveira Bueno, Bernardo Svartman, e à Flora Lahuerta, pelas fotos da revista Sombra.

À Guilherme Marcondes, Orlando Pedroso, João Spacca, Rodrigo Sommer e Carlos Nine pelo empréstimo de material valioso para o trabalho.

À Silvio Dworecki e Élide Monzéglio (in memoriam) pelas aulas de desenho.

À Sonia Luyten e Chico Homem de Melo, pelas contribuições e sugestões.

À Andrés Sandoval, Laura Teixeira, Fernando Gonçalves de Almeida, Maira Rios, Felipe Noto, Fabiana Tannuri, Marly Menezes, Will, Custódio, Renato Alarcão, Fábio Zimbres, Marco Ajdaric, pelo apoio, conversas e informações. 



\section{RESUMO}

A pesquisa é voltada para o estudo da obra de Saul Steinberg, com enfoque nas contribuições de sua produção para o desenvolvimento do cartum moderno e das artes gráficas. Para tanto, busca sistematizar a vida e obra de Steinberg (1914-1999), com ênfase nas transformações ocorridas em seu trabalho no decorrer de sua carreira, relacionando-as ao conjunto de sua produção, ao contexto histórico e à produção das artes gráficas - cartum, ilustração, desenho gráfico. O trabalho busca desenvolver uma análise do desenho do artista, partindo da hipótese de seu caráter moderno baseado em síntese e simplicidade. É intenção desta pesquisa, também, contribuir com o mapeamento de parte da história das artes gráficas do Brasil e do mundo, neste caso privilegiando a produção gráfica moderna do século XX.

\section{Palavras-chave}

Saul Steinberg, desenho, artes gráficas; cartum, ilustração, desenho gráfico, design gráfico, histórias em quadrinhos, The New Yorker, desenho moderno, modernismo, simplicidade, depuração, ambigüidade, ilusão, paródia, estilo. 



\section{ABSTRACT}

The research deals with the study of the work of Saul Steinberg, with focus in the contributions of his work to the development of the modern cartoon and graphic arts. It tries to systematize the life and work of Steinberg (1914-1999), with emphasis in the transformations occured in his work, related to his whole production, to the historial context, and to the production of the graphic arts. The research tries to develop an analysis of the Steinberg's drawing, taking into consideration the hypothesis of its modern particularity - established in synthesis and simplicity. Is an intention of this research to contribute with the mapping of part of the graphic art history of Brazil and the world, focusing in the graphic modern production of the 20th century.

Key words

Saul Steinberg, drawing, graphic arts, cartoon, illustration, graphic design, comics, comix, The New Yorker, modern drawing, modernism, simplicity, ambiguity, illlusion, parody, style. 


\section{SUMÁRIO}

1 INTRODUÇÃO

7 ROMÊNIA:

O ESPÍRITO DE OBSERVAÇÃO NA INFÂNCIA DE STEINBERG

15 STEINBERG NA ITÁLIA:

O ESTUDANTE DE ARQUITETURA E CARTUNISTA

18 Steinberg cartunista: os desenhos na Bertoldo e Settebello

24 A Bertoldo e os cartunistas italianos: desenhos simples de traço fino

37 Perseguição, prisão e fuga da Europa

41 STEINBERG A CAMINHO DA AMÉRICA:

DEPURAÇÃO E DESENHO MUDO

46 Trabalhos na Argentina, Republica Dominicana e New Yorker

53 STEINBERG NOS EUA E NA GUERRA:

O DOCUMENTARISTA VISUAL

57 Steinberg na Guerra: o desenho "seco" e seletivo de documentação

66 Contexto: a reportagem visual de outros desenhistas

68 Os viajantes

71 STEINBERG EM NY:

O HUMOR MUDO DO CARTUM MODERNO NA NEW YORKER

73 Steinberg na New Yorker: o cartum mudo e gráfico

75 Contexto: o desenho mudo 
79 Contexto: depuração, abstração e simplificação no Modernismo

83 Contexto: Modernismo e desenho simples nas ilustrações do meio editorial

94 Contexto: Modernismo e desenho simples na New Yorker

102 Contexto: o desenho de outros ilustradores e artistas

112 The Art of Living e a América de Steinberg

117 Steinberg no Brasil

120 Steinberg e a arte sob encomenda: cartões de natal, murais e propaganda

127 STEINBERG:

O INFLUENTE CARTUNISTA E ILUSIONISTA

130 Steinberg: ilusão e ambigüidade gráfica

138 Ambigüidade gráfica: antecedentes e referências contemporâneas

147 Steinberg: viagens e passaportes

153 Cartunistas influenciados por Steinberg

170 Steinberg e os cartunistas brasileiros

183 NAS CAPAS DA NEW YORKER:

OS CARTUNS FILOSÓFICOS E ALEGÓRICOS DE STEINBERG

188 Steinberg e os cartuns filosóficos

191 As alegorias americanas

193 A objetualização de signos

196 As máscaras 
197 Steinberg capista

205 Steinberg cartazista.

207 AS PARÓDIAS DE ESTILO

209 Do "estilo" nos cartuns às Paródias Gráficas

211 O estilo como problema de identidade

214 As questões da arte e do artista

219 Os carimbos e postcards

222 Mistura de abordagens

224 Viagens, exposições e um assistente

229 STEINBERG:

CRÍTICO DA CIDADE, ARQUITETURA E ESTILOS

233 Steinberg: a influência do comix underground nos desenhos urbanos

249 O crítico de arquitetura e urbanismo

256 Tridimensionalidade e mistura de mídias nas Mesas, trompe-l'oeil e assemblages

259 Desenhos de observação

260 O viajante e a Romênia

262 Últimos trabalhos, reflexões e obras

265 CONCLUSÃO

269 REFERÊNCIAS 



\section{INTRODUÇÃo}

Desenhista e cartunista do meio editorial de 1936 a 1999, Saul Steinberg (1914-1999) percorreu considerável parte do século XX publicando em revistas de destaque do cenário mundial, em especial na The New Yorker. Seu desenho produziu uma das imagens mais plagiadas das artes gráficas, a famosa capa para a New Yorker que mostrava a visão do mundo segundo o americano médio, View of the World from 9th Avenue. Também importante referência de seu trabalho foi o personagem anônimo de seus cartuns, um homenzinho narigudo que provavelmente inspirou boa parte da produção posterior do cartum, animação e propaganda. Mas uma breve observação de sua obra mostra que Steinberg foi muito além destes dois ícones, desenvolvendo uma variedade enorme de abordagens e experimentações gráficas. Mais do que isso, sua influência é perceptível na obra de muitos artistas gráficos, sendo constantemente citada. Essa condição de referência não ocorre à toa; Steinberg participou de uma "ruptura" na cultura do desenho editorial, desenvolvendo um trabalho de maior amplitude gráfica, caracterizado pela síntese gráfica, maior integração entre forma e conteúdo, e ausência de palavras. Desta ruptura tomaram parte não apenas cartunistas estrangeiros como André François e Tomi Ungerer, como os brasileiros da geração Pasquim, Millôr Fernandes, Ziraldo, Jaguar e cia.

Apesar desta posição de destaque, pouco foi escrito sobre este cartunista americano de origem romena. Alguns artigos importantes, como o de Harold Rosenberg, publicado em 1978, se esforçavam em contextualizar seu trabalho no âmbito das artes plásticas, deixando uma grande lacuna em relação à sua contribuição para a àrea editorial. Apenas recentemente determinados esforços têm sido empreendidos no estudo e divulgação da obra de Steinberg. Em relação ao seu trabalho para revistas, foi lançado em 2005 o livro Steinberg na New Yorker, de Joel Smith, sobre a produção feita para o veículo que mais publicou o cartunista, de 1941 até 1999. Outro livro de Smith, Saul Steinberg: Illuminations, lançado no final de 2006, trouxe pela primeira vez uma ampla análise do desenvolvimento de toda a sua obra. 
No entanto, uma contextualização mais aprofundada do trabalho deste cartunista híbrido, que transitou por revistas e galerias, ainda se faz necessária. A proposta desta pesquisa, portanto, é a de analisar o desenvolvimento da obra de Steinberg, com ênfase na contextualização dos principais aspectos de seu trabalho. Comparações com as artes plásticas serão inevitáveis, em função de certas abordagens em seus trabalhos, mas a pesquisa promoverá uma incursão maior no campo do cartum, da ilustração, do design gráfico. O trabalho parte da hipótese de um desenho moderno em Steinberg, e pretende analisar as principais características, temas e abordagens de sua obra, assim como a amplitude destas no cenário das artes gráficas. Estas análises terão como parâmetro a arte gráfica moderna, representada por sua produção visual e teórica. A eleição destes elementos de análise partiu de textos escritos sobre o cartunista, de comentários do próprio Steinberg, e da observação de seu trabalho.

O desenho simples, sintético, de traço fino feito à caneta de seus cartuns foi o primeiro aspecto a ser levantado. Harold Rosenberg enfatiza a importância do traço de Steinberg, com sua linha de um mestre escritor e calígrafo, seu estilo fundado no desenho das crianças, - aspecto que lhe rendeu comparações com Klee - em diversas passagens do texto de 1978. Lina Bo Bardi também aponta o desenho seco e depurado do cartunista como referência de um modo de desenhar moderno, adequado aos arquitetos. O próprio Steinberg afirma o seu desinteresse na performance, na execução laboriosa, salientando a importância da idéia em seus desenhos simples. Não por acaso, seu primeiro livro se chama All in Line (Todo em Linhas). A presença de seu traço fino é significativa no conjunto de sua obra, e é um dos aspectos fundamentais do novo cartum moderno. O humor mudo também foi objeto de atenção, pois se mostra presente em praticamente todo o seu trabalho a partir dos cartuns para a New Yorker, fruto da busca do cartunista em explorar os aspectos gráficos dos desenhos. Um terceiro fator diz respeito à ilusão gráfica: ao uso dos recursos de ambigüidade e imagens duplas. Além de Rosenberg, que comenta a sua capacidade em desenvolver jogos prestidigitadores, é Gombrich quem aborda a questão com grande ênfase em seu livro Arte e Ilusão, destacando o conhecimento de Steinberg sobre a filosofia da representação. A paródia gráfica, termo sugerido por Manuel Gasser em 1954 e considerado um novo passo na produção de Steinberg, também é um aspecto dos mais importantes, presente de modo incisivo a partir de 1965. Steinberg também se referia em entrevistas ao seu interesse nos estilos e boundieseries, desde os tempos de infância. Temas importantes apontados por Rosenberg como as questões da arte, do self e das máscaras, estão intimamente relacionadas e tomam forma por meio das paródias. Também falam de estilo os desenhos urbanos feitos a partir de meados dos anos 1960, em cenários explosivos inspirados na história em quadrinhos underground.

O livro Steinberg at the New Yorker também reforça estes elementos selecionados, através da divisão de seus capítulos. Vendo através de metáforas, Pensado e falado - sobre a conversão de elementos gráficos em objetos manipuláveis -, abordam os recursos de ilusão. Mundo de arte, Mundo feito por si mesmo, se referem às paródias e uso de estilos.A 
importância do personagem de desenho simples difundido por Steinberg também é ressaltada por Joel Smith no texto introdutório.

O trabalho procura agregar e estabelecer relações entre diversos tipos de informação: dados históricos; análises críticas e históricas sobre Steinberg e sua obra; reflexões, informações históricas descritas pelo próprio artista; o trabalho de outros artistas da época e o contexto cultural; textos de história das artes gráficas que ajudem a inserir o artista no contexto cultural. A pesquisa foi estruturada em capítulos, que acompanham o desenvolvimento da vida e obra de Steinberg. A opção pela ordem cronológica possibilitou uma maior organização de informações e fatos, necessária em função do pouco que havia sido escrito pelo cartunista até então. As contextualizações e questões a serem discutidas foram inseridas de acordo com as fases do trabalho de Steinberg. Cada capítulo, portanto, é caracterizado por uma fase, definida pela eleição de um aspecto que se sobressai aos outros ou que inaugura um novo momento. Deste modo, a juventude de Steinberg na Itália é uma fase claramente diferente de sua infância na Romênia, e cada momento merece um capítulo distinto. Das lembranças de Steinberg sobre a Romênia (1914-1932) foram extraídas informações sobre o meio onde cresceu, sua formação, experiências e interesses - com rebatimentos em seu futuro trabalho. Na Itália (1933-1941), é abordada sua formação como arquiteto e, especialmente, sua estréia como cartunista profissional na revista Bertoldo. É feita a análise comparativa do trabalho de Steinberg com os outros cartunistas italianos, em busca de influências e de uma maior compreensão do papel desempenhado por Saul nestas publicações, algo pouco abordado nas recentes publicações americanas sobre o cartunista. O momento de transição na República Dominicana (1941-1942) também vira um capítulo, que fala do processo de depuração de seus cartuns feito a partir da relação com agentes que procuravam publicá-lo nas Américas, e suas primeiras aparições em revistas do continente antes de chegar aos Estados Unidos. O capítulo seguinte trata da chegada de Steinberg aos Estados Unidos e de sua ida à guerra (1942-1944), conferindo destaque à sua produção como documentarista visual, e tecendo comparações com outros trabalhos do gênero. Os tempos de pós-guerra nos Estados Unidos (1945-1953) são abordados no quinto capítulo, com ênfase nos seus cartuns na New Yorker, caracterizados por cartuns de linha fina em humor mudo, que jogam com alterações de elementos desenhados a partir da sobreposição de situações inesperadas. As questões do desenho moderno e do humor mudo são consideradas e contextualizadas, em levantamento da produção gráfica moderna feito com a intenção de analisar a amplitude das contribuições de Steinberg. A passagem de Steinberg pelo Brasil, em 1952, também é comentada. A obra The Line, criada em 1953 para um mural em Milão, marca um divisor de águas, inaugurando um maior interesse de Steinberg por ambigüidades gráficas (1953-1959). Neste sexto capítulo, é também feito um levantamento histórico sobre a utilização do recurso. Nos anos 1950, Steinberg já se mostrava um artista influente, e suas obras gráficas do período eram representativas de seu trabalho. Deste modo, é neste momento da pesquisa que são analisados trabalhos de artistas influenciados por Steinberg, levando em consideração a produção 
do humor brasileiro. No estudo da estruturação dos capítulos, se mostrou evidente a fase das alegorias (1960-1965), o período em que Steinberg assume a condição de grande capista da New Yorker. O recente livro Comic World, de Topliss, confere ênfase às alegorias americanas no estudo do trabalho de Steinberg. Além da análise destes trabalhos alegóricos, são analisadas as capas e cartazes de Steinberg e sua contextualização. A exposição Le Masque inaugura a a fase das paródias gráficas (1965-1973), nos seus mais variados aspectos e abordagens. O último capítulo (1973-1999) corresponde a uma atenção voltada a situações urbanas e à arquitetura, cujos trabalhos foram publicados em portifólios na New Yorker desde 1973. A influência dos quadrinhos underground nos desenhos de Steinberg é comentada, assim como sua produção de desenhos com comentários urbanos. O último capítulo também destina espaço às incursões de Steinberg pela arte tridimensional e pelo desenho de observação.

Os recentes lançamentos sobre a obra de Steinberg, escritos por Joel Smith, assim como a publicação The Complete New Yorker, forneceram um material precioso para a pesquisa. Também contribuiu o livro Reflections and Shadows, uma entrevista dada pelo artista e transcrita por Aldo Buzzi, seu amigo. Steinberg raramente escreveu algo sobre si mesmo, e as outras informações do gênero aparecem em algumas cartas e como frases esporádicas em artigos. O conhecido artigo de Rosenberg, de 1978, também foi referência das mais importantes. Os textos de Manuel Gasser publicados na revista internacional Graphis durante as décadas de 1950 e 1960 contribuíram para a análise do trabalho do cartunista, direta e indiretamente, em artigos sobre Steinberg, outros artistas importantes da época, editoras, galerias e exposições. A Steinberg Foundation também teve papel importante na pesquisa ao enviar diversos catálogos com textos significativos, dentre eles o texto de Robert Hughes, escrito em 1978 para a revista Time. Foi estabelecido com a Steinberg Foundation um interessante intercâmbio que resultou em contribuições para o livro Saul Steinberg: Illuminations. 


\section{ROMÊNIA: \\ O ESPÍRITO DE OBSERVAÇÃO NA INFÂNCIA DE STEINBERG}

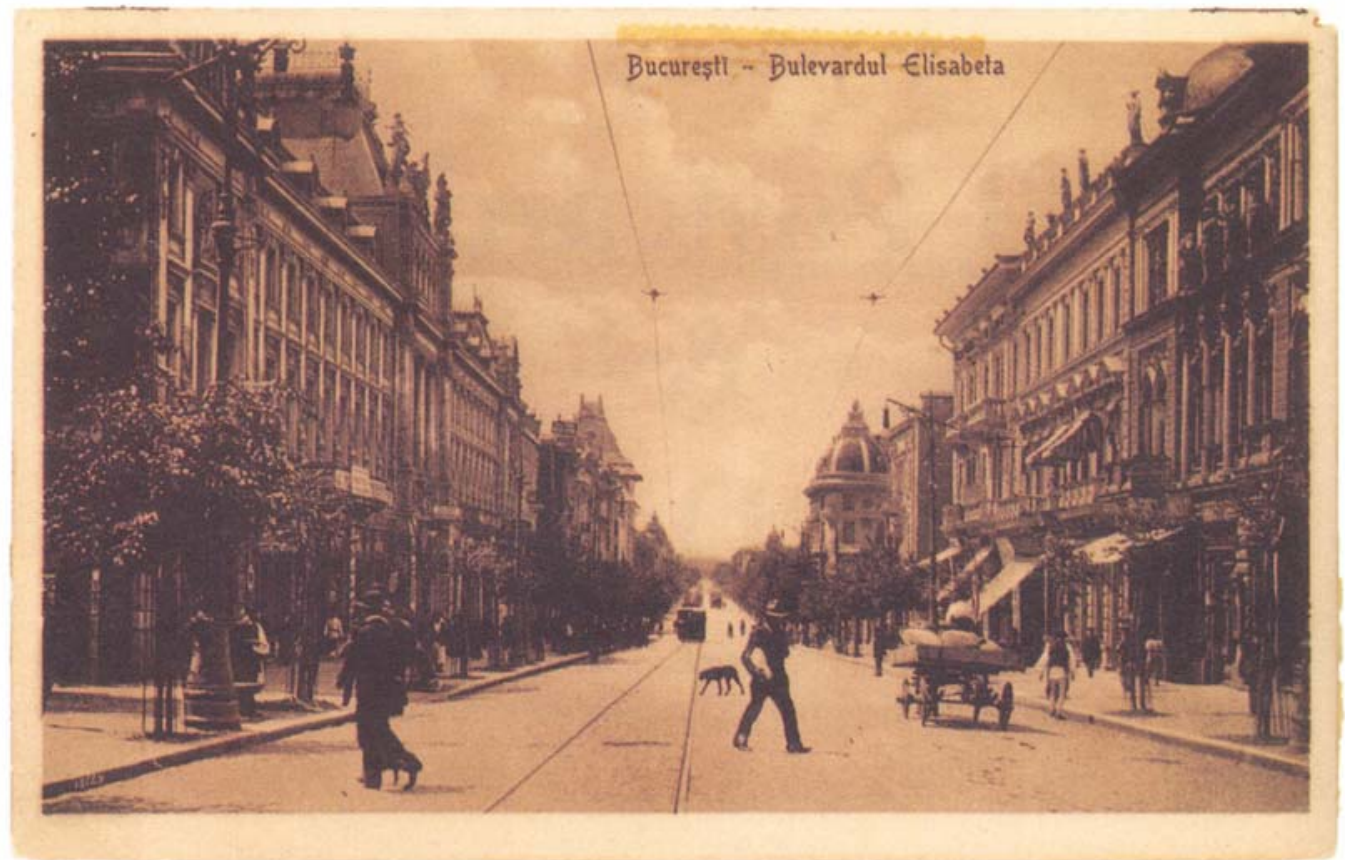

Figura 1. Cartão-postal antigo de Bucareste, Romênia, 1924

Maior referência de muitos dos grandes cartunistas dos últimos sessenta anos, Saul Steinberg curiosamente não menciona as revistas em quadrinhos e os cartuns como objetos de interesse em sua infância. Em suas lembranças, o pequeno Steinberg parece, desde os primeiros anos de idade, mais motivado em explorar e analisar as características e peculiaridades dos objetos e do ambiente à sua volta - sejam eles blocos de tipos, selos, caixas de chocolate ou os bolos feitos pela mãe -, do que mergulhar no universo de uma linguagem específica. Tal comportamento também viria a ser uma característica de sua carreira artística, de livre trânsito pelos diversos campos da criação e com certo desapego a redutos e estilos.

Ao recordar fatos vivenciados no passado para um público, o autor costuma fazer a seleção e a edição destas memórias, evidentemente. As lembranças de Steinberg, deste modo, lançam luz sobre aspectos relevantes de sua conduta artística, mas deixam dúvidas sobre a dimensão de seu interesse no cartum durante a infância e começo da juventude. O envolvimento com o trabalho dos cartunistas não deve ter sido desprezível no período que antecedeu o início de carreira do jovem cartunista Steinberg, dado o domínio da linguagem exercido nos primeiros anos de trabalho, como veremos adiante. De qualquer modo, mesmo sem termos conhecimento destes aspectos mais específicos, é perceptível a sensibilidade no olhar observador do artista, presente em suas recordações mais remotas. 
Nascido em 15 de junho de 1914 em uma família de classe média judaica de segunda e terceira geração na Romênia, na vila de Ramnicul-Sarat, situada no sudeste do país, Steinberg muda-se seis meses depois para Bucareste, então com meio milhão de habitantes. São tempos turbulentos: em agosto de 1914 começa a I Guerra Mundial, que se estenderia até 1918. Apesar da participação da Romênia como aliada das potências da Tríplice Entente, o conflito não parece ter atingido o cotidiano da família de Steinberg, ao contrário do que viria a ocorrer na II Grande Guerra. Em Bucareste, a família Moritz se junta aos tios de Saul, pequenos comerciantes envolvidos com pintura de placas, relojoarias, comércio de livros, papelarias. O garoto Saul tem, então, nesse período de crescimento, o conhecimento de três línguas: o romeno, francês e "a língua secreta de meus pais", como ele mesmo comenta, o "Yiddish" (Hughes, 1978, p.51).

Em 1914, quando Steinberg nasceu, a arte moderna já vinha dando grandes saltos. Picasso, Braque e outros artistas desenvolviam o cubismo, que se encontrava em sua última fase, desde 1907. Cabeças, de Paul Klee, com seu traço simples e infantil, era criação de 1913. Foi neste ano, também, que Duchamp realizou uma série de obras que procuravam atuar no contexto da arte do período, como Triturador de Chocolate, 9 Moldes Metálicos, Caixa de 1914 , dentre outras. Os futuristas vinham fazendo suas publicações, com capas que traziam ousadas experimentações tipográficas, como Zang Tumb Tumb de Marinetti, lançada naquele ano. As revistas humorísticas começavam a apresentar considerável aprimoramento em seu

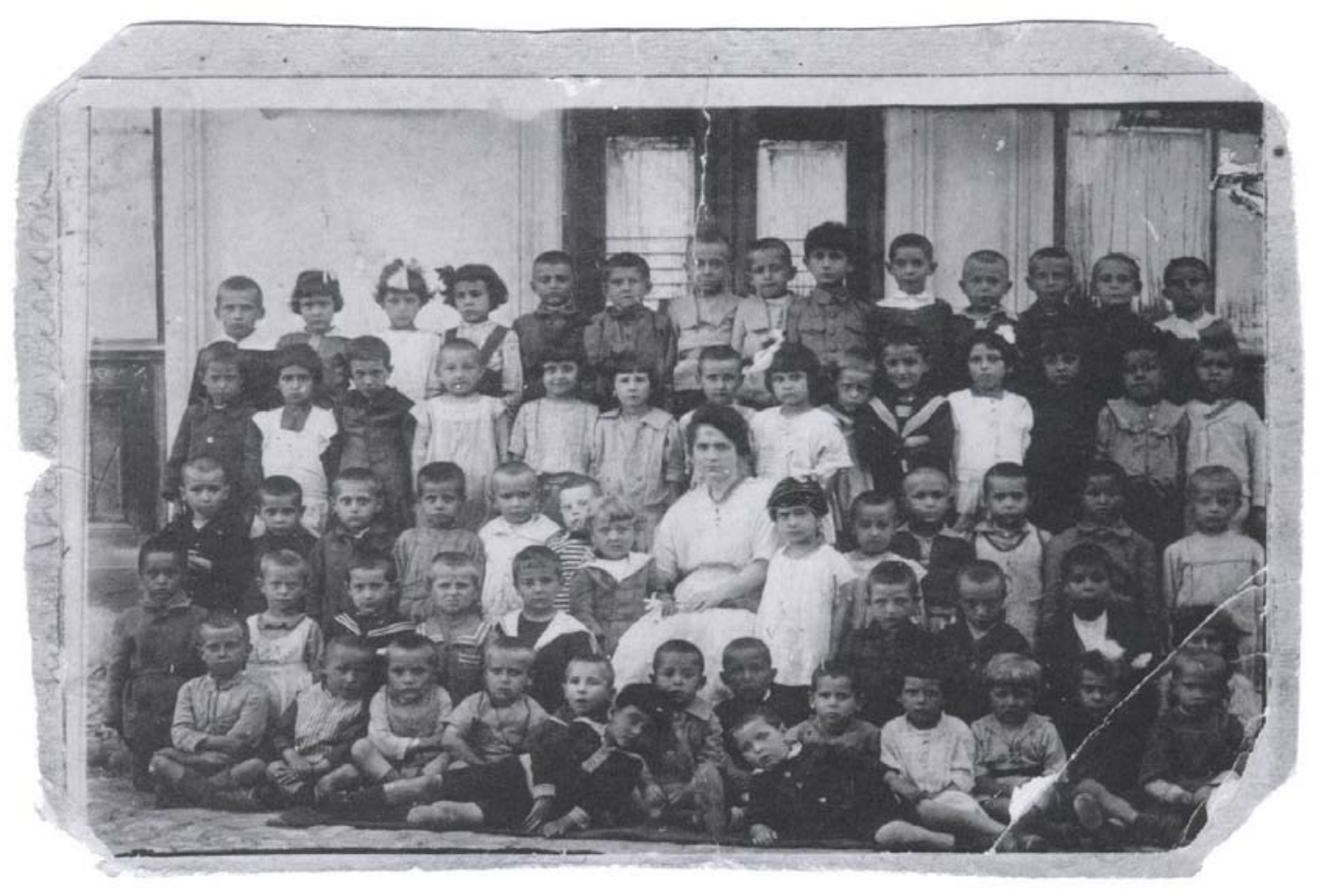

Figura 2. Jardim da infância, Bucaeste, 1920. Saul está na fila de trás, no canto extremo esquerdo. 
desenho gráfico e na linguagem dos cartuns, como a revista satírica alemã Simplissicimus. Nos quadrinhos, fazia nove anos que as primeiras páginas do revolucionário Little Nemo, de Winsor McCay, haviam sido publicadas no The New York Herald. A popular criação Pafúncio e Marocas, de Geo McManus, começava como tira em 1913, para depois se tornar página domingueira em 1916 e ser o destaque das family strips. Os acontecimentos são muitos e, obviamente, não se resumem a estes. Apesar das limitações de comunicação naquele tempo, onde a presença do rádio era ainda incipiente no mundo, e do isolamento da Romênia se comparada a outros grandes centros europeus, o país recebia alguma influência cultural de Paris. Mas é difícil mensurar o que o país recebia de informações de fora. Por certo, muito mais do que qualquer elemento de vanguarda, eram as bondieuseries que se faziam presentes no cotidiano dos habitantes de Bucareste.

As recordações de Steinberg, em especial as concedidas em entrevista ao amigo Aldo Buzzi, centram-se na sua percepção de objetos e ambientes. Os fatos do passado, desta "infância muito forte", dão vazão a lembranças sobre o modo como fazia relações entre diferentes aspectos das coisas. Totalmente imerso neste "território" - termo geográfico usado pelo artista para demarcar este período de sua vida -, Saul vivenciou os longos dias de sua infância embriagado com qualquer coisa, desde as mais elementares. Sem perceber, o jovem romeno se perdia em devaneios, criando pontes entre elementos observados e diferentes sentidos, como "a luminosidade do dia e o cheiro e tudo (...)" (cit. por Hughes, 1978, p.51).

Cheiros vagos, e ao mesmo tempo, alguns específicos: o cheiro do outono; de certas lojas; o cheiro do início do inverno, quando o tempo começa a ficar frio; o primeiro incêndio na casa, com a lâmpada acesa às cinco da manhã. $O$ fogão de metal tinha um cheiro especial quando aceso pela primeira vez, já que sua superfície era untada para evitar que se enferrujasse. E havia o cheiro da lâmpada a óleo. (Steinberg, 2002, p.5)

Ao que parece, a imaginação de Steinberg não parecia depender em demasia dos tradicionais veículos carregados de fantasia, como revistas, livros infantis, brinquedos. "Cresci sem brinquedos", conta Steinberg ao se lembrar da infância (Steinberg, 2002, p.6). Os pais, Moritz Steinberg e Rosa Jacobson Steinberg (Boxer, 1999), não eram propriamente artistas, no sentido convencional do termo, mas no ambiente que involuntariamente concederam ao filho, exerceram um papel atuante neste "território" cheio de estímulos. O pai era um impressor, tipógrafo e encadernador de livros, que viria mais tarde a se tornar um fabricante de caixas de papelão, abrindo "caminho para o romance maduro que o filho teria com (...) toda essa variada fauna do mundo bidimensional criado pelo homem" (Updike, 1999, s.p). Com apenas dois ou três anos de idade, Steinberg já tinha seus primeiros contatos com as letras, signos de pontuação e números a partir dos quais iria criar tantos desenhos (Gill, sem data, p.3). Posteriormente, passa a freqüentar a pequena oficina de caixas de papelão do pai, ambiente impregnado pelo cheiro de "estúdio de artista" e de colagens, segundo suas recor- 

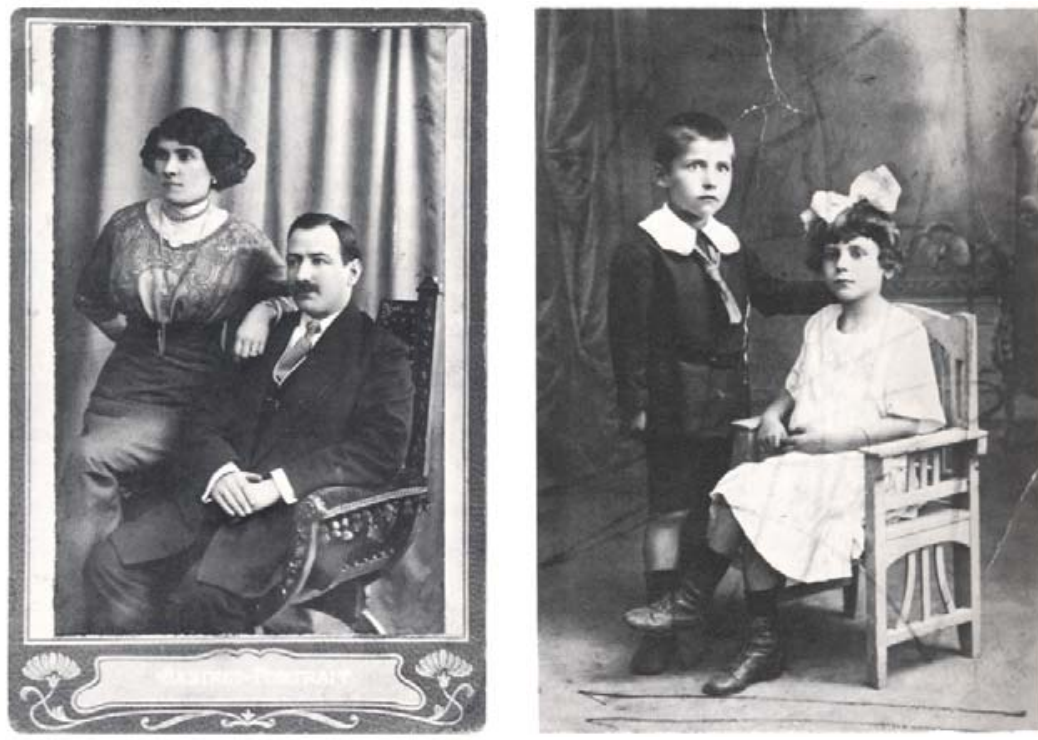

dações (Steinberg, 2002, p.6). Em suas mãos, os papéis (...), selos, o papelão, as reproduções de madonnas de museu (literalmente, arte em caixas de chocolate), e os blocos de tipos se transformaram em seus primeiros brinquedos. Não se tratava apenas da passagem de qualquer coisa à condição de brinquedo, mas também à condição de "outra coisa". Desde cedo, os elementos gráficos já se configuravam em objetos.

Eu tinha, desde o começo, um grande tipo de madeira usado para pôsteres; logo, se mais tarde viesse a fazer, por um exemplo, o desenho de um homem segurando um ponto de interrogação pela base circular, essa não seria uma invenção tão significativa - era algo familiar para mim. (cit. por Hughes, 1978, p.51).

Mas não foi apenas o pai que proporcionou ao filho, mesmo sem pretender, a chance do desfrute de estímulos estéticos. Algumas das lembranças significativas que Steinberg viria a ter de sua mãe, posteriormente, estão relacionadas à culinária; ela fazia bolos que o filho considerava "muito bonitos para comer" (Boxer, 1999, s.p). "O mais importante era seu espírito de observação", resume. Para o garoto sempre atento ao que a mãe via e percebia, ela se mostrava extraordinária em suas observações e descrições: "Tinha um modo de descrever algo verbalmente que era uma coisa essencial". Steinberg recorda como era engraçado como o desatento pai, mesmo presente às situações, nunca percebia o que era visto pela mãe. Mesmo assim, Moritz acompanhava com curiosidade as interpretações da esposa. Quando os dois voltavam de alguma visita para casa, era comum Rosa contar às crianças algo que tinha visto, adicionando todo o tipo de interpretação, parênteses e notas de rodapé. Para Steinberg, "isso é muito mais a preparação para um artista do que - bem, pense em todas as crianças de grandes mestres que poderiam ter aprendido qualquer coisa. Então, minha mãe fez alguns bolos, mas não os fez melhor do que qualquer outra mãe", esclarece, deixando evidente que 


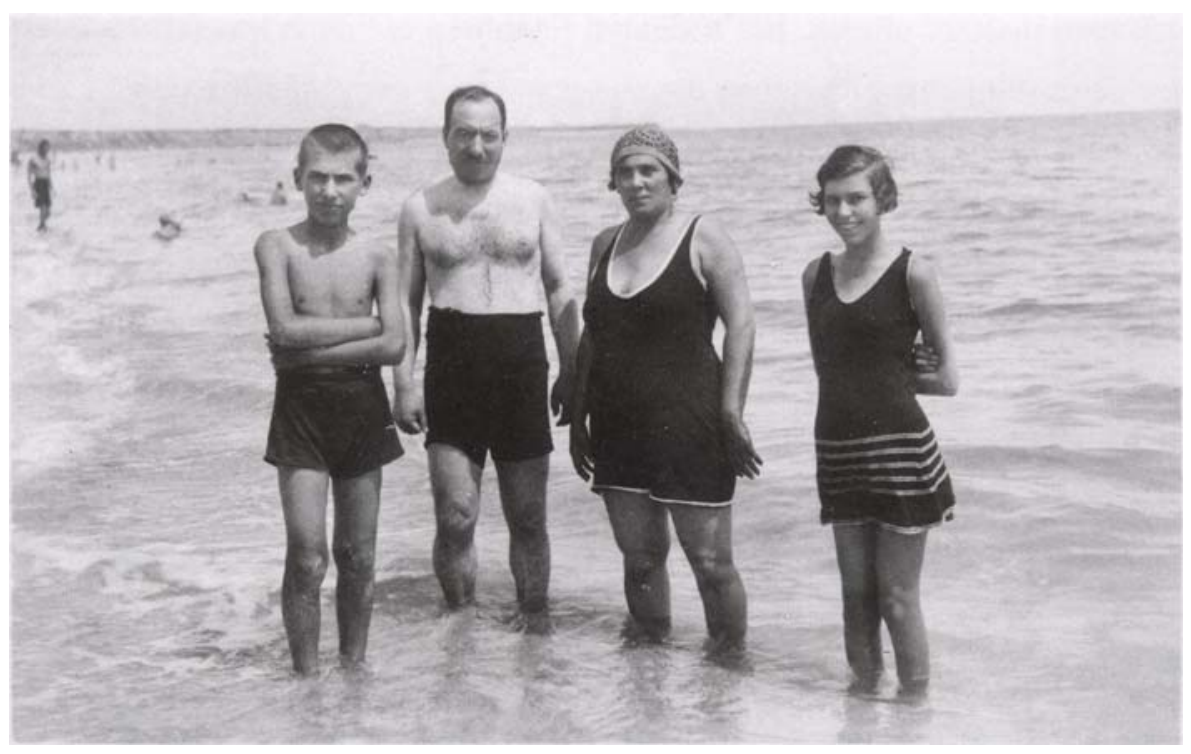

Figura 3. Os pais de Steinberg, Moritz e Rosa, em 1912

Figura 4. Saul com Lica, em 1920

Figura 5. Saul, Moritz, Rosa e Lica Steinberg, Mar Negro, 1926

o diferencial estava no espírito de observação compartilhado com a mãe. Fica evidente como Saul, em suas recordações, procura enfatizar um modo de observar que pode ser empregado em situações diversas, ao mesmo tempo em que demonstra desapego a personagens fictícios e linguagens específicas. E preocupa-se em demonstrar que este modo de olhar não é algo artificial ou exterior à sua vida, mas fruto do desenvolvimento de sua infância, de seus hábitos mais espontâneos. "Veja, desenho e tudo o mais, especialmente para uma criança, não é nada, é algo natural" (Gluek, 1970, p.114). No que dependesse da vontade dos pais, no entanto, Steinberg não seria um cartunista: "Em minha família, ser um artista era uma desgraça", confessou certa vez (cit. por Gill, 1978, p.68).

A vida da família era dominada por Rosa, que apesar de suas qualidades era também uma mulher ansiosa, de julgamentos rápidos e personalidade temperamental. Era com ela que Saul tinha mais ligação, ao mesmo tempo em que - sob sua influência - terminava isolado de Moritiz, que transmitia medo a ambos. Tal situação conferiu a Steinberg, ao longo da vida, um permanente estado de alerta ao poder feminino, assim como à tirania. $\mathrm{O}$ artista, por volta dos setenta anos, chega a se dar conta e comentar: "Descubro apenas agora...que Rosa era tímida. Sua arrogância". O orgulho da mãe fica comprovado pelas privações em vida após a Grande Guerra, em contraste com a situação de tios e parentes que enviavam pacotes com presentes de lugares distantes e com nomes exóticos como "Bronx". Para Steinberg, os brinquedos de Hoover Relief tomavam a forma de objetos mágicos, "para reverenciar - não para brincar". Na sua visão, "a América era a julgadora, inocente, distante da intriga local e dos tabus, a esperança permanente dos oprimidos" (cit. por Smith, 2006, p.24).

A família não se resumia, obviamente, aos pais. Sua mãe tinha cinco irmãs: Sofi, casada com Moritz Grinberg, um pintor de letreiros; Aneta, a mulher do crupiê "Micu" ("pequeno") Cohen; Pesa, esposa de Jack Kramer, dono de uma loja de relógios e instrumentos musicais; Sali, casada com o vendedor de livros Simon Marcovic; e por fim, a caçula Ana, 
a menos bonita e querida delas, casada com outro vendedor de livros, o desajeitado Tio Adolf. Rosa ainda tinha um irmão, Jacques, que havia alterado seu nome original - Isac Jacobson - quando se casou pela segunda vez. Steinberg era muito apegado à irmã, Lica Roman, uma futura artista que veio a falecer em Paris em 1975. De seus muitos tios, verdadeiros ou não, Tio Moritz e seu irmão Josef eram os mais interessantes para Steinberg, por serem pintores de anúncios e lidarem com coisas relacionadas à pintura. Moritz limitava-se a pintar amplas inscrições de anúncios a serem dispostos sobre as ruas em ocasiões de ofertas, festivais, comícios políticos, coisas baratas e de curta duração. Em algumas ocasiões a pintura era feita diretamente nas paredes, e nestes casos enviava empregados para executar os serviços. Josef, além de pintar letras, também elaborava temas e imagens para lojas que pretendiam ser atraentes para os pedestres analfabetos. Passavam-se meses até que a melhor idéia era aprovada pelos lojistas: o canhão dourado ou uma águia do mar com um peixe em suas garras.

Elemento importante de seu trabalho, determinados estereótipos artísticos já chamavam a atenção de Steinberg naquela época, como as chamadas de padarias, leiterias e confeitarias, que ao adicionarem quase sempre imagens às inserções tipográficas sobre fundo preto, refletiam a influência generalizada de Paris sobre a Romênia daquele tempo. Eram paisagens ovais e pastoras, cenas de felicidade e nobreza. "Nos espelhos ou nos prato de vidro, em dourado ou em fundo preto, tio Josef pintava uma Romênia que procurava parecer-se com a corte de Versalhes, em felizes paisagens com cidadãos em trajes nacionais, todos consideravelmente adequados às confeitarias, restaurantes e lugares do gênero", recordou Steinberg, atento aos clichês de seu tempo. Compunha o seu imaginário, também, os vendedores ambulantes de cartões-postais sujos, livros baratos, selos e jornais que circulavam pelos típicos e movimentados pátios internos da cidade (Steinberg, 2002, p.14). Os estereótipos não se resumiam à concepção popular dos letreiros, estendendo-se também à aplicação de cópias de obras de arte em produtos comerciais. Como observou Steinberg, "tantas coisas se tornam bondieuserie no final - respeitáveis e belas, mas cômicas porque são tamanhos clichês" (Gluek, 1970, p.112). Em sua infância romena, era grande o acesso a este tipo de material:

A residência da família tinha "grandes conjuntos de reproduções dos mais populares trabalhos de arte, da Renascença à arte moderna daquele tempo. Certas Madonnas pintadas por artistas menores da Renascença procuravam dar uma perfeita imagem do cristianismo popular, ou melhor, de um tipo de cristandade de pasteleiro, o que os franceses chamam de bondieuserie. Millet era ideal para caixas de chocolate, porque ele combinava o classicismo da Renascença com socialismo, o que naquele tempo não era apenas popular, mas também virginal (...) E ali havia também Rafael: a Madonna de Dresden; e o anjo pensador, com seu cotovelo apoiado em uma nuvem. Muitas destas imagens eu estava vendo pela primeira vez, sem perceber que eram arte, pintura. Mais tarde, corri atrás delas novamente em livros de arte e as reconheci". (Steinberg, 2002, p.12) 
Outra referência para o jovem Saul, na época, é o álbum de família, "um professor" para ele, cheio de fotos que seriam seus "primeiros modelos". Havia fotos com seus parentes, dos mais novos aos mais velhos, "tiradas por excelentes fotógrafos inspirados pelas pinturas de Delacroix e Ingres". Outras, ao contrário, eram fotos horríveis tiradas pelos próprios familiares, em que a inexperiência produzia imagens onde todos apareciam com "bigodes de Hitler", resultado da sombra do nariz. O exercício de encontrar peculiaridades estilísticas nas fotos, numa relação entre características da foto e outros aspectos da vida, também viria a ser feito no sentido inverso. Era possível ver uma foto ou mesmo uma pintura de folk-art em pessoas que subitamente ficavam imóveis por alguns segundos (Steinberg, 2002, p.12).

Não foi apenas o pai que permitiu que Steinberg circulasse em ambientes cheios de materiais de desenho e papéis. Dois de seus tios tinham papelarias e livrarias, que vendiam textos escolares e literatura popular, como histórias de aventura com bandidos e As Mil e Uma Noites. A maior parte os produtos vendidos era material de escola, como lápis, borracha, tinta - rosa ou azul, papel azul para cobrir livros, papel milimetrado de matemática, cadernos de anotação, dentre muitos outros elementos posteriormente presentes na obra do desenhista romeno (Steinberg, 2002, p.17).

Steinberg era uma criança comum, que nunca freqüentou uma escola de arte ou algo do gênero, mas que sempre desenhou. Ao terminar a escola primária, ingressa em 1924 no Liceul Matei Basarab, uma escola grande e rígida, direcionada especialmente ao latim. Nesse período, Steinberg despende o verão em Buzau, uma cidade próxima a Bucareste, onde seu avô era um alfaiate militar.

Apesar de um estudante relutante nos tempos da escola de latim, Saul se torna a partir de então um leitor voraz, "cuja aparência séria servia de máscara para uma florescente imaginação" (Smith, 2006, p.24). Steinberg recorda: "Minha educação, (...) meu comportamento, veio do hábito de leitura. Encontrei meu mundo real, e meus verdadeiros amigos, nos livros". Aos dez anos, "muito cedo", lê Maxim Gorky. Aos doze, devora Crime e castigo; da França, doses consideráveis de Julio Verne, Emile Zola e Anatole France, "cuja qualidade era fantástica para mim", comenta o artista (cit. por Hughes, 1978, p.51). Fica bastante impressionado com anotações autobiográficas de Gorky, "uma excelente metáfora de como eu me sentia", explica Steinberg.

É preciso considerar a hipótese do artista como um órfão, um prodigioso órfão, cujos pais o encontram em algum lugar - naquelas plantas que dão origem ao papiro, talvez. Fingir-se de órfão, sozinho, é uma forma de narcisismo. Suponho que todas as crianças possuam esta repugnante forma de autopiedade. (cit. por Hughes, 1978, p.51)

Uma vez graduado do colegial, em 1932, entra na Universidade de Bucareste, frequentando os cursos de Filosofia e Letras. Na adolescência, Steinberg se considera particularmente um deslocado. (Hughes, 1978). Ele não pode desfrutar da "boa Romênia", como os homens 
Figura 6. Saul, com nove anos, em 1927

Figura 7. Classe da Universidade de Bucareste, março de 1932. Saul está de pé na primeira fila, no canto extremo esquerdo.
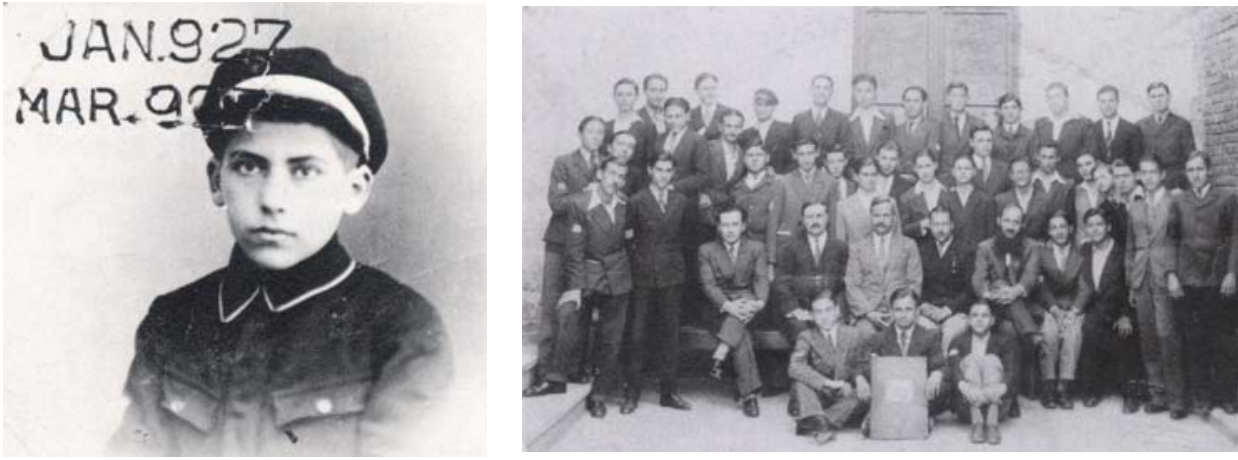

de trinta, quarenta, ou cinquenta anos - os homens de sucesso - podem. Na condição de garoto, "não tinha direitos".

Enquanto não tivesse dinheiro, não poderia desfrutar as terríveis liberdades da Romênia, que eram invariavelmente abusos, ou levar a vida de um cavaleiro que, se tem algum dinheiro, pode sempre encontrar pessoas para comprar. Minha adolescência na Romênia foi como ser um negro no estado do Mississipi. (Steinberg, 2002, p.3)

Os elementos estilísticos não apenas de alguns objetos e detalhes, mas de todo o ambiente romeno, chamam a atenção de Steinberg. "No momento em que abriu os olhos, ele estava convencido de que aquele ambiente de opereta, com camponeses peculiarmente trajados e soldados de cavalaria bigodudos, haviam sido calculados para provocá-lo", conta o crítico Rosenberg. A defesa imediata de Saul foi tornar-se invisível ao fundir-se com o ambiente à sua volta. Na escola, possivelmente nos tempos de Liceul, Steinberg tinha - como ele mesmo recorda - "um uniforme militar e um número parecido a uma placa de licença, de modo que qualquer um poderia pegar meu número e me denunciar" (Rosenberg, 1978, p.13).

Steinberg, um artista que de modo tão pervasivo havia influenciado os Estados Unidos, considerava fortuito o fato de ter nascido na Romênia. Em 1914, o território era um "corredor, um palimpsesto no qual vários poderes coloniais - Rússia, Hungria, Turquia haviam deixado seus traços. Steinberg define-se, então, como um "culturalmente nascido Levantino - seu país vai do subúrbio oriental de Milão todo o caminho em direção ao Afeganistão" (cit. por Hughes, 1978, p.51).

Bucareste, nos dias de minha juventude, era uma cidade peculiar, uma cidade enfant-prodige, onde a vanguarda coabitava com o primitivismo, como em certos lugares onde dois ou três rios convergem e se misturam, onde há algo essencial que não tem nada a ver com o personagem comum do lugar, algo que emerge em um momento particular quando culturas, as forças do sul, norte, leste e oeste reúnem-se e geram um tornado, um furacão, uma tromba d'água, ou se você preferir, um redemoinho - Dada. (Steinberg, 2002, p.13) 


\section{STEINBERG NA ITÁLIA: \\ 0 ESTUDANTE DE ARQUITETURA E CARTUNISTA}

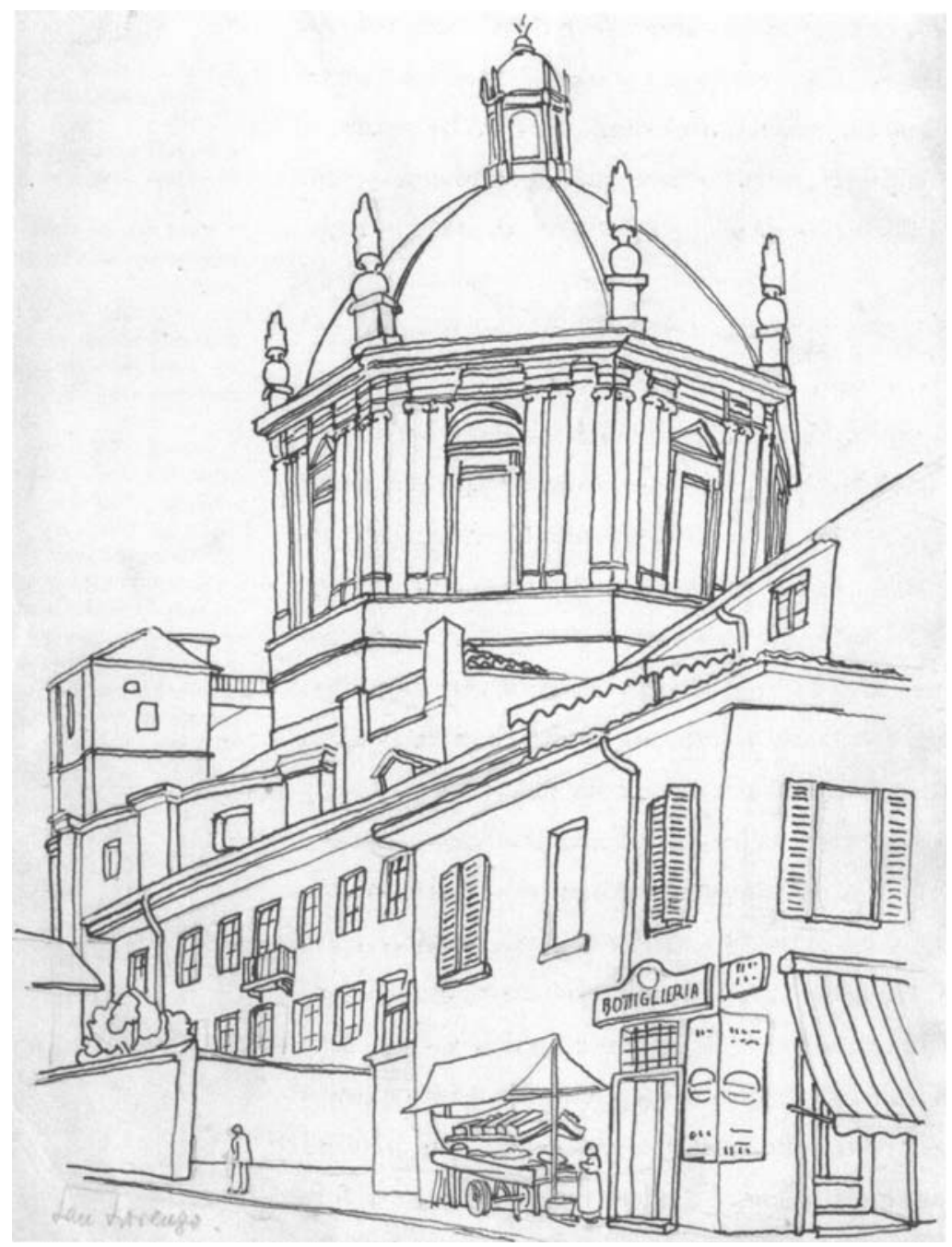

Figura 8. Desenho da catedral de San Lorenzo, Milão. Tinta sobre lápis, 1935

Após cursar um ano de Filosofia em Bucareste, então com dezoito anos, Steinberg parte para uma de suas "inúmeras expatriações" (Hughes, 1978, p.51). Vai a Milão, na Itália, sendo registrado no curso de politécnica da Facoltà di Architettura - Reggio Politecnico de Milão. Deixar sua terra natal aos 19 anos em direção à importante cidade italiana representou um grande salto rumo ao então mundo moderno. "A Romênia de sua infância era reminiscência do antigo Império Otomano e se encontrava culturalmente isolada dos centros de poder da Europa. Além disso, era um país sem um centro de alcance mundial como Viena ou Berlin" (Dalen, 2004, p.3). Já Milão congregava maior movimentação cultural tendo sido, além de tudo, a terra natal do futurismo. De qualquer modo, as primeiras atenções do artista na cidade não se voltam para suas peculiaridades urbanas e artísticas, nem à situação nova de estar na universidade, mas ao impacto da sensação de estar sozinho. "A solidão foi a minha 
Figura 9. Steinberg nos anos 1930, como estudante de arquitetura da Politecnico.

Figura 10. Steinberg em Milão, anos 1930

Figura 11. Perspectiva, 1938. Guache sobre papelão.

Figura 12. Milão - Meu Quarto - Bar del Grillo, 1937. Tinta sobre papel.
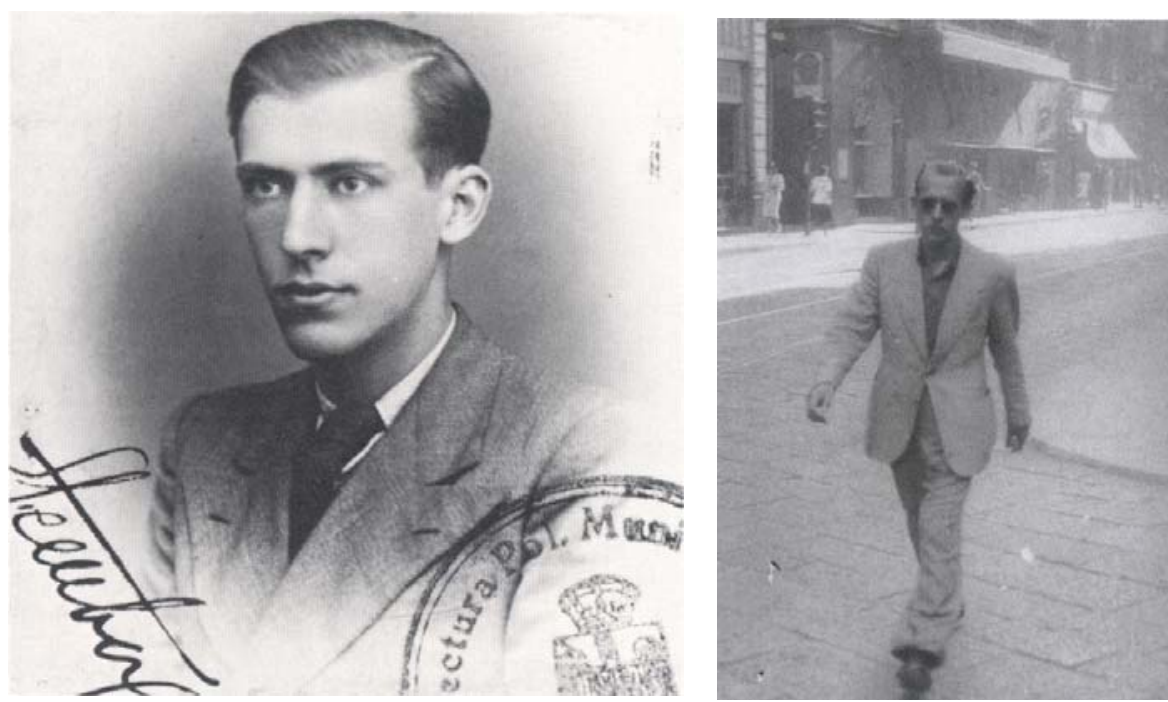

maior experiência neste período: a descoberta e a novidade da solidão, seus prazeres e terrores". (Steinberg, 2002, p.25).

Apesar de tudo, o Steinberg observador não abandona seus hábitos, mantendo-se atento ao ambiente, objetos e costumes locais. Pela primeira vez na condição de estrangeiro, aquela Itália governada por Mussolini apresentava uma infinidade de elementos novos para provocar e instigar o artista: homens de negócio desfilavam por horas com camisetas negras e botas, e Il Duce realizava discursos longos para multidões. Steinberg também adere a um modo de vestir peculiar, com cabelos compridos e bigode espesso, típicos de um estudante da época (Rosenberg, 1978, p.14).

No período em que ficou na Itália, Steinberg primeiro reside na Casa dello Studente. Mais tarde, passa a dividir apartamento com outras pessoas, e finalmente se transfere para um quarto situado acima de um bar, Il Grilo, na via Pascoli n.64. Da convivência com os estudantes, amadurece a amizade com Aldo Buzzi, que perduraria até o final de sua vida (Smith, 2006, p.252).

Na Reggio Politecnico, a Bauhaus exercia forte influência. O diretor Piero Portaluppi da faculdade e o professor de desenho de Steinberg, Tommaso Buzzi, apesar de tradicionalistas, estavam conscientes das transformações da época. Já o instrutor Giò Ponti envolveu-se na organização da Trienal de Milão entre 1933 e 1939. Um dos graduados na geração de Steinberg, Ernesto Rogers, viria a deixar uma herança racionalista. Dentre os grandes nomes da arquitetura, o trabalho de Le Corbusier era o que mais interessava os alunos (Smith, 2006, p.251).

As viagens para diversos lugares e culturas seriam freqüentes ao longo de sua vida. Em 1934, a classe faz viagens de campo para Ferrara e Roma, uma importante e boa recordação. Nesta viagem, Steinberg realiza pela primeira vez desenhos de observação (Steinberg, 2002, p.69). Saul ainda retornaria à Romênia, em nova viagem, para iniciar as férias de verão, vi- 

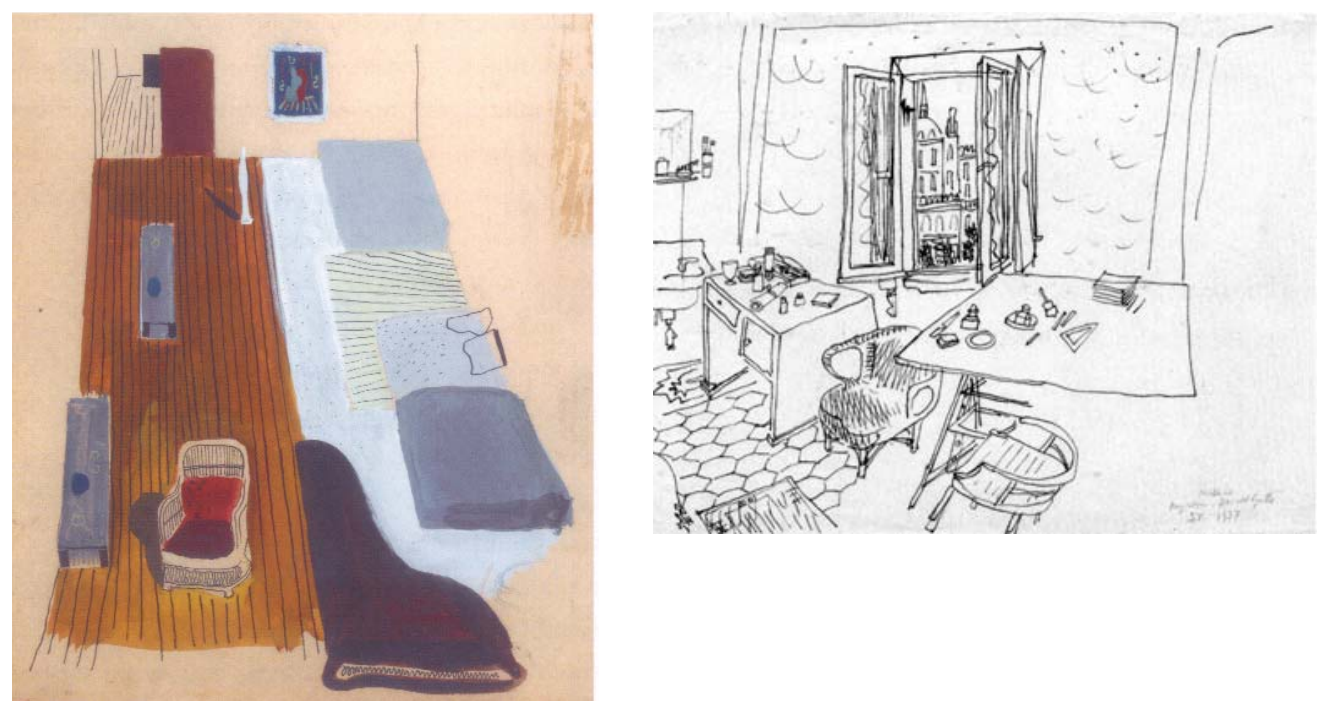

sitando Gênova, Nápoles, Catania, Piraeus, várias ilhas gregas, Istambul e Constanza (Rosenberg, 1978, p.235).

Ao longo destes sete anos de estudo em território italiano (1933-1940), divide seu tempo entre estudar arquitetura e criar cartuns para os periódicos do país (Rosenberg, 1978, p.235). Demora a concluir o curso, pois consome boa parte de seu tempo trabalhando como cartunista (Life, 1951, s.p.).

Estava claro para mim que eu nunca poderia me tornar um arquiteto, devido ao horror de lidar com pessoas que a arquitetura implica. Sabia disto desde o princípio, mas segui em frente. É preciso aprender algumas coisas elementares. Como apontar um lápis. O fato é que a maioria dos estudantes foi para a arquitetura do mesmo modo que eu, considerando-a uma desculpa ou um álibi. (cit. por Hughes, 1978, p.51)

Uma vez formado em arquitetura, Steinberg nunca viria a projetar uma única construção em sua vida (Boxer, 1999).O crítico Harold Rosenberg chegou a refletir sobre a relação entre a formação arquitetônica e os futuros desenhos de Steinberg, "com reflexos nas pontes e estações de trem ornamentadas, nos castelos de contos-de-fada, nos arranha-céus com estilos de época, interiores estilizados, esboços de cidades utópicas, e formações e nuvens ornamentais que fornecem elementos exóticos a seus desenhos" (Rosenberg, 1978, pg.14). No entanto, Steinberg mais tarde recusou a idéia do currículo neo-bauhausiano ter exercido uma profunda influência. "Era uma escola confortável...onde se aprendia mais com os colegas de escola", chega a comentar (Smith, 2006, p.26). Apesar de não conferir grande mérito à qualidade do ensino da faculdade, sua escolha pelo curso de arquitetura na época sugere um razoável interesse pelo assunto. Este presumido envolvimento com os temas da área é sugerido na quantidade de desenhos de edificações e espaços urbanos feitos em sua carreira. Além disso, é possível que a disciplina da arquitetura tenha estimulado o desenvolvimento do traço simples e contínuo de seu desenho. 
Figura 13. Barbe, primeiro cartum de Steinberg. Bertoldo n.31, 27 de outubro de 1936, p.3

Figura 14. Musica da Camera, cartum atribuído a Steinberg. Bertoldo n.34, 6 de novembro de 1936, p.4

Figura 15. Partenze per L'Aldilà. Primeiro cartum com a assinatura "Steinberg" na Bertoldo, n.35, 10 de novembro de 1936, p.2

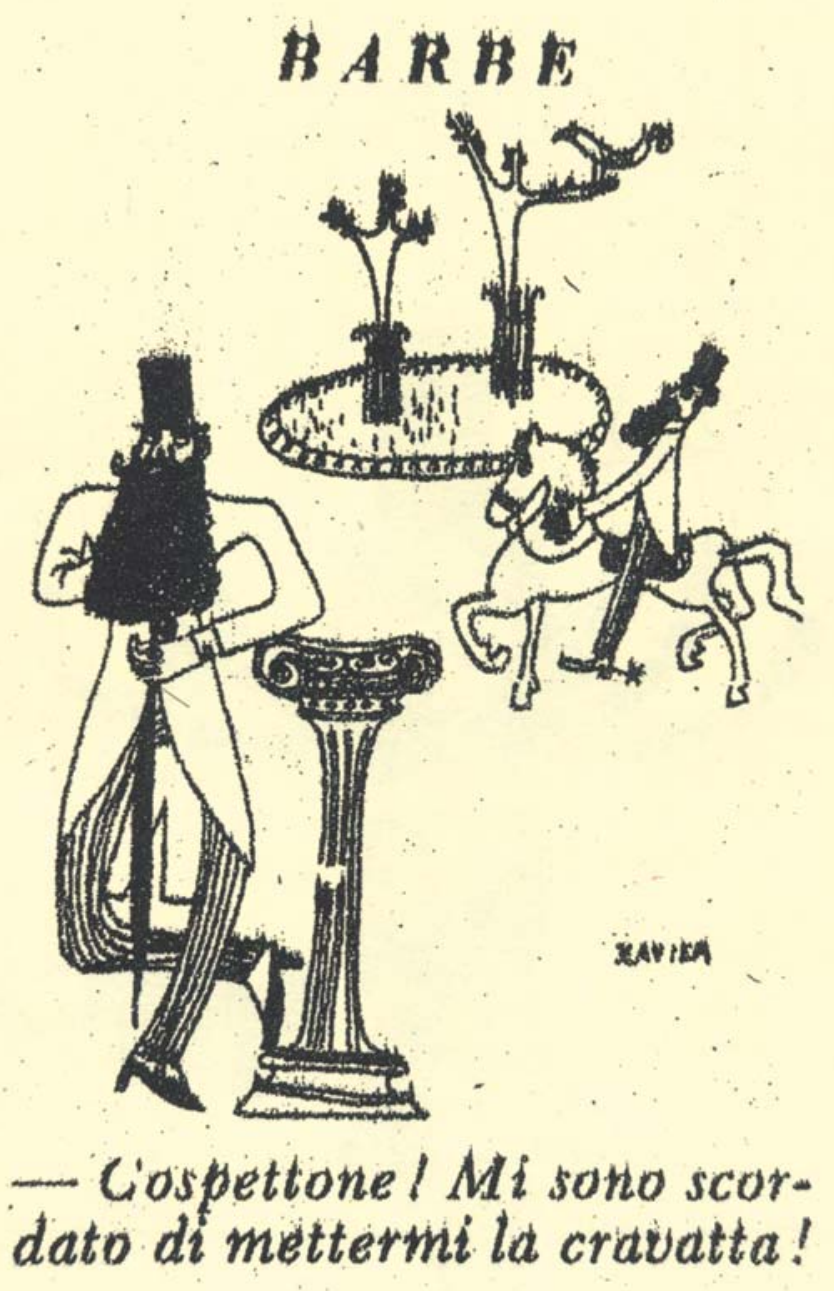

Steinberg Cartunista: os desenhos na Bertoldo e Settebello

"Mais do que os complicados desenhos do professor Danusso, interessavam a Steinberg os desenhos de Mosca, de Marchesi, Manzoni, Barbara e do 'grupo Bertoldo' de Milão, todos estes cartunistas italianos". (Bardi, 1952, s.p). Em 27 de outubro de 1936, justamente, Steinberg começa a publicar na revista italiana Bertoldo, fundada pelo novelista italiano Giovanni Guareschi, publicação quinzenal de humor impressa em Milão. A Bertoldo já se encontrava na edição n. 31. Estava dado o primeiro passo em sua carreira de desenhista. "Tive sucesso imediatamente; publiquei meu primeiro desenho e a revista me pagou por ele"(Hughes, 1978, p.51). Assinava "Xavier", uma vez que "um nome que se inicia com "X" é um nome absurdo", disse em entrevista (Guareschi; Guareschi, 1994, p.336). Seu protagonista era um vitoriano de cartola em situação formal que, com sua barba escondendo o torso, exclamava: "Oh meu Deus! Esqueci de colocar uma gravata!" (Smith, 2006, p.26). Na edição n.34, em novembro, seu cartum Música da Camera aparece sem assinatura. E já no número 

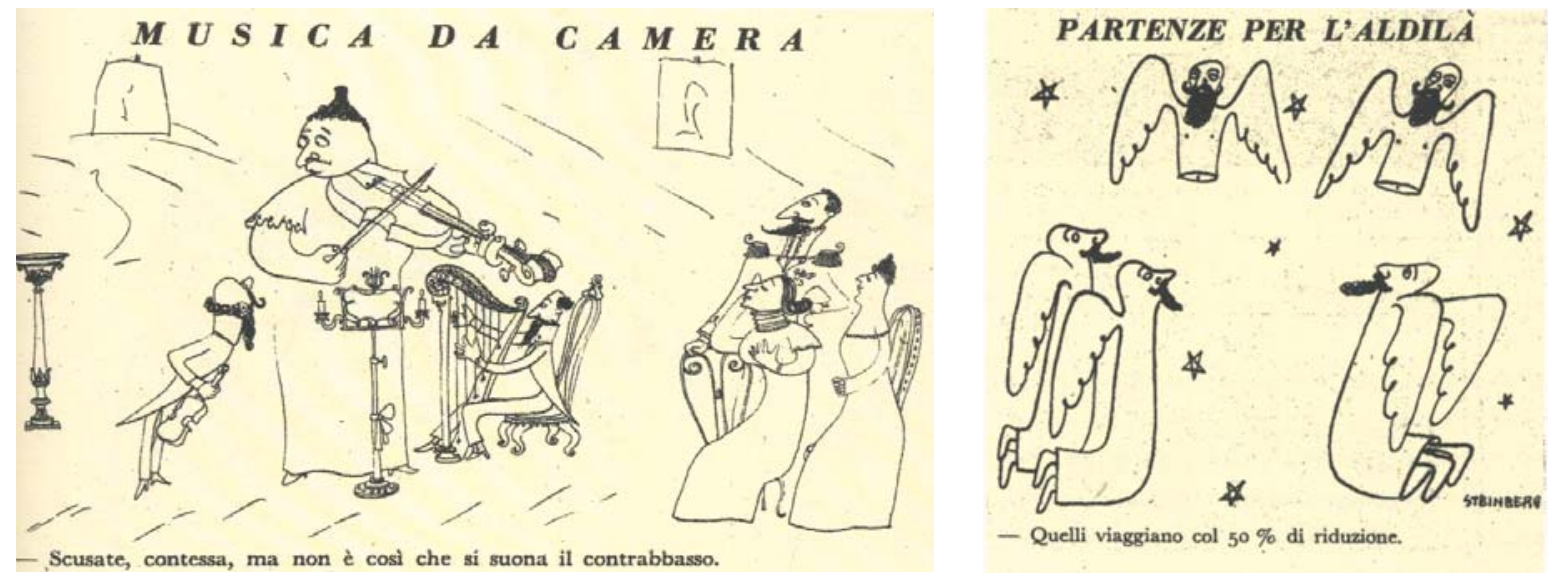

seguinte, a piada Partenze per L'Aldilà ostenta a primeira assinatura com o nome "Steinberg". Saul passaria a publicar de modo permanente na Bertoldo durante dois anos, criando mais de duzentos desenhos, até março de 1938. Depois, devido à perseguição racial, não poderá mais ostentar as ilustrações com sua assinatura. Mas mantém o contato com a redação. A partir de 1941, a Bertoldo passará a publicar cartuns anônimos - cerca de cinquenta - quase seguramente a ele atribuídos, "pelo estilo inconfundível e a presença de elementos expressivos característicos de sua precedente produção" (Mangini; Pallottino, 1994, p.94).

Os cartuns de Steinberg já nascem com traço fino. O primeiro publicado na Bertoldo, Barbe, é feito de um desenho sem sombras, hachuras e os recursos tradicionais usados para conferir volumetria e ressaltar a perspectiva. São frequentes, no entanto, os títulos e legendas, evidenciando que ainda estava por se desenrolar o percurso rumo ao desenho mudo, "gráfico" e autônomo.

Sempre tive uma tendência ao desenho, apesar de não ter muito talento. Descobri minha habilidade em Milão, quando meu primeiro desenho foi publicado. Tive que fazê-lo em dez minutos, mas quando ele foi estampado na revista fiquei olhando para ele por horas, hipnotizado. Comecei a fazer um demorado passeio ao longo de cada aspecto da linha. Na verdade não era o desenho, mas a mim mesmo que eu estava admirando (cit. por Mangini; Pallottino, 1994, p.93).

Enviando seus cartuns para a revista, Steinberg podia se permitir a um razoável facsímile da vida de cafés e boulevares sobre a qual havia lido quando criança em Anatole France: comprando novas gravatas na Galleria, passando o tempo no Ristorante Biffi. "Tive o raro, maravilhoso prazer de receber dinheiro de algo que gostava de fazer e então gastá-lo tão logo o conseguia. Enquanto almoçava, sabia que era meu gato - quero dizer, o desenho de meu gato - que estava consumindo; seguidos da árvore, da lua e assim por diante" (Hughes, 1978, p.51). Mesmo morando tantos anos na Itália, considerava ter conhecido pouco do país e mesmo de Milão, já que seus interesses não eram prioritariamente culturais 
no período: "Meu principal interesse neste momento eram as garotas. O que eu estava procurando era o amor, me encontrar através do amor. Estava sempre fora, nunca ficava em casa. Não conseguia estudar, me concentrar ou ler" (Steinberg, 2002, p.25).

Seus primeiros trabalhos parecem ter sido mal recebidos pelos leitores. "Era algo novo, e eles não gostavam de coisas novas", conta o artista (Time, 1943, p.79). De qualquer modo, "o grupo de Milão percebeu no jovem e tímido estudante do Politécnico um gênio que estava surgindo", salienta Bardi em texto sobre o artista:

Steinberg estava trabalhando no Politécnico de Milão quando percebeu possuir um espírito humorístico que os diretores do jornal milanês Bertoldo logo compreenderam tratar-se de uma mina. E era de fato uma mina que não se esgotava. (Bardi, 1952, s.p)

Steinberg publicou uma quantidade enorme de desenhos entre 1936 e 1940. Eram habitualmente três prazos de entrega e pagamentos por semana. À medida que desenvolveu seu trabalho, angariou uma quantidade crescente de fãs. Havia a condição favorável do estrangeiro que nada tem a perder. E o universo milanês, com seus bares, escritores esforçados em alimentar o artista com piadas, imitadores em formação, promoveu condições propícias ao desenvolvimento da carreira do cartunista de origem romena. Seu sucesso chamou a atenção de Cesare Civita, da editora milanesa Mondadori. Cesare e seu irmão Victor iriam mais tarde desempenhar um papel importante na carreira de Steinberg (Smith, 2006, p.27).

Figura 16. Steinberg, W de Primavera, 1937 Bertoldo n.20, p.6

Figura 17. Giorgio de Chirico, Cassandra (Le Vaticinateur), 1915

Figura 18. De Chirico, La Cultura Italiana.

Figura 19. Gianfilippo Uselini, // Gelataio, 1957

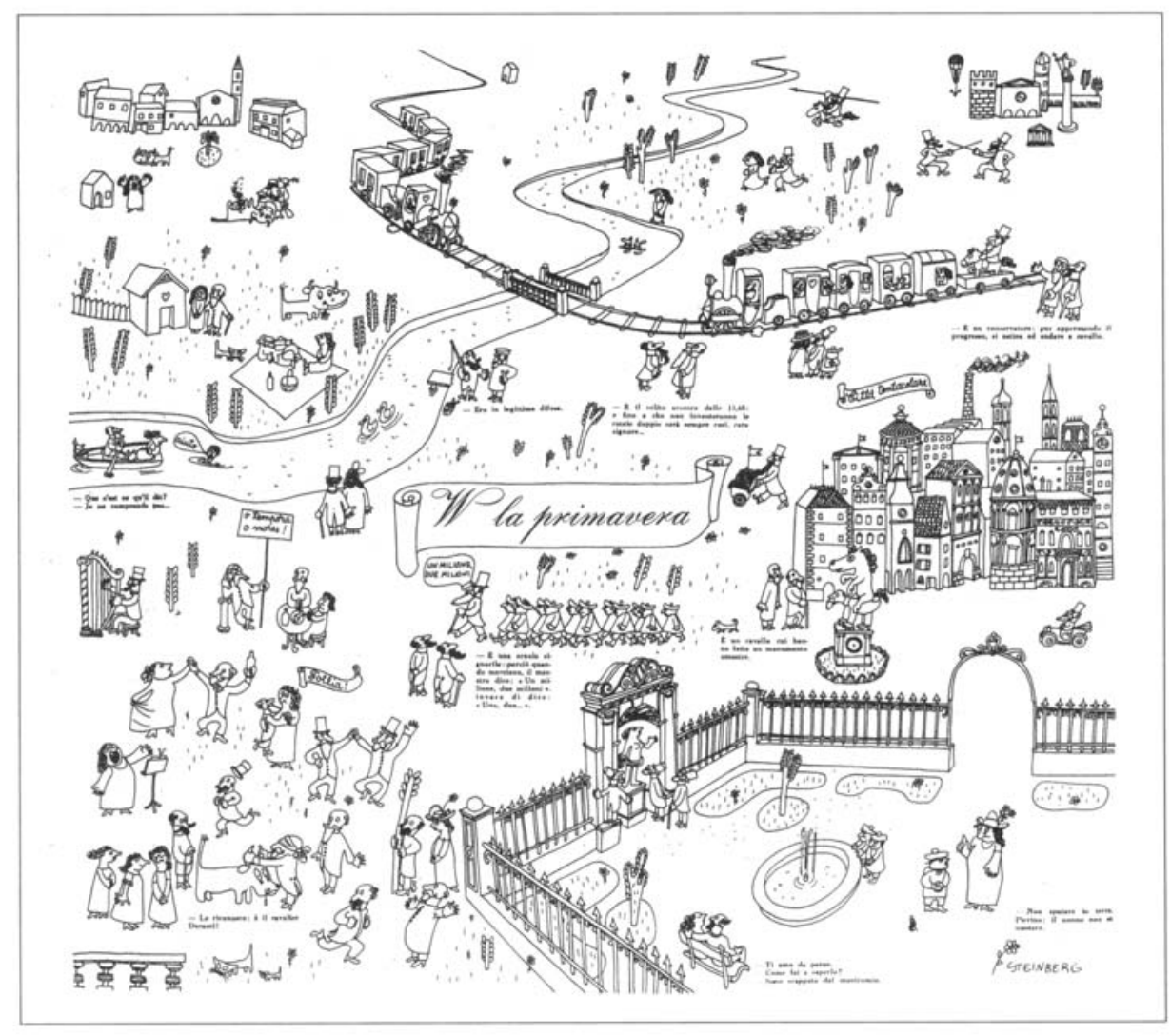


Além da Bertoldo, Steinberg passa a colaborar, a partir de 1938, para a publicação rival Settebello. Apesar da produção deste período não ter, praticamente, chegado ao conhecimento dos fãs fora da Itália, seus trabalhos de página inteira publicados na Settebello, denominados Il Milione, se tornaram uma grande atração e "não representam um capítulo menor em sua carreira" (Smith, 2006, p.27). As páginas da Bertoldo e Settebelo, densas com prosas humorísticas, versos e piadas curtas, eram enriquecidas por cartuns de uma imagem e tiras humorísticas. Muitas edições também incluíam desenhos de aproximadamente uma página inteira, como a Panorami de Steinberg, cada uma com uma série de falas e pequenas piadas (Smith, 2006, p.82).

Nos cartuns de Steinberg desta fase, é comum o uso de uma perspectiva que se caracteriza por linhas do horizonte situadas ao alto, com o espaço visto de cima e elementos em escala semelhante espalhados pela imagem. O mesmo uso de perspectiva fica evidente em um de seus desenhos de prática arquitetônica, feito no final dos anos 1930, que mostra a decoração de um espaço interior. Como observa Joel Smith, "para um cartunista de um único quadro, que trabalha com um plano de piso limitado, um horizonte elevado significa uma área extra para seus personagens". Mesmo quando o espaço para os desenhos era grande, Steinberg mantinha a aplicação do recurso, como nas imagens de cinco colunas de largura Panorami di Steinberg, publicadas na Bertoldo. Uma vez que este recurso era muito presente na arte produzida na Itália dos anos 1930, é possível cogitar um tributo ao artista Georgio de Chirico, estrela internacional italiana da época (Smith, 2006, p.27). De Chirico viveu e tra-
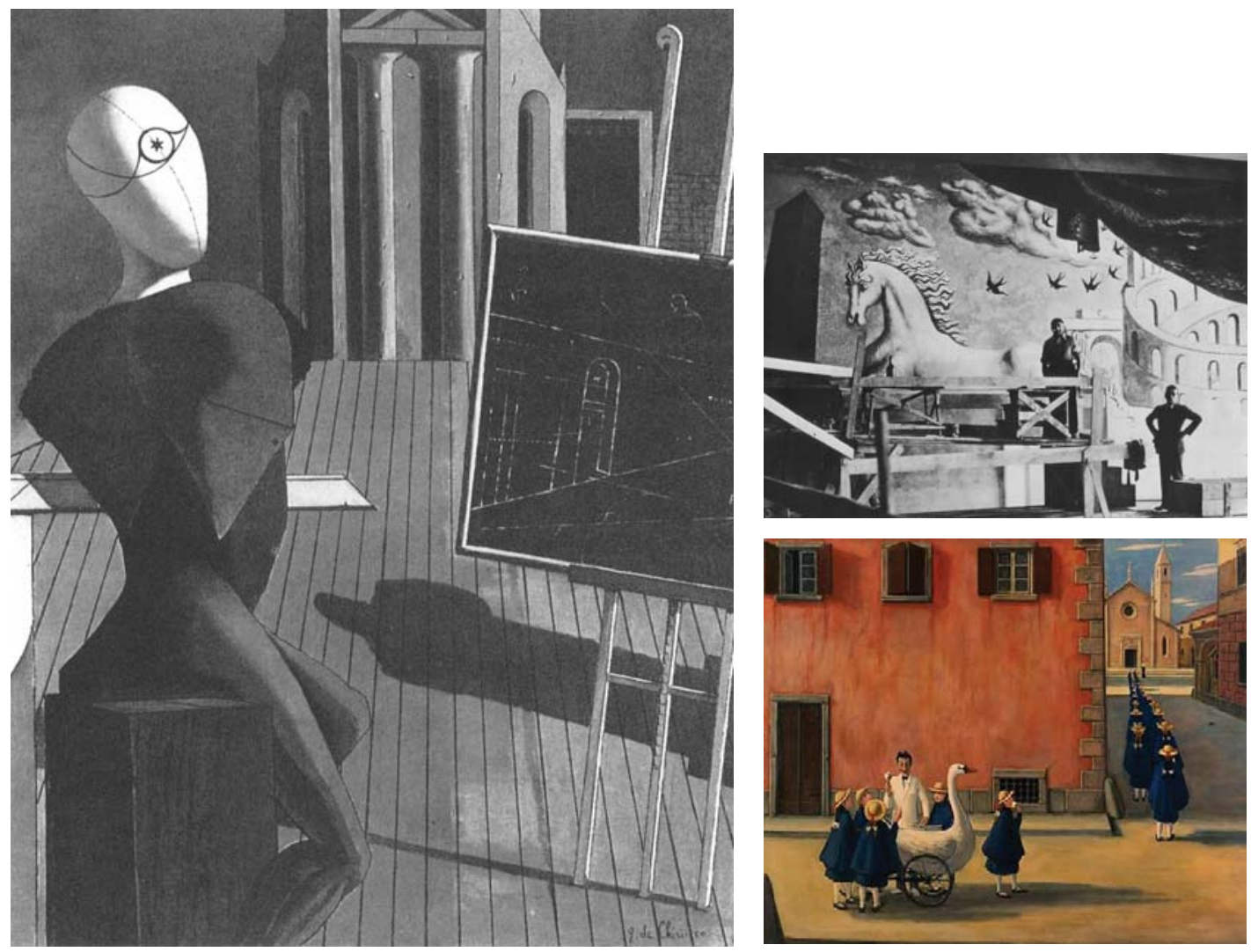

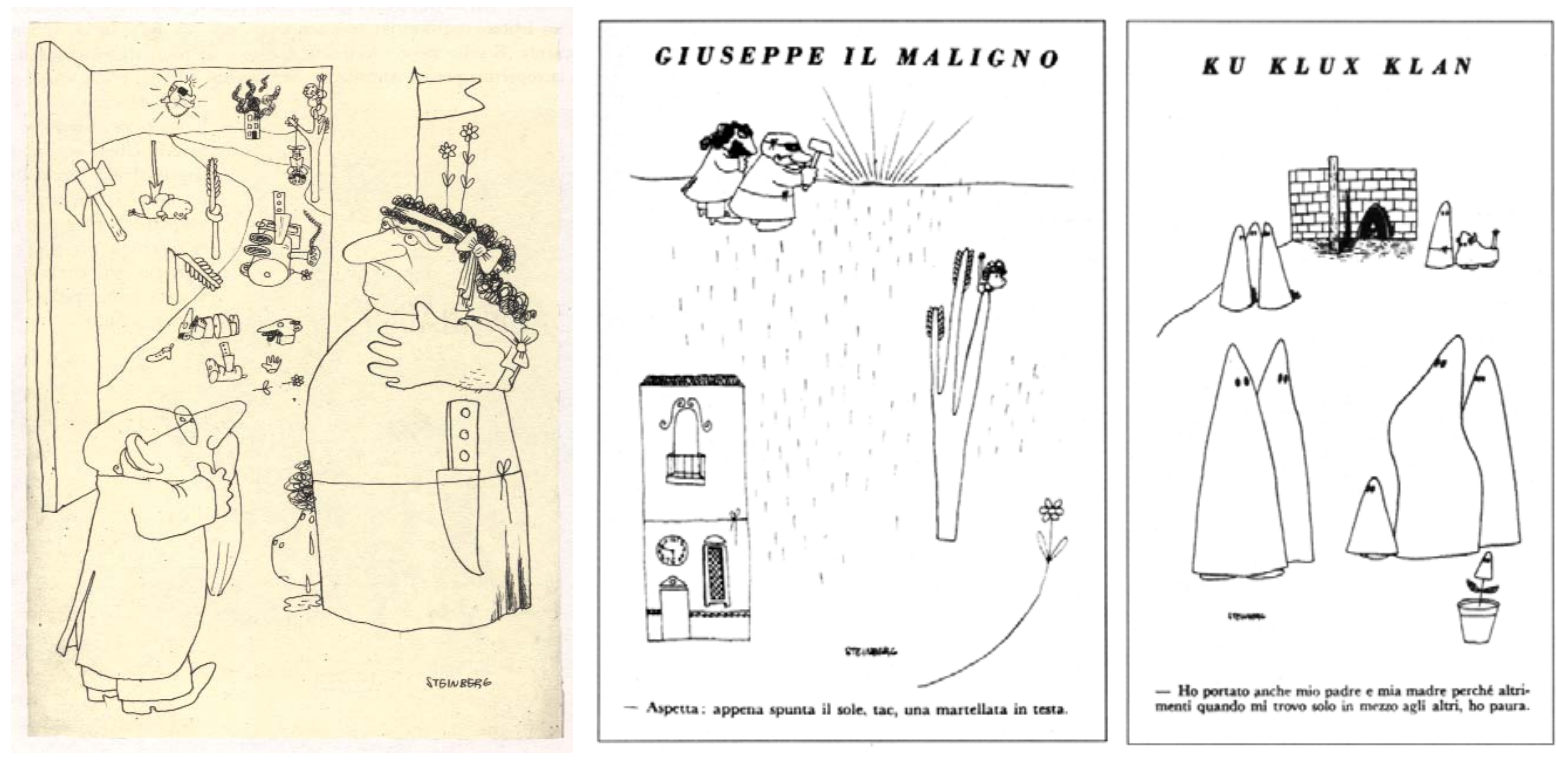

balhou em Milão de 1933 a 1934, e Steinberg provavelmente viu seu mural produzido no período para a Trienal de Milão, chamado La Cultura Italiana, no Palazzo dell'Arte. (Smith, 2006, p.236).

Além de De Chirico, outra possível influência dentre os pintores italianos do período seria Gianfilippo Usellini, um favorito da crítica nos anos 30, cujo realismo mágico e seu universo Belle Époque - uma mistura de De Chirico, Magritte, Ernst e pintura naive - encontra ecos nos trabalhos em guache desta fase inicial de Steinberg (Smith, 2006, p.236). Seria interessante imaginar até que ponto o trabalho destes dois italianos não foi uma considerável referência para o elemento surreal presente nos cartuns de Steinberg publicados na Bertoldo. O estilo de Steinberg neste início de carreira apresenta personagens, em muitos casos, mais rechonchudos e volumétricos do que em sua fase posterior. A linha é mais sinuosa, lenta. Seu estilo - aquele que não traz a intenção da paródia - alterna muitas soluções, como diferentes desenhos para mãos, pés e olhos. Estes são, em várias figuras, oblíquos, grandes; em outros, de grande dimensão, circulares e ovais, mas sem pupilas - recurso que teria vida mais longa. A expressão carregada de alguns personagens não conferia aos cartuns o tom leve, sutil e atemporal de seus futuros trabalhos. De qualquer modo, estas características estavam em desenvolvimento, na alternância de soluções.

Steinberg desenvolve desde cedo em sua carreira um trabalho ao qual podemos atribuir um papel político, de crítica e opinião. A percepção generalizada de certa trivilialidade, talvez de caráter inofensivo, conferia aos cartunistas de jornal italianos uma espécie de licensa única para criticar o regime fascista, sob os recursos da metáfora, do absurdo e da releitura histórica. Merece destaque, neste contexto, os cartuns de Zia Elena (Tia Elena). Levando em consideração as recordações de Steinberg, suas posições políticas e a feição carrancuda da personagem, é inevitável cogitar que se trata de um ser híbrido que mistura aspectos de sua mãe Rosa e uma caricatura velada de Mussolini (Smith, 2006, p27). 

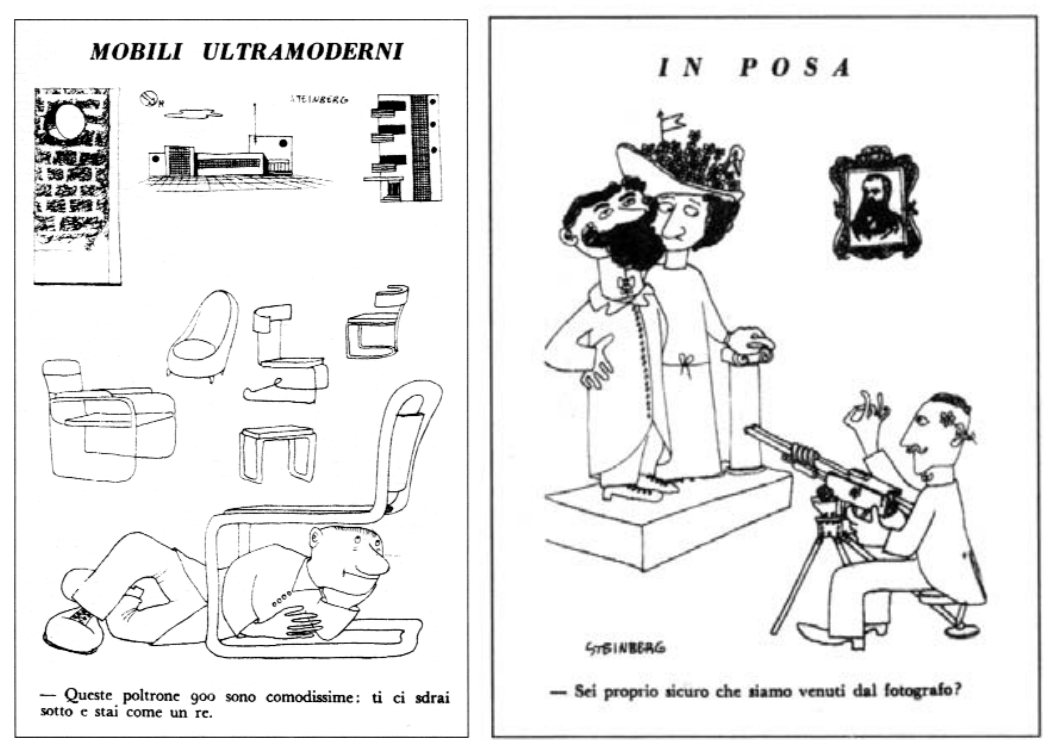

Figura 20. Steinberg, Zia Elena, Bertoldo, n.6, 21 de janeiro de 1938, p.2

Figura 21. Steinberg, Giuseppe il maligno, Bertoldo, n.1, 1938, p. 1

Figura 22. Steinberg, Ku Klux Klan, Bertoldo, n.3, 1938, p.6

Figura 23. Steinberg, Mobili ultramoderni, Bertoldo, n.92, 1937, p.4

Figura 24. Steinberg, In posa, Bertoldo, n.32, 1937, p.5

Considerável parcela das idéias de seus cartuns para a Bertoldo eram elaboradas pelos escritores da revista (Smith, 2006, p.82). Tratava-se de uma prática comum não apenas na Itália: a americana The New Yorker empreendia o mesmo procedimento de criação. É possível que tal método tenha representado um entrave ao desenvolvimento de soluções de humor mudo, gráficas e sintéticas. Eram piadas resolvidas a partir da compreensão da linguagem escrita; sendo assim, a tendência era o desenho acompanhar a frase ou ilustrar uma concepção literal. Não há dúvidas de que esta divisão de trabalho, mesmo com suas limitações, permite uma produção cartunística de qualidade. No entanto, para artistas interessados em refletir sobre o desenho, como Steinberg, tal mecanismo provavelmente era um complicador.

De qualquer modo, mesmo nos desenhos, já são perceptíveis certas manifestações de humor intelectual. "O processo de desnaturalização de personagens, coisas e situações, atravéz do uso de elementos reais reduzidos a clichês, dará vida a um mundo paralelo, irreal mas coerente a si mesmo" (Mangini; Pallottino, 1994, p.96). Vários de seus cartuns adquirem um ar fantasioso e surrealista, no absurdo de situações, na construção do desenho, na escala dos elementos e personagens, e na inserção de figuras inusitadas - como, por exemplo, um leãozinho no topo de uma planta decorativa, sem relação direta com o tema do cartum; ou uma planta vestida de Ku Klux Klan em analogia aos personagens da piada. Vários trabalhos do período sugerem uma precoce abordagem de temas desenvolvidos ao longo da carreira, visível no modo como trata adornos e elementos de estilo, ou como fala dos assuntos da arte. As colagens feitas na época, com a inserção de pequenas fotos de arquiteturas, animais e figurinos nos desenhos a traço, também prenunciam seus futuros trabalhos.

Saul Steinberg, posteriormente, demonstrou desconforto com sua produção na Itália. Quando editores italianos propuseram a publicação de seu volumoso trabalho para a Bertoldo em uma antologia, ele vetou a idéia. Ficou evidente, deste modo, a sensação de que seu período de treinamento havia fracassado, em retrospecto, em antecipar sua futura car- 
reira (Smith, 2006, p.82). É possível, também, que o artista tenha procurado se preservar, evitando expor a um público maior um trabalho de começo de carreira com influências perceptíveis. Seu interesse em não estimular especulações sobre referências substanciais transparece em algumas de suas entrevistas, como quando fala de Paul Klee.

\section{A BERTOLdo E OS CARTUNistas ITALiAnOs: DESENHOS SIMPles DE TRAÇO FINO}

O primeiro número da revista Bertoldo foi lançado em 1936. Tratava-se de uma publicação quinzenal, que saía às terças e sextas. Nasce da iniciativa de Cesare Zavattini, primeiro idealizador e organizador do jornal, e do editor Angelo Rizzoli. Apesar do envolvimento inicial, ambos se desentendem antes mesmo de encontrarem um nome para a publicação. Com a

saída de Zavattini, os jovens Mosca e Metz assumem a direção do veículo. Com a definição do título Bertoldo, Mario Bazzi desenha o logotipo do jornal. Para resolver o problema de indisciplina dos novos e criativos colaboradores, Angelo Rizzoli oferece ao cartunista Giovannino Guareschi, voz ativa contra o regime político de então e futuro criador dos famosos personagens Peppone e don Camillo, o cargo de redator-chefe. Após um primeiro número de prova, datado de 1 de julho de 1936, naquele mesmo mês é lançada a primeira edição oficial, ao preço de 30 centesimi. A Bertoldo viria a fechar em setembro de 1943, tendo sido quinzenal até seu quarto ano, e semanal até o último número (Mangini; Pallottino, 1994, p.45). O fim da revista foi decorrente de atritos com o regime Fascista, dentre eles os problemas que Mosca teve com censores em virtude da peça La Sommossa (A Insurreição), uma sátira aberta às posturas e discursos de Mussolini.

De modo geral, a publicação tinha $60 \%$ de seu espaço destinado aos trabalhos gráficos, com cartuns e ilustrações de vários gêneros. O restante era voltado para a parte escrita, com romances, piadas. Com formato de 57 x $40 \mathrm{~cm}$, o aspecto da primeira página só viria a ser alterado no quarto ano, em virtude da edição humorística-literária, com a folha inteira destinada aos cartuns, em número variável de oito a doze trabalhos (Mangini; Pallottino, 1994, p.45).

A abordagem gráfica de vários dos cartunistas da Bertoldo se caracterizava pelo uso do traço fino, simples, sem volume. O humor editorial de então passava por grandes transformações na Itália, com o surgimento de uma vis comica, ou vis grafica, que adquiria maturidade com características totalmente novas ao espírito italiano e à intelectualidade de então. Em tempos de grande turbulência política e social, às vésperas de uma catástrofe e imediatamente após a proclamação do Império, "os retóricos e sentimentais italianos subtamente se tornaram secos, astutos e sutis" (Sinisgalli, 1953, p.454). Surge uma nova poesia, denominada "poesia hermética", despida de eloquência ou heroísmo, "nascida de um desespero real e efervescente amor pela vida". Correlacionando as variadas manifestações culturais, Sinisgalli acrescenta: 


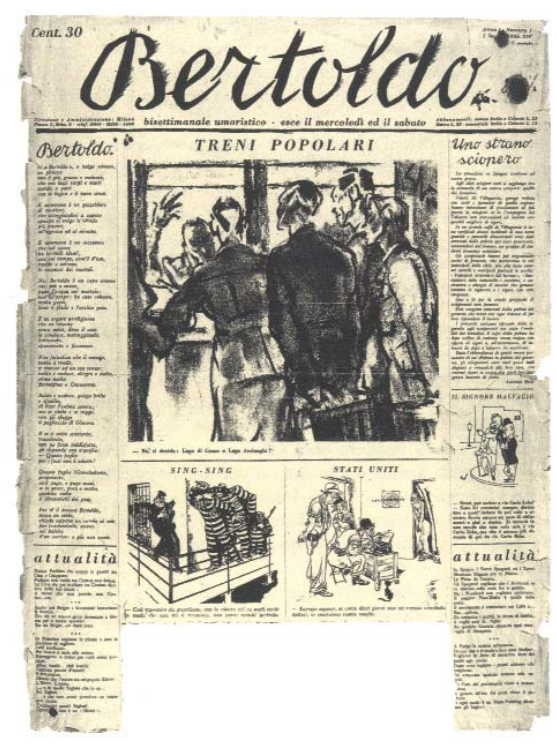

Figura 25. Bertoldo n.1 (prova), 1 de julho de 1936, p.1

Figura 26. Bertoldo n.1, 14 de julho de 1936, p.1

Figura 27. Milão, 1936. Foto da redação da Bertoldo. Da esquerda para a direita: Molino, Ortensio, Falconi, Marotta, Frattini, Marchesi, Metz, Guareschi, Mosca, Manzoni, Rizzoli, Bazzi.
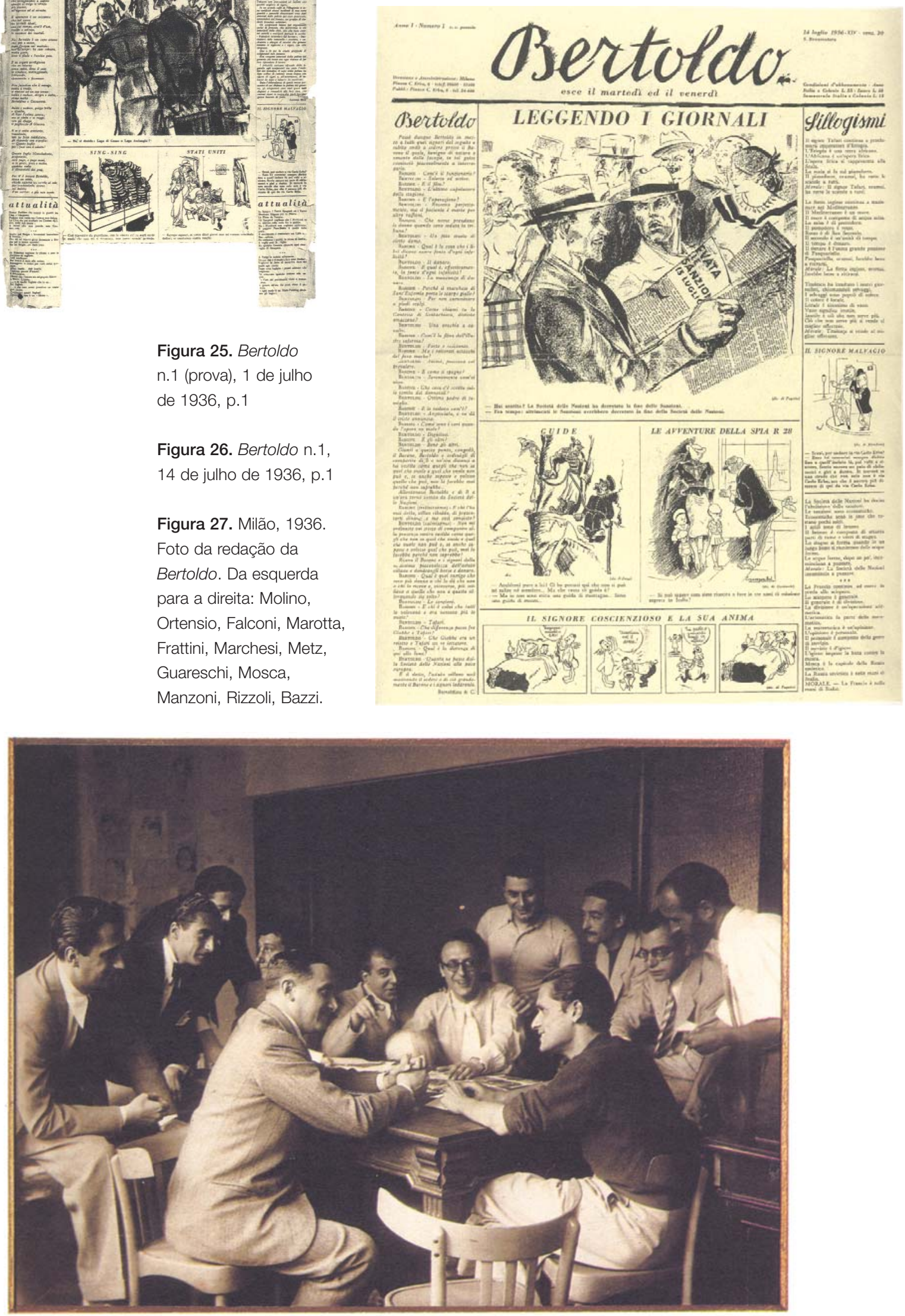
Paralelamente, se desenvolve um engenhoso e metafísico modo de pensamento, representado por curiosos mitos dos quadrinhos, e por escritores sem grandes pretensões e aspirações satíricas: Zavattini e Campanile, com seus muitos discípulos; Mosca, Mondaini e Manzoni. Uma grande vegetação de signos brotaram ao seu redor (...) Então apareceu uma safra de pequenas figuras, velhos infantis e crianças adultas (Sinisgalli, 1953, p.455).

O espírito gráfico destes novos desenhos tinha pouquíssimas relações àquele de Hogarth ou Damier. Sinisgalli observa que "toda esta nova geração parecia ser composta por artistas improvisados, diletantes sem treinamento e conhecimento anatômico, artistas apenas por empenho. (...) Sua verve comum, seu frenesi, era todo voltado para as cenas que inventavam, e não para a qualidade de sua linha" (Sinisgalli, 1953, p.455). É com o despreendimento destes e de outros cartunistas que novos parâmetros estéticos surgem nas publicações das primeiras décadas do século.

Steinberg não foi o fundador do desenho de linha fina, nem no contexto geral do cartum, e nem na Bertoldo. Mas participou, no campo da produção editorial, de seu período de desenvolvimento inicial. $\mathrm{O}$ desenho, em qualquer área da criação, vinha passando por um processo de simplificação e depuração significativo desde o final do século XIX. Mas neste início de carreira, as influências mais próximas e diretas são provenientes da própria produção cartunística italiana. Para Joel Smith, a técnica solta e brincalhona de Steinberg foi construída no exemplo de Giovanni Mosca, um dos importantes colaboradores da Bertoldo, cujos personagens habitam um "bruto universo cenográfico" (Smith, 2006, p. 82). A linha de Steinberg, no entanto, assume muitas vezes grande elegância e delicadeza. Se em um primeiro olhar o estilo de Mosca apresenta significativas diferenças com o de Steinberg, ape-

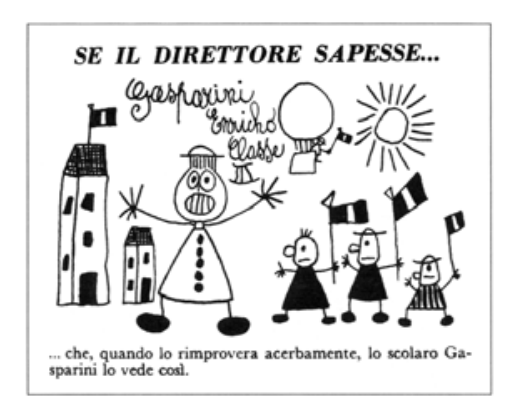

Figura 28. Mosca, Se il direttore sapesse..., Bertoldo, n.83, 1936, p.2

Figura 29. Mosca, Cav. Ambrogio Vitali, Bertoldo, 1937, n.17, p.1

Figura 30. Mosca, Disperazione, Bertoldo, n.13, 1937, p.5

Figura 31. Mosca, Non dire 4 se non 10 hai nel sacco, Bertoldo, n.16, p.4

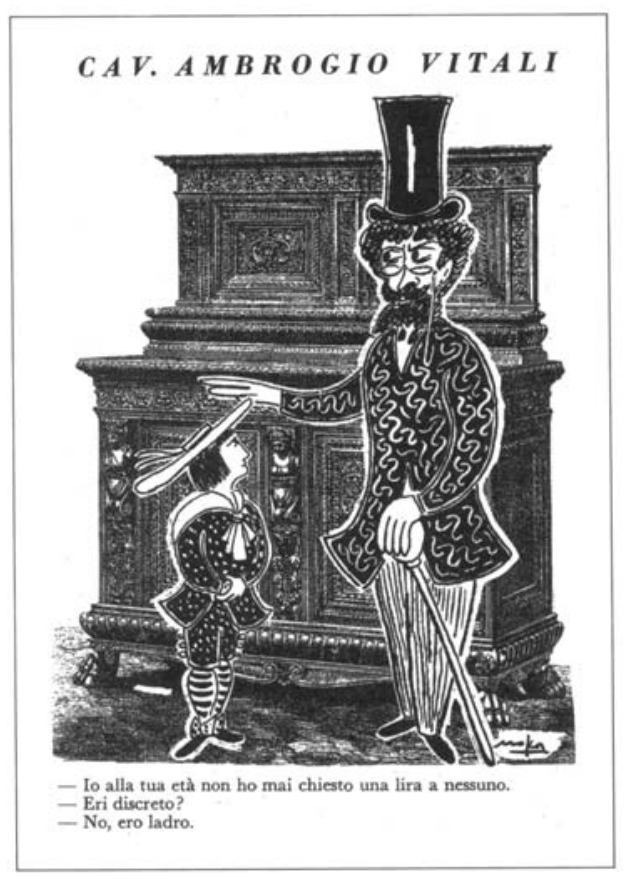


sar do desenho a traço, Mangini e Pallottino apontam que "dois elementos fundamentais caracterizam o desenho de Mosca e de outros bertoldianos desta mesma escola, como Steinberg e Manzoni: uma disposição à hiperdecoração e ao abandono de qualquer critério de verossimilhança, evidente na total anarquia dimensional de espaço e figura, que dá origem a uma atmosfera suspensa, surreal" (Mangini; Pallottino, 1994, p.92). Apesar destes pontos em comum, fazem a ressalva de que "não há influências particulares do grupo bertoldiano no estilo de Steinberg, apesar de existir uma indubitável afinidade com os desenhistas do novo filão "surreal", sobretudo em certas soluções de Mosca no uso do espaço e na decoração, e com o desenho-colagem de Guareschi" (Mangini; Pallottino, 1994, p.101). Seja como influenciado ou influenciador, é claramente perceptível o importante papel de Steinberg na nova linha de cartuns italianos, que em seu conjunto tinham considerável relação com seu trabalho.

Uma abordagem comum a vários dos cartunistas da Bertoldo, que revela a troca de influências entre os membros do grupo no período, é a Panorama. Trata-se de uma página com vários cartuns, todos inseridos em uma mesma paisagem e espalhados de acordo com as situações e o cenário, sem separações tradicionais entre eles. A idéia já havia sido explorada por Mosca na publicação Marc'Aurelio. Em 1937, Steinberg estréia o recurso na Bertoldo, com W de Primavera. Além de Mosca, Guareschi e Manzoni também viriam a fazer seus panorami, em contextos variados, como em grandes construções e magazzini (Mangini; Pallottino, 1994, p.112).

Uma importante referência no período é Guareschi. O estilo gráfico do cartunista e redator-chefe da Bertoldo é particularmente variável, mas está quase sempre a serviço do caráter inovador dos cartuns de linguagem moderna italianos. Aberto às experimentações, insere desenho em fotografias, cria colagens, e elabora fotomontagens com o uso de escul-
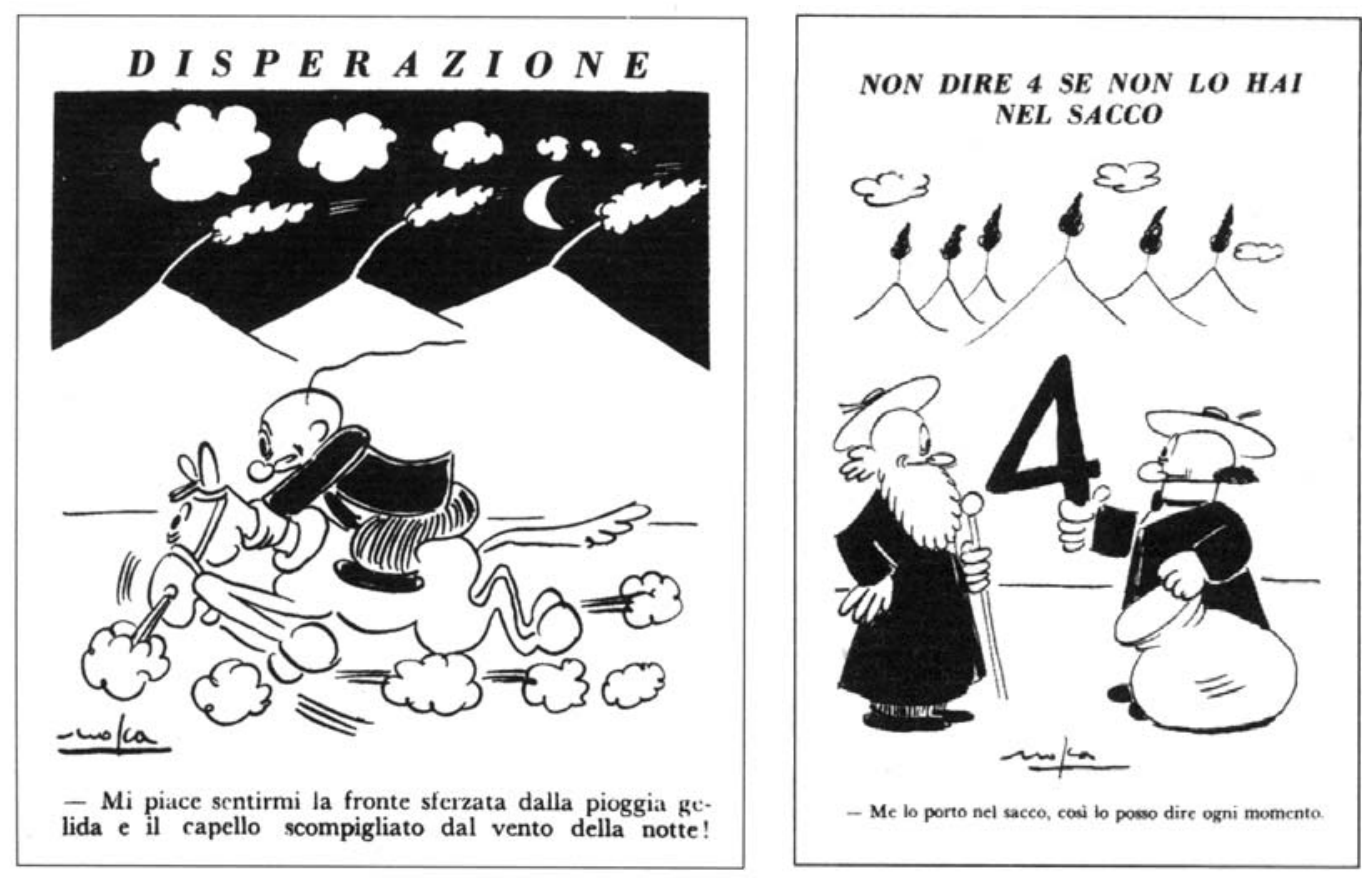


\section{GR A I I I II A G A ZZI I I}
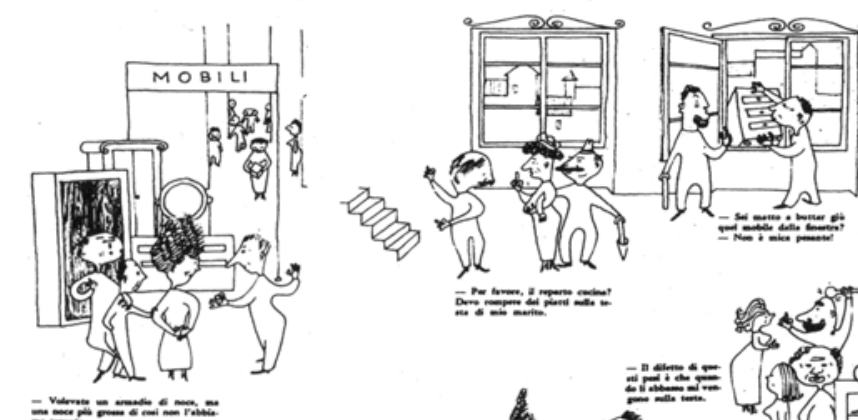

$\Rightarrow=$

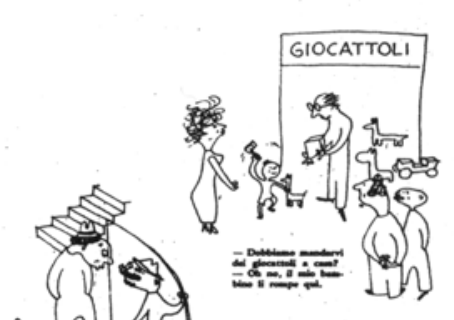

a

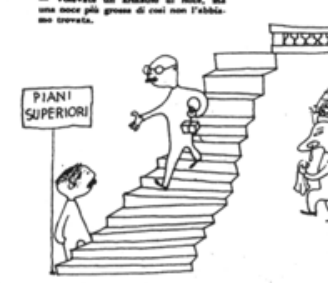

\section{는}

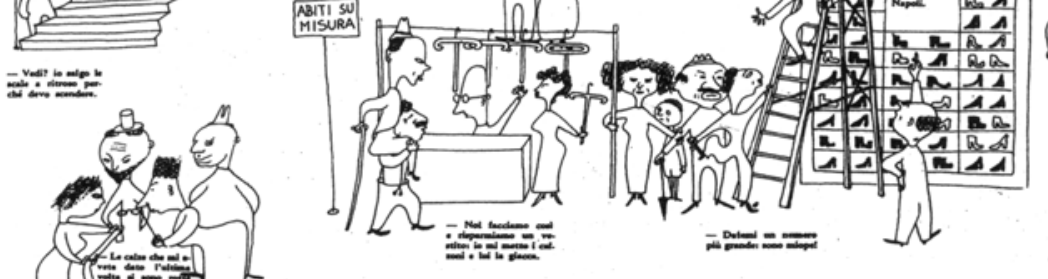

(1)

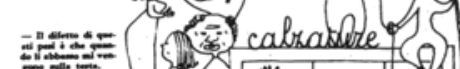

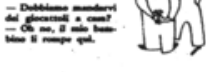

\section{(}
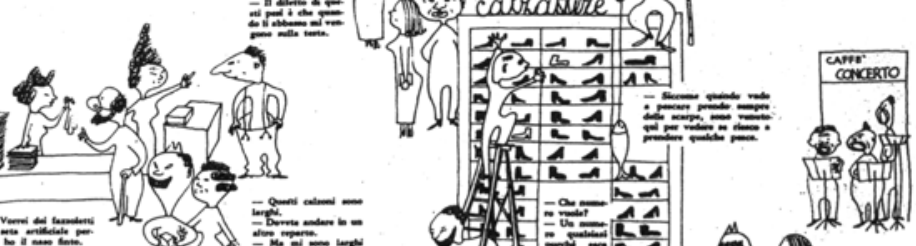

A
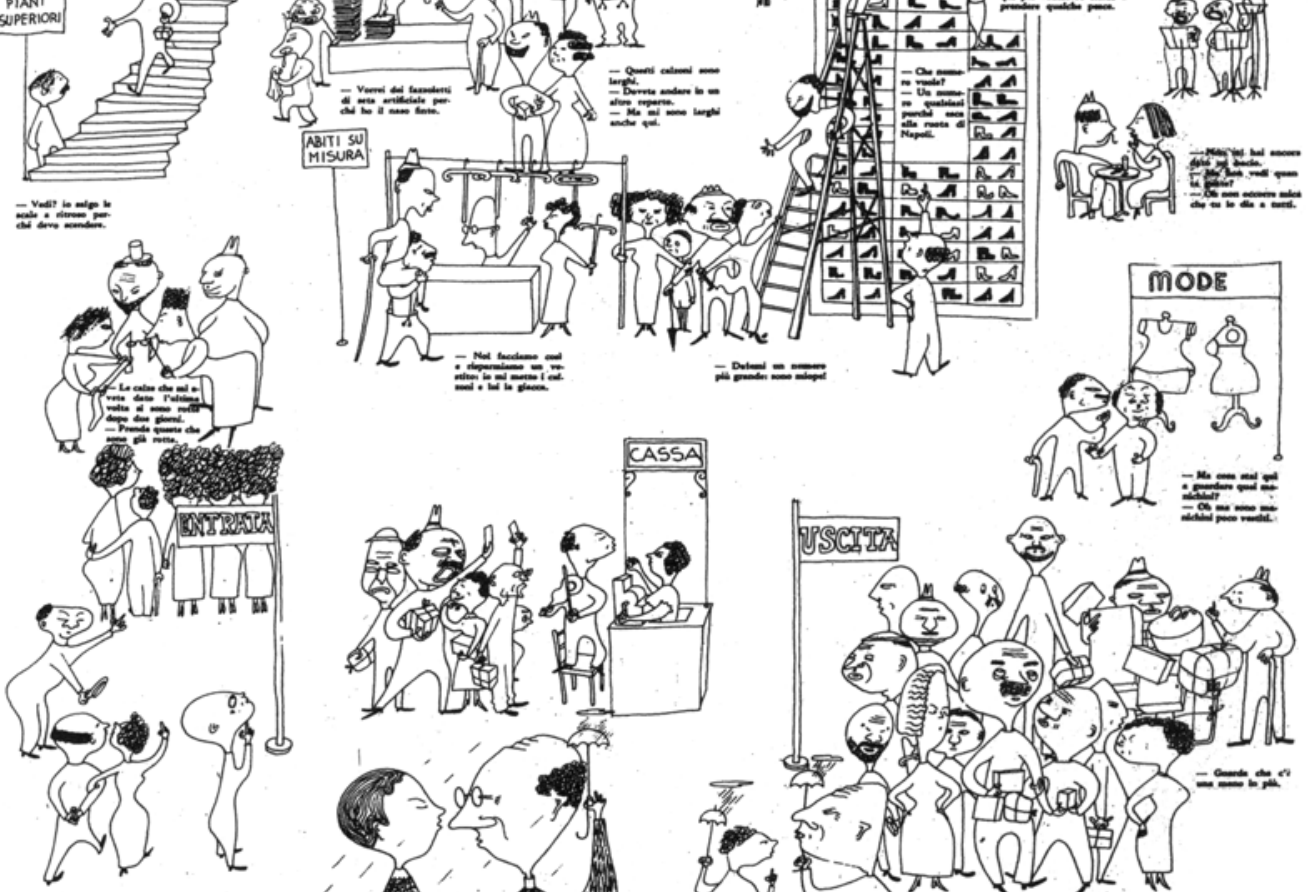

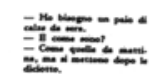

制得证
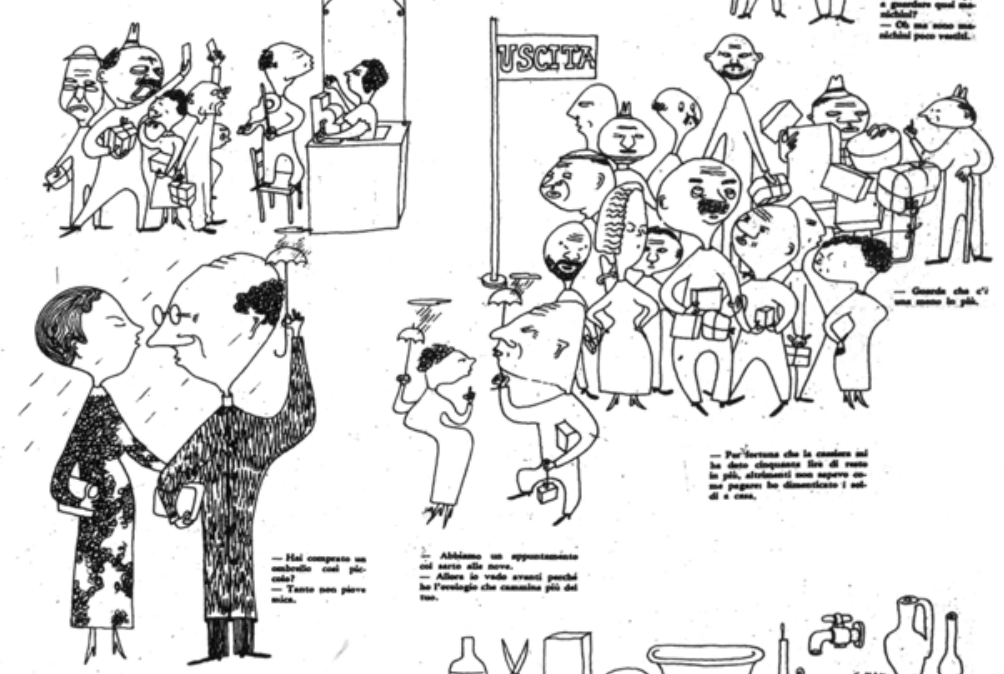
Qी

经理

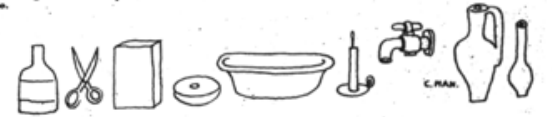

Figura 32. Manzoni, Grandi

magazini, Bertoldo, n.38,

1938, p.5

Figura 33. Guareschi, 800

anni dopo, Bertoldo, n.85, p.6

Figura 34. Steinberg,

Panorami di Steinberg,

Bertoldo, n.2, 1938, p.6 

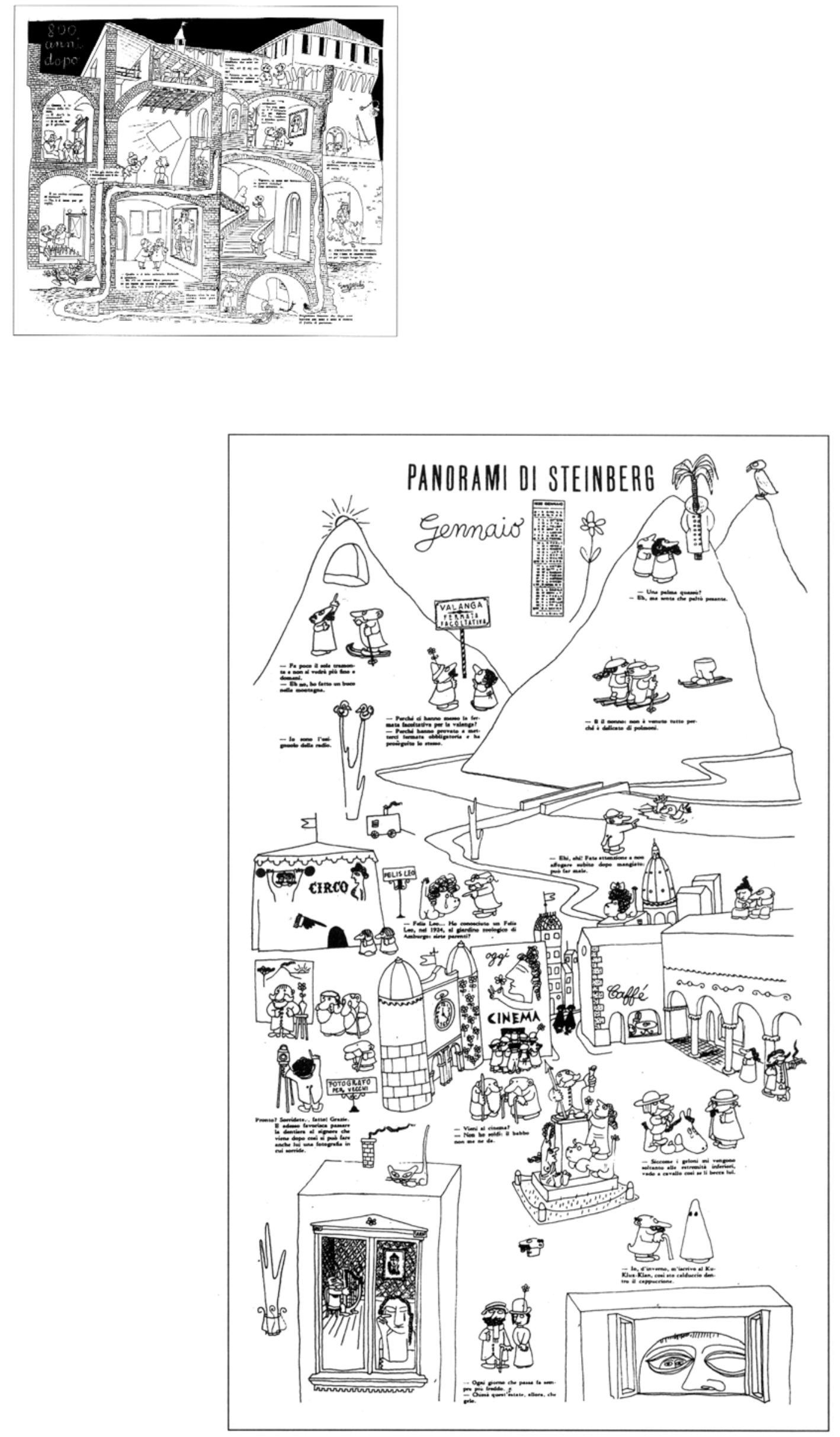
turas e cenografias desenvolvidas para tal finalidade. Não demoraria a Steinberg também fazer experiências com colagens. Já o "Guareschi desenhista" aparece inicialmente com um estilo de traço leve aliado ao uso tradicional do chiaroscuro - sutilmente aplicado. Em pouco tempo, passa a transitar por um estilo de traço mais duro, bem marcado, de linha uniforme e contínua, com zonas claras e escuras bem definidas e compactas (Mangini; Pallotino, 1994, p.71). Apesar das características de linha fina, o desenho de Guareschi apresenta diferenças estilísticas com os de Steinberg, em especial nas feições expressivas dos personagens: são comuns os olhos arregalados, rugas e dobras nas faces, narigões com alguma verossimilhança e personalidade própria, comuns em caricaturas. As situações também apresentam maior movimento, com figuras dispostas em distâncias variadas e grandes aproximações, em alguns casos. Já nas tiras, o tamanho pequeno e o formato promovem soluções com desenhos mais simples e poucos detalhes (Mangini; Pallotino, 1994, p.72).

A importância do trabalho de Mosca para Steinberg é constantemente citada, em parte por seu trabalho ser grande referência naquele contexto e período. O estilo do traço presente em significativa parte de seus cartuns - rápido, cheio de interrupções, delineando personagens de olhos grandes com expressão de exclamação -, não é o que mais os aproxima. Mas algumas características presentes na obra de ambos merecem atenção. O ambiente de considerável parcela dos cartuns de Mosca é o fin de siècle, com personagens austeros e damas em ricas vestes oitocentistas. Muitos destes trabalhos trazem cenários cheios de adornos, como nos vários desenhos de Steinberg que exploram interiores ornamentados. Os personagens oitocentistas, com barba, cartola e roupas negras, são figuras mais contidas, magras e sérias, que geram um ambiente menos circence e extrovertido. Já em outras obras, é utilizado um estilo assumidamente infantil, de paródia. E Mosca também recorre, como Guareschi, ao recurso da colagem. Por fim, um outro ponto de contato entre Mosca e Steinberg seria a presença do elemento surreal no trabalho de ambos.
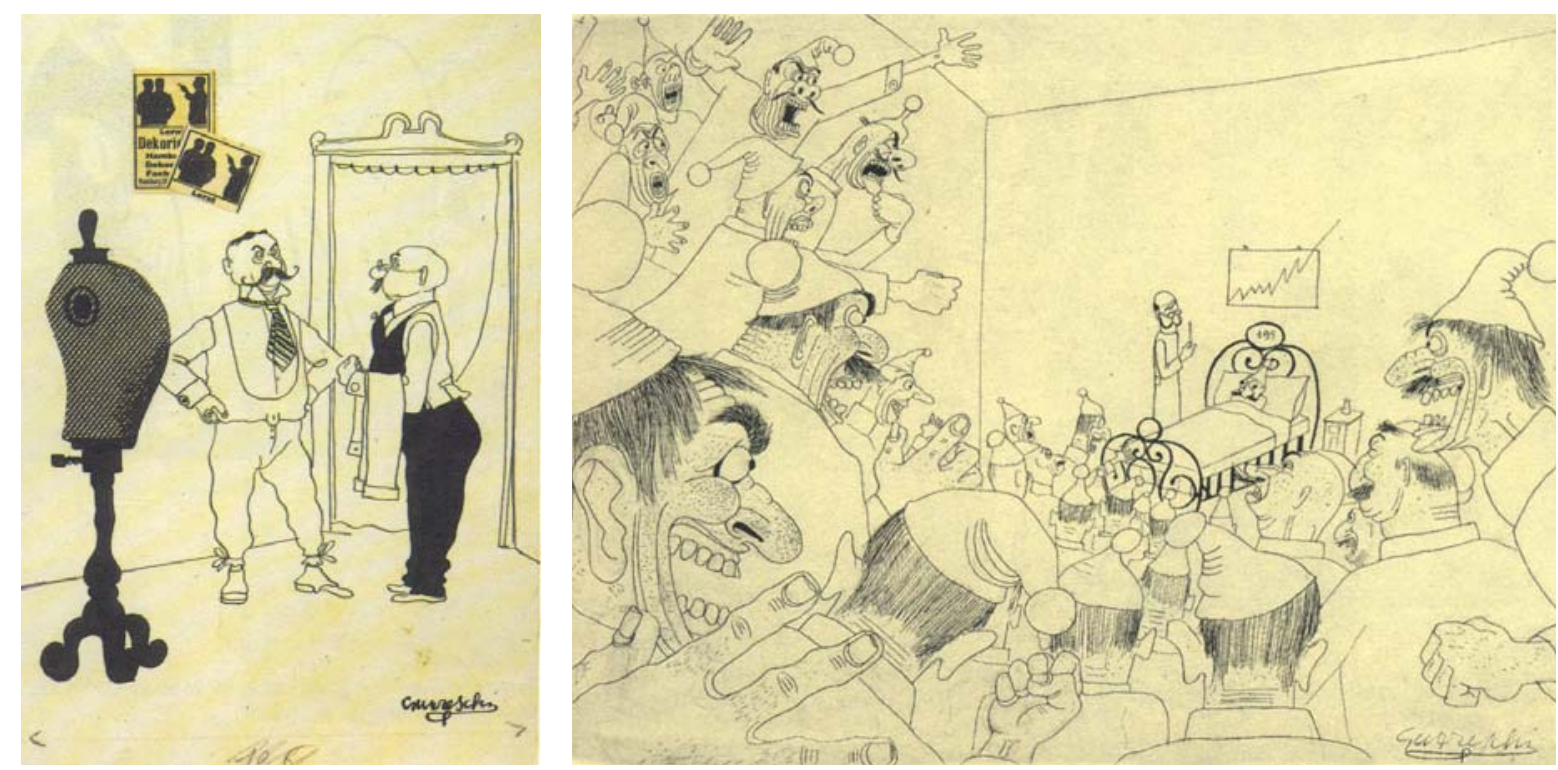

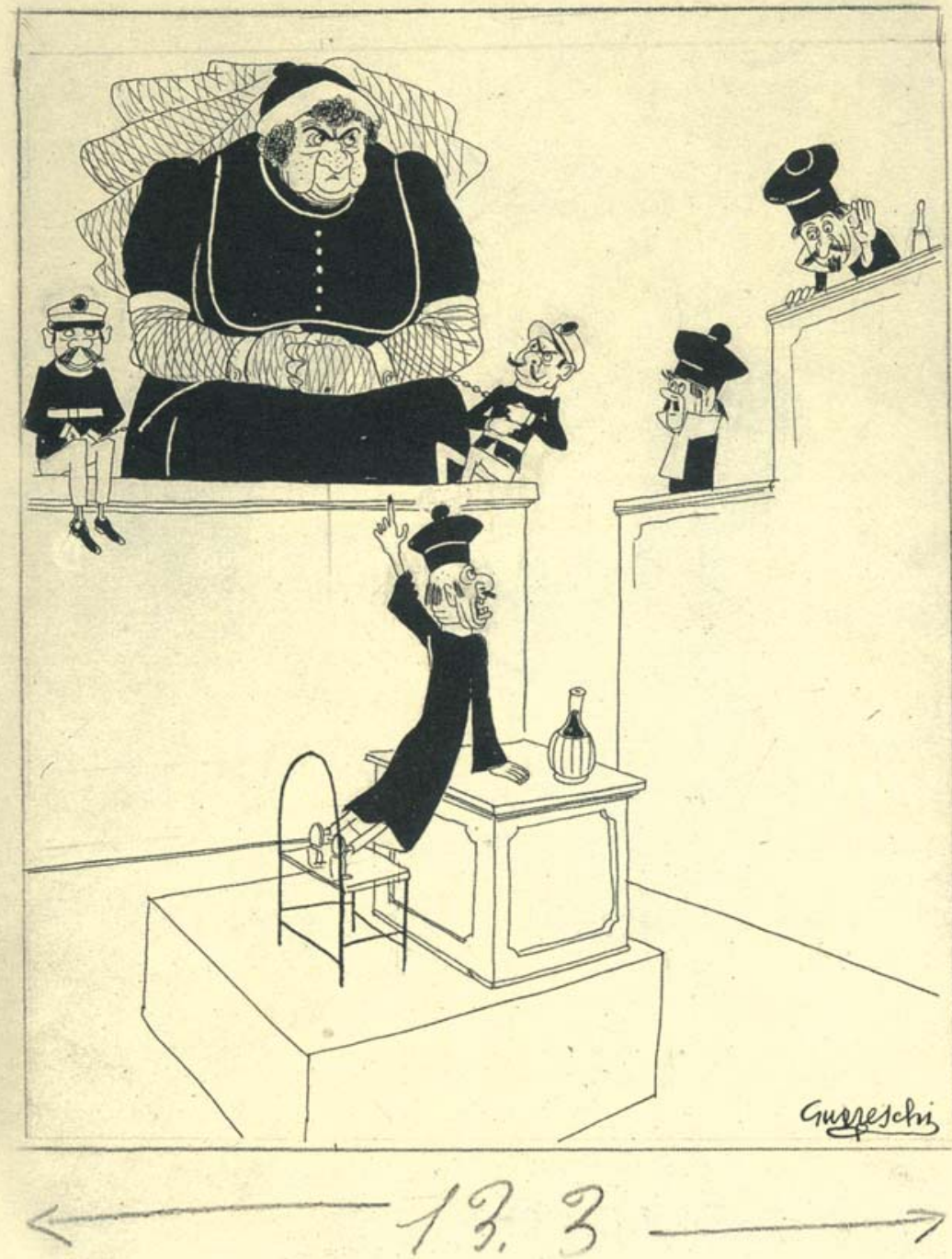

Figura 35. Guareschi, colagens no cartum Dal Sarto, Bertoldo, n.102, 1937, p.3

Figura 36. Guareschi, Ospedali Americani, Bertoldo, n.63, 1937, p.6

Figura 37. Guareschi,

L'Avvocato difensori, Bertoldo, n.72, 1937, p.2

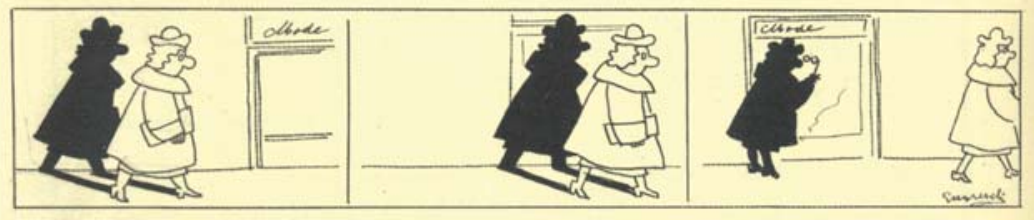

Figura 38. Guareschi, Vanità

D'ombra, Bertoldo, n.91, p.1 

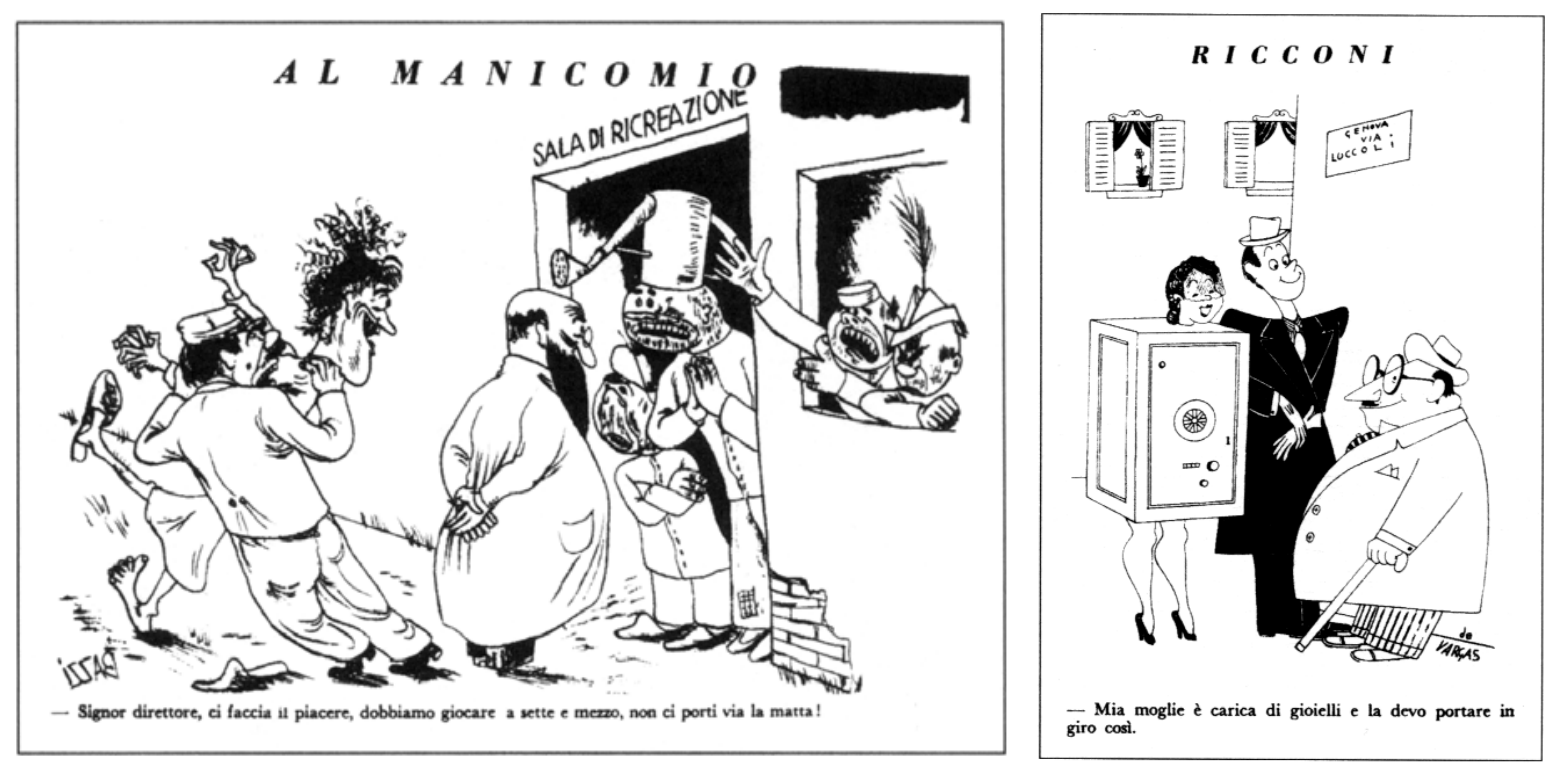

O trabalho de Mario Bazzi é interessante por apresentar, na Bertoldo, um desenho de linha fina com outro tipo de influência: uma acentuação expressionista que poderia ser comparada à de George Grosz (Mangini; Pallotino, 1994, p.63). Os personagens assumem, por vezes, feições grotescas e macabras. Os ambientes tendem a adquirir um clima conturbado, e cada figura se mostra com uma expressividade específica no olhar, nos trejeitos, na personalidade. Já na obra do cartunista De Vargas, o nariz triangular e pontiagudo, comum no conjunto da obra de Steinberg, surge como elemento expressivo recorrente (Mangini; Pallotino, 1994, p.109).

Dentre os diversos cartunistas da revista, o estilo de Manzoni é o que mais se assemelha ao de Steinberg, na sutileza do traço simples e nos contornos das feições dos personagens. Manzoni é provavelmente um dos primeiros notáveis artistas com clara influência de Steinberg; há indícios de que Guareschi aconselhava o cartunista a desenhar à moda de seu "protetor". Surge na Bertoldo com um desenho de contornos precisos, acentuando a influência de Steinberg a partir de 1941 (Mangini; Pallotino, 1994, p.139).

A proximidade do desenho de Mondaini com o trabalho de Steinberg também é evidente. A atmosfera dos cartuns é suspensa, pouco dramática, ambientada por figuras introvertidas. O desenho mais arredondado ou oval da cabeça dos personagens, o contorno do nariz, o traço um pouco mais solto e sujo, e o uso de certos grafismos, em sutilíssimo chiaroschuro, conferem diferenças em relação a Steinberg. Por volta do fim de 1938, Mondaini passa a incorporar de modo considerável em seus desenhos os "elementos expressivos steinbergnianos" (Mangini; Pallotino, 1994, p.76). Em um cartum de 1941, por exemplo, sua influência transparece no contorno do nariz dos personagens.

Por volta de 1941, outro desenhista iria assumir influências do artista: Manzi (Mangini; Pallottino, 1994, p.105). A análise de seu traço poderia servir para Steinberg: 

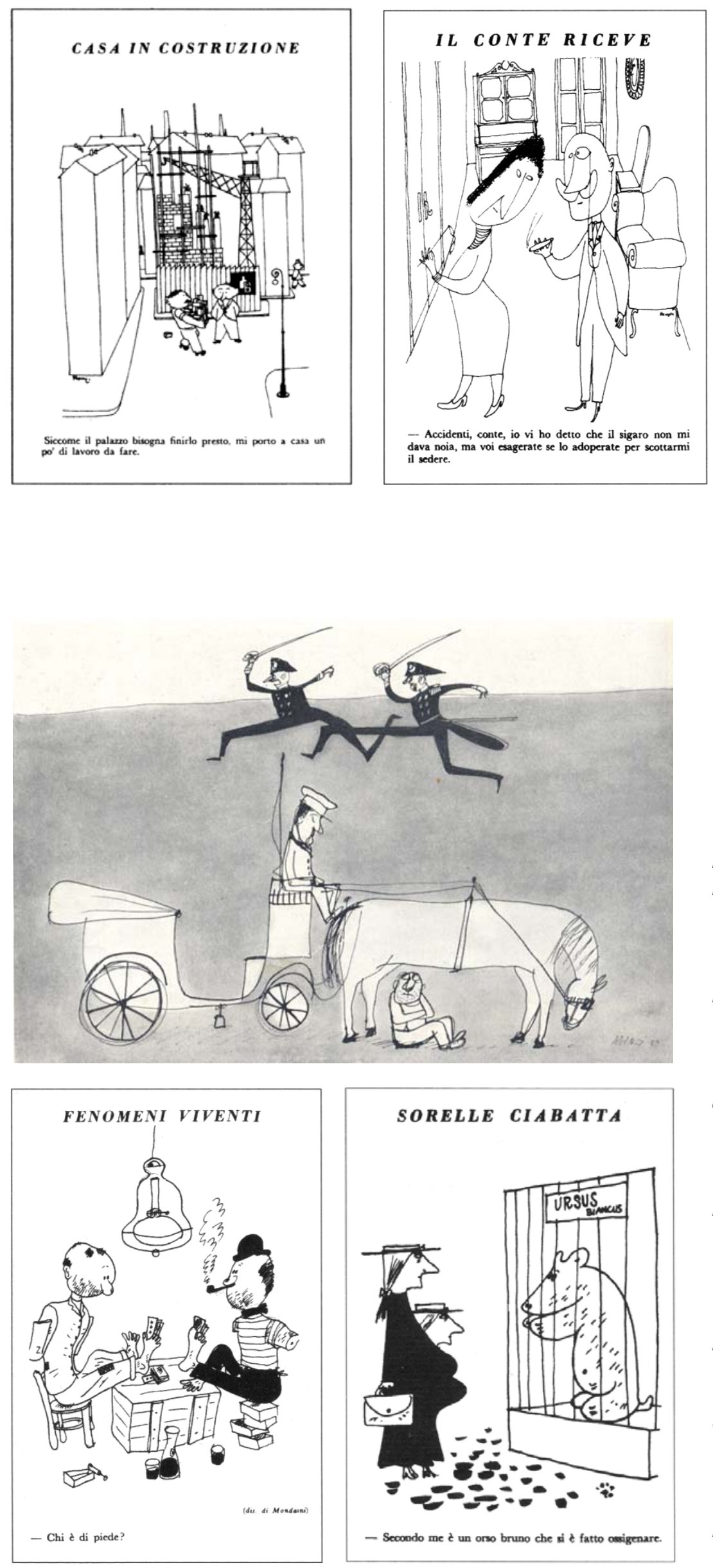

Figura 39. Bazzi, Al

Manicomio, Bertoldo, n.48, 1936, p.48

Figura 40. De Vargas, Ricconi, Bertoldo, n.101, 1938, p.3

Figura 41. Manzoni, Casa in construzione, Bertoldo, n.64, 1939, p.1

Figura 42. Manzoni, /l Conte Riceve, Bertoldo, n.2, 1942, p. 2

Figura 43. Manzi, cartum publicado na revista Graphis, Manzi, 1953

Figura 44. Mondaini, Sorelle Ciabatta, Bertoldo, n.8, 1941, p.2

Figura 45. Mondaini,

Fenomeni Viventi, Bertoldo, n.1, 1936, p.3 
Os desenhos de Manzi estão próximos dos esboços, rascunhos e piadas de um filósofo, psicólogo, ou engenheiro, de uma criança tentando formular suas idéias, mais do que as imagens de um pintor. Seu estilo é "tecnológico", para usar um termo que tem se tornado recorrente na Itália para sugerir que a proposta do trabalho de um artista não é especificamente estética (Sinisgalli, 1963, p.202).

Algumas características o diferem de Steinberg, segundo Sinisgalli: "Seu trabalho gráfico não conta com o poder sugetivo de pontilhados e arabescos, como o de outros artistas, incluindo alguns famosos como Steinberg ou Maccari; ele não se vale da ilusão, mas do impulso e peso de uma idéia". Ainda na intenção de diferenciar a obra de Manzi, elege outros artistas como referências importantes a seu trabalho: Picasso e Dubuffet - seu gosto pela art brut é assumido (Sinisgalli, 1963, p.202).

\section{IL FIGLIO DEL MINISTRO FRANCESE}

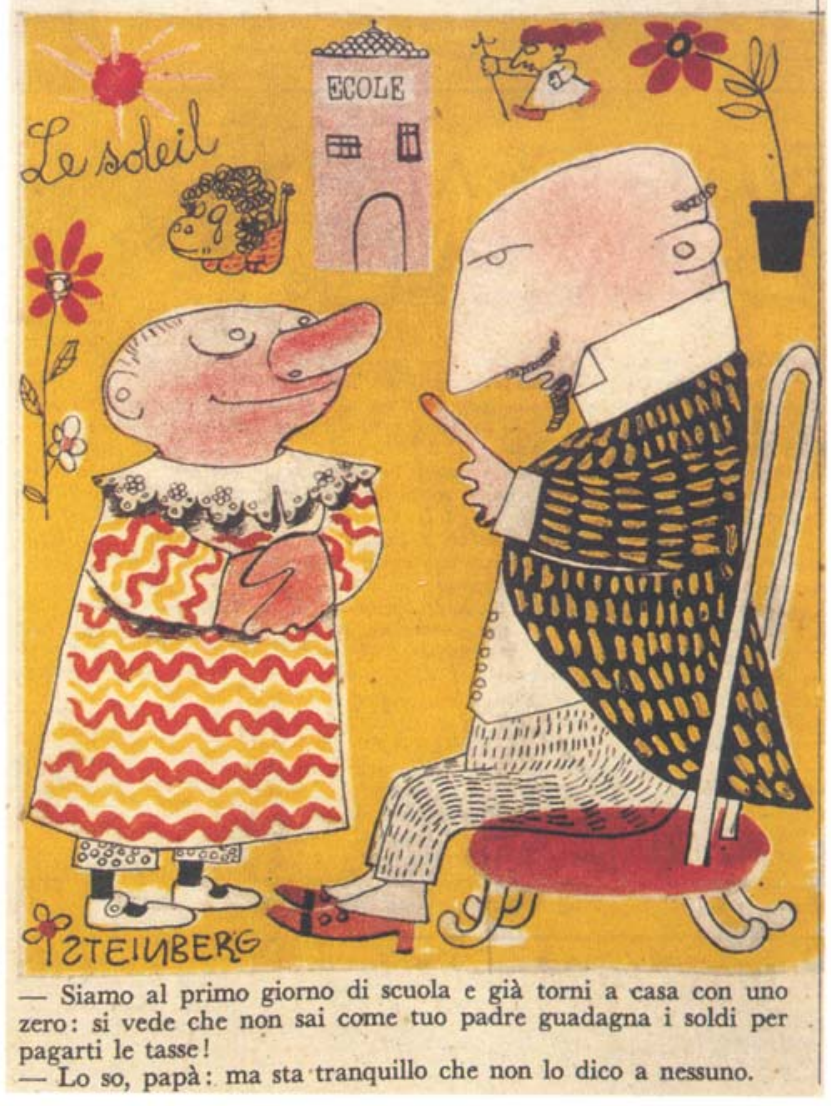

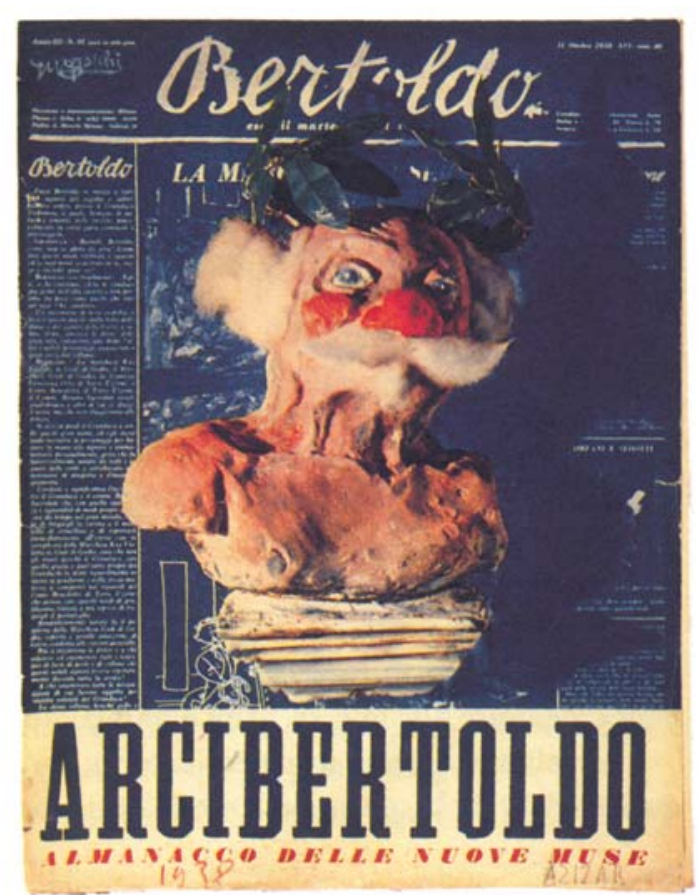

Figura 46. Steinberg, I/ figlio del ministro francese, Bertoldo, n.83, 1937, p.1

Figura 47. Guareschi, capa da Arcibertoldo de 1938

Figura 48. Bertoldo, n.57, 1937, p.8 


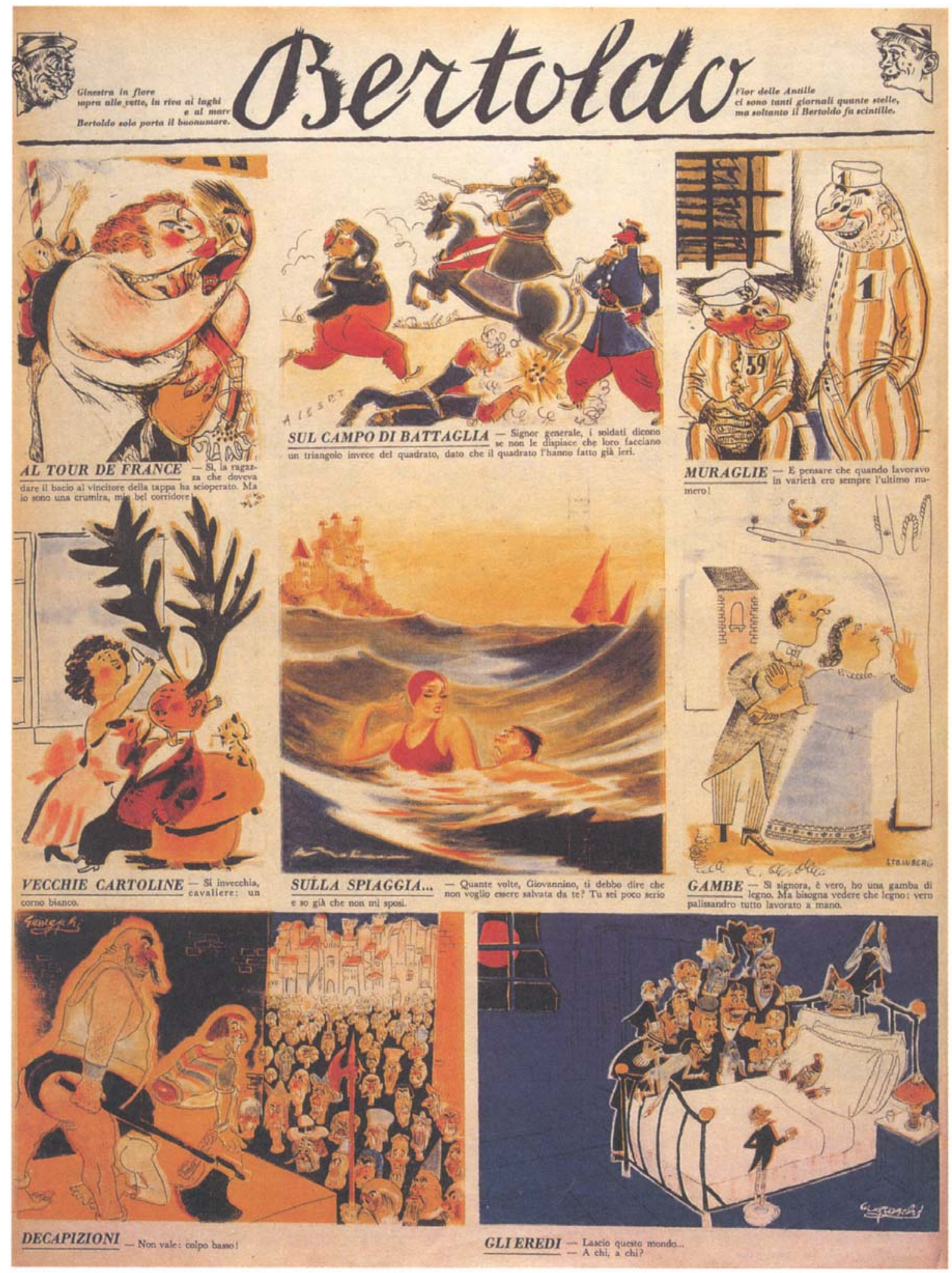




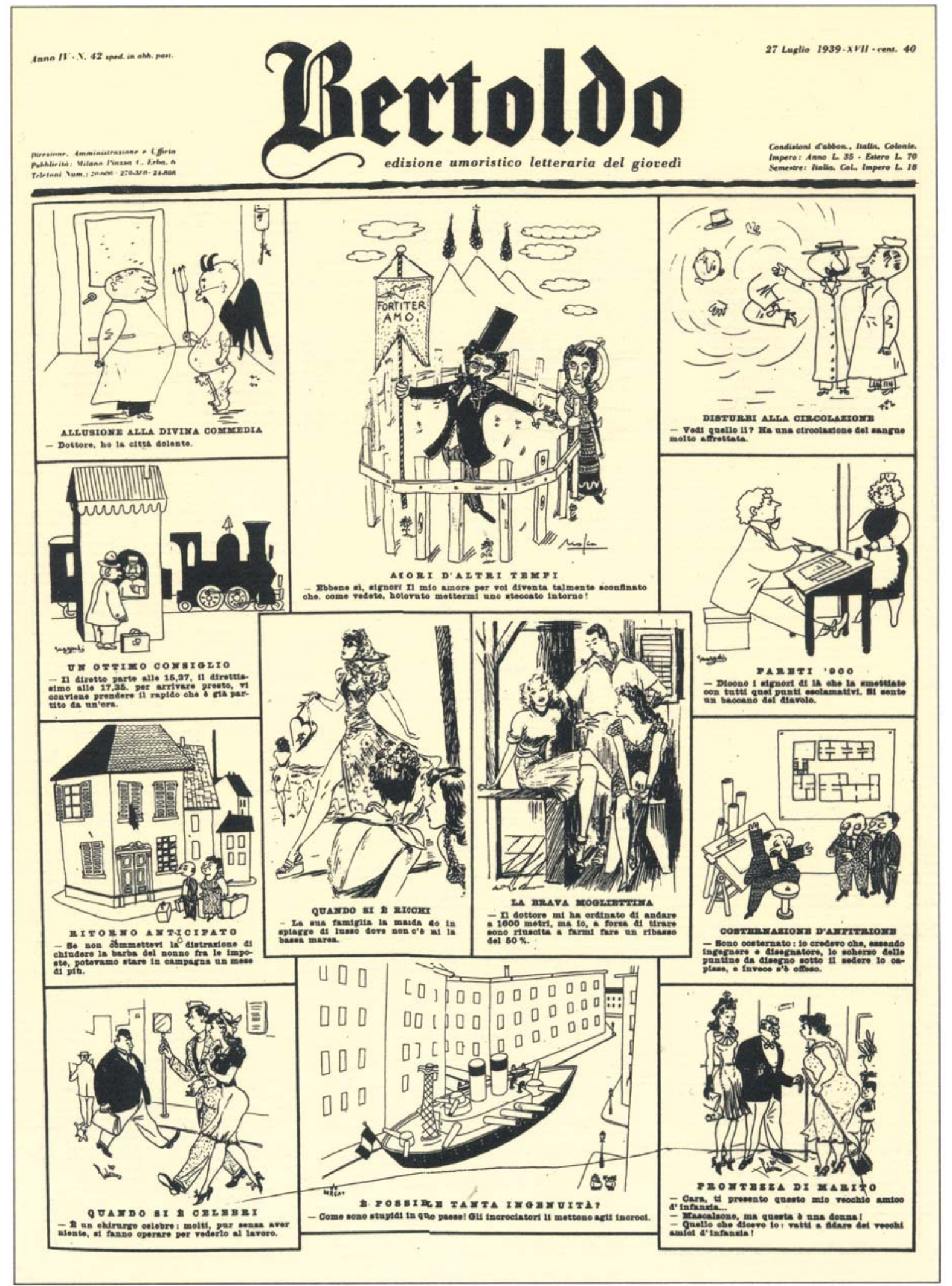

Figura 49. Capa da Bertoldo, n.42, 1939 
Apesar da efervescência criativa do universo dos cartuns italianos, a expectativa de dias melhores no país não era grande. Como observa Joel Smith, "em curto tempo, a carreira de arquiteto foi fechada para Steinberg pelas leis raciais de 1938 da Itália que oficialmente impediu os judeus de exercerem suas profissões" (Smith, 2006, p.27). Após ser graduado como Dottore em arquitetura em 1940, Steinberg teve seu diploma outorgado por Victor Emmanuel III - Rei da Itália, Rei da Albânia e Imperador da Etiópia, depois da conquista de Mussolini - para um homem identificado como "de raça judaica" ("di razza Ebraica"). "O belo para mim", contou posteriormente Steinberg, "é que este diploma foi dado pelo Rei; mas ele não é mais Rei da Itália. Ele não é mais Rei da Albânia. Ele não é sequer mais Imperador da Etiópia. E eu não sou mais arquiteto. A única coisa que permanece é razza Ebraica" (cit. por Hughes, 1978, p.51).

A situação de Steinberg não era simples. Não deveria voltar para seu país natal, uma vez que o estado Romeno havia começado a tomar posse das propriedades judaicas em agosto de 1940, se tornando aliado da Alemanha em novembro. Sua maior esperança era a mesma de muitos dos judeus em situação semelhante, ou seja, conseguir imigrar para os Estados Unidos. Smith comenta que "muitos detalhes deste ano horrível que se seguiu foram perdidos através da relutância de uma vida inteira de Steinberg em dar atenção ao período - e por seu apoio (se não propagação) do mito de que ele havia casualmente carimbado sua passagem pela imigração, em direção a um barco que sairia de Portugal" (Smith, 2006, p.27).

O fato é que sua condição de estudante havia expirado, seu programa de residência italiana tinha acabado sob leis raciais com mandato para a expulsão dos judeus estrangeiros, e as cotas para imigração americana se tornavam cada vez mais escassas. Seu dia-a-dia em Milão passou a consistir em tentar obter vistos, publicar o máximo de cartuns que pudesse, e enganar a polícia, alternando estadia na casa de amigos e da namorada, Ada Ongari. Enquanto isso, advogados nas Américas trabalhavam para garantir uma viagem segura ao Caribe. Já fora da Mondadori e atuando como agente de ilustradores, com escritório em Nova York e Buenos Aires, Cesar Civita se mostra um grande aliado nessa empreitada. A prima de Steinberg em Nova York, Henrietta Danson, seu chefe e personalidade do rádio Cornelius Vanderbilt Jr., e seu marido Harold, diretor de publicidade da Paramount Pictures, também procuraram ajudar o cartunista nesse processo de fuga da Europa. Cartas eram regularmente enviadas para o Departamento de Imigração em Washington D.C. E Civita, a partir de 1939, passa a promover o trabalho de Steinberg nas revistas do Novo Continente. Steinberg publica em revistas argentinas e brasileiras em 1939, e estréia nos Estados Unidos em 1940 (Smith, 2006, p.27). 
Na primavera de 1940, após conseguir chegar a Lisboa, Steinberg sofre um revés com sua papelada, resultando na volta à Milão e na perda de todo o progresso conseguido nos últimos meses. De volta à cidade italiana, continua fugindo da polícia: "Eu sabia que as autuações poderiam ocorrer entre seis e sete horas da manhã. Por algumas semanas fiquei acordando um pouco antes das seis, e tão logo lavasse minha cara, pulava na minha bicicleta e transitava pelas ruas como um homem a caminho do trabalho" (Steinberg, 2002, p.26). Steinberg mora, nessa época, no Il Grilo, um bar próximo à universidade, que alugava alguns quartos para os estudantes. Uma manhã, no mesmo momento em que o artista se prepara para ir para a rua como todos os dias, alguém vem avisá-lo que os policiais "estão aqui, lá embaixo". Steinberg consegue sair pelo pátio sem ser visto, e quando volta às oito horas, depois de telefonar para conferir que haviam ido embora, é recebido como herói por todos (Steinberg, 2002, p.27). Saul passa quase um ano na clandestinidade, dormindo às vezes no Il Grilo, e às vezes no estúdio de amigos. Nesse período, havia conseguido os vistos necessários, menos o italiano, que só seria entregue após um pedido feito com sua presença física, prova de que estava obedecendo a lei (Steinberg, 2002, p.32). Com sua prisão, na primavera de 1941, seu dossiê é legalmente completado e finalizado. Para Steinberg, sua perigosa estratégia funcionou.

Tenho um pouco de amnésia em relação àquele tempo: estava experimentando uma emoção que cobria meus olhos, ouvidos, todos os meus sentidos com uma espécie de acolchoamento, de modo a ocultar a gravidade da situação de mim mesmo. Sentia-me como se estivesse representando, me vendo como se fosse outra pessoa, algo como a situação de um homem desenhando uma figura de um homem - um sintoma, talvez, de uma infância persistente, que não acaba (...). (Steinberg, 2002, p.32)

Tão logo vai para San Vittore - uma prisão clássica -, Steinberg se sente especial: "Todos os persongens importantes foram para a prisão" (Steinberg, 2002, p.33). Apesar da situação adversa, Steinberg recorda: "Por ser jovem, tudo aquilo era uma grande aventura para mim. Gostava de pensar que estava participando da vida de um modo intenso: não era apenas um leitor de romances, mas um verdadeiro herói,como sempre quisera ser. E vi o momento se tornar verdadeiro quando o sonho se tornou realidade" (Steinberg, 2002, p.33).

Steinberg é conduzido à estação em Milão e enviado de trem para Abruzzi. Antes de embarcar, recebe a visita de dois amigos, Donizetti e Aldo, e de sua namorada Ada, que lhe entrega alguns remédios - "quinina, acho" - contra a malária. "Isto, também, era felicidade", recorda Saul: "tinha uma mulher que me amava e dois amigos. Antes disso, possuía apenas minha família - isto é, pessoas que não tinha inventado e nem encontrado por conta própria". No vagão, Saul segue sozinho com dois policiais que tentam manter os outros passageiros à distância. Mesmo nas situações mais difíceis, o apreciador de analogias faz suas divagações. "Não demorou muito para que eu passasse a ser objeto de curiosidade, porque as pessoas 
perceberam que eu estava sendo levado à prisão, e as garotas estavam especialmente interessadas", conta Saul, lembrando que, para as garotas da época, "o prisioneiro é um romântico, um personagem aventureiro, que havia feito algo ilegal e que, deste modo, poderia fazer algo ilegal por elas (...)". Estrangeiro, jovem, admirado e desejado pelas garotas, Steinberg se sente perfeito (Steinberg, 2002, p.34).

Depois de dos dias de viagem, chegam a Tortoreto, em Abruzzi. O "acampamento" é uma vila da qual poderia se avistar o mar, cujo acesso não era permitido a quem estava na prisão. O lugar era pequeno, com talvez cinquenta prisioneiros: alguns poucos judeus, russos brancos, ciganos, pessoas sem cidadania, refugiados, sendo acolhidos "de um modo claramente temporário e humano, se comparado aos outros campos", observou Steinberg, concluindo: "eu estava com sorte" (Steinberg, 2002, p.35).

Foi enquanto estava em Tortoreto que ele foi avisado de que poderia ir para Lisboa (Smith, 2006, p.29). No dia em que Steinberg e Gogg - o amigo austríaco que fez na prisão - receberam a notícia de que estavam livres, seus companheiros ofereceram a eles um jantar especial, com muito pão e o mais saboroso chá. No dia seguinte, todos se despediram até a esquina da estação. O trem deixou Tortoreto passando por detrás da prisão, sendo possível avistar todos agitando, em despedida, pedaços de pano e toalhas (Steinberg, 2002, p.36). Uma vez livre, Steinberg parte para Milão, segue de lá para Roma, e voa para Lisboa via Barcelona. Chega na cidade portuguesa no dia 16 de junho, embarcando para as Américas em 20 de junho de 1941, no S.S. Excalibur (Smith, 2006, p.252). 

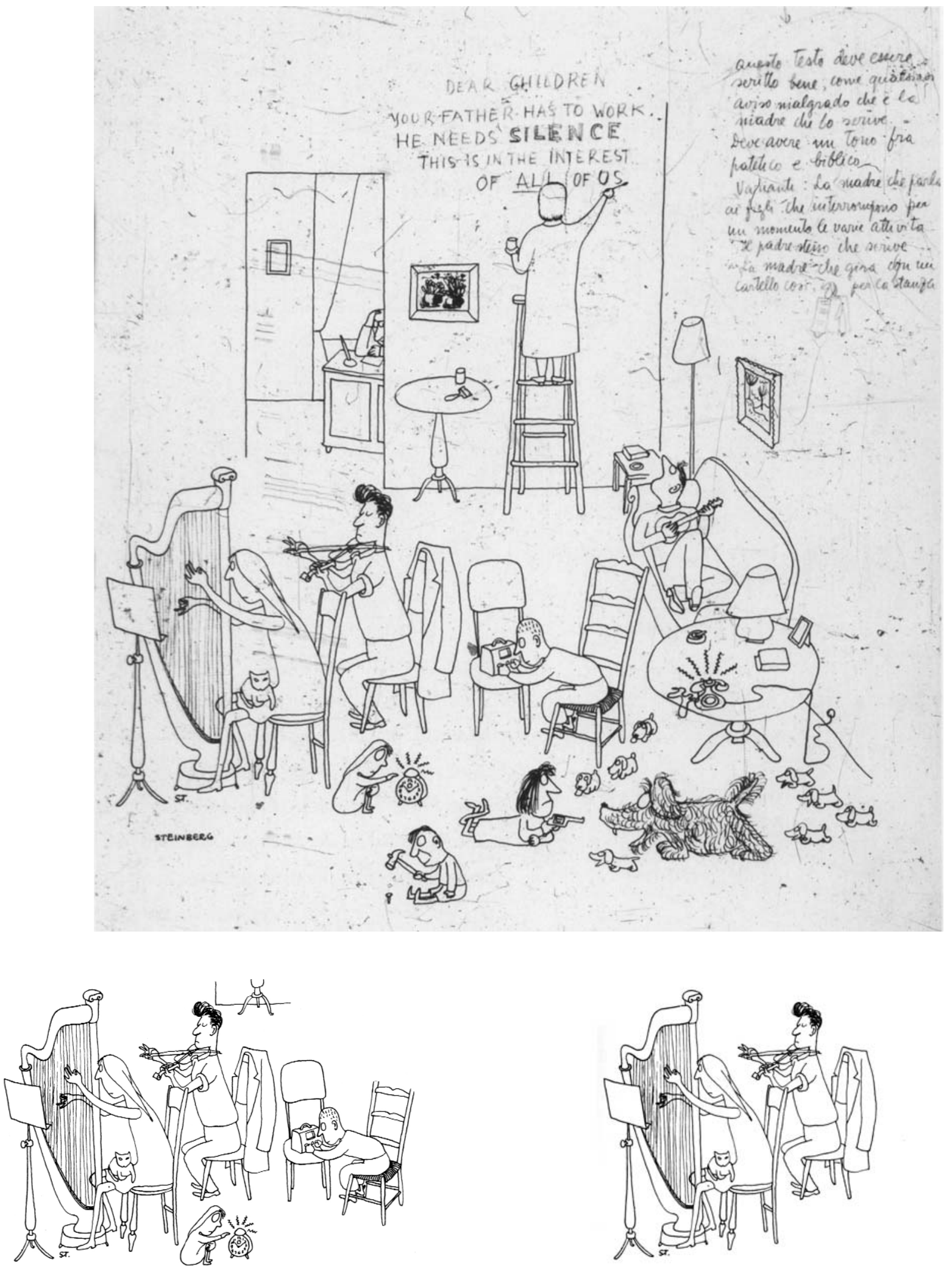

Figura 50. Desenho sem título, de 1941 ou 1942. No alto, anotação de Steinberg para Victor Civita propõe variações possíveis para a imagem.

Figura 51. Publicado na New Yorker, 20 de novembro de 1943

Figura 52. Reproduzido no All in Line, 1945 


\section{STEINBERG A CAMINHO DA AMÉRICA: \\ DEPURAÇÃO E DESENHO MUDO}

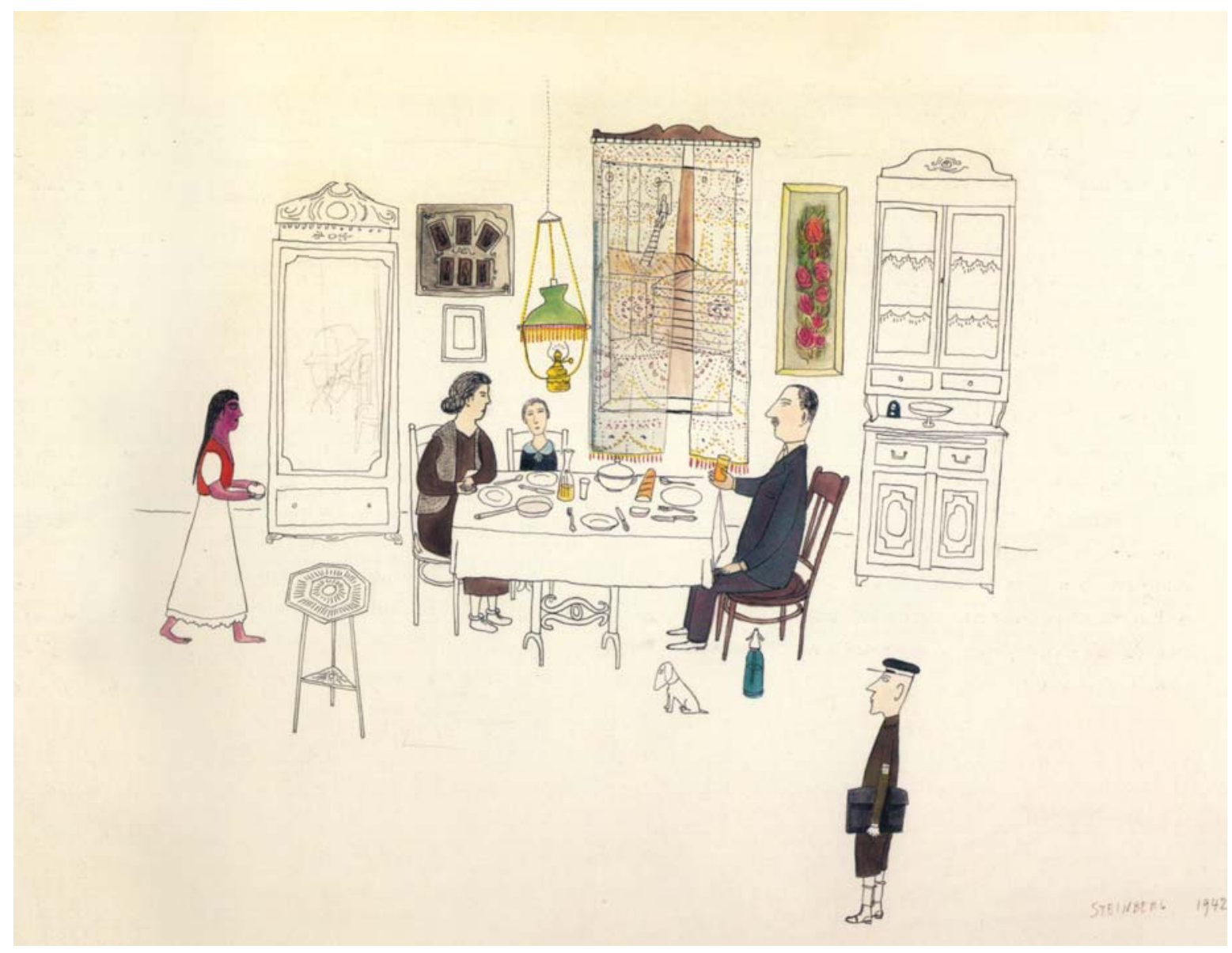

Figura 53. Steinberg. Strada Palas. Tinta, lápis e aquarela em papel, 1942

Diante das circunstâncias da guerra na Europa, Steinberg se sentia afortunado por estar a caminho da América. A viagem para a República Dominicana incluiu uma passagem por Ellis Island, uma estação de imigração dos Estados Unidos. Steinberg passa um sufocante 4 de julho na estação, sendo em seguida deportado para a República Dominicana em um bote de carga. (Hughes, 1978). Finalmente chega a Ciudad Trujillo (Santo Domingo), uma quente e pacata cidade portuária cheia de refugiados da Espanha fascista, Alemanha, e Itália (Smith, 2006, p.29). Ali, a Associação de Povoação Dominicana lhe garantiu condições para ficar no país por um ano (Smith, 2005, p.14).

Steinberg, com então vinte e sete anos, passa o verão de 1941 tentando ajustar sua vida na capital do país caribenho, e se estabelece na rua Moses Garcia n.46. Em Cuidad Trujillo, Steinberg adquire "novas vestimentas, emergindo como um cavaleiro colonial, no 

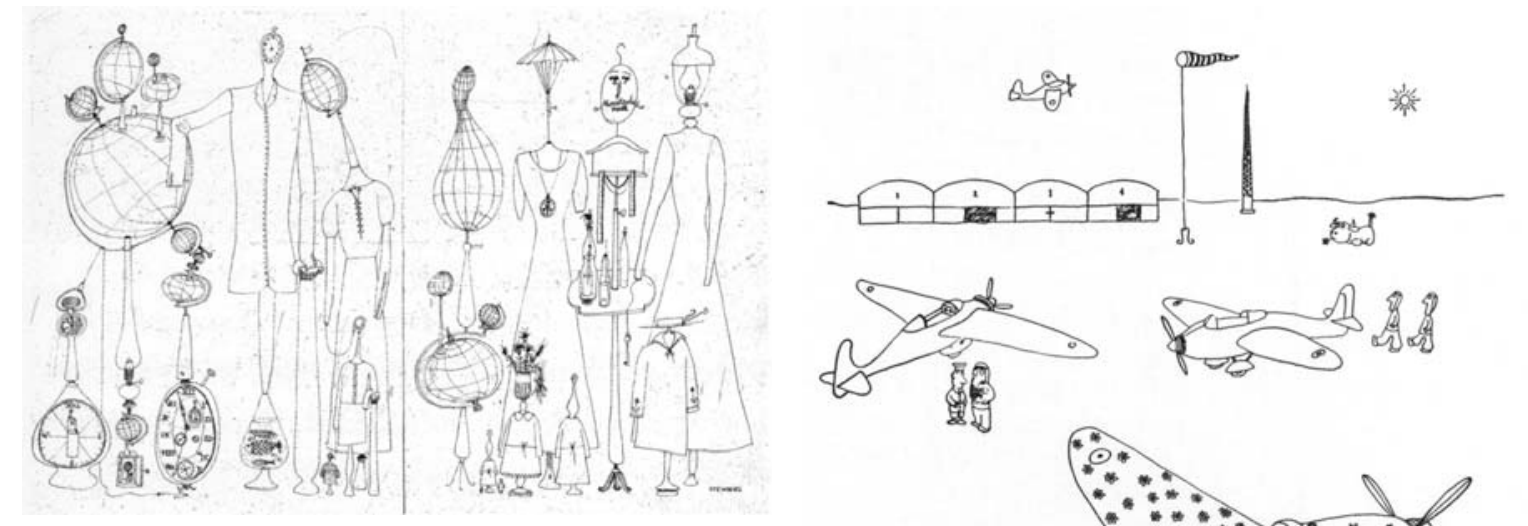

Figura 54. Desenho enviado para o escritório de Cesar Civita em Nova York, 1942

Figura 55. Cartum publicado na Harper's Bazaar, Persiflage from Paris, p.62, 15 de março de 1940

Figura 56. Speaking of pictures... - life in the "Guatavir" line. Life, p. 14 e 15, 27 de maio de 1940

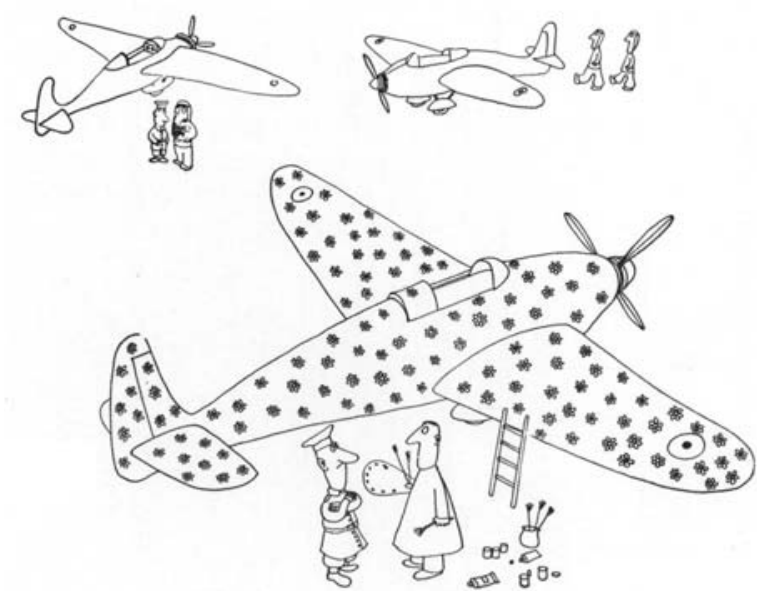

"You see, if it comes down in a meadow, no one will notice it . . ."

estilo plantador, em terno de linho branco e largo chapéu panamá" (Rosenberg, 1978, p.14). Uma de suas primeiras iniciativas é começar as solicitações para uma entrada aos Estados Unidos pelo sistema de cotas. (Smith, 2006, p.252). Com vistas à sua transferência, o jovem Steinberg se dedica à leitura de Huckleberry Finn para treinar seu inglês (Updike, 1999).

Neste ano ele envia cerca de quarenta pacotes, contendo mais de 100 desenhos no total, pelo mar para Cesar Civita em Buenos Aires e para seu irmão, Victor Civita, em Nova York. A assistente de Victor, Gertrude Einstein, remete cartas de volta para Steinberg, o instruindo a partir das respostas que recebia dos editores americanos (Smith, 2006, p.252). Além de distribuir os cartuns de Steinberg para editores de arte de revistas apropriados, ao longo do ano Einstein e os Civitas proporcionaram um permanente retorno à longa distância para o artista, que procurava adptar seu humor ao gosto americano. Este se configura em um momento muito importante para o trabalho de Steinberg, de definição de um claro caminho em direção à simplicidade e eliminação de elementos secundários. "Suas composições começam a ser depuradas, suas figuras perdem a aparência rechonchuda maleável que havia sido sua marca registrada em Milão" (Smith, 2006, p.29). Mais do que tudo, como observa Smith, um notável resultado desta troca íntima editorial foi a gradual mudança do tradicional cartum dependente de texto e frases a favor de desenhos que promoviam uma incisiva inspeção de suas próprias peculiaridades e características (Smith, 2005, p.14). Em desenhos trocados com os Civitas, é possível perceber com clareza o processo de depuração ocorrido sob a orientação deles, através de notas com comentários e sugestões escritas no próprio 


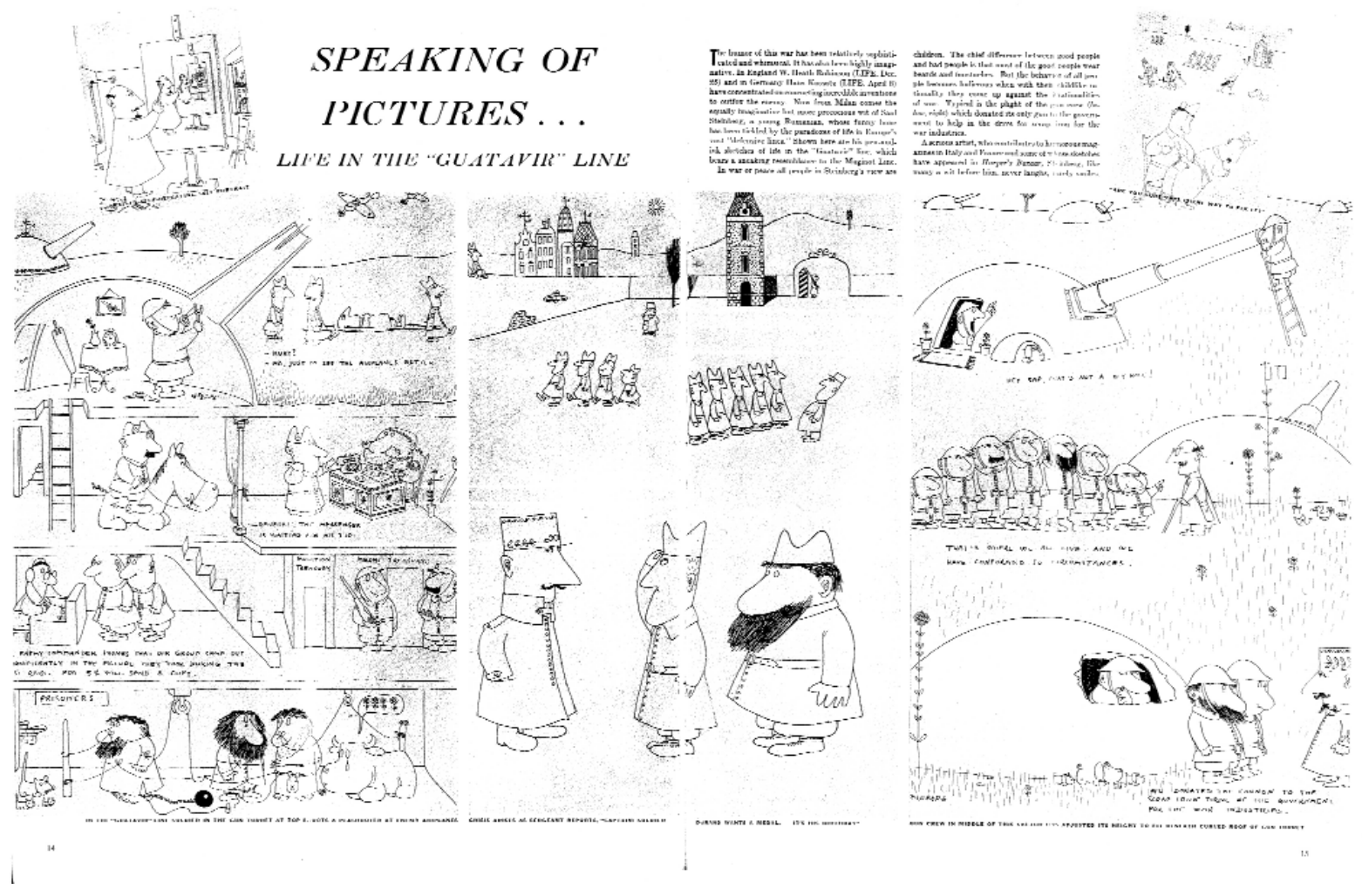

corpo dos desenhos. Ao que parece, o futuro fundador da Editora Abril exerceu um papel relevante e direto no processo de formação da arte de Steinberg.

Quando pisou em solos dominicanos, o artista já tinha um pequeno mas significativo currículo de publicações em revistas do novo continente. Enquanto ainda estava na Europa, Steinberg já havia estreado na Harper's Bazaar n.73, em 15 de março de 1940. Intitulada Persiflage from Paris, são duas páginas de humor com traço simples e uma frase por cartum (Harper's, 1940, p.60). Publicou na Life no mesmo ano, em 27 de maio, com três páginas de cartuns sob o título Speaking of Pictures... - Life in the 'Guatavir' Line e breve texto:

O humor desta guerra têm sido relativamente sofisticado e curioso. Têm também se apresentado altamente imaginativo. Na Inglaterra, W. Heath Reobinson (Life, 25 de dezembro) e na Alemanha, Hans Kossatz (Life, 8 de abril) têm se concentrado em tramar incríveis invenções para tirar o máximo proveito do inimigo. Agora, de Milão, vem o igualmente imaginativo e mais precoce talento de Saul Steinberg (...). Estão à mostra aqui os seus desenhos em tinta e caneta sobre a vida na linha "Guatavir", que sugere alguma semelhança com a Linha Maginot. Seja na guerra ou na paz, todas as pessoas, na visão de Steinberg, são crianças. A diferença básica entre boas pessoas e más pessoas é que as boas pessoas usam barbas e bigodes. Mas o comportamento de todos se mostra mais engraçado quando, com suas racionalidades infantis, se voltam em direção às racionalidades da guerra. Exemplo típico disto é (em determinado cartum) o empenho da equipe de armas, que havia doado sua própria arma para o gover- 
no para ajudar com entulho de ferro para a indústria da guerra.

Trata-se, enfim, de um sério artista, que contribui para revistas de humor na Itália e na França e cujos desenhos aparecem na Harper's Bazaar. Steinberg, como muitos talentos antes dele, nunca ri, raramente sorri (Life, 1940, p.15).

O artista ainda fez uma ilustração em outubro de 1940 na revista Town \& Country, para o texto The shot heard round the county, de Oliver Wainwright (Town \& Country, 1940, p.50). Estes trabalhos ainda apresentam as fortes características do período italiano, com personagens "rechonchudos" e mais volumétricos, vários cartuns em uma cena e piadas com frases e falas acompanhando o desenho. Os temas, de modo geral, são relativos à guerra; há ainda uma incipiente preocupação com assuntos relativos à arte, situações hierárquicas, camuflagens. Os mascotes chorões, que desempenham papel secundário nas piadas, também se fazem presentes nestes trabalhos, ressaltando as semelhanças com os cartuns da Bertoldo e Setebello.

Na passagem de 1940 para 1941, colabora para a primeira edição da revista brasileira Sombra, fazendo capa e cartuns. Trata-se, ao que parece, da primeira capa de revista feita por Steinberg. Saul não fez uma capa, no sentido tradicional do termo, para as revistas italianas Bertoldo e Setebello, pois estas publicavam várias imagens e cartuns em sua página de abertura. Nos Estados Unidos sua primeira capa para a New Yorker só viria a ser publicada em 1945. E sobre seus primeiros trabalhos para a Argentina, o que se sabe até o momento é de sua participação na Cascabel, que começou em 1941. Sendo assim, tudo indica que a capa da

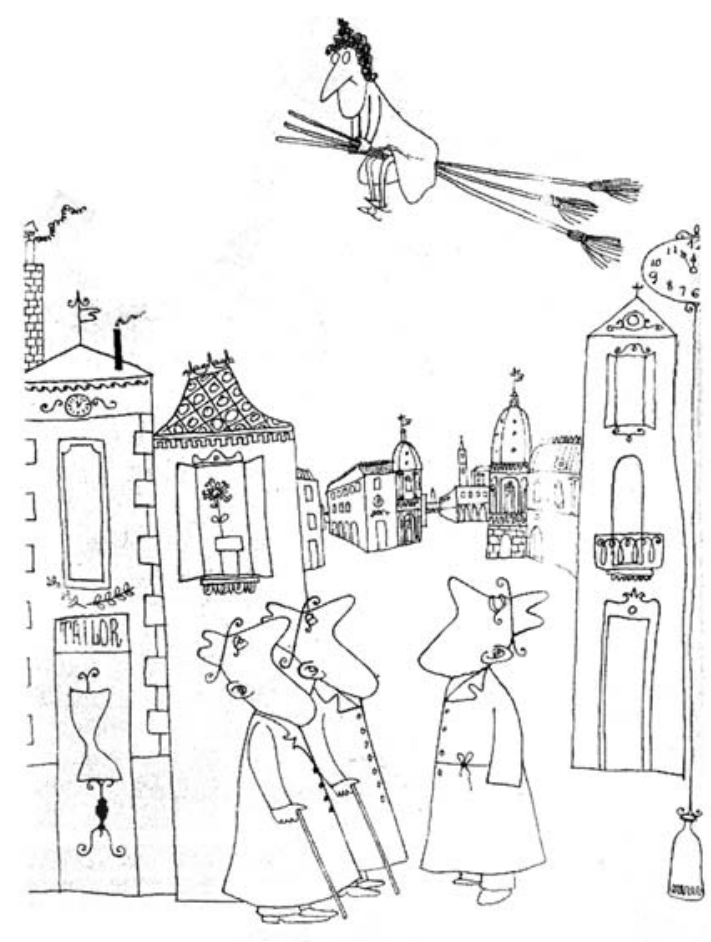

SPECTATOR: "IT'S A NEW AND MODERN TYPE OF THREE-M"TORED WITCH

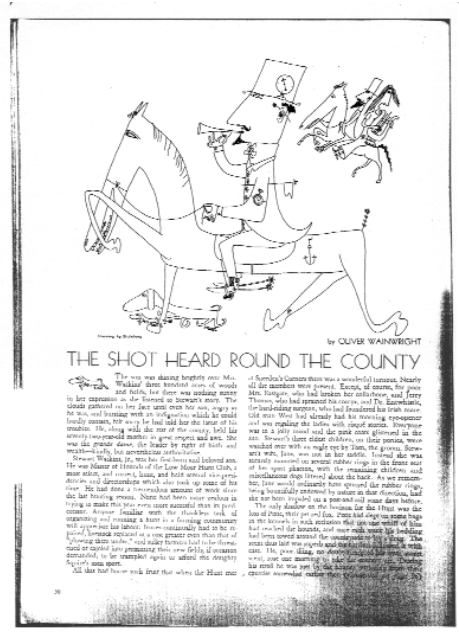

Figura 57. Speaking of pictures.. - life in the "Guatavir" line. Life, p. 17, 27 de maio de 1940

Figura 58. The Shot heard round the country, Town \& Country, outubro de 1940. 


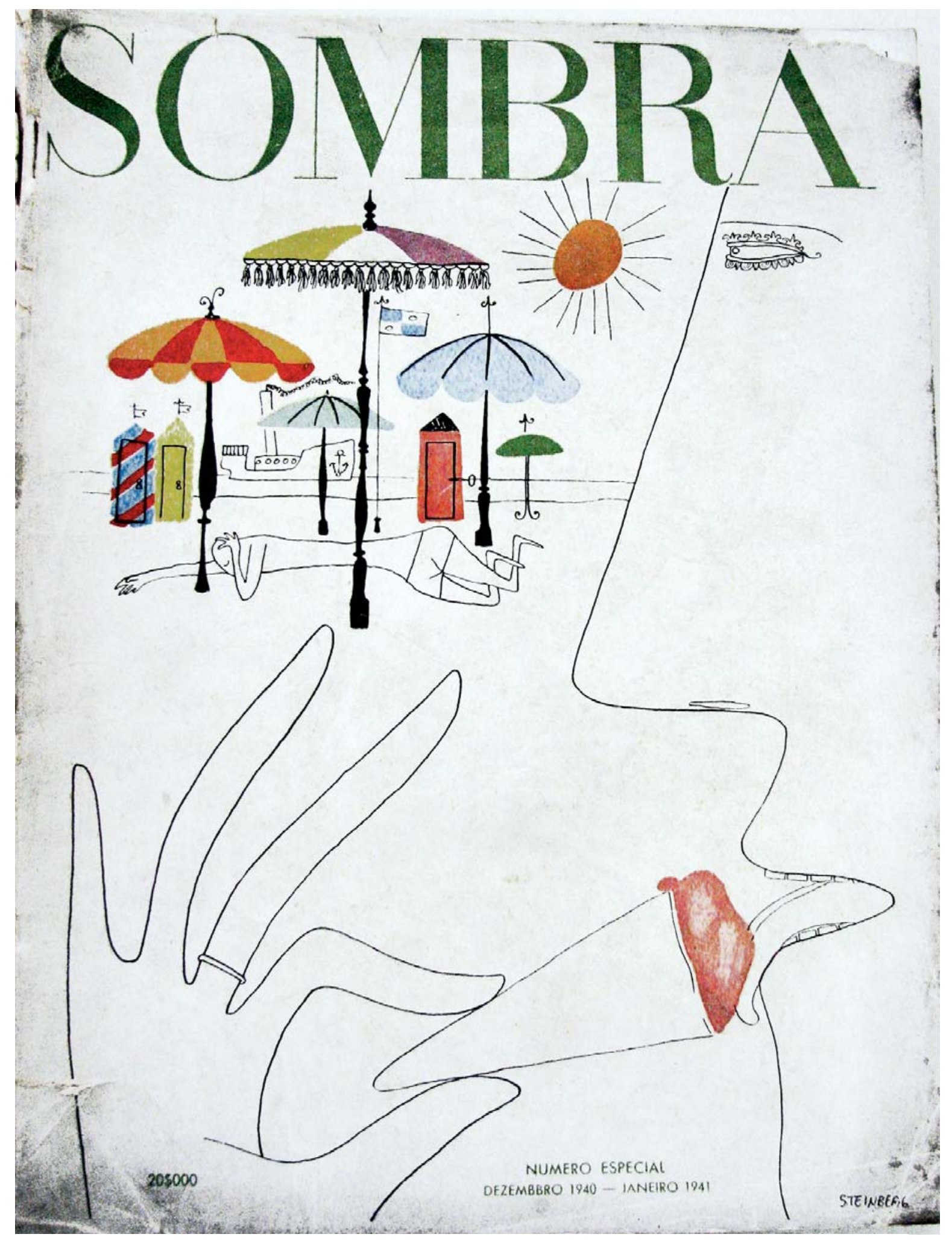

Figura 59. Capa da revista Sombra, n.1, dezembro de 1940 - janeiro de 1941 
Sombra foi a primeira capa de Steinberg. Fica a constatação, sobretudo, de que Steinberg começou sua carreira fora da Europa publicando, também, em uma revista brasileira.

A revista Sombra tinha envergadura literária e destacou-se também pelo refinamento visual, que refletia tendências do design internacional (A Revista no Brasil, Editora Abril, p.28). Suas 136 páginas, em amplo formato de 33,5 x $26 \mathrm{~cm}$, expunham cultura, artes, poemas, contos, moda, coluna social. "Essa publicação vai fixar o lado elegante e civilizado do Brasil", anunciou o poeta Augusto Frederico Schmidt no número de estréia (Sombra, 1941, s.p). A primeira edição da revista carioca foi publicada em dezembro de 1940/ janeiro de 1941, em um "número especial de Natal", e definia-se como de regularidade mensal. Walther Quadros era o diretor responsável, e Aloysio de Salles, um dos diretores efetivos. "Além do francês Jean Manzon comandando a fotografia, Sombra tinha colaboradores como Mário de Andrade, Stefan Zweig e Vinícius de Moraes" (A Revista no Brasil, Editora Abril, p.131). Schmidt, em texto de apresentação, procura justificar o título da publicação ao dizer que "no tropico, a sombra é a liberação, o consolo e a recompensa do esforço de viver. A sombra é o que há de permanente, de verdadeiro e de antigo, entre tantas cousas verdes e ephemeras" (Sombra, 1941).

O desenho de capa de Steinberg também, curiosamente, dialoga com o significado da revista. Mostra o perfil de uma pessoa, em destaque, tomando um sorvete. Mais ao fundo, um homem aparece deitado no chão, tirando um cochilo debaixo de uma grande sombra formada por inúmeros guarda-sols, em um ambiente ensolarado. O desenho é praticamente preto e branco, com detalhes pontuais coloridos, evidenciando a postura da revista de busca pelas tendências atuais e arrojadas no mundo.

Steinberg é um dos destaques da revista no número de estréia, totalizando dez cartuns em sete páginas distribuídas em três partes ao longo da revista. O texto de apresentação parece se basear no artigo da revista Life, ao comentar o jeito introvertido do artista:

Steinberg é um homem que nunca ri. Aliás, se sua physionomia é triste, nada mais faz do que refletir a sua própria sorte... Rumeno e ancioso por uma vida de paz na América, não conseguiu attingir o nosso continente. Os desenhos, entretanto, fizeram o que o desenhista não pôde fazer: Harper's Bazaar e Life publicaram nos Estados Unidos os esplendidos trabalhos de Steinberg. Sombra, agora, o faz no Brasil (Sombra, 1941, p.48).

\section{Trabalhos na Argentina, Republica Dominicana e New Yorker}

Na República Dominicana, Steinberg começa a publicar no La Nacion, de Ciudad Trujilo. E as aparições em revistas das Américas continuaram. Em novembro de 1941, publica duas páginas de humor na revista americana Mademoiselles (Mademoiselles, 1941, p.114). Um pouco antes, em 25 de outubro, estréia na The New Yorker, com um cartum sobre uma estu- 
dante de pintura e seu centauro às avessas: cavalo na frente, homem atrás. Apesar deste trabalho ainda não mostrar nenhum sinal do processo de depuração pelo qual vinha passando, o cartum foi aprovado (Smith, 2006, p.29).

Quando Einstein levou uma série de desenhos de Steinberg para Geraghty na New Yorker, este já havia visto os portifólios publicados, um ano antes, na Harper's Bazaar e Life (Smith, 2005, p.16). Brenda Gill, em artigo sobre Steinberg publicado na Horizon, relata que Geraghty, muito impressionado, levou os desenhos para Harold Ross, editor e fundador da revista, que inicialmente os recusou. Antes de devolver os originais, Geraghty teve o cuidado de fazer fotocópias deles. Ao encontrar o colega Russel Maloney no corredor fora da sala de Ross, Geraghty mostrou os desenhos, provocando sua admiração. Aconselhou Maloney, então, a se dirigir a Ross para dizer com veemência o que achava. Além de defender os desenhos do artista, Maloney foi enfático na surpresa diante da recusa inicial de Ross. Foi então que Ross chamou Geraghty ao telefone para exclamar que não havia rejeitado os desenhos: "Apenas não vi como iríamos publicá-los. Não é absolutamente a mesma coisa!" (cit. por Gill, 1978, p.70). Após a publicação do primeiro trabalho, a atração entre o cartunista e a revista foi mútua, como relata Smith:

Em 17 de novembro de 1941, quando Steinberg finalmente conseguiu sua cópia da The New Yorker com seu trabalho, ele escreveu, em seu inglês de iniciante, para seu primo em Nova York: "Estou muito satisfeito ao perceber como importante e elegante é esta revista. Havia lido ela na Itália também e conheço também ótimas publicaçõe inglesas como a Punch e a Humorist, etc, mas acho que a New Yorker está no topo. É motivo de muito orgulho para mim" (Smith, 2005, p.16).
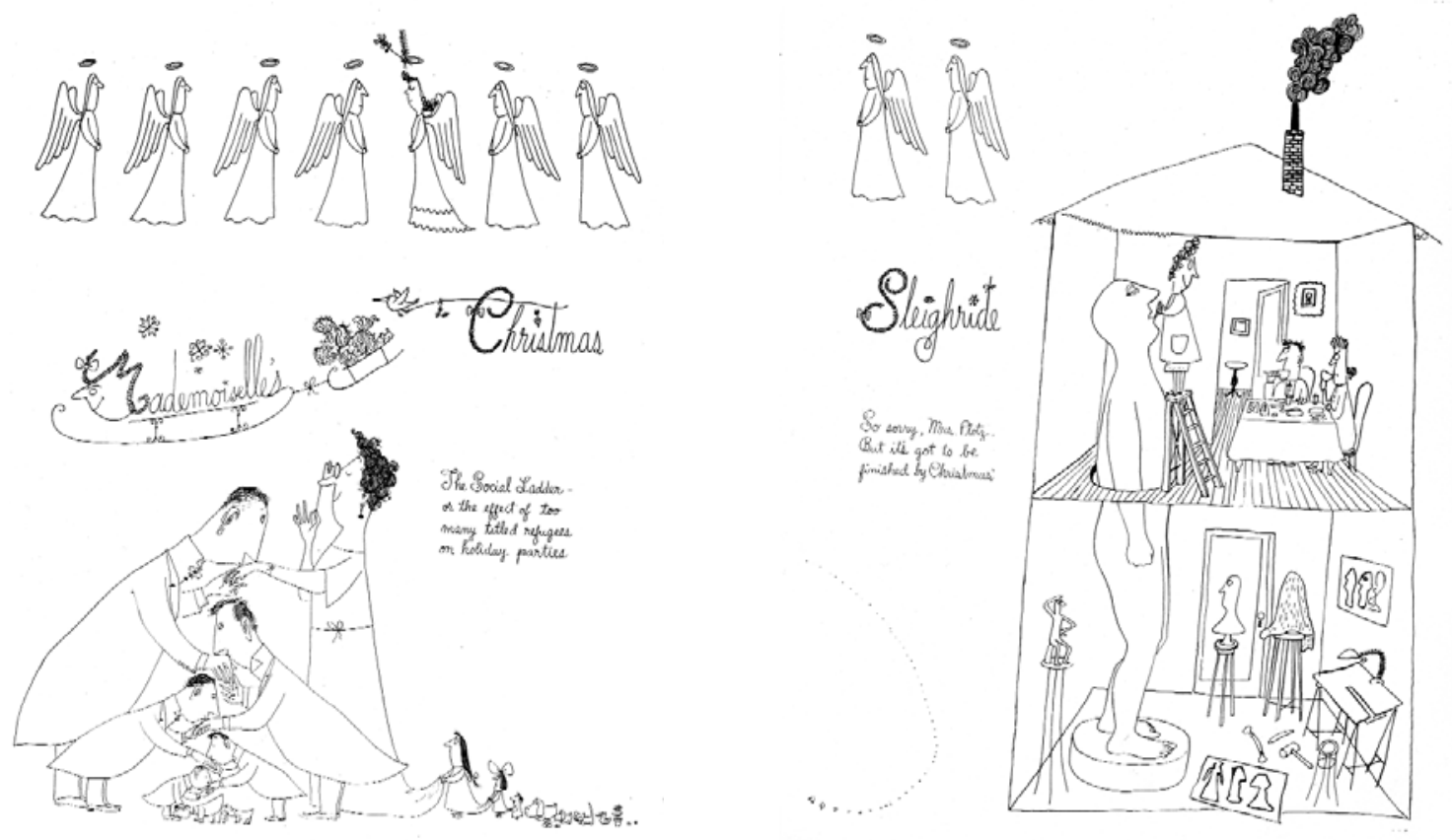

Figura 60. Mademoiselle's Christmas. Mademoiselle, dezembro de 1941, p.114 e 115 

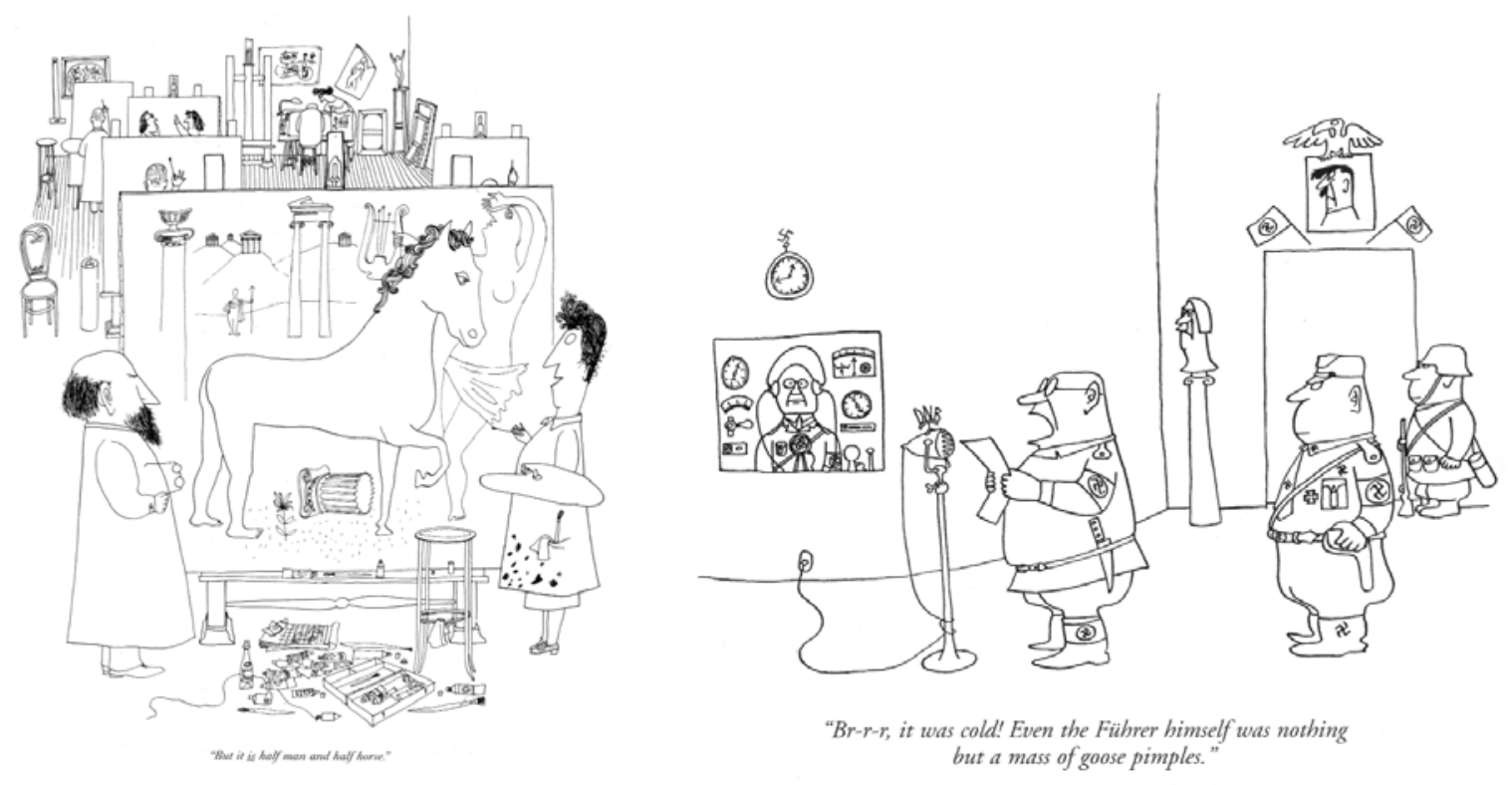

Geraghty teve também severas discussões sobre a contratação de Steinberg com Ross. Para convencê-lo, privilegiou a idéia de considerar o caso como uma oportunidade de investimento, merecedora de um contrato, ao invés de considerações sobre seu drama de refugiado ou o tipo de cartum de guerra que Steinberg vinha desenvolvendo (Smith, 2005, p.16). Nesse período, o editor administrativo da revista Ik Shuman passa a pesquisar o caso da imigração de Saul. Em uma nota emitida na mesma semana que a carta de celebração de Steinberg, em 21 de novembro, Shuman incita Ross e Geraghty a evitar dizer o seguinte para os oficiais do governo: " (...) nós garantimos que trabalhos como estes (de Steinberg) seriam uma violação da lei que pró́be contratos de trabalho para presumíveis imigrantes" (cit. por Smith, 2005, p.18). A proposta de Shuman era comunicar aos oficiais que os editores sentiam que o talento de Steinberg o capacitaria a pegar o trabalho. Tal argumentação ficou comprovada nos vários trabalhos publicados por ele a partir do primeiro semestre de 1942, em seu período de espera pelo visto, como no American Mercury, PM, Liberty, assim como em duas aparições na Mademoiselle e cinco novos cartuns na New Yorker (Smith, 2005, p.18).

Os seis primeiros trabalhos de Steinberg na New Yorker, feitos entre dezembro de 1941 e outubro de 1942, apresentam abordagens variadas. O primeiro, segundo Smith um "descarado recuo às piadas da Bertoldo", diferencia-se dos outros por ainda mostrar um personagem "rechonchudo" dos velhos tempos e um cenário complexo, cheio de detalhes e inserido na perspectiva que desenvolveu na Itália. Já os cartuns seguintes expõem uma clara opção de Steinberg por ambientes mais depurados e personagens mais simples e longilíneos, com nariz saliente pontudo e olhos grandes, sem pupilas. Apesar do segundo cartum publicado ser de humor mudo, ainda é frequente o uso de legendas acompanhando os desenhos. Os temas da guerra também são muito frequentes, com charges sobre os ditadores.

Entre 1941 e 1942, os Civitas introduzem trabalhos de Steinberg na revista de humor argentina Cascabel, importante publicação que durou de 1941 a 1947 (Giunta, website, s.d). 

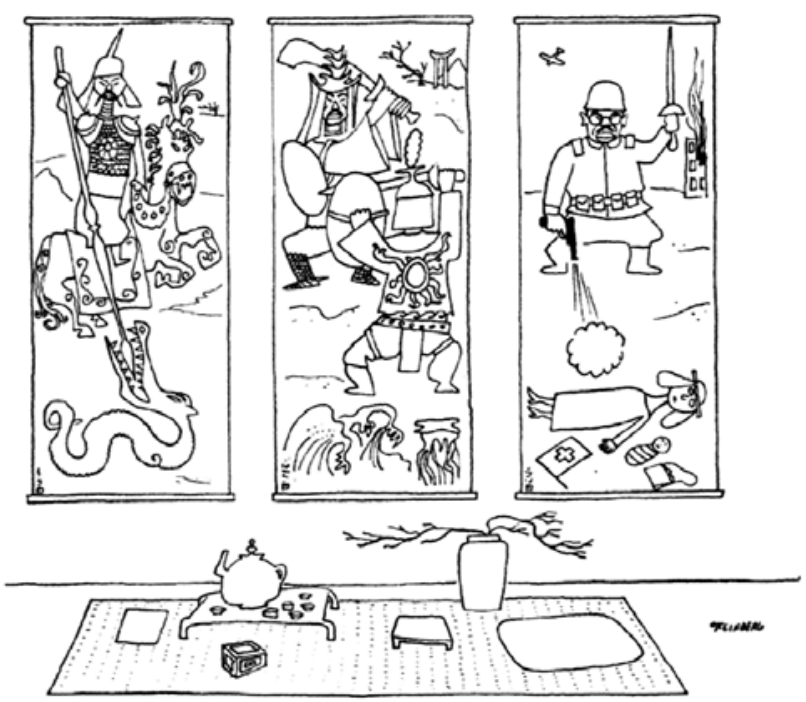

Figura 61. New Yorker, 25 de outubro de 1941

Figura 62. New Yorker, 21 de fevereiro de 1942

Figura 63. New Yorker, 16 de maio de 1942

Opositora do regime de Perón, a revista exerceu um humorismo crítico sobre o novo governo. Politizada, era um contraponto a outra importante publicação argentina do período, a Rico Tipo, que fazia um humor para homens e centralizava suas atenções em figuras femininas provocantes. Em termos políticos a Cascabel havia assumido, para a Segunda Guerra Mundial, uma posição aberta a favor dos aliados. O governo de Perón procurou responder às provocações humorísticas editando suas próprias revistas, como a oficialista $E l$ Descamisado (Matalana, website, p.9). Dirigida por E. Villalba Welsh, a Cascabel teve como colaboradores Carlos Warnes, Conrado Nalé Roxlo, Discépolo, Oski, Ianiro, Landrú, Lino Palacio, dentre outros (Giunta, website, s.d). Alguns destes eram claramente influenciados pelo trabalho de Steinberg.

O artista aparentemente colaborou com a publicação argentina desde as primeiras edições, já que ela se inicia em 1941. Pouco deste material foi documentado. É possível conferir, em alguns de seus trabalhos publicados na revista em 1942, o humor depurado e mudo que vinha sendo trabalhado por ele no período. Há também situações interessantes, de maior integração à página, diferentes dos costumeiros desenhos isolados e blocados em área definida. Em um destes casos, uma construção vertical abriga duas piadas, lembrando um pouco a Panorama dos tempos da Bertoldo, apesar de situada em espaço menos generoso. A área exígua e longilínea para os cartuns promoveu uma solução que explora a verticalidade da construção ambientada na página e que abriga as situações. Os personagens situados do lado de fora do prédio, ao apontarem para o alto, parecem curiosamente chamar a atenção para o bloco de texto adjacente.

Steinberg chegou a produzir, durante sua estadia na República Dominicana, algumas pinturas a guache sobre papelão. Em janeiro de 1942, no final de sua estadia no país, exibiu algumas destas obras na singela Exibição Nacional de Belas Artes. São poucas as que restaram deste período, no entanto. Uma ficou com o próprio Steinberg, e outra foi dada para 
sua prima, Henriquetta. Nessa última, datada de 1941, é empregado um recurso utilizado com frequência nos trabalhos publicados na Itália: "em um quarto estreito, com suas paredes cheias de esquisitices pictóricas, pessoas sentadas posam formalmente, como se fosse para uma fotografia de retrato, ficando atrás uma janela que dá acesso ao mundo exterior" (Smith, 2006, p.84). No caso desta pintura, a cena exterior expõe elementos naturalistas e fantásticos. Segundo Smith, a modalidade efetuada dentro do quarto não é nem realista nem surrealista: "mais sutil, trata-se de um lugar onde a realidade é apanhada no ato de "brincar" com si mesma, originais tentando assemelhar-se com suas representações convencionais". As diversas escalas dos personagens, onde não se sabe bem o que são pessoas e o que são bonecas, e as sombras nos rostos típicas de faces fotografadas, provocam estranhamento. Neste jogo ilusório entre pintura e realidade, a impessoalidade estampada nos rostos de todos os "fotografados", sem distinção entre figuras maiores e menores, ressalta o mistério evocado pelas variadas estaturas. É possível considerar que os dois personagens menores são bonecas dispostas de frente pela menina que está no colo da mãe: "um caso de maternidade imitada em brincadeiras da infância e pessoas imitadas por brinquedos" (Smith, 2006, p.84). Steinberg produziu razoavelmente durante sua estadia na República Dominicana, mas sempre tendo em vista sua ida aos Estados Unidos. Os esforços de todos os parentes, amigos e da revista The New Yorker pareciam estar surtindo efeito. Em maio recebeu o visto, mas as possibilidades de transportes estavam escassas. (Smith, 2006, p.253). Em junho de 1942, o artista finalmente voou de Santo Domingo para Miami, na esperança de ser recebido por um mercado promissor (Smith, 2005, p.18).

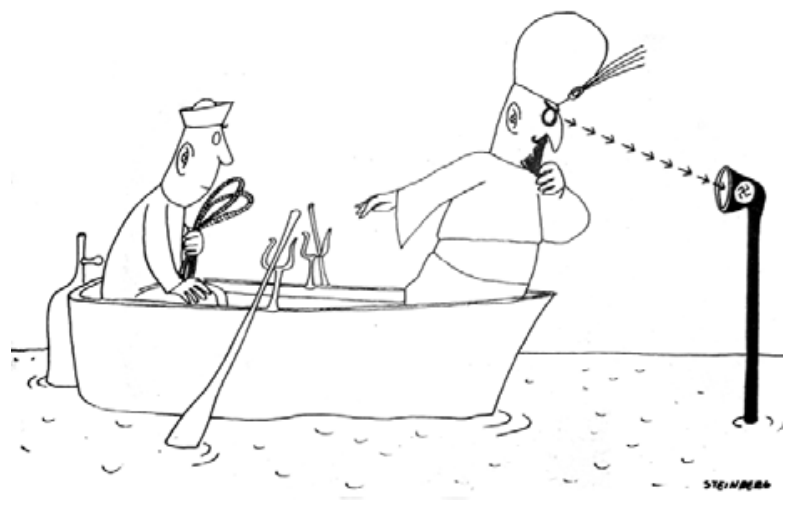

Figura 64. Cartum de Steinberg publicado na Cascabel, 1942

Figura 65-66. Capas da Cascabel, anos 1940

Figura 67. Página da Cascabel com cartuns de Steinberg, 1942
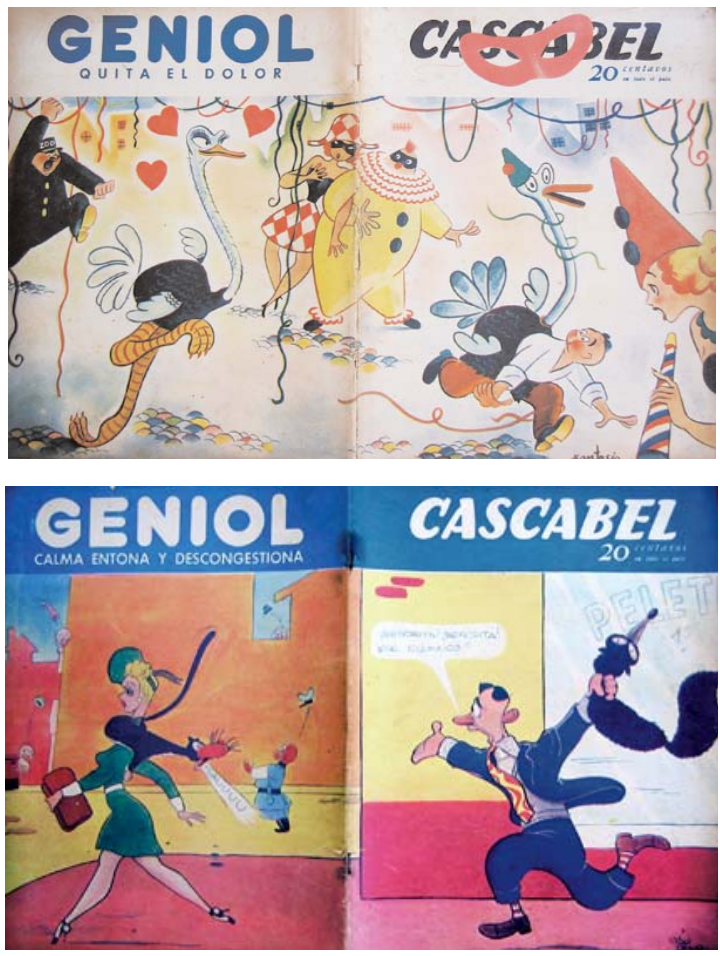

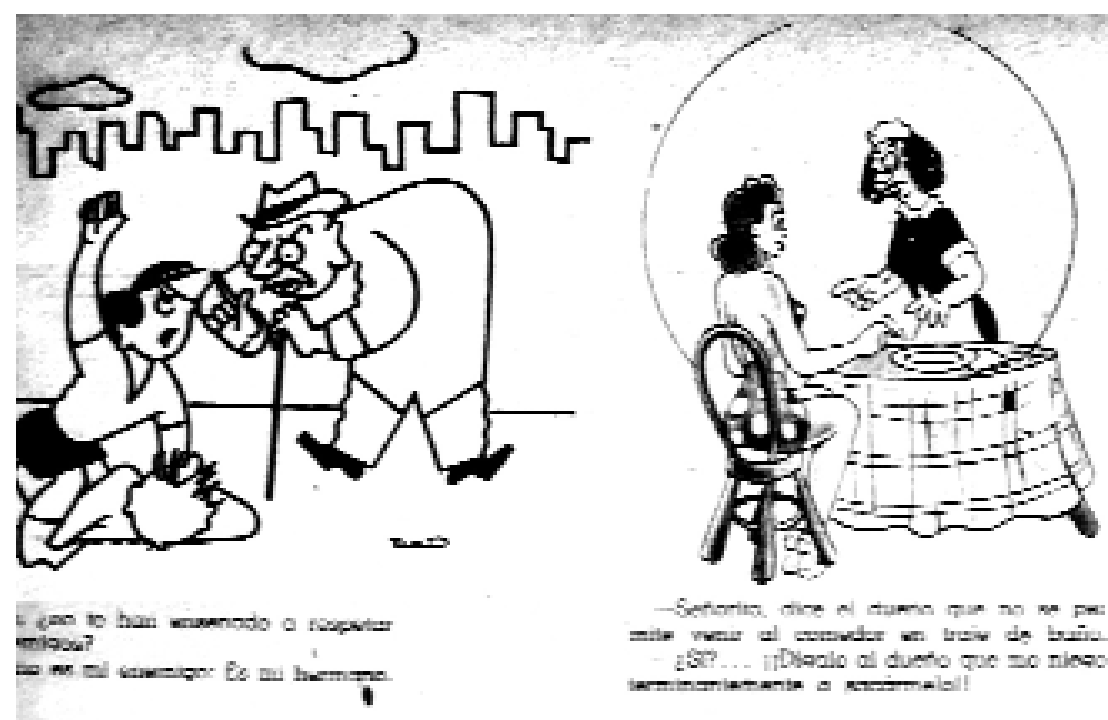

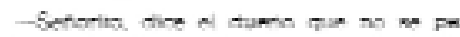

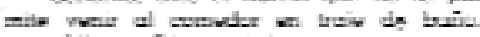

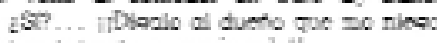

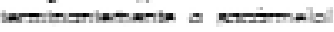

\section{¿QUE TAL LE SIENTAN A USTED LOS ADORNOS DE SU MUIER?}

1 espetbirulo de un sunur serio y resprtable scompofiede pere uns sethor: ubiurta mon uno funda de piel de

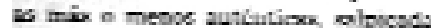
vidricu de colores $y$ eurmads con

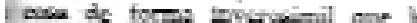
Alurun nomo el últims vriba on ner ins. wa slgo goe ab por limenemte

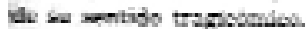

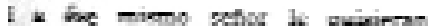
dor un sombrers colorbdo yer le

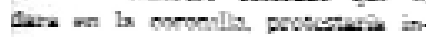

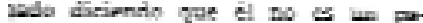
2. Rurs die relover mancr. dobi

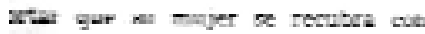

uns decornción gut mind al diablo todi b supoesta sericted de gre ef hace gala

La trapudix reside en el maigradio apuante dal minr seno our mo tiene ntro remedis quo mmeterse i lo "rir revis" de sr mujer. o ermar una so-

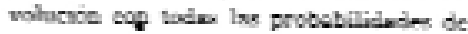
perdarts

Lo comies witi en el fentivenco aduers

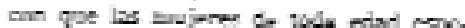
ral comparer la ulmimaio de ka hor bees y dvjar s los ocros mupers a lo alurn of une iechele
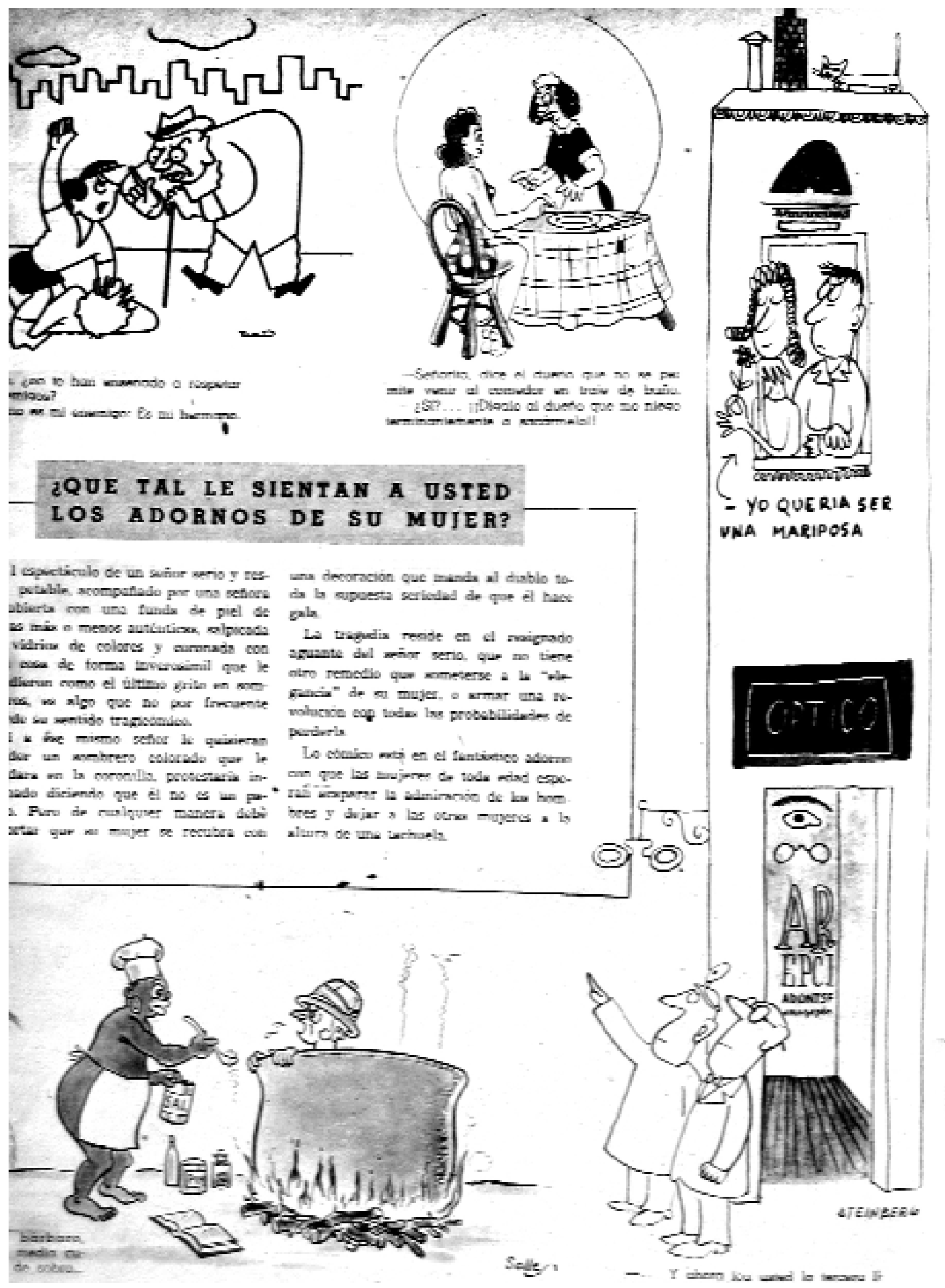


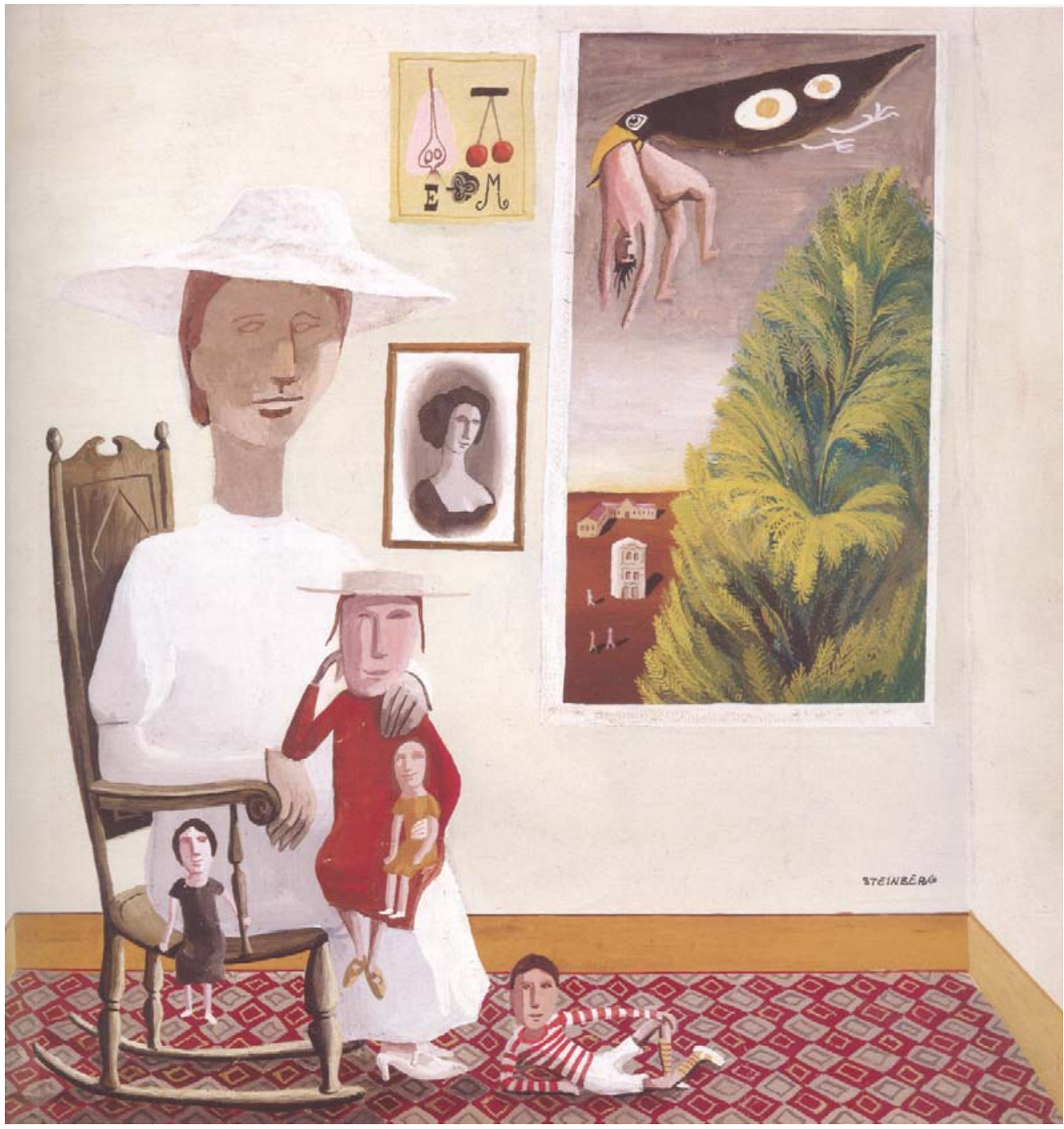

Figura 68. Untitled (Seated Group), trabalho a guache feito por Steinberg na República Dominicana, 1941 


\section{STEINBERG NOS EUA E NA GUERRA: $O$ DOCUMENTARISTA VISUAL}

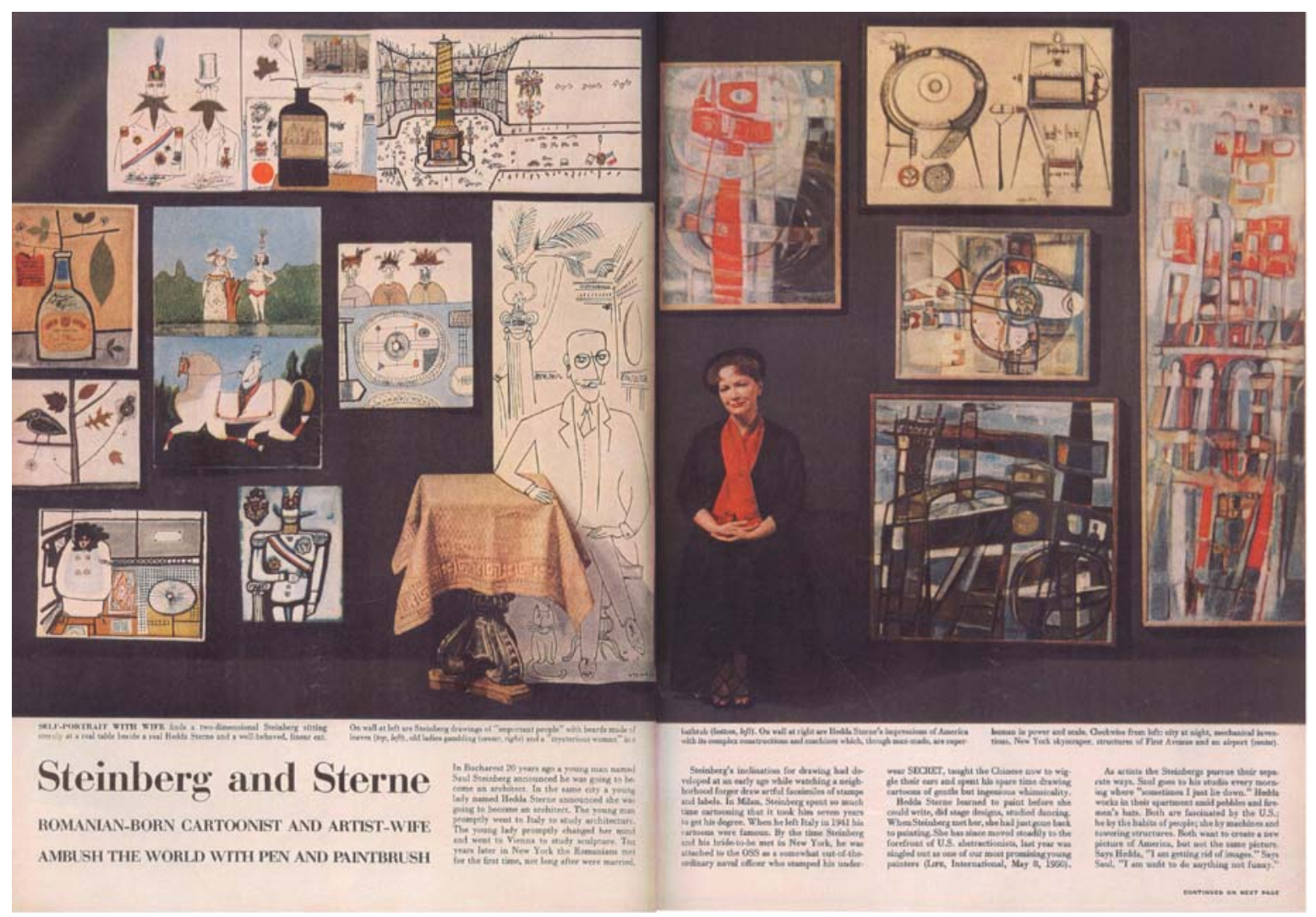

Figura 69. Página dupla de abertura de artigo na Life. Steinberg and Sterne, 1951

Finalmente em posse de seu visto, Steinberg chega aos Estados Unidos como imigrante em julho de 1942, aportando em Miami. Segue da Flórida para a primeira de suas inúmeras viagens de ônibus pelo país, rumo a Nova York - uma sugestão de Einstein (Smith, 2006, p.30). $\mathrm{Na}$ viagem, aprecia a vista da paisagem americana. Como observa Hughes, ele havia chegado ao seu exílio definitivo (Hughes, 1978). "Imediatamente, se sente em casa. Fica impressionado com a mulher americana, especialmente as de "meia idade, gordas, que ficam comendo nas cafeterias sempre um pedaço de pão, sempre sorridentes". (Time, 1943, p.79). O jovem artista se apresenta pleno de confiança. Quando atinge o solo americano, já é um dos favoritos da New Yorker. Recorda que quando chegou à sua terra, a primeira pergunta que tinha em mente para fazer às autoridades era: "Onde estão os repórteres?" (cit. por Gill, s.d., p.5).

Apesar do conforto de um emprego regular, quatro anos imersos em papeladas burocráticas e incertezas o convenceu de que seria conveniente tentar a cidadania americana. O caminho mais imediato para o passaporte era o serviço militar. Como era míope e corria o 

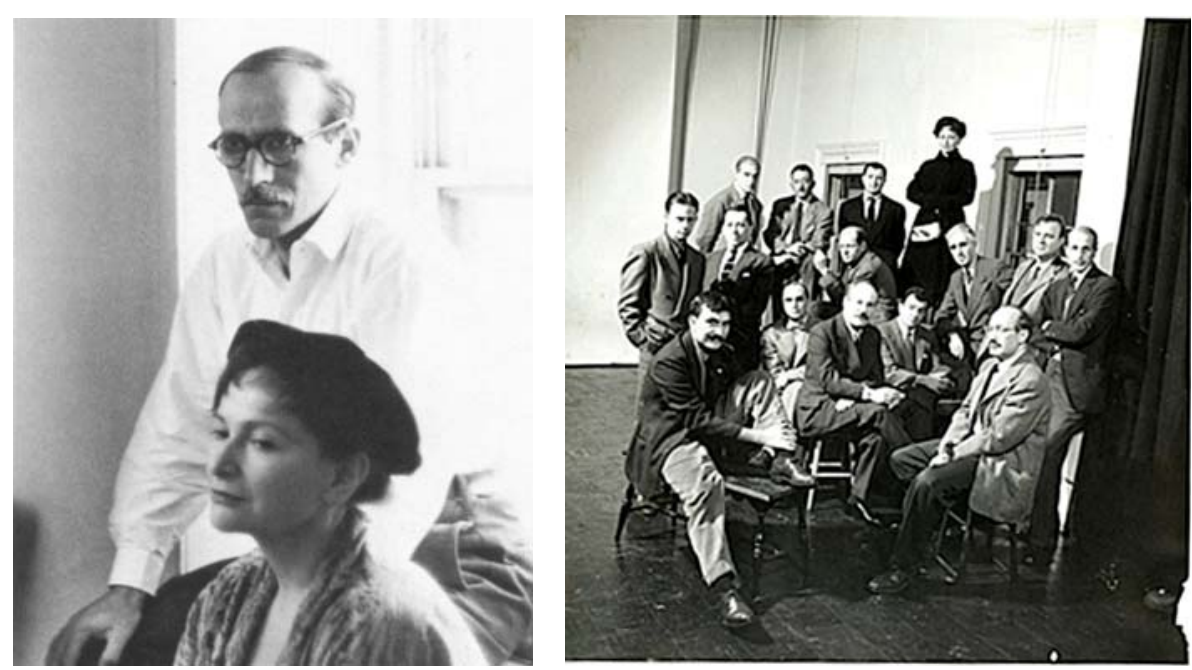

risco de não ser aceito, recebeu ajuda de Harold Ross, que entrou em contato com amigos próximos influentes, como Elmer Davis (OSS), diretor do Escritório de Informação de Guerra, e William J. Donovan do Escritório de Serviços Estratégicos (OSS). A estratégia consistia em arranjar para o artista um trabalho com propaganda que poderia ser adequado a suas habilidades, permitindo a ele se manter desenhando para a revista (Smith, 2006, p.30). No dia 24 de agosto de 1942, é classificado como I-A, tornando-se disponível para imediato serviço militar. Logo em seguida, em novembro, o artista é empregado no Escritório de Informação de Guerra, Divisão Gráfica, em Nova York Naquela altura, suas habilidades como propagandista já haviam sido colocadas à prova em uma mostra coletiva de cartuns anti-Eixo, aberta em fevereiro na Art Studantes League, sendo posteriormente - após turnê pelo país - exibida com o nome de Cartoons of Today no The Metropolitan Museum of Art de Nova York (Smith, 2006, p.253).

Uma vez na metrópole americana, Saul se estabeleceu no Hotal Lafayette, situado no University Place, na 9th Street (Smith, 2006, p.254). Steinberg não chegou à desafiadora Nova York totalmente desamparado, e logo teve acesso a alguns círculos sociais e de amigos, constituídos por "três frentes", segundo Joel Smith. A primeira, relativa ao amigo milanês Constantino Nivola, um antigo designer editorial da Olivetti que havia chegado aos Estados Unidos com sua esposa, Ruth Guggenheim, em 1939. O carismático Nivola congregava pessoas e grupos por meio de sua condição de diretor de arte da moderna revista Interiors; tinha também um estúdio na East 8th Street e uma mesa permanente na Del Pezzo. Este era um restaurante italiano próximo ao Rockefeller Center, onde Nivola apresentava os artistas, arquitetos, escritores e designers - americanos e imigrantes - uns aos outros. Em segundo lugar, a associação de Steinberg à revista New Yorker o inseriu em um outro meio, onde fez rapidamente amizade com Geraghty, Charles Addams, William Steig, dentre outros. Em terceiro lugar, o artista conheceu Hedda Sterne, sua futura esposa. Em seu círculo de amizades estavam grandes artistas imigrantes, como o arts impresario Peggy Guggenheim, o arquiteto Frederick Kiesler, os artistas plásticos Arshile Gorky, Hans Hofmann, John Graham, dentre 


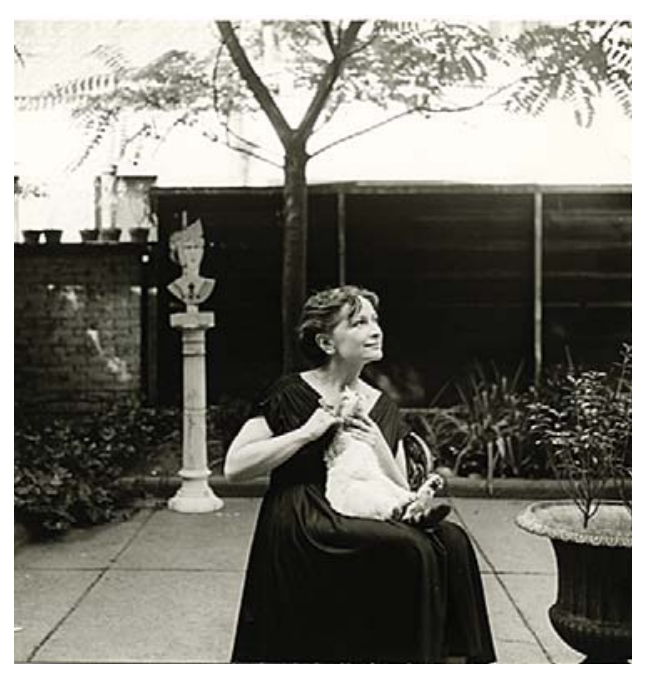

Figura 70. Steinberg e

Hedda, anos 1940

Figura 71. Steinberg e a

New York School.

Figura 72. Hedda

Sterne, 1940

outros. Sendo assim, os diferentes meios que viriam a definir a vida americana de Steinberg nas seis décadas seguintes, relacionados ao design e arquitetura, à intelligentsia das revistas, e à chamada New York School - um grupo informal de poetas, pintores e músicos ativo entre os anos 1940 e 1960, envolvidos com jazz, expressionismo abstrato, música e arte de vanguarda - estavam constituidos desde seus primeiros meses na cidade (Smith, 2006, p.30).

Steinberg se casa, em outubro de 1944, com Hedda Lindenberg Sterne. Conheceu-a em 1943, após aceitar um convite para tomar chá no estúdio do apartamento da então "fã", na East 50th Street (Smith, 2006, 30). Hedda havia convidado o desenhista para o encontro após ficar admirada com seus desenhos publicados na revista Mademoiselle. Depois de imediata afinidade, passam a ser corresponder, período em que ela se divorcia de seu marido (Smith, 2006, p.253). Logo os dois passam a viver juntos no apartamento de Hedda. Assim como Steinberg, Sterne nasceu na Romênia, em Bucareste, e também resolveu cursar arquitetura. Enquanto o cartunista foi para a Itália, Hedda mudou de idéia e foi a Viena estudar escultura, dez anos antes dos dois romenos virem a se encontrar pela primeira vez em Nova York. Quando Steinberg a conheceu, ela havia acabado de voltar à pintura, depois de passar por Paris, Londres, e ter feito cursos de design e dança. Após pisar em Nova York em 1941, Hedda viria, desde então, "se mover em direção à vanguarda dos expressionistas abstratos americanos", observa a revista Life em artigo sobre o casal publicado nos anos 50, época em que Sterne recebeu maior prestígio (Life, 1951, s.p ).

Impressionada com as vastas proporções de Nova York, com seus contornos e poder mecânico, Hedda sentiu que deveria desenvolver um modo pessoal de expressar estas formas e forças. Deste modo, se voltou para temas como projetos de engenharia e máquinas de guerra, aeroportos e ruas de cidade (Life, 1951, s.p). A artista, no entanto, aborda o assunto de modo diverso da exaltação futurista; olha para seu modelo, a máquina, como uma personagem a ser pesquisada, a ser compreendida em seu conjunto. Um artigo publicado na revista brasileira Habitat sobre sua obra, também na década de 1950, sugere influências de Gorki, de Pollock, de Matta Etchaurren e até do maquinismo do italiano Munari (Habitat, 1952). 


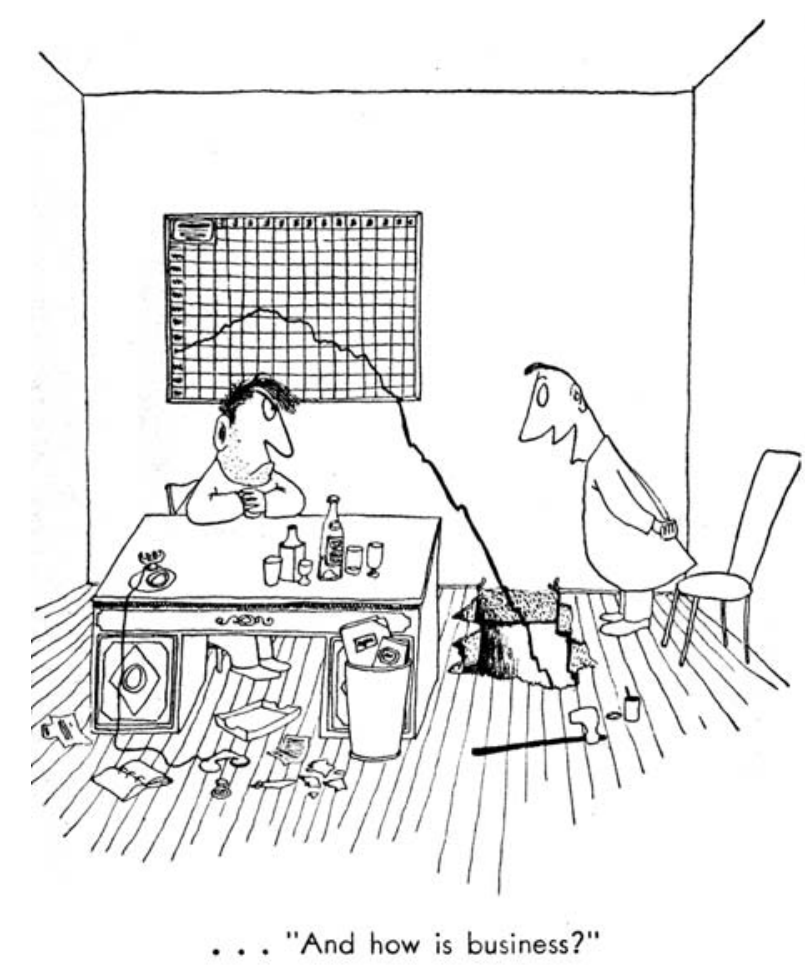

Figura 73. ...And

how is business?, publicado no All in Line. O cartum aparece em artigo da Time, de 1943, sobre a exposição na Wakefield Gallery.

Por fim, no artigo da Life, o casal recebe uma análise do conjunto de suas obras que os aproxima em sua condição de imigrantes recém-chegados: "Ambos estão fascinados pelos Estados Unidos; ele, pelo hábito das pessoas; ela, pelas máquinas e estruturas de construção. Ambos querem criar um novo retrato da América, mas não o mesmo retrato". Enquanto Hedda diz estar ficando livre das imagens, Saul conclui: "sou inepto a fazer qualquer coisa que não seja engraçada" (Life, 1951, s.p).

Com uma saída estável de desenhos para a New Yorker e o jornal PM, Steinberg parte para uma viagem de trem de costa a costa do país, de Chicago a Los Angeles, retornando via Arizona e Texas. Queria ver os estúdios da Disney e MGM em operação, ou mesmo o Oceano Pacífico (Smith, 2006, p.253). "Não se compara dirigir a ter esta vista da cabine de dormir. A janela é como uma tela. Chegar com o apito do trem no Arizona e ver os índios na estação, mesmo diante do fato deles não terem penas - era o que eu esperava!" (cit. por Hughes, 1978, p.51). Robert Hughes analisa, em artigo dos anos 1970:

Tudo isso era, em parte, um balé de faz-de-conta e esteótipos. A América de Steinberg, como confirmada nesta viagem, provou ser tanto uma invenção quanto era na obra Mahagonny de Bertold Brecht: horizontes planos isolados ou interrompidos por grandes plataformas - as denominadas "mesas" do sudoeste dos Estados Unidos -, cinemas em forma de palácios rococó-Art Déco; as faces tubulares, duras e metálicas dos empresários do Meio-Oeste e suas massivas mas decaídas esposas, olhando inexpressivamente através do aro de seus óculos; (...) garotas de pernas compridas e caubóis se balançando em seus altos sapatos, que lembram pernas-de-pau. Os desenhos testemunham à América a inexprimível estranheza nos olhos de um jovem europeu que ainda não podia falar em inglês. (Hughes, 1978, p.51) 
Enquanto estava em sua viagem de costa-a-costa na Califórnia recebe, em janeiro de 1943, um aviso para se dirigir à junta de recrutamento. Depois de retornar para o leste do país, recebe em 20 de fevereiro a cidadania americana e uma insígnia da Marinha (US Naval Reserve). Uma vez admitido no país, Steinberg se vê novamente em um uniforme, desta vez o de oficial naval (Rosenberg, 1978, p.14). Estabelece-se, neste período, em Washington, apresentando-se para o treinamento da Inteligência Naval como um artista do Combate Psicológico (Psychological Warfare artist) (Smith, 2006, p.253). Apesar de todas estas mudanças repentinas, Steinberg consegue manter o seu cronograma de publicações.

Durante os preparativos em Washington, Steinberg tem uma exposição dupla com o amigo Nivola organizada por sua futura agente, Betty Parsons (Smith, 2006, p.30). Intitulada Desenhos em cor por Steinberg, Pinturas por Nivola, a mostra estréia em 12 de abril de 1943, na Wakefield Gallery - uma galeria/livraria onde Parsons era empregada -, em Manhattan, Nova York (Smith, 2006, p.253). O artista estava para ir à guerra, mas deixava em terras americanas uma quantidade significativa de trabalhos para prepará-lo para uma posterior carreira no pós-guerra. Na exposição, trabalhos em aquarela, têmpera e linha (Time, 1943, p.79). Um dos trabalhos expostos é o cartum And How is Business?, em que explora de modo precoce - ainda que em um desenho pouco maduro - um recurso de ilusão gráfica. Uma resenha, publicada em 26 de abril daquele ano pela revista Time sobre sua mostra, deixa transparecer algumas das impressões, algo surpeeendentes, de Steinberg sobre o meio editorial americano:

Steinberg sente que os Estados Unidos não tem, de fato, uma realmente boa revista de humor, pensa que a New Yorker é muito erudita para toda a nação. Seu próprio tipo de humor atinge gostos de todos os gêneros. Ao se alistar na Marinha dos Estados Unidos em janeiro deste ano, ele recebeu uma comissão para o mês seguinte. Hoje, Steinberg está em Washington, esperando para navegar além-mar. (Time, 1943, p.79).

Steinberg na Guerra: o desenho "seco" e seletivo de documentação

Anexado à 14th Força Aérea, parte em maio de São Francisco para missões em outros territórios: Wellington (Nova Zelândia), Perth (Australia), Colombo (Ceilão). Em 16 de julho de 1943, é enviado ao remoto Happy Valley, próximo a Kunming, no oeste da China, como "observador do tempo", mesmo tendo escasso conhecimento de metereologia (Hughes, 1978, p.52) e sendo fluente em várias línguas (Smith, 2006, p.30). Steinberg integra-se à Organização Cooperativa Sino-Americana (Sino-American Cooperative Organization SACO), que operava sob a vigilância da Marinha e da OSS. Além de retransmitir previsões do tempo para o Pacific Theater, treina sabotadores nativos contra os japoneses (Smith, 2006, p.31) e ensina a guerrilha chinesa a explodir pontes. Durante um ano voou pelo montanhoso 
Figura 74. Steinberg em Kunming.

Figura 75. E Pluribus Per Diem (SACO Warrior), 1943. Tinta e aquarela sobre papel.

Figura 76. Livro de instruções para os soldados da O.S.S., 1943
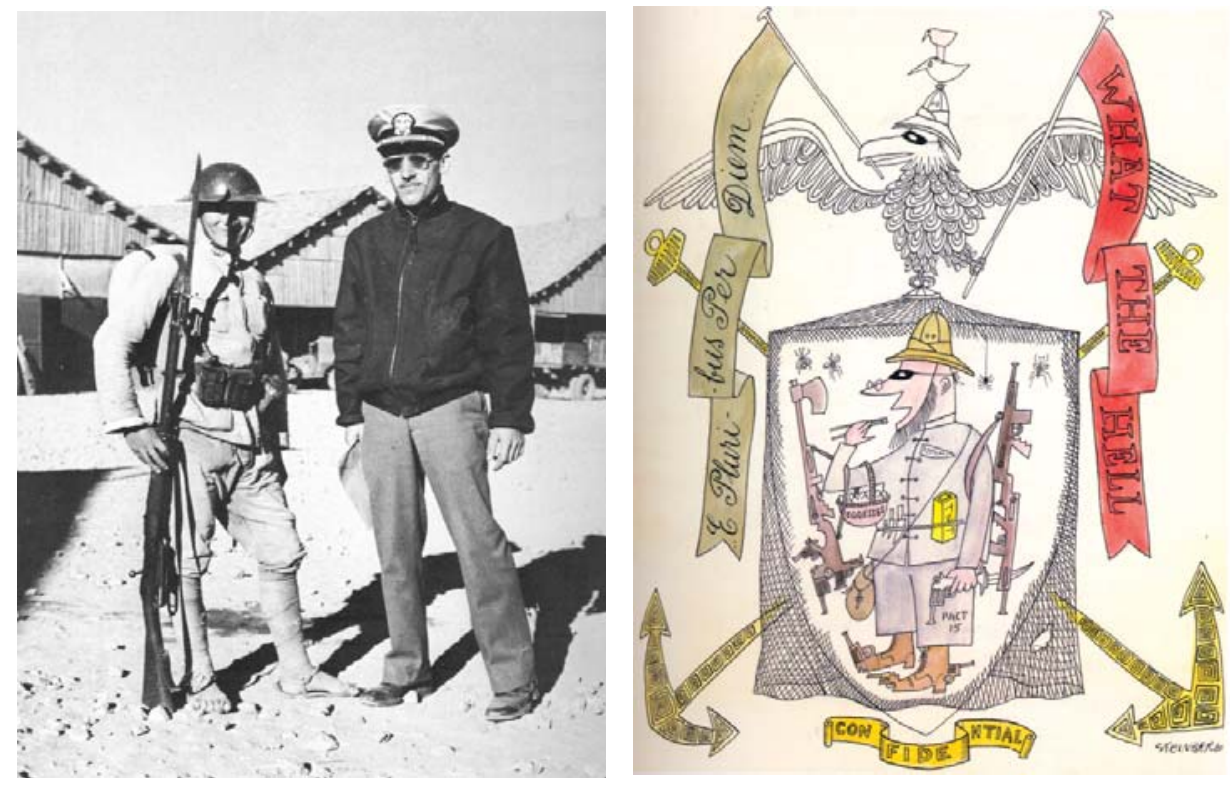

trajeto conhecido como "a Corcova", entre a China e a Índia, para conferir se os explosivos chegavam a suas destinações (Boxer, 1999, s.p). Por fim, chegou a ilustrar uma irônica brochura de informações para o pessoal fixado na China, e elaborou um brasão pouco amedrontador para a SACO. Steinberg desenhou muito no tempo livre também, e sobre qualquer tipo de superfície, como sugere um de seus desenhos em que anota o modo como inseriu imagens em paredes, interagindo com elementos do quarto (Smith, 2006, p.31). Steinberg fez desenhos entusiamados em um livreto de vinte páginas que escreveu e ilustrou para a O.S.S. em 1943. Era um livro de instrução para soldados americanos que estavam para fazer o mesmo vôo sobre a Corcova (the Hump), "rumo a um lugar onde os locais eram capazes de espreitar sobre a janela olhando para os pêlos de seu corpo e considerar seu jipe na estrada como um espírito demoníaco em perseguição" (Kramer, 2000, p.59). Existe a suposição, de parte do crítico Harold Rosenberg, de que a presença de Steinberg na China era justificada, apesar do problema da língua, por suas habilidades artísticas. Sua verdadeira missão seria a de auxiliar na comunicação com a guerrilha chinesa através de sua habilidade de dizer coisas por meio de desenhos. O problema, como notou Steinberg em certa ocasião, é que a boa comunicação feita com os chineses não se estendia aos americanos, já que não sabia falar bem em inglês. Sua bem-humorada teoria sugere que a missão era a de confundir os agentes da inteligência inimiga, obrigando-os a imaginar o que aquele forasteiro estava fazendo na marinha americana na China (Rosenberg, 1978, p.14).

Uma fase menos esdrúxula, mas ainda inusitada, aparece em seguida. Em 1944, Steinberg se vê livre da Marinha, sendo transferido para Cairo, Algiers, Nápoles e Roma. Essa transferência é feita por William Donovan, diretor do Escritório de Serviços Estratégicos. O artista finalmente assume tarefas mais apropriadas ao seu perfil e condizentes com seus compromissos com a propaganda, na Operação Morale (Smith, 2006, p.31). A 


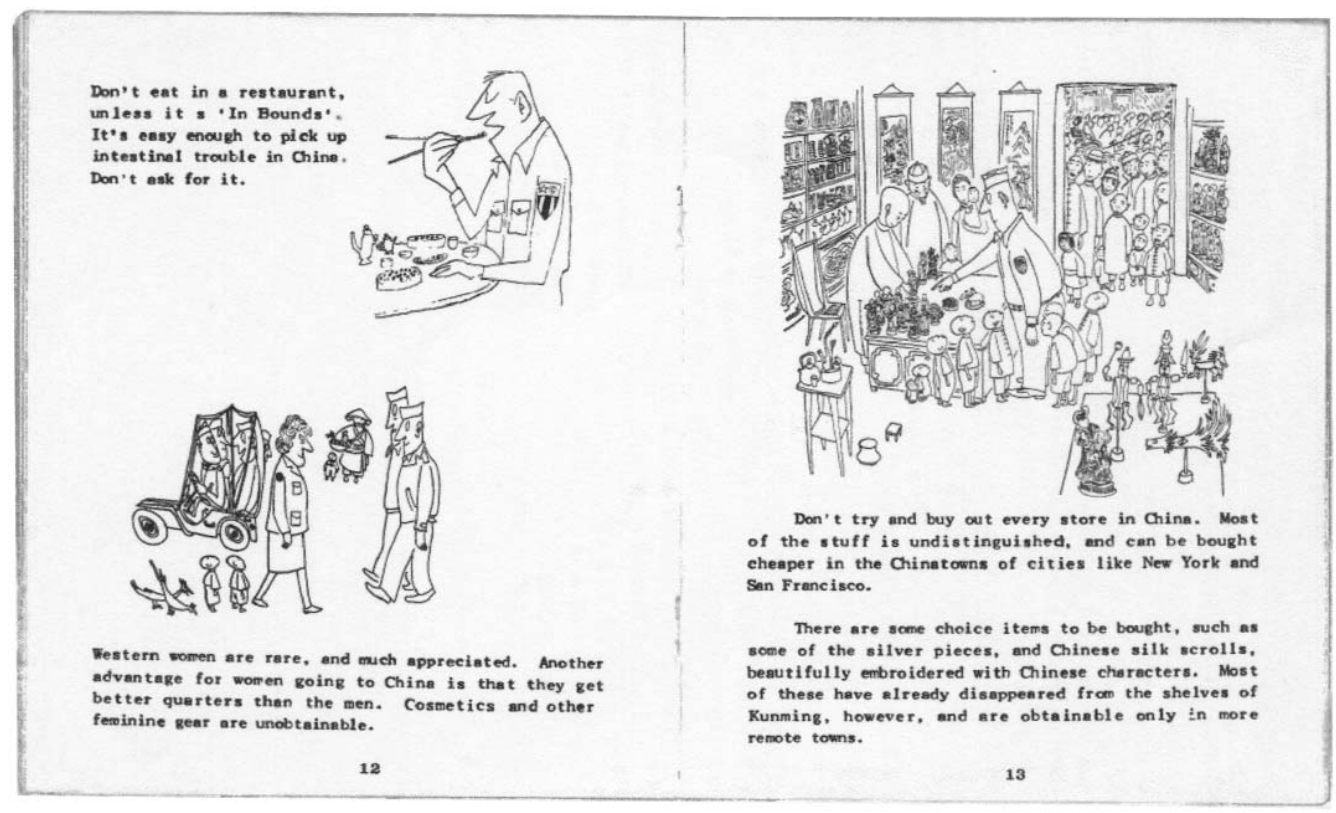

finalidade de Steinberg é desenhar cartuns para inspirar resistência antinazista dentro da Alemanha (Boxer, 1999, s.p) e pelo continente. Deste modo, Saul se manteve "desenhando travestis de Mussolini, Himmler e Hitler", um pouco mais ferozes no tratamento do sombreado de suas expressões do que nos cartuns publicados na PM (Smith, 2006, p.31). O artista cria imagens assustadoras de Hitler com crânios escondidos atrás, e da face deformada de Mussolini com um dos olhos pulados para fora. Em um cartum, "Benito e Adolf - dançarinos arianos", Mussolini e Hitler aparecem lutando seminus (Boxer, 1999, s.p). Steinberg fez, além de cartuns, cartões-postais, flyers, capas para folhetos com músicas. Para assinar os trabalhos, não precisava usar nomes falsos e apelidos, uma vez que não se envolvia em serviços comprometedores, utilizando costumeiramente o "Lieutnant Steinberg UNSR".

Estes desenhos eram deixados atrás de linhas inimigas e impressos em jornais falsos, que se faziam passar por publicações inexistentes dos movimentos de resistência alemães e italianos. O Das Neue Deutschland (A Nova Alemanha), organizado pelo escritório da Operação Morales em Roma, trazia uma chamada que dizia: "Este jornal alemão caiu nas mãos dos Aliados durante a ocupação de Paris". A esperança era a de que o público alemão acreditasse que um partido de oposição alemão de dentro do Reich promovesse a publicação. Joel Smith observa, neste período, sinais contundentes de um precoce envolvimento de Steinberg com as questões do estilo como linguagem e disfarce. O artista assume, em determinado momento, o papel de um propagandista americano disfarçado de alemão, adotando a persona gráfica de um agitador alemão amador, de estilo expressionista. Um tipo especial de arte-espiã, que pedia "sobriedade e especificidade estilística" (Smith, 2006, p.32).

Desde seu período inicial na China, passando por sua jornada no Norte da África via Calcutá e seus meses de serviço na ocupada Itália, foram produzidos dez portifólios de desenhos que apareceram periodicamente na The New Yorker em 1944 e1945. Como observa 

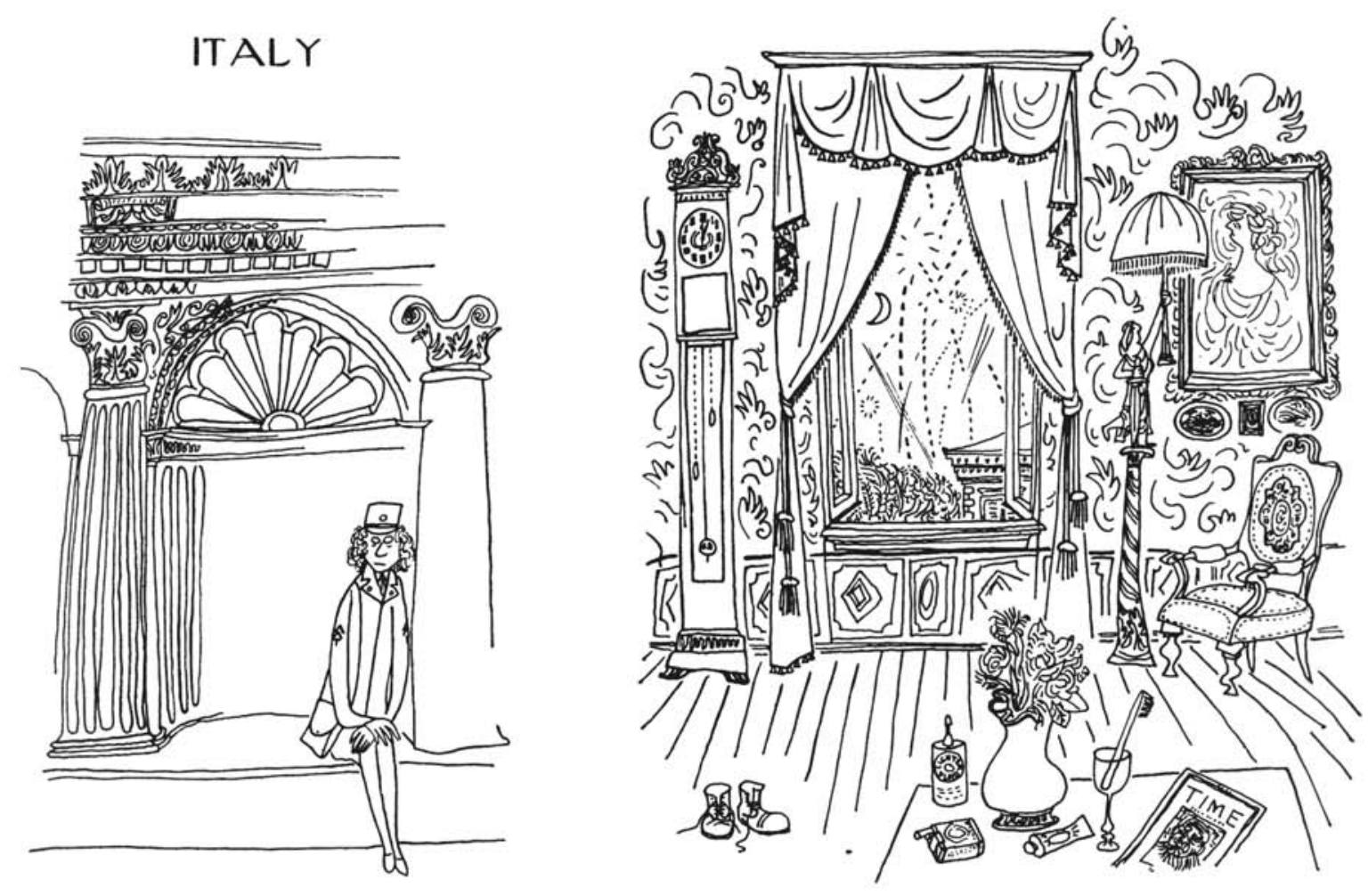

Ack-ack through open window

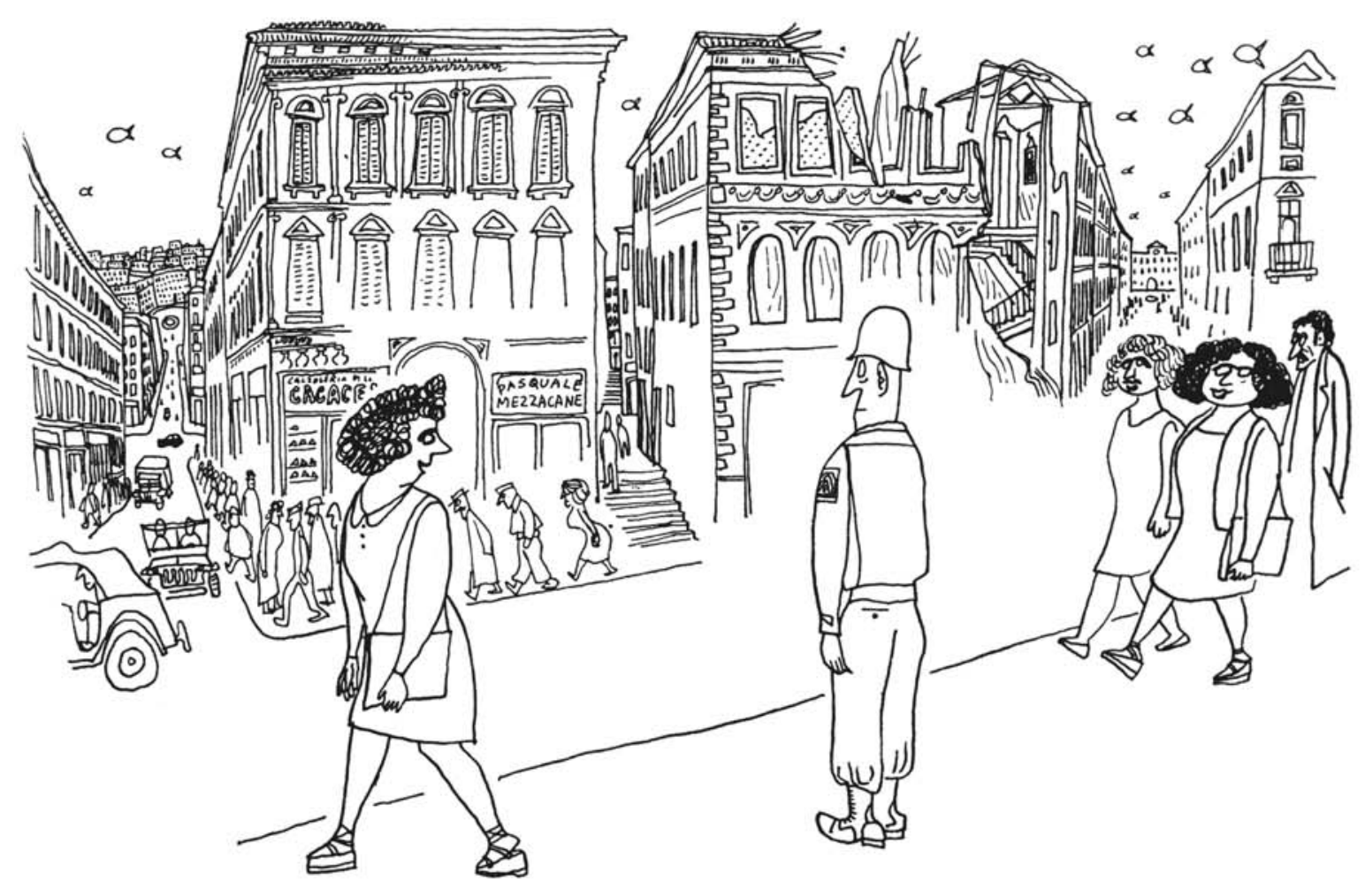



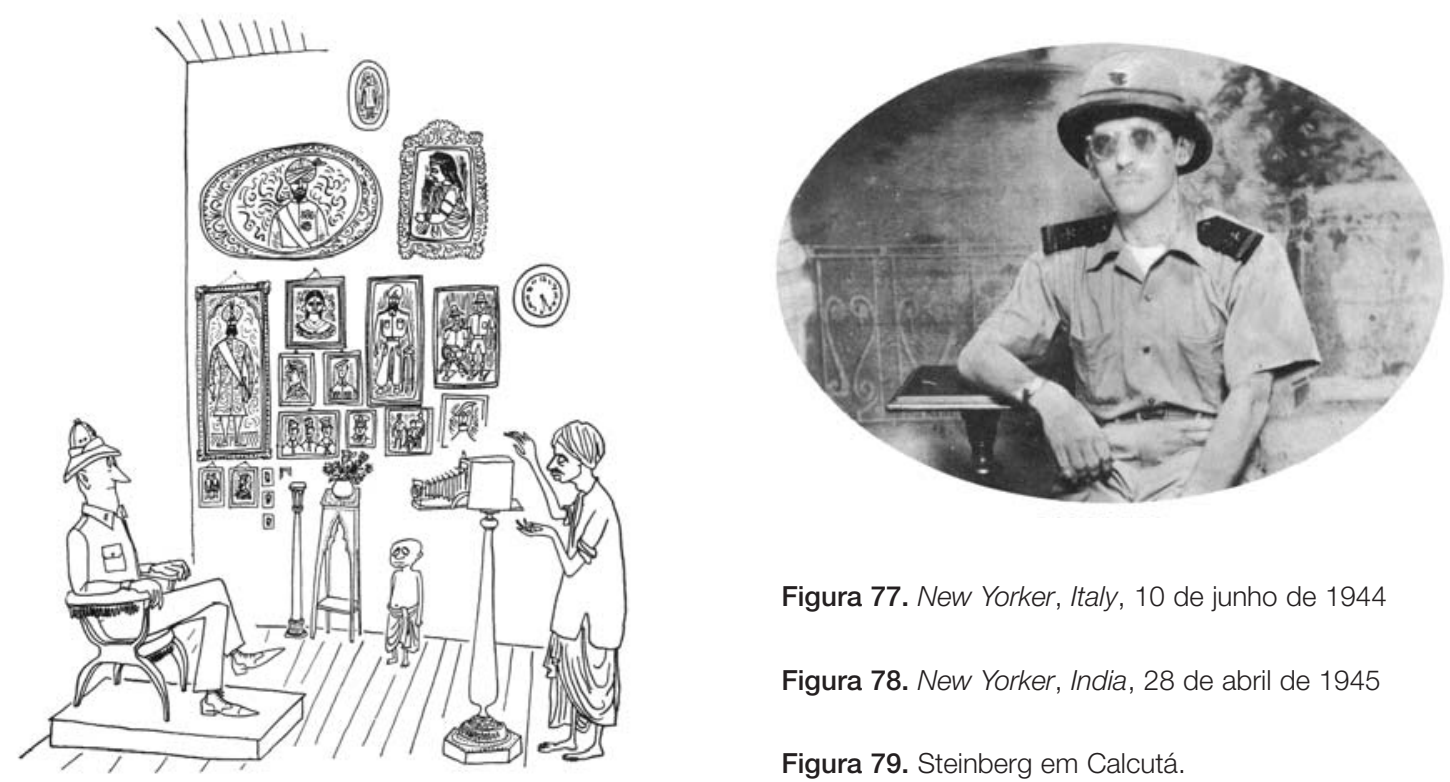

Figura 77. New Yorker, Italy, 10 de junho de 1944

Figura 78. New Yorker, India, 28 de abril de 1945

Figura 79. Steinberg em Calcutá.

Joel Smith, "os sessenta e nove desenhos cobriram vinte páginas inteiras, constituindo-se na maior contribuição para a cobertura de guerra da revista e fortalecendo a reputação de Steinberg" (Smith, 2006, p.31).

Em setembro de 1944, Steinberg recebe ordens para retornar via Norte da África para Washington D.C., para se reapresentar no escritório da OSS da capital americana (Smith, 2006, p.254). Ali, deu uma entrevista interna sobre as Operações Morale. De volta aos Estados Unidos, passa a transitar entre Nova York e Washington até o final de 1945, quando suas obrigações terminam (Smith, 2006, p.32). Estas viagens eram feitas de trem, em um uniforme de tenente. Logo após sua volta, casa com Hedda Sterne em outubro, em Nova York, e passam a viver juntos no pequeno apartamento-estúdio da esposa, situado na cobertura de um edifício localizado na East 50th Street. Ali, morariam até 1952 (Smith, 2006, p.254).

Quando a guerra acaba, em 1945, Steinberg retorna às suas ocupações favoritas: desenhar e viajar, uma coisa alimentando a outra (Hughes, 1978, p.52). Em janeiro daquele ano, sua primeira capa é publicada nos Estados Unidos para a New Yorker, sobre a viagem à China no período de guerra. O cartunista passa a reunir a sua primeira coleção de desenhos, já planejando uma publicação. Nesse período, Victor Civita havia fechado um contrato de um livro com Duell, Sloan \& Pearce, editores dos livros do cartunista William Steig, colaborador da New Yorker. O título inicial, Everybody in Line, se consolidou em uma primeira noite social no começo de 1945, com a presença de Steig, Geraghty, e outros. Na mesma semana, entre 26 de abril e 2 de maio, vários fatos marcantes ocorreram, como bem observa Joel Smith: no diário de Steinberg é anotado que o All in Line - já com o título definitivo - seria lançado em junho; que Mussolini e Hitler estavam mortos; e no dia seguinte, que Steinberg estava demitido da OSS (Smith, 2006, p. 32).

Em 1945 o livro é publicado, com desenhos dos tempos de guerra, feitos a partir de observações das diversas localidades visitadas: China, Índia, norte da África e Itália (Rosenberg, 1978, p.237). All in Line se tornou rapidamente um bestseller, elevando 

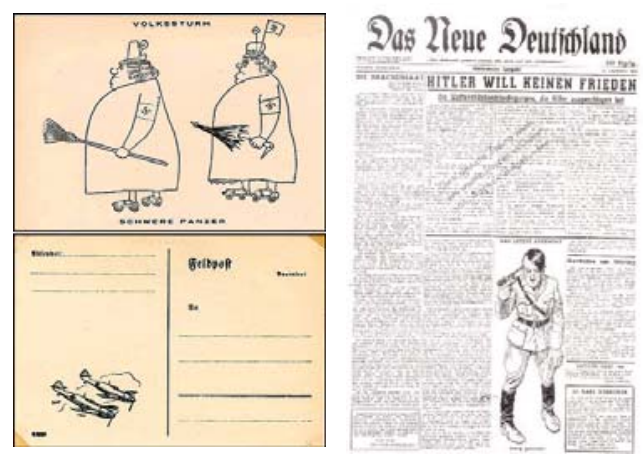

Figura 80. Cartão com ilustrações de Steinberg.

Figura 81. O jornal falso Das Neue Deutschland.

Figura 82. Der Schuldige (O Culpado), publicado no Das Neue Deutschland, 26 de julho de 1944

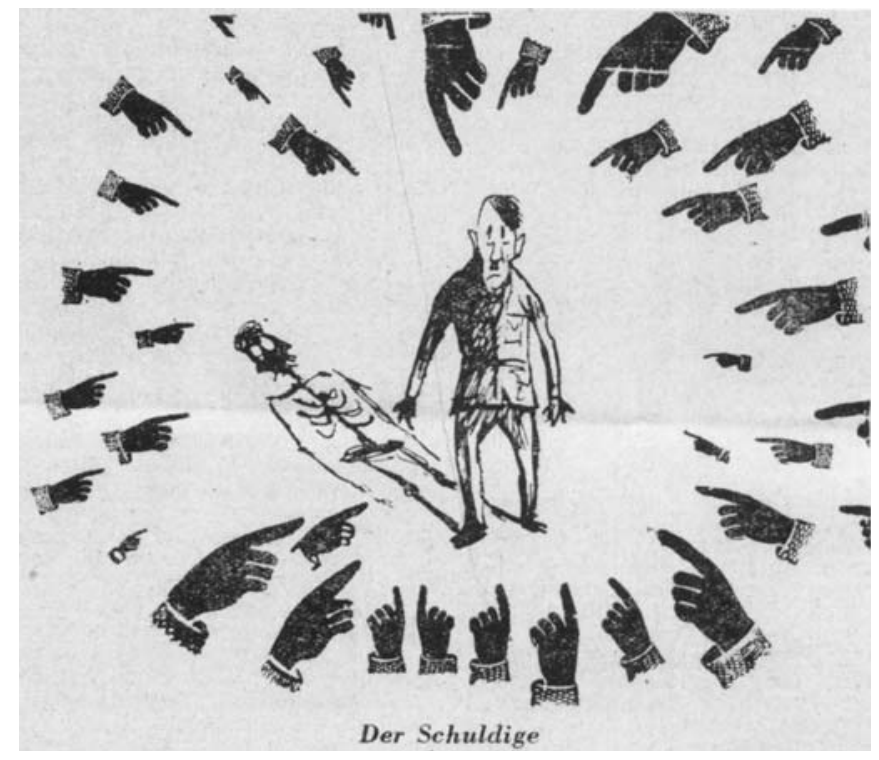

Steinberg à condição de grande celebridade. Smith observa como os cartuns sobre a guerra atuaram diretamente no sucesso do livro:

Naqueles anos de vitórias, a popularidade do livro tinha menos a ver com a metade inicial uma charmosa compilação de piadas publicadas na América até aquele momento - do que com as sessenta páginas finais, Guerra, que mostravam reimpressões de seus cartuns antifascistas, assim como as versões expandidas dos já amplamente republicados portifólios de guerra da New Yorker. Em junho de 1945, com os conflitos no Pacífico rumando em direção ao seu fim, estes desenhos sinalizavam para a imediata recordação de uma já vencida mas ainda não terminada guerra. (Smith, 2006, p.32).

Os trabalhos sobre guerra de Steinberg, publicados nos Estados Unidos, contrastam com a abordagem de outros ilustradores e artistam que fizeram comentários sobre os conflitos. Merece atenção, no caso de Saul, uma abordagem mais sutil, menos voltada para a dramatização dos horrores da guerra. Nos cartuns da PM, Hitler e Mussolini aparecem de modo caricato, mais ridicularizados do que demonizados, talvez um modo de não mitificálos como sublimes e temidos "grandes vilões" da história. Já os portifólios de guerra deixam as atrocidades de lado para privilegiar o tédio e frivolidades presentes no dia-a-dia de grande parte dos combatentes. Steinberg parece assumir mais o papel de documentarista de sua própria situação, falando também da experiência de seus colegas e de aspectos inesperados da guerra. A condição de Saul no conflito, sem envolvimento direto com confrontos bélicos e sangrentos, proporcionou esta visão mais amena. O olhar observador do ex-estudante de arquitetura também ajudou a determinar o tom destes desenhos, seletivos na demarcação de comentários visuais sobre os locais visitados. Para Joel Smith, a expressão mais leve dos trabalhos de Steinberg deve ter agradado os americanos. Com a visão de vencedores iminentes, provavelmente queriam vislumbrar um final digno para um conflito bélico, com relatos e 


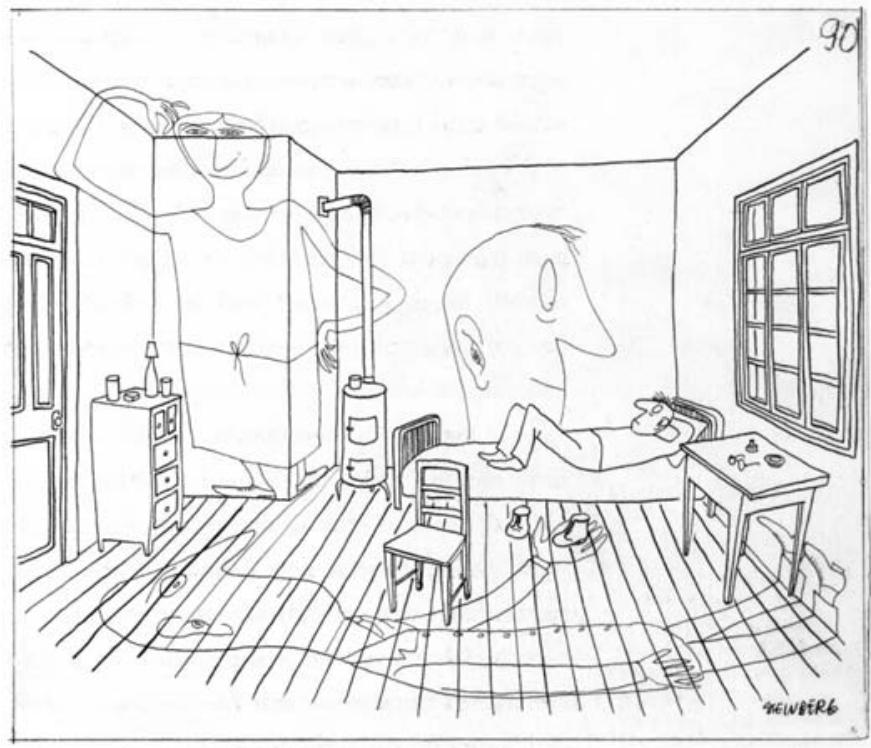

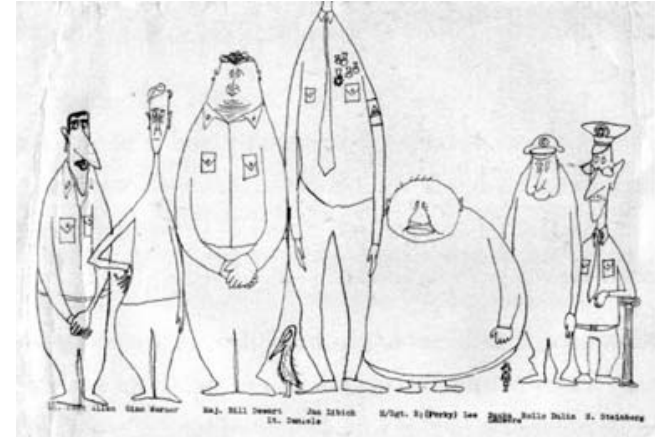

Figura 83. "Decorações que fiz em um quarto (U.S. Army Hotel) onde estive por alguns dias. Estou grato por ter me mudado".

Figura 84. Desenho do pessoal da Morale Operations, OSS, Roma, 1944

comentários sobre a guerra que evitassem se debruçar sobre o derramamento de sangue, apontando para o fim inevitável dos confrontos (Smith, 2006, p.32). Os desenhos de guerra de Steinberg eram apropriados à New Yorker, uma "devotada revista civil", que no contexto da guerra "resolveu permanecer deste modo". Naquele momento, por exemplo, o trabalho do cartunista William Steig "não perdeu nada de sua inocência (...)", como é possível perceber na capa para a edição de 1943 da New Yorker: mesmo em um momento de guerra, se faz presente a leveza de uma criança que sonha (Angell, 2001, p.90).

Os desenhos dos portifólios de guerra definem um momento importante no desenvolvimento do trabalho de Steinberg, evidenciando um processo de depuração que já vinha acontecendo desde seus primeiros cartuns publicados nos Estados Unidos. Vários dos primeiros trabalhos para a New Yorker, feitos em 1943, apontavam para uma preocupação mais "gráfica" e voltada para a exploração dos recursos próprios do desenho. Estes traba-

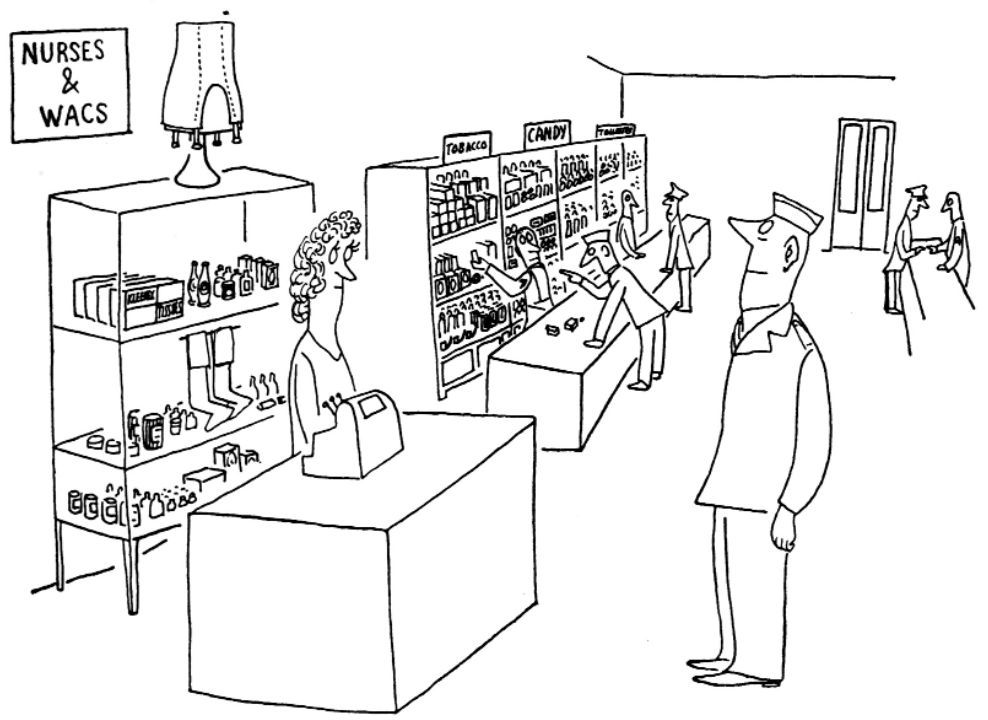

Figura 85. The New

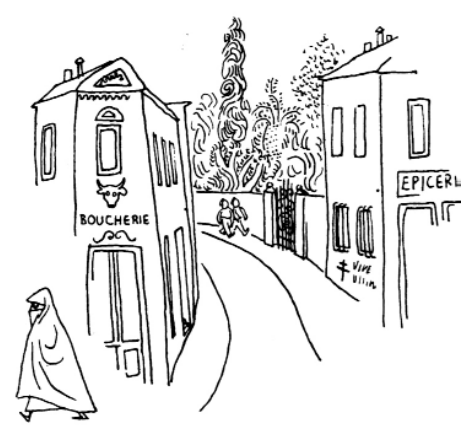



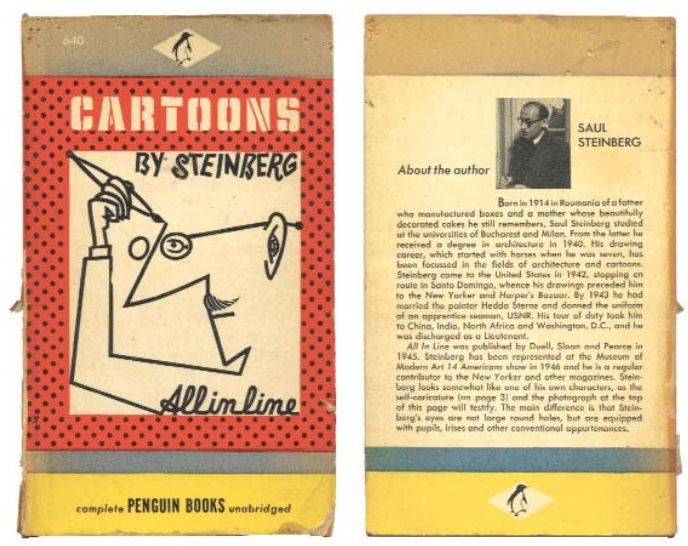

Figura 86. Capa e contracapa da versão de All in Line em livro de bolso, editado pela Penguin Books.

Figura 87. Primeira capa para a New Yorker, 13 de janeiro de 1945

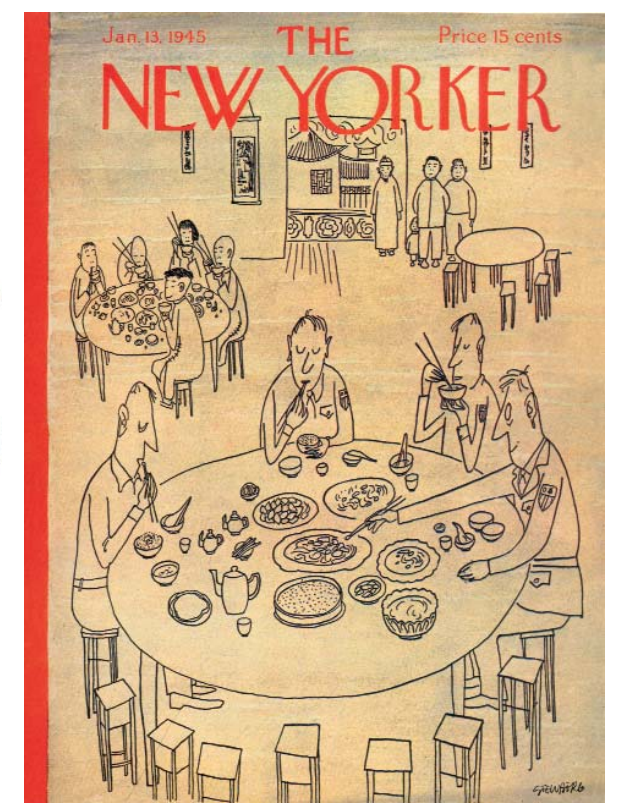

lhos mudos expunham uma maior atenção ao contorno e à linha, fazendo-os se desdobrar em novos usos e formas, e serem lidos de modo diferente. Já os trabalhos dos portifólios, apesar de menos "gráficos" e mais documentais, evidenciam o domínio adquirido pela experiência dos últimos anos. O aspecto documental condiciona Steinberg a fazer uso de suas habilidades na depuração e seleção da enorme quantidade de objetos, fatos, comportamentos e situações a serem comentadas. O artista demonstra saber selecionar os aspectos a serem comentados suprimindo detalhes desnecessários e reforçando outros. Explora a riqueza de detalhes de vestimentas, mobiliários e construções quando isto lhe interessa, sem perder controle do conjunto do desenho, mantendo o equilíbrio entre o limpo e o rebuscado. Henry Pitz chega a notar esta ênfase nas peculiaridades dos locais visitados em artigo de 1951, publicado na American Artist, em que os nativos, a arquitetura, a fauna e a flora situados como cenário sempre tinham "mais substância e personalidade que os vagueantes G.I.s" (Pitz, 1951, p.41).

É relacionado a esse gênero de trabalho documental e de observação das cidades, feito naqueles anos, que a arquiteta modernista Lina Bo Bardi chega a tecer elogios ao "desenho de arquiteto" de Steinberg:

O desenho "seco" e analítico é a exigência básica da arquitetura moderna, a qual elimina a representação cenográfica, sombreada e indistinta, em que a imagem é abafada por outros fatores que se sobrepõem à idéia da arquitetura. O desenho "magro" é quase um "não-desenho" e não quer fazer concorrência à obra já realizada, como acontecia com as grandes perspectivas cenográficas que, em certo sentido, esgotavam a obra arquitetônica numa estéril sobre-estrutura. Le Corbusier desenha magnificamente, de maneira "intelectual", e poderia "descrever" em lugar de desenhar; e Saul Steinberg, que também é arquiteto, pode ser tomado como exemplo de síntese analítica, estreita e perfeita como documentação de uma, por assim dizer, linguagem arquitetônica desenhada (Bardi, 2002, p.65). 
sintética" sem claro-escuro, observou; "já compreendi: desenhar a la Steinberg"; ao que retrucamos: "Exatamente a la Steinberg"; Steinberg é arquiteto, formado e educado na escola do desenho sêco e analítico. Nos costumamos aconselhar aos es. tudantes, para que adquiram a indispensavel segurança analítica no desenho de arquitetura, o que nos aconselhava um velho professor de "História dos Estilos" verdadeiro "pompier" como profissional, mas possuidor de sérias intuições didáticas: usar uma grande fôlha de papel de embrulho, e desenhar com carvão, diariamente, dezenas de "aste" aquelas mesmas que são traçadas pelos meninos que aprendem a escrever: "astes", porém, de mais de um metro de comprimento. Esse sistema, é, no fundo, racional, e significa acostumar a mão à independência analí tica; êste gênero de desenho servirá ao arquiteto para captar os "caracteres" de um organismo; já que, no que toca a "apresentação cenográfica", somos favoráveis, como dissemos, a uma absoluta modéstia, àquilo que o arquiteto Giuseppe Pagano definia, na Escola Politécnica de Milão, como "desenhar com a mão es. querda".

Resumindo pois: o professor deverá expôr, numa série de conferências ilustradas com desenhos, projeçōes e, possivelmente, filmes, as obras mais representativas da história da arquitetura.

Esforçar-se-á por transmitir aos estudantes a consciência do arquiteto, em sentido técnico e ético, e procurará acima de tudo realizar um sistema, um "método", através do qual o estudante pos. sa esclarecer a sequência da projetação; como observamos, êsse método basearse-á nas medidas humanas, na dos "es. paços ocupados", na indagação e colheita de dados, no esquema distributivo.

Êste rápido estudo, muito breve para matéria tão complexa, mas que resulta de anos de experiência direta, quer apenas contribuir ao ensino de uma disci plina que não vai "pari passu" com a arquitetura, mas que, pelo contrário está, com relação à mesma, num atrazo que prejudica a formação dos futuros arquitetos.

É natural que os moços aprendam todos os sistemas que servem para representar a arquitetura; mas as maquetes deverão, na Escola, servir como estudo e ser executadas com sobriedade de materiais. Aí está uma maneira excelente de se dar vida à bela idéia que Focillon, depois dos enunciados rigidamente marxistas, de-
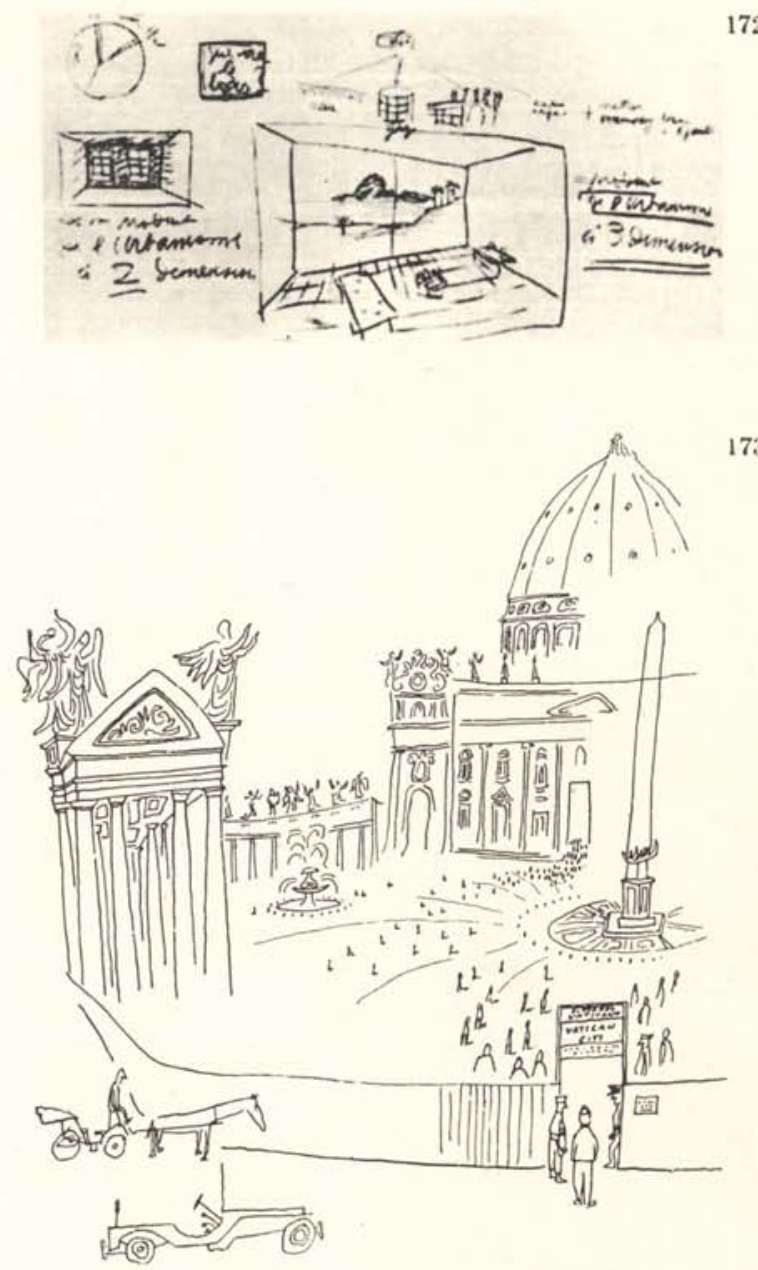

173

O desenho "seco" e analítico é a exigência básica da ar. quitetura moderna, a qual elimina a representaçāo scenográfica, sombreada e indistinta, em que a imagem é abafada por outros fatores que se sobrepōem à idéia da arquitetura. O desenho "magro" é quasi um "nāo.dese. nho" e nâo quer fazer concorrência à obra já realizada, como acontecia com as grandes perspectivas scenográficas que, em certo sentido, esgotavam a obra arquitetô. nica, numa esteril sobre.estrutura. Le Corbusier desenha magnificamente, de maneira "intelectual", e poderia "descrever" em lugar de desenhar; e Saul Steinberg, que também é arquiteto, pode ser tomado como exemplo de sintese analítica, estreita e perfeita como documentação de uma, por assim dizer, linguagem arquitetônica dese. nhada.

172 Derenho original de Le Corbusier, um da série das conferências que o arquiteto fez no Rio de Janeiro, 1936. (Coleção do A.).

173 Desenho de Saul Steinberg, Basílica de São Pedro, Roma (S. S., Todos en lineas. Buenos Aires, 1950).

Figura 88. Página de Contribuição Propedeutica ao Ensino da Teoria da Arquitetura em que Lina Bo Bardi comenta o trabalho de Steinberg. Escrito originalmente em setembro de 1957. 
Nestes desenhos "magros" são exibidos, muitas vezes, ambientes cheios de ornamentos, elementos decorativos, detalhes arquitetônicos e estilísticos. No entanto, o artista frisou em inúmeras ocasiões seu interesse em evitar a "performance" e o exibicionismo técnico em sua obra. Os rebuscamentos, portanto, partem da necessidade objetiva de fazer um comentário para determinada circunstância. O "estilo" e o "virtuosismo" surgem como foco do desenho - trata-se, justamente, de comentá-los.

O comentário de Lina e as manifestações do próprio Steinberg sugerem, desta forma, a maturação de um modo de desenhar "moderno", que vem se desenvolvendo desde os primeiros cartuns para a Bertoldo. Tais características modernas se manifestam tanto em suas características formais - simplicidade, síntese, foco definido - como em sua condição de extensão direta e objetiva do pensamento e da reflexão, a favor de comentários a serem delineados.

\section{CONTEXTO: A REPORTAGEM VISUAL DE OUTROS DESENHISTAS}

Steinberg não foi o primeiro desenhista a comentar a guerra de dentro dela. Tampouco o pioreiro da "reportagem visual". Outros ilustradores, cartunistas e artistas fizeram seus documentos e relatórios gráficos dentro de inúmeras situações. A Primeira Guerra já havia gerado uma série de desenhos que documentavam os conflitos. Quando os conflitos vieram em 1914, a maior parte dos semanários da imprensa mundial usavam ilustração e fotografia. A câmera fotográfica era um instrumento barato e conveniente para registrar determinadas situações, mas o público estava acostumado à idéia da guerra como palco para exercícios heróicos e másculos, e neste sentido era comum recorrer à velha prática de "ilustrar a notícia". Estes trabalhos eram muitas vezes criados a partir de esboços de veteranos ou por pintores de batalhas "imaginativos" como Caton Woodville. No entanto, alguns artistas se nota-

bilizaram como protagonistas de guerra, como os artistas-combatentes Beckmann, Otto Dix, George Grosz, Luc Albert-Moreau, Pechstein e Senozac. Ao contrário da abordagem de Steinberg, o trabalho destes artistas retratou a guerra como um pesadelo. Criaram um registro comprometido e passional que podia apenas ser visto nos periódicos de gênero literário ou nos efêmeros portifólios de vanguarda, como a alemã Der Krieg e a francesa L'Elan. Dix havia sido um soldado que carregava metralhadoras e seu portifólio de gravuras publicado na Der Krieg expunha um universo imerso em fúria, povoado por cadáveres monstruosos. Beckmann tinha se voluntariado para serviços nas unidades médicas de modo a evitar confrontos e não ter que matar, mas teve que conviver com mortos-vivos (Hogarth, 1967, p.56). O resultado do trabalho destes artistas parece, como no caso de Steinberg, refletir a intensidade e a gravidade da experiência que cada um teve na guerra.

Nos anos 1920, após a Primeira Guerra, Grosz e outros artistas continuaram a publicar suas crônicas e comentários sociais gráficos em jornais vanguardistas de Berlin, então o centro dos grupos dadaístas e expressionistas mais importantes. Segundo Hogarth, nas 
páginas destas publicações, "Grosz começou sua grande crônica dos culpados e inocentes que iriam fazer dele o maior artista-repórter dos anos 20, senão o maior desde Daumier". Revistas comunistas como a Eulenspiegel também investiam em trabalhos do gênero, como os da artista Kathe Kollwitz, que se notabilizou por documentar a vida proletária em um tom de maior complacência ao sofrimento da vida noturna dos distritos da classe trabalhadora de Berlin. Muitos dos mais dramáticos trabalhos de Grosz e Kathe Kollwitz foram também publicados em periódicos ousados como a Simplicissimus e a Der Knuppel (Hogarth, 1967, p.61). Um pouco depois, durante os anos 1930, sob as consequências sociais e econômicas da catastrófica quebra da Bolsa de Nova York de 1929, em um mundo dividido em ideários como os preconizados pela Rússia comunista ou por Hitler e Mussolini, renomados intelectuais e artistas como Grosz e Kollwitz se associaram a publicações da imprensa antifascista como Paris Monde, New York New Masses, The London Left Review, Paris Vu. O trabalho de Grosz merece menção especial por apresentar alguns pontos importantes quando comparados aos de Steinberg. Se o tom da obra de ambos é diferente, e o traço de Grosz é anguloso e expressionista, acentuando o aspecto macabro da personalidade dos personagens, vale chamar a atenção para o seu caráter cartunístico, o desenho de linha fina, e a documentação de costumes. A crítica de Grosz, no entanto, é mais incisiva, ácida e cortante, contrastando com a sutileza elegante de Steinberg.

Enquanto o mercado editorial nos anos 1930 passa por grandes transformações, com o surgimento ou maturação de diversas publicações como Time (1923), The New Yorker (1925), Esquire (1934), Life (atingindo grande sucesso a partir de 1936) - sendo conferido espaços aos modernos artistas americanos -, ilustradores continuavam a fazer relatos gráficos, em contextos atuais. A Fortune, lançada em 1930, chega a contratar artistas para viajar por seu país retratando os projetos do New Deal. Tomando parte em um cenário de valoriza-
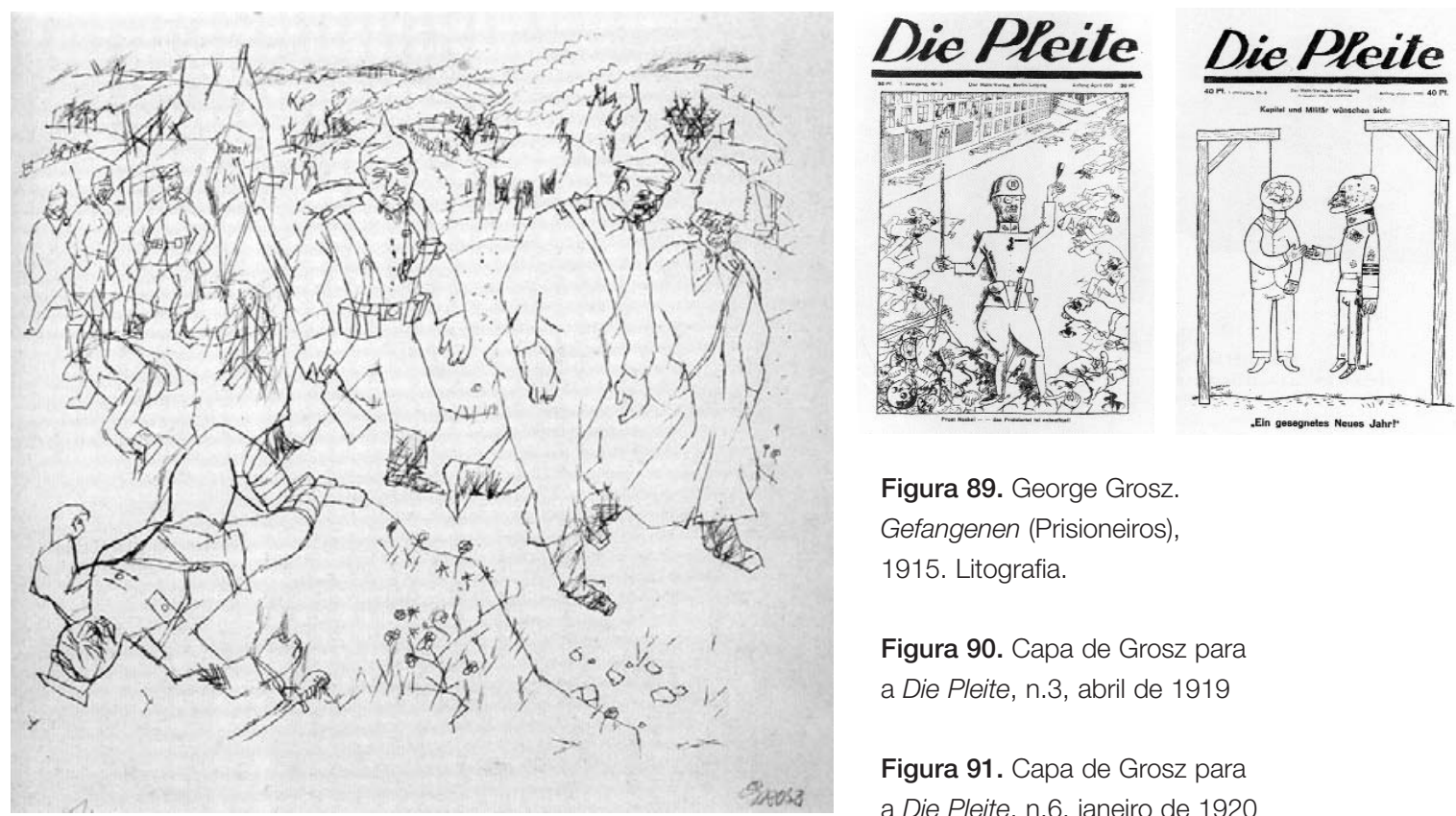

Figura 89. George Grosz. Gefangenen (Prisioneiros), 1915. Litografia.

Figura 90. Capa de Grosz para a Die Pleite, n.3, abril de 1919

Figura 91. Capa de Grosz para a Die Pleite, n.6, janeiro de 1920 
ção dos artistas do mercado americano, a Fortune publicava em suas páginas trabalhos de John Steuart, Edward Hopper, Diego Rivera, Ben Shahn (Hogarth, 1967, p.73). Já sob o advento da Segunda Guerra, a revista Life, pioneira do fotojornalismo desde 1936, resolve investir em novas abordagens para a cobertura do conflito. Contrata e envia uma série de artistas para os campos de batalha, umas vezes sozinhos, e em outras situações acompanhados pelos correspondentes de guerra da Time e Life. Ao mesmo tempo, a equipe da revista Fortune explorava suas "reportagens visuais" de outro modo, mais preocupada com os aspectos sociais e econômicos do conflito. Designava, muitas vezes, trabalhos para artistas europeus que viviam exilados na América. (Hogarth, 1967, p.74). Após a Segunda Guerra, boa parte da melhor reportagem visual ainda podia ser encontrada na Fortune - sob a direção de arte de Leo Lionni -, como a Honourable Discharge de Ben Shahn, publicada em setembro de 1947 (Hogarth, 1967, p.79).

\section{Os VIAJANTES}

O trabalho de Steinberg com os portifólios ressalta outra das características marcantes de sua vida e trabalho: as viagens e a visão do viajante. Após a guerra, os passeios continuaram, prolongando-se ao longo de toda a vida do artista. Saul e Hedda, "provocados por um esnobismo geográfico" - nos dizeres de Hughes -, se tornam epicuristas de viagem (Hughes, 1978, p.52). Após a guerra e um súbito momento de calma, Geraghty chega a comentar, em 1945, que "Steinberg precisa de excitação" (cit. por Smith, 2006, p.35). Em 1944, Steinberg já havia feito sua primeira viagem após o retorno aos Estados Unidos, justamente para a terra natal, a Romênia. Vai a Bucareste de uniforme para encontrar sua família. Apesar de fotografias corroborarem este fato, nos anos seguintes o artista viria a dizer que não havia visitado a Romênia desde os anos 30 (Smith, 2006, p.254).

Se o primeiro ano pós-Guerra é calmo, já em 1946 Steinberg viaja para a Inglaterra, França, Itália, se encontrando com amigos, dentre eles Aldo Buzzi, e presenciando os julgamentos de Nuremberg como repórter especial da New Yorker. Em viagem à Alemanha, cria as páginas do portifólio Berlin, a ser publicado em março e abril de 1947 na revista -, em que retrata a desolação e pobreza do pós-guerra. Passa por Monte Carlo, e antes visita Paris, onde faz amizades com Janet Flanner, correspondente da New Yorker, e o fotógrafo Henri Cartier-Bresson. Este o apresenta a artistas franceses e intelectuais, e nestes encontros Steinberg chega a elaborar retratos de Simone de Beauvoir e Jean-Paul Sartre. Em 1947, as viagens continuam: em abril visitam o Mexico, com Hedda, o ilustrador mexicano Miguel Covarrubias e outros. Na volta, param em Cincinnati, Ohio, para esboçar a cidade em função do projeto de um mural que havia sido requisitado a eles. Mas a viagem mais especial deve ter provavelmente sido feita no mesmo ano, pelos Estados Unidos (Smith, 2006, p.254). Steinberg resolve comprar um Cadillac usado conversível de Igor Stravinsky, e ele e Sterne 
caem na estrada. Durante a próxima década, eles viriam a viajar por todos os quarenta e oito estados do país. Segundo Smith, Steinberg não conseguia ficar muito tempo quieto, e após algum tempo de trabalho, saía para dar um passeio, visitar amigos. E quase todo o ano fazia uma viagem de carro ou ônibus durante semanas pelo país, ou despendia algum tempo na Europa (Smith, 2006, p.35). Tais viagens não eram mero lazer ou puro entretenimento, e podem ser consideradas parte de seu processo de trabalho, dado o modo como promoviam reflexos diretos em seus desenhos e comentários.

Steinberg gosta de relembrar suas jornadas. "Adorava chegar em um novo lugar e me deparar com novas situações, como um recém-nascido que vê a vida pela primeira vez, quando ela ainda tem o ar da ficção. Isso dura um dia" (cit. por Hughes, 1978, p.52). Como observa Hughes, "os anos 40 e 50 talvez tenha sido o último período na Europa em que uma viagem era uma viagem, ainda não filtrada e homogeneizada pelo turismo de massa. Isso deve ter se apresentado a Steinberg como uma forma de exílio controlado - a máscara da expatriação" (Hughes, 1978, p.52). Dentre suas viagens, eram especiais aquelas realizadas de trem, como comenta Steinberg:

Ao viajar de trem, você vê, antes de qualquer coisa, o lado de trás das cidades. A visão é "lateral", enquanto que, para o homem, a visão mais natural é a de frente, como em um automóvel (...). E você vê uma paisagem que é uma continuação daquela da televisão, que só é vista, de fato, enquanto se está sentado. (...) Ao viajar de ônibus, a pessoa que senta na primeira fila desfruta da "visão ideal", a mais rara e mais nobre delas (Steinberg, 2002, p.52).

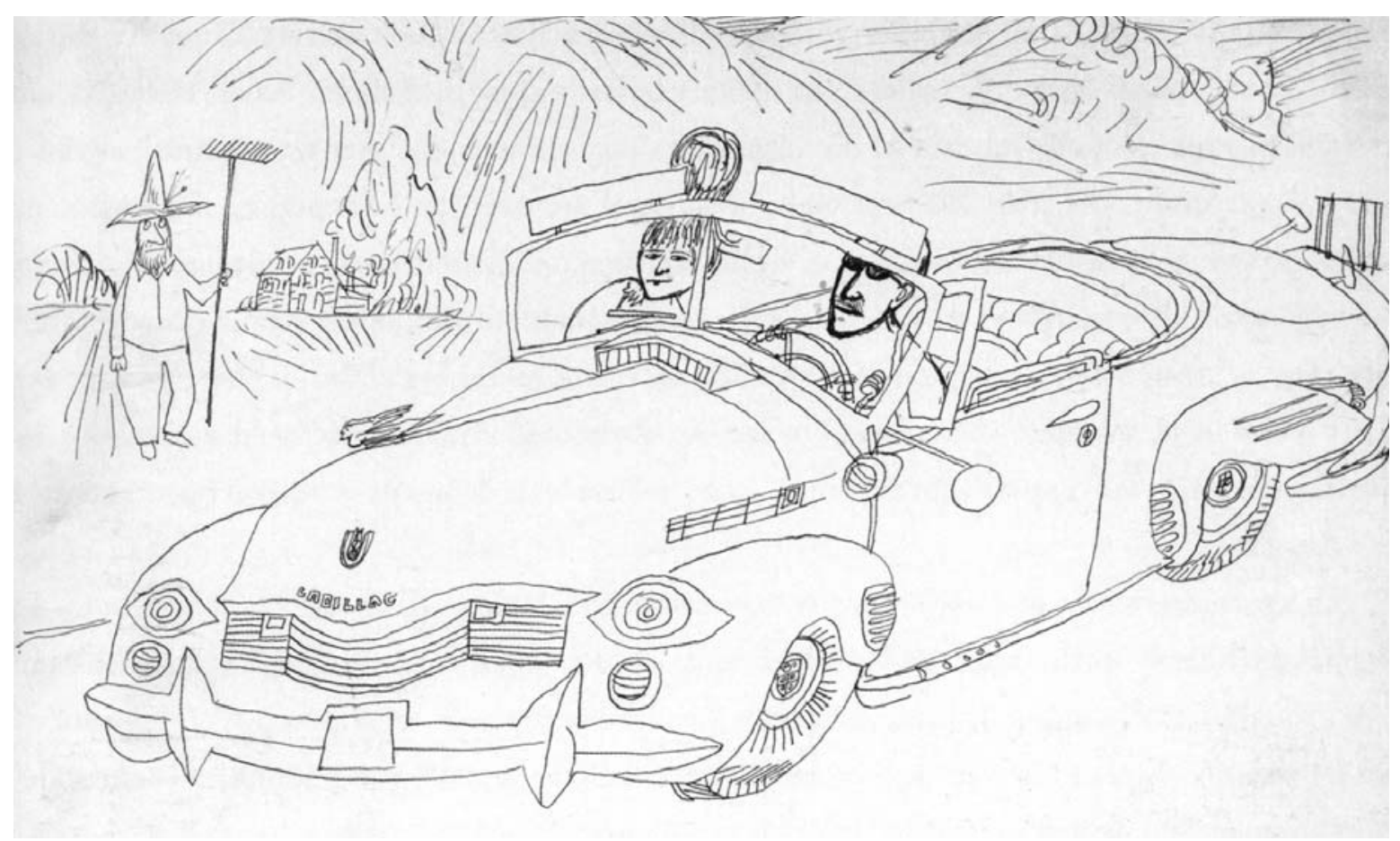

Figura 92. Auto-retrato com Hedda Sterne, Cadillac e fazendeiro. Vermont, verão de 1947. 


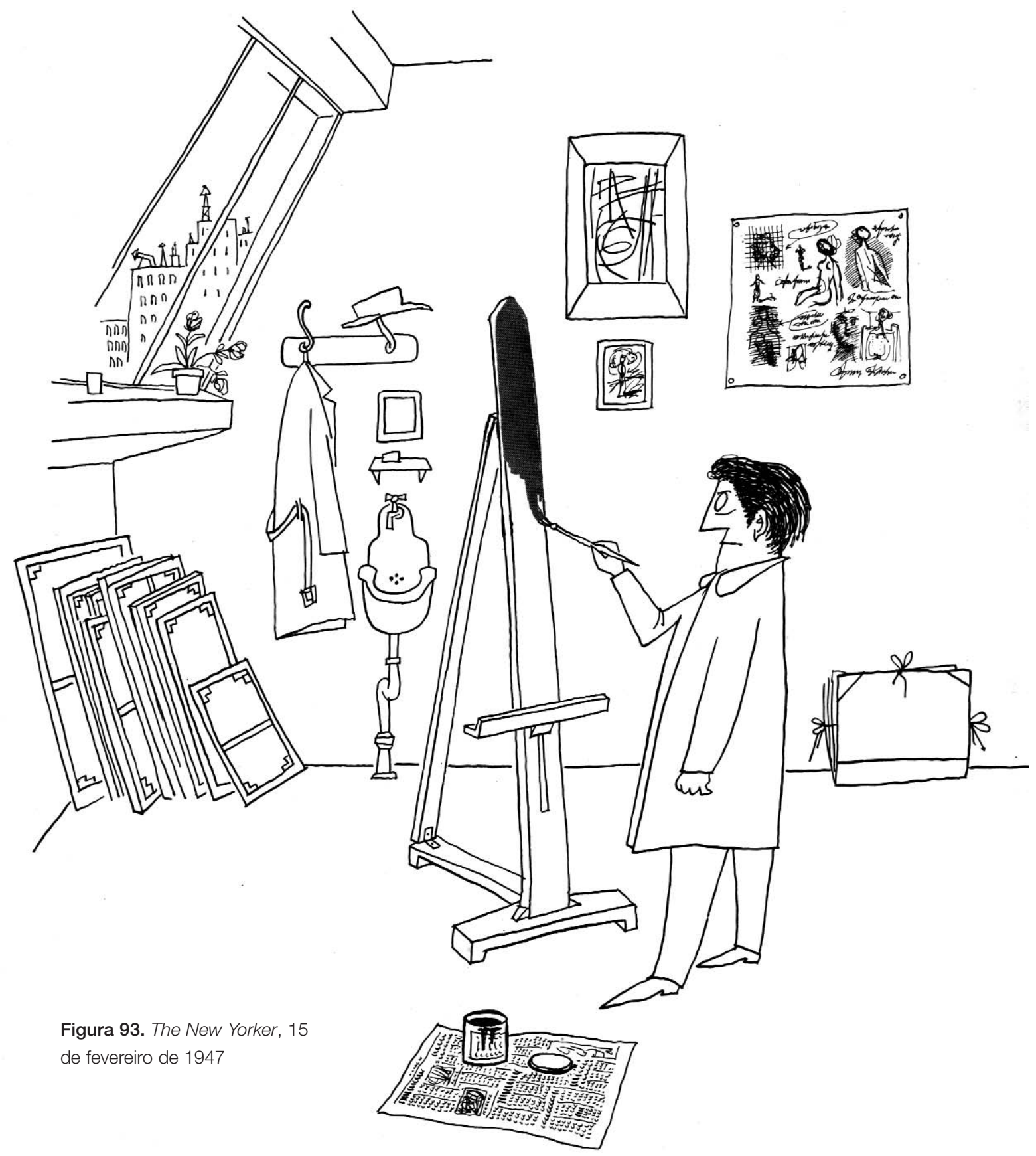




\section{STEINBERG EM NY: \\ 0 HUMOR MUDO DO CARTUM MODERNO NA NEW YORKER}

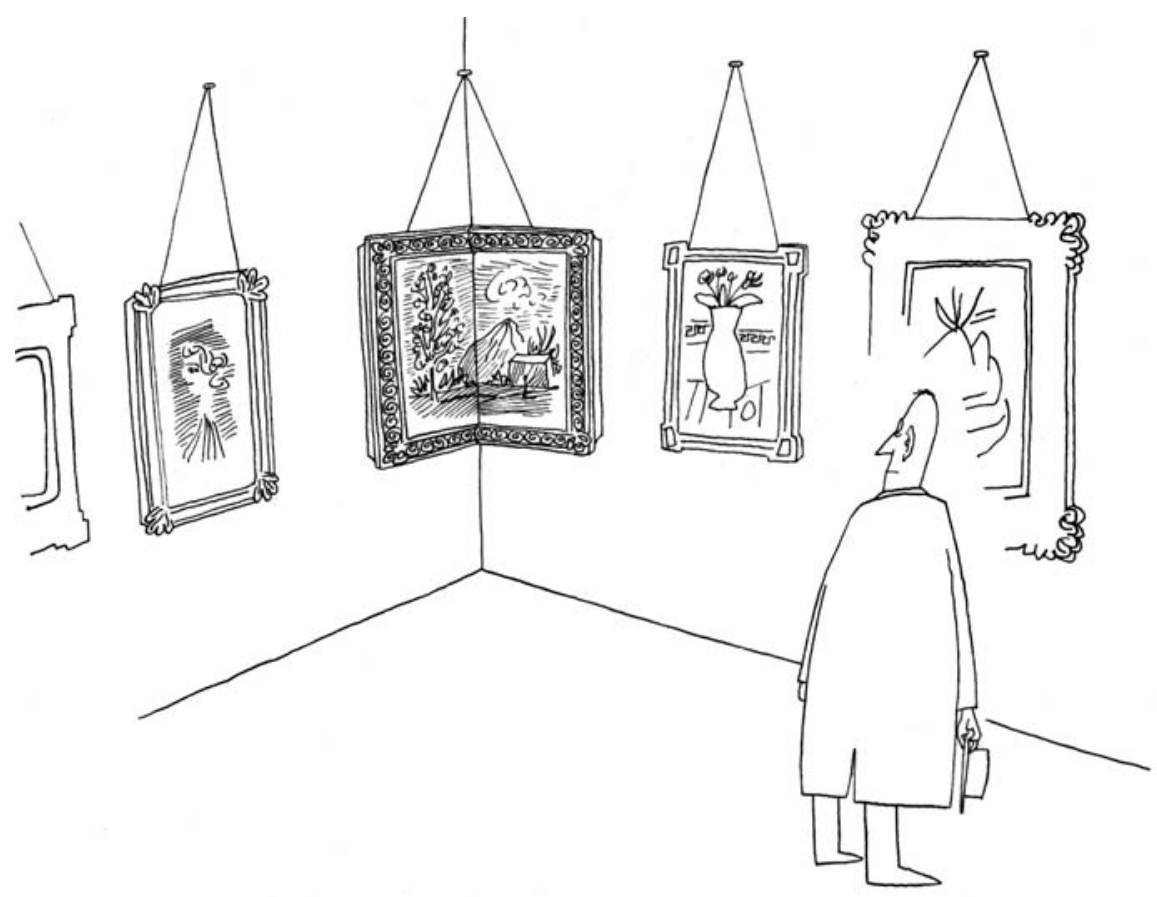

Figura 94. The New Yorker, 6 de abril de 1946

Desde sua chegada aos Estados Unidos, inserido nos círculos de amizade de Nivola, da New York School e do meio editorial, Steinberg não demora a conhecer as celebridades de Nova York: "Chagall, Max Ernst, Léger, Duchamp; e nossos nativos...(...), Pollock, de Kooning, John Graham...é uma pena não ter conhecido Mondrian. Magritte chegou aqui muito tarde", recordou certa vez o artista (Steinberg, 2002, p.57). Saul se encontrava em um ambiente fervilhante e revigorado por ares modernistas vindos da Europa, uma vez que Nova York assumia uma condição privilegiada no cenário mundial do pós-guerra. Se Berlin havia sido, para muitos, a capital do modernismo nos anos 20, o mesmo com Paris nos anos 1930, os diversos acontecimentos que culminaram na Segunda Guerra alteraram o eixo para os Estados Unidos e Nova York:

Para os nativos nova-iorquinos, assim como para aqueles americanos que se mudavam para lá em busca de suas fortunas e aqueles que iriam emigrar da Europa, Nova York se tornou o novo centro de criatividade entre 1920 e 1950. Foi ali que o modernismo encontrou uma casa, próspera e madura. (...) O ambiente e as possibilidades criaram uma atmosfera cosmopolita. (...) O formalismo da estética Modernista foi trazida para a América primeiramente pelos imi- 
grandes designers, artistas e arquitetos que chegaram a Europa em 1930. O abrupto volume de talento individual que convergiu para a América nestes anos foi incrível. A expansão do fascismo pela Europa forçou muitos a procurar uma nova e mais segura casa e, para alguns, a falta de tradição na América era uma atração a mais, um novo começo. (...) Durante esta década, cerca de 717 artistas, 380 arquitetos e 100 designers gráficos fizeram seu êxodo para a América. (Remington, 2003, p.52).

É logo após o final da Segunda Guerra Mundial, em tempos de normalidade e otimismo, que Steinberg - inserido em um contexto favorável - participa da exposição itinerante coletiva Fourteen Americans, organizada por Dorothy C. Miller para o Museum of Modern Art de Nova York (Smith, 2006, p.34). Ocorrida em 1946, trata-se sem dúvida de um marco em sua carreira e demonstração de reconhecimento por sua obra. Seus trabalhos são exibidos ao lado dos de Arshile Gorky, Isamu Noguchi, e Robert Motherwell (Saul Steinberg Foundation, website, s.d). Alguns destes desenhos de Steinberg comentam e avaliam os custos da guerra, como a destruição de Monte Cassino e a angustiante vaporização de Hiroshima. Como observa Smith, "isoladas do trabalho no Fourteen Americans, estas imagens ficariam deslocadas nas páginas de seu próximo livro. Como sugeria seu título, The Art of Living (1949), a vida americana logo voltou sua atenção para si mesma e passaria a ter pouco tempo para misericordiosas buscas sobre o passado" (Smith, 2006, p.35). Aos poucos, Steinberg se configurava em um profissional híbrido, inserido em meios variados como o editorial e o das
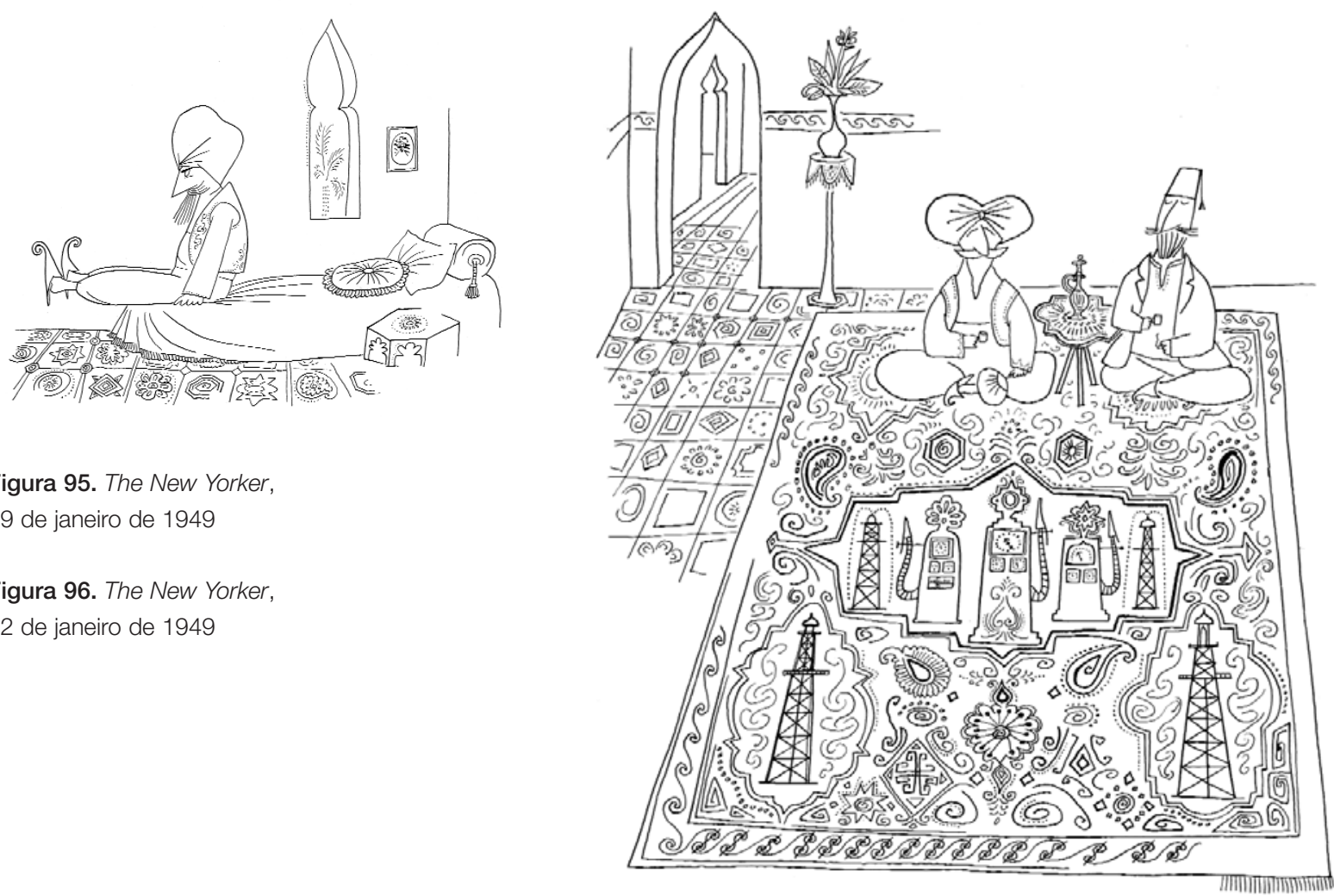
artes plásticas. De qualquer modo, naquele momento ele ainda era, aos olhos do público, um cartunista da New Yorker em primeiro lugar (Smith, 2006, p.36).

O Steinberg cartunista vivia uma condição diferenciada em seu campo de atuação. A expectativa em relação aos seus cartuns não estava voltada para a piada comum, cujo único princípio seria o riso como resultado final, por meio do choque ou de situações meramente exageradas e expansivas. Como nota Smith (Smith, 2006, p.36), o Steinberg do pós-guerra emergia com o status de um artista de nível "AA", com responsabilidades e papel especiais. Os cartuns de Steinberg na New Yorker, mesmo aqueles publicados em sua fase inicial na revista, expõem um palco para experimentações, um lugar teatral e abstraído da realidade. Os editores não buscavam em Steinberg cartuns em temas locais ou relativos aos acontecimentos do momento como o Congresso, a ascensão da televisão, mulheres motoristas, etc. "Ao contrário, ele - como Charles Addams, William Steig, Helen Hokinson ou Peter Arno era encarregado de trazer às páginas da revista um universo que era distintamente o seu. Seu trabalho era fazer a New Yorker Steinbergniana" (Smith, 2006, p.36).

\section{STEInberg NA THe NeW Yorker: O CARTUM MUdo E GRÁfico}

Se as legendas aparecem nos primeiros cartuns de Steinberg para a The New Yorker, elas logo cederiam espaço para a total emancipação do humor mudo. Além dos portifólios sobre guerra, que exerciam mais o papel documental e de reportagem gráfica, a abordagem mais comum das vinhetas "gráficas" iniciais são as situações com adaptação e transformação de objetos, a partir de um cruzamento destes com outros acontecimentos, gerando resultados absurdos. Um exemplo seria o cartum que expõe a situação de um quadro de uma exposição coincidindo com um canto da sala. A mescla de duas situações incongruentes gera uma terceira: o quadro é adaptado e transformado para se adequar - de modo inesperado - ao canto, dobrando-se ao meio em noventa graus. Em outro exemplo, em uma de suas inúmeras piadas com árabes, um tapete persa deixa de lado suas configurações tradicionais para adquirir adornos pouco comuns, em decorrência do tipo de negócio e interesse - exploração de petróleo e dinheiro - de seus usuários. Alguns objetos sofrem alterações em função da incompatibilidade destes em relação aos hábitos dos personagens. O personagem árabe, acostumado a ficar sentado em tapetes, mantém a sua postura quando inserido em outro contexto, como quando disposto sobre uma cama. Pode-se considerar que a cama, neste caso, sofreu uma alteração no modo como é usada.

Tão logo Steinberg começa a trabalhar para a New Yorker, e o artista tem para si a liberdade de efetuar suas investigações de maior interesse, estudando o modo como o desenho poderia falar sobre o próprio desenho. Já em 1943 evidenciam-se cartuns com abordagem "gráfica", em trabalhos que expõem uma atenção à linha dos elementos representados, ao seu percurso e modo como define os contornos dos objetos, que podem se desdobrar em 


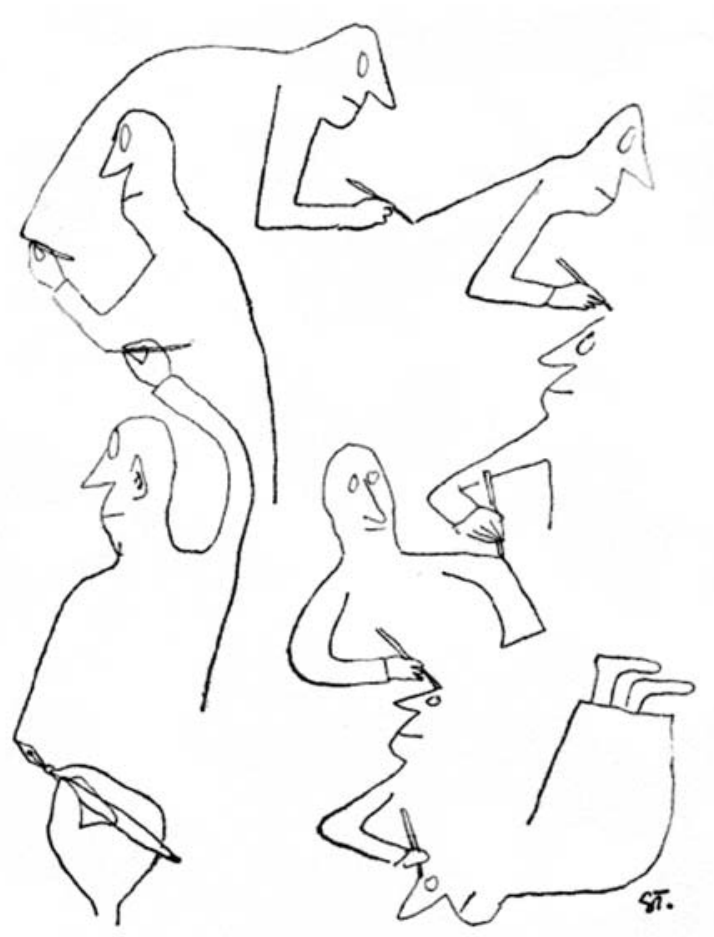

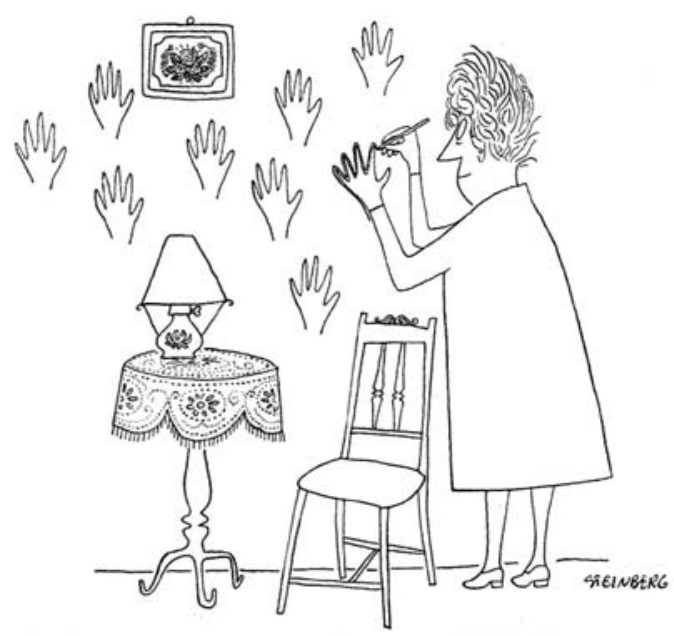

Figura 97. The New Yorker, 3 de fevereiro de 1945

Figura 98. The New Yorker, 18 de dezembro de 1943

novos usos e formas. Em um dos cartuns, uma mulher enxerga nos contornos de suas mãos algo mais do que meras silhuetas, utilizando-a como elemento decorativo na parede de sua casa. Este tipo de pesquisa tem grande avanço, ao menos na The New Yorker, em um cartum de fevereiro de 1945, em que as linhas do contorno são assumidas como "desenho" de modo contundente. Nele, a linha ganha uma ênfase tão grande quanto os objetos representados, deixando no ar a dúvida sobre o que está em primeiro plano: o que é "real" e o que é traço. $\mathrm{Na}$ situação apresentada, um homem passa a não ser apenas um homem, mas uma linha de desenho, que pode ser vista como tal e ganhar a autonomia.

Para Steinberg - artista atraído por lápis, canetas, e tinta -, esta linha contínua de seus desenhos datava "da infância e é provavelmente um modo de escrever dos meus tempos de analfabeto" (Rosenberg, 1978, p.235). Mas a técnica do desenho não era para ele uma perseguição estética, funcionando mais como "caligrafia, um modo de ser educado" (Gluek, 1970, p.114). Sua habitual técnica depurada e simples, portanto, era fruto de um modo "deseducado" de exprimir suas idéias: "Quero dizer algo. E ao dizer algo sem educação, faço isso parecer bonito e economicamente correto. Uma das mais altas formas de elegância é mostrar falta de esforço (...)" (Gluek, 1970, p.114). Ao refletir sobre o modo como concebia estas linhas, dizia que "desenhar é uma forma de raciocinar no papel" (cit. por Hughes, p. 48). Essa definição que possui paralelos com outra, feita pelo crítico de arte Harold Rosenberg, sobre seu trabalho: "Ele é um escritor de imagens, um arquiteto de falas, um desenhista de reflexões filosóficas. Sua linha de um mestre escritor e calígrafo, estéticamente 
agradável em si mesma, é também a linha de um ilusionista formulando charadas e piadas sobre aparências" (Rosenberg,1978, p10). Para Jane Kramer, "as imagens de Saul eram uma ácida conversa entre o olho de sua mente e a mente de seus olhos" (Kramer, 2000, p.59). A comparação com a escrita era feita pelo próprio Saul:

Qualquer trabalho é como escrever. Um longo tempo atrás, Leonardo disse, "Pittura è cosa mentale - a pintura é uma coisa do intelecto. Certamente também a poesia, e a literatura, e a música. Como um compositor compõe? Ele senta em uma mesa e escreve, exatamente como um romancista. Esta idéia que temos do compositor sentando em um piano é absurda, é comédia musical.O compositor sério senta exatamente como um escritor. Tenho uma escrivaninha - uma escrivaninha maior, claro; preciso de mais espaço. Mas sento e olho para este pedaço de papel e penso, o que irei fazer? (Gluek, 1970, p.113).

\section{ConteXto: o Desenho MUdo}

Tais recursos gráficos inserem Steinberg no grupo dos cartunistas que, desde as primeiras décadas do século, vinham promovendo mudanças e conduzindo o humor rumo ao cartum mudo. Steinberg não inventou o humor mudo em seu sentido mais elementar - um cartum sem palavras -, mas pode ser considerado referência fundamental, que atuou diretamente em seu desenvolvimento, conferiu soluções e abordagens únicas e exerceu influência sobre uma quantidade enorme de cartunistas e artistas gráficos do mundo todo.

Quando estreou na New Yorker, a revista já vinha publicando trabalhos com humor mudo desde os primeiros números. A primeira edição da revista, datada de 21 de fevereiro de 1925, apesar de ainda incipiente em cartuns mudos, traz um trabalho de Frueh - criador da capa da segunda edição da revista - sem fala de personagens. No entanto, há ainda a presença de texto na placa do metrô, elemento-chave neste caso, e um título inserido abaixo da imagem. Em tempos futuros, chamadas e títulos viriam a ser suprimidos em muitos casos, sem provocar danos à compreensão do cartum, mas o uso recorrente nas piadas da New Yorker nos anos 1920 pode ser considerado um vício ou um hábito cultural, mais do que algo de imprescindível necessidade. De qualquer modo, apesar deste trabalho de Frueh não ser um cartum mudo "por excelência", apresenta e antecipa o silêncio e a simplicidade do cartum moderno. Nesta primeira edição há ainda uma página de quadrinhos mudos do mesmo Frueh, ainda com um título desnecessário no rodapé. Muitas histórias em quadrinhos mudas de Frueh, Otto Soglow - criador do personagem Reizinho -, Gardner Rea, dentre outros, viriam a ser publicadas na revista. No entanto, a arte sequencial muda não deve ser inserida na categoria do cartum mudo, dadas as peculiaridades próprias da linguagem dos quadrinhos, que lida com imagens dispostas graficamente em sequência e interrelacionadas entre si. 
Figura 99. Frueh, The New Yorker, n.1, 21 de fevereiro de 1925

Figura 100. Otto Soglow, The New Yorker, On Enlivening the City, 24 de março de 1928

Figura 101. Otto Soglow, The New Yorker, On Enlivening the City, 14 de abril de 1928

Figura 102. Frueh, The New Yorker, 8 de agosto de 1925

Figura 103. Frueh, The New Yorker, Solving the Traffic Problem, 1926

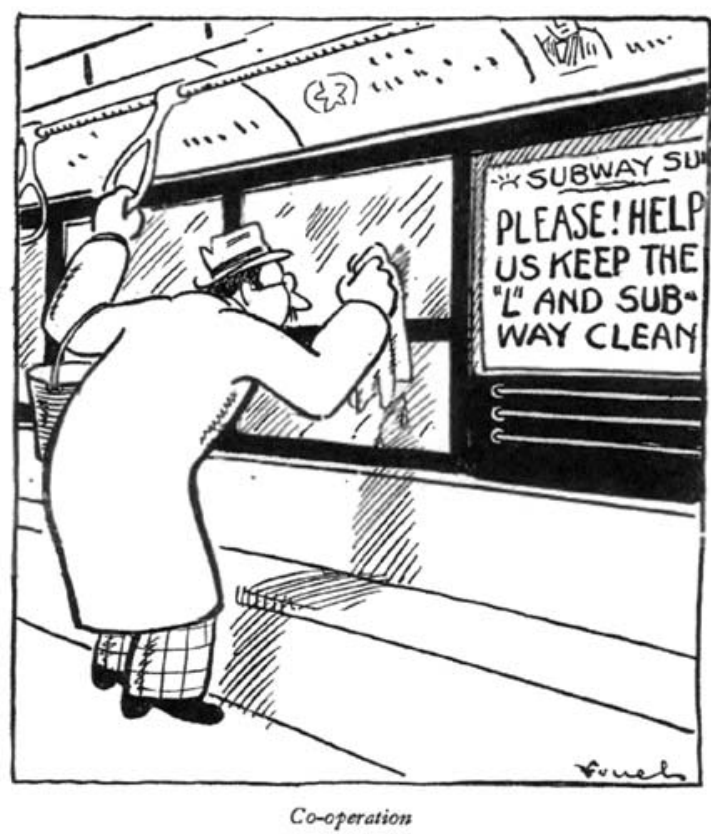

Frueh continuou publicando seus cartuns "quase" mudos, como na série de piadas criadas em 1925, referentes ao "Mayor Hylan", prefeito de Nova York de 1918 até aquele ano. Nestes trabalhos, utiliza sempre placas com inscrições referentes ao prefeito, com alterações nos dizeres de acordo com as situações criadas. Dentre outros cartuns mudos dos primeiros números da revista, merece menção alguns de Otto Soglow denominados The Enlivening City, publicados em 1928. São desenhos com soluções esdrúxulas para as cidades, estabelecendo conexões entre equipamentos urbanos e os brinquedos dos parques de diversões. O único elemento tipográfico além da assinatura do autor é o título, que se repete a cada cartum apenas para apelidar a série. Ainda dentro dos cartuns de temática urbana, Frueh recorre ao humor "quase" mudo para também fazer a sua série, onde o texto aparece em títulos com pequenas variações, como "Resolvendo o problema do estacionamento".

Muitos dos trabalhos mudos dos primeiros números da The New Yorker são vinhetas e ilustrações, dentre elas as capas. Estas se evidenciam como imagens de grande síntese grá-

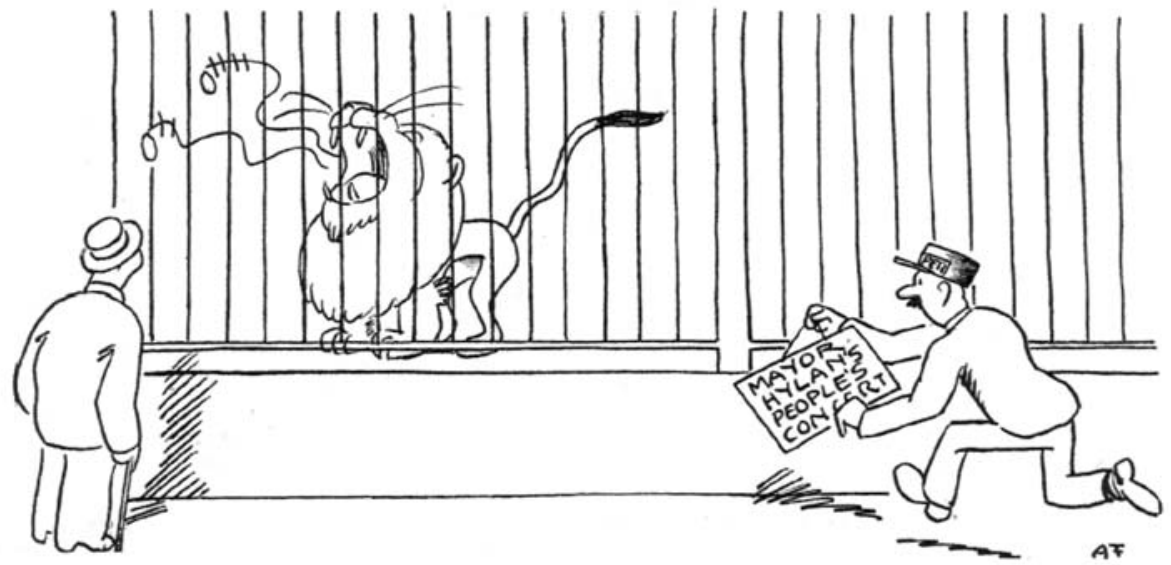



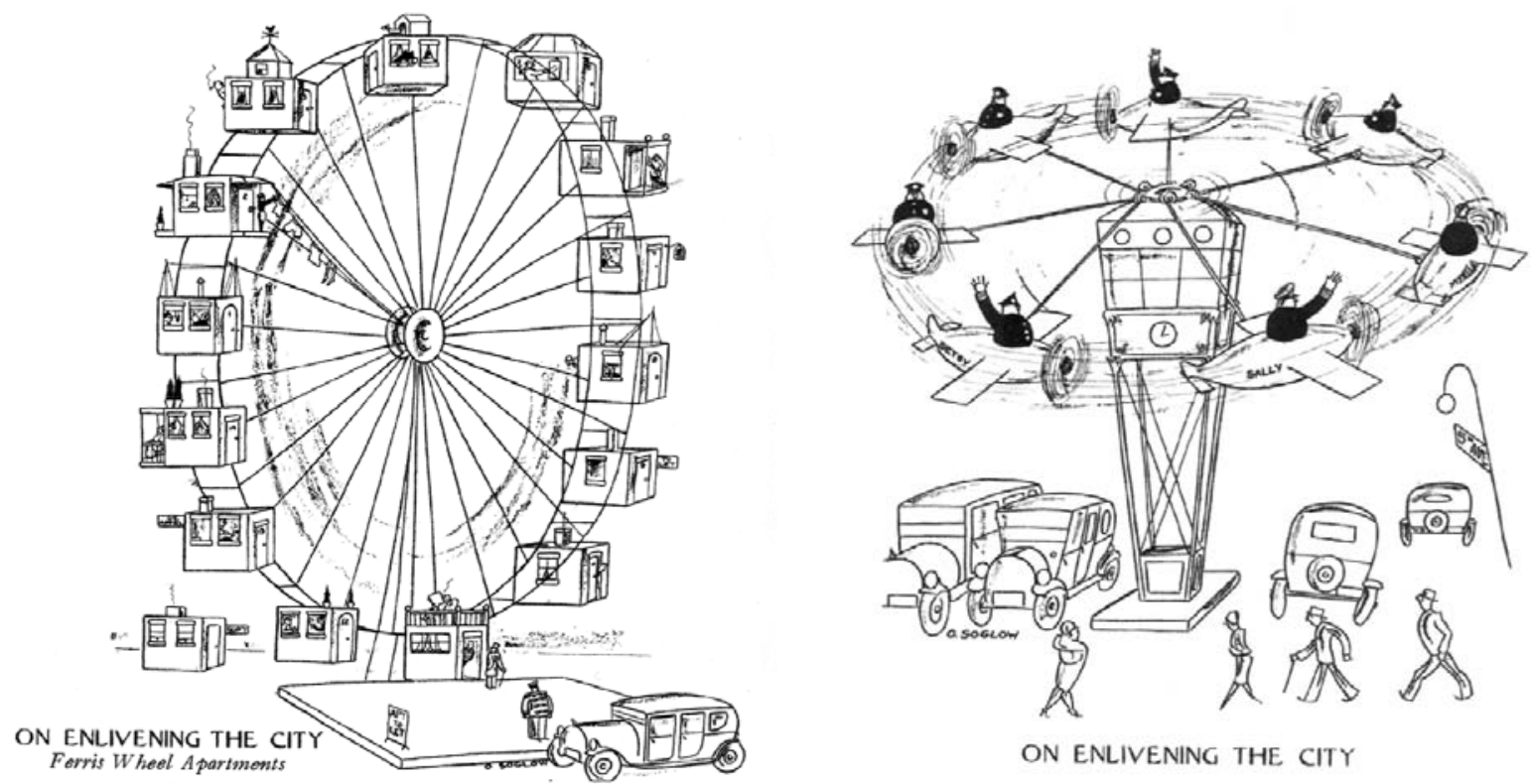

ON ENLIVENING THE CITY

fica que, ao apresentarem alguma dose de humor, sugerem proximidade e vínculo com o cartum mudo, deixando uma tênue dúvida sobre sua categorização. Algumas capas foram feitas por Rea Irving, primeiro editor de arte da revista, idealizador de seu projeto gráfico e criador do dandy de cartola Eustace Tilley. Estas chamam a atenção pelo modo como conciliam linguagem moderna e humor, em trabalhos de síntese, depuração, clareza, foco definido, sem legendas e acessórios. É preciso recordar que há não muito tempo atrás, era hábito nas ilustrações dos semanários o uso de palavras acopladas a personagens e objetos alegóricos para esclarecer o significado de cada um. Sendo assim, a história do humor mudo parece transitar por caminhos próximos aos do desenvolvimento da ilustração moderna. Muitas das capas de Rea Irving, por exemplo, podem ser consideradas cartuns de humor muito sutil. Como observa Lorenz, "ele poderia sugerir uma personalidade completa pela obliquidade de uma sobrancelha ou pela inclinação de uma mandíbula" (Lorenz, 1997, p.124). Em algumas delas, é comum o recurso da transformação de uso ou forma de objetos em função do cruzamento

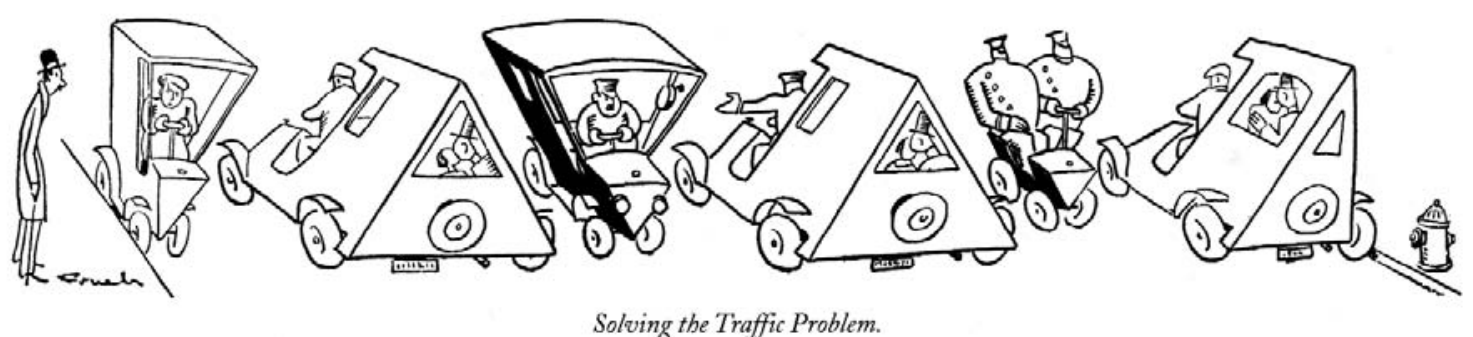




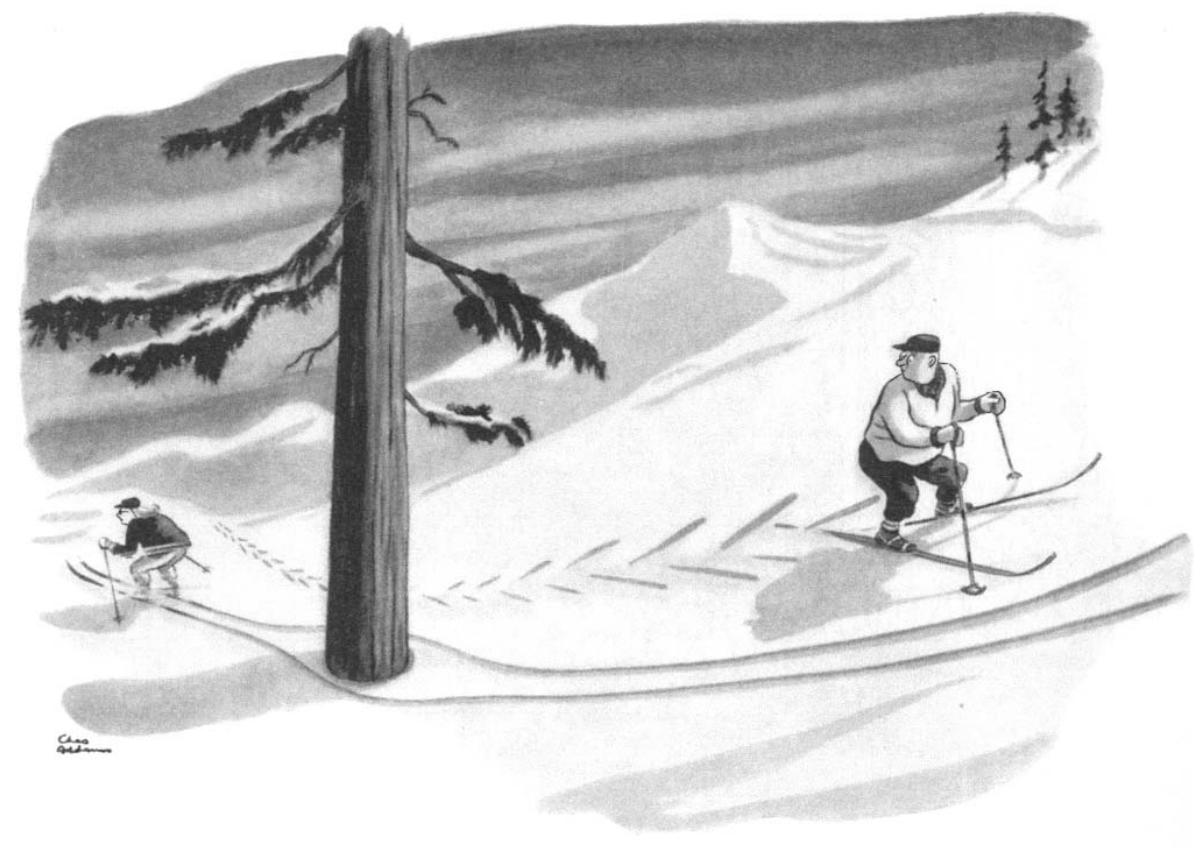

de contextos diferentes: na capa da quarta edição, a flauta de um Pan é confundida com um galho de árvolhe por um pássaro. Já na polêmica capa da oitava edição (que rendeu reclamações de religiosos), o chapéu cheio de flores na cabeça do anjo adiciona à auréola a função de servir como moldura radiante do elemento decorativo. Em ambos os casos, o olhar é claramente dirigido a um elemento-chave da ilustração.

Quando Steinberg estreou na New York em 1941, alguns famosos cartuns mudos já haviam sido criados, como o do esquiador de técnica mirablante, criado por Charles Addams em 1940. No entanto, este recurso era usado esporadicamente por alguns cartunistas da revista. Saul viria a se destacar ao resolver praticamente todos os seus trabalhos sem recorrer a legendas. Se dentre os primeiros vinte cartuns de Steinberg na New Yorker metade ainda usavam legendas e texto, ao final dos 100 primeiros seriam totalizados apenas 22 mudos. A inovação, no entanto, não se resumia ao simples fato dos cartuns não recorrerem a texto, mas também às peculiares abordagens gráficas e temáticas de Steinberg. É o que comenta Manuel Gasser, em artigo de 1965 na revista Graphis:

Quando Saul Steinberg veio à tona em meados dos anos 1930, a "revolução do cartum" já estava a caminho, e o desenho, previamente apenas a ilustração de uma anedota, havia se tornado um fim em si mesmo no cartum sem palavras. Um olhar aproximado a esses desenhos, no entanto, revelam que na verdade eles haviam apenas absorvido a legenda e as traduzido em termos pictóricos. A natureza da piada não havia sido afetada por esta pequena operação, e de fato era possível traduzí-la de volta em palavras. Steinberg foi o primeiro a enfrentar o desafio de dar o próximo passo, e apresentar ao público cartuns que não eram engraçados apenas por sua expressão gráfica. Ele assim criou algo que pode ser chamado de cartum abstrato (Gasser, 1965, p.21). 

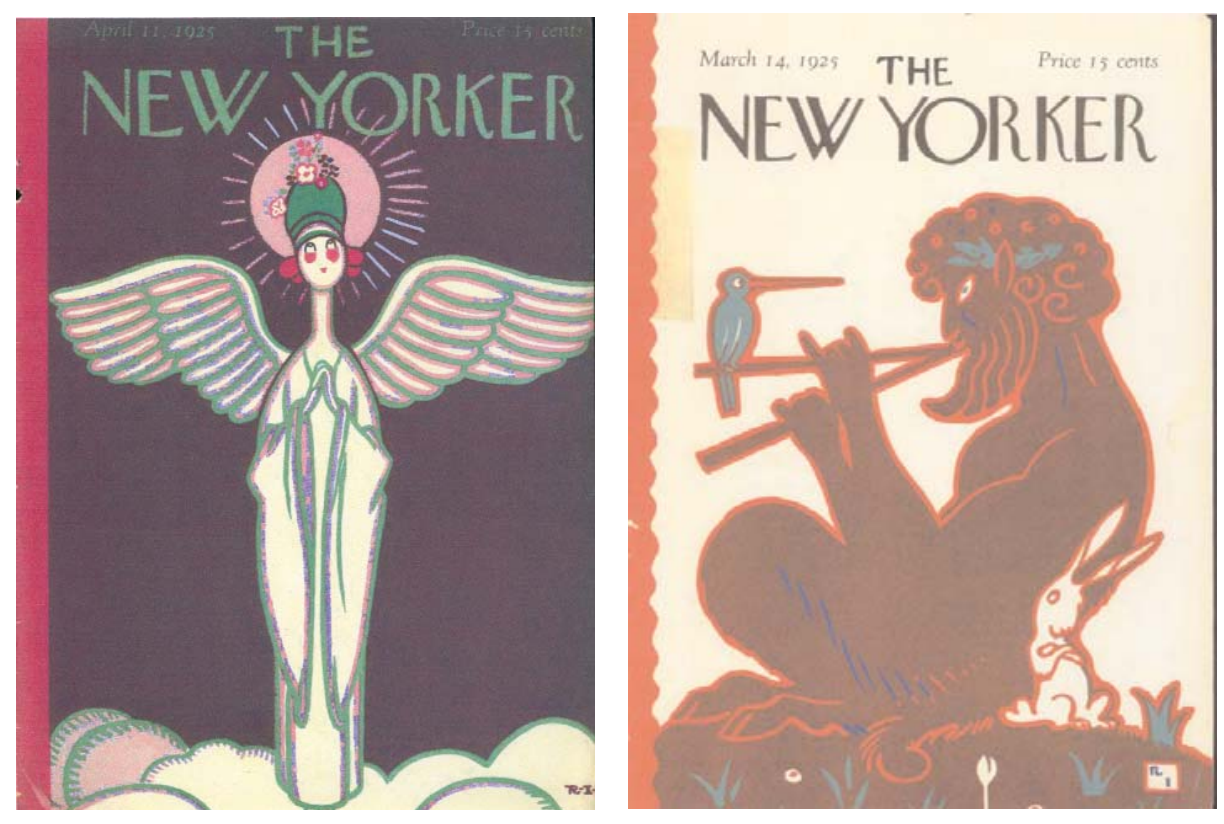

Figura 104. Charles Addams, The New Yorker, 1940

Figura 105. Rea Irving, The New Yorker, 11 de abril de 1925

Figura 106. Rea Irving The New Yorker, 14 de março de 1925

Contexto: DepuraÇÃo, AbSTRaÇão e SimplificaÇÃo no Modernismo

Dentre os diversos elementos da obra de Steinberg que contribuem para o caráter original de seu humor mudo está o desenho simples de linha fina. Sua técnica não tinha um valor em si, mas no modo como estava a serviço de uma idéia: "Minha técnica não significa nada. Ela é simples; pode ser copiada por todos e eu mesmo não acho que ela é original. Não estou procurando originalidade na técnica" (Gluek, 1970, p.113). Steinberg não foi o inventor da simplicidade e nem do traço fino, mas seu tratamento e a abordagem proporcionaram algo novo no contexto do cartum mundial. Quando Steinberg estreou na New Yorker, o desenho vinha sofrendo transformações em todas as áreas, em meio ao advento do modernismo e dos movimentos de vanguarda artística, há várias décadas. As novas formas criadas pelos cartazistas, assim como pelos cubistas, futuristas e outros movimentos de vanguarda foram também, aos poucos, absorvidas pelos ilustradores e caricaturistas do meio editorial. O processo de simplificação, depuração, abstração presente de vários modos nestes movimentos foi motivado por buscas e acontecimentos diversos, mas sob o termo genérico de modernismo o historiador Argan resume estes grupos em "correntes artísticas que, na última década do século XIX e na primeira do século XX, propõem-se a interpretar, apoiar e acompanhar o esforço progressista, econômico-tecnológico, da civilização industrial" (Argan, 1988, p.185). Sob este posicionamento comum diante da sociedade, começa a transparecer a busca por uma elevada tensão formal nas obras dos diversos campos artísticos:

A tendência à abstração, à simplificação e ao elementarismo foi um dos motores das vanguardas artísticas e arquitetônicas de princípios do século: Adolf Loos, Mies van der Rohe, Hannes Meyer ou Ludwig Hilberseimer elaboraram propostas de uma redução máxima na 
arquitetura e no urbanismo. Como fizeram Piet Mondrian, Kasimir Malevich, Wassili Kandinsky e Paul Klee na pintura ou Gertrude Stein, Ezra Pound, Ernst Hemingway e Raymond Carver na literatura (Montaner, 1997, p.169)

Em meio à complexidade das transformações, Roger Remington enxerga na virada do século o nascimento de uma nova postura, de valorização da simplicidade, no modernismo:

Modernismo era mais do que o nome de um estilo. Era uma filosofia, um modo de ver a vida, um estado de mente. Em um sentido amplo, o modernismo enunciava o que Frank Lloyd Wright defendia quando dizia que o que era mais necessário à arquitetura era uma filosofia, não uma estética. O modernismo emergiu depois dos 1900 como uma rejeição radical dos tradicionais valores dos vitorianos. Todo elemento vitoriano era descartado em um movimento dramático entre pensadores progressistas em direção ao caminho mais simples que era visto como mais apropriado ao novo século vinte. (...) Assim como os vitorianos abraçavam a complexidade e o embelezamento, os modernistas advogavam a simplicidade. $\mathrm{O}$ artista Hans Hoffmann uma vez disse, "a habilidade para simplificar significa eliminar o desnecessário de modo que o necessário possa falar". Estes visionários também procuravam por um novo tipo de funcionalismo que Hoffman chamava de "o necessário". Um novo espírito de inovação estava no ar e presente em toda arte e design. Ao final da Primeira Guerra, criativos designers gráficos, artistas e arquitetos estavam desafiando as formas estabelecidas (Remington, 2003, p.16).

Neste processo de simplificação, o desenho a traço exercia o seu papel, como comenta Ferreira Gullar: "O desenho a traço, que é mais puro, é sinônimo de "eliminar": desenhar a traço é dizer tudo com pouco. O desenho em si é uma abstração. É pegar uma figura, um objeto, uma paisagem e fazer o traço criá-lo de novo. Utilizar-se das formas reais e criar com elas uma nova realidade: a obra de arte" (cit. por Lima, 1963, p.1604).

As artes gráficas, além da relação com as mudanças nas artes plásticas, vinham passando por transformações consideráveis, motivadas pelo surgimento de novas técnicas. Desde o final do século XIX, com o surgimento da litografia, as ilustrações dos posters haviam introduzido "uma nova estética de imagens econômicas e simplificadas, decorrentes dos meios utilizados para reproduzi-las", através da obra de cartazistas como Jules Chéret, Pierre Bonnard e Henri de Toulouse-Lautrec (Hollis, 2001, p.5). Ainda antes do final do século XIX, soluções de grande síntese e impacto gráfico eram elaboradas para cartazes, como no desenho do cão do poster da revista Simplicissimus, criado em 1896 por Thomas Theodor Heine, com aplicação de apenas duas cores de impressão e sábio uso do branco do papel não-impresso. Ou no trabalho de Nicholson e Pryde - que trabalhavam juntos sob o nome de Beggarstaffs - ao empregarem a técnica da silhueta, "uma maneira muito econômica de 

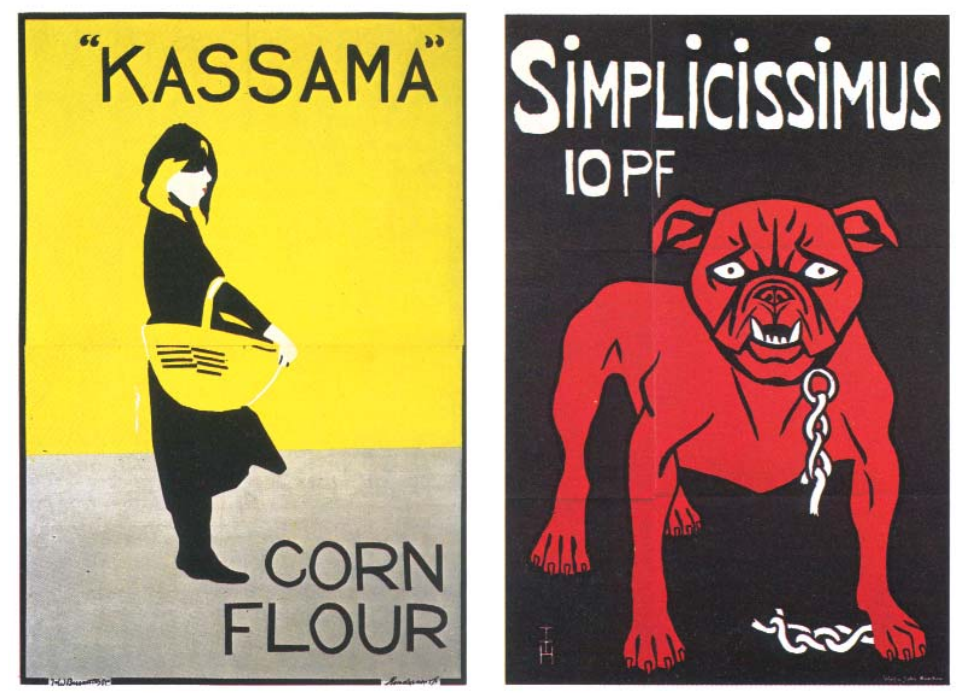

Figura 107. Beggarstaffs, "Kassama" corn flour, 1900

Figura 108. Thomas Theodor Heine, poster da Simplicissimus, 1896

Figura 109. Capa da Jugend, feita por I. R. W., vol.4, n.20, 1899

Figura 110. Capa da Ver Sacrum, vol.2, n.3, artista desconhecido, 1899

Figura 111. Capa de L'Assiete au Berre, n.46, de Félix-Edouard Vallotton, 1902

produzir pôsteres para reprodução, já que os tons eram todos uniformes" (cit. por Hollis, 2001, p.7).

A ousadia editorial de determinadas revistas satíricas lançadas no final do século XIX contribuiu para a disseminação das novas linguagens modernas. A fundação da publicação semanal satírica Simplicissimus, em 1896, marca a mudança em direção aos fluidos gráficos modernos e expressionistas. Tratava-se de uma nova abordagem em relação às tradicionais Punch, da Inglaterra, Petit Journal pour Rire, da França, ou Life, Puck e Judge dos Estados Unidos. (Hollis, 2003, p.16). Junto da revista de arte e cultura Jugend, fundada no mesmo ano, "sinalizavam uma rebelião da juventude contra o estabelecido romantismo e academicismo (...)". (Hollis, 2003, p.17). Tanto a Simplicissimus quanto a Jugend eram de Munique; de terras austríacas veio a Ver Sacrum (1897), publicação de design gráfico inovador da Secessão, com ousado uso do espaço em branco e que empregava ornamentos em formas geométricas (Heller, 2000, p.12). Em Paris surgiu o jornal satírico L'Asiette au Beurre, de 1901, que publicou em suas páginas a obra de Félix-Edouard Valloton. As imagens deste artista apresentavam "formas simplificadas que desafiam categorizações estilísticas, mas são

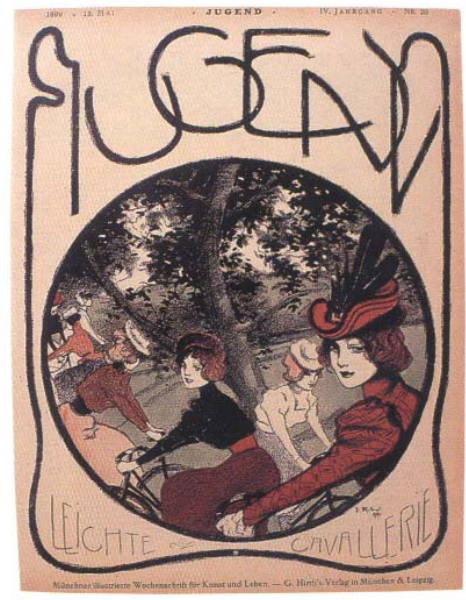

UERSACRVM ZEITSCHRIFT.DER. UEREINIGUNG BILDENDER KUENSTLER OSTTERE

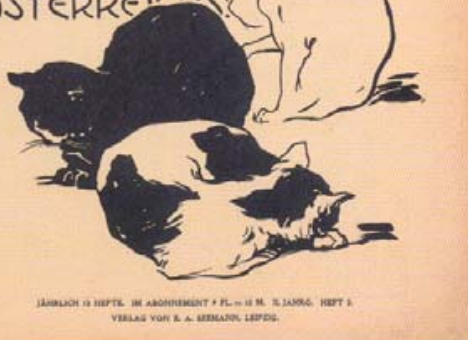

L'Assiette au Beurre

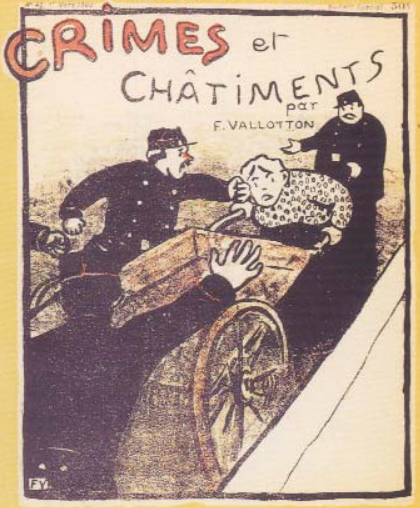



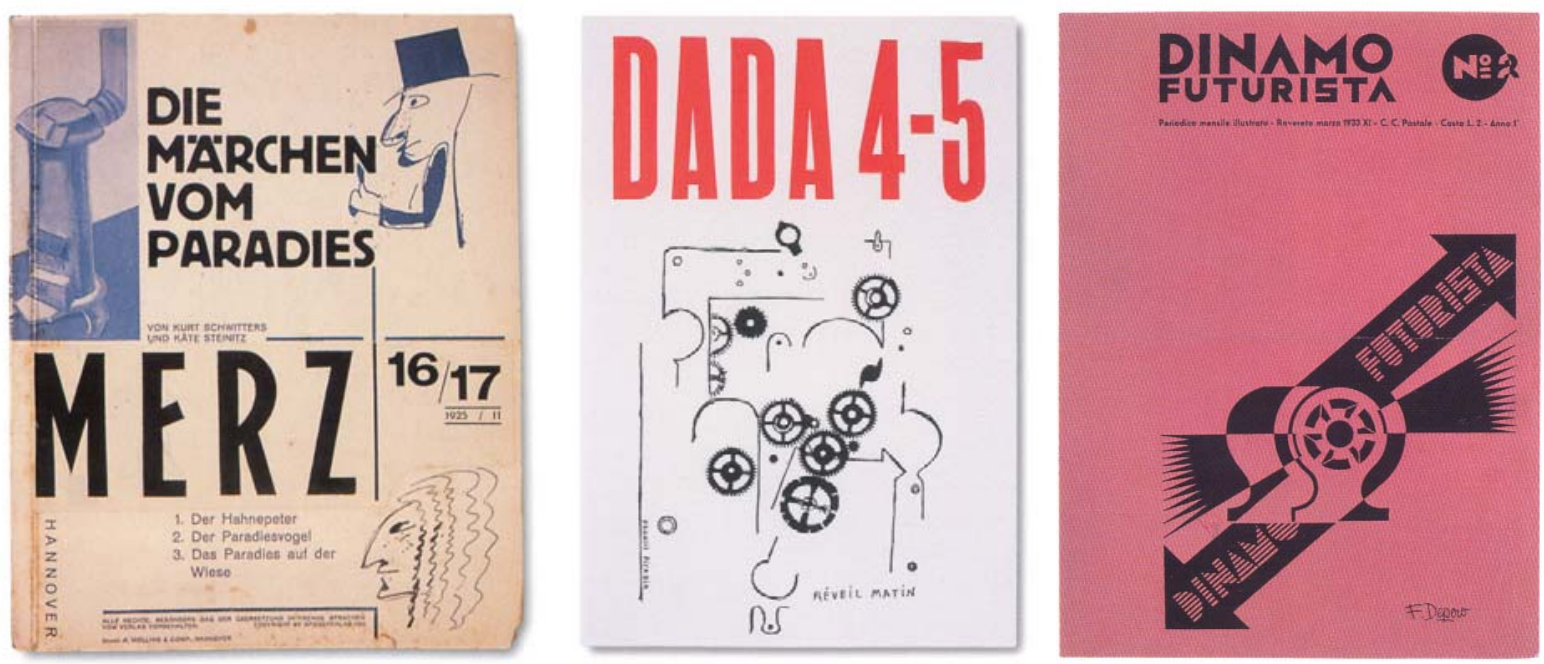

estridentes em sua simplicidade primitiva" (Hollis, 2001, p.25).

A mentalidade do modernismo se espalhou por todos os campos da criação influenciando decisivamente nas novas formas criadas. "O ímpeto dos movimentos artísticos de vanguarda europeus proporcionou as bases para a nova abordagem do modernismo no design", observa Remington (Remington, 2001, p.17). Na Rússia, os construtivistas procuraram disseminar sua estética da arte no design de teatro, de posters, moda e tecnologia. Já os futuristas da Itália, inspirados no movimento e na máquina, criaram um estilo dinâmico para sua arte e design gráfico, que poderia ser chamado de "cubismo em movimento". Em Paris, os designers foram influenciados pelos artistas cubistas Picasso e Braque - admiradores de Cézanne -, que proporcionaram novos modos de ver a realidade na arte. Suas pinturas representavam objetos em três dimensões de tal modo que, de uma vez, era possível enxergar visões simultâneas em um mesmo plano. O cubismo, através de sua ambiguidade de forma, era apenas um dos movimentos artísticos que estavam rejeitando a tradição; os manifestos eram divulgados em publicações por toda a Europa (Remington, 2001, p.17). Uma grande quantidade de revistas de vanguarda foi criada para assumir o papel de veículos dos

Figura 112. Merz, n.16-17, tipografia de Kurt Schwitters, desenhos de Kathe Steinitz.

Figura 113. Dada, n.4-5, arte de Francis Picabia, 1919

Figura 114. Dinamo Futurista, n.2, editada por Fortunato Depero.

Figura 115. AlZ, vol.6, n.7., 1927

Figura 116. Mécano, n.1., von Doesburg, 1922

Figura 117. Páginas de Was ist Dada?, design de Grosz e John Hearfield, 1920

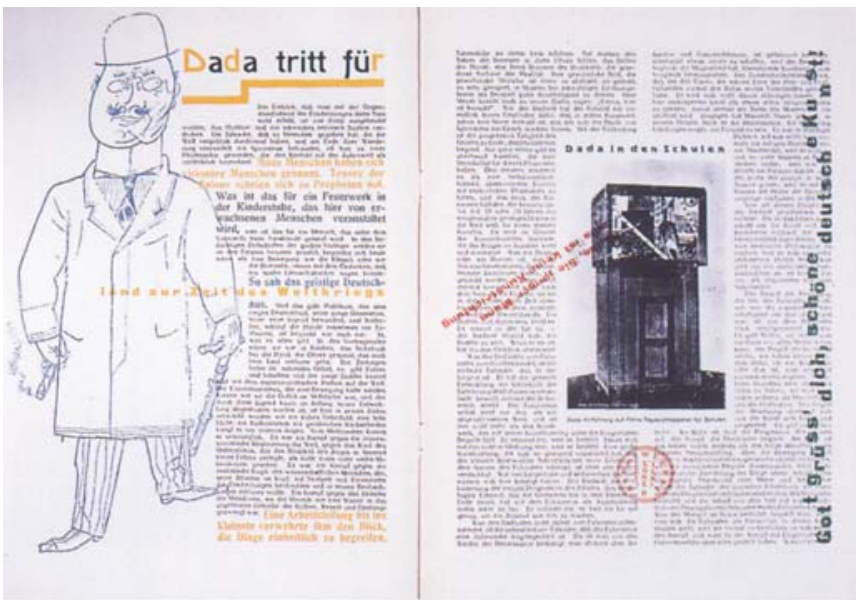



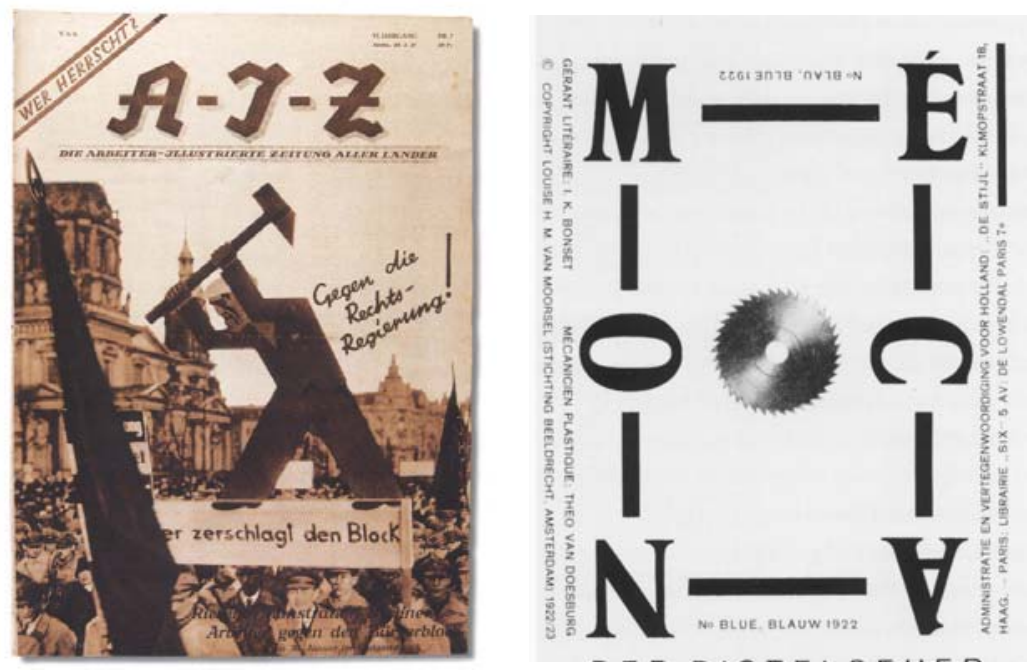

novos tempos e idéias, como as futuristas Noi e Dinamo Futurista, as dadaistas Mersz, Mécano, Dada, Was ist Dada?, a antinazista AIZ, a comunista Die Pleite, a modernista racionalista De Stijl, dentre outras. Neste contexto de ruptura, artistas por vezes atuavam em campos diversos, nas artes plásticas e no meio editorial, como o futurista italiano Fortunato Depero e George Grosz. Depero, por exemplo, foi para os Estados Unidos em 1928 e durante sua visita chegou a fazer capas para a Vanity Fair, Vogue e The New Yorker, além de posters e produtos de promoção (Remington, 2001, p.53).

\section{CONTEXTO: MOdernismo E DESENHO SIMPleS NAS ILUSTRAÇÕES DO MEIO EDITORIAL}

As formas e soluções estéticas do modernismo, das vanguardas artísticas e da arte gráfica dos cartazistas aos poucos foi sendo incorporadas por publicações de grande público do mercado editorial. Na década de 1910 revistas como a americana Vogue ostentavam ilustrações em estilos inspirados no avant-garde em sua capa, com trabalhos de George Plank e Helen Dryden. Sobre as influências destes artistas, é possível reconhecer, "predominantemente, a ilustração britânica de Edward Burne-Jones, Walter Crane e Kate Greenaway". No caso de Plank, há a contribuição das obras do "fin de siècle de Paris e Viena", em especial nos aspectos decorativos e no serpentear da linha de Mucha ou Klimt (Packer, 1980, p.15). Dryden viria a ser uma das poucas significativas sobreviventes deste período, continuando a produzir para a Vogue com boa regularidade e variedade até 1923 ((Packer, 1980, p.17).

$\mathrm{Na}$ década de 1910, no Brasil, os trabalhos de J. Carlos podiam ser apreciados nas capas da revista Careta. O artista formava com Klixto e Raul o "trio de ouro" da imprensa ilustrada brasileira no início do século XX. Todos eles foram, de algum modo, influenciados pela arte do caricaturista português Julião Machado, atuante no Brasil desde 1895. A chegada de Julião coincidiu com a adoção de uma inovação técnica na imprensa ilustrada que con- 
Figura 118. Capa de Helen Dryden para Vogue, 1917

Figura 119. Capa de Plank para a Vogue, 1918

Figura 120. (abaixo) Vinheta de Julião Machado para A Bruxa, final do século XIX.
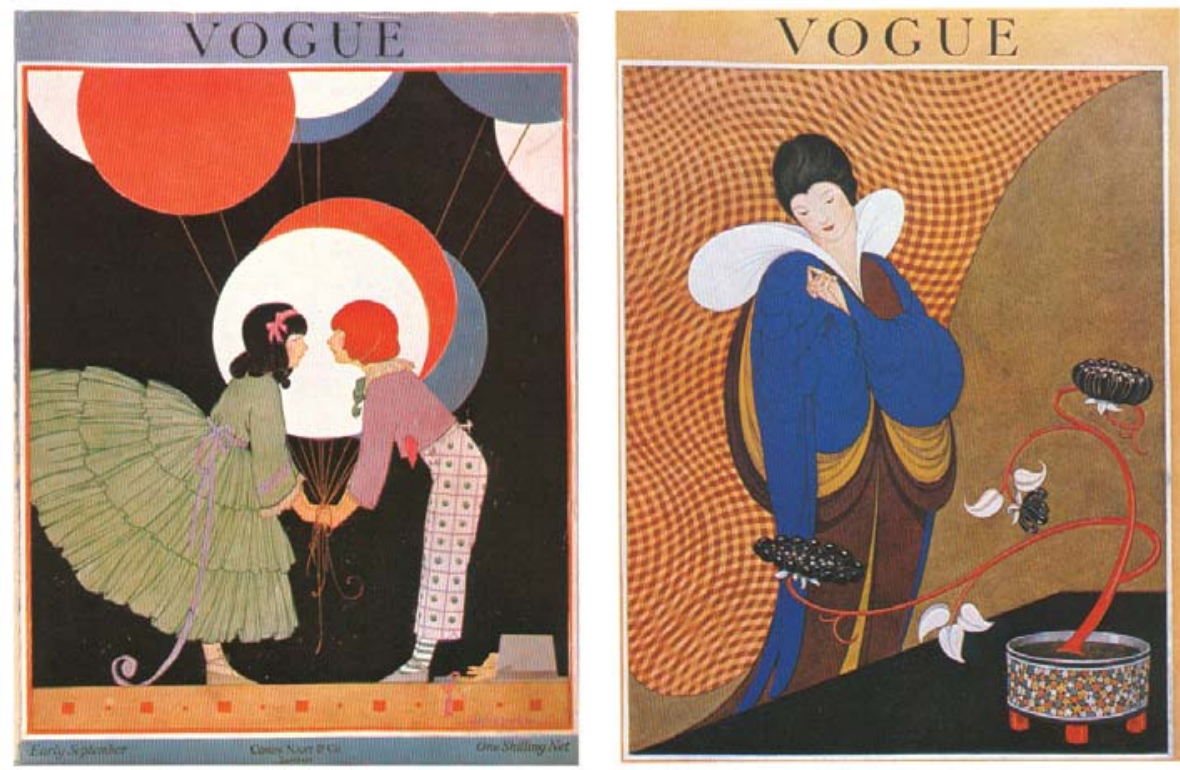

tribuiu para a disseminação de um novo estilo, influenciado pelos caricaturistas franceses, como Gerbault, e pelo tcheco Mucha. A litografia, dominada com maestria por Angelo Agostini e seus discípulos começou a perder espaço para a zincografia, de recursos mais amplos. Como observa Pedro do Lago, "nos anos seguintes as técnicas sofisticaram-se ainda mais com a autotipia, que permitia também a publicação de fotografias, libertando a caricatura da fidelidade aos traços dos personagens que retratava" (Lago, 2001, p.48). A influência do francês Daumier, a técnica do esfuminho e as figuras sombreadas cederam espaço a trabalhos com maior ênfase à linha. Neste aspecto, além do "trio de ouro", vale mencionar o pioneirismo de Rian, primeira ilustradora brasileira, em seus desenhos de ágeis linhas pinceladas, com resultados que atingem considerável simplicidade para a época. Estes trabalhos, feitos a partir de 1913, recebiam a influência do cartunista francês Sem, que na virada do século já fazia desenhos de linha fina leves e elegantes. Mas é J. Carlos, pelo volume, qualidade e características de seu trabalho ao longo de quase 50 anos de ilustração, que se destaca no campo do

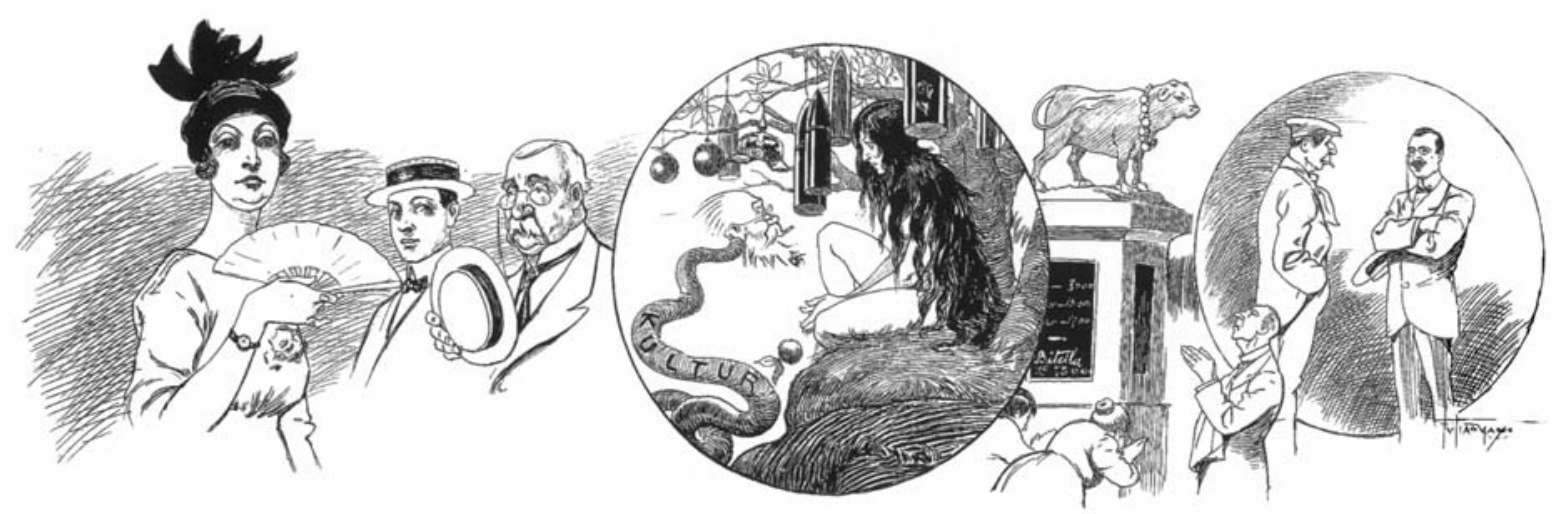



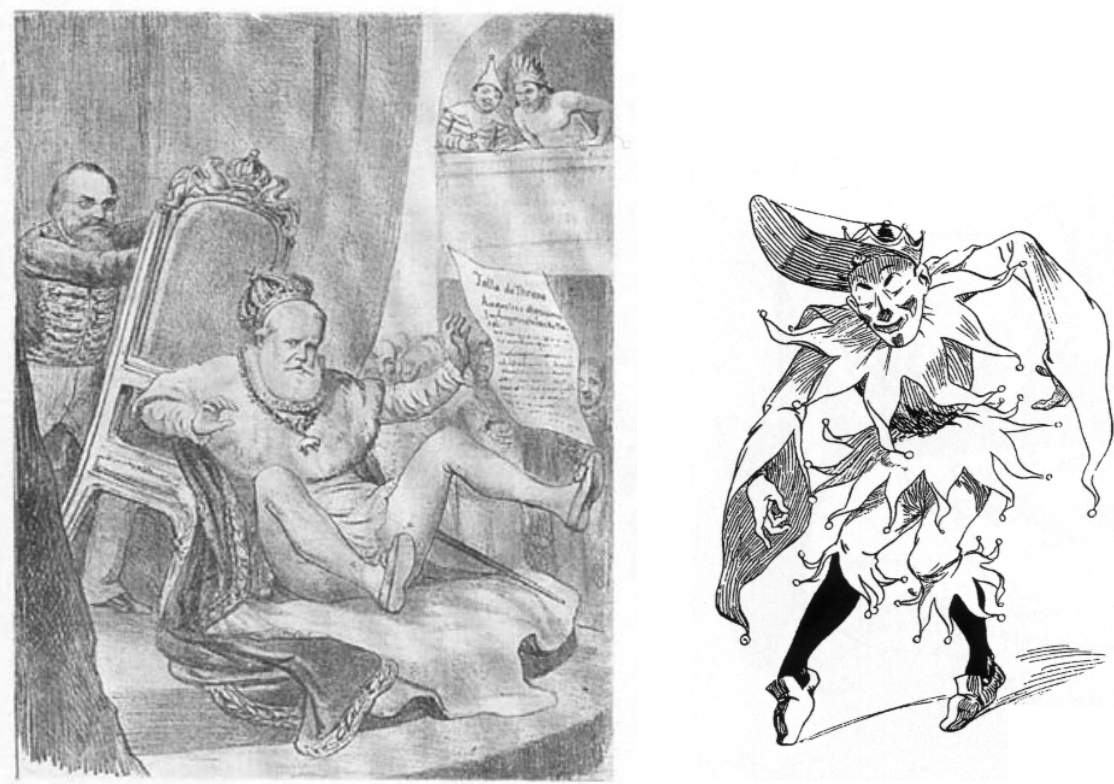

Figura 121. Angelo Agostini,

Revista llustrada, 1882

Figura 122. K.Lixto, vinheta para a Kosmos, 1906

Figura 123. Desenho de Raul, 1924

Figura 124. Trabalho de Ryan para a Fon Fon, 1910

desenho gráfico moderno brasileiro. Nas palavras de Julieta Sobral, "J. Carlos foi, em sua época, o melhor exemplo de um designer moderno, demonstrando uma capacidade de síntese e elegância impressionantes, mesmo para os parâmetros de hoje" (Sobral, 2005, p.125). Como observa Herman Lima, em seu História da Caricatura do Brasil:

O que J. Carlos trazia para a caricatura brasileira era alguma coisa de arejado e de novo (...). Uma limpidez e uma rapidez de traço que vai muitas vezes da risca do cabelo à ponta do pé do indivíduo, num serpenteio magistral; uma bravura do contorno que dizia tudo, sem o recurso do modelato e da meia-sombra (...) (Lima, 1963, p.1074).

Ilustrador desde 1902, J. Carlos foi co-fundador da revista Careta em 1908, onde trabalhou até 1921, retornando a ela, após intervalo, em 1935. "Se O Tagarela e A Avenida, semanários nos quais trabalhou nos primeiros anos, podem ser vistos como uma fase de for-
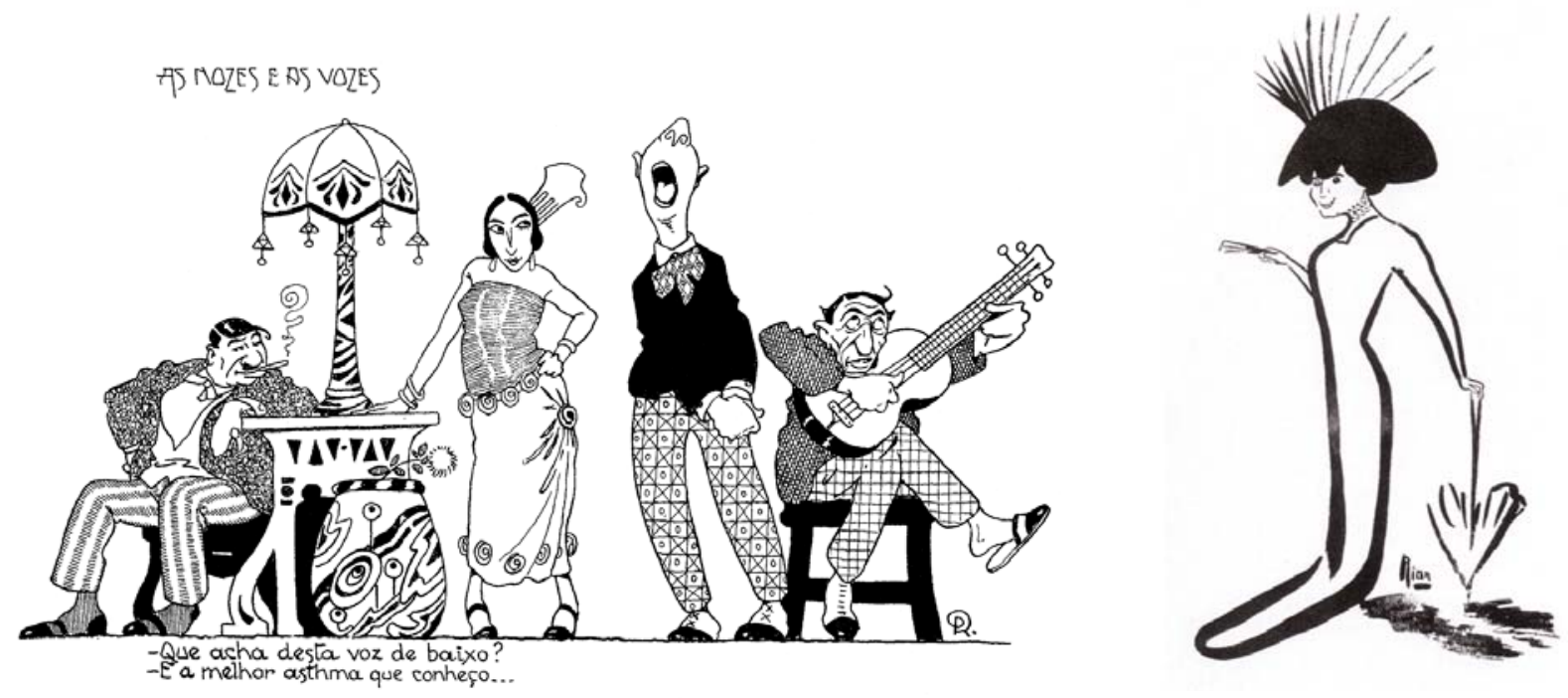

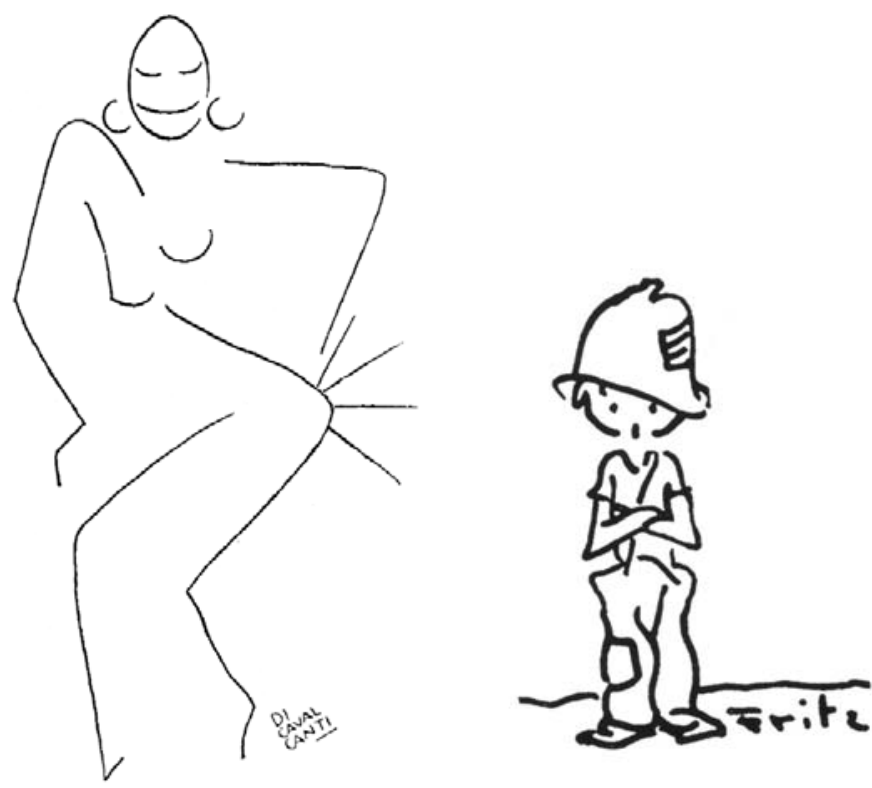

Figura 125. Desenho de

Di Cavalcanti, Josephine

Baker, Para Todos, 1928

Figura 126. Garoto

desenhado por Fritz.

mação, a Careta parece ter servido como uma verdadeira especialização", comenta Sobral (Sobral, 2005, p.128). São, mais uma vez, as peculiaridades técnicas que promoveram novos resultados gráficos, já no início de carreira do artista:

As suas próprias características de impressão balizaram - e de certa forma incentivaram - a despretensão artística de J. Carlos. Se em outras publicações, como O Cruzeiro, Fon-Fon e Ilustração brasileira, o desenhista ganhava ares de artista, ao dispor da reprodução de seus trabalhos em quadricromia, na Careta e em outras revistas isso não acontecia. Não havia trabalho com pincel. Não pintura mas grafismo: J. Carlos desenhava linhas a nanquim" (Dapieve, 2000, p.10).

O traço de J. Carlos passou por evoluções e fases, acompanhado as referências artísticas da época, ficando mais simples e limpo com o decorrer do tempo. Nas palavras de Nathalia Cavalcante, "J. Carlos absorveu a influência dos dois movimentos europeus, o art noveau e o art déco, imprimindo em seu trabalho, entretanto, uma espécie de tempero brasileiro, particularmente carioca" (Cavalcanti, website, s.p). Quando comparado com o traço de Steinberg, a linha de J. Carlos ainda apresenta a precisão e a limpidez geométrica dos movimentos de seu tempo. Os contornos são mais calculados, definidos e encorpados que o desenho "infantil" de Steinberg. Já a depuração e economia de alguns trabalhos antecipam ousadas experiências de Steinberg. Sua síntese configura-se em uma das características mais modernas de seu trabalho por conseguir a exatidão com o mínimo que a linha oferece, subtraindo elementos, deixando subentendidas linhas não-desenhadas, conciliando traços, a princípio diversos, em um único.

J. Carlos destacava-se, mas outros cartunistas brasileiros merecem ser mencionados pela simplicidade do traço. Neste aspecto, dentre os artistas atuantes nas três primeiras 

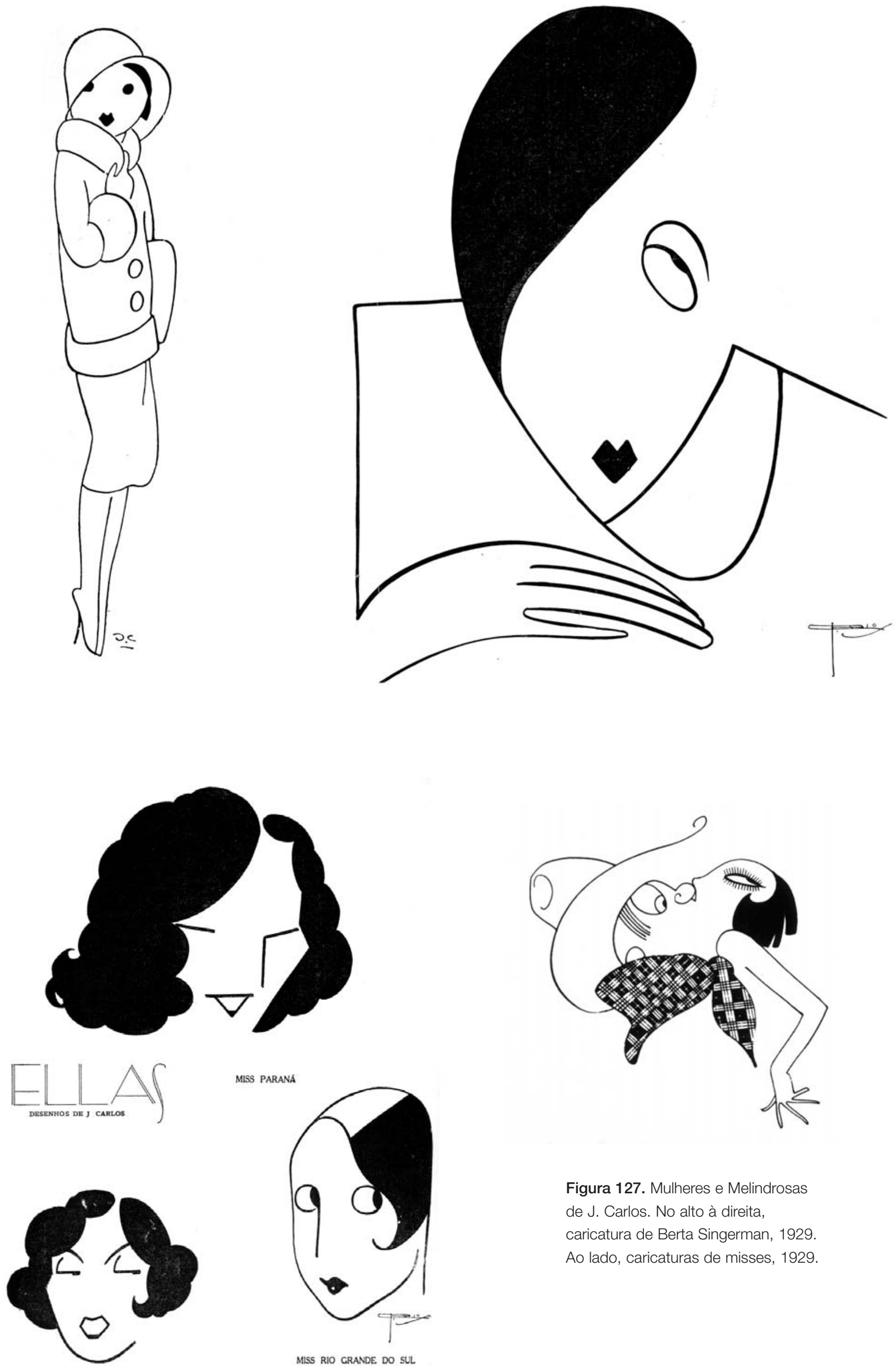

Figura 127. Mulheres e Melindrosas de J. Carlos. No alto à direita, caricatura de Berta Singerman, 1929. Ao lado, caricaturas de misses, 1929. 

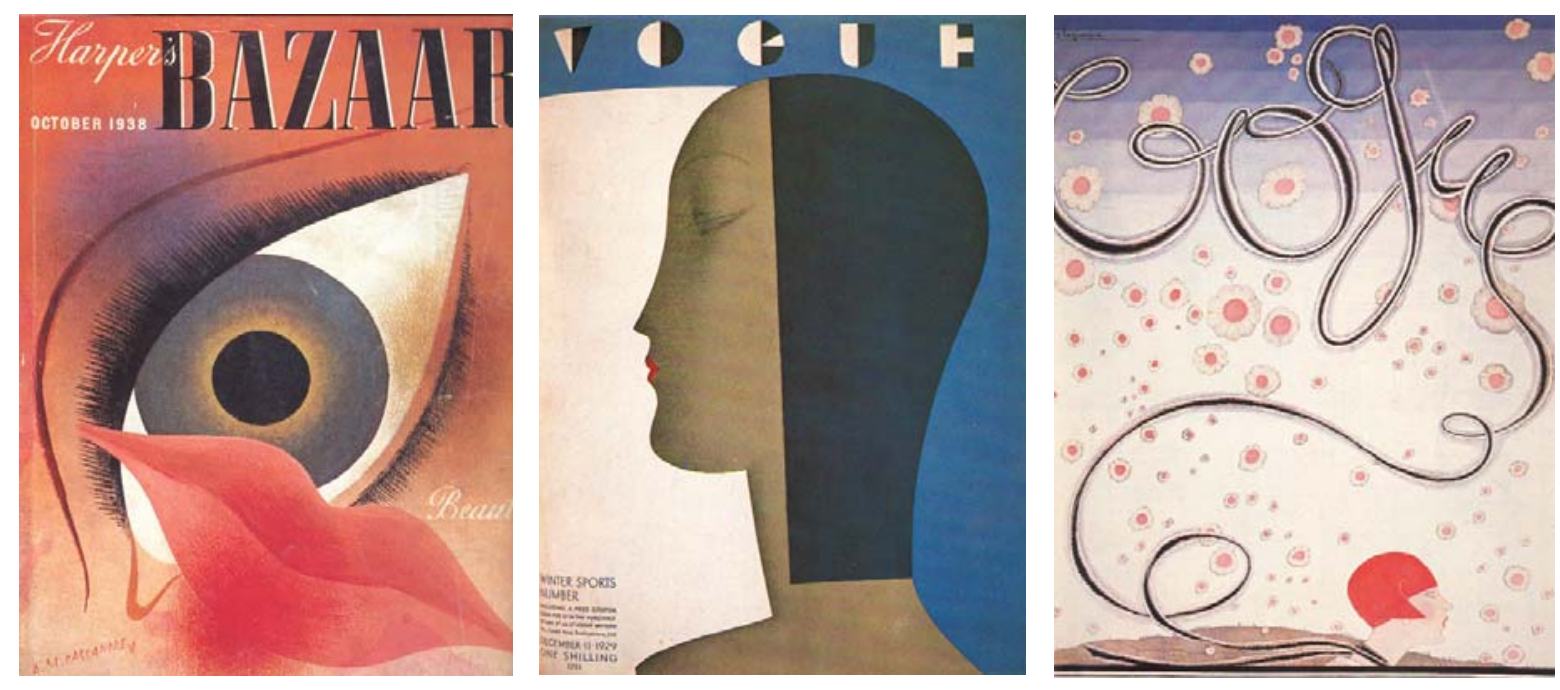

décadas do século XX, outro que impressiona é Fritz. Com influências do francês Poulbot, seu desenho é mais solto, vigoroso e ágil, com menor estilização geométrica. Já Di Cavalcanti, artista da Semana de Arte Moderna de 1922 que também exerceu carreira de cartunista, consegue resultados de síntese notáveis em certos casos, como no desenho de Josephine Baker publicado na revista Para Todos em 1929. Feito com pouquíssimas linhas, distanciadas umas das outras, estas são definidas pelo contorno sinuoso exterior do corpo da personagem.

Muitas das publicações dos anos 1920 e 1930 incorporaram as estéticas do avantgarde que haviam sido introduzidas nas capas das revistas culturais progressistas. Dentre elas destacam-se as revistas de moda, como a Harper's Bazaar e a Vogue, que ao assumirem estas diretrizes procuravam caracterizar-se pelo bom gosto e refinamento. Nos anos 1920 a Harper's Bazaar contratou uma grande referência na estilização da art moderne, o artista Erté, e nos anos 1930 encaminhou capas ao renomado cartazista francês, com consideráveis influências do art déco, A. M. Cassandre. Benito era o estilista gráfico da arte das capas em estilo high-deco da Vogue (Heller, 1996, 73). Algumas de suas ilustrações para a Vogue sugerem uma clara homenagem ao escultor moderno Brancusi. Seu trabalho se tornaria cada vez mais simples ao longo de sua carreira, "explorando contrastes e antagônicas combinações de tons e cores, muitas vezes fraturando figuras em sua idiossincrática versão de cubismo tardio" (Packer, 1983, p.202). Lepape também foi um dos mais importantes ilustradores da Vogue até o final dos anos 1930, em capas com influências do avant-garde, expondo elegantes moças de pescoços longos que lembravam Modigliani.

Mas as ilustrações com influências modernas não ficavam relegadas às revistas de moda. Algumas publicações de humor do começo do século XX, mais leves e engraçadas do que os tradicionais tablóides satíricos de então, voltaram suas atenções para a sociedade e as artes, com reflexos nas ilustrações. A revista humorística Life, fundada em 1883, teve mudanças de diretrizes em 1900, período em que avanços na impressão trouxeram as cores às capas da publicação. A partir de então, se tornou um grande mostruário do desenho de 

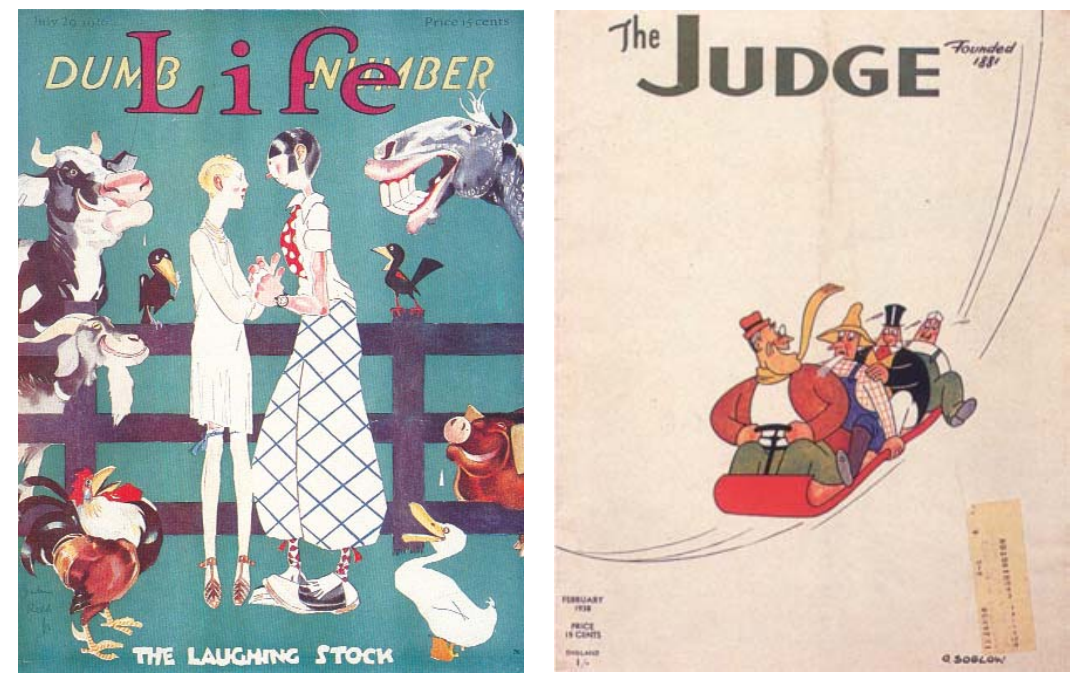

Figura 128. Capa de Cassandre para a Harper's Bazaar, 1938

Figura 129. Capa de Benito para a Vogue, 1929

Figura 130. Capa de Lepape para a Vogue, 1928

Figura 131. Trabalho de John Held, Jr. em capa da Life, 1926

Figura 132. Capa de Otto Soglow para a Judge, 1938

humor. Como observa Steven Heller, começaram na Life artistas como James Montgomery Flagg, Coles Philips, Norman Rockwell, John Held Jr. e outros que iriam se tornar famosos em suas associações com outras revistas. Mesmo a Judge, que no final dos anos XIX seguia a linha dos tablóides satíricos tradicionais, passou por reformulações, assumindo o formato de revista e publicando histórias em quadrinhos e cartuns (Heller, 1996, p.61). Suas capas expunham trabalhos de ilustradores que seriam vistos, na mesma época, também na New Yorker, como Gardner Rea e o cartunístico de linha fina Otto Soglow.

Um dos destaques da Life era John Held Jr., ilustrador que soube retratar o espírito do art déco e da Jazz Age dos anos 1920. Numerosos críticos do período perceberam sua grande influência. Para M. Inge, o artista foi "provavelmente um dos mais amplamente reconhecidos cartunistas dos anos 1920" (Inge, 1990, p.81). Segundo Corey Ford, "Fitzgerald a batizou de Jazz Age, mas John Held Jr. desvelou seu estilo e costumes. Sua angular garota de roupa decotada foi aceita pelos mais velhos como o protótipo de juventude moderna, o símbolo da revolução moral...Talvez nenhum comic artist teve um maior impacto imediato em uma geração" (cit. por Armitage, 1987, p.61). Ao conciliar estes estilos de
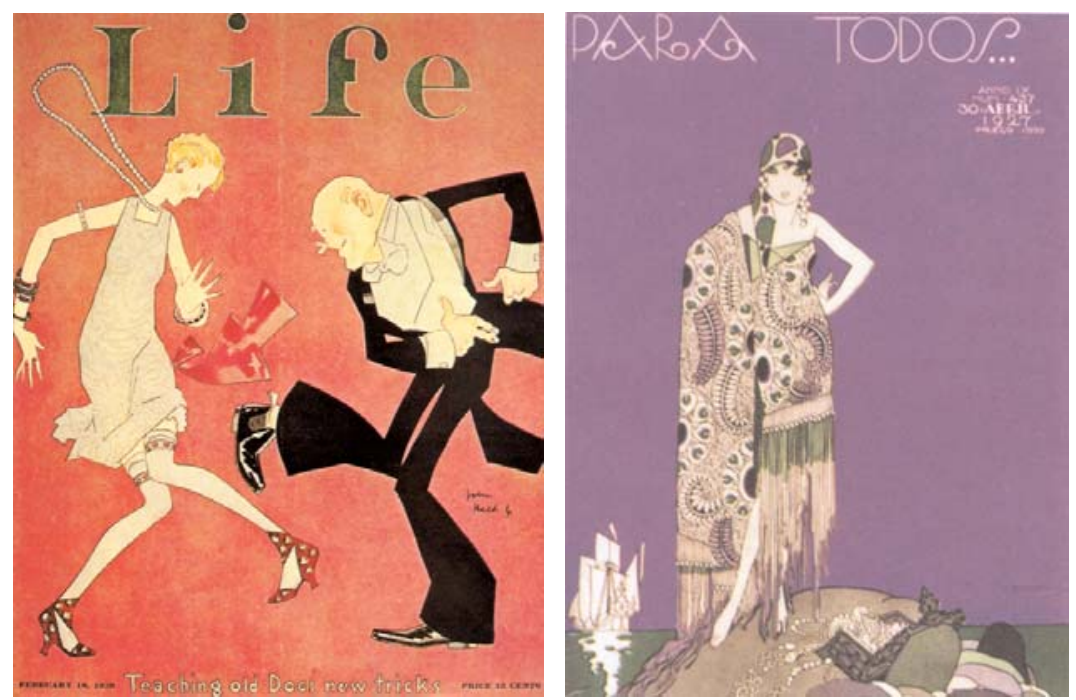

Figura 133. Capa de John Held, Jr. Life, 1926

Figura 134. Capa de J. Carlos, Para Todos, 1927 
época e percepção comportamental do período com o humor e personagens de feições cartunescas, John Held Jr. parece assumir nos Estados Unidos papel semelhante ao de J. Carlos no Brasil, na referida década. Exemplo disso é a atenção comum à figura feminina típica da época: as garotas de Held Jr. e a Melindrosa de J. Carlos. O trabalho de J. Carlos, ao longo das décadas de 1910 e 1920, à medida que caminhava em um processo de simplificação, iria também perder aos poucos o ar austero e sóbrio, e ganhar contornos e feições mais cartunescas e caricaturais, típicas dos desenhos animados. Held Jr. também transitava entre o desenho estilizado sério e cenas com personagens cabeçudos e olhos de pontinhos. No entanto, a ousadia no trabalho de síntese e economia da linha presente nos desenhos de J. Carlos aparece em menor amplitude nas ilustrações de Held Jr. Neste aspecto, faz mais sentido comparar o brasileiro com Al Hirschfeld, apesar das evidentes diferenças de estilo. É importante frisar que não entraram nestas comparações um outro estilo de Held Jr., devotado à gravura, publicado em revistas como a New Yorker.

Ainda na linha do desenho cartunizado da Jazz Age, a Vanity Fair também tinha capas com ilustrações do gênero, como as criadas por Anne H. Sefton e A. Fish. Esta revista, que foi extremamente influente ao conseguir atingir a média e alta cultura nos Estados Unidos no final dos anos 1920 e durante os anos 1920, se destacou com capas de ilustração satírica e comentário gráfico do mais alto nível, feita por artistas como Paolo Garreto e Miguel Covarrubias (Heller, 1996, p.43). Nesta época despontam trabalhos de caricaturas com contornos geométricos, influências do cubismo, da art moderne e, em certos casos, da arte popular e primitiva de outros países. Parte do aspecto moderno do trabalho do cartunista

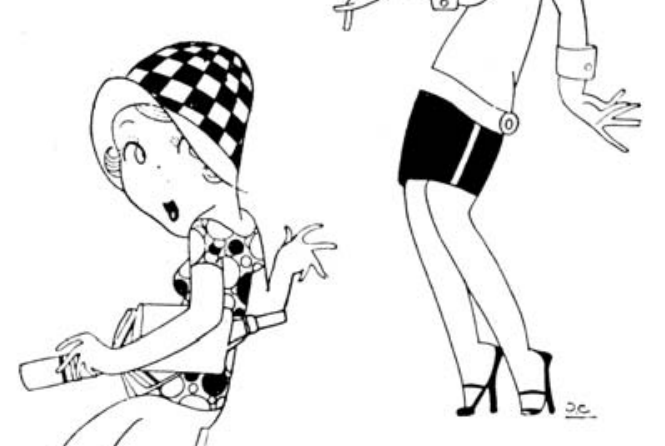

Figura 135 e 138. Nos dois cantos da página, as Melindrosas de J. Carlos

Figura 136. Desenho de Fish, 1920

Figura 137. Desenho sem data de John Held, Jr.

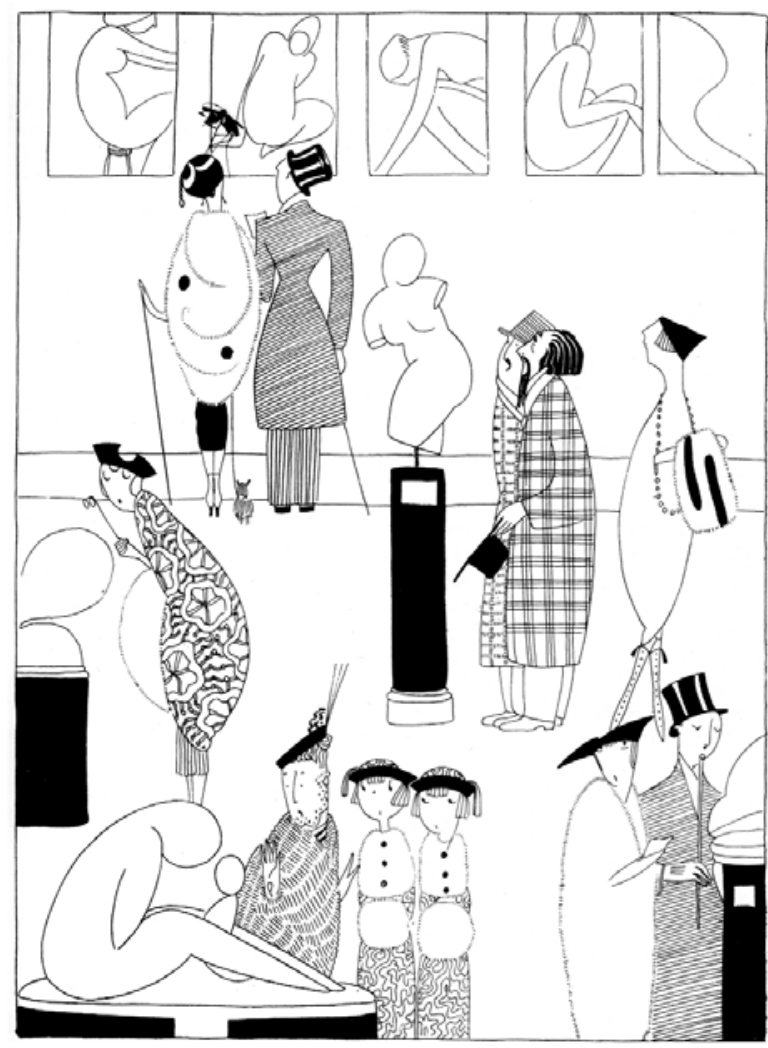


mexicano Covarrubias, por exemplo, era decorente de uma forte influência da arte colombiana. No Brasil é possível fazer um paralelo da obra destes artistas com a de Guevara, paraguaio que chegou no país em 1923, mesmo ano em que o mexicano Covarrubias passou a morar em Nova York. A arte de ambos variava entre o geometrismo volumétrico pintado e desenhos com linha em preto e branco. Como observa Pedro do Lago, "a inovadora arte geométrica de Guevara na caricatura pessoal, com os volumes acentuados pelos meio-tons, teve impacto sobre seus contemporâneos e influenciou decisivamente os jovens desenhistas então iniciantes, como Théo, Alvarus, Nássara, Mendez e Augusto Rodrigues" (Lago, 2001, p.116). O trabalho de Guevara era meramente informado pelo cubismo, sendo o termo "cubístico" usado por Loredano ao analisar este aspecto de sua obra:

Na década seguinte à dos "anos decisivos do Cubismo" (1908-1914), Guevara introduz em caricatura no Brasil a "decomposição e geometrização das formas" que caracteriza visualmente aquela tendência artística. Mas só se utiliza da linguagem, nunca da idéia de Picasso e Braque. Seus retratos nunca são objetos representados "como se fossem contemplados simultaneamente por todos os lados", muito menos revelam uma preocupação do desenhista com a "essência da problemática cubista, que na verdade se confunde com a questão fundamental da arte contemporânea, expressa na pintura como a contradição figurafundo": questionar a própria possibilidade de pintar", questionar "a linguagem da pintura" (Loredano, 1988, p.18).
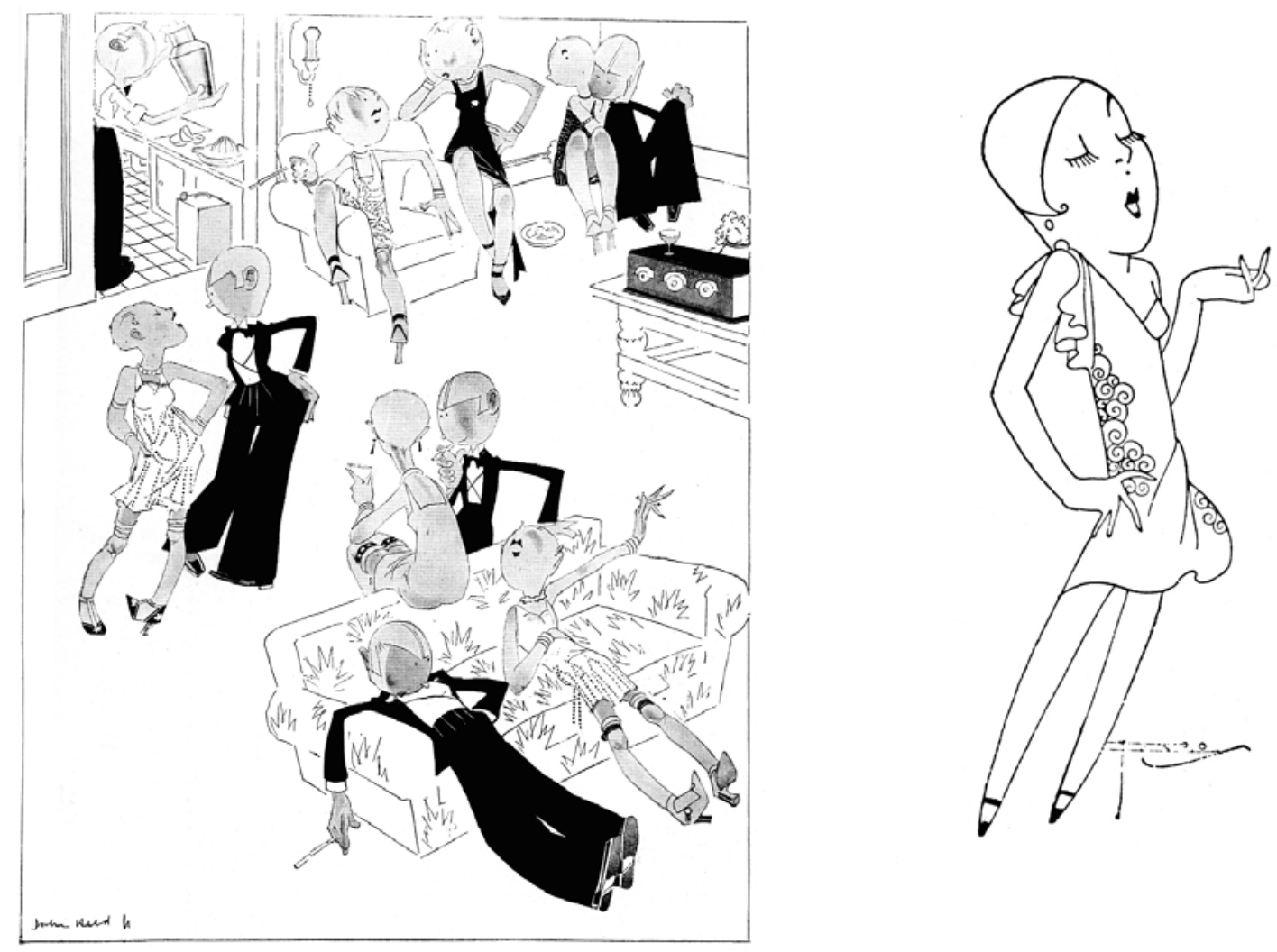

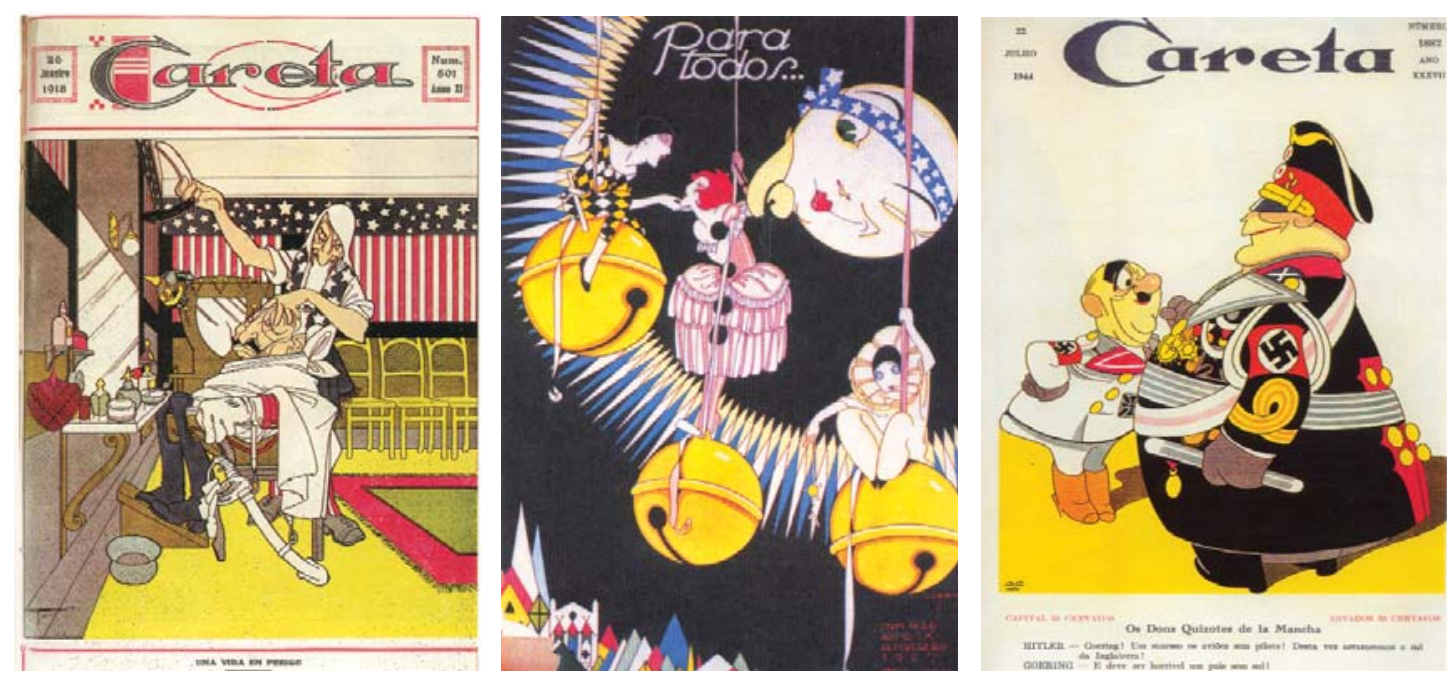

Figura 139. J. Carlos, Careta, 1918

Figura 140. J. Carlos, Para Todos, 1927

Figura 141. J. Carlos, Careta, 1944

Figura 142. Guevara, caricatura de Berta Singerman, 1929

Figura 143. (abaixo) Guevara,

caricatura de Olegário Mariano, 1929
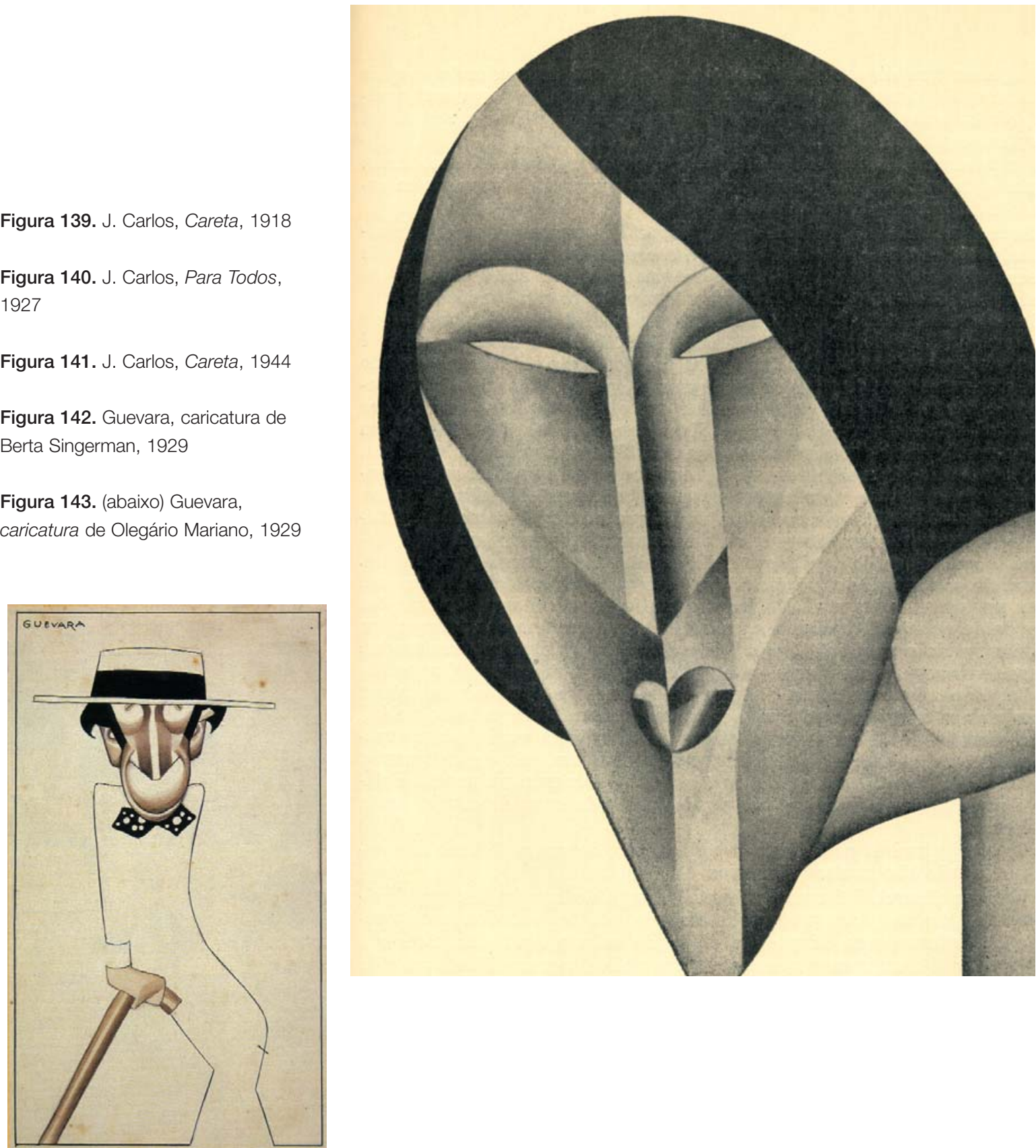

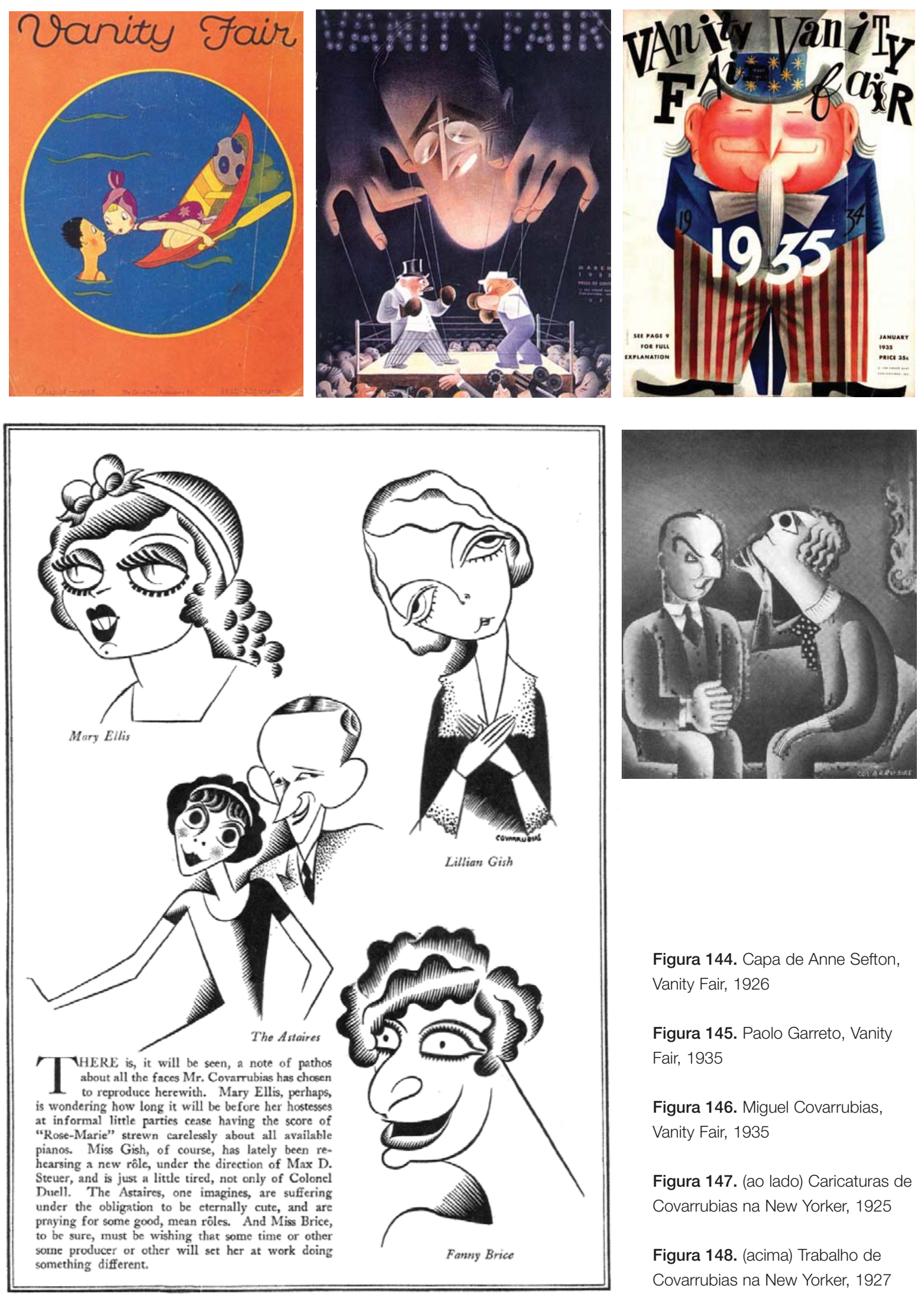

Figura 144. Capa de Anne Sefton, Vanity Fair, 1926

Figura 145. Paolo Garreto, Vanity Fair, 1935

Figura 146. Miguel Covarrubias, Vanity Fair, 1935

Figura 147. (ao lado) Caricaturas de Covarrubias na New Yorker, 1925

Figura 148. (acima) Trabalho de Covarrubias na New Yorker, 1927 

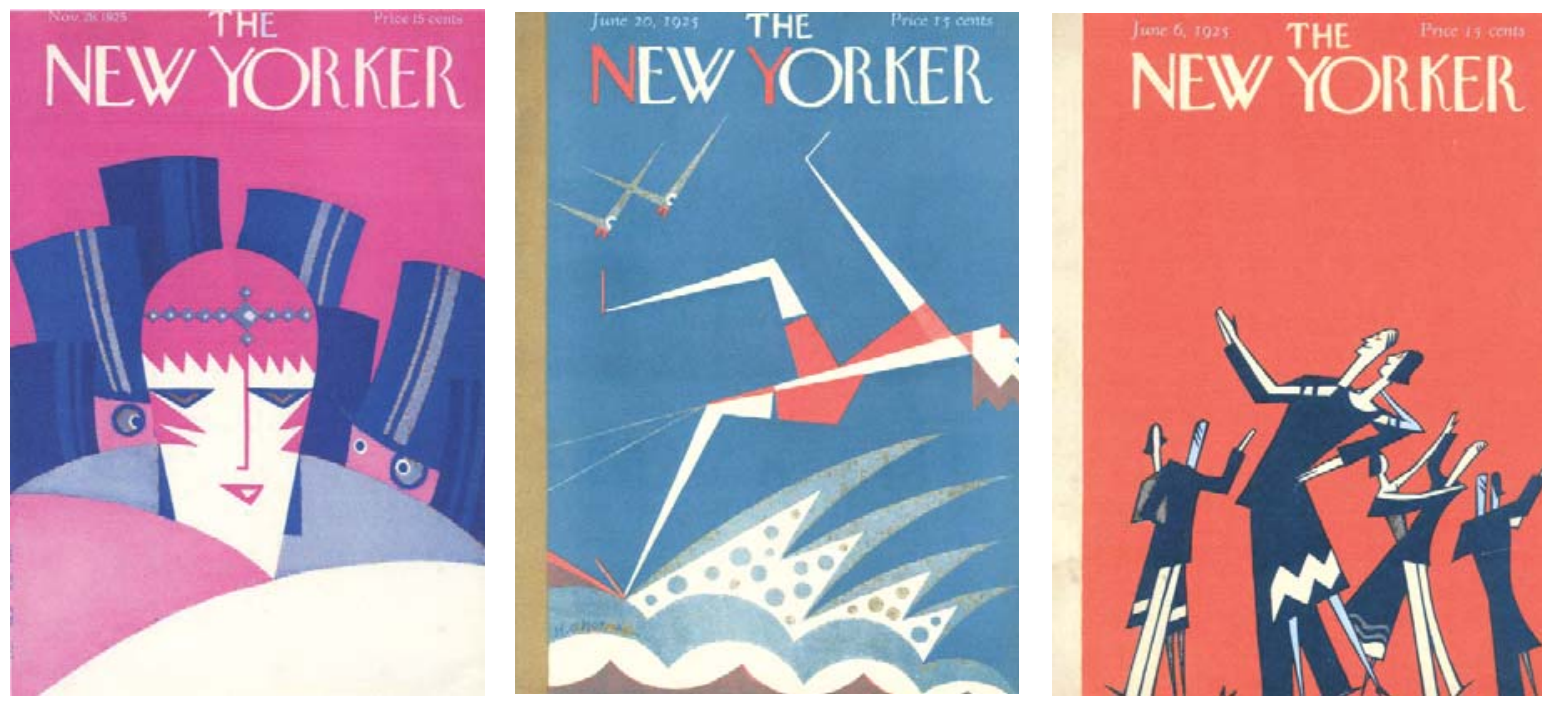

Contexto: Modernismo e desenho simples na The New Yorker

A New Yorker, em seus primeiros anos, promovia capas que aliavam a estilização modernista com um humor sutil nos trabalhos de Rea Irving, H. O. Hofman e Julian de Miskey. O já mencionado Irving tinha um desenho de "assegurada elegância" (Mouly, 2000, p.79) e "rara sutileza" (Lorenz, 1997, p.124). Seu estilo era "decorativo e deliberadamente sem profundidade de perspectiva; tinha a qualidade da caligrafia chinesa, com uma audácia de cor ocidental, no entanto" (The New Yorker, 1972, p.132). Este aspecto decorativo tinha aplicação criteriosa, sendo muito comum a presença de áreas vazias em seus desenhos. Como observa Lee Lorenz, "seus trabalhos era notáveis por sua linha sinuosa e composição balanceada de modo primoroso" (Lorenz, 1996, p.70). As capas de Hofman carregavam no impacto de grandes áreas geométricas com cores chapadas e na deformação inusitada das formas, com influências do cubismo e futurismo. Já as de Julian de Miskey tinham um apelo mais leve e sutil, com personagens esbeltos, magros e narigudos, em desenhos que conjugavam áreas chapadas e linha fina. Miskey - que assinava seu trabalho com um "M" - "foi um dos mais prolíficos e rico em recursos da primeira onda de artistas da New Yorker. Ele fez vinhetas, cartuns, e capas, e e ajudou a criar o estilo decorativo de The Talk of the Town, que foi mais tarde aperfeiçoada por Otto Soglow" (Lorenz, 1997, p.124). "M" foi um dos primeiros colaboradores

Figura 153 e 154. Vinhetas de

Hofman e M. para a New Yorker, 1925

Figura 155. Quadrinho de tira de Soglow, The New Yorker, 1927

Figura 156. Cartum de Otto Soglow, The New Yorker, janeiro de 1928

Figura 157. Quadrinho de tira do Reizinho. The New Yorker, 1931
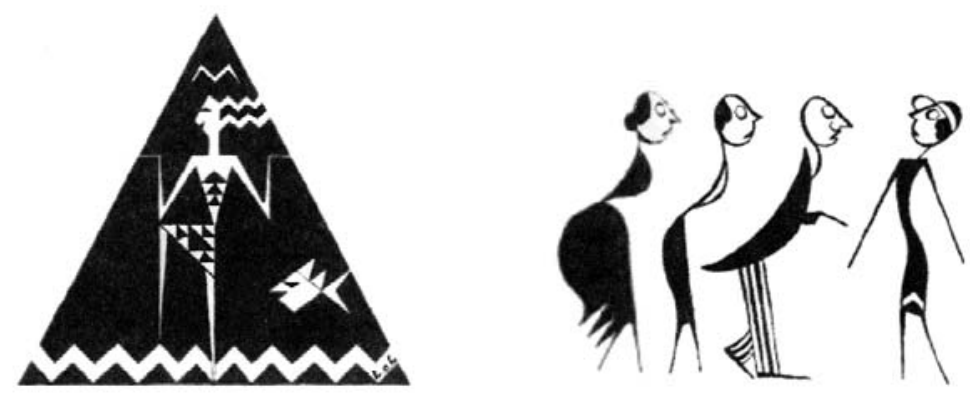


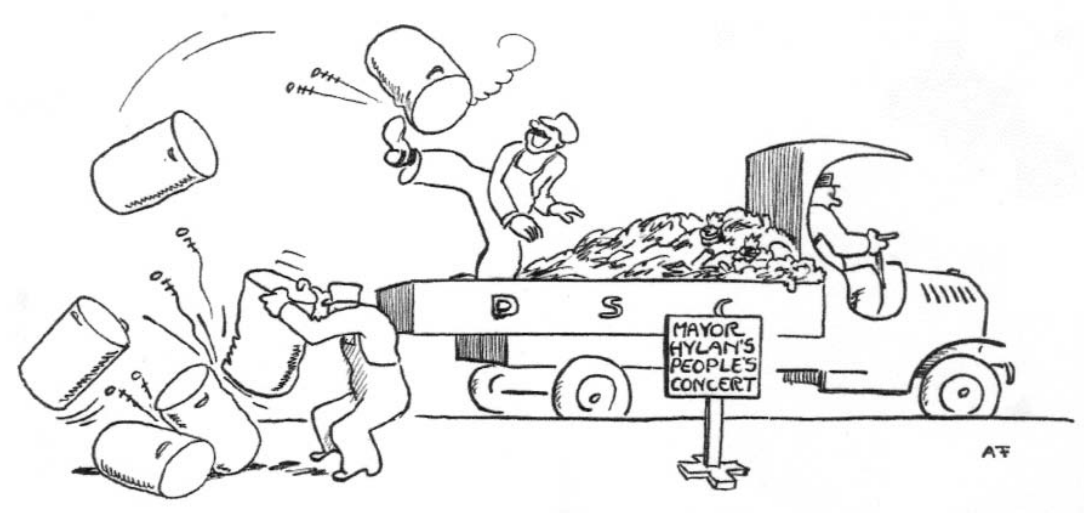

Figura 149. Capa de Hofman para a New Yorker, 28 de novembro de1925

Figura 150. Hofman, The New Yorker, 20 de junho de 1925

Figura 151. Capa de Julian de Miskey para a New Yorker, 6 de junho de 1925

Figura 152. Frueh, The New Yorker, 4 de julho de 1925

da publicação a desenvolver o típico personagem cartunesco de nariz ponteagudo, com formato triangular. Ambos, Hofman e de Miskey, fizeram muitas vinhetas em preto e branco nas páginas internas da New Yorker, com soluções de grande concisão e simplicidade gráfica. Otto Soglow é outro artista que desenvolveu seu trabalho na década de 1920 e promoveu personagens cartunescos em desenho simples. O universo de seus cartuns era "limpo e ordenado, direto e inocente" (The New Yorker, 1975, p.140). Seus primeiros trabalhos não apresentavam a concisão bem resolvida com o qual é conhecido: " (..) tinham uma regular quantidade de detalhes, mas à medida que o tempo foi passando, seu trabalho se tornou cada vez mais puro, até finalmente um Soglow ser um desenho sem um único detalhe que pudesse ser chamado de externo, sem qualquer embelezamento, sem uma linha que não parecesse essencial ou inevitável" (The New Yorker, 1975, p.140). Soglow desenvolveu seu desenho em curto espaço de tempo e foi um dos pioneiros do desenho simples de cartum na revista. Otto "trabalhava nestes desenhos modestos com grande seriedade, consumindo horas em cada um deles para atingir o significado e a composição adequados" (The New Yorker, 1975, p.140). Nas histórias do Reizinho, que estreou na New Yorker em 1931, certos personagens por vezes também apareciam com o nariz de formato triangular, um detalhe que se tornaria muito comum nos personagens dos cartuns de Steinberg. Outro importante cartunista da fase inicial da revista é Frueh, que tem um desenho simples mas com hachuras leves, em um traço
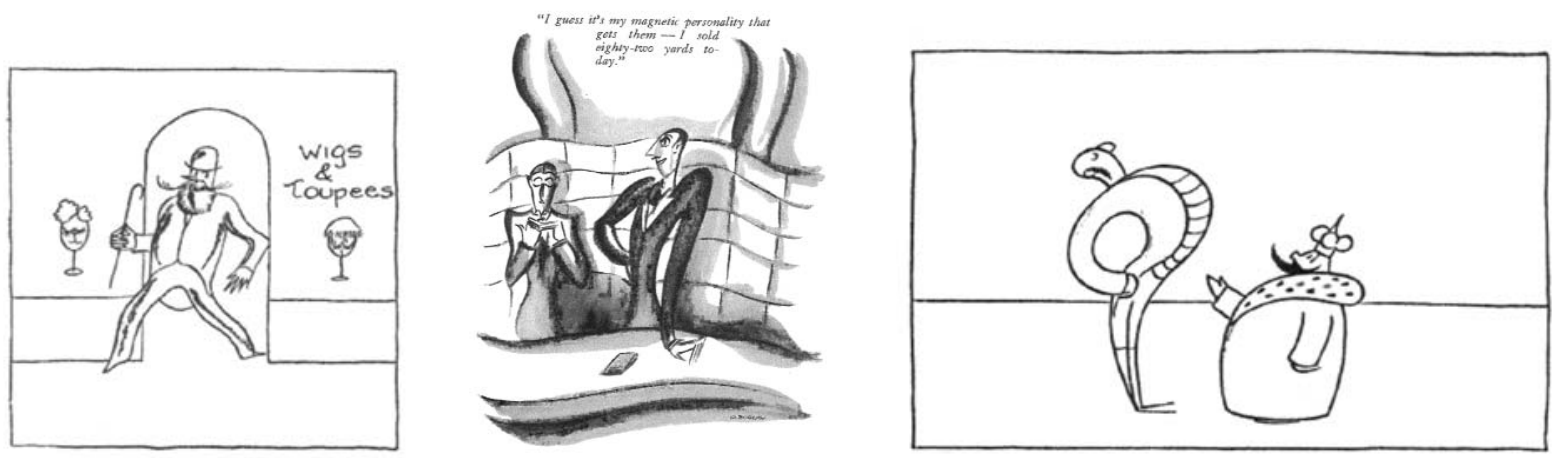

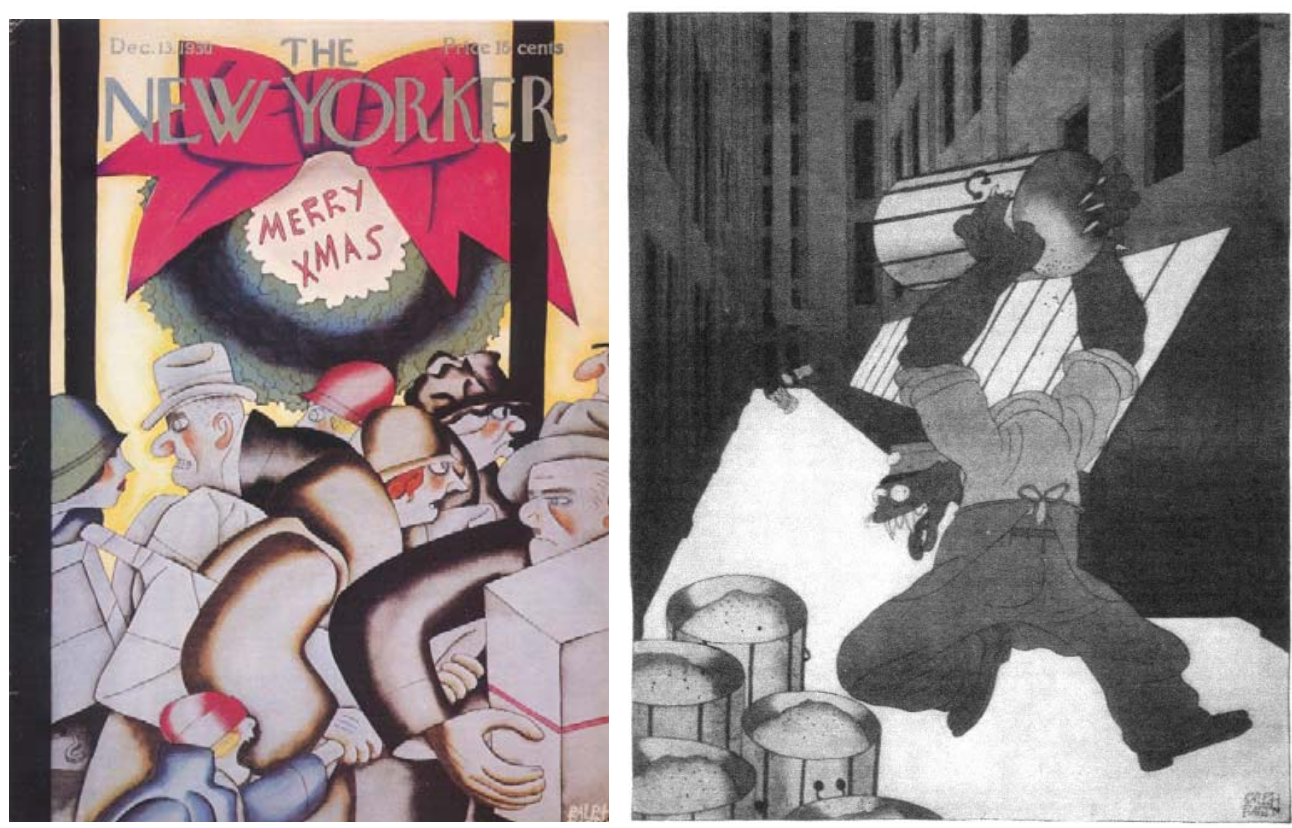

despojado e despretencioso a serviço da narração dos acontecimentos da piada. "Ele desenhava de modo simples e arrojado, em caneta e tinta, e, como tem sido verdade sobre tantos artistas, quanto mais velho ficou, mais simples e arrojado se tornou", avaliou a New Yorker sobre o conjunto de sua obra (Gill, 1968, p.184).

Ralph Barton, caricaturista que criava para a New Yorker criaturas deformadas, desproporcionais e macabras em ambientes carregados e melancólicos, conciliava linha fina e pintura. No entanto, em grande parte de seus desenhos pintados, "o fundo é pressionado em direção ao primeiro plano com uma insistência encontrada na arte oriental e (...) no cubismo" (Updike, 1989, p.113). Para Updike, seus desenhos, "como os de Modigliani, combinam uma alta dose de sensualidade com uma paixão pelo design" (Updike, 1989, p.118). Barton também fazia desenhos claros, com seu traço extremamente leve e hábil sobre fundo totalmente branco. Apesar das diferenças no traço, o apreço de Barton à linha moderna fica exemplificada no apreço que tinha a "Sem"; ele e o francês eram admiradores mútuos, "como as cartas de Sem nunca falham em indicar" (Kellner, 1991, p.139). O artista também tinha evidente admiração por Covarrubias, a quem prestou generoso prefácio em livro do caricaturista mexicano (Kellner, 1991, p.142). Updike nota que "a linha de caneta de Barthon são como arames que estão todos conectados; seus desenhos soltam um sussurro peculiar, uma ameaça ausente na linha limpa de desenhistas similares como Josef Capek, Nicolas Bentley, Rea Irvin e Gluyas Williams" (Updike, 1989, p.114). O artista já havia atingido considerável renome nos anos 20; em 1924, ao começar a ilustrar na Vanity Fair, Kellner observa que "ele estava produzindo uma nova série semanal para a Judge que assegurava a ele prestígio como um caricaturista (...) incomparável a qualquer um até o subsequente sucesso de $\mathrm{Al}$ Hirschfeld" (Kellner, 1991, p.111). Posteriormente, ele viria a ser um dos "editores consultivos e cartunista original da New Yorker" (Kellner, 1991, orelha). Barton chocou seus admiradores e amigos - dentre eles, Charles Chaplin - ao se suicidar precocemente, com qüarenta 


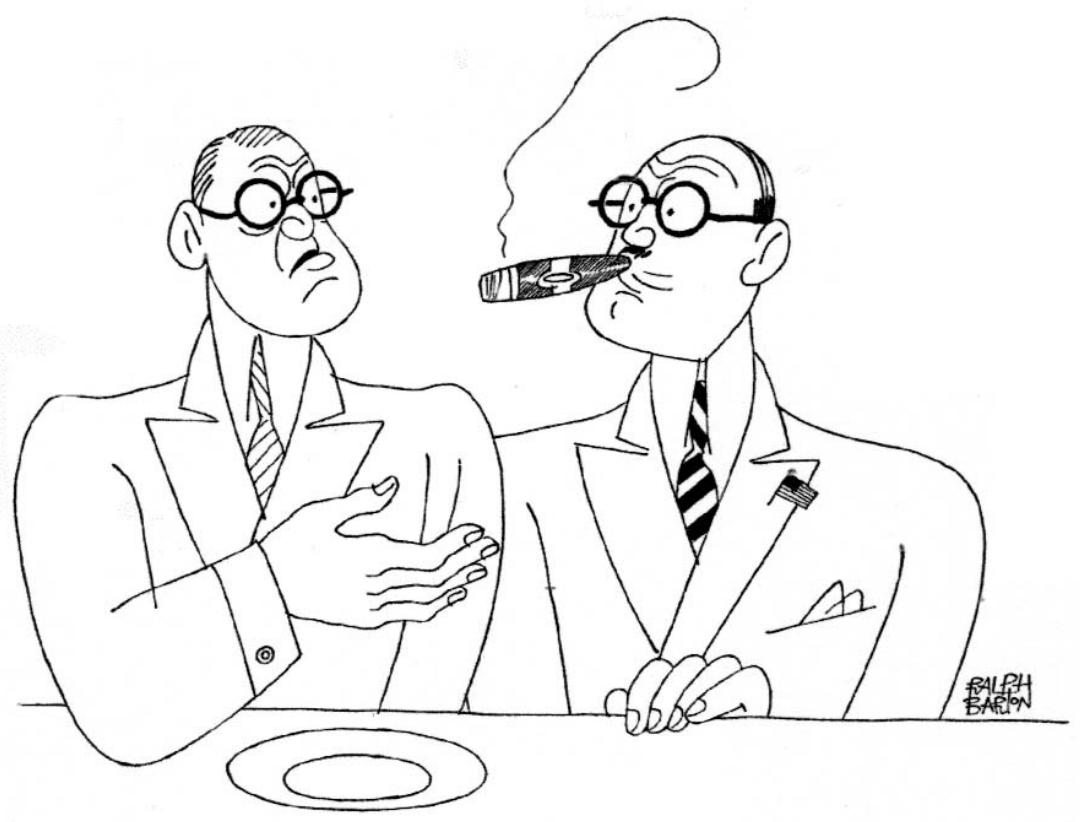

anos de idade, em 1931 (Updike, 1989, p.115). Sua importância na época inspirou uma exposição organizada pela Rhode Island School of Design em 1968, denominada The Jazz Age as seen through the eyes of Ralph Barton, Miguel Covarrubias, and John Held, Jr. (Updike, 1989, p.117). A importância destes três artistas na época do jazz fica clara neste parágrafo do livro The Last Dandy, Ralph Barthon, escrito por Bruce Kellner:

Em Nova York, ficou evidente, à medida que a década progredia, que vários outros ilustradores menores eram acusados de imitar Barton. No começo de sua carreira, o maior rival de Barton era John Held Jr. Ambos haviam desenhado regularmente para as mesmas publicações; ambos haviam começado com altamente estilizadas, e até preciosas figuras. Pontos para bocas, (...) marionetes com aparência de bonecas. Em pouco tempo, no entanto, eles desenvolveram suas próprias linhas singulares. Ninguém poderia confundir o trabalho de Barton com as gravuras em linóleo de gaios (...) ou as garotas pernudas e college boys em agasalhos (...) de John Held Jr. A única genuína competição que Barton e Held já tiveram veio em meados dos anos 1920 quando o caricaturista mexicano Miguel Covarrubias explodiu em imediata popularidade; seu treinamento formal deu a suas promissoras figuras uma qualidade substancial totalmente sua (Kellner, 1991, p.71).
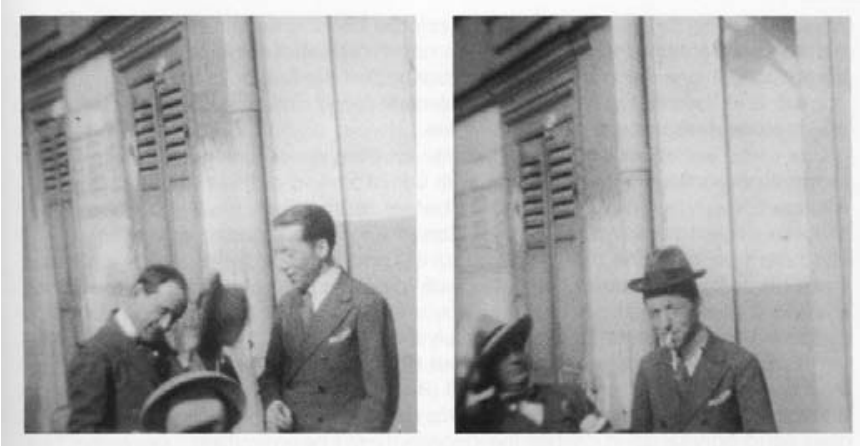

Figura 158. (alto, à esquerda) Capa de Ralph Barton para a New Yorker, 13 de dezembro de 1930

Figura 159. Barton, The New Yorker, 1926

Figura 160. Barton, The New Yorker, 1925

Figura 161. (ao lado) Barton e Sem, 1926 
Em Nova York, ficou evidente, à medida que a década progredia, que vários outros ilustradores menores eram acusados de imitar Barton. No começo de sua carreira, o maior rival de Barton era John Held Jr. Ambos haviam desenhado regularmente para as mesmas publicações; ambos haviam começado com altamente estilizadas, e até preciosas figuras. Pontos para bocas, (...) marionetes com aparência de bonecas. Em pouco tempo, no entanto, eles desenvolveram suas próprias linhas singulares. Ninguém poderia confundir o trabalho de Barton com as gravuras em linóleo de gaios (...) ou as garotas pernudas e college boys em agasalhos (...) de John Held Jr. A única genuína competição que Barton e Held já tiveram veio em meados dos anos 1920 quando o caricaturista mexicano Miguel Covarrubias explodiu em imediata popularidade; seu treinamento formal deu a suas promissoras figuras uma qualidade substancial totalmente sua (Kellner, 1991, p.71).

De 1925 aos anos 1940, década em que Steinberg estreou na The New Yorker, muitos novos colaboradores adentraram na revista, contribuindo com trabalhos de abordagem variada. Em artigo de 1946 para a revista de arquitetura Domus, o amigo Aldo Buzzi já enxergava nomes - dentre eles, contemporâneos colaboradores da New Yorker que seriam pertinentes para uma comparação:

Este não é o lugar para examinar, de um ponto de vista geral, a obra de Steinberg: o Steinberg virtuoso da linha ou (sabemos ser a coisa mais importante) o Steinberg desenhista moral (o humor é um campo muito estreito; mais que Thurber, Arno, Bemelmans, seus presumíveis rivais americanos, teríamos que falar de Hogarth, Grosz, Daumier) (Buzzi, 1946, p.20).

James Thurber, originalmente escritor, estreou como desenhista uma década antes de Steinberg, em 1931. Os desenhos dos primeiros cartuns se apresentam como "anotações", lembram croquis que são feitos rapidamente para o registro de uma idéia. São gestos despretenciosos, com falta de rigor no estudo dos contornos, que parecem surgir na rapidez do pensamento, apenas para sinalizar a existência dos elementos da cena. Seu desenho não viria a mudar muito, mas aos poucos o exercício contínuo conduz a um maior domínio do traço. Se Steinberg costumava se comparar a um escritor, o cartunista-escritor Thurber fazia analogias com outro profissional: "Escrevo humor do mesmo modo que um cirurgião opera, porque é um meio de vida, porque tenho uma grande urgência em fazer, porque muitos desafios interessantes estão levantados, e porque tenho a esperança de que irá fazer algum bem" (cit. por The New Yorker, 1961, p.247). Para Adam Gopnik, "os desenhos de Thurber são genuinamente matissianos, no sentido de dependerem de uma simples, animada linha para expressarem algo sobre o enclausuramento da vida moderna. É uma nostálgica, ansiosa linha. (...) Seus desenhos eram (...) em sua maior parte séries de hieróglifos, piadas compulsivas (...)" (Gopnik, 1994, p.175). Seu perfil é semelhante ao do brasileiro Luís Fernando Veríssimo: são escritores que passaram a se exprimir também pela linguagem dos cartuns, e que souberam fazer uso de um desenho simples, em perfeito equilíbrio com a idéia e os diálogos, a 

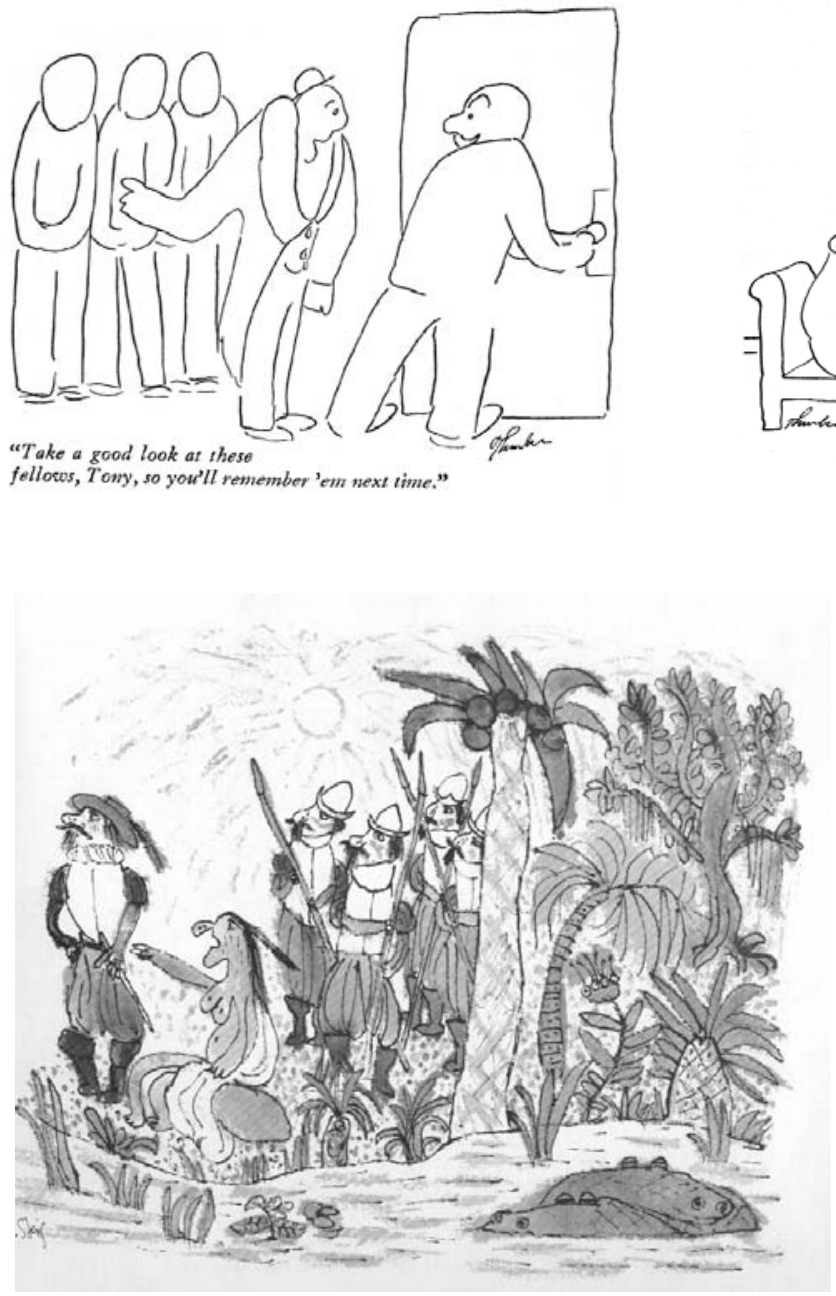

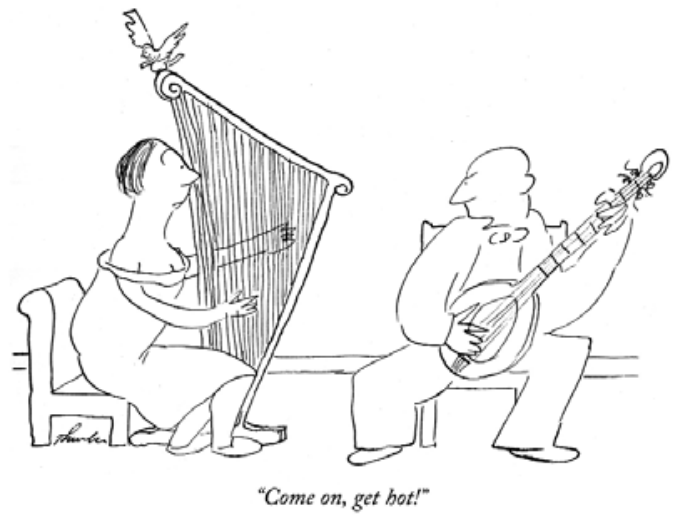

Figura 162. ( alto, canto esquerdo) Primeiro cartum de Thurber na New Yorker, 1931

Figura 163. Thurber, The New Yorker, abril de 1936

Figura 164. (ao lado) Desenho de Steig. Publicado em WIlliam Steig - Drawings, 1979.

\section{Figura 165 e 166. Steig.} Publicados em The Lonely Ones, 1942

Figura 167. Steig. Publicado na reedição de The Lonely Ones, 1970

serviço da comunicação de uma situação humorística. Seus temas costumam ser voltados a complicados relacionamentos, verdadeiras "Guerras entre os Sexos" (Constable, 1954, p.9). "As legendas capturam a esperança prepotente e irascível de sua infeliz era, tanto quanto suas pressões", analisa Gopnik, para quem alguns de seus mais famosos cartuns "são engraçados porque encontram uma sugestão de normalidade em uma situação impossível, que é o que a vida moderna exige" (Gopnik, 1994, p.176). Seu traço "infantil" é dos que mais se aproximam do desenho de Steinberg, dentre os artistas da New Yorker.
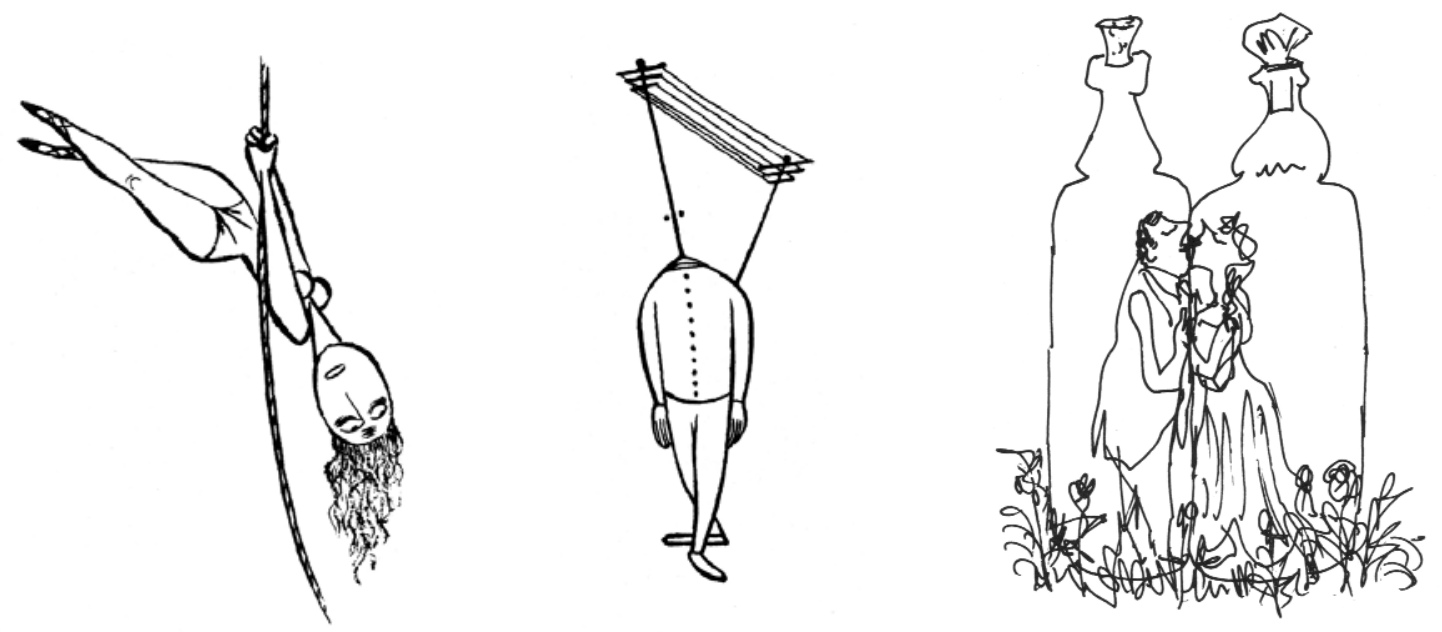

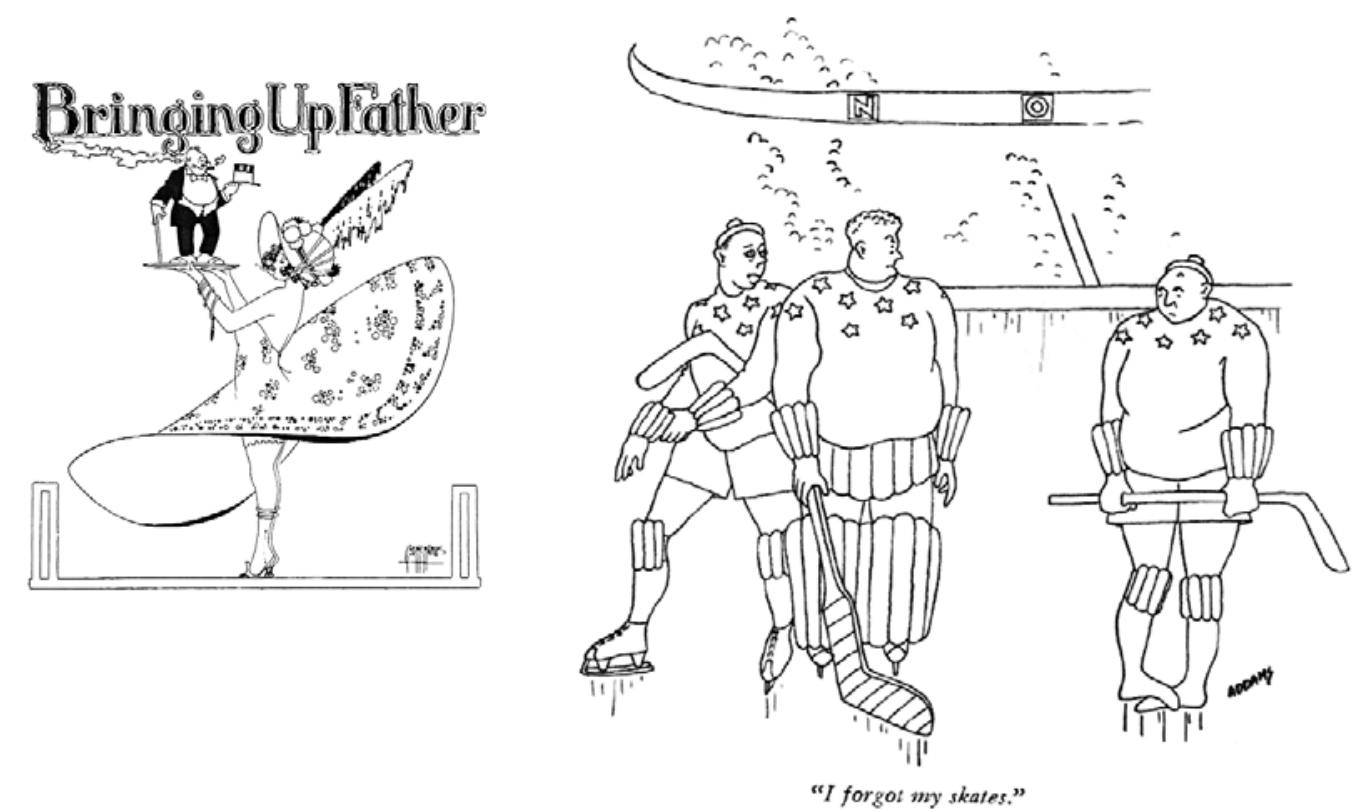

Os desenhos de William Steig em seus trabalhos experimentais, publicados em livros no final dos anos 1930 e começo de 1940, também são importante referência. Para Smith, tanto Steig como Steinberg exerciam seus papéis de artistas "AA" na New Yorker, segundo o preceito "não tenho que ser engraçado". Steig parece ter atingido o território de desenhos reflexivos antes, nos livros About People, de 1939, e The Lonely Ones, publicado em 1942. "A maneira era polêmica, o caminho era surreal e abstrato", lembra Smith (Smith, 2006, p.37). Na visão de Lillian Ross, os "desenhos eram brilhantes, penetrantes, e, uma vez mais, engraçados (...). Nem ele nem qualquer outra pessoa havia feito algo parecido antes. Em estilo, ele antecipou o que viria ser feito nas próximas duas ou três décadas" (Ross, 1979, p.6). Havia semelhanças no desenho simples, de compreensão moderna. Mas em The Lonely Ones, por exemplo, o traço em caneta e tinta de Steig aparecia em tons levemente expressionistas, adequado às investigações psicológicas dos personagens. Os trabalhos deste livro apresentavam descrições da condição humana "marcadas com tinta carregada e simbólica"

Figura 168. (alto, canto esquerdo) Bringing Up Father, de George McManus.

Figura 169. Charles Addams, primeiro cartum na New Yorker, fevereiro de 1933

Figura 170. (outra página) Gardner, primeiro cartum na New Yorker, agosto de 1925

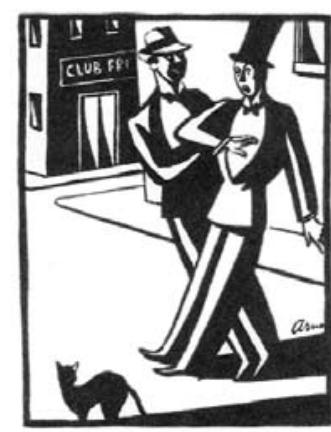

Figura 171. Rea Gardner, The New Yorker, dezembro de 1936

Figura 172. (ao lado) Peter Arno, desenho do primeiro cartum na New Yorker, setembro de 1925

Figura 173. Peter Arno, The New Yorker, 1927

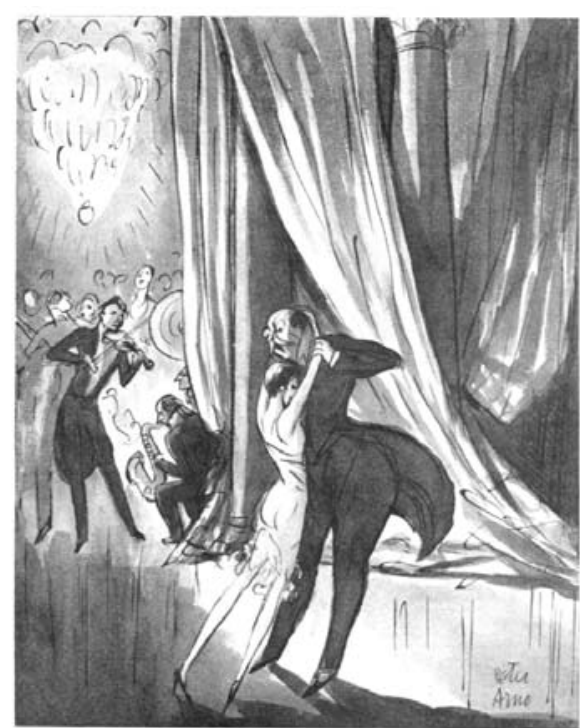

"Good God, woman! Think of the social structure!" 

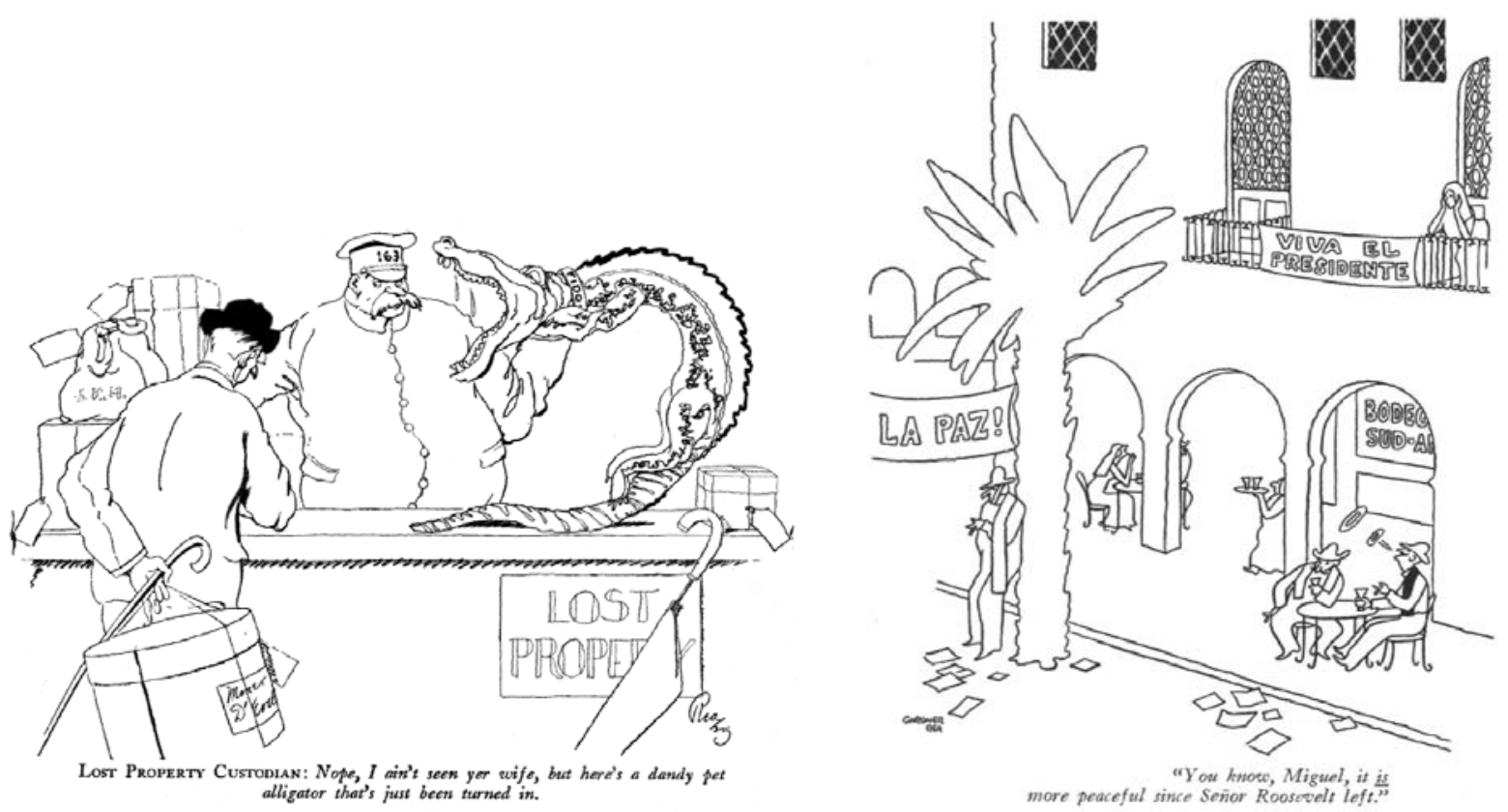

(Angell, 2003, p.72). Era possível notar outras consideráveis diferenças: "Steinberg, apesar de não ser menos orientado ao universo interior que Steig, não buscava anatomizar estados emocionais. Ao contrário, ele deixou sua linha minimalista falar pelo caminho do sub-texto e irresolução, cedendo parte do papel reflexivo ao leitor" (Smith, 2006, p.37). É importante ressaltar que o Steig das revistas, apesar de "AA", era bastante diferente. Wolcott Gibbs comenta no prefácio de The Lonely Ones que "Steig tem sido um humorista de sucesso há muito tempo, mas aparentemente isso não parece ser o suficiente para ele (...). Os quarenta e seis desenhos deste livro são as últimas manifestações desta compulsão peculiar (...)" (Gibbs, 1970, p.9). Estas obras, de fato, contrastavam com os trabalhos de Steig para a New Yorker, onde o artista recorria a um desenho cheio, sombreado, de "maneira realística" (Ross, 1979, p.5), e de abordagem mais otimista. Posteriormente, em novas experimentações, sua linha começou a ficar mais leve e extremamente livre: "ele havia parado de desenhar em rascunhos e poderia esperar, caneta na mão em sua prancheta, a agir a partir da próxima idéia ou estilo que aparecesse" (Angell, 2003, p.72). Alguns destes desenhos chegaram a ser publicados na reedição de The Lonely Ones, de 1970. O livro William Steig - Drawings, de 1979, é composto em sua totalidade por estes desenhos soltos de Reis Arthurs, cavaleiros, figuras mitológicas, cenas da Gênesis e Exodus, dentre outros temas. Para Lillian Ross, os "ângulos e linhas retas são raros em seu trabalho recente; suas linhas arcam, e deslizam, e mergulham, e escalam e giram" (Ross, 1979, p.7).

Curioso é o caso de Charles Addams, artista que viria a se notabilizar como criador da Família Addams. Estréia na revista em 1933, com cartuns feitos em leves desenhos de linha fina, em resultados que lembram vagamente o estilo de Hergé, deflagrador da "escola belga" e criador do personagem Tintin em 1929. O trabalho de Addams logo passaria por uma grande transformação, rumando para desenhos mais "cheios", pintados. Este "caminho inverso" não se mostrou uma regressão; o tratamento dos desenhos contribuiu para conferir a ambientação e o clima adequados aos seus soturnos cartuns. O desenho de linha firme e 
segura de alguns cartunistas da época lembra as histórias em quadrinhos sob influência do art Noveau e art déco, como a tira Pafúncio e Marocas, criada por Geo McManus em 1913. "McManus empregava uma linha limpa nos painéis de seus quadrinhos, com formas estilizadas, cenários art noveau, e arquitetura detalhada de modo organizado" (Inger, 1990, p.82). Os desenhos de Rea Garder na New Yorker caminharam rapidamente para estas características, passando dos resultados tradicionais cheios de detalhes do começo de 1925 para soluções claras de linha fina em 1926, até atingir maior simplificação nos anos 1930. Em uma comparação com este gênero de traço, a linha de Steinberg, apesar de "pensada", é mais irregular, sugerindo a despretenção estilística de um desenho infantil.

Peter Arno, outra referência importante da New Yorker, cujo trabalho foi importante para "determinar o tom e direção da revista", começa publicar seus cartuns logo em 1925 (Gill, 1968, p.156). Peter, às vezes, "poderia trabalhar vinte e quatro horas direto em uma única idéia" (Gill, 1968, p.156). "As piadas de Arno eram cheias de vida, e sua linha era mais arrojada do que de qualquer um - a lapela cintilante do casaco de linho branco, a marca de batom, a inclinação carnal de um bigode do velho rico -, e ele enfeitava suas grandes damas e frequentadores de teatro, e cavaleiros (...) porque era muito mais divertido para ele desenhá-los daquele modo, em vestimentas", recorda Roger Angell (Angell, 1997, p.134). Os primeiros desenhos apresentam uma linha firme, com manchas compactas negras cobrindo certas áreas de sombra. Seu traço logo se torna solto e rápido, desenvolvendo imagens "cheias", com sombras rabiscadas em riscos grossos, ganhando em expressividade. O belo desenho expansivo de Arno está distante do traço reflexivo e intelectual de Steinberg.

\section{CONTEXTO: O DESENHO DE OUTROS ILUSTRADORES E ARTISTAS}

Quando o assunto é linha, síntese e simplificação, um nome como o de Al Hirschfeld é obrigatório. Segundo R. C. Harvey, "Hirschfeld foi o último de uma geração que proliferou nos anos mais remotos do último século, prosperando com o florescimento do jornalismo de revistas, e atingiu sua apoteose nos anos 20 e 30, particularmente nas páginas da Vanity Fair" (Hirschfeld; Spiegelman, 2004, p.6). A linha econômica de Hirschfeld emergiu com destaque em 1926, em caricaturas para os jornais de New York. Suas primeiras influências vieram de Al Frueh e Miguel Covarrubias. Ele dividiu um estúdio com Covarrubias no começo de carreira, e foi o cartunista mexicano que, segundo Hirschfeld, demonstrou a ele que "caricaturas poderiam ser design, formas abstratas arranjadas em configurações comunicativas" (Hirschfeld; Spiegelman, 2004, p.7). Nos anos 1920, foi durante uma estadia de cinco meses na casa de Covarrubias em Bali - na ausência dele -, que Hirschfeld confessa ter voltado seus interesses para a linha, "na linha pura, e sem sombreamento, sem nada", diz. A comparação com o trabalho de Steinberg é inevitável, pois como observa Art Spiegelman em uma entrevista, Steinberg e Hirschfeld foram as pessoas que mais se envolveram em fazer desenhos 
"onde a linha é a história inteira" (Hirschfeld; Spiegelman, 2004, p.26). No entanto, para Spiegelman, o traço destes dois artistas transmitem personalidades totalmente diferentes. Talvez a diferença básica entre ambos está no interesse de Hirschfeld em usar a linha para contar uma história, enquanto que a preocupação de Steinberg é a abstração, um trabalho mais filosófico. Ou seja, "a idéia de uma linha como um sinal abstrato" (Hirschfeld; Spiegelman, 2004, p.26). Por outro lado, a relação de conteúdos implícitos no próprio modo de desenhar, tão presente em Steinberg, também pode ser percebida neste comentário de Hirschfeld, feito em 1958: "Acredito que tem havido uma sutil mudança em meu estilo nos últimos poucos anos, (...) e que a razão para isto é que as pessoas estão mudando. Elas estão se tornando mais estandartizadas. Estão ficando cada vez mais parecidas" (The New Yorker, 1958, p.44). Para além das comparações, Hirschfeld conhecia Steinberg e admirava seu trabalho:

Eu me entendia muito bem com Steinberg. Ele era um camarada difícil. Tornou-se recluso no final de sua vida. Não o encontrava muito quando ele se mudou para Long Island. E ele passou a se levar muito a sério também. Achava que era o Saul Steinberg, entende? (Hirschfeld; Spiegelman, 2004, p.26).

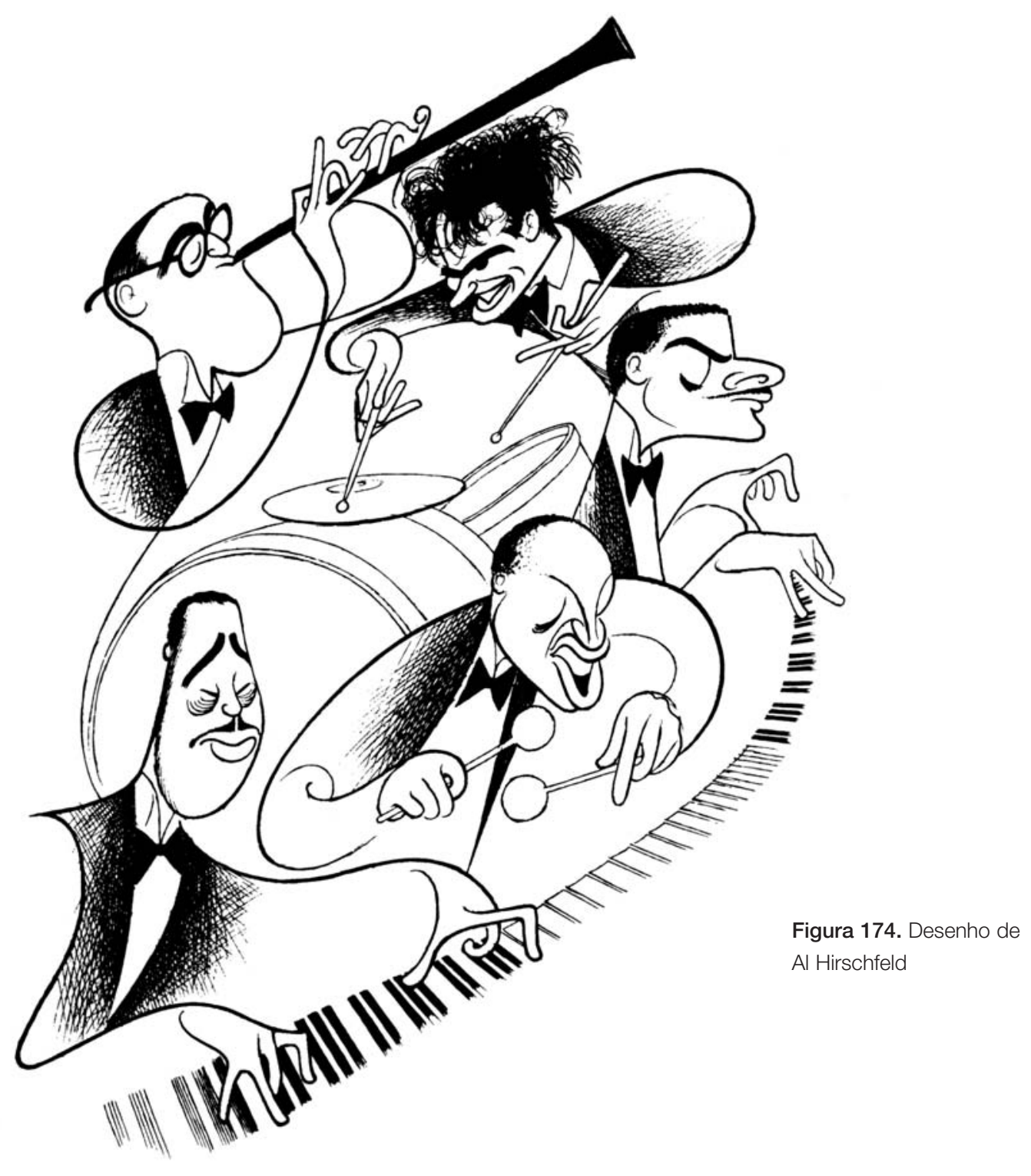




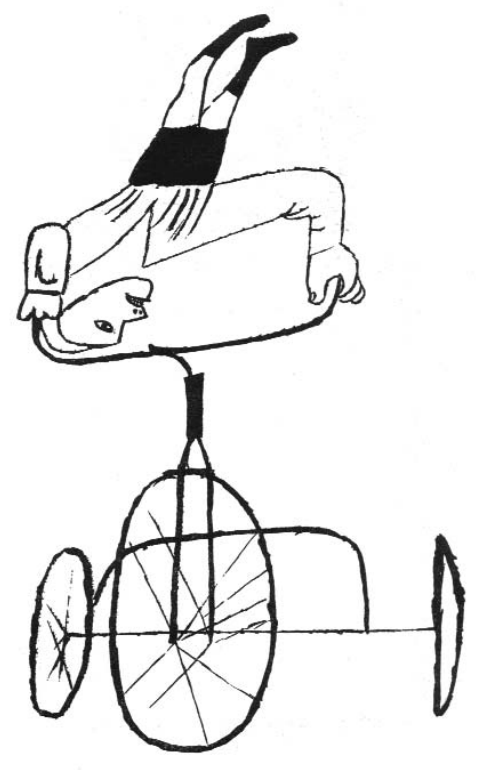

Figura 175. (acima) Ben Shahn, desenho para cartão de Natal. Publicado na Graphis, n.62, 1955

Figura 174. George Grosz, Stressenzene mit Zeichner (Cena de rua com desenhista), 1917

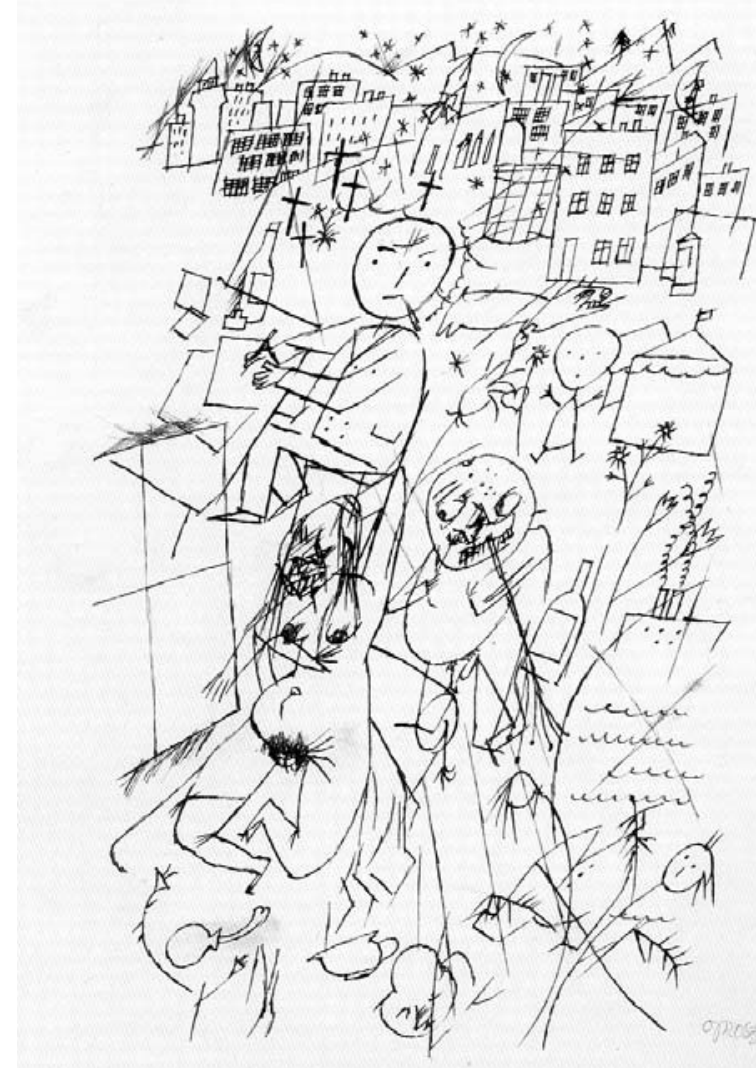

O traço seco e infantil de Steinberg vai além das comparações restritas ao meio editorial. Seu interesse pela linha lembra, de algum modo, o dos artistas plásticos e gráficos George Grosz, Ben Shahn e Paul Klee. O humanista Shahn foi representante do realismo social dos anos 1930, cuja "marca de verdade" era a "vitimização sob o capitalismo" - ao contrário do gozo na construção socialista do realismo soviético -, segundo Rosenberg (Rosenberg, 1976, p157). Shahn tinha, dentre suas maiores virtudes, "uma grande habilidade para combinar uma aparência de (...) realismo com uma enorme sugestão atmosférica, uma habilidade para fazer imagens concretas fluírem sem muito esforço para o simbólico, uma abordagem profundamente filosófica, e uma natural percepção romântica, o que torna para ele sempre possível encontrar o emocionalmente evocativo nos lugares-comuns", segundo artigo da New Yorker (Coates, 1947, p.64). Havia no trabalho de Shahn, por outro lado, uma sutileza no trato do aspecto sentimental, como ele mesmo comentou: "Não se pode, penso, lotar os desenhos com uma grande quantidade de conteúdos de sentimento. Desenhos devem ser pequenas revelações íntimas; elas devem ser brilhantes ou cortantes, elas podem ser vislumbres fragmentários de grandes sentimentos ou temerosas situações, mas sinto que a idéia incrível pede uma grande orquestração de cor, profundidade, textura e forma" (Shahn, 1957, p.29). Apesar de uma especial atenção a "tons emocionais" (Shahn, 1957, p32), abor- 
dagens investigadoras do "interior" das situações desenhadas que pouco remete a Steinberg, havia a proximidade com seu desenho no emprego de uma "estilizada maneira semi-naive" (Coates, 1947, p.64). A linha de Shahn, no entanto, era mais enérgica, carregada. Para Rosenberg, "Shahn se inspirou nos grandes artistas-polemistas do passado, Goya e Daumier, que eram os ídolos comuns dos pintores da era da depressão e da ameaçadora guerra; mas ele tirou mais do modernismo - dos cubistas e Picasso, dos muralistas mexicanos, expressionistas alemães, surrealistas (The Rea Stairway é merecedora de crédito a Max Ernst), e artistas naive americanos e europeus" (Rosenberg, 1976, p.156). Ao ter como referência tal variedade de artistas modernos, Shahn acabou chegando a uma linguagem de época que serviu de inspiração para as áreas das artes gráficas - como Steinberg, até para os desenhos animados dos anos 1950 (Amidi, 2006, p.21).

Já os desenhos de Grosz feitos a partir de 1915, em sua fase berlinense pós-guerra, tinham muito da simplicidade e referências posteriormente vistas nos trabalhos de Steinberg: "Sua linha [de Grosz] se tornou arrojada, muito afiada e enganosamente simples. Ele abandonou o uso de tons a favor de contornos claros, suaves. Ele também imitou a não-arte dos desenhos naive, especialmente a pichação em paredes de banheiros públicos que ele admirava e copiava" (Whitford, 1997, p.85). O próprio Grosz disse certa vez: "Em mictórios eu copiava desenhos folclóricos que pareciam, para mim, as mais diretas expressões e traduções de sentimentos poderosos. Era estimulado, também, pelos desenhos de criança devido à sua falta de ambigüidade. Deste modo, gradualmente cheguei a esse estilo de desenho afiado no qual costumava descrever o que via (...)" (cit. por Whiford, 1997, p.80). No entanto, a repetição de formas angulares - uma convenção pictórica derivada do futurismo - (Whitford, 1997, p.77), e o modo como seus maneirismos primitivos evocavam "a atmosfera de um mundo que ficou louco, no qual todo o comportamento civilizado foi abandonado" (Whitford, 1997, p.77), tornavam seu trabalho consideravelmente distinto dos desenhos de Steinberg.

A comparação com Klee ocorre de modo mais frequente. Artigos já foram publicados tecendo conexões sobre os dois, como Klee, Steinberg, Mac Laren, escrito por Max Egly em 1965, onde até o animador canadense foi inserido. De fato, em outro artigo, Klee e Steinberg, de John Hollander, este observa que "Norman McLaren produziu algumas efetivas animações no "estilo Klee" em filmes como Fiddle Dee Dee (Hollander, 1955, p.422). Em relação a Steinberg, Hollander chega a sugerir que "seus primeiros trabalhos, como aquele dos cartunistas, podem mostrar algumas influências óbvias [de Klee]" (Holander, 1955, p.426).

Não é possível precisar até que ponto Steinberg de fato teve Klee como referência. A obra do artista austríaco criou um universo de elementos gráficos que aos poucos contribuiu, em meio a diversas vertentes estilísticas provenientes de trabalhos dos artistas modernos, para a configuração de novos estilos de época, como o dos anos 1940. É possível que alguns recursos gráficos usados por ambos - como as estruturas ramificadas de construções e pontes pode ter chegado a Steinberg de modo indireto, portanto. Vale lembrar que a linha de 


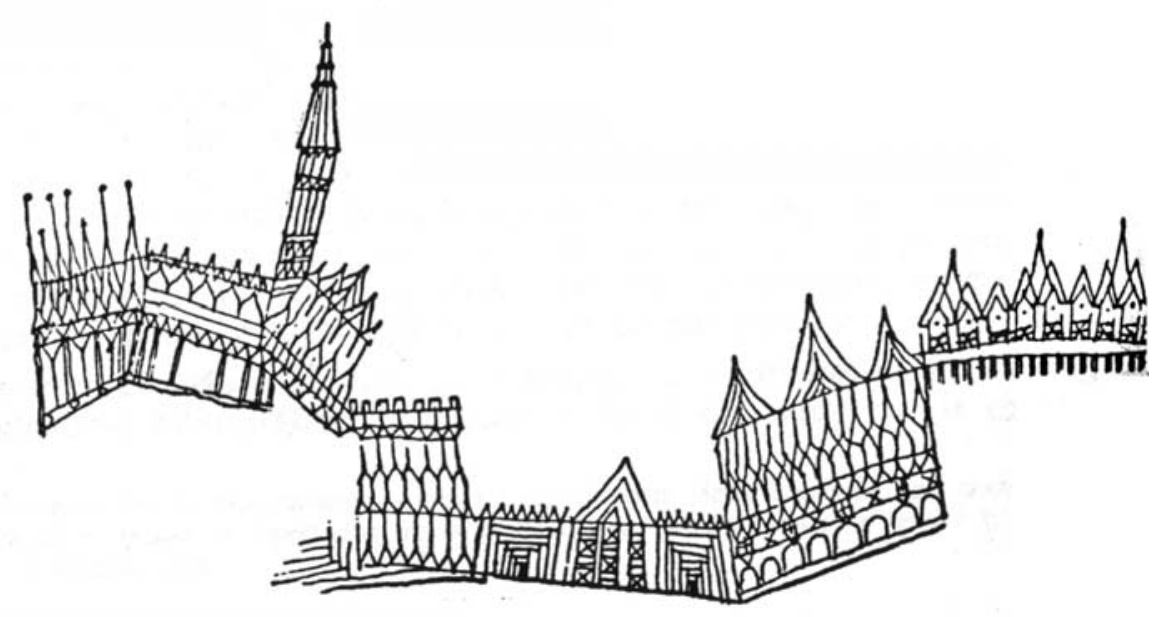

Steinberg, em seu início de carreira, aparentava ter proximidade maior com a produção dos italianos da Bertoldo do que com Klee. Provavelmente, algum interesse pelo artista aumentou após sua chegada aos Estados Unidos, mas estas são apenas suposições. De qualquer modo, Steinberg demonstra que tinha uma obra de Klee, ao tecer um comentário irônico para o amigo Aldo Buzzi sobre os vícios do mundo artístico, certa vez: "Tenho um pequeno desenho de Klee o qual, se você olhar de perto, poderá ver um cabelo - de seu bigode ou cílios, é difícil dizer - incrustada na tinta desde quando ela estava líquida. E então eu, também, tenho minha relíquia: um cabelo de Klee", conclui (Steinberg, 2001, p.89). Em 1969, Steinberg chegou a expor em uma mostra chamada Saul Steinberg and Paul Klee: An Exhibition of Drawings, na The Art Gallery da University of Califórnia de Santa Bárbara (Smith, 2006, p.259). De qualquer forma, a influência de Klee no trabalho do cartunista de origem romena foi desmentida por Steinberg novamente, em entrevista a Gopnik:

Deus sabe o que eu admirava quando comecei (...). Eu não tinha absolutamente nenhuma formação, nenhum interesse em Arte - ...as pessoas me dizem que eu derivo [minha linha] de Klee, de repente. Minha resposta a isso [é que] nós dois tivemos as mesmas influências: desenhos de criança, ornamentos populares, a arte dos loucos - e também no meu caso a experiência com arquitetura, que tinha um pouco a ver com a filosofia da Bauhaus de transformar escrita em desenho - basicamente uma fantasia da Bauhaus" (cit. por Smith, 2006, p.82).

Figura 175. (alto, página esquerda) Fragmento de desenho de Klee.

Figura 177. (canto página esquerda) Klee, 1928

Figura 176 e 178. (página direita) Steinberg, desenhos publicados em The Art of Living.

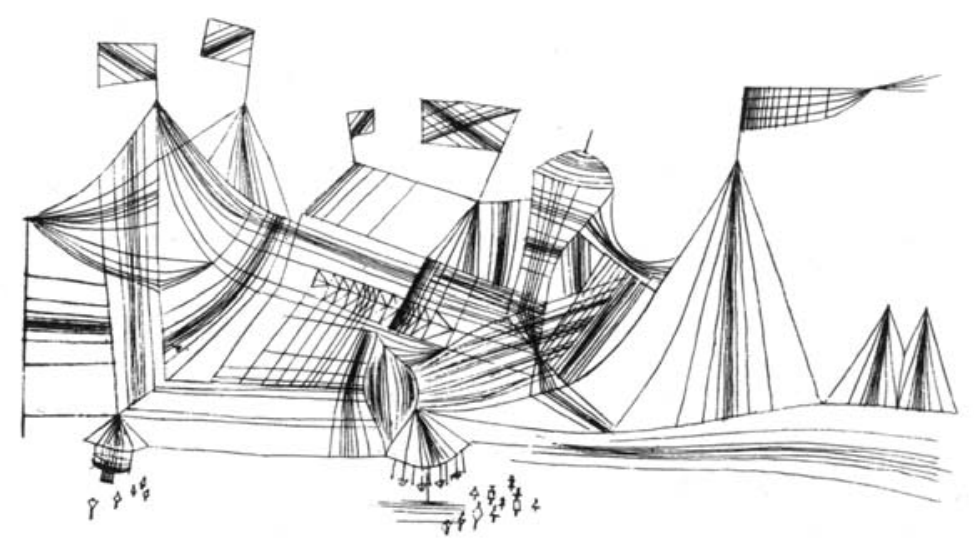




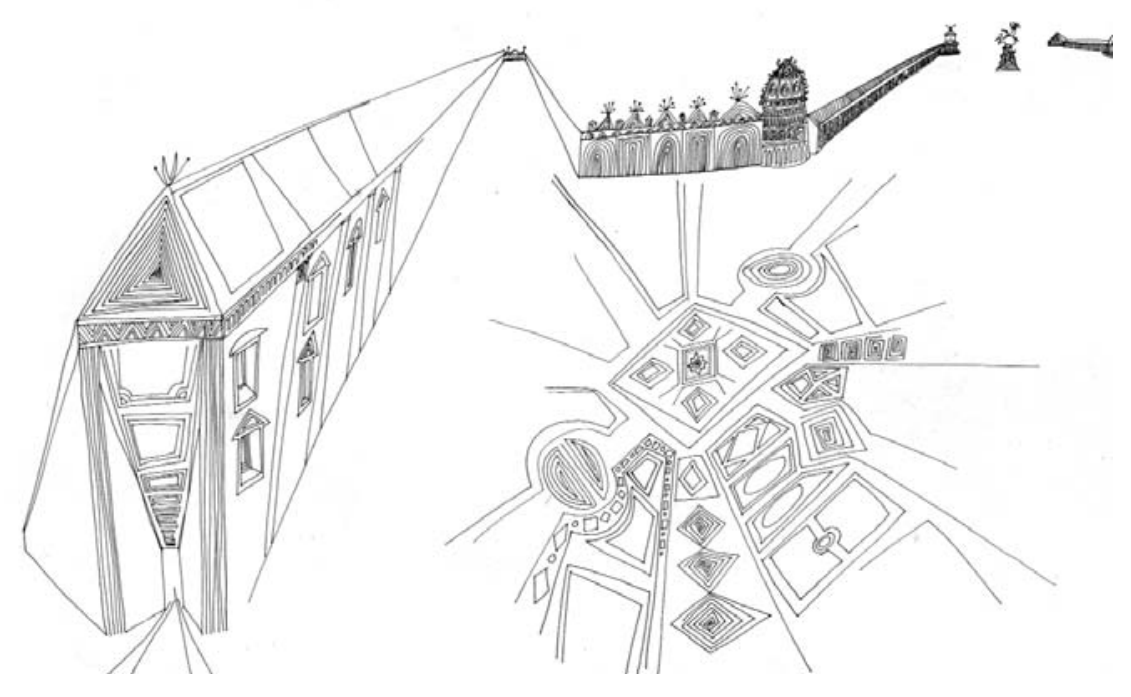

Outro artista plástico que fez desenhos em linha que, de algum modo, podem ser relacionados a Steinberg foi seu amigo Alexander Calder. Joel Smith, ao comentar a adequação do trabalho de Steinberg para cartões-postais do MoMA de 1945, devido à sua capacidade em aliar o refinado estilo contemporâneo com o cartum popular, enxerga qualidades semelhantes em desenhos de Calder feitos um ano antes. Em 1944, Calder havia feito ilustrações com desenhos de linha-fina para a coleção de textos ritmados Three Young Rats, uma colaboração com o então curador do MoMA James Johnson Sweeney. A introdução do livro, escrita por Sweeney, qualifica as imagens de Calder tendo como referência o desenho infantil, a partir da idéia de que "o mais natural dos modernistas é a criança" :

Intensidade de foco é o presente da criança (...). A criança tem um penetrante olhar para o detalhe, tanto psicológico como físico. A criança está mais próxima ao carpete, ao chão - ao primitivo - que o adulto. A mente da criança pensa por imagens. E ela assume um prazer perverso em tirar destas imagens associações incongruentes que muitas vezes têm a qualidade de frescas e impressionantes metáforas (cit. Smith, 2006, p.118).

O estilo de época que se desenvolveu durante os anos 40 e 50, com influência considerável dos artistas modernos, também merece atenção. As capas de discos destacaram-se como suportes para este novo estilo. Como nota Eric Kohler, nos anos 1940, "o modo como a músi-

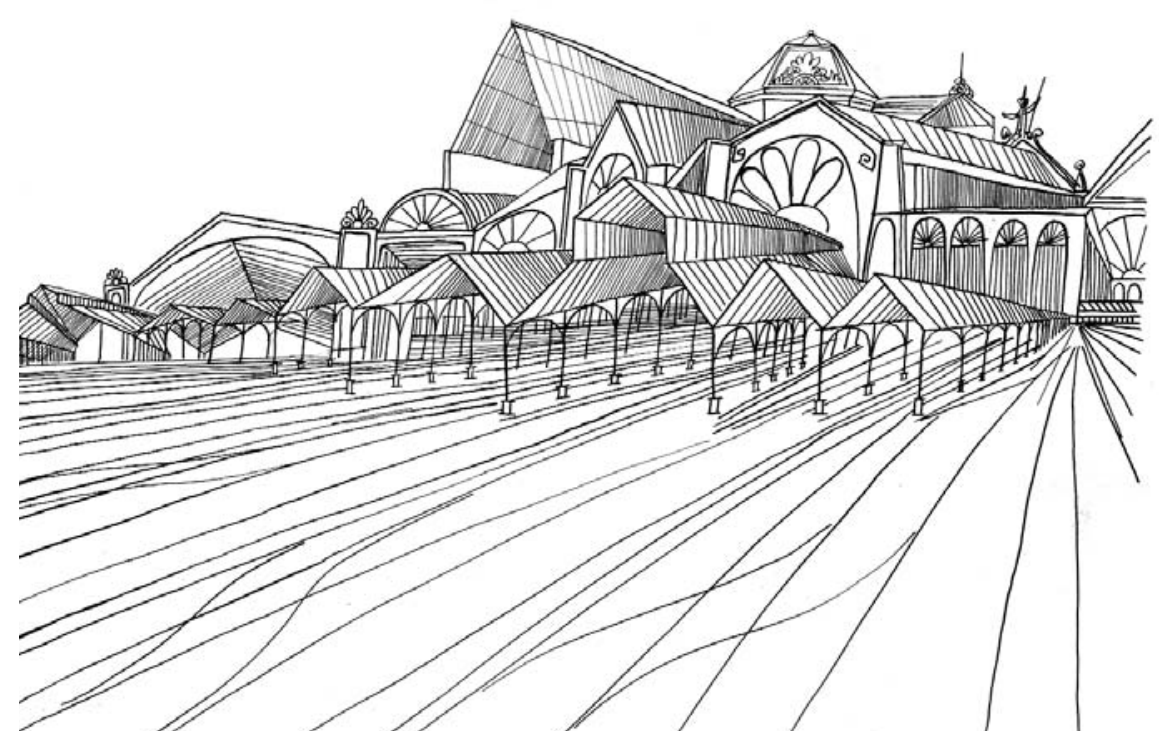




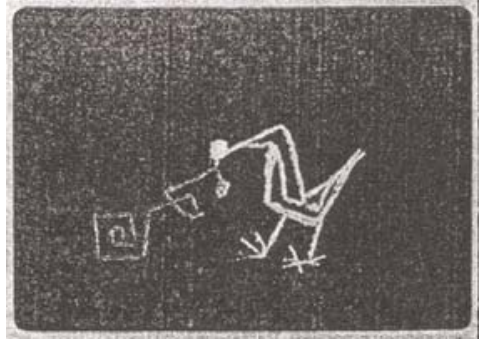

Figura 179. (acima) Norman

McLaren, Fiddle Dee Dee

Figura 180. Calder,

Three Young Rats, 1944

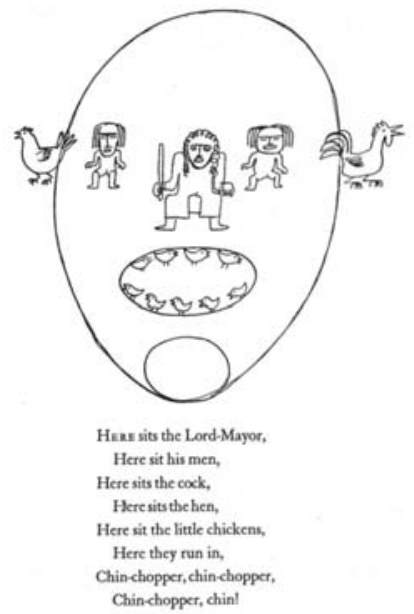

ca era comercializada e embalada tomou uma virada dramática com a aparição de um álbum da Columbia Records (...) dos hits musicais de Rodgers e Hart", a partir da arte de capa criada "por um jovem designer chamado Alex Steinweiss" (Kohler, 1999, p.13). Dentre as características de seu trabalhos estavam "o arrojado uso de tipografia, cores chapadas, e um tema central com imagens estilizadas" (Kohler, 1999, p.17). Ao invés de empregar fotos, Steinweiss preferia adotar uma "abordagem estilizada simbolista de elementos musicais e culturais para retratar a música" (Kohler, 1999, p.19). Outro artista que merece destaque neste contexto é Jim Flora, conhecido por suas ilustrações para capas de jazz. A inserção de personagens cartunescos e narigudos na linguagem da época é uma de suas características peculiares. Flora era, desde cedo, "um admirador do trabalho de artistas mexicanos contemporâneos, incluindo Rivera, Orozoco, Siqueiros e Taymayo. Estas influências, "combinadas com o Surrealismo e o cartoon, se tornaram a inspiração para os desenhos de suas capas de disco", nota Kohler. (Kohler, 1999, p.33). Homenzinhos narigudos em traço infantil ou em estilo chapado muito simples viriam a aparecer nas capas do período, como em algumas de Guidi. Este estilo de época dos anos 1940, curiosamente, nunca teve um nome. Eric Kohler observa que "muito freqüentemente o design desta década é visto como um último suspiro de art

Figura 181. Alex Steinweiss, 1945

Figura 182. Guidi, 1948

Figura 183. Jim Flora, 1954

Figura 184. Mary Blair, arte de concepção para It's a Small World, anos 1960.
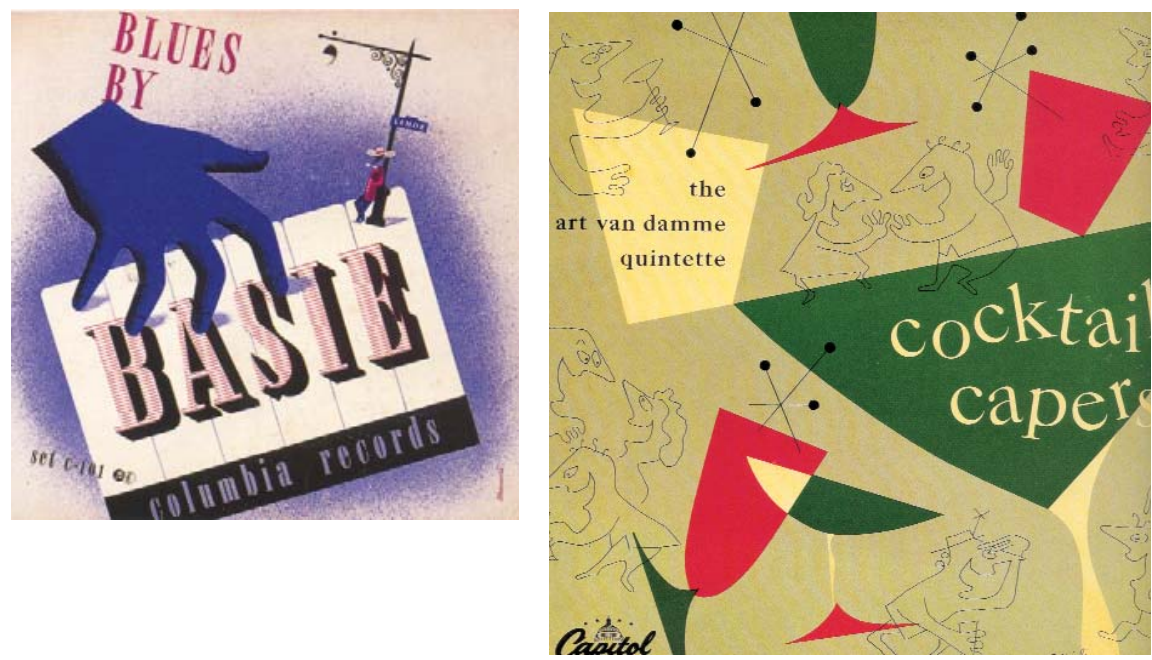
déco, ou na melhor das hipóteses uma ponte entre aquele estilo e modernismo suíço dos anos 1950" (Kohler, 1999, p.13). No entanto, são muitas as suas inovações, como "o uso maciço de tipografia e estampas do século dezenove em um contexto moderno, (...) as tiras verticais, a sempre presente "caixa de sombra", e o uso do surrealismo" (Kohler, 1999, p.13). A partir da metade dos anos 1950, as gravadoras começaram a adotar um visual mais corporativo e menos individual (Kohler, 1999, p.63). A ascenção do design suíço e suas tipografias sem adornos, do realismo sob influência da mentalidade do pós-guerra, e a americanização do Estilo Internacional na arquitetura "apagaram todos os permanentes elementos do art déco pré-guerra e dos estilos modernos aerodinâmicos" (Kohler, 1999, p.65). Apesar das mudanças, parte da estética dos anos 40 permaneceu, como nas capas de Jim Flora.

O estilo daquela época também pode ser observado no trabalho de Mary Blair, criadora de desenhos de concepção para animações dos estúdios Disney. "A elegância e cores vibrantes dos filmes de Disney do começo dos anos 1940 até a metade dos anos 1950 veio, primariamente, de Mary Blair", observa Canemaker (Canemaker, 2003, p.viii). Sua estilização "era o pólo oposto ao da representação "ilusão de vida" associada aos filmes animados de Disney. Seu trabalho é plano, anti-realista, e infantil (faux naif), pintado com uma paleta de cores irrealisticamente selvagem. Sua obra evoca a abstração leve de Milton Avery e Marguerite Zorach, mais do que o caseiro estilo de representação de Norman Rockwell e Gustaf Tengreen, que também influenciaram o design de Disney" (Canemaker, 2003, p.ix). Suas maiores influências vieram dos mais variadas origens contemporâneas, como as ilustrações de moda da Vogue e Harper's Bazaar, as capas da New Yorker, os murais de Siqueiros, a folk art e as cores da América do Sul, "as furiosamente coloridas e concisamente desenhadas caricaturas de Paolo Garretto e Miguel Covarrubias na Vanity Fair", dentre outras (Canemaker, 2003, p.xii). O saber gráfico de suas caricaturas, escreveu Wendy Wick Reaves, "expressou uma forma diluída de arte moderna, derivada não apenas do avant-garde artístico mas do design gráfico contemporâneo, moda, teatro, e das artes populares" (cit. por Canemaker, 2003, p.xii).
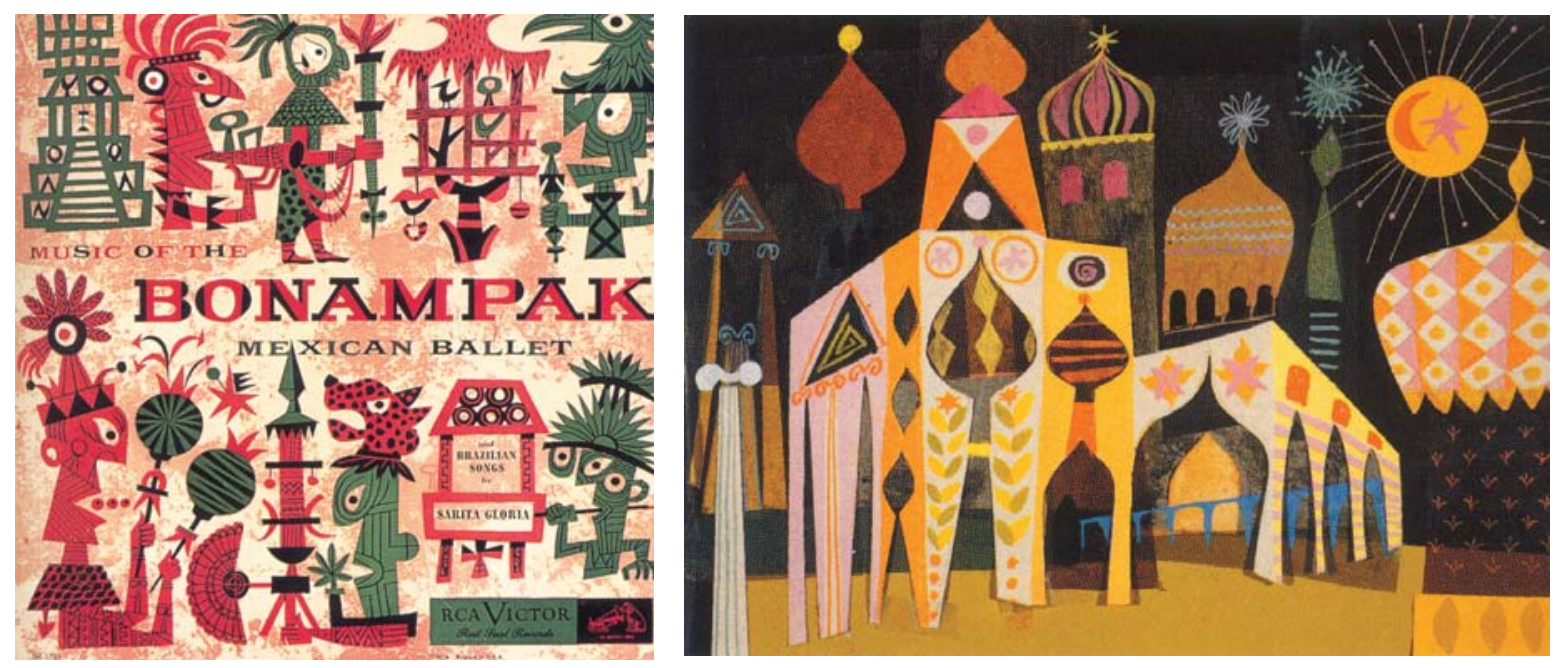

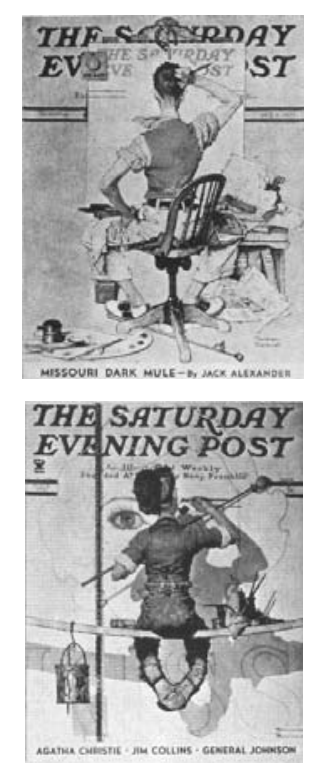

Figura 185 e 186. (acima) Capas de Rockwell para o Saturday Evening Post, anos 1920

Figura 187. Norman Rockwell, 1944

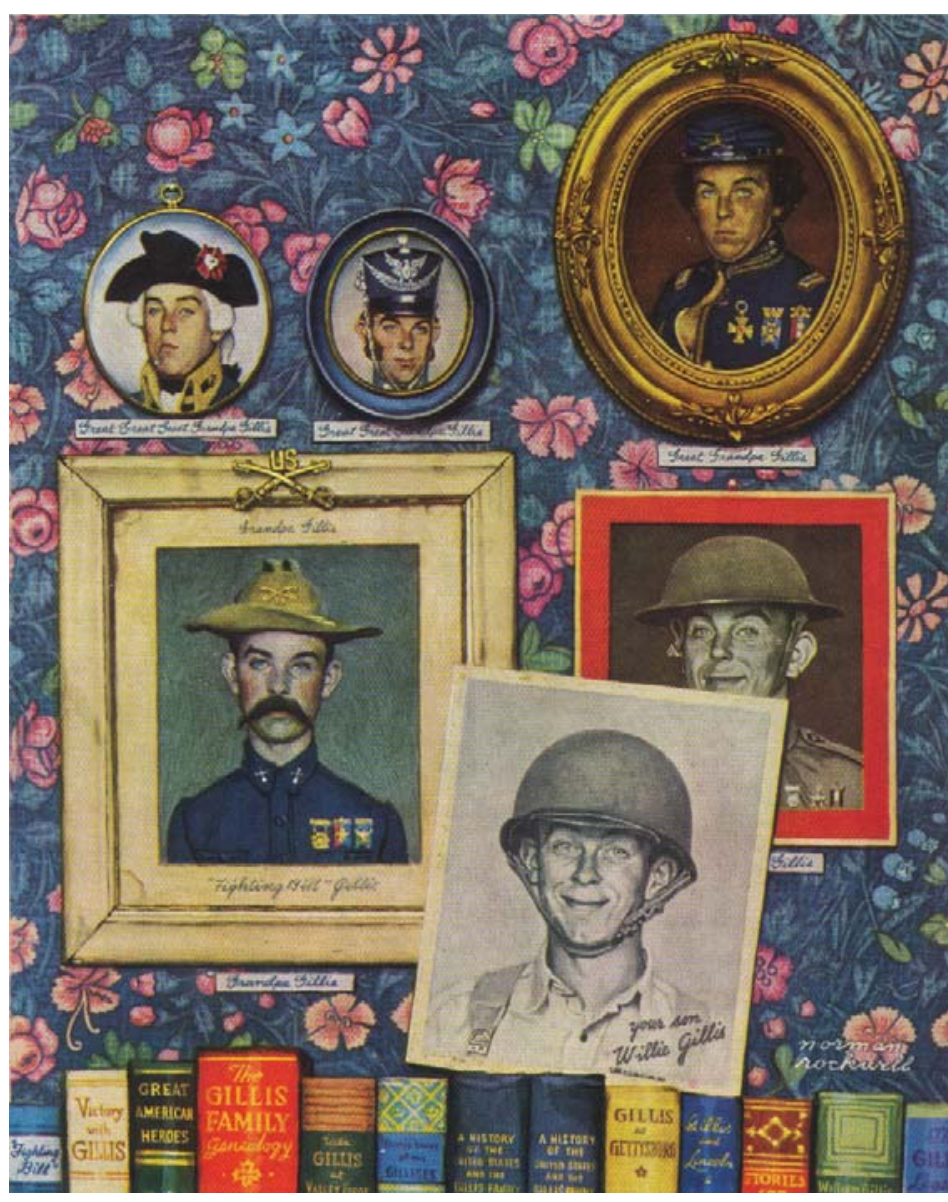

Desenhistas com ampla influência de artistas modernos, como Ben Shahn e Mary Blair, se viram integrados em um contexto regado por estilos de época aos quais eles se identificavam, se tornando eles mesmos criadores influentes. A presença, em muitos dos trabalhos do período, de elementos de artistas que empregavam a linha como Klee e Miró, assim como o uso do personagem de cartum, ajudou a compor um universo estilístico que também incorporava Steinberg. Nos trabalhos em que recorria a adornos que lembravam Klee, por exemplo, a impressão de um clima anos 1940 e 1950 nos trabalhos de Steinberg fica mais evidente.

Se a comparação do trabalho de Steinberg com artistas como Hirschfeld é pertinente pela proximidade na inovadora abordagem gráfica, não é menos necessário falar de obras representativas de outros gêneros, como a do ilustrador Norman Rockwell. Vale lembrar que ao mesmo tempo em que diversas publicações expunham em suas páginas os trabalhos de vanguarda e as novas abordagens da ilustração e do cartum, vertentes mais tradicionais permaneciam com ampla aceitação e presença no mercado editorial. Quando Steinberg publica seus primeiros cartuns na New Yorker, em 1941, Rockwell já era um dos ilustradores mais renomados do mercado por suas ilustrações para o Saturday Evening Post e outras publicações. Apenas quatro anos depois, em março de 1945, e ele já receberia um extenso Profile, de dois capítulos, na New Yorker. Essa seção, dedicada a grandes personalidades, abria com um primeiro parágrafo que dizia o seguinte: "Norman Rockwell, um dedicado pintor de tão conhecidas instituições americanas como os garotos descalços, salões vitori- 
anos e jantares de ação de graças, tem ele mesmo se tornado uma instituição americana" (Jarman, 1945, p.34). Em outro trecho, o artigo observa que "a Time fez seu status institucional oficial ao descrevê-lo como "provavelmente o mais amado artista americano vivo" (Jarman, 1945, p.34). Apesar de mais conhecido por suas capas para o Post, Rockwell começou sua carreira em 1911 ilustrando livros, o primeiro deles para Condé Nast (Guptill, 1946, p.71). Não demorou para ingressar no mercado de revistas, trabalhando como editor de arte da Boy's Life, também fazendo as capas e duas ilustrações por número. Em 1916, chegou ao Post, enquanto fazia ilustrações para diversas outras revistas. Elaborou capas, ao longo de sua carreira, para publicações como The Country Gentleman, Ladies'Home Journal, Life, Judge, dentre outras. Ainda jovem, este talentoso admirador de "Abbey e Howard Pyle" (Reed, 1984, p.112) - grandes referências da ilustração nas duas últimas décadas do século XIX - já assumia o posto de um dos ilustradores mais importantes do país (Guptill, 1946, p.72).

Um momento especial acontece no Profile da The New Yorker quando um cartum mudo de Steinberg, em sua fase inicial na revista, faz uma "visita" a uma das páginas do texto sobre o maduro Rockwell, confirmando o cruzamento de gerações. Em contraste com o interesse por abstração de Steinberg, o texto de Rufus Jarman constata que "os leitores do Post muitas vezes declaram que eles admiram Rockewell porque os personagens de suas pinturas se parecem exatamente do modo como devem ser. Ele não acredita na idéia de colocar o seu público ante a incoveniência de tentar desvendar uma fantasia ou abstração" (Jarman, 1945, p.34). O aspecto tradicional do realismo de Rockwell é observado neste trecho, que afirma que "por trinta anos ele tem produzido intensamente pinturas populares sobre pessoas do século XX que estariam perfeitamente em casa em uma varanda do século XIX" (Jarman, 1945 , p.34). Sua abordagem de pouco interesse por rupturas também promoveu reações negativas: "Alguns dos críticos de arte profissionais, que como classe são desdenhosos com a ilustração, têm chamado seu trabalho de tolo, plano, e desinteressante" (Jarman, 1945, p.34). Tais posições eram, em parte, decorrência da divergência de interesses no campo da criação artística, que atingiu extremos com o surgimento das vanguardas e de novas preocupações. Rockwell chegou a viajar para Paris, trazendo referências de trabalhos de Picasso para seu estúdio e elaborando uma versão "moderna" para uma capa do Post, com resultados negativos e a consequente recusa daquela versão pelo editor da revista (Guptill, 1946, p.24). Se o olhar do crítico de arte da época privilegiava e estava atento a abordagens que não eram vistas em Rockwell, um público com outro repertório enxergava algo além do conteúdo "plano" e superficial preconizado por certos setores da classe artística. O trabalho de Rockwell, apesar de se apresentar tradicional e sentimental em comparação com a estética moderna do período, tinha um aspecto "filosófico" - nos dizeres de um texto sobre sua obra -, " na sua insistência em fazer seu próprio comentário sobre a vida, mais do que meramente retratar incidentes levantados por um redator de manuscritos" (Guptill, 1946, p.80). Ao assumir uma visão própria, o artista contrariou certos limites impostos pelas convenções do 
meio editorial, retratando o homem comum, velhos, pessoas caricatas ou feias, por exemplo (Guptill, 1946, p.79). Rockwel buscava, em suas ilustrações, descobrir a atmosfera de uma história e expressá-las através desta qualidade básica, ao invés de apenas ilustrar o fato mais dramático de um acontecimento (Guptill, 1946, p.85) Em sua postura como observador dos costumes do cidadão americano urbano - já que não tinha interesse em pintar paisagens campestres, mas sim as pessoas -, Rockwell estabelece um ponto de conexão com Steinberg, em seus inúmeros desenhos sobre as cidades e as criações do homem. Ambos foram, de modos muito diferentes, dois dos maiores comentaristas da sociedade americana. Em Rockwell, interpretações gentis e amáveis de "pioneiros da América" encontrados em velhos americanos; em Steinberg, uma visão mais irônica, atenta aos estilos e artefatos usados como uniformes pelos homens para se apresentar à sociedade. Em Rockwell, o olhar do típico americano tradicional do interior. Em Steinberg, a visão do estrangeiro.

\section{The Art of Living e a América de Steinberg}

Depois da guerra, a vida americana logo passou a ser o foco das atenções de Steinberg. Como observa Joel Smith, "Steinberg viu e fez o perfil de uma América de modo diferente de qualquer outra pessoa. A explicação usual, de que ele enxergava a América com os olhos de um forasteiro, vai às vezes direto ao ponto" (Smith, 2006, p.35). A condição de Steinberg o leva a perceber, com seu amigo Richard Lindner, um aspecto cromático americano próprio, nada relacionado à natureza, mas aos produtos e artefatos da indústria de massas - uma breve antecipação da Pop Art. Para Smith, no entanto, o fato de Steinberg ser estrangeiro não explica totalmente sua singularidade. Outros dois fatores deveriam ser levados em conta: primeiro, sua relação com seu público, que contribuiu para direcionar o repertório de tópicos elaborados por ele; em segundo lugar, o interesse artístico em documentos desprovidos de funções artísticas, que vieram a se tornar uma das preocupações centrais de todo o seu trabalho (Smith, 2006, p.35).

Fruto destas observações, primeiras experiências e viagens pelos Estados Unidos, em 1949 é lançado seu segundo livro, The Art of Living. Nele, aborda assuntos e elementos urbanos como cadeiras, metrô, taxis, calçadas, ruínas, perspectivas. Também desenha pássaros, gatos, cavalos, mulheres e a arte (Rosenberg, 1978, p.238). Muitos dos desenhos deste livro, além de possuírem um certo ar estilístico dos anos 1940, apresentam uma sequência "musical" nos tratamentos dos detalhes que sugerem uma proximidade com certos trabalhos de Klee. Os desenhos das estações de trem com suas tramas, os detalhes dos edifícios em perspectiva, as plantas e redes dos chapéus das senhoras, insetos e aviões que parecem insetos, todos estes elementos cheios de pontinhos e riscos seqüenciados lembram trabalhos de Klee. Os desenhos sobre cidades também constituem boa parte das páginas do livro, servindo como documentos do modo de vida americano da época. Apesar da publicação ser uma obra do 

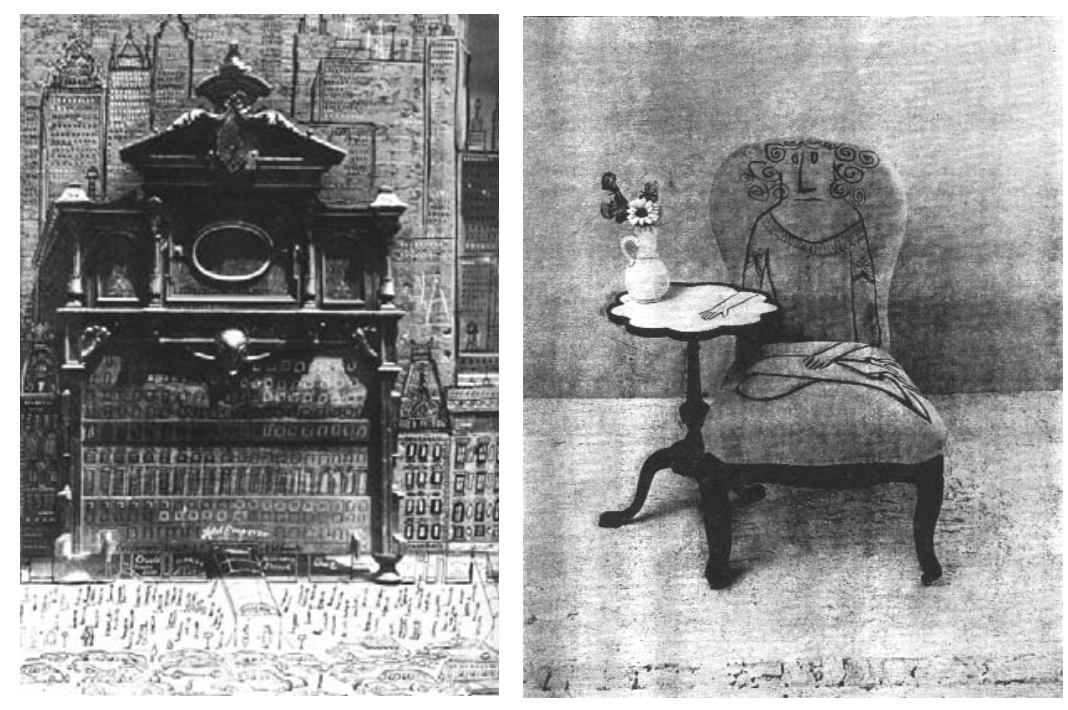

Figura 188. Steinberg,

Downtown, 1951

Figura 189. Steinberg, intervenção em cadeira

Steinberg cartunista, ela já levanta os insumos para as futuras abordagens do artista. Em meio aos cartuns da New Yorker são esboçadas experiências que viriam a se tornar importantes no decorrer de sua carreira como: trabalhos com documentos, monumentos, preocupações sobre arte, elementos gráficos subvertidos, ambiguidades gráficas, paródias de estilo. No mesmo ano, outras experiências importantes são realizadas por Steinberg. O cartunista faz seu primeiro desenho em objetos, utilizando outros suportes para seus trabalhos, com intervenções em cadeiras, banheiras e caixas. Mas o artista gráfico mantém o seu interesse no resultado impresso, revelando fotografias destas experiências. Eram comuns, também, intervenções nas próprias fotos. Se tornava evidente, já naquele período, que o trabalho de Steinberg passava por transformações significativas, com abordagens que alçavam vôos para além do humor tradicional. De qualquer forma, a personalidade de sua obra neste período ainda é conduzida de modo preponderante pelo desenho simples, com homens narigudos, dentro do universo de referências do cartum. É a fase dos desenhos de comentários sobre aspectos urbanos, que se identificam com os desenhos sobre as viagens na guerra. Os trabalhos mostram vistas de espaços interiores e exteriores cheios de detalhes, mas em desenho de linha fina, sem as grandes misturas estilísticas que viriam a fazer parte de sua obra. São cartuns resultantes do pensamento de um desenhista moderno, afeito à "idéia" mostrada de modo simples, e avesso aos devaneios performáticos de outras técnicas, como a pintura, "essencialmente uma coisa narcisística" (cit. por Gluek, 1970, p.112). Em uma entrevista, Steinberg chega a comentar:

Os óleos, os acrílicos, são tão bonitos e hipnóticos. Pintura toma muito tempo, ela me seduz, é muito bonita. E a tecnique da pintura é uma técnica prolixa - mesmo falando dela, me torno prolixo. Ela tem trabalho, labor, métier. Tem muitos aparatos, máquinas, para complicá-la todos aqueles pincéis, turpentinas, óleos, vernizes; e a preparação dos quadros, o estiramento e todo o resto, é em si a administração de uma jornada. Agora, se em cima disso, alguém não tem uma inflamante necessidade para pintar, bem...alguns pintores tinham que pintar. Soutine, por exemplo. Delacroix (Gluek, 1970, p.112). 
Figura 190 e 191.

Steinberg, desenhos publicados em The Art of Living

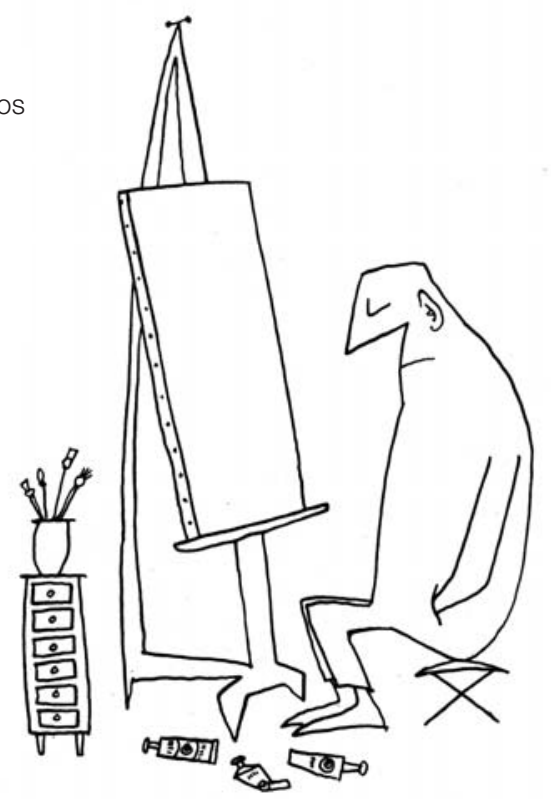

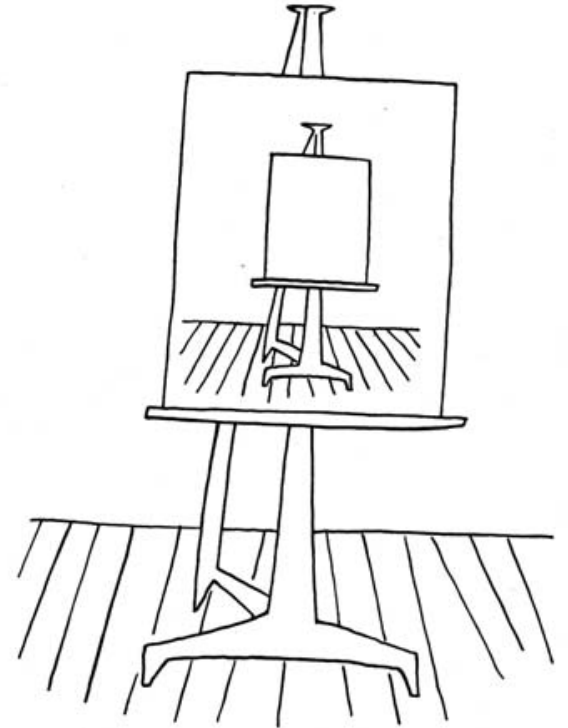

Diferentemente de outros cartunistas, Steinberg não se submetia às condições tradicionais impostas pelos editores. Quando um editor de arte queria algum desenho seu, ele usualmente ia ao seu estúdio folhear a pilha de desenhos já realizados dispostos sobre sua mesa (Spitz, 1951, p.72). Saul trabalhava sentado, olhando em direção à vista do sul do Central Park que tinha do décimo andar de seu apartamento-estúdio em East 50th Street, no qual morava com Hedda desde 1944. Ali ele havia acampado nos dois quartos da frente, com poucas mesas para alguma utilidade, cadeiras, pranchetas, e luminárias ajustáveis situadas à frente das janelas dianteiras. Ao desenhar, não costumava fazer rascunhos de concepção de idéias, nem recorria a fases de desenho progressivas; o desenho crescia, de linha preta a linha preta, até que fosse concluído. "Às vezes, ele era completamente bem sucedido, às vezes, não", diz Spitz em seu texto de 1951 sobre o artista (Spitz, 1951, p.72). Seu trabalho, segundo o próprio Steinberg, "não é realmente um trabalho organizado", tendo mais a ver com o que acontece com os animais, ou na natureza (cit. por Gluek, 1970, p.113):

Penso que o artista é uma espécie de conexão entre a sociedade de um homem inteligente e a natureza; ele tem a qualidade de não saber ao certo e saber ao mesmo tempo; sendo dirigido pelo instinto e criatividade. É uma improvisação constante, degrau-por-degrau, e a coisa mais próxima que posso dar (...) como resposta é: ao fazer um desenho ou mesmo começar uma frase - vamos conversar sobre iniciar uma frase - tenho uma idéia muito vaga do que irei dizer. Durante o tempo que digo isso, a conclusão e a idéia principal, espero, virão. Como? Mergulhando nela. Estou no alto de um platô e pulo. Caio, caio, e no último momento atinjo um galho muito confortável que está por acaso ali. Eu o agarro - e voilá! Estou seguro. Mas me arrisco. E é assim que a maior parte do trabalho é feita (cit. por Gluek, 1970, p.113). 
A vida de Steinberg seguia agitada, como sempre, naqueles tempos. Em 1948 o artista faz viagens para Londres, Suíça, Itália e França. No ano seguinte, viaja no Queen Elizabeth para a Europa, vindo a conhecer Saul Bellow em Paris, e tornando-se ambos muito amigos desde então. As exposições também eram frequentes, como as individuais realizadas no Institute of Design, a Nova Bauhaus de Chicago, em 1948, e no Museum of Art, da Rhode Island School of Design, em 1950. O artista também cuidava dos parentes. Seus tios e tias viviam agora em Israel. Quanto aos pais, em 1948 chegaram a ficar hospedados, com visto temporário, na casa do irmão de Hedda em Paris, o regente de orquestra Edward Lindenberg. Dois anos depois, Steinberg arranja uma estada permanente para os pais em Nice, passando a visitá-los sempre nos anos seguintes. Nestas viagens, seriam comuns as idas aos cassinos franceses, que resultariam em vários desenhos publicados no livro The Passport, de 1954.

No verão de 1950, mais aventuras: Steinberg é contratado para fazer sua mão "atuar", como Gene Kelly, no filme An American in Paris. Apesar de ficar livre do serviço no primeiro dia, ele e Sterne passam julho e setembro em Brentwood, na Califórnia, alugando uma casa de Annabella Power e fazendo encontros sociais com Kelly, Bolly Wilder, Oscar Levant, Igor Stravinsky, Christopher Isherwood, Charles e Ray Eames, dentre outros. Charles Eames chega a propor a criação de um "filme de um desenho da cidade", com trilha sonora, possivelmente baseado no trabalho The City, exposto por Steinberg em 1946 na mostra Fourteen Americans. Depois da estadia na Costa Oeste, o casal retorna de ônibus e trem para Nova York passando por Las Vegas e atravessando as planícies dos estados do Meio-Oeste (Smith, 2006, p.255). Logo no ano seguinte, Steinberg se estabelece em Palermo e viaja pelo sul da Itália em meios de transporte locais como bondes elétricos e barcos de travessia. A sucessão de viagens, ano a ano, é enorme e evidencia a condição privilegiada de Steinberg. O ritmo continuaria o mesmo durante ainda muito tempo.

Não menos movimentado seria o ano de 1952. Steinberg comenta ao crítico John Gruen que "prefere viver em Nova York para estar presente aos acontecimentos que ali se sucedem" (Helkenen, 1980, p.2). De volta à Big Aplle após o período na Itália, no final de janeiro, o casal se muda para um duplex com sala de sinuca, sala para entreter convidados e quintal, na East 71st Street (Smith, 2006, p.48). Rosalind Constable, em artigo de 1954, chega a expor os aposentos da residência: "(...) o jantar é comido na vasta cozinha, no canto da qual há uma grande e confortável mesa. Mas a atmosfera de gemutlichkeit (conforto) europeu de classe média é destruída pelo fato de um moderno aquecedor elétrico estar esmaltado em vermelho cor de papoula, e um mármore aparente, roliço como um perdiz, dominar o final da sala. (...) O mármore aparente é uma aquisição recente, esculpida por Nivola, e solenemente enviada algumas semanas atrás (...)" (Constable, 1954, p.24). Um inverterado party-goer, frequentemente vistos nas festas, Steinberg costumava fazer um segundo jantar toda noite, muitas vezes, após estes eventos, sentando-se por volta de uma hora da manhã com sua mulher Hedda para o que chamava "um novo jantar", com carne, vinho e sobremesa (Constable, 1954, p.9). A espaçosa casa de Saul e Hedda "abrigava amplos círculos das 
artes" (Smith, 2006, p.48). Steinberg recebia visitas de artistas franceses, italianos e americanos; amigos curadores do MoMA, escritores e artistas da New Yorker; e atores que tinham relações com Herbert Berghof e Uta Hagen. Dentre os amigos vistos de modo mais frequente estavam os escultores Alexandre Calder e David Hare; o crítico Harold Rosenberg; o violinista Alexander Schneider; os escritores .Joseph Mitchell e Niccolò Tucci; os pintores Williem de Kooning, Ad Reinhardt, Mark Rothko, e Richard Lindner; o arquiteto Marcel Breuer; o editor de arte da New Yorker, James Geraghty; e o curador de filmes do MoMA Iris Barry (Smith, 2006, p.256). No entanto, segundo Smith, com poucas exceções, o universo visual destes visitantes correspondia ao da pintura e fotografia, e não ao dos artistas da New Yorker. Os amigos da revista tendiam a ser os escritores, como Mitchell, Geoffrey Hellman, S. J. Perelman, Mary McCarthy. Do contingente além-mar, Janet Flanner e Vladimir Nabokov. Joel Smith analisa a relação entre o grupo de amigos escritores de Steinberg e seu papel como desenhista:

Encontrando-se bem-vindo entre diversos escritores provavelmente o ajudou a revisar sua própria imagem, do cartunista para o "escritor que desenha". A diferença não era meramente uma questão de status, mas de audiência ou, mais precisamente, de amplitude de alcance: um escritor não planta gags para gratificar um folheador de páginas, mas para pôr em movimento e sustentar a maquinaria mental de leitores (Smith, 2006, p.48).

Àquela altura, em 1952, um intenso período de exposições individuais já havia sido inaugurado com a mostra na Galleria L'Obelisco de Roma, em 1951 (Smith, 2006, p.48). De janeiro a fevereiro de 1952, Steinberg tem exposição dupla nas galerias Sidney Janis e Betty Parsons, quando estas duas galerias estavam no mesmo endereço e piso em Nova York (Smith, 2006, p.256). Em maio, vai para Londres ver uma mostra de seu trabalho instalado no Institute of Contemporary Arts, e no outono ele e Sterne viajam juntos para o Brasil (Smith, 2006, p.48)

Figura 192. Folheto de divulgação da exposição no MASP em 1952. Fonte: Biblioteca do MASP.

Figura 193. Steinberg com Lina Bo Bardi no Rio de Janeiro, 1952

Figura 194. Steinberg no Retiro dos Bandeirantes, no Rio de Janeiro. Publicada na revista Habitat. Foto de Pietro Bardi.

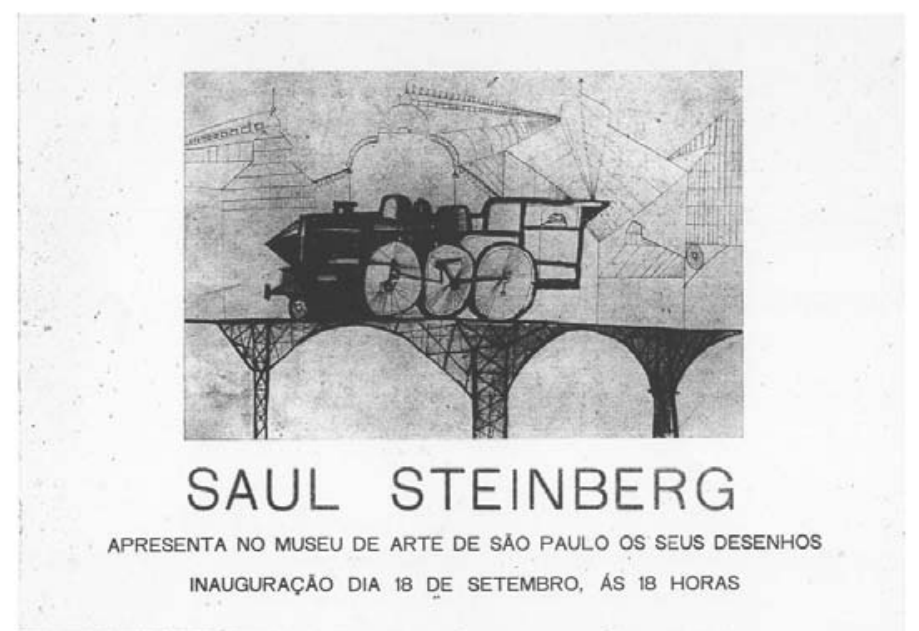


Ainda em 1952, Steinberg viaja à América do Sul, visitando São Paulo, Rio de Janeiro, Bahia, Manaus e o Amazonas no Brasil, além de Buenos Aires na Argentina (Rosenberg, 1978, p.239). A visita a São Paulo é resultado de um convite de Pietro Bardi e Lina Bo Bardi para uma exposição no MASP. Bardi troca cartas e se comunica com Steinberg por meio de inúmeros telegramas, de modo geral em italiano. Participa deste processo de convencimento, desde os idos de 1950, seu amigo Victor Civita, editor da Editora Abril, como é possível atestar em texto de Bardi:

A amizade que liga quem dirige esta revista com o antigo companheiro de estudos, a admiração para seu trabalho, nos levaram convidar, juntamente com o editor Civita, que editou os livros do desenhador, o popularíssimo Steinberg para fazer uma sua exposição no Museu de Arte de São Paulo. Na exposição figurarão os trabalhos de Steinberg e aqueles de sua esposa, sra. que é também pintora e artista de renome (Bardi, 1952, s.p).

Na América Latina, a família Civita havia aberto uma editora no Brasil - a editora Abril - e outra na Argentina. A Editora Abril argentina, administrada por Cesare Civita, chega a publicar o livro All in Line (Todo em Línea), em 1948. Em uma das cartas enviadas a Steinberg, Civita procura expor ao artista, em italiano, as virtudes da cidade de São Paulo, do museu e de outras importantes exposições que estão sendo realizadas:

San Paolo é uma grande cittá che si sta sviluppando rapidamente e bene e che offre anche Del ponto di vista culturale e artístico diverse attrative. In inverno specialmente e cidé ora, ćé um rápido susseguirsi di artisti eminenti (Brailowsky, Gulda, Solomon, Marian Anderson, Yehudi
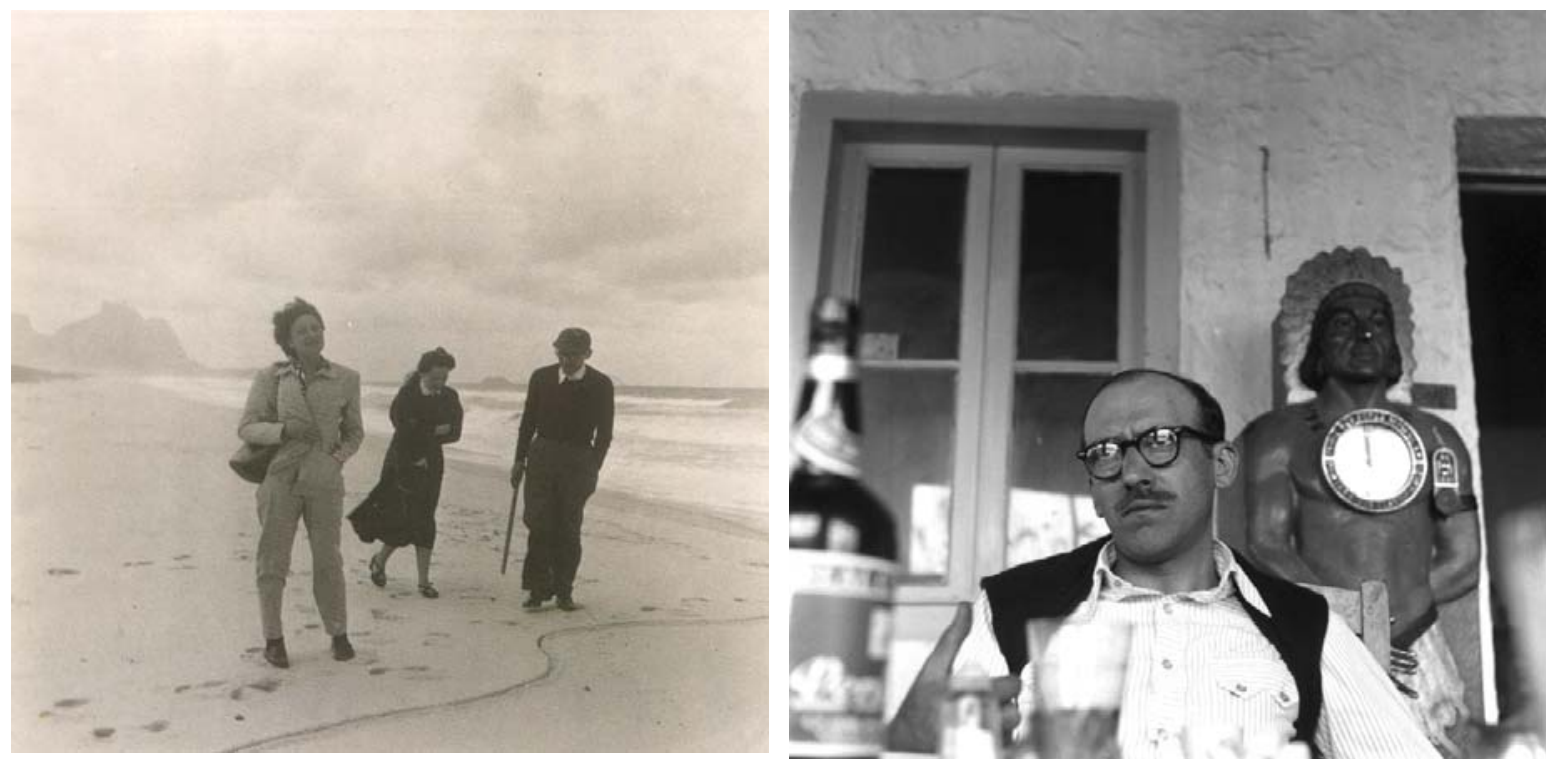


\section{HABTAT}

revista das artes no Brasil
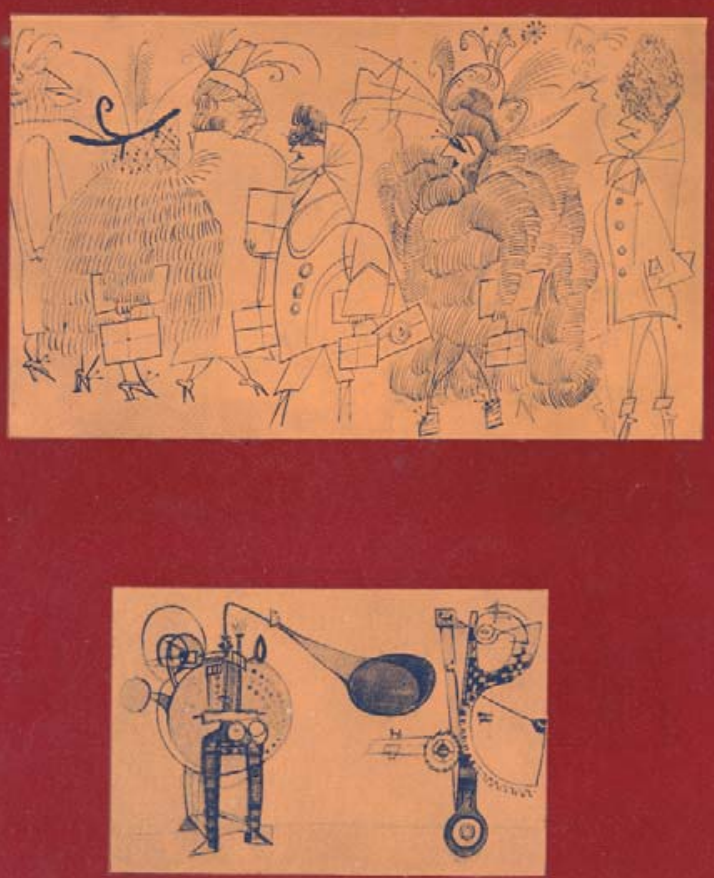

Figura 195. Capa da

Habitat, n.9, 1952, com

desenhos de Steinberg e Hedda.

Figura 196. Carta de

Steinberg a Bardi,

publicada na Habitat.

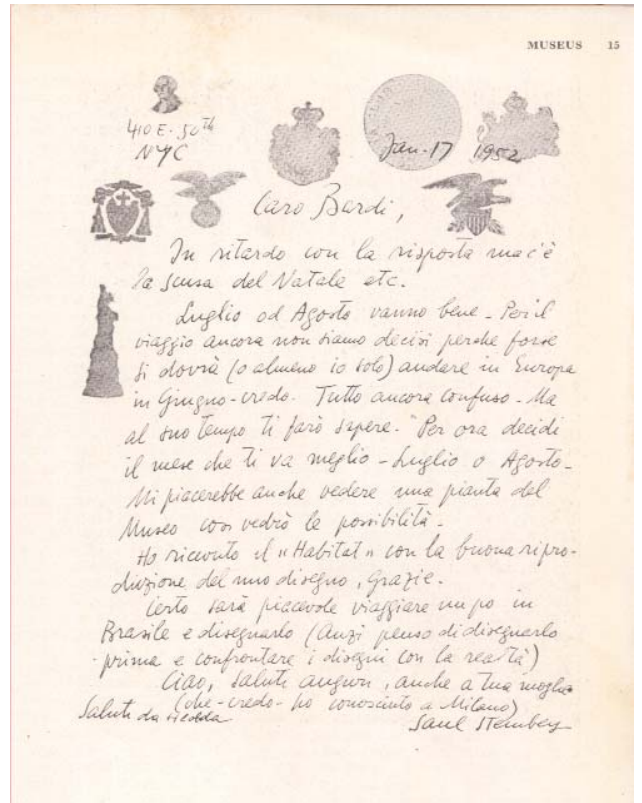


Mehuhim) nonché compagnie teatrali di primo ordine come quella della Comedie Française Che há dato applauditissime rappresentazioni.

Il Museu de Arte Moderna esplica uma attivitá multo interessante seguendo su piano piú ridotto um programma símile a quello del Museo di New York. A giorni si inauguerá poi il nuovo Museu D’Arte sorto e curato dal buon amico Prof. Bardi che tu bem conosci. Ho parlato com lui a lungo dite a hai in lui um amico e grande ammidatore. (...)

La prima espozioni sará dedicata a Le Corbusier. Stanno preparando le mostre successive e Bardi há espresso il desiderio di fare uma bella mostra di disegni tuoi. (Civita, 1950, s.p)

Em janeiro de 1951, Bardi envia um convite formal para Steinberg, em inglês. Em março do mesmo ano, envia uma carta ao consulado americano, pedindo auxílio para a empreitada. Após diversas trocas de correspondência, a exposição de Steinberg e de Hedda, no Museu de Arte de São Paulo, fica acertada para ser inaugurada no dia 18 de setembro de 1952. Bardi publica, na sexta edição da revista Habitat, o artigo Steinberg no Brasil, com imagem da carta de Steinberg confirmando sua vinda ao país. "Publicamos esta carta para mostrar aos amigos do Museu de Arte que a exposição de Steinberg será feita, sem dúvida nenhuma, ainda este ano", escreve Bardi. (Habitat, 1952, p.15). O texto de divulgação da exposição apresenta o artista:

O Museu de Arte apresentará a partir do próximo dia 18, uma exposição de Saul Steinberg, o poeta da caricatura, o observador mais agudo produzido pela arte contemporânea. Steinberg consolidou sua fama mundial com uma série de trabalhos publicados em todos os idiomas e em milhões de exemplares, que formam uma das visões mais autênticas do espírito contemporâneo. Com seu desenho, Steinberg escreveu páginas divertidas e ao mesmo tempo melancólicas, sobre a sociedade e acontecimentos desses últimos quinze anos. Suas caricaturas estão se tornando o poema da ironia. Steinberg soube colher o ridículo em todas as coisas inúteis, em todas as ambições erradas e vaidades deformadas. Steinberg inventou um mundo novo, mediante o mero julgamento de seu próprio mundo. Inventou as lágrimas, aquelas pérolas suspensas nos olhos tristes das pessoas que parecem símbolos antiqüíssimos de ternura e emoção. Inventou flores, florezinhas, folhas, como uma vegetação de fábula maliciosa. Inventou os óculos agudos como telescópios e cegos como túneis, que são o símbolo da miopia humana. Inventou todo um mundo triste, mas humano. Junto à obra de Steinberg, apresentará seus trabalhos - como já o tem feito muitas vezes - Hedda Sterne, a esposa de Steinberg, pintora da vanguarda dos Estados Unidos. Artista absolutamente paradoxal, por sua íntima aderência ao objeto real, que encontrou na máquina, nas maquinarias do mundo industrial moderno um objeto perturbador, incompreensível, prestes sempre a enfrentar uma metamorfose que nunca se realiza. Máquina tremenda, obsedante. Sobre essas máquinas ambíguas, a pintora exerce recursos pictóricos, encontrando às vezes visões de uma realidade alucinadora. (Bardi, 1952, s.p) 
Bardi se refere a Steinberg como um artista de grande prestígio. Em mais um texto, diz:

O Museu de Arte, nesses últimos dois anos preocupou-se de atrair para São Paulo todos os melhores espíritos da arte contemporânea: Max Bill, Neutra, Le Corbusier, Calder, isto é, os espíritos mais sutis que operam hoje em dia no campo da arte. Agora, à série acima o Museu de Arte tem o prazer de acrescentar a apresentação de Saul Steinberg, um dos espiritos mais agudos de nossa época, uma expressão típica de nosso tempo (Bardi, 1952, s.p).

No período a exposição, a revista Habitat dá destaque a Steinberg e Hedda em sua nona edição. Na capa, um desenho de cada, ambos recebendo também artigos e páginas com imagens de suas obras. No artigo Steinberg no Brasil, Flavio Motta comenta: "Steinberg veio pessoalmente ao Brasil para inaugurar sua exposição no Museu de Arte. Havia uma certa curiosidade em conhecer o homem dos desenhos já conhecidos" (Motta, 1952, p.17 ). Em São Paulo, Steinberg viria ser ficar hospedado na casa de vidro projetada pela arquiteta Lina Bo Bardi. Situada, na época, diante de uma extensa e exuberante mata, Saul chega a comentar: "ela [a casa] circunda a cena de um "massacre de insetos" noturno" (Smith, 2006, p.256). Na cidade, se encontra com Flavio Motta e visita Victor Civita, numa época em que a Editora Abril ainda dava os primeiros passos. Em visita ao Rio de Janeiro, define a cidade como uma "Bucareste tropical", com "bondes elétricos abertos, dois trailers; milhares de monumentos equestres; predadores que circulam pela calçada em busca de cadáveres" (Smith, 2006, p.256).

\section{STEINBERG E A ARTE SOb ENCOMENDA: CARTÕes DE NATAL, MURAIS E PROPAGANDA}

A partir de meados dos anos 1940, Steinberg passaria a fazer significativa quantidade de arte sob encomenda, com destaque para cartões, murais e algumas propagandas de revista. Como observa Smith, apesar do espaço conquistado por Steinberg na New Yorker, ele também "procurou outros lugares, em busca de riqueza, tanto visual quanto financeira" (Smith, 2006, p.44). Naquela época, Steinberg considerava uma parte de seus desenhos ineditáveis, e procurava encontrar meios de dar vazão a este material. O artista conversava com Geraghty e Ross sobre esta situação, como em uma carta em que diz ao editor da New Yorker: "Tenho estado muito ocupado nos últimos meses, [criando] desenhos ineditáveis para moda ou revistas de literatura, ilustrações para livros que não li e outras coisas apressadas que me fazem sentir como um contador" (cit. por Smith, 2006, p.239). A favor de Saul estava a tendência do momento nas revistas do pós-guerra, no desenho linear e "encrespado". Steinberg forneceu desenhos ricamente detalhados para as recém aumentadas páginas dos jornais de arquitetura, em tempos livres da racionalização de papel do período de guerra. Estas propagandas, muitas vezes, não requeriam nada mais específico do que muitos detalhes steinbergnianos, 
sendo "a idéia simplesmente prender a atenção do leitor" (Smith, 2006, p.44). Era comum, portanto, a utilização de vários de seus desenhos acabados e inéditos, cheios das reconhecíveis construções e cidades com pormenores, como o da propaganda do perfume D’Orsay para a New Yorker, em 1946. Steinberg também viria a fazer inúmeras propagandas na revista nos anos 1950, para companhias de vermouth, padrões e estampas de vestido, e rádios (Gasser, 1956, p.376).

Outro veículo alternativo para seus desenhos eram os cartões de Natal. Seu primeiro trabalho nesse campo foi voltado para o cartão do The Museum of Modern Art, em 1945, com a imagem de um Papai Noel sendo conduzido por uma rena, ambos soltos em um espaço cheio de abstrações de flocos de neve. Ao aliar refinadas linhas contemporâneas à linguagem popular do cartum, o desenho de Steinberg se mostrava adequado às intenções do museu de estender de modo amplo o modernismo ao público americano. $\mathrm{O}$ artista se manteve fiel a esse padrão até 1952, nos cartões do MoMA e da Brentanós Books. Nestas obras, fez a figura de Papai Noel andando de skate, tocando violino,dando as mãos para uma cópia de si mesmo, e se mesclando a uma àrvore de Natal. A figura excêntrica e afável deste Papai Noel foi bem sucedida com o público, e permitiu novos trabalhos a Steinberg, alguns de grande magnitude, como para a Hallmark (Smith, 2006, p.118). Para o MoMA, Saul produziu um ou dois cartões de férias por ano até 1952. Depois deste período, o contrato com a Hallmark colocou fim neste processo, mas até 1962 o museu continuou reimprimindo seus desenhos à medida que estes se esgotavam (Smith, 2006, p.243). Os trabalhos para a Hallmark conferiram certo conforto monetário, em desenhos feitos com certa rapidez: de 1953 a 1959 o cartunista recebeu um cheque de $\$ 10.000,00$ todo mês de janeiro pelo cartão da empresa, um salário razoável de um ano naquele tempo. Ao mesmo tempo, a empresa tinha equipamentos e artesãos suficientes para permitir a Steinberg diversas experimentações: limites de cor, recortes, e impressões em relevo que exploravam detalhes arquitetônicos de um edifício. Ao longo de todo este tempo, alguns aspectos foram mantidos, como a relação mágica sempre explorada entre o Papai Noel e os pássaros (Smith, 2006, p.118).
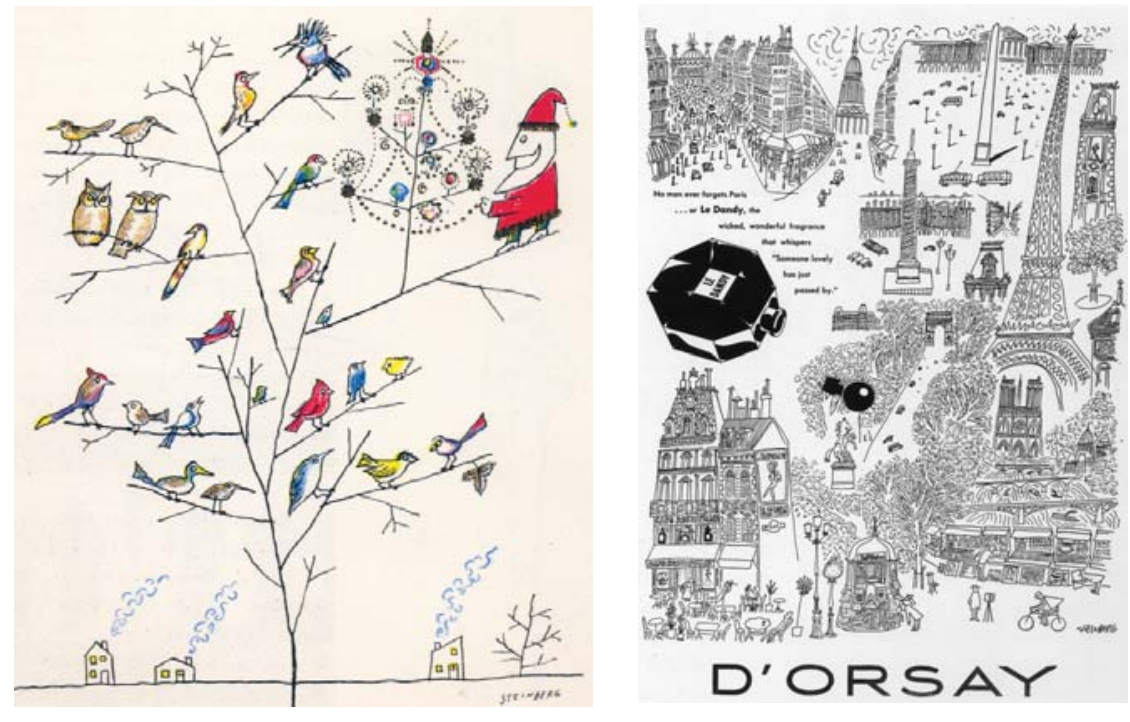

Figura 197. Steinberg, cartão de Natal. Santa Claus and birds in tree, 1952 ou depois.

Figura 198. Steinberg, propaganda para o perfume D'Orsay, The New Yorker, maio de 1946 
Figura 199. (ao lado) Publicado em The Art of Living, 1949. Detalhe de desenho para mural da American Export Lines, 1948

Figura 200. (abaixo) Desenho do painel para o mural no Terrace Plaza Hotel,

Cincinnati, instalado em 1948

Figura 201. (na outra

página, a partir da esquerda) Skyline Room, Terrace Plaza Cincinnati, com mural de Steinberg.

Figura 202. An Exhibition for Modern Living, 1949. Detalhe do mural de Steinberg.
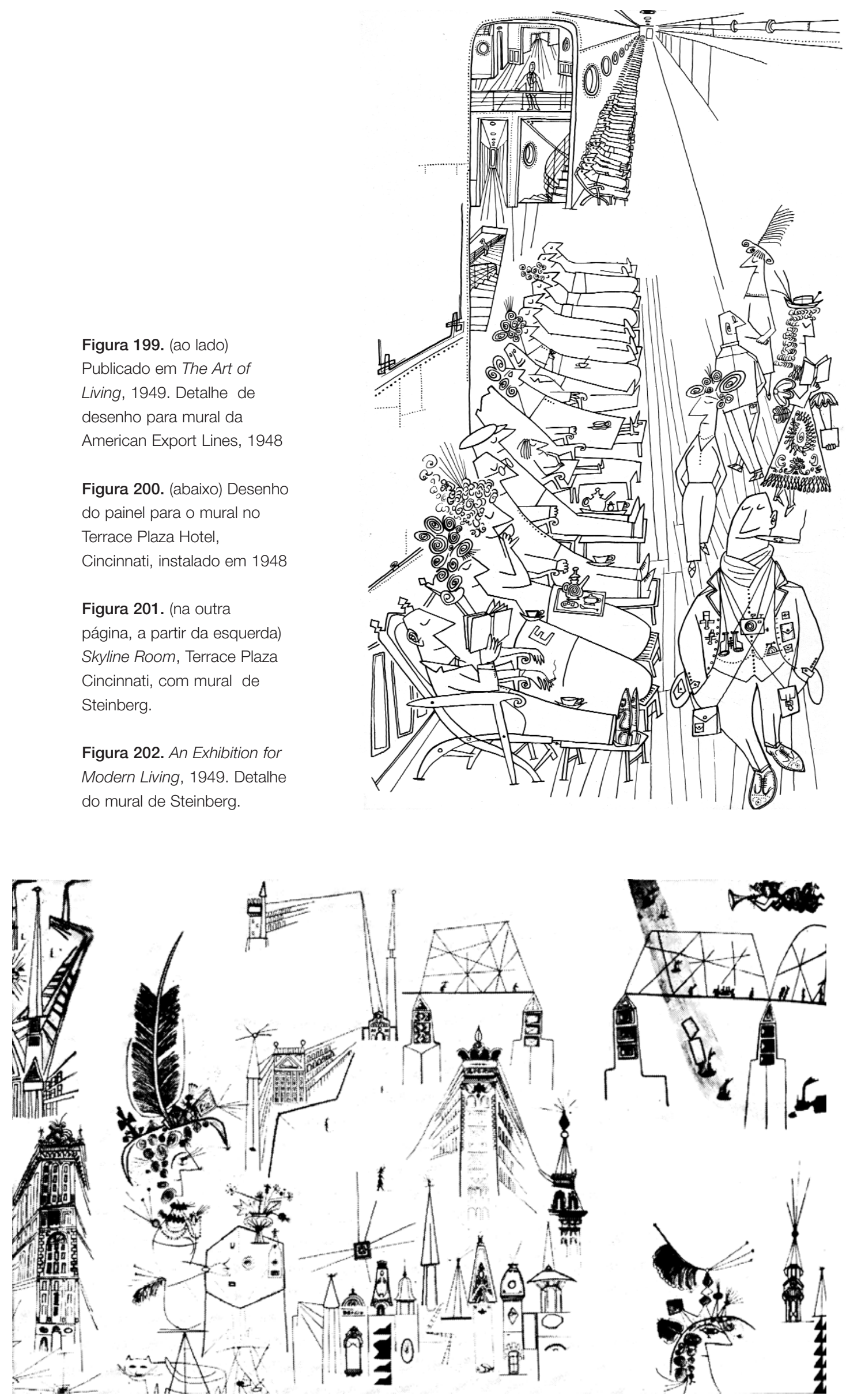
Um meio de arte sob encomenda significativo feito por Steiberg nestes tempos foi o mural. Sua produção foi especialmente intensa entre 1947 e 1949, com quatro murais produzidos; o artista faria mais três murais até 1961, dois deles dentre os mais importantes, um para Milão e outro para Bruxelas. O artista gráfico, acostumado a resolver trabalhos dentro das proporções e modo de produção das revistas, teve que enfrentar desafios e encontrar novas soluções técnicas para escala e situações diversas, compensando a pouca experiência com sua inventividade. Sua primeira encomenda veio em 1947, quando Saul desenhou uma cena eqüestre de Central Park no sétimo andar da loja de departamentos do Bonwit Teller em Nova York. O desenho original foi feito na escala habitual, na metade de um papel de desenho "Strathmore", e foi preciso um "exército de hooligans" para passá-lo ao tamanho final (Smith, 2006, p.44). Como o método se provou imperfeito, Steinberg providenciou para o próximo trabalho, feito naquele mesmo ano, um estúdio alugado de seu amigo fotógrafo Gjon Mili, e pintou as oito pinturas a óleo sobre lona. A obra foi feita para a sala de jantar do Terrace Plaza Hotel, em Cincinnati, Ohio. Um artigo sobre este projeto de Skidmore, Owings \& Merrill, publicado na revista The Architectural Review, comentou a adequação do traço de Steinberg ao espaço da sala: "o (...) desenho de linha de Steinberg se ajusta muito bem ao comprido restaurante, onde qualquer coisa mais pesada poderia ser opressiva" (The Architectural Review, 1948, p.84). Apesar do esforço técnico e de estar mais satisfeito que no trabalho anterior, o desenhista se mostrou esgotado ao término do processo. Finalmente, em 1948, Steinberg chegou a uma solução apropriada: tratar o mural como uma página de publicação. Com o objetivo de criar uma série de murais de bar para os navios Four Aces da American Export Line, o cartunista cruzou o oceano e enviou de Paris uma quantidade de desenhos sobre a vida a bordo de um navio. Estes desenhos foram fotograficamente ampliados em vinil, cada qual sendo aplicado em um navio. Como resultado, quatro murais e quatro pagamentos, pelo esforço de um. O artista empregou a mesma técnica em
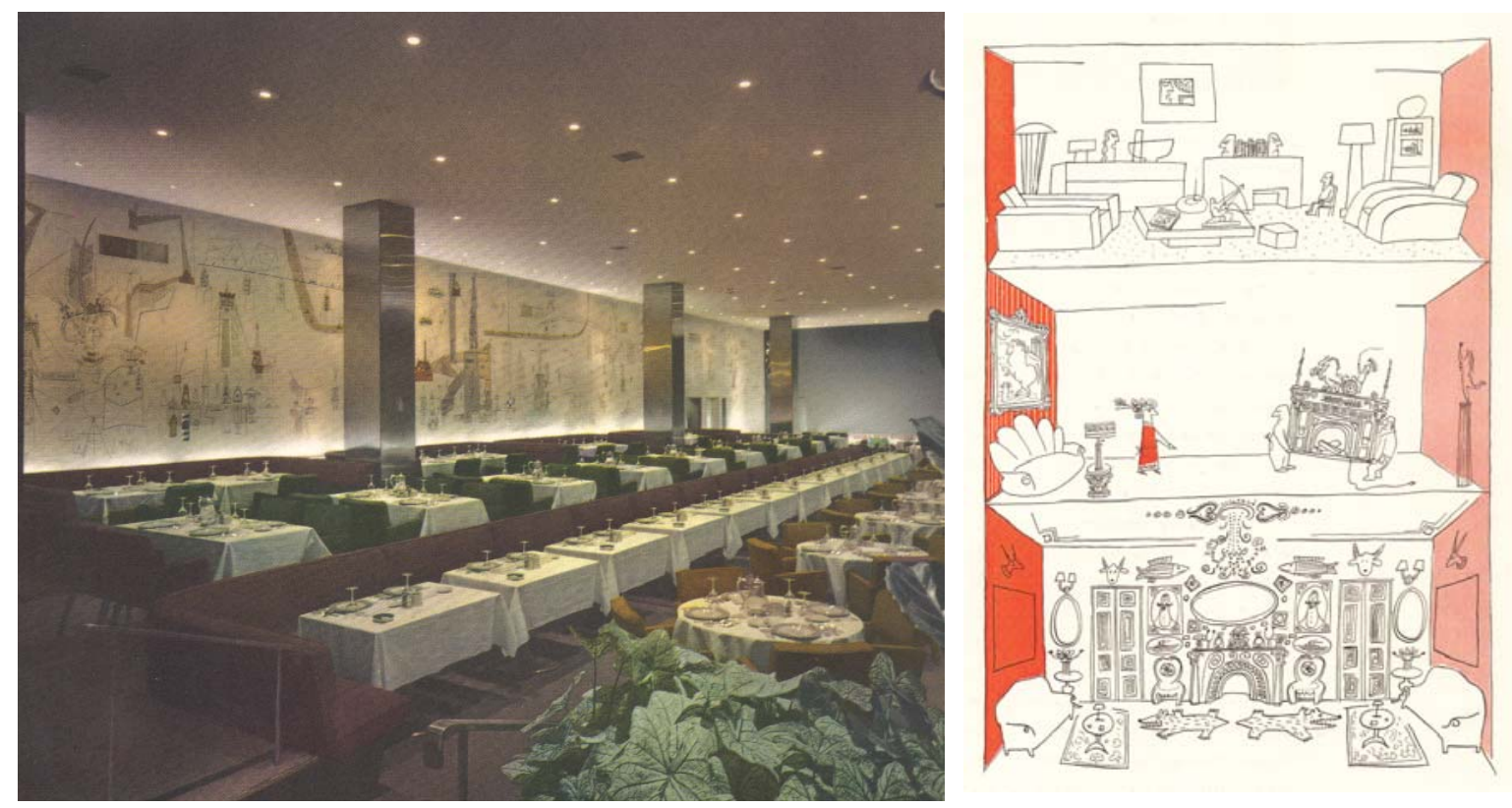
1949, em um mural para a marcante mostra de design de interiores modernista de Alexander Girard, An Exhibition for Modern Living. Imagens fotográficas gigantes de seus desenhos, retocadas com cor segundo suas especificações, mostravam uma cidade em vistas fragmentadas, em interiores repletos de produtos da vida moderna como tostadeiras aerodinâmicas. Instalada no The Detroid Institute of Arts e no J.L. Hudson Department Store, e expondo dentre seus duzentos participantes trabalhos como os de Charles e Ray Eames, Florence Knoll, Alexander Calder e Mark Tobey, Steinberg comentava seu papel com humor: "Os arquitetos estão mostrando as coisas boas que têm feito (em sua opinião) nos últimos vinte anos. E eu mostro...as coisas horríveis ou idiotas que têm sido feitas" (cit. por Smith, 2006, p.44). Como conclui Smith, a mostra serviu para reforçar a imagem de Steinberg no contexto do modernismo: "A exibição, para a qual Steinberg aceitou um pagamento simbólico, selou sua identidade nos círculos do design e arquitetura como o desenhista-laureado do modernismo" (Smith, 2006, p.44).

Cinco anos depois, Saul realizou o seu mais ambicioso e efêmero mural, para uma exposição de arquitetura e design, a 10th Trienal de Milão. Os desenhos de Steinberg compuseram as paredes do um labirinto para crianças idealizado pela firma BBPR (Belgiojoso, Peressutti e Rogers). Eram seis muros abertos, sem cobertura, que configuravam uma formação semelhante à de um trevo de três folhas - com um Calder disposto no meio -, situadas em um jardim ao lado do Palazzo dell' Arte de Milão. Steinberg realizou os desenhos em longos rolos de papel, imaginando situações para serem dispostas nas três folhas. Como observa Smith, "cada desenho era ampliado para um papel na escala dos muros, e então repousado sobre uma camada fresca de argamassa úmida nas paredes. Os artesãos, em uma técnica conhecida como sgraffito, gravaram os desenhos e tiraram o papel" (Smith, 2006, p.48). Steinberg, então, improvisava desenhando sobre as imagens gravadas no muro, acrescentando elementos como a torre do castello Sforzesco, visível daquela posição (Smith, 2006, p.48). A relação do labirinto com o parque à sua volta foi explorada também quando, "em um ponto, um par de deliciosas sereias steinbergnianas parecem ter uma contraparte, de ferro fundido do século dezenove, em uma ponte vista através de um vão ladeado por elas" (McCallum, 1954, p.403). Este trabalho foi atração e teve ótima recepção de público - adultos e crianças -, agradando mesmo os céticos do design contemporâneo (Smith, 2006, p.48). Quatro anos depois, Steinberg ainda viria a fazer o mural The Americans, para a Feira Mundial de Bruxelas. Até então, os desenhos para os murais seguiam as abordagens em linha fina simples do Steinberg "cartunista". O trabalho de Milão também era em traço simples, mas a inserção no contexto da obra, a relação com o entorno, e o modo como trabalhou e unificou a linha do desenho, conferem a este mural uma condição especial. O trabalho de Bruxelas também viria a ser um de seus murais de maior expressão, com a inserção de novas soluções gráficas, compatíveis com o trabalho do artista em 1958. 

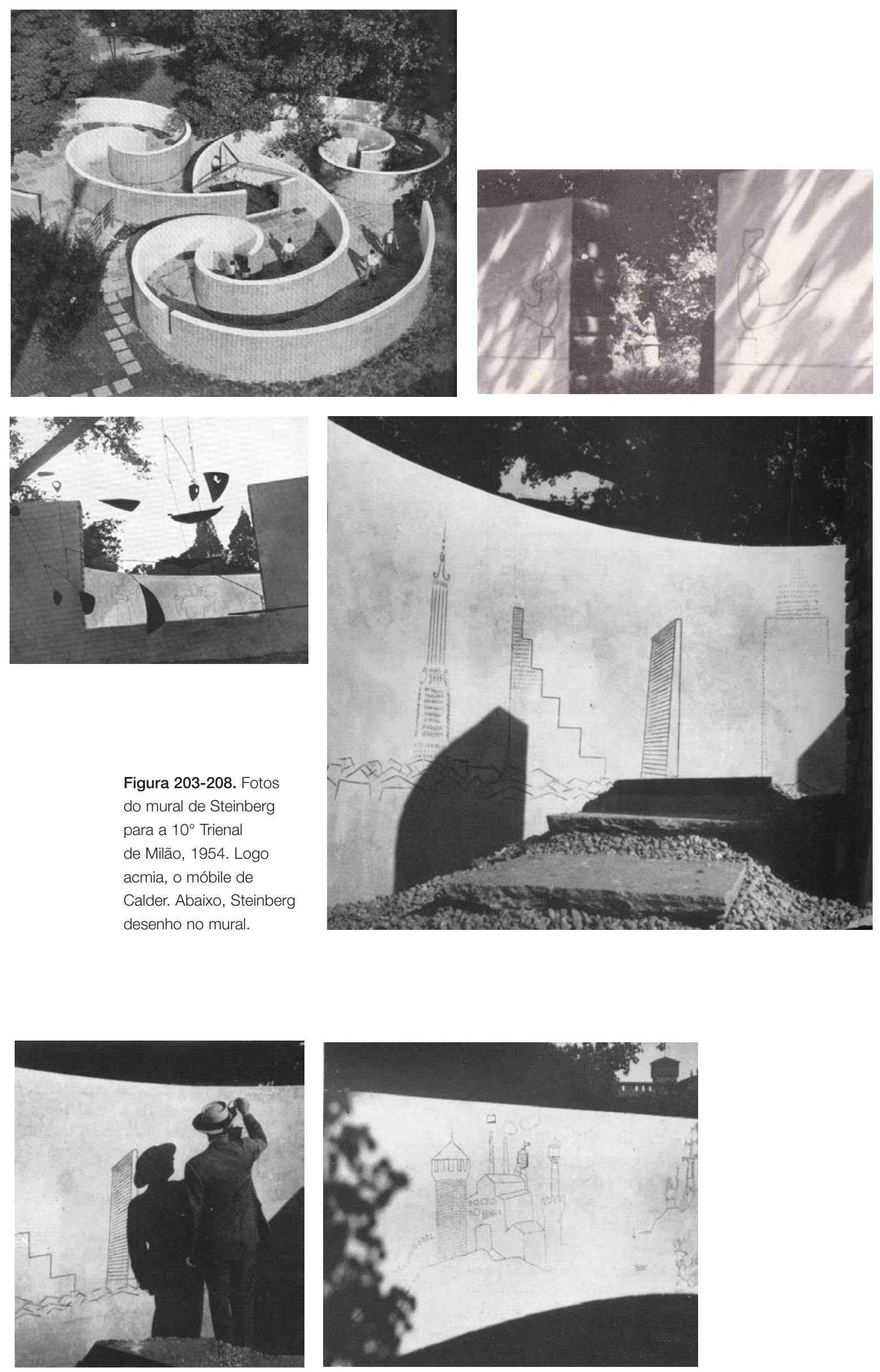


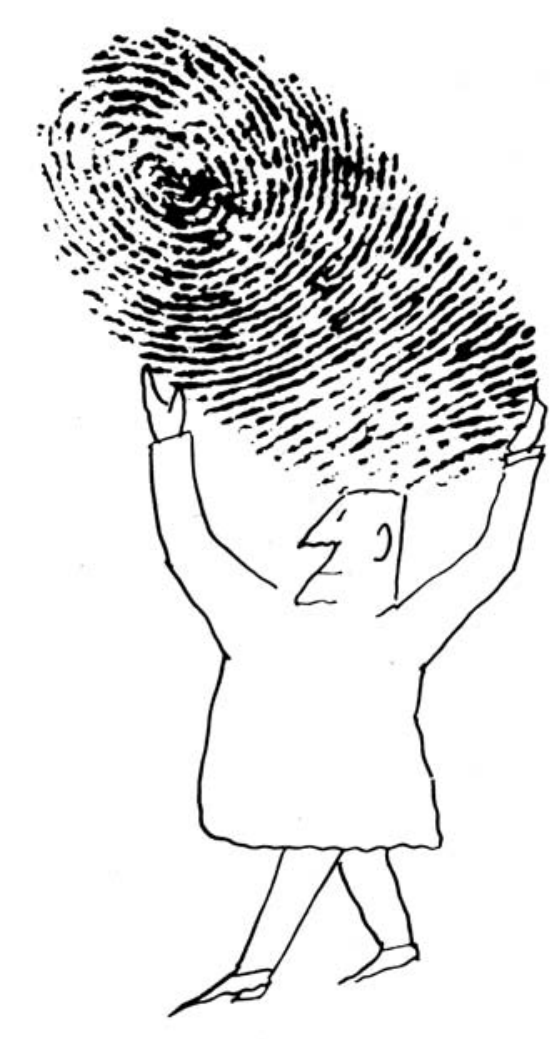

Figura 209. Desenhos

de Steinberg com

impressões digitais

objetualizadas

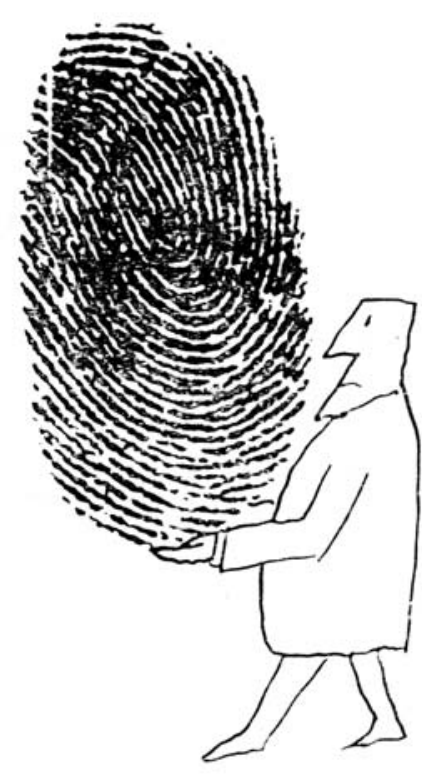




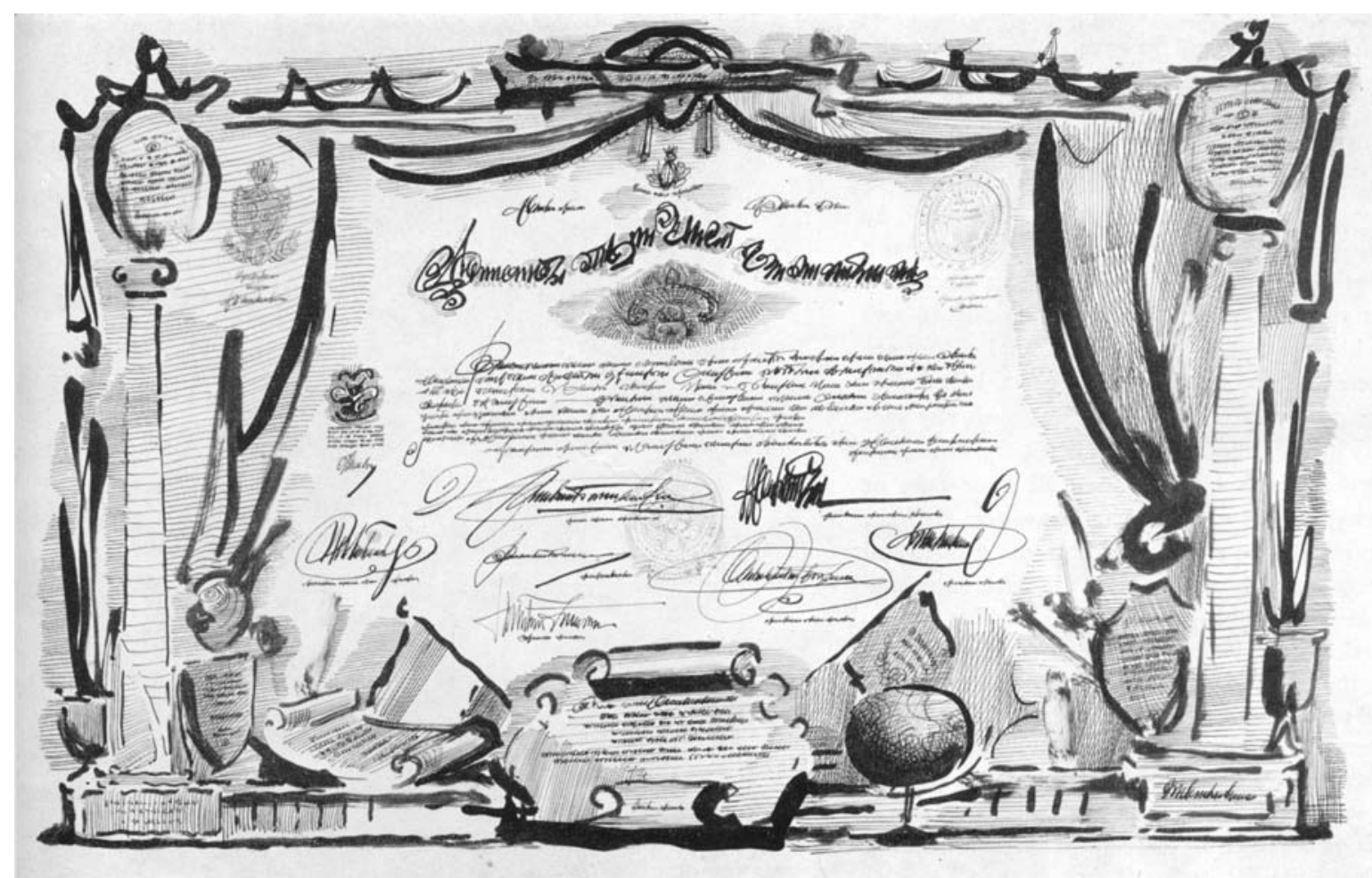

Figura 210. Documento exibido pela primeira vez na exposição da Galeria Meght, em 1953.

Em 1953, Steinberg expõe pela primeira vez em Paris, na Galerie Maeght. O espaço assumia uma liderança dentre as galerias francesas, nesta época, há já alguns anos. Ganhou tal posição depois da guerra, e se manteve nesta condição desde então. Sob a direção cuidadosa de Aimé Maeght e seu diretor de arte, M. Clayeux, promoveu naqueles tempos exposições individuais que são um registro do desenvolvimento da arte moderna como um todo, como mostras de Braque, Matisse, Mirò, Chagall, Calder, Giacometti, Bazaine, Lam, Chastel, Ubac e Tal Coat, todos vistos regularmente (...). O cultivo ativo de uma vasta variedade de movimentos conferiu à Galeria Maeght ampla reputação pelo mundo afora. Sua personalidade, no entanto, provinha claramente do papel como mediadora perspicaz e versátil no campo das belas artes e da arte gráfica aplicada, que fez dela, dentre outras coisas, uma editora de livros luxuosos e de arte. (...) No campo do design de livros, foi a Aimé Maeght que obteve sucesso em envolver artistas como Mirò e Braque nos detalhes técnicos dos vários métodos de impressão (Stahly, 1954, p.514).

A mostra em Paris evidenciava uma nova abordagem nos trabalhos de Steinberg, consideravelmente diferente dos habituais desenhos no estilo cartunístico. Foram expostos inúmeras obras desenvolvidas na época, com selos, documentos, assinaturas e carimbos. 
Como observa Smith, "o envolvimento de Steinberg com um mais profundo significado das representações o levaram a desenvolver uma variação única de arte como documentário: "uma arte sobre documentos que passam pelas mãos das pessoas todos os dias" (Smith, 2006, p.37). Permeava estas obras, também, a sugestão à condição de estrangeiro do cartunista de origem romena: "De todas as pistas que podem nos ajudar a encontrar uma direção no labirinto de Steinberg, nenhuma é mais valiosa que a imagem que Steinberg faz de si mesmo como um viajante, um atravessador de fronteiras, um incansável geógrafo itinerante" (Gill, 1978, p.72). A inovação dos documentos foi percebida na época da mostra francesa, como no artigo de Manuel Gasser Steinberg takes a new turn, publicado na revista Graphis.

Não são caricaturas ou cartuns na acepção normal das palavras. E chamá-los de trabalhos abstratos, apesar de tentador e não sem alguma justificativa, dificilmente seria algo aceito pelo próprio criador. Então, talvez, nós devêssemos chamá-los simplesmente de "paródias gráficas", observa (Gasser, 1954, p.208).

Ao utilizar o termo "paródia" já em 1953, Gasser antevê aquela que seria uma das preocupações mais importantes e freqüentes no trabalho de Steinberg. O interesse pela paródia de estilo já vinha sendo germinado de modo sutil por Steinberg nos trabalhos sobre interiores ornamentados e arquiteturas de estilo variado, mas o desenho e a linha permaneciam integrados, até então, ao seu estilo básico de cartum. Os desenhos detalhados eram parte do próprio estilo do artista, um estilo "steinbergniano", como observou Joel Smith. Já os carimbos, caligrafias e elementos gráficos destes novos trabalhos escapavam das habituais referências do universo do cartum. Vieram de fora, são elementos "alienígenas" ao típico desenho de linha steinbergniano. Em contraste às referências de então, uma vez dispostos nos trabalhos de Saul, se transformaram em "estilos" parodiados, apontando os novos caminhos a serem trilhados pela obra do artista. No entanto, há quem considere redutor resumir estes trabalhos a meras paródias, frisando a complexidade dos "documentos", como comenta Joel Smith, ao buscar aproximações entre estas obras e a arte desenvolvida por muitos dos amigos artistas de Steinberg:

Tomar estes falsos documentos como mera paródia - um laborioso esvaziamento da autoridade institucional - é perder muito de sua força visual. Sim, falsas assinaturas, como as de Large Document, satirizam a pomposidade de funcionários, mas também apresentam a variação - em outra escala- de Steinberg para a arte abstrata de seu tempo. (...) Os floreados de Steinberg são não-figurativos (i.e. ilegíveis), com certeza, mas - longe de resistirem à interpretação - eles são virtualmente impossíveis de não serem interpretados, graças ao instinto de leitores que nos leva a ver um dado estilo de escrita à mão como vigoroso, ou preguiçoso, ou estranho, ou severo. (...) Os melhores expressionistas abstratos, ele [Steinberg] notava, pintavam com todo o seu corpo, "de acordo com seu sistema cinético, seu sistema muscular". 
Quando este princípio catártico foi trazido à escala manual de seu trabalho, o resultado foi uma caligrafia além do conhecimento da escrita, expressando a inteligência da mão com a pureza dos gestos vistos nas conversas. (Smith, 2006, p.114).

As obras expostas na Galerie Maeght não eram resultado de preocupações instantâneas, ocorridas em 1954. Steinberg já vinha fazendo pesquisas do gênero há alguns anos. A manifestação mais remota de Steinberg em caligrafia falsa foi resultado de uma resposta dada, em 1946, a uma solicitação da curadora Dorothy C. Miller para o Relato do Artista que deveria acompanhar seu trabalho no Fourteen Americans. O artista escreveu seu "texto" em rebuscada e ilegível caligrafia, manifestando suas impressões dentro da lógica visual do desenho. As assinaturas não eram elementos quaisquer. Posteriormente, ao perguntarem a ele os artistas que mais o haviam influenciado, o artista chegou a querer oferecer alguns nomes, mas chamou a caligrafia "de minha verdadeira professora" (cit. por Smith, 2006, p.114). A partir de 1947, ele começou a enviar, de modo seletivo, papéis e cartas a amigos, de acordo com as necessidades. Naquele ano, por exemplo, enviou um documento para Henri Cartier-Bresson, uma carta com exuberante caligrafia e pequenos selos. Steinberg também começou a emitir diplomas e certificados de prêmios para presenteá-los em grandes ocasiões, como nascimentos, importantes aniversários, e aposentadorias. Como Hedda Sterne, que recebeu dupla graduação nas disciplinas de cozinheira e lavadora de pratos (Smith, 2006, p.112).
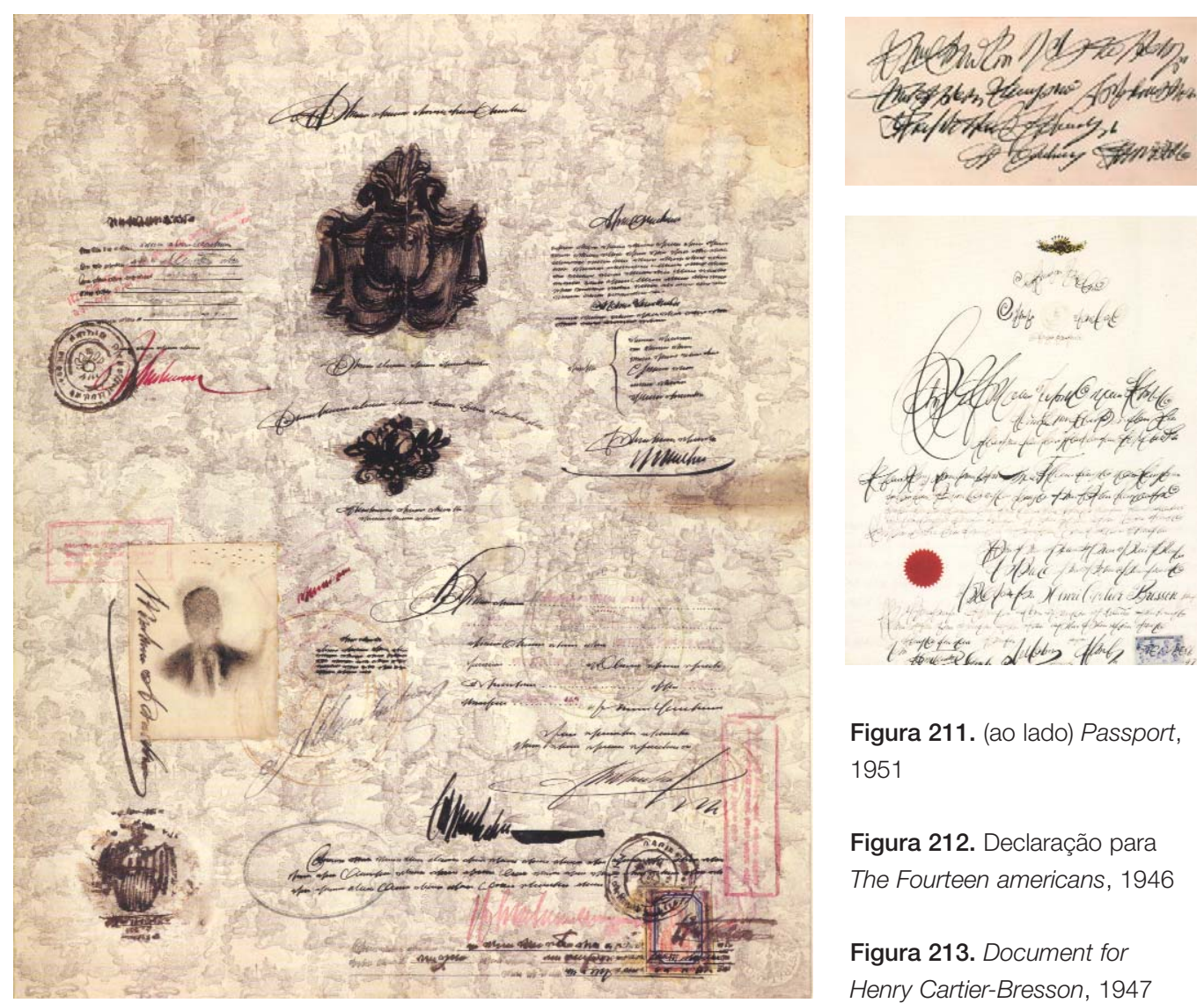

Figura 211. (ao lado) Passport, 1951

Figura 212. Declaração para The Fourteen americans, 1946

Figura 213. Document for Henry Cartier-Bresson, 1947 
Talvez inspirado pela ocasião da exposição na Galeria Maeght, Steinberg anota em outubro de 1953: "Fazer carimbos de cópias do polegar" (cit. por Smith, 2006,p.257). Tratava-se, talvez, de "sua arte e humor aumentando cada vez mais o foco em contradições entre a sociedade de massas e o culto ao individualismo" (Smith, 2006, p.257). Um pouco antes, em maio de 1954, Steinberg havia publicado seu primeiro trabalho com uso de sua impressão digital do polegar na revista The New Yorker. No entanto, não era um trabalho como os "documentos", mas um cartum onde os elementos básicos de um rosto de cartum - dois pequenos círculos para os olhos, um risco para a boca outro pro nariz - eram dispostos sobre a impressão digital, transformando-a. Este era apenas um dos muitos trabalhos da época em que o artista usava o recurso da ambigüidade, um tipo de ilusão gráfica. É um procedimento que joga com a capacidade de um determinado elemento gráfico representar mais de uma coisa. Na New Yorker, o primeiro trabalho com claro uso deste recurso foi feito em fevereiro de 1945, em um desenho que explora a situação ambígua de linhas que não deixam claro se são componentes de um personagem ou se são linhas desenhadas. Este cartum sugere sua intenção metalingüística - de comentário de sua linguagem - ao mostrar no resultado final o processo de criação, com as linhas sendo desenhadas por canetas. Durante um bom tempo, no entanto, Steinberg privilegiou outro tipo de cartum na New Yorker, mais voltado para cruzamentos conflitantes de situações, gerando ajustes e deformações de personagens e objetos. Em 1950, o cartum em que um peixe aparece assumindo dois papéis, o de peixe e de olho do gato, ainda se mostra isolado.

Não demoraria para, em 1953, Saul começar a explorar com maior freqüência os recursos de ambigüidade. Uma atenção especial é conferida às possibilidades do elemento gráfico linha, retomando o cartum de 1945. Não por acaso, naquele ano de 1953 Steinberg havia feito o desenho The Line para o mural exposto na Trienal de Milão, com uma versão concisa sendo publicada na New Yorker no mês seguinte. Este trabalho é uma verdadeira aula de ambigüidade gráfica, onde o artista expõe, de modo quase didático, como uma mesma linha pode ter seu sentido alterado à medida que muda o contexto. Esta mudança de contexto ocorre em função da alteração dos elementos desenhados que dialogam com a linha. Em

Figura 214. The New Yorker, maio de 1950

Figura 215. The New Yorker, maio de 1954

Figura 216. The Line, 1954
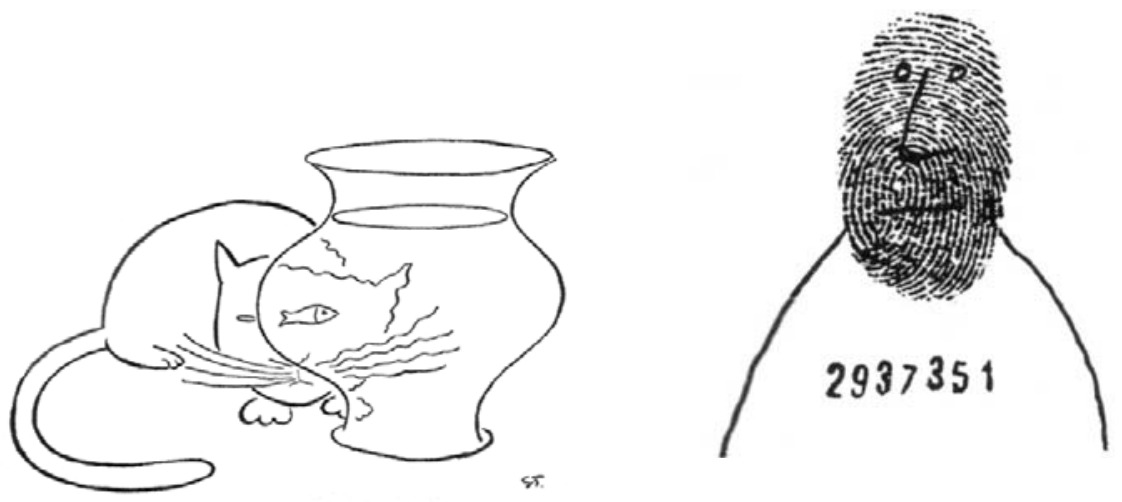
The Line, apenas a linha permanece "imutável" em seu percurso horizontal. Seu significado, no entanto, muda constantemente; em certas ocasiões é a linha do horizonte, em outros um canto de sala ou a beirada de uma mesa. Ao mesmo tempo, algo não se altera: a linha, desenhada por uma mão na extremidade do desenho, faz lembrar o tempo todo que é - além de tudo que representou - uma simples linha desenhada, um elemento gráfico. As qualidades deste trabalho são comentadas por Joel Smith:
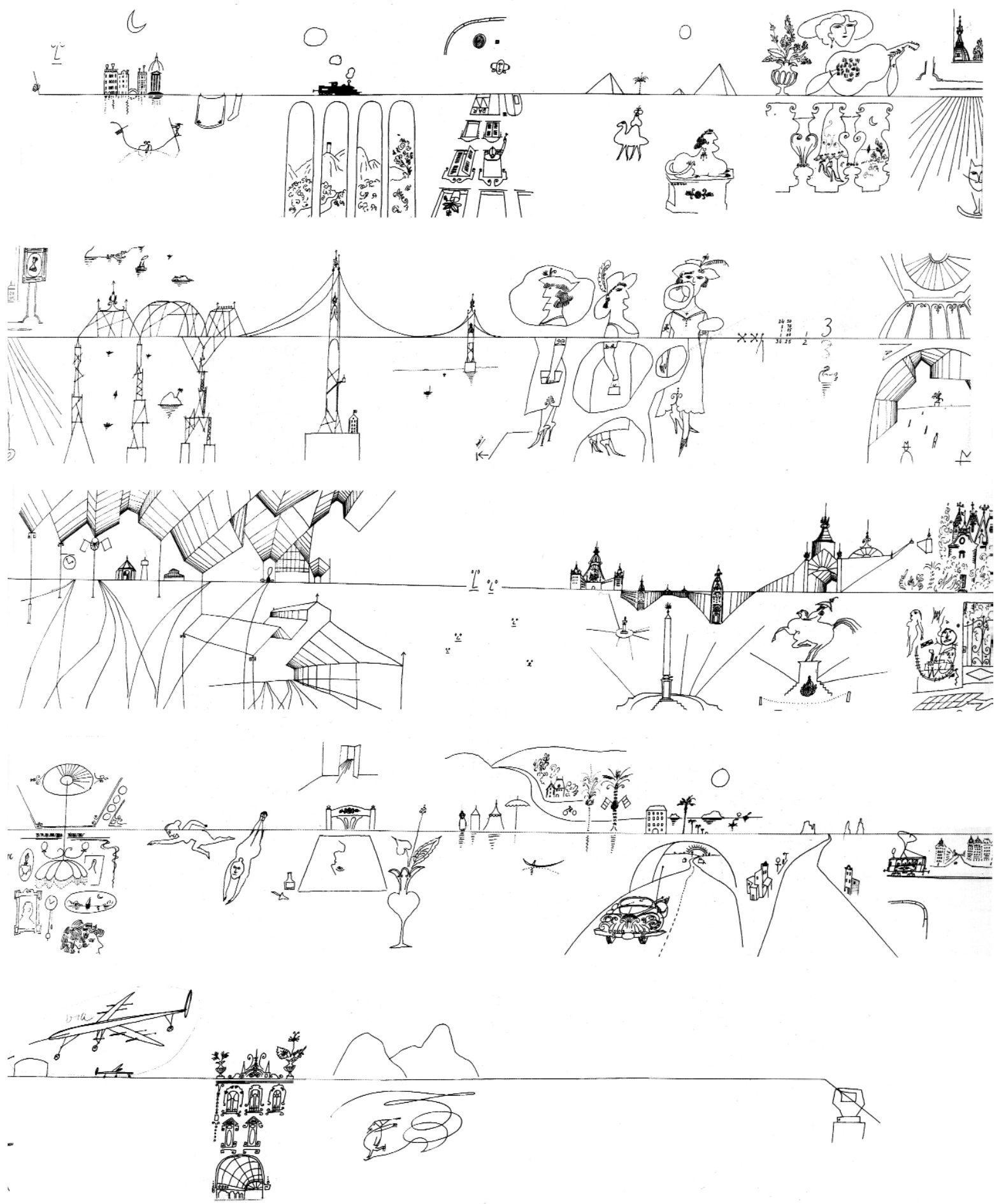
Em The Line, a variedade de formatos serve para expor a riqueza semiótica da ferramenta fundamental da arte de Steinberg, a linha de ponta-fina de tinta. O desenho de 33 pés de comprimento, que desvela sua forma harmoniosa, demonstra que a simplicidade e maleabilidade de uma linha são uma coisa só. O princípio pode servir de manifesto para a visão de arte de Steinberg como um mundo aberto ao livre usufruto da mente, onde tudo é o que um artista, ou um olho, faz dele: uma linha (horizontal) é uma linha (de estrada de ferro) é uma linha (de lavanderia). (...) The Line - uma completa turnê pela realidade, começando e terminando com uma mão que desenha sua formação - oferecia uma lembrança vívida de que o papel do desenho pertencia à mais simples e potente invenção de todos os tempos: uma vareta (Smith, 2006, p.130).

Foram vários os desenhos publicados na revista The New Yorker nesta época que faziam uso deste jogo ilusório com linhas. Mais simples, publicados como pequenas vinhetas, alguns são verdadeiros marcos da síntese gráfica. Em certos casos, Steinberg subvertia o caminho natural do contorno que definia uma silhueta, surpreendendo o olhar domesticado. Estes exercícios confirmavam a consciência de que uma linha de desenho era antes de tudo um elemento gráfico, sujeito a reformulações que não dependiam do apego à cópia da realidade ou às convenções. Steinberg sabia, por exemplo, que um elemento colocado na altura da cabeça de um corpo desenhado, por mais distorcido que fosse, ainda assim transmitiria a idéia de uma cabeça. Com base nesse limite tênue entre a representação e os elementos gráficos, Saul fazia uso da liberdade permitida. Com isso, em muitos casos, realçava e dramatizava certas situações. Fizeram sucesso as diversas propagandas publicadas em meados dos anos 1950 na New Yorker, em jogos ilusões que mesclavam - em muitos casos - desenho e fotos (Gasser, 1956, p.376). Em outra fase na New Yorker, cria em 1957 diversos desenhos de "mulhereslinha", procurando subtrair elementos a partir a coincidência de contornos de objetos e personagens, em resultados de grande síntese gráfica. Trata-se de um tipo de ambigüidade sutil, que tende a evocar a idéia de depuração, mais do que a busca por "imagens duplas". De qual-
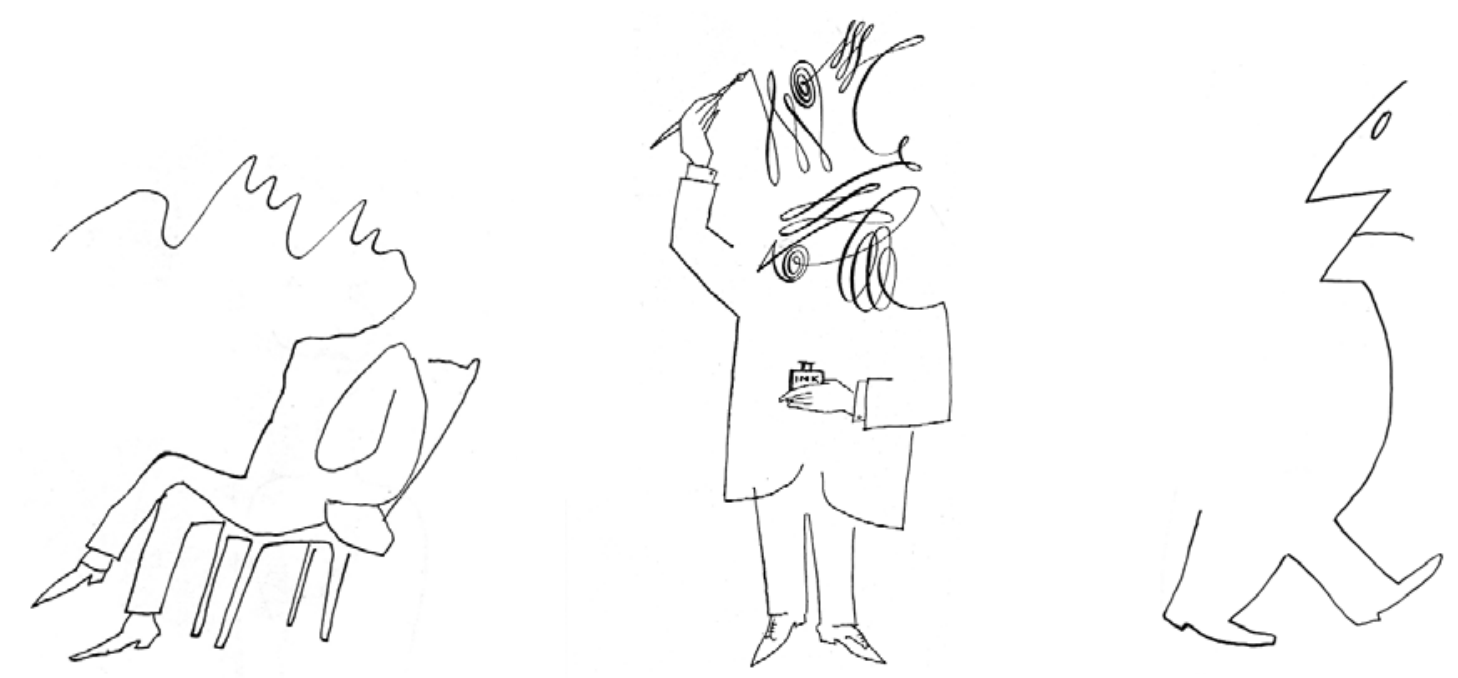
Figura 217. (ao lado) Propaganda da SImplicity

Pattern Company na New Yorker, anos 1950.

Figura 218. Publicada em Dessins

Figura 219. The New Yorker, 10 de julho de 1954

Figura 220. The New Yorker, 26 de dezembro de 1954

Figura 221. The New Yorker, 27 de abril de 1957

Figura 222. The New Yorker, 13 de abril de 1957

quer forma, o tratamento é de tal modo voltado ao desenho simples e sintético de traço fino contínuo, que a situação do desenho eventualmente cede espaço ao personagem "linha". Outro desenho feito em 1957 é uma variação desta abordagem, feita com prédios. Dada a forma simples dos prédios modernistas, Steinberg conseguiu desenhá-los com apenas um traço que, ao assumir autonomia e percorrer diferentes caminhos, criou tramas variadas.

A abordagem também abriu portas a experiências com deformações mais contundentes de formas, e com paródias de estilo. Aos poucos, as linhas e elementos gráficos dos desenhos de Steinberg foram assumindo conformações cada vez mais variadas e absurdas. Se uma impressão digital estabelecia alguma semelhança com um rosto, pelo formato circular, faces de personagens começam a ser delineadas por rebuscamentos caligráficos. Steinberg passa a conferir formas visuais não apenas a elementos "visíveis", mas também a sons, pensamentos e falas desenhadas. Estas, na realidade do desenho, poderiam agora adquirir personalidades próprias, a partir do emprego inusitado de estilos, como em suas primeiras experiências do gênero na New Yorker, de 1955. Ao enfatizar nestes trabalhos o uso de estilos "alienígenas", que contrastam com o desenho simples, um personagem como o "som" de determinado instrumento, além de ser ele mesmo, se eleva à condição de elemento gráfico
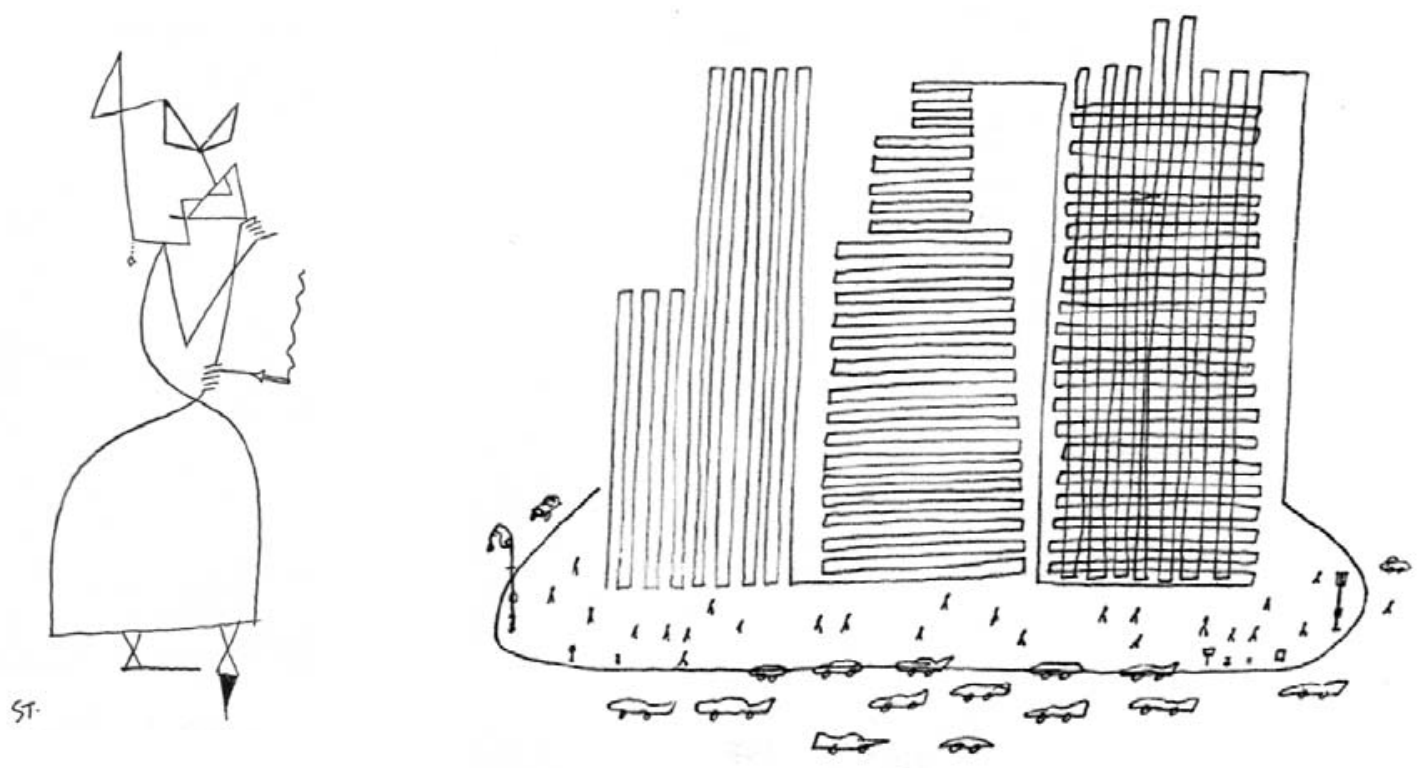


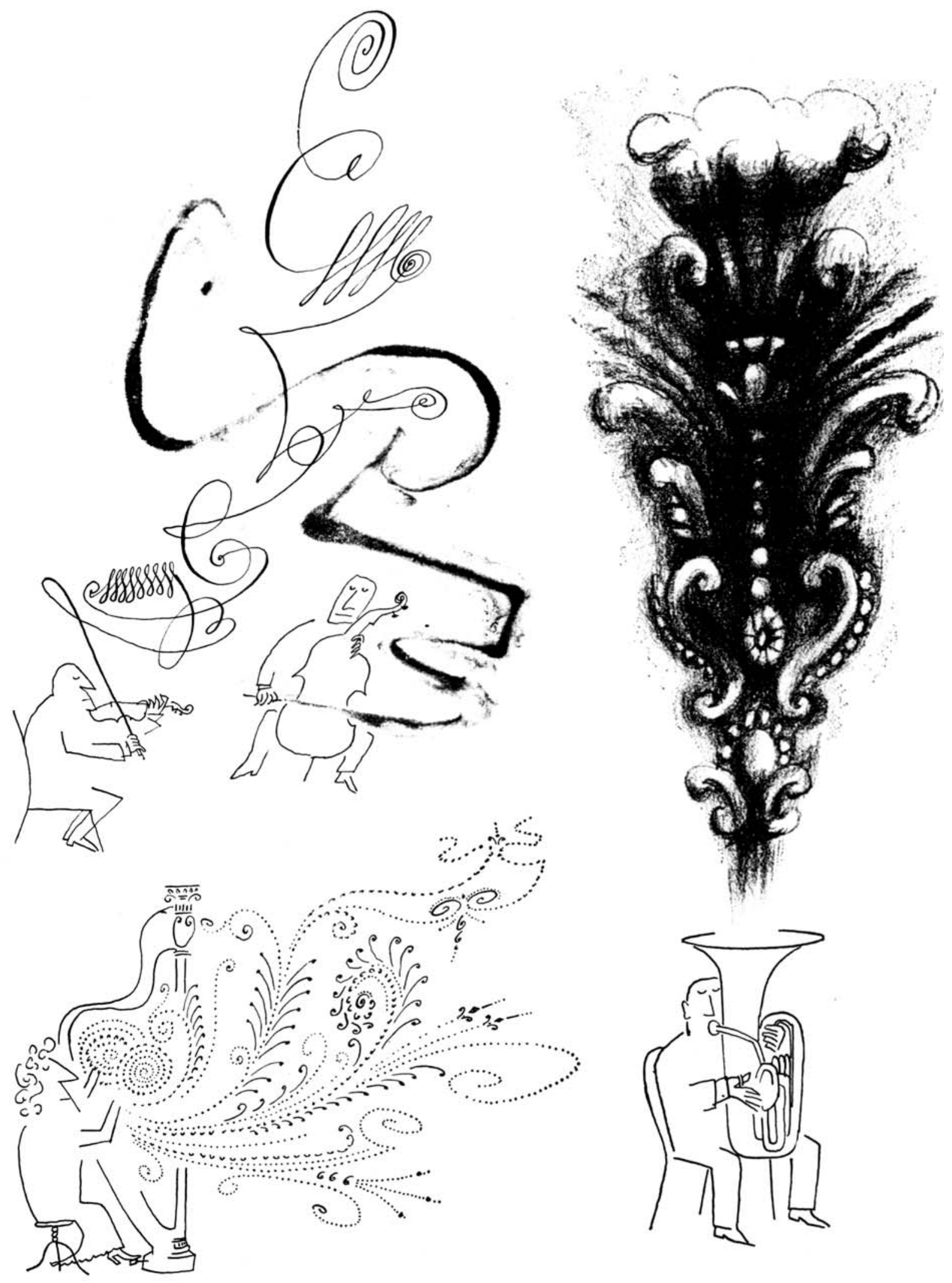


autônomo. Desenhos com a estilização de falas de conversa seriam uma variação da mesma pesquisa, aparecendo na New Yorker pela primeira vez em 1957. Os "estilos" destas obras ganham em variedade, assumindo formas cada vez mais esdrúxulas como a escrita de um analfabeto, desenhos geométricos, composições cubistas, curvas em art noveau. As próprias pessoas falantes são desenhadas, por vezes, em um estilo que escapa do traço simples e limpo de Steinberg. Cada estilo do desenho confere personalidade à fala das pessoas, sugerindo o modo como os indivíduos se apresentam e atuam nas relações sociais.

Desde as primeiras experimentações com ambigüidade, Steinberg procurou subverter não apenas a linha, mas também qualquer outro elemento gráfico. O livro The Art of Living já trazia as primeiras abordagens do gênero, na transformação de pautas musicais em chuva ou em elástico de aparelho de ginástica. As pautas viriam a ser utilizadas novamente, como na capa que fez, muitos anos depois, para a New Yorker em 1967. Assim como em The Line, trata-se de uma "lição" sobre ambigüidade, ao mostrar no uso de um mesmo elemento gráfico a variedade de possibilidades. Saul também criou vários trabalhos com papéis de escola, transformando suas linhas em prédios modernos com o auxílio de sutis sugestões acrescentadas no desenho, como pára-raios situados no topo do quadriculado. O historiador Gombrich chega a analisar um de seus desenhos do gênero, de gatos em uma gaiola: "Normalmente, ignoramos as linhas num papel quadriculado, mas uma vez que compreendemos a posição dos gatos, vemos que a única hipótese que se coaduna com o caso é que eles estejam subindo por uma gaiola de arame e imediatamente as linhas cruzadas se transformam para nós na representação de uma gaiola" (Gombrich, 1959, p.207).

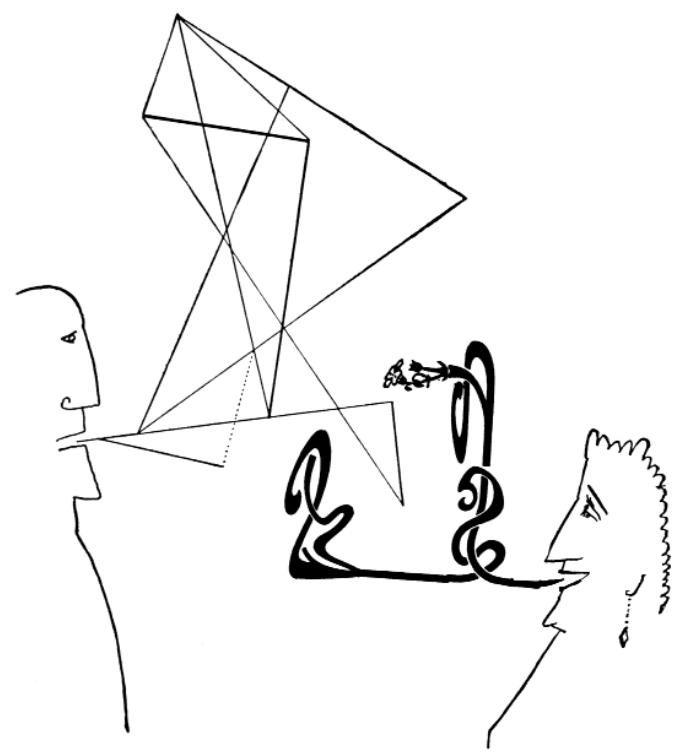

Figura 223. (à esquerda) Página da New Yorker, 12 e fevereiro de 1955

Figura 224. Desenhos publicados na New Yorker, 1 de junho de 1957

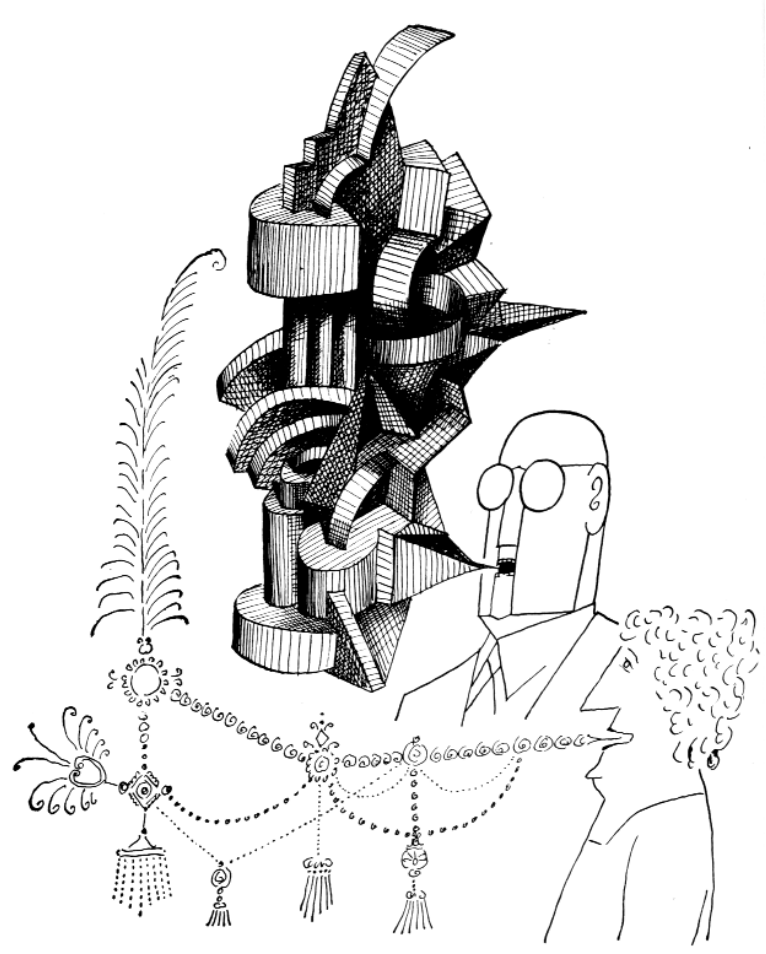


Salientando sua capacidade de manipular elementos, são comuns também os desenhos em que personagens transitam pela folha da página carregando assinaturas e impressões digitais. Com o tempo, pontos de interrogação, elementos tipográficos e quaisquer outros objetos se tornariam passíveis de serem manipulados, carregados, transformados em outra coisa, com outros usos. É possível que a precoce experiência do artista na infância com objetos de escola, tipografia, desenho, tenha contribuído para este olhar atento à manipulação e recriação imaginativa de elementos. Por todos estes trabalhos, Gombrich afirmou que "talvez não haja artista vivo que saiba mais sobre a filosofia da representação que esse humorista" (Gombrich, 1986, p. 207).

Depois dos grossos volumes que têm sido escritos sobre a maneira pela qual o espaço pode ser representado em arte, os desenhos de Steinberg servem como um lembrete oportuno de que nunca é o espaço que se representa, mas coisas familiares em determinadas situações (Gombrich, 1986, p.208).

Figura 225. (abaixo) Desenho publicado em Dessins

Figura 226. (nesta página, ao lado) Graph Paper Building, 1950

Figura 227. (outra página, no alto) Desenho de 1951

Figura 228. Graph Paper Architecture, 1954

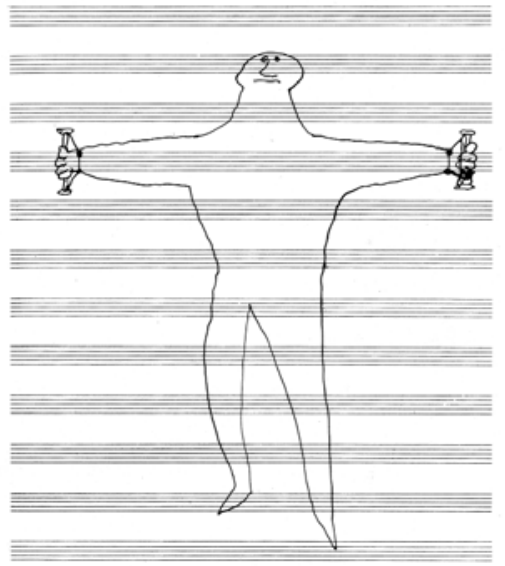

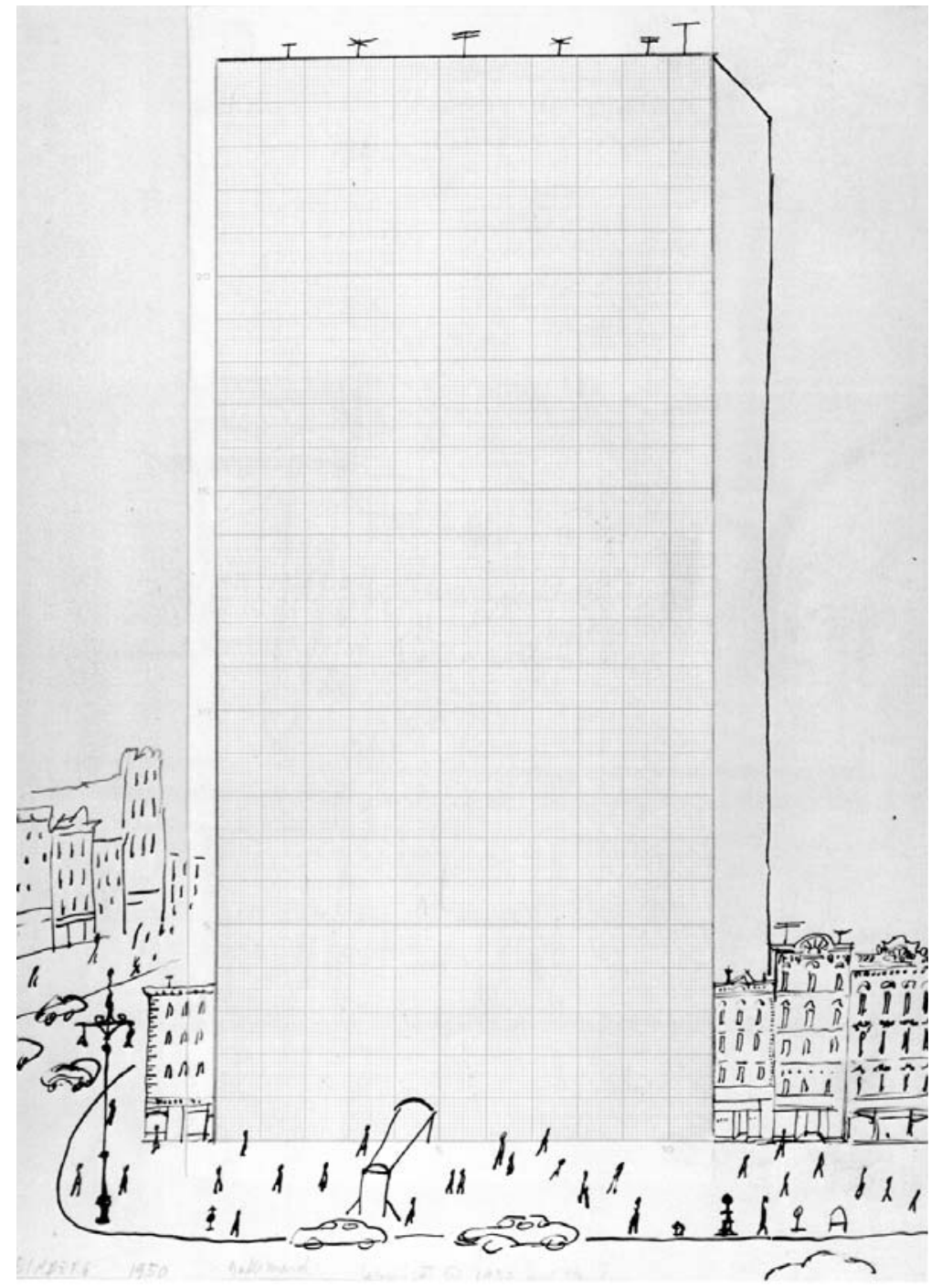



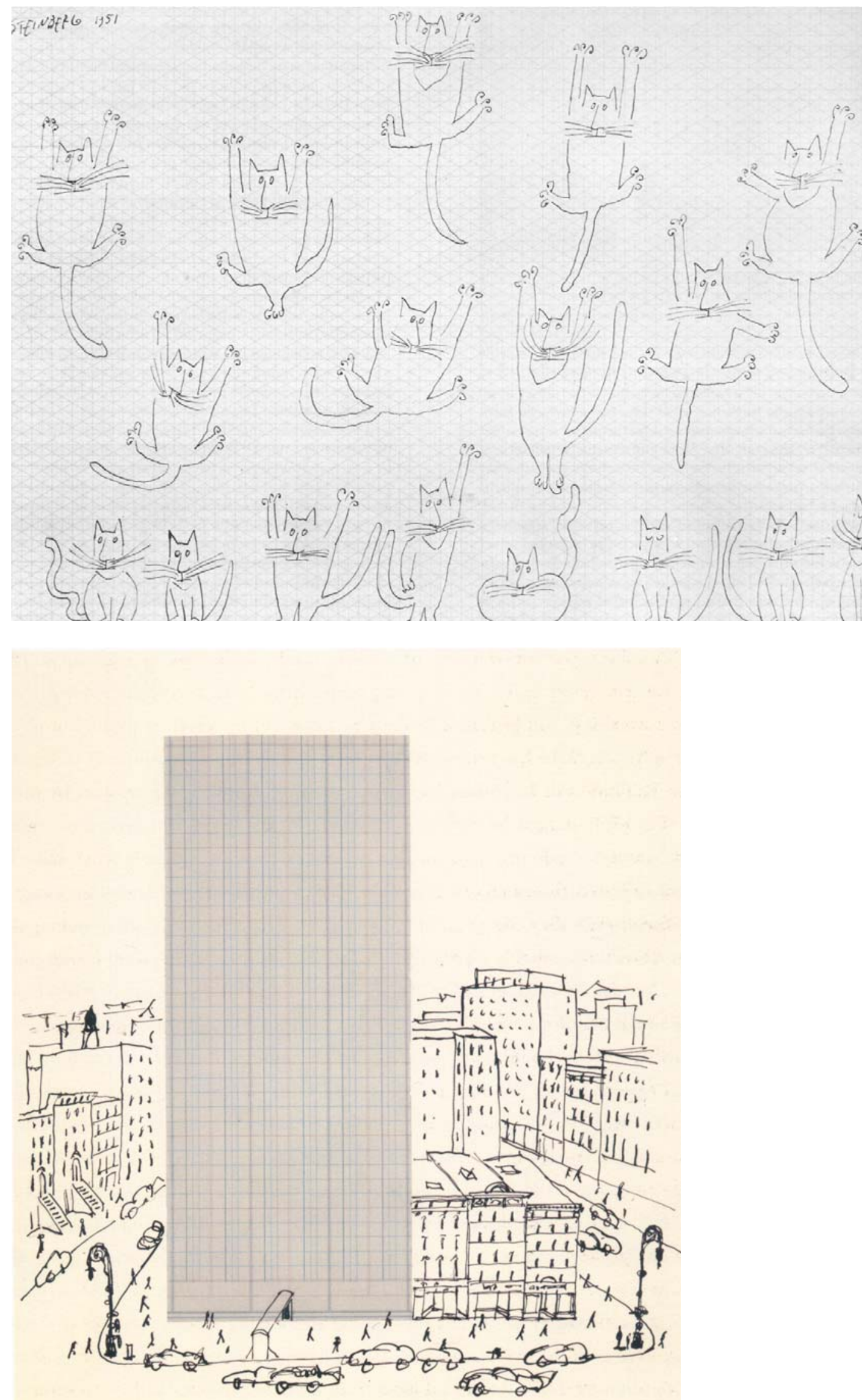

ST 1954 

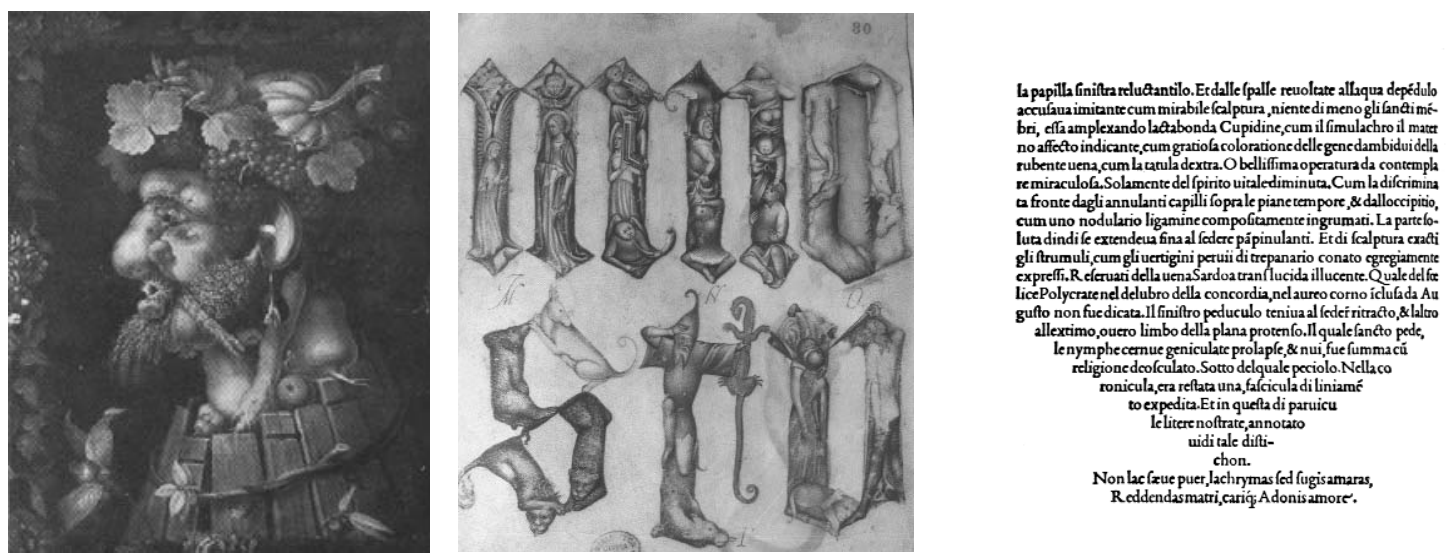

AMBIGÜIDADE GRÁFICA: ANTECEDENTES E REFERÊNCIAS CONTEMPORÂNEAS

Ao criar desenhos com ambigüidade gráfica, Steinberg recorre a um recurso criado há longa data. Como observa Bruno Munari, "desde os tempos de Giuseppe Arcimboldo, no século XVI, que as imagens duplas eram usadas no campo da comunicação visual (...) para comunicar simultaneamente várias informações" (Munari, 1998, p.321). Nas pinturas deste artista milanês, os vegetais, frutas, flores e outros objetos pintados eram usados como "elementos gráficos" que, ao serem organizados, atuavam como partes constituintes de rostos de pessoas. Mesmo antes de Arcimboldo, a ambigüidade era vista nas "letras antropofórmicas" de determinados livros, como as criadas por Giovannino de Grassi entre 1389 e 1398 . O uso de elementos tipográficos como componentes de jogos gráficos com mais de uma leitura é um capítulo importante da ambigüidade visual, percorrendo os séculos em variadas experiências. Dentre os recursos de tipografia figurativa, há o desenho de contornos inusitados para blocos de textos, conformando silhuetas de objetos reconhecíveis, como os criados pelo tipógrafo Aldus Manutius, o grande impressor veneziano do século XV (Print, 1955, p.15). Ou a criação de "linhas" de texto com caminhos soltos que, em seu conjunto, definem um desenho, vistos nos caligramas de Jacques Cellier de Reims, de 1585, por exemplo. A variedade de caligramas criados ao longo do tempo é numerosa, sendo alguns dos mais famosos os elaborados pelo poeta do avant garde Apollinaire (Anderson, 1969, p.186). As experiências de
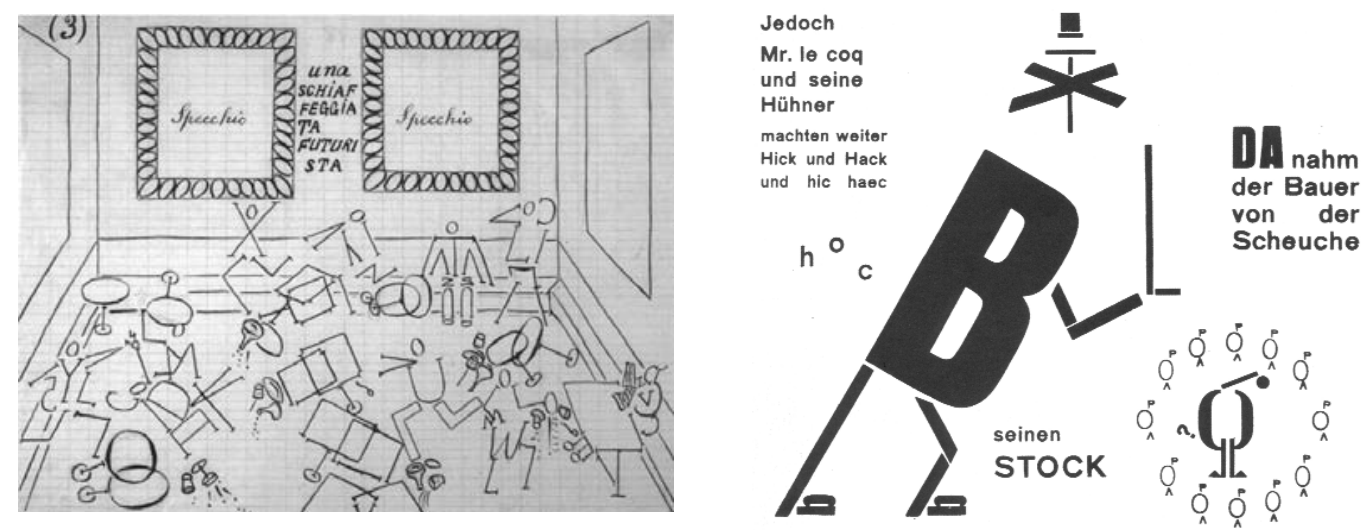

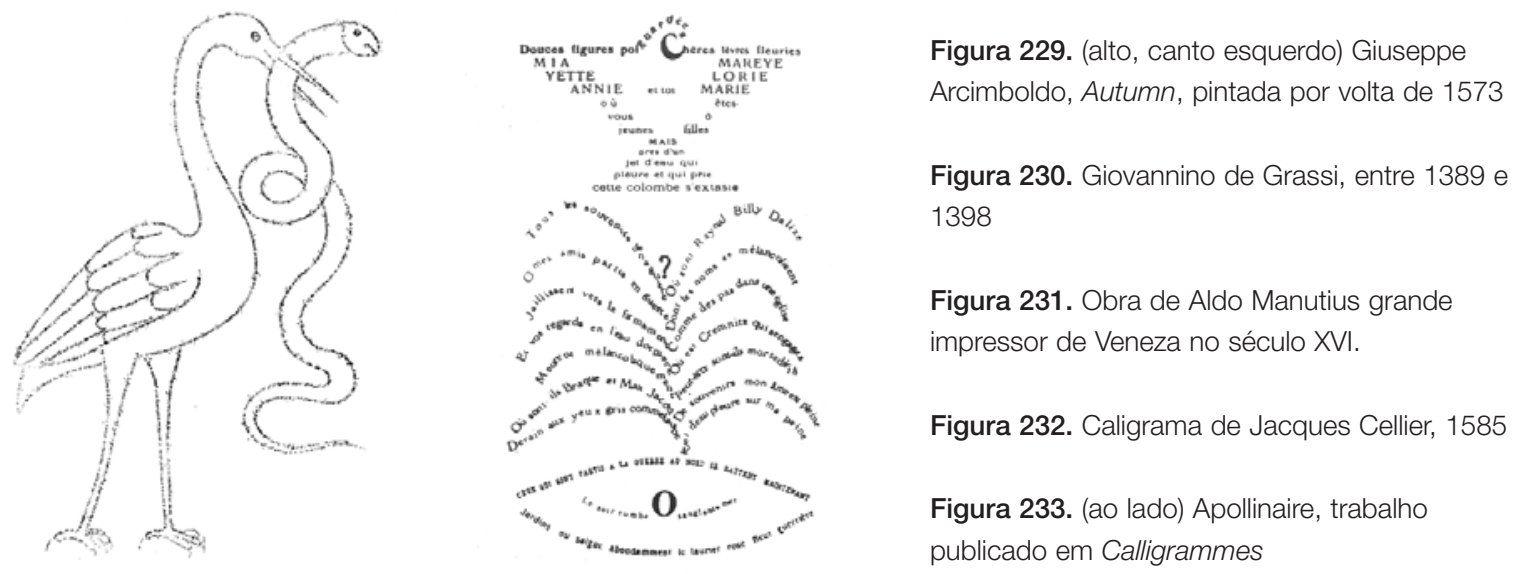

Apollinaire viriam a inspirar trabalhos experimentais com tipografia no século XX. Os movimentos de vanguarda fizeram amplo uso de recursos de ambigüidade com letras e números. Como observa Joel Smith, ao analisar um trabalho de Steinberg com objetualização de números, "um conhecido precedente no tratamento da escrita como desenho foi a arte italiana futurista", exemplificada na obra de Pasqualino Cangiullo de 1916, Uma Schiaffeggiata Futurista (Smith, 2006, p.152). Alguns destes trabalhos são marcos do design moderno, como o conto de Kurt Schwitters e van Doesburg denominado The Scarecrow, de 1925, em que elementos tipográficos são organizados de modo a formarem personagens. Letras se tornam braços, pernas, tronco, cabeça, pés, etc. Na obra de 1928 do russo El Lissitzky, chamada Addition, Subtraction, Multiplication, Division, é seguida a mesma lógica.

Outro veículo que promoveu inúmeras experiências com ambigüidade ao longo do tempo foi o Baralho Transformado. Cada jogo de cartas trazia um modo diferente e inusitado de inserir os naipes da peça tradicional em imagens, conferindo a eles novos significados. As primeiras cartas transformadas foram ilustrações da edição alemã de Hudibras, em 1801, com naipes convertidos em rostos de personagens (Field, 1987, p.6). Entre 1880 e 1930, a cultura dos Chalk Talks também contribuiu para manter difundida a lógica da transformação de elementos nos Estados Unidos. Estes eram atos populares - típicos de uma época de circos de pulgas, museus de moedas e freak shows - onde um cartunista ou performer desenhava imagens para uma audiência. Como observa Dan Nadel, "as imagens criadas por estes

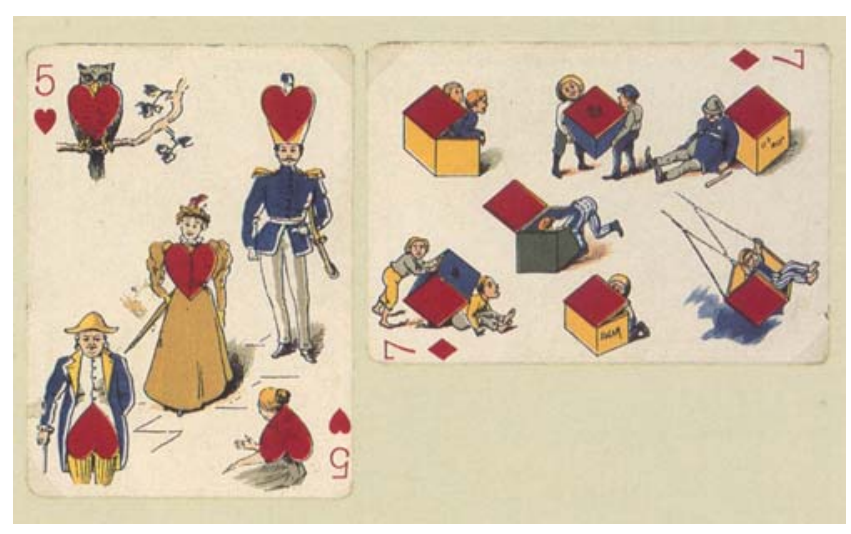

Figura 234. (na outra página, no canto esquerdo) Pasqualino Cangiullo, Una Schiaffeggiata Futurista, 1916

Figura 235. Kurt Schwitters e van Doesburg, The Scarecrow, 1925

Figura 236. Baralho transformado, Vanity Fair, United States Playing Cards Company, 1895 

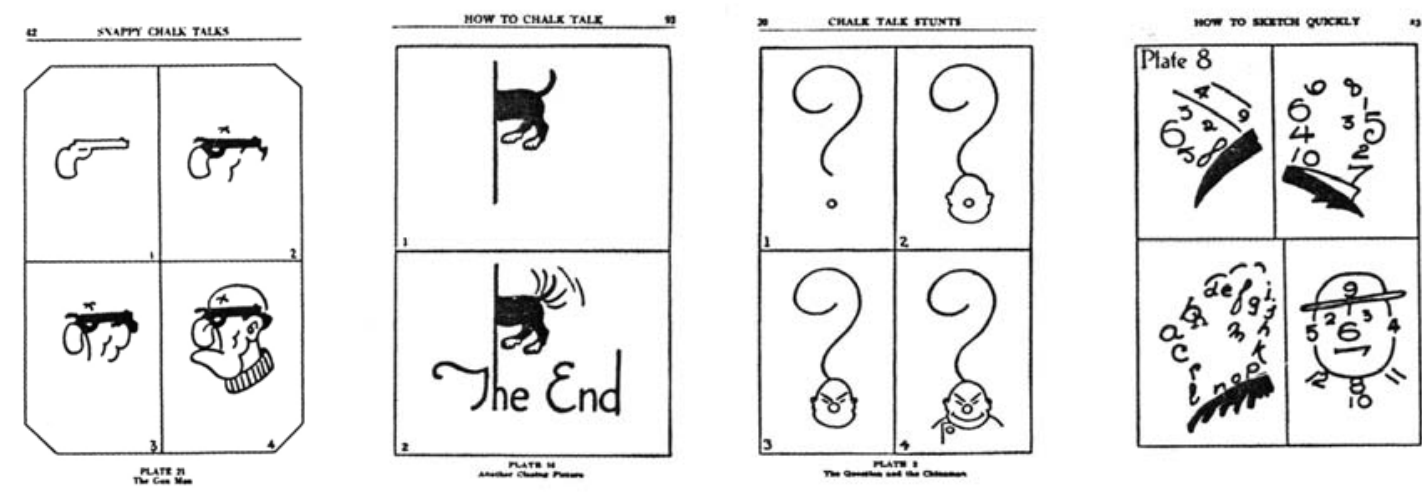

artistas eram antes de mais nada desenhos que, com a adição de linhas ou formas estrategicamente colocadas, inesperadamente desenvolviam-se em algo novo: um ovo se tornava uma face, e a face se tornava um homem com uma barba" (Nadel, 2003, p.62). O que restou desta prática foram livros sobre o assunto, alguns deles com instruções sobre os procedimentos, que em certos casos mostravam o passo-a-passo das transformações. Ao contrário da costumeira auto-suficiência dos desenhos ambíguos de uma imagem só, o Chalk Talk lidava com a surpresa ocorrida no momento da transformação. Sendo assim, considerável parte das imagens finais, se vistas separadas, não traziam ambigüidade; o que havia era a diferença entre um desenho inicial e um final. Havia, logicamente, muitas exceções, como no caso em que a haste estendida da letra "h" assume a condição de linha de contorno de um muro, sugerida por um cão escondido, recurso semelhante ao usado em The Line de Steinberg. De qualquer forma, seja qual for a situação, os Chalk Talks difundiam a idéia de possibilidade de alteração de significado de um elemento gráfico, estimulando um modo diferenciado de ver. Um outro modo inusitado de lidar com ambigüidades foi elaborado por Gustave Verbeck nos quadrinhos Upside Downs, criados em 1903, onde uma segunda história era contada com o mesmo desenho, quando a página era virada de cabeça pra baixo (Moya, 1986, p.31).

Muitas das imagens duplas viriam a ser usadas na obra do surrealista Salvador Dali. Em Rosto Paranóico, de 1935, um selo postal de uma tribo se transforma na cabeça de uma
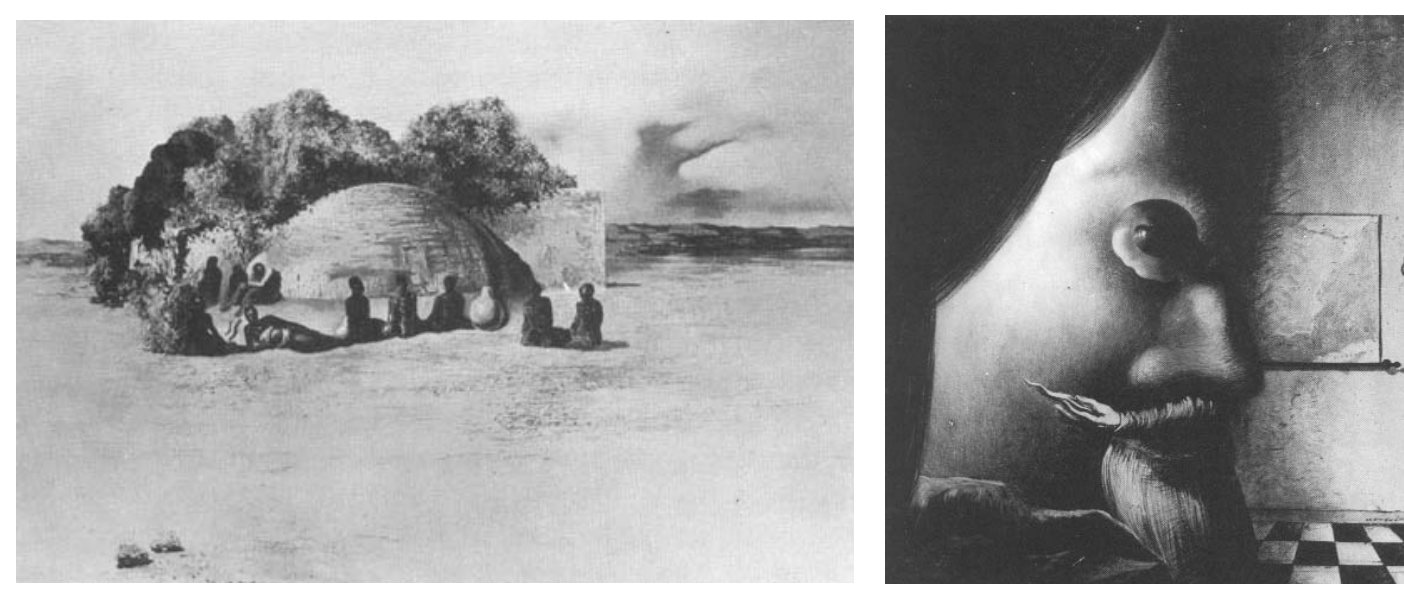

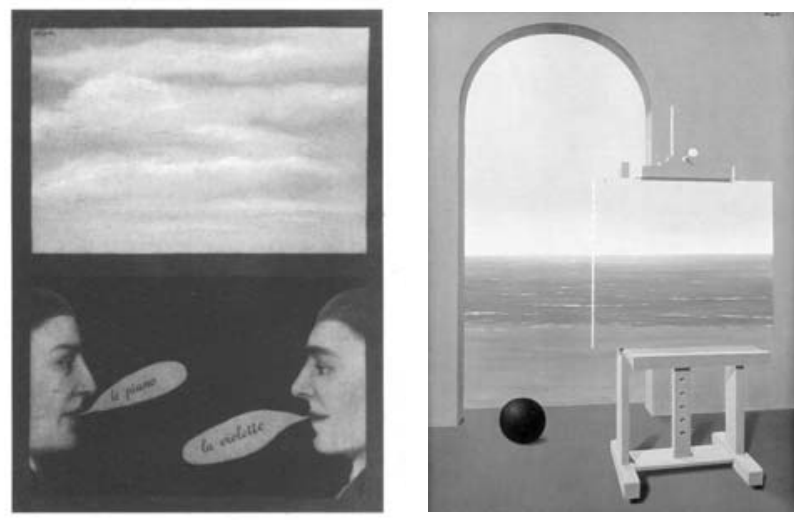

Figura 237. Exemplos de Chalk Talks

Figura 238. René Magritte, L’Usage de la parole, 1928

Figura 239. Salvador Dalí, Rosto Paranóico, 1935

Figura 240. Dali, La imagem desaparece, 1938

Figura 241. Dali, Mercado de esclavas (...), 1940

Figura 242. Estudos ilusórios de Dalí

mulher picassiana. Em La imagen desaparece, de 1938, a cena com uma mulher é convertida na face de um homem com bigode. Já na obra Mercado de esclavas com la aparición del busto invisible de Voltaire, de 1940, é o rosto de Voltaire que subitamente é sugerido no meio de uma imagem com escravas.

Magritte, evidentemente, não pode deixar de ser mencionado, por ter explorado de modo tão incisivo a questão ilusória da representação. Sua influência foi grande no universo da ilustração, em especial a partir dos anos 1960, em um tipo de abordagem conceitual que já vinha sendo explorada por Steinberg e outros pioneiros. Como nota Hollis, ao se referir a esta "onda" do período: "René Magritte, o surrealista belga, teve talvez a mais profunda influência na ilustração americana durante os anos 1960, exemplificada nos trabalhos de Paul Davis, artista da Push Pin Studio. Diferentemente de Salvador Dali, o surrealismo de Magritte era menos enraizado nas interpretações de sonhos freudiana que nas irônicas justaposições que testavam a percepção comum. Ele mais tarde construiu uma clara, apesar de misteriosa, linguagem simbólica que ilustradores descobriram ser aplicável aos temas editoriais comuns" (Heller, 2006, p.89).

As pinturas de Magritte que mostram paisagens de fundo completadas na tela pintada representada nos fazem lembrar que o cenário de fundo também é feito de tinta, do mesmo modo que Steinberg dizia: "O que desenho é desenho, [e] desenho deriva de desen-
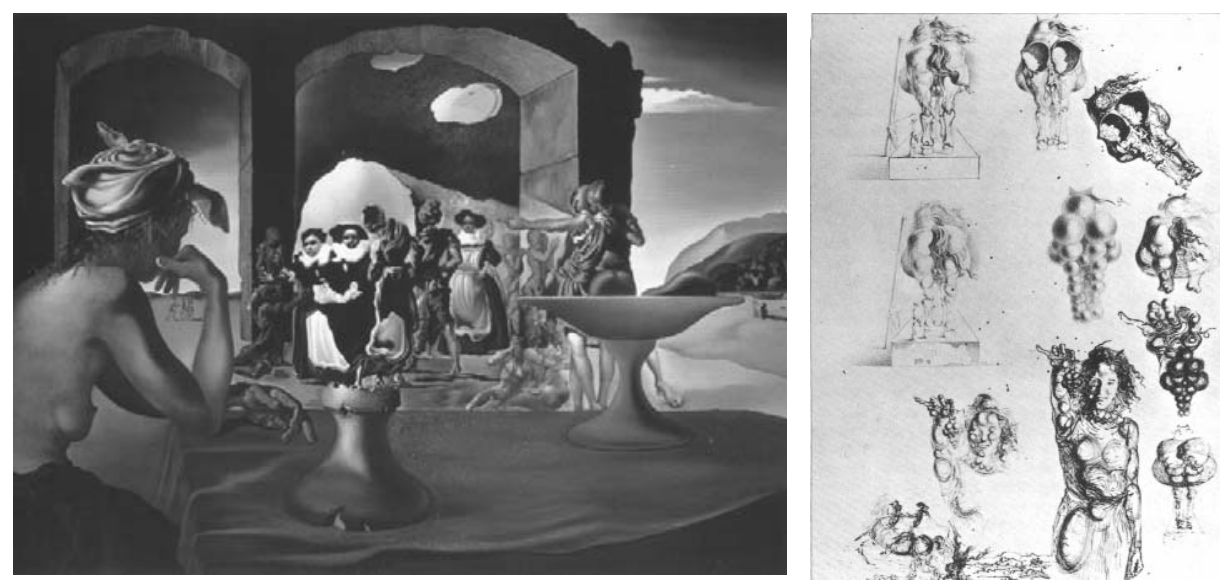
Figura 243. Escher, 1948

Figura 244. Desenho de Steinberg, publicado em The Passaport, de 1954

Figura 245. Steinberg,

desenho posterior

Figura 246. (abaixo, à esquerda) Loupot, 1928

Figura 247. Jean Carlu, 1929

Figura 248. Jean Carlu, 1942

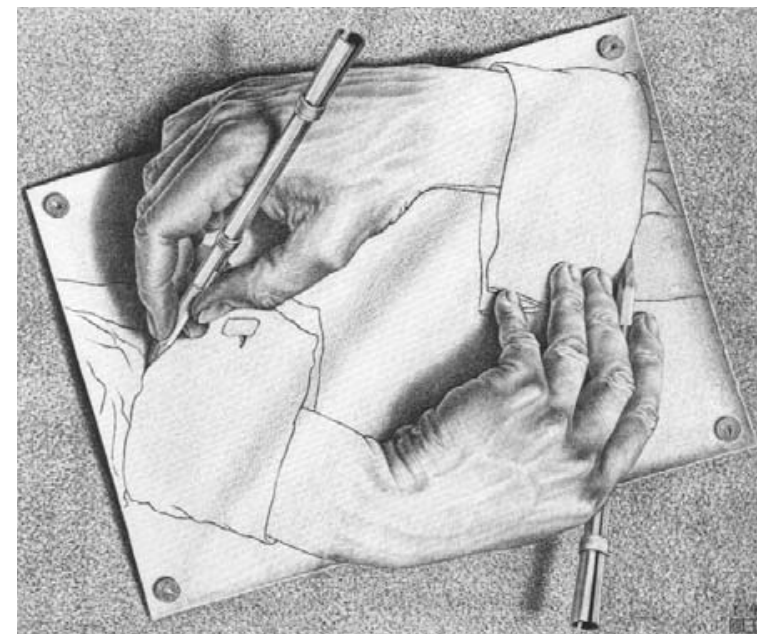

ho. Minha linha quer lembrar constantemente que ela é feita de tinta" (cit. por Rosenberg, 1978, p.19). Saul, no entanto, apesar de ter uma obra de Magritte em sua coleção pessoal, considerava o artista demasiadamente virtuoso no tratamento que conferia à finalização de sua arte pintada. Da obra do pintor, o cartunista prefere uma de suas primeiras, justamente a que comprou de seu agente, Sidney Janis. Este lhe devia quatrocentos dólares, mas Steinberg, ao invés do dinheiro, ficou com a pintura L'Usage de la Parole, de 1928. A obra havia participado da mostra organizada por Janis depois da dele, uma exposição onde Magritte não vendeu nada, ou talvez uma pintura. "Era um bom negócio para Janis", comentou Steinberg, certa vez, ao seu amigo Aldo Buzzi (Steinberg, 2002, p.57).

Tenho um Magritte do começo de carreira, de 1926, um de seus melhores, acho, e bem pintado com sua famosa paciência. É um retrato duplo de André Breton: dois perfis, um dizendo "Le piano" e o outro respondendo "La violette". As falas dos balões vindo das duas bocas são de uma densa e opaca cor salmão-violeta, e são consideravelmente alongadas no formato. Talvez ao escolher esta cor, Magritte procurou mostrar a continuação das duas línguas. É provavelmente uma brincadeira com as histórias em quadrinhos. Ao mesmo tempo, a pintura representa o verso de uma pintura a óleo. Magritte pintou nele, em marrom-escuro, quase preto, o contorno de uma maca (outra brincadeira surrealista), que seria o verso da própria pintura, ou especialmente a pintura sendo vista transparentemente, pelo lado de trás (Steinberg, 2002, p.57).
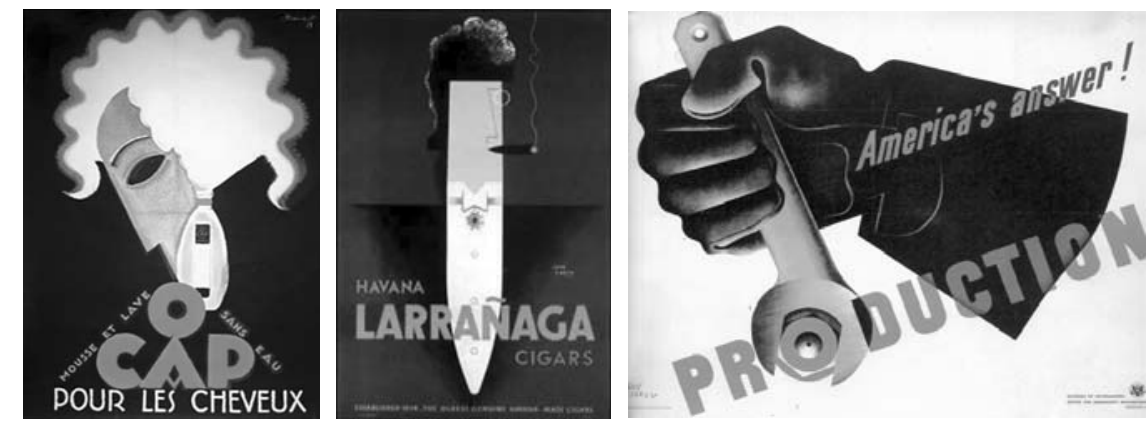

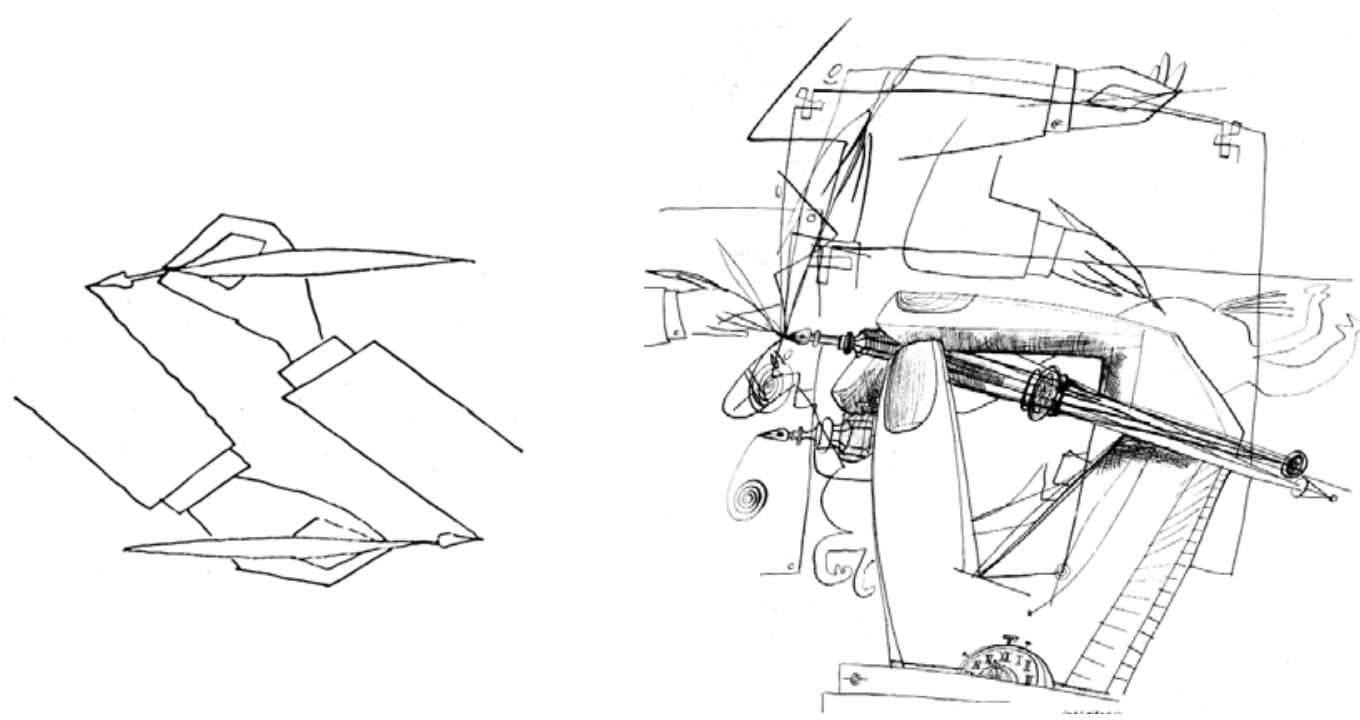

Outro artista que explorou ao longo de sua carreira o recurso da ambigüidade foi Escher. Suas obras com ilusão tridimensional foram precedidas por outras criações, como trabalhos de Piranesi e Hogarth feitos no século XVIII (Gombrich, 1986, p.214). O desenho de uma mão desenhando outra - ou vice-versa - de Steinberg, publicada no livro The Passport de 1954, é uma versão em linha-fina da litografia feita por Escher em 1948. Ao inserir toda a imagem no universo do desenho de linha, Steinberg realçou o mistério e a ambigüidade da obra. O cartum publicado na New Yorker em 1945, no entanto, já utilizava uma lógica de construção do desenho semelhante.

Nas artes gráficas o recurso de ambigüidade foi muito usado pelos cartazistas atuantes nas primeiras décadas do século passado, como Cassandre, Loupot e Jean Carlu. Em um cartaz de 1928, por exemplo, Loupot converteu a espuma de um produto para cabelos no próprio cabelo, em solução de foco definido e grande concisão gráfica. Jean Carlu também desenvolve cartazes com ambigüidade desde cedo, como no trabalho em que sugere o formato longilíneo do charuto cubano Larrañaga, de 1929, no homem em destaque - estendendo-se ao seu colarinho. Em 1942, Carlu desenharia o poster America's Answer! Production para o Office for Emergency Management. Como nota Hollis, "a imagem em destaque, de um punho com luva segurando uma chave de mecânico, como se estivesse apertando um parafuso (o "o" na palavra "production") é o paradigma de um trocadilho gráfico, no qual uma letra é substituída por outro objeto ou imagem" (Hollis, 2000, p.108). As influências cubistas e do art déco em Cassandre, e seu entendimento da função do pôster como veículo de mensagens de apreensão imediata e direta resultavam em pôsteres de grande impacto e síntese gráfica. Mais do que simbolismos e segundas leituras, o que interessava era a força imediata do desenho em atingir a atenção do espectador. Em alguns casos, no entanto, a influência do surrealismo passou a se fazer presente, em especial nas capas criadas a partir do final dos anos 1930, dando vazão a soluções mais fantasiosas, com elementos de duplo significado. A ambigüidade no trabalho dos cartazistas passou a ser muito comum, chegando a caracterizar o trabalho de cartazistas com ampla produção a partir dos anos 1940, como o suíço Leupin, o francês Savignac, Herve Morvan e - a partir dos anos 1950 - os poloneses, 
Figura 249. Savignac, 1981

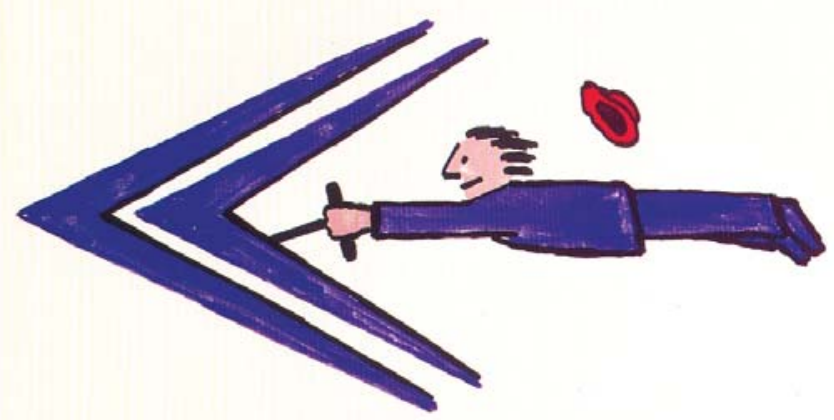

Figura 250. Savignac, 1972

Figura 251. Savignac, 1950

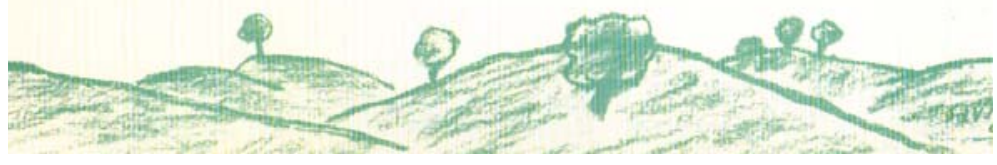

como Roman Cielslewicz e Wiktor Gorka. A ilusão em Savignac era resultado de sua busca pela simplificação, com integração de elementos, uma reação à técnica de justaposição de idéias. "Uma única imagem para uma única idéia" era seu objetivo, obtido através daquilo que chamava de escândalo visual", geralmente uma combinação extravagante e surrealista, cujo humor inesperado transmitia uma idéia sem a necessidade de palavras" (Hollis, 2001, p.159). Para chegar a uma única imagem muda, a imagem dupla era muitas vezes a solução, como no trabalho Laines d'Aoust feito em 1950, em que o resultado do tricô é a própria pessoa que tricota; nos cartazes criados para a Citröen em 1981, com transformação do logotipo da empresa em asa delta; ou no cartaz de contestação à via expressa feito em 1972, em que as torres da catedral de Paris são convertidas em braços de um ser desesperado que submerge em um mar negro de veículos. As soluções de ilusão gráfica passaram, mais tarde, a servir de opção nos trabalhos de Milton Glaser e da Push Pin, no começo dos anos 1960. Há também o trabalho do japonês Shigeo Fukuda, designer bastante conhecido no mundo artístico

Figura 252. Lepape, Vogue, 1929

Figura 253. Rea Irving, The New Yorker, 1925
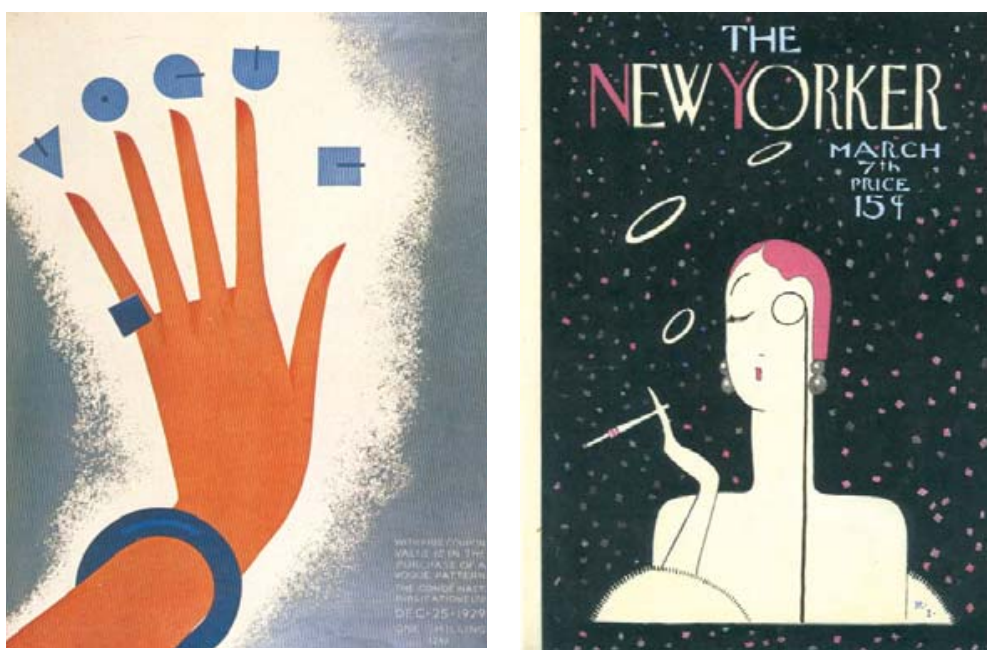

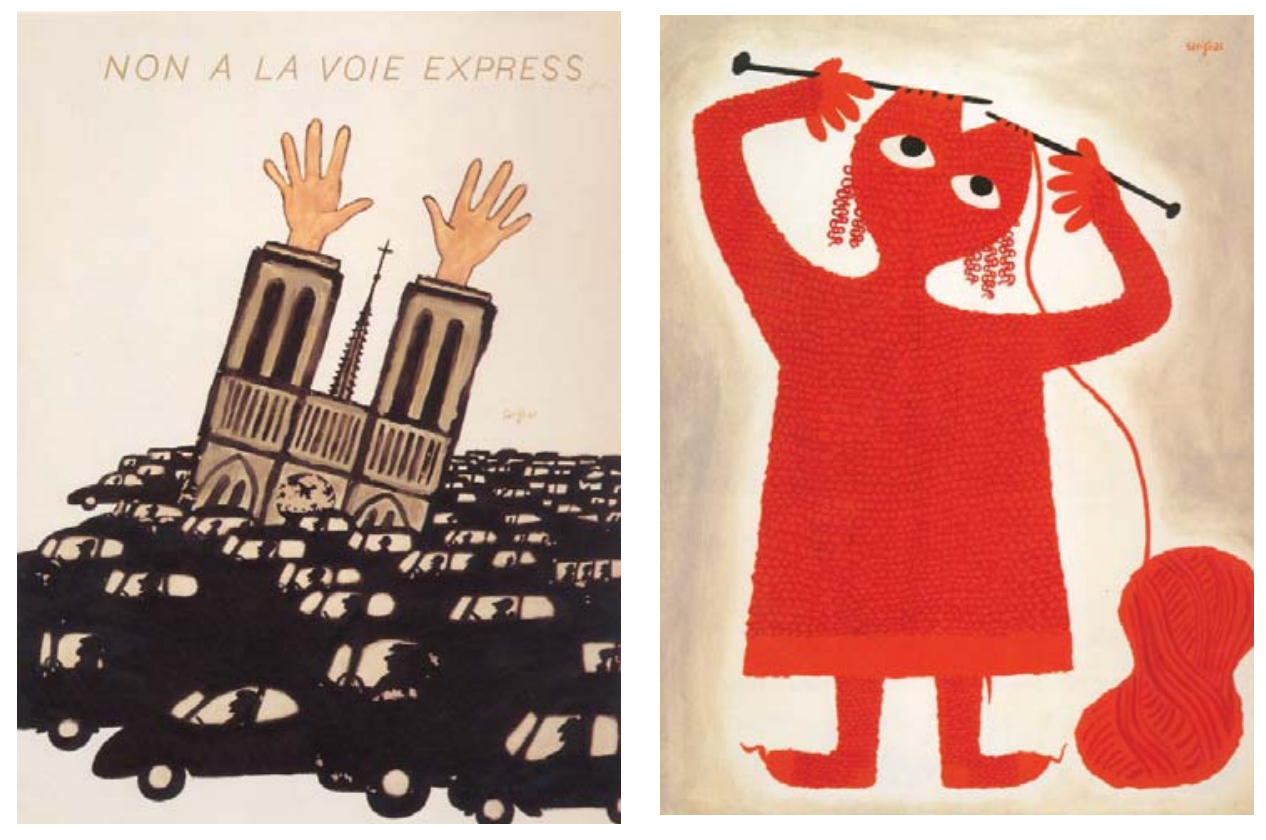

internacional, "um mestre nesse tipo de trabalho", segundo Bruno Munari (Munari, 1998, p.321).

Capas de certas revistas americanas também traziam muitas destas soluções ao longo dos anos 1920 e 1930. A Vogue, ainda nos anos 1920, fez grandes experimentações com o título da revista, deformando-o em plantas, anéis de brilhante e outros objetos. A partir da década de 1930, há uma intensificação dos recursos de ilusão na Vanity Fair, nos trabalhos de Paolo Garreto. Em uma criada em 1933 sobre o 4 de julho americano, um estilizado Tio Sam sentado toma a forma da letra 4. Naquele mesmo ano, Garreto viria a fazer um planeta Terra com elementos de bomba, pronto para estourar. Na New Yorker havia poucas abordagens do gênero em seus primeiros anos; na terceira edição da publicação, a capa de Rea Irving faz a fumaça assumir um formato circular ocupando a letra "o" do título. Na Harper's Bazaar destaca-se o trabalho do cartazista Cassandre, que recorre ao ilusionismo com uma freqüência nunca vista em seus trabalhos com pôsteres. Em trabalho de 1937, uma rosa-dos-
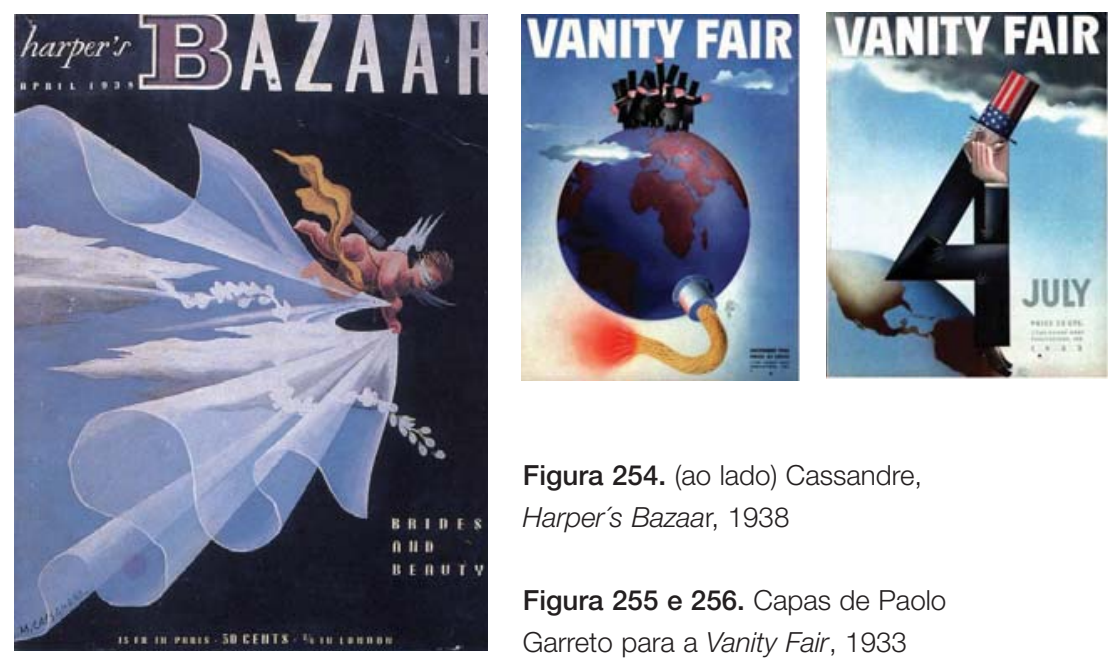

Figura 254. (ao lado) Cassandre,

Harper's Bazaar, 1938

Figura 255 e 256. Capas de Paolo

Garreto para a Vanity Fair, 1933 
ventos é convertida em uma flor; em 1938, os contornos de um país retratado em um mapa assumem as formas do rosto humano. A ambigüidade gráfica viria a ser muito usada na revista Esquire durante os anos 1950 e 1960, quase sempre em brincadeiras com a mascote da publicação, nos trabalhos de importantes artistas gráficos como o diretor de arte Henry Woolf. Hollis nota que "quando Wolf tornou-se diretor de arte em 1952, a Esquire tinha um logotipo e uma marca - uma cabeça redonda, com dois olhos arregalados e um bigode branco", a mascote que aparecia nas capas desde os primeiros números, publicados no começo da década de 1930. "Wolf manteve ambos, mas explorou-os e, mais tarde, absorveu-os nas fotos ou montagens de seus designs para capas de revista. O rosto com bigode apareceu sob a forma de uma cabeça frenológica, na parte de trás de uma cadeira de ferro trabalhado, num balão, num ovo, num botão de campanha e num selo postal" (Hollis, 2001, p.131). Quando George Lois assume posteriormente a direção de arte da revista nos anos 1960, as soluções deixam de lado o personagem-símbolo, mas as imagens fotográficas mantêm o apelo a ilusões gráficas. Como observa Remington, "as capas da Esquire de Louis eram poderosas no sentido de que cada uma tinha a inteligência, ironia e ambigüidade que a fez memorável" (Remington, 2003, p.159).

O uso da ambigüidade não era recorrente nos cartuns, se intensificando a partir dos anos 1950, sob a influência de importantes artistas, dentre eles Steinberg. Enquanto outros veículos que faziam uso de linguagem cartunística - como os cartazes de Leupin e as capas de Garreto - recorriam às ambigüidades, os cartuns permaneciam com uma certa tradição de resolver piadas em legendas, com situações muitas vezes absurdas, mas sem a urgência de uso da imagem dupla. No meio cartunístico, portanto, Steinberg merece crédito como um dos pioneiros do uso do recurso.
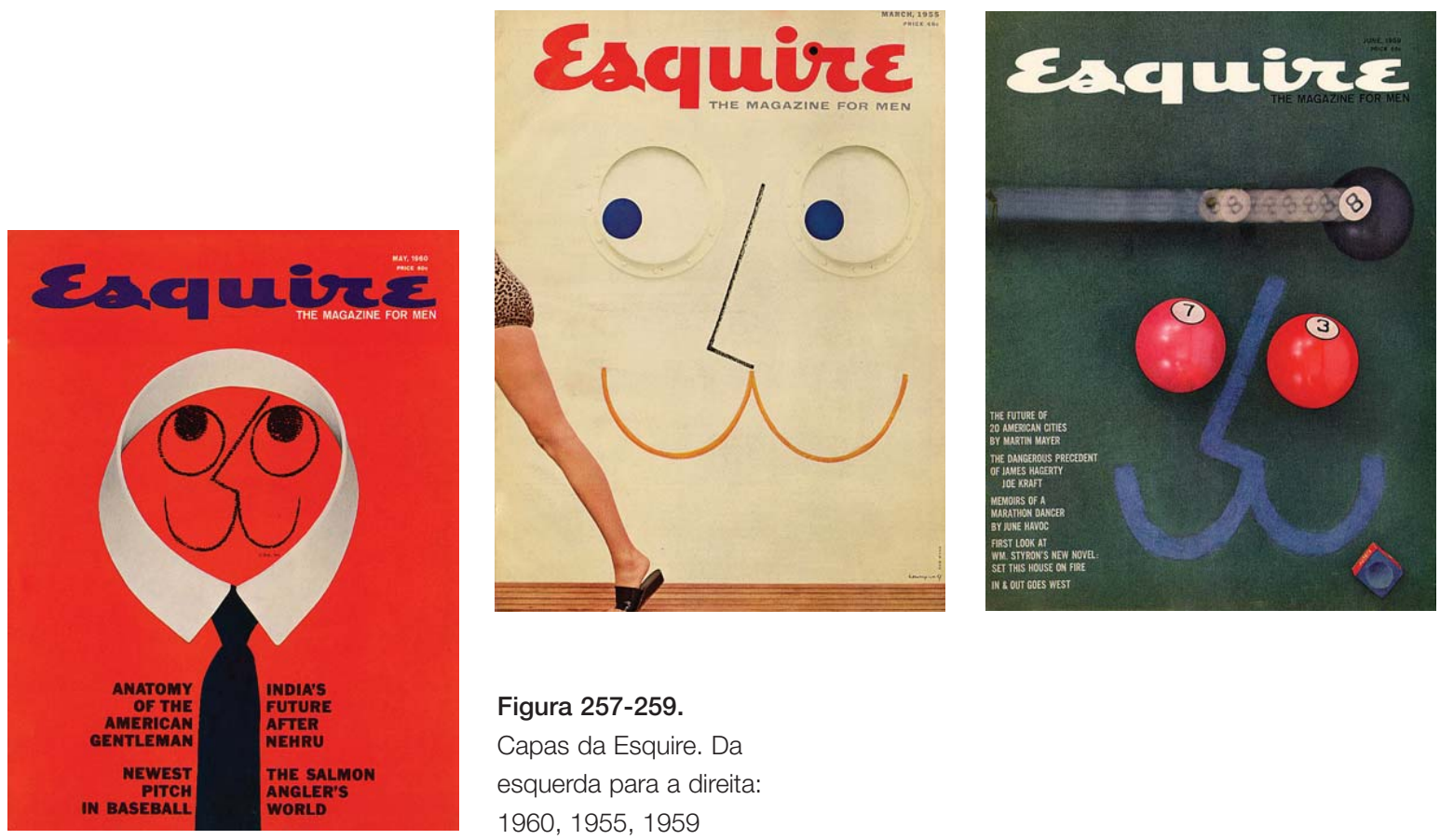

Figura 257-259.

Capas da Esquire. Da esquerda para a direita: 1960, 1955, 1959 
Entre maio de junho de 1954, Steinberg viaja com o time de beisebol Milwaukee Braves para acompanhar jogos na Filadélfia, Cincinnati, Pittsburgh, Chicago, Nova York, e ao seu próprio estádio, produzindo sua primeira série de desenhos sobre o esporte para a revista Life. Até então, ele não acompanhava os jogos de beisebol, mas se envolveu com sua subcultura rapidamente, (Smith, 2006, p.134), assumindo mais uma nova paixão extracurricular, além dos gatos. Steinberg recordou, certa vez: "a primeira vez que fui a um jogo de beisebol, não entendi nada, mas ainda assim estava curioso sobre este jogo onde não há quase ação e, no entanto, as pessoas acompanham com grande expectativa e emoção" (Steinberg, 2002, p.50). Ele considerava o esporte não apenas um "jogo alegórico sobre a América", mas uma metáfora do ideal de conduta. Para Saul, o jogador "deve ter uma certa rapidez lírica e sorte que pertence mais à poesia do que ao aspecto atlético da vida. O beisebol está mais próximo da arte devido à experiente solidão do jogador" (cit. por Hughes, 1978, p.52). A proximidade entre o esporte a algumas posturas do artista Steinberg fica sugerida neste depoimento:

O beisebol é um esporte filosófico, psicológico, baseado, como na vida, na coragem e no medo - pense em um jogo de xadrez ou em uma tourada. Os jogadores têm uma extraordinária habilidade, reflexos rápidos, e acima de tudo um espírito inventivo, uma criatividade que pode ser considerada poética e que coloca os campeões do esporte próximos do artista. Os grandes jogadores não querem se parecer com atletas mas mais com homens de negócio; e eles mostram uma certa indiferença em relação a suas habilidades; eles não conversam sobre beisebol. Do mesmo modo agem os bons pintores, enquanto os medíocres se vestem como artistas e falam de nada mas arte (Steinberg, 2002, p.51).

Dentre os desenhos feitos para a Life, alguns apontam abordagens futuras. Como observa Smith, ao analisar o desenho Stadium at Night (Ebbets Field), publicado em julho de 1955, na Life: "o céu noturno manchado com clarões de luz elétrica sobre o estádio antecipa as paisagens celestes de vinte anos depois, feitas em óleos e aquarelas, esponjas e contagotas" (Smith, 2006, p.134).

Ainda em outubro de 1954, é lançado The Passport, um livro com grande variedade e quantidade de trabalhos. Na publicação, Steinberg confere destaque aos documentos tão explorados no período. O título ajuda a colocar em evidência tais trabalhos, fazendo menção ao tema da imigração e dos burocráticos modos de identidade, com certo componente autobiográfico relacionado à própria condição de imigrante e "estrangeiro" do artista. São expostos documentos falsos, passaportes, diplomas, certificados, fotografias falsas - com autógrafos falsos -, gravuras falsas, falsas etiquetas de vinho, cartas, diários, manuscritos, falsos ex-votos, caligrafias e cacografias, impresões digitais. Os temas da América e de outros lugares visitados também se fazem presentes, em paradas e desfiles, festas, ballet, jogos de bil- 
har, cowboys, palmeiras, amazonas, automóveis, locomotivas, estações de trem, pontes, verão e inverno, modismos. Saul também aborda assuntos urbanos e arquiteônicos, como a arquitetura vitoriana, art nouveau, favelas, arranha-céus, carimbos de edifícios. Os cães, gatos e esfinges conferem ainda maior diversidade à publicação. (Rosenberg, 1978, p.240).

As viagens prosseguem. Em 1953, fica um bom tempo em Paris, visitando também a Itália e a Turquia. Dentre os passeios seguintes, merece destaque o retorno a Paris em 1955, onde passa a morar entre março e agosto. Fica com Sterne em Wellfleet, Massachusetts, até setembro, começando a procurar um lugar para uma segunda casa. Durante os próximos três anos, Saul experimenta Paris, pequenas cidades francesas e italianas, e Gênova, e chega a alugar casas de verão com Sterne em várias localidades dos Estados Unidos (Smith, 2006, p.258). Um ano após morar em Paris, em 1956 Steinberg viria a publicar Dessins, uma compilação francesa baseada, em grande parte, nos três livros anteriores (Smith, 2006, p.258).

Em 1956, Steinberg viaja para a Rússia, no mesmo ano conhece o Alaska, e no ano seguinte, a Espanha (Rosenberg, 1978, p.241). O artista viajou para o país comunista como repórter visual da New Yorker, após os esforços pessoais de William Shawn em conseguir os papéis e documentos necessários para a viagem. Foi à Rússia em fevereiro de 1956, conhecendo, ao longo de três semanas, Moscow, Kiev, Odessa, Tashkent, Tbilisi, e Samarcanda. Saul, apesar de ter escolhido visitar a Samarcanda pelas razões "românticas" do passado glorioso da região e sua presença remota no mapa, tomou o trabalho seriamente, fotografando o dia inteiro e escrevendo e criando esboços durante a noite. Em uma das ilustrações, fica evidente o processo de escolhas e depuração do ato de desenhar: Steinberg preservou alguns elementos do rascunho, como o desnível da rua, e inseriu um carro tirado de uma fotografia de outro lugar, provavelmente o veículo de seu guia. Toda a cena foi então jogada aos fundos, como um pequeno cenário para dois personagens em destaque (Smith, 2006, p.138). Foram produzidos dois portifólios, publicados na revista sob o título A Reporter at Large - Samarkand,
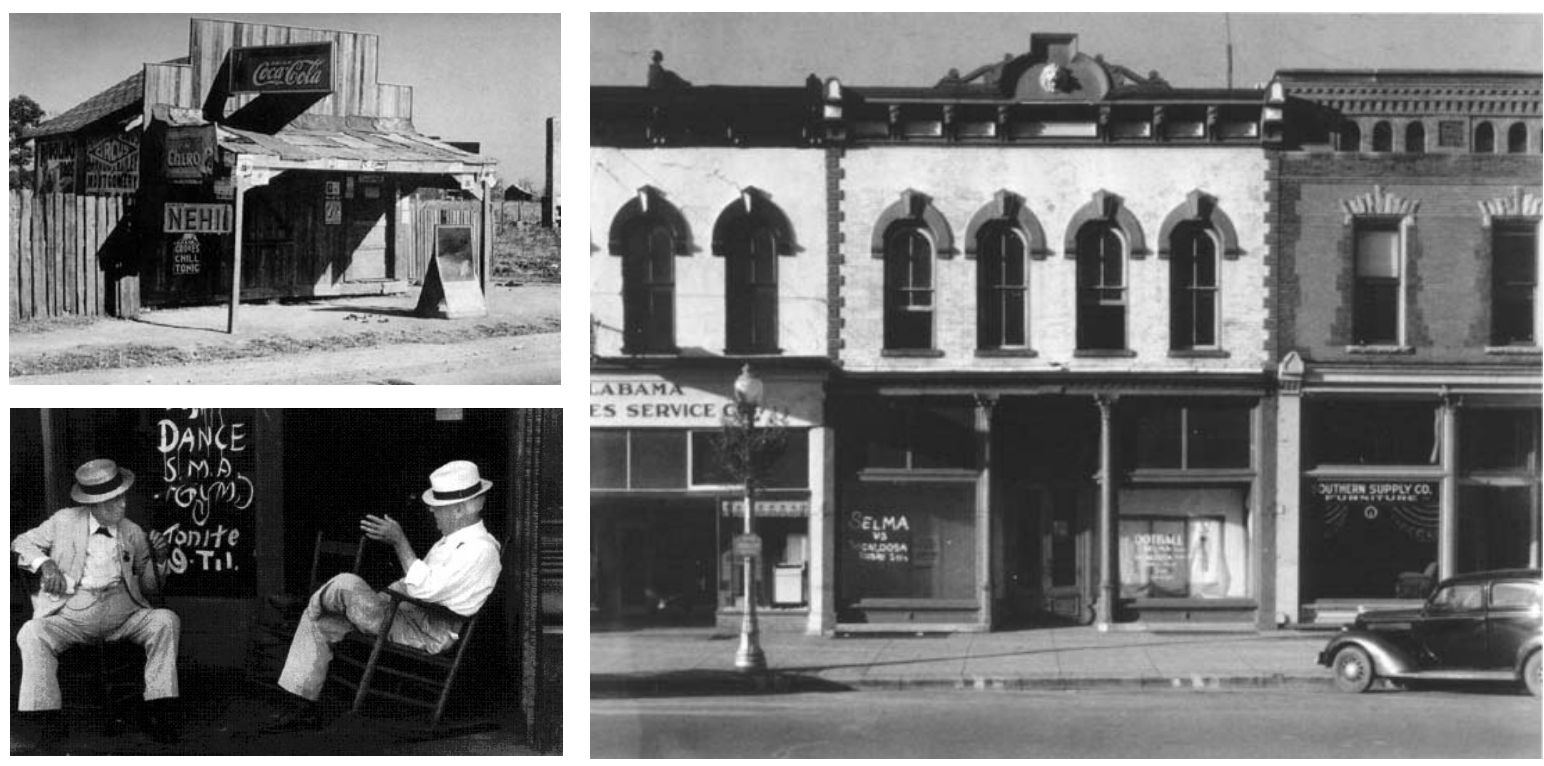

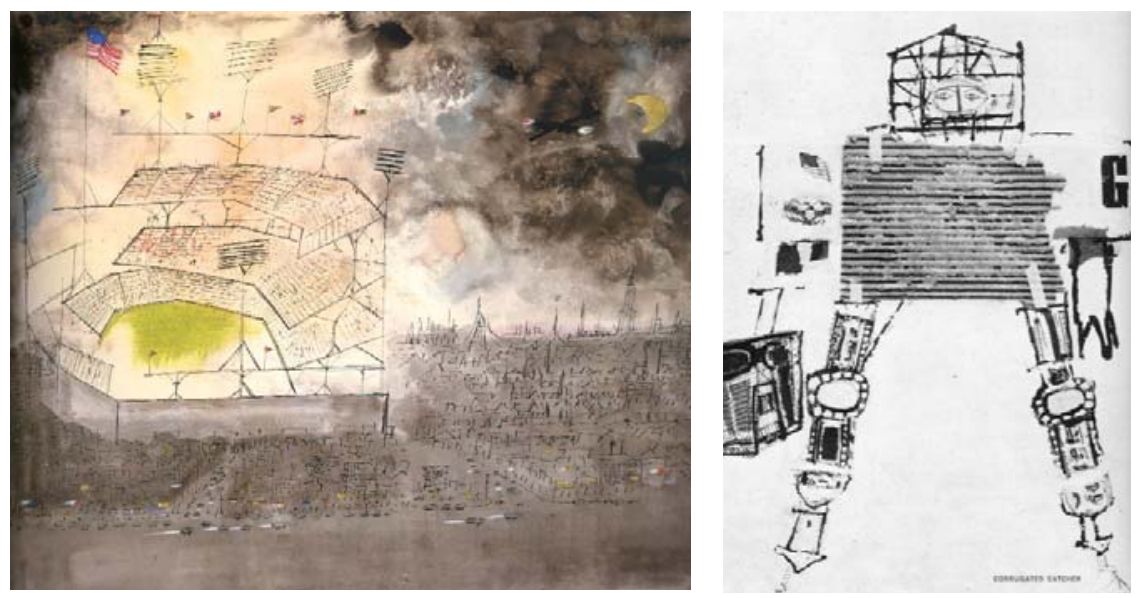

Figura 260. Steinberg,

Stadium at night (Ebbets

Field), 1954

Figura 261. Steinberg.

Desenho publicado na

Graphis, 1956

U.S.S.R., em maio, e Winter in Moscow, em junho. O cartunista já vinha há algum tempo lutando por um espaço mais amplo e com abordagens diferentes na revista, tendo em vista, dentre outras coisas, portifólios que seriam produzidos a partir de notas de viagens feitas ao sul do país, que acabaram nunca sendo publicados. Naquele período, começava a se esboçar de modo mais claro os conflitos entre seu trabalho como cartunista da New Yorker e artista de exposições. Para Geraghty, "a Revista Steinberg e a Galeria Steinberg não podem ser a mesma pessoa", salientando que o próprio Steinberg não deveria pedir tal coisa (Smith, 2006, p.50). Àquela altura, a New Yorker já não era a maior fonte de renda de Saul, com a sua cliente Hallmark pagando muito bem. Como observa Rosalind Constable, dois anos antes de Steinberg ir para a Rússia: "Hoje em dia Steinberg confere apenas duas semanas por ano para seu trabalho na New Yorker, se exaurindo com um maço de uns quinze cartuns a cada seis meses" (Constable, 1954, p.24).

No começo do verão de 1958, Steinberg viaja para o Kentucky e West Virginia para visitar os homens do campo, os brancos pobres, que sempre o interessaram "porque eles são, de algum modo, os ancestrais da América de hoje" (Steinberg, 2002, p.52). Saul viu neles

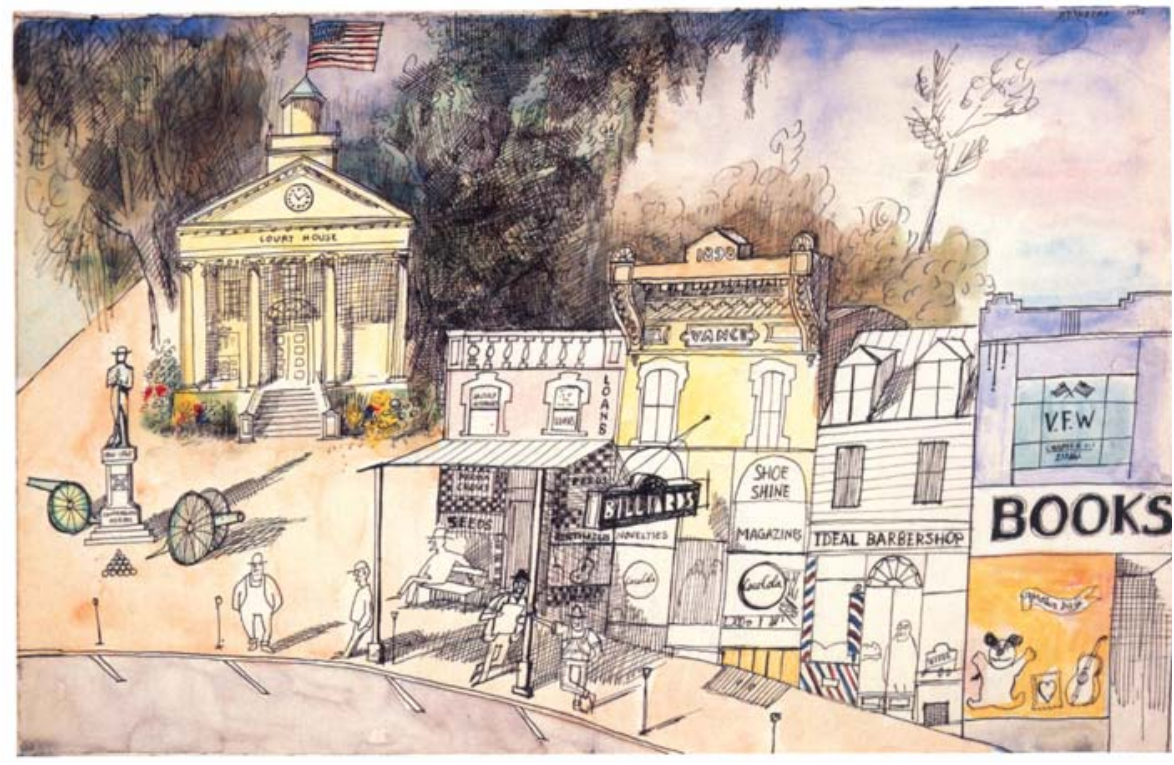

Figura 262 e 263. Fotos de Walker Evans

Figura 264. Walker Evans. Main Street Block, Selma, Alabama, 1935.

Figura 264. Steinberg The South, 1955 
"muitos dos protagonistas da ficção americana, personagens de Faulkner, heróis do cinema, caubóis, ladrões, mendigos - os verdadeiros personagens americanos". Para o cartunista, "a burguesia, as pessoas respeitáveis, estas estão em todos os lugares e sempre do mesmo jeito" (Steinberg, 2002, p.52). Os interesses de Steinberg nessa outra América eram semelhantes aos expressos nas fotografias de seu amigo Walker Evans, que segundo Saul era "um artista do nível de Picasso e Joyce" (Smith, 2006, p.120). Na obra de ambos transparece, de fato, o olhar atento sobre as casas de madeira, vendas de beira de estrada, anúncios populares e suas tipografias peculiares, velhos acomodados em bancos e pilastras, carros, objetos, pontes. $\mathrm{Na}$ segunda parte do reconhecido livro American Photographs (1938), esse Editor de Fotografia Especial da revista Fortune havia mostrado "que a estrada americana, quando vista de perto e claramente, com suas barracas de fábricas, estações de gás, sindicatos, estúdios de retratos, apresentavam o dinâmico retrato de um permanente e ignorado passado". Para Smith, "adaptar a lição ao desenho deu a Steinberg o começo de sua prática com o micro-documentário no qual ele iria revigorar seus olhos e mãos repetidamente nas décadas seguintes" (Smith, 2006, p.120).

No mesmo ano, Steinberg cria um mural para o pavilhão americano na Feira Mundial de Bruxelas de 1958, com uma colagem panorâmica intitulada The Americans (Steinberg Foundation, s.d, website). Estes "americanos" representados no painel - de face inexpressiva, com camisetas e óculos -, eram moralmente e culturalmente tão próximos da vida real, que havia uma expectativa do diretor de arte do pavilhão para "considerável controvérsia"

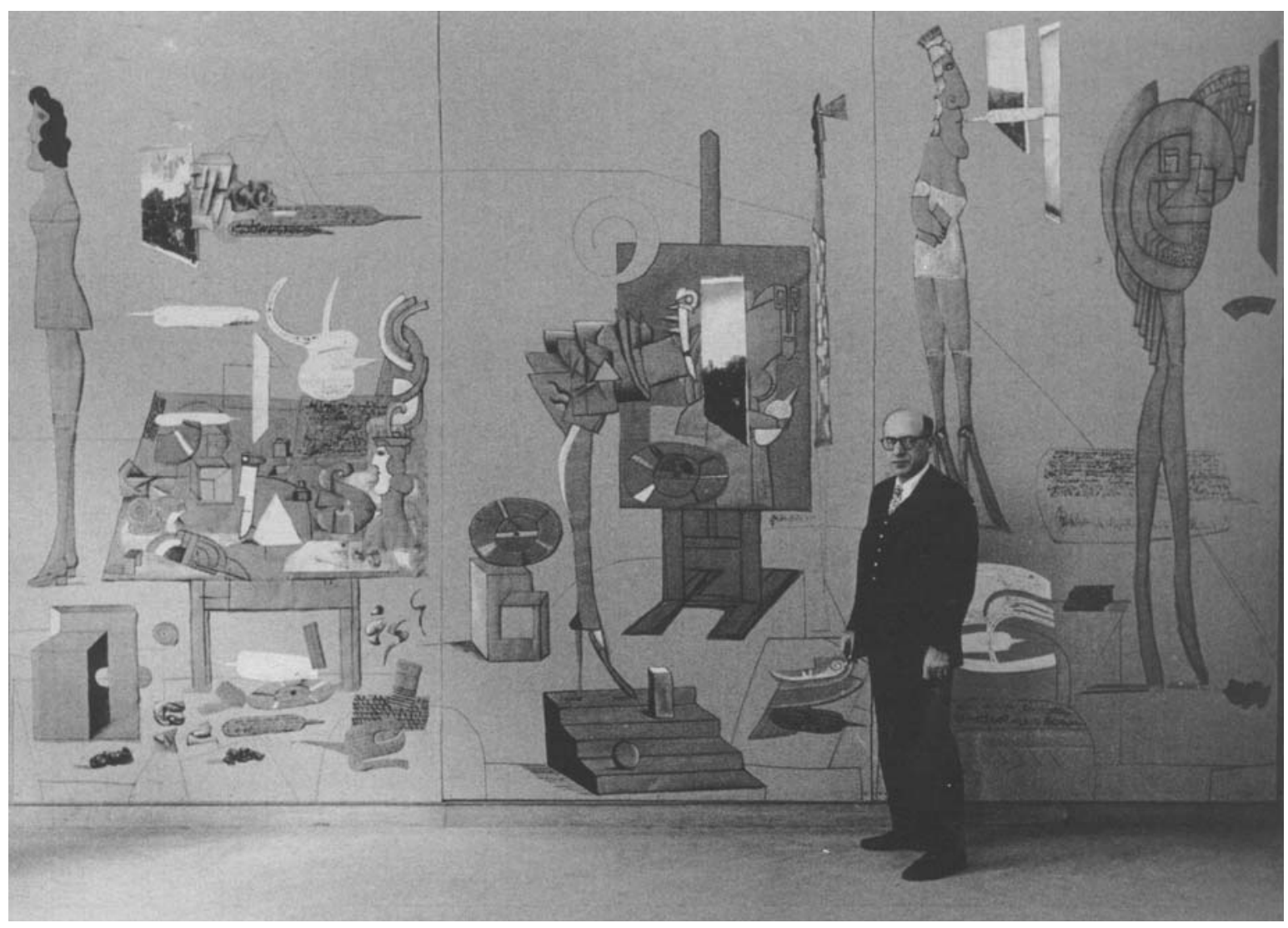



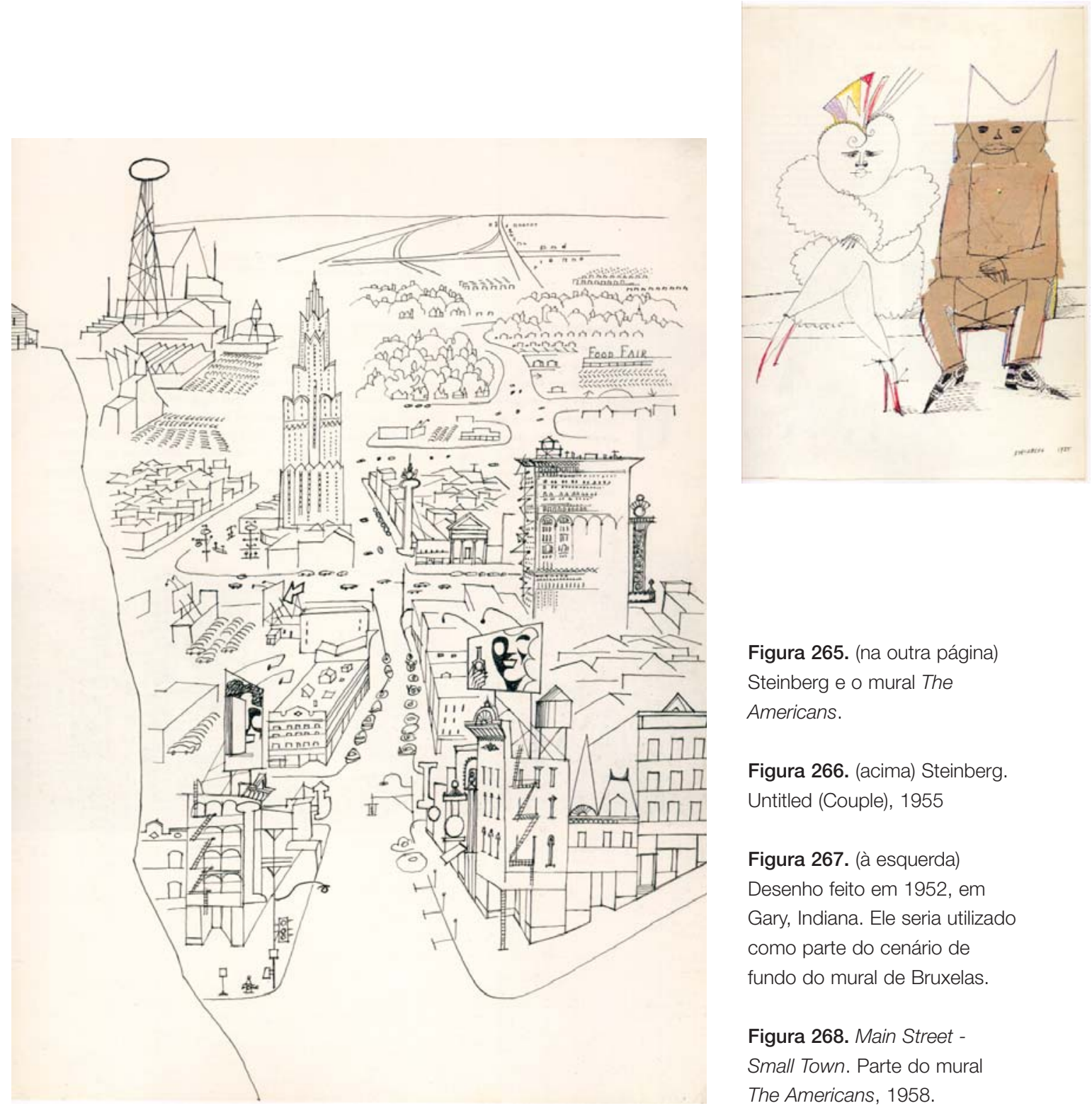

Figura 265. (na outra página)

Steinberg e o mural The

Americans.

Figura 266. (acima) Steinberg. Untitled (Couple), 1955

Figura 267. (à esquerda)

Desenho feito em 1952, em

Gary, Indiana. Ele seria utilizado

como parte do cenário de

fundo do mural de Bruxelas.

Figura 268. Main Street -

Small Town. Parte do mural

The Americans, 1958.

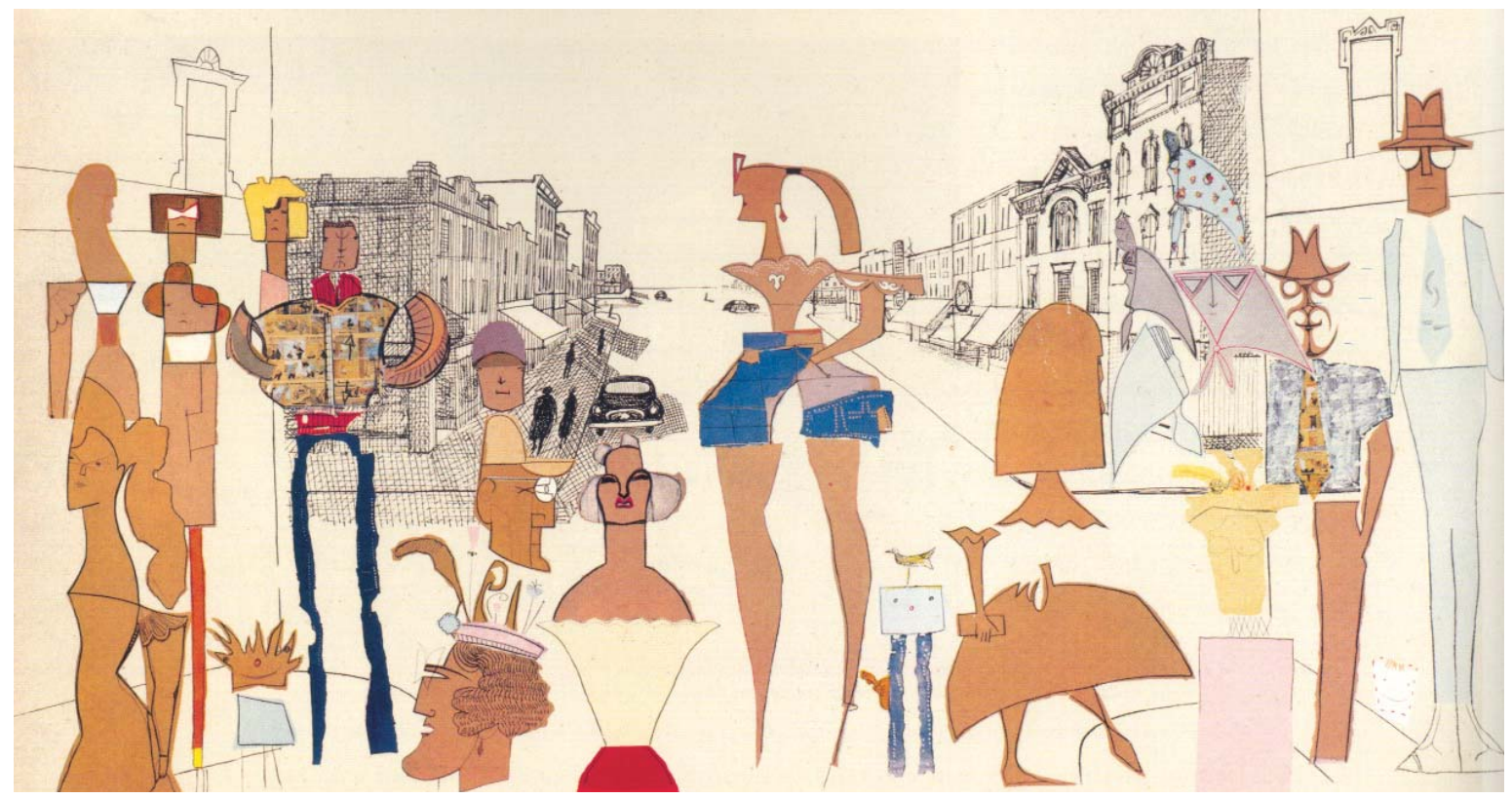




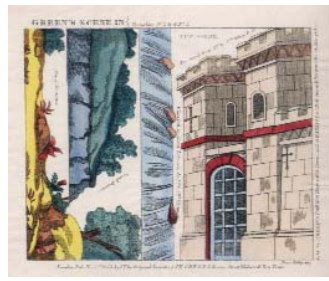

Figura 269. (acima) J. K. Green (artista), J. Redington (editor). Dougles: A Tragedy, 1834

Figura 270. Steinberg. Desenho de cortina para a peça The County Ory, de Rossini, 1958.

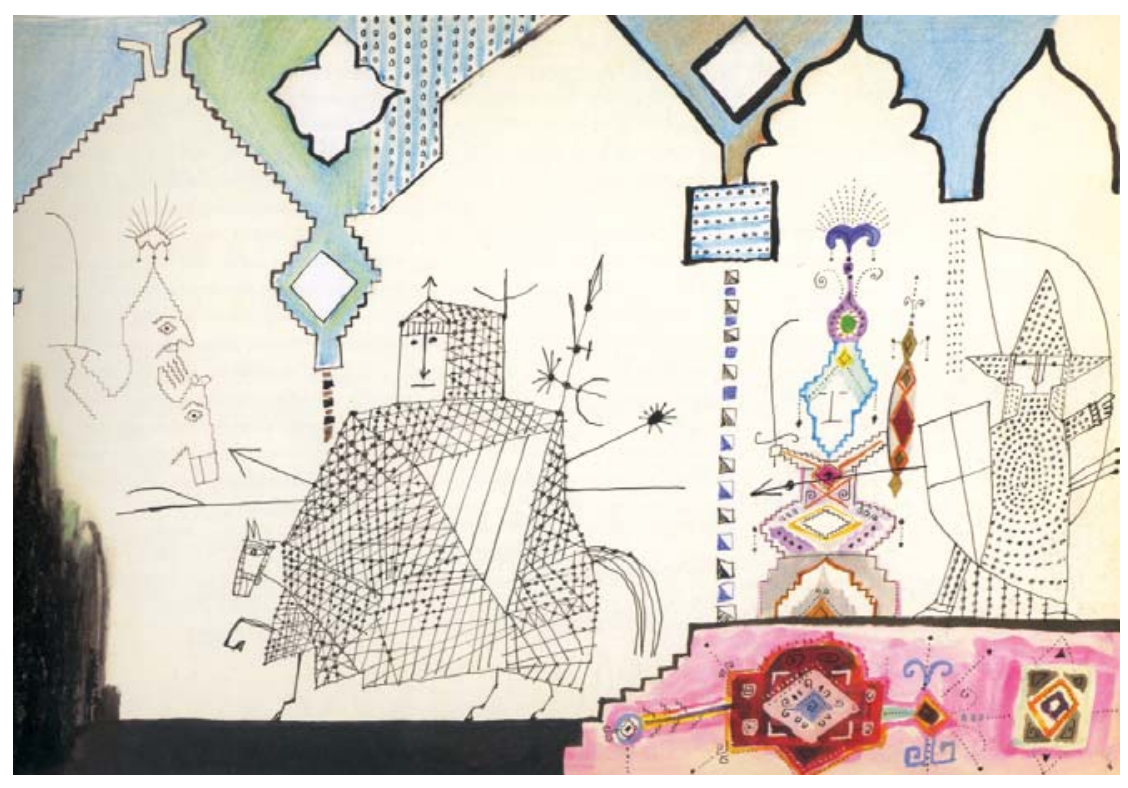

(Smith, 2006, p.50). Dentro de uma atmosfera de liberdade promovida naquele ano, o artista teve como foco o dia-dia da população, como ele chegou a dizer a um repórter: "Não mostro pessoas trabalhando porque elas fazem a mesma coisa todo dia. O que desenho é a América que come, dorme, lê, joga, que se entretém" (cit. por Smith, 2006, p.52). Para Smith, este seria, "o clímax de sua carreira em murais públicos" (Smith, 2006, p.50). De fato, a abordagem é bastante diferente dos murais feitos anteriormente. As colagens e mistura de estilos em experimentações diversas contrasta com a linha fina encontrada nos murais de até então. $\mathrm{O}$ artista fez o fundo em desenho de linha fina, com cenas de "arquétipos das paisagens americanas" (Smith, 2006, p.142). Estas cenas provinham de anotações visuais feitas por Saul em suas muitas viagens pelo país. Para as figuras, Steinberg empregou um recurso utilizado três anos antes no trabalho Untitled (Couple), em que usou a linguagem da colagem para distinguir duas gradações de cor de pele, aplicando papel de coloração semelhante à do papel craft para um dos personagens (Smith, 2006, p.136). Já no mural, volta a usar o papel craft, desta vez para distinguir os personagens do fundo, sem diferenciação de cor de pele. Essa diversidade plástica envolveu novas soluções técnicas, como observa Smith:

As seções do mural foram montadas em um grupo de paredes auto-portantes no andar aberto do projeto do pavilhão americano com cúpula de Edward Durrel Stone. Antes de chegar a Bruxelas, Steinberg enviou uns quinze desenhos em linha, feitos em caneta e tinta, de espaços americanos. Fotograficamente aumentadas a aproximadamente 10 pés de altura, as cenas foram colocadas juntas para produzir paisagens, cada uma assumindo uma faceta da "América" segundo a imaginação que a Europa tinha dela: A Estrada, Rua Principal - Cidade Pequena; Centro da Cidade - Grande Cidade; Farmácia; Coquetel; Beisebol; e (em uma simplificada fusão de Estados de clima quente) Califórnia, Flórida, e Texas. Estas cenas abertas serviram a Steinberg como panos de fundo para um elenco de "Americanos" de papel craft criados por ele e sobrepostos no próprio local (Smith, 2006, p.52). 
Ainda nesse ano, Steinberg faz o cenário de Count Ory, uma ópera de Giuacchino Rossini executada em 1959 na Juilliard Opera Theater, em Nova York. Saul "desenhou vários cenários e peças de teatro, que tiveram suas proporções testadas em fotografias de um grupo de figurinos de argila. $\mathrm{O}$ conjunto foi então convertido à verdadeira escala por um time de pintores". A Abertura Visual, uma cortina da abertura, é composta pelo "conde ausente" da história e seu bobo Saraceno, enquadrados por um "pastiche de elementos medievais e mouriscos". Alguns papéis de recortar com peças de palco do século XIX, colecionados por Steinberg, parecem ser, em parte, a fonte de inspiração para a elaboração do espaço "cartumcubista" criado (Smith, 2006, p.144).

\section{Cartunistas influenciados por Steinberg}

Em 1951, um elogioso artigo publicado na American Artist evidenciava a intenção de consagrar Steinberg como referência do cartum de seu tempo: "Seus imitadores aumentam a cada dia. Há uma escola "Steinberg". Há um grande público para Steinberg. Ele é uma influência e um marco" (Pitz, 1951, p.40). O reconhecimento pelo trabalho de Steinberg e sua posição de destaque no cenário do desenho de humor pode ser sentido na quantidade de artistas influenciados por ele. Sua obra ditou, de vários modos, os caminhos do cartum e de outras artes durante anos. É possível perceber, observando o desenrolar da produção de cartuns ao longo do século passado, o alcance de sua obra - no desenho limpo, nos personagens simples e narigudos, no humor mudo, na abordagem conceitual, nos jogos gráficos e com uso de ambigüidade, no uso de variados estilos com paródia. Vários dos desenhistas influenciados por Steinberg mereceram artigos, durante a década de 1950, na revista de artes gráficas suíça Graphis. Sobre um deles, o cartunista Witting, Manuel Gasser comenta:

Da mesma forma que nenhum pintor consegue escapar da influência de Picasso, nenhum novo artista do cartum consegue evitar um encontro com Saul Steinberg. Isto certamente se aplica ao jovem de 27 anos de idade Dane Verner Witting, cujo estilo mostra de modo evidente sua derivação do de Steinberg. No entanto, esta não é uma séria acusação contra Witting. Já que o desenho de humor moderno dispensa os textos explicativos, a forma é apenas um componente. O outro, não menos importante, é a imaginação pictórica, a idéia. Aqui, na idéia, as possibilidades são irrestritas e sem-número. Aqui, todos têm sua chance. E Witting é um que a agarrou (Gasser, 1953, p.394).

A primeira semelhança entre os cartuns de Witting e Steinberg reside no uso do humor mudo e no desenho de linha fina e seres narigudos típicos do cartum. Verner consegue, no entanto, uma personalidade própria em seu estilo, no modo como resolve certos pormenores. Os olhos de seus personagens são triangulares, com pupilas rentes ao nariz, solução 

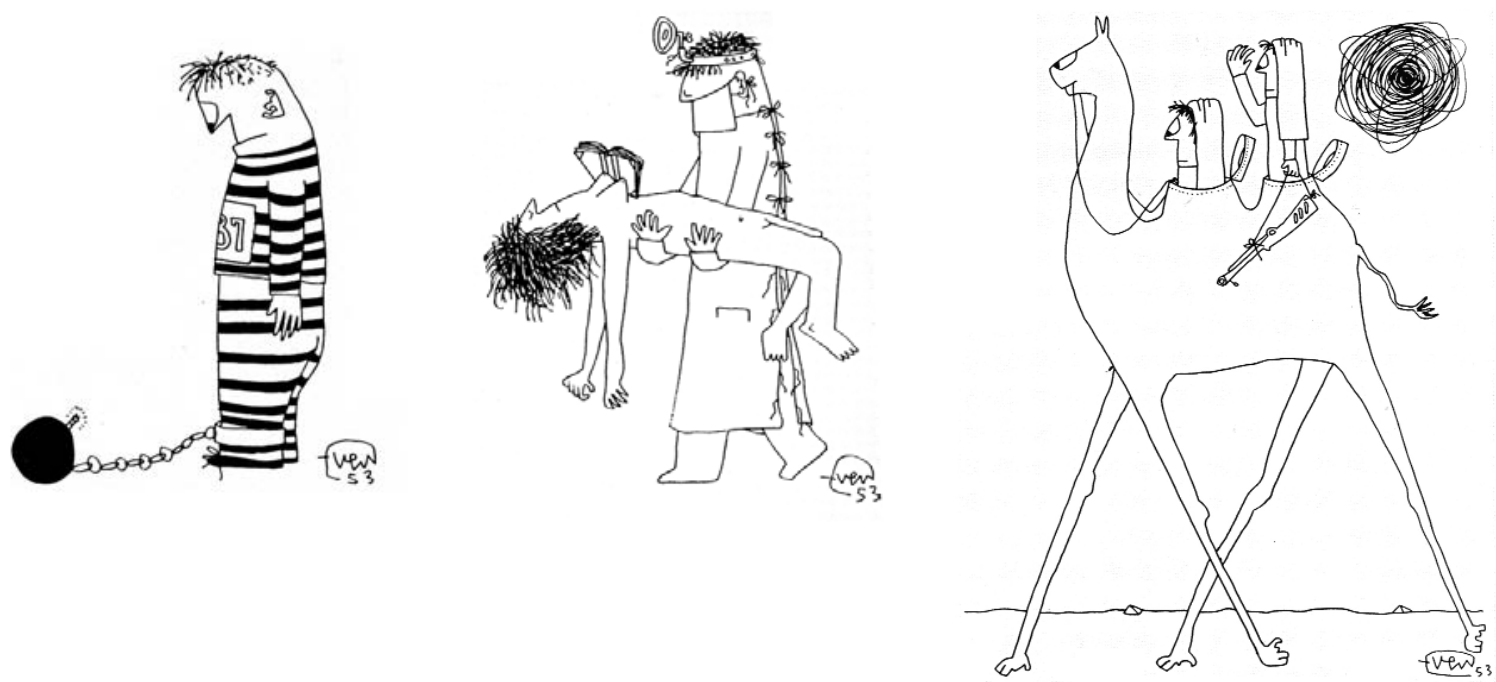

nunca usada por Saul. O interesse de Witting está no humor sutil, que explora estranhezas e situações aparentemente absurdas. Este absurdo, no entanto, tem a sua lógica: um recurso muito usado por Witting é a exploração de contradições, pela transformação de objetos e elementos do desenho, resultado da relação entre duas situações distintas que foram inesperadamente sobrepostas. Dentro dessa lógica, por exemplo, um médico aproveita o formato dos seios de uma paciente adormecida, adaptados em um anteparo inusitado, para ler seu manual enquanto caminha segurando ambos. Alguns trabalhos também fazem uso da similaridade de formas entre elementos, esboçando alguma ambigüidade gráfica, como no exemplo do peso de prisioneiro, "transformado" em bomba. Como observa Gasser, "esta sabedoria pictórica que nasce da forma (...), esta "lógica gráfica", como deve ser chamada, é a especialidade de Verner Witting e constitui sua força e fascinação" (Gasser, 1953, p.39).

Outro a ser comparado a Steinberg é o desenhista de linha fina Paul Flora, nascido em Tyrol em 1922. Sua ironia é um dos aspectos de seu trabalho a serem destacados por Gasser, que completa: "Flora parodia tudo, do desenho dos africanos àqueles de Saul Steinberg. E ele parodia com tal entusiasmo e inspiração que o observador muitas vezes encontra dificuldade para dizer onde o próprio comentário irônico de Flora começa e onde a

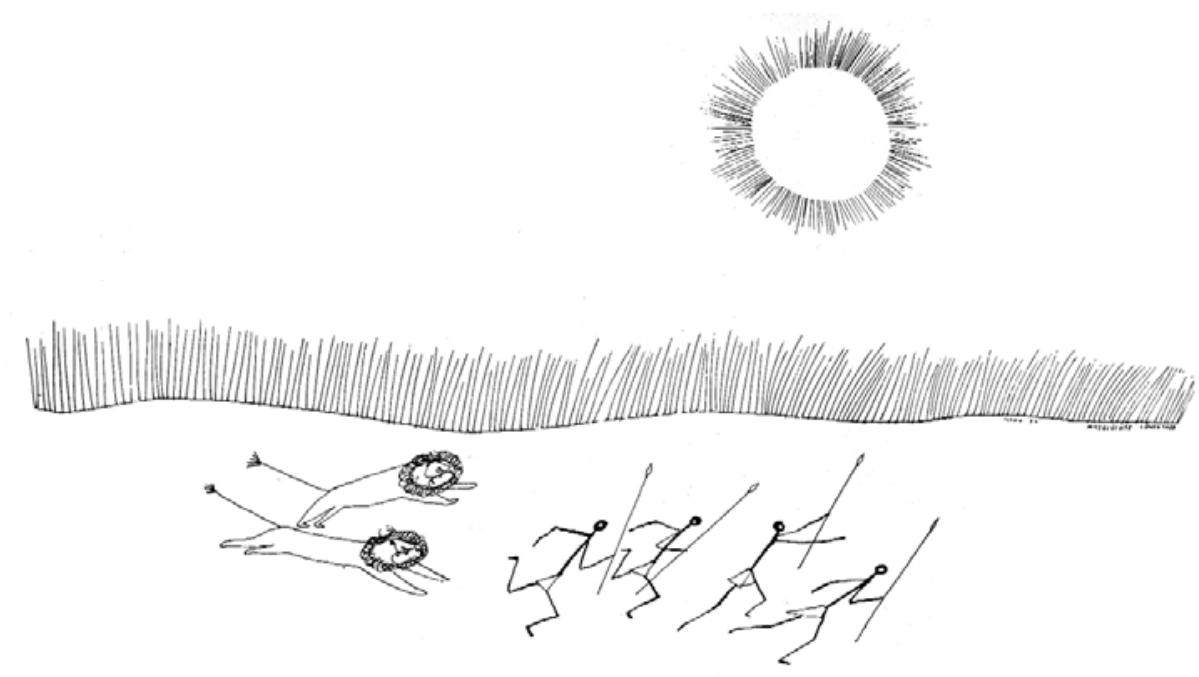



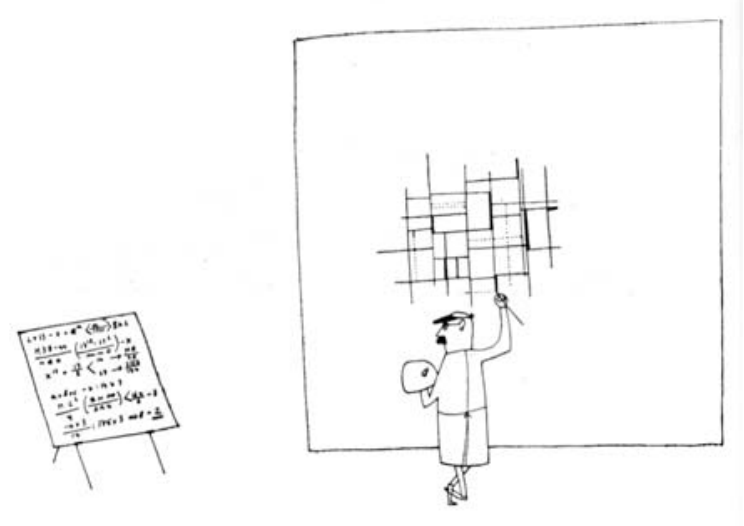

Figura 271 e 272. (no alto, na página da esquerda) Cartuns de Verner Witting

Figura 273-275. Desenhos de Paul Flora

máscara da paródia começa" (Gasser, 1955, p.440). Na verdade, ao contrário do que afirma Gasser, o traço de Steinberg presente no trabalho de Flora não parece ser uma paródia, mas o próprio estilo do cartunista suíço, como linguagem básica de todos os seus cartuns. Isso não tira o mérito de Flora, que apresenta, apesar das semelhanças, um desenho com personalidade própria, no traço - de linhas bem finas e entrecruzadas - e no desenho dos personagens. Nos cartuns expostos neste artigo da Graphis, há de fato brincadeiras com os diversos estilos artísticos, relacionando-os a situações absurdas. No entanto, o "estilo artístico" parodiado permance confinado ao seu espaço habitual, desenhado ou pintado no quadro, sem se confundir com o traço fino de Flora. Parte considerável do exercício com paródias de Saul iria mesclar estilos diversos, colocando-os em um mesmo patamar de realidade, com elementos do cubismo, pontilhismo, desenho infantil e outros atuando como personagens em nível de igualdade. Flora de certo modo faz isso, mas a presença do quadro sugere uma "realidade exterior" ao estilo parodiado. Por outro lado, os seres de desenho africano presentes na cena com leões caminham para o tipo de paródia steinbergniana comentada aqui. De qualquer modo, este estilo primitivo ainda é consideravelmente próximo ao "estilo Flora", distantes da mescla explosiva que Steinberg viria a promover para futuros trabalhos em Le Masque, por exemplo.

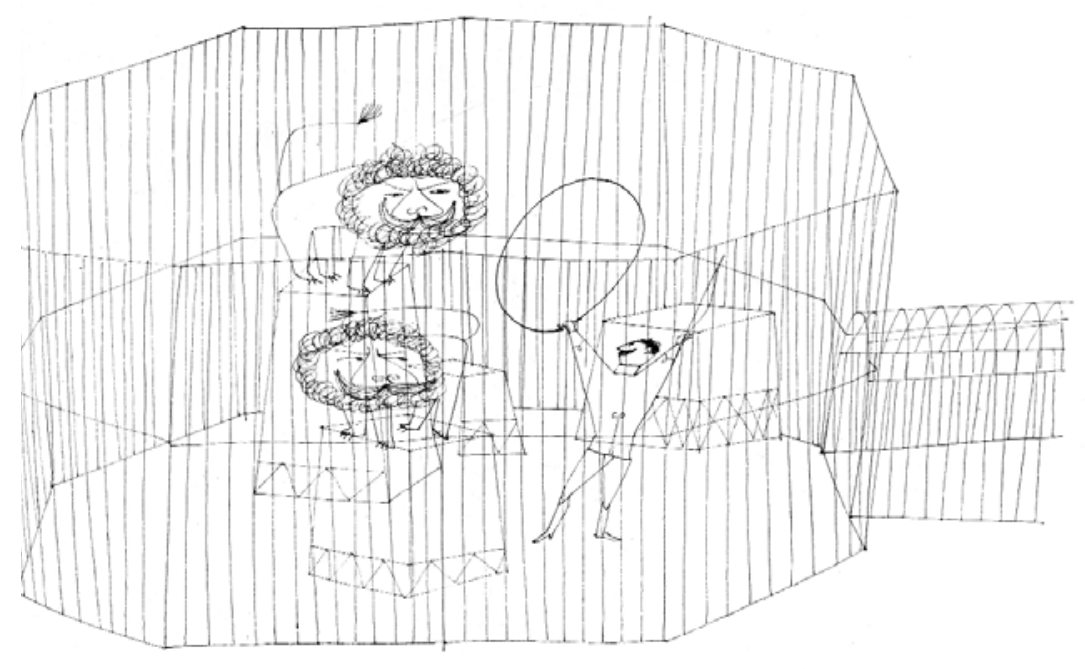


Figura 276. (ao lado)

Trabalho de Roy Morgan

Figura 277 e 278.

Mark Boxer, publicados

na Graphis em 1957

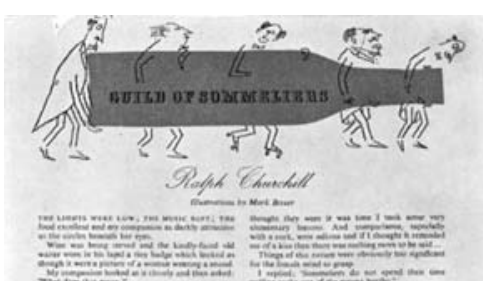

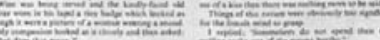
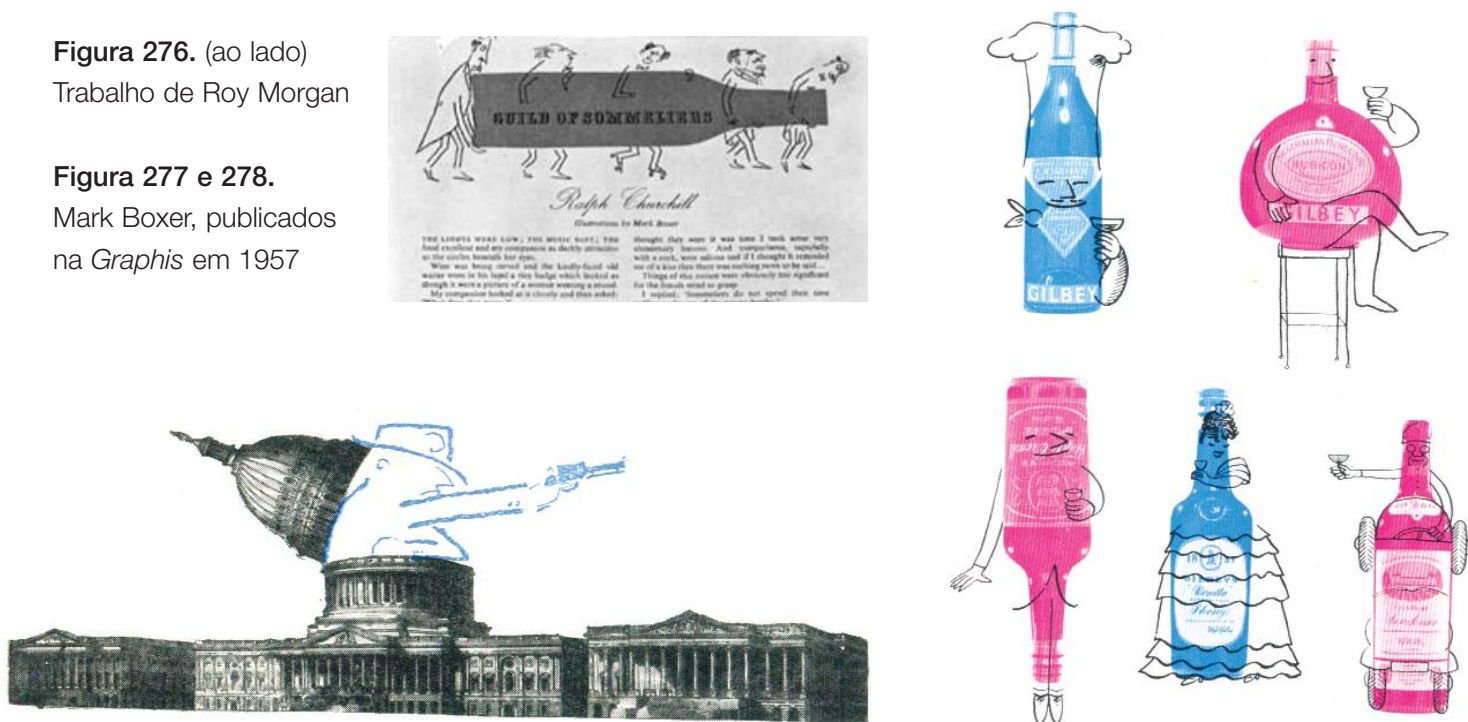

Alguns desenhos de Mark Boxer para o mercado inglês também evidenciam a influência de Steinberg, no desenho simples e mudo, e nos recursos utilizados. Em um truque de ambigüidade que se aproveita da similaridade de objetos, a cúpula do edifício é transformada em tampa de um esconderijo. É uma solução que lembra o cartum de Witting onde, ao invés de uma cúpula, são as corcovas de um camelo que servem de esconderijo. Outro trabalho de Boxer expõe vinhetas que se assemelham aos desenhos de Steinberg; para além do estilo do desenho, os personagens carregam a garrafa com o título da seção do mesmo modo que os personagens de Saul levam em suas mãos impressões digitais e elementos gráficos. O cartunista Roy Morgan também faz uso do recurso de ambigüidade tão ao gosto de Steinberg. Com o acréscimo sutil de algumas linhas, garrafas de bebidas são transformadas em pessoas e personagens.

Francis Deransart, nascido em 1935 em Dieulefit, é outro cartunista com assumida influência de Steinberg. Em artigo da Graphis, Pierre Descargues comenta que "Steinberg se tornou seu mestre" (Descargues, 1963, p.420). "Olhei tanto para ele", confessa. "Ele começou a ser uma obsessão. No final das contas, escondia os livros que tinha dele, para ficar longe dele como precaução, já que tinha que começar a explorar linhas contrárias de abordagem. Steinberg dominava a linha. Tentei fazer o que pude com manchas de cor" (cit. por Descargues, 1963, p.420).

Figura 279 e 280.

Cartuns de Francis

Deransart publicados na

Graphis em 1963
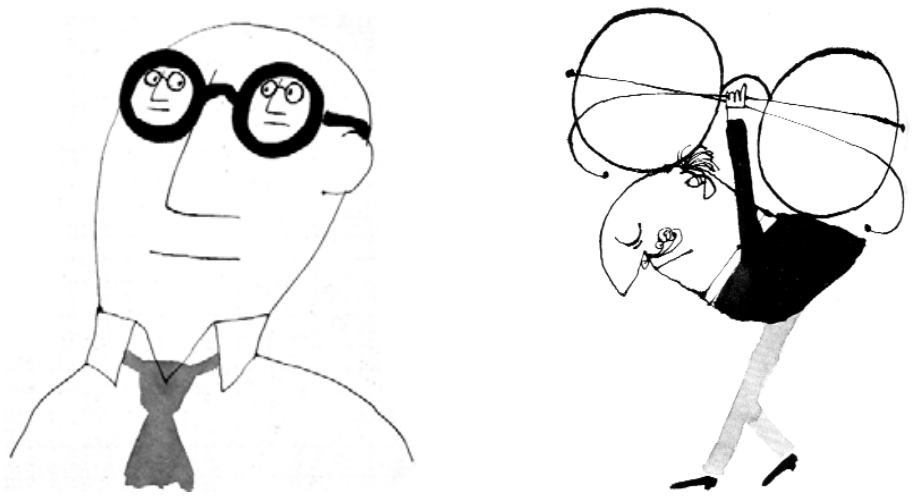

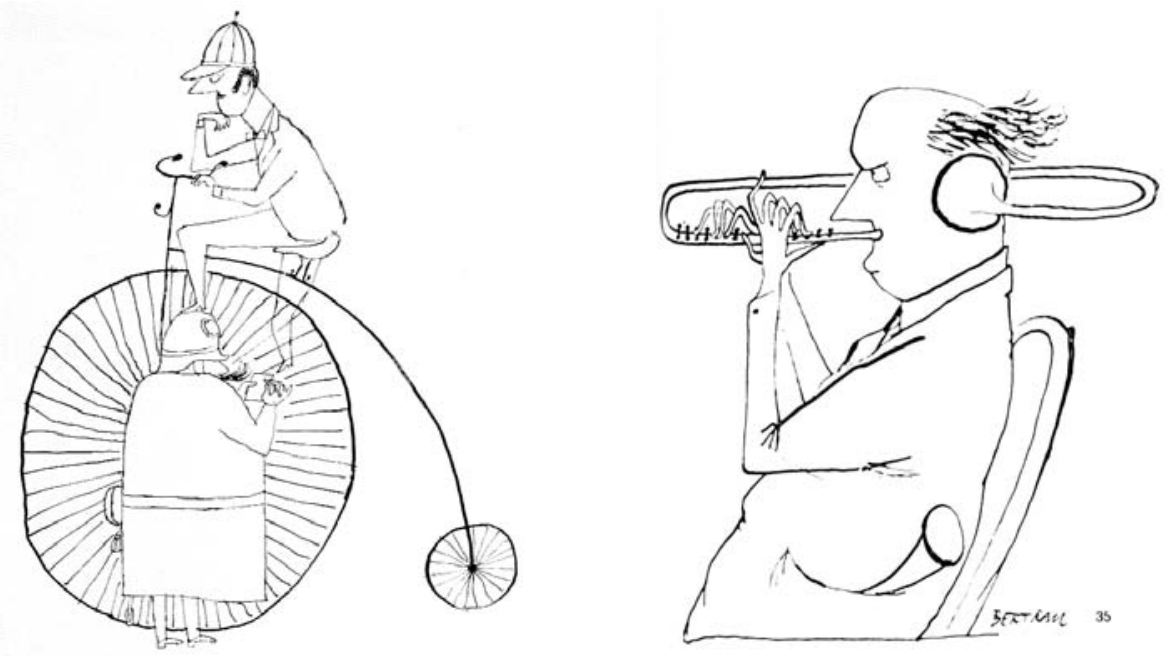

Figura 281 e 282.

Cartuns de Bertram,

publicados na

Graphis em 1954

Sobre o trabalho do cartunista Bertram, Rozendaal identifica personagens como "pequenos homens, mulheres e animais", que "estão longe de incorporar o ideal de beleza grega" (Rozendaal, 1954, p.293). O estilo de Bertram é variável, sugerindo influências por vezes expressionistas, em alguns momentos de André François, e nos cartuns, de Steinberg. Neste último caso, a influência poderia ser também de André François, que em certos momentos apresentou um humor a traço fino semelhante ao de Steinberg. Se as capas de Bertram mostram imagens "cheias", com fundo pintado e traço grosso, em seus cartuns são comuns soluções de adaptação e alteração de objetos e situações. Como a do ciclista, sentado em bicicleta antiga, que descansa a perna no capacete do policial enquanto toma uma multa - o tamanho inusitado da bicicleta proporcionando uma adaptação àquela circunstância. Já o desenho de um homem que toca corneta também mostra uma transformação do objeto, adaptado à situação, com o som de qualidade duvidosa voltando diretamente para os tímpanos do músico.

Um outro artigo da Graphis escrito por Manuel Gasser, sobre cinco cartunistas suíços, comenta como era freqüente encontrar artistas que apresentavam proximidade com o trabalho de Steinberg. Gasser se refere a três deles - Spahr, Haem (Meury), e Barth - como influenciados pela escola americana, cuja característica está na variedade de temas, ao con-
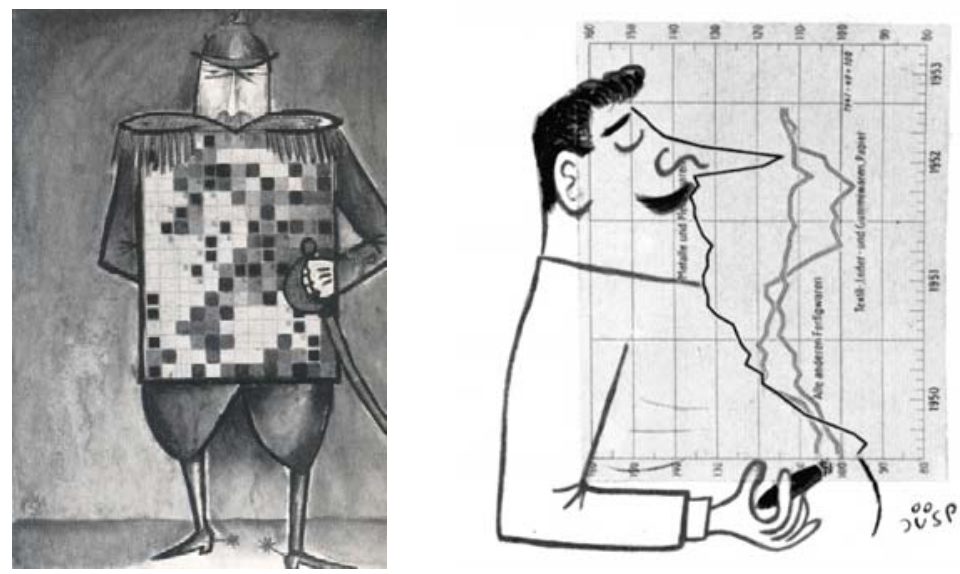

Figura 283 e 284. (da direita para a esquerda) Haem e Spahn, publicados na Graphis em 1957 
Figura 285 e 286. Richard Erdoes. Publicado na Graphis em 1954

Figura 287 e 288. (na outra página, no alto) Campanha da Nettleton Shoe Company. Publicada na Graphis em 1957

Figura 289. (na outra página, canto inferior) Cartum de Oski, publicado na Cascabel nos anos 1940

Figura 290. Cartum de Oski.
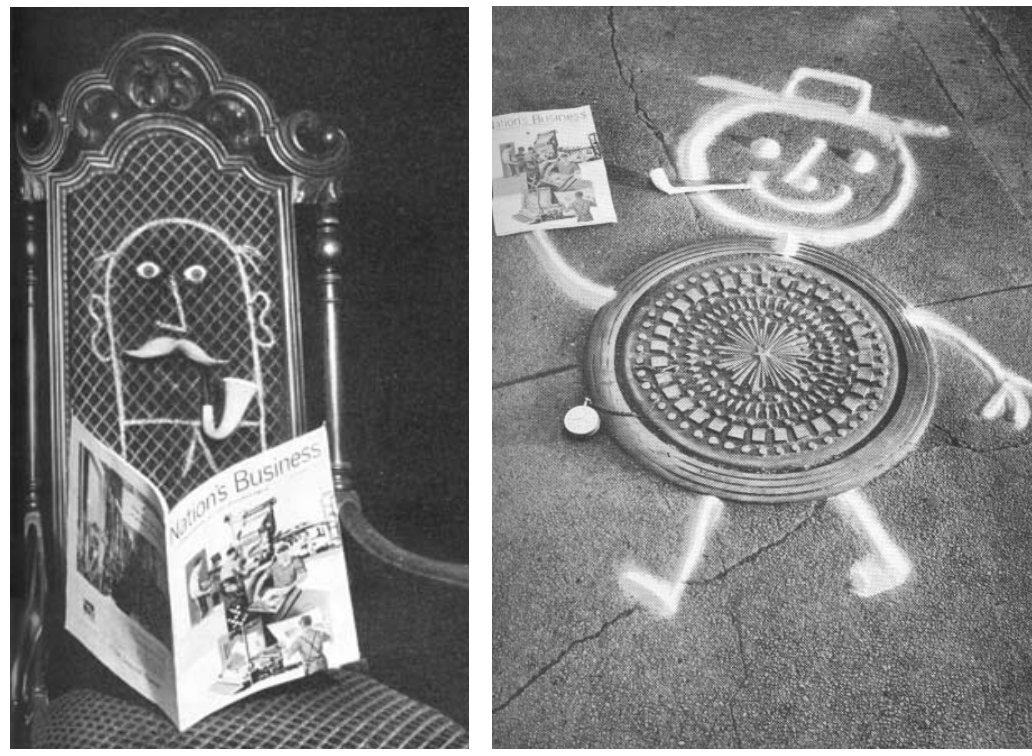

trário de Lindi e Steger, mais focados em assuntos específicos. Sendo assim, "Haem extrai sua inspiração de quadrados de uma palavra cruzada, ou Spahr interpreta uma curva de produção [de gráficos] como uma fumaça de cigarro, e seguindo a associação, desenha um cigarro que se ajusta à fumaça, e um gordo bigodudo que se ajusta ao cigarro". O cartum de Haem (Meury) com fumaças de cigarro em estilos diversos, correspondentes às características de seus usuários, chega a sugerir grande influência dos jogos gráficos de Steinberg, em que diferentes estilos são conferidos à fala de pessoas, sons musicais, pensamentos, ou mesmo à aparência dos personagens. Gasser complementa que "o nome de Steinberg como pai deste método associativo não é nenhuma novidade", salientando seu papel como pioneiro deste tipo de abordagem no meio dos cartuns.

O artista gráfico Richard Erdoes, ao comentar os trabalhos em que promove intervenções de traços em objetos, se refere à influência despertada por ações de bruxas vodus vistas em uma viagem ao Haiti, com o uso de farinha para fazer desenhos de símbolos sobre a terra escura. Três anos depois, em Nova York, Erdoes resolveu desenvolver, ele mesmo, experimentos semelhantes, comprando o mesmo material e registrando os resultados obtidos com a ajuda de um amigo fotógrafo. Com o tempo, ele recorreu a materiais variados como pedras e madeira. Posteriormente, para uma campanha da revista Nation's Business de 1954, Erdoes fez diversas situações baseadas nas intervenções com materiais: sutis traços de cartum conferiam vida a pratos; personagens eram gerados a partir de contornos delineados na areia; desenhos a giz em torno de uma tampa de bueiro faziam deste elemento o corpo de um homenzinho. O recurso, no entanto, é semelhante ao aplicado há poucos anos por Steinberg, a partir de 1949, com desenhos em banheiras, móveis e outros objetos reais. A imagem criada por Erdoes, de um senhor desenhado em uma cadeira, comprova a similaridade com obras de Saul. Para além do recurso, há também a proximidade no traço cartunesco simples, que naqueles anos assumia a condição de "estilo de época", se espalhando pelas diversas áreas das artes visuais. 

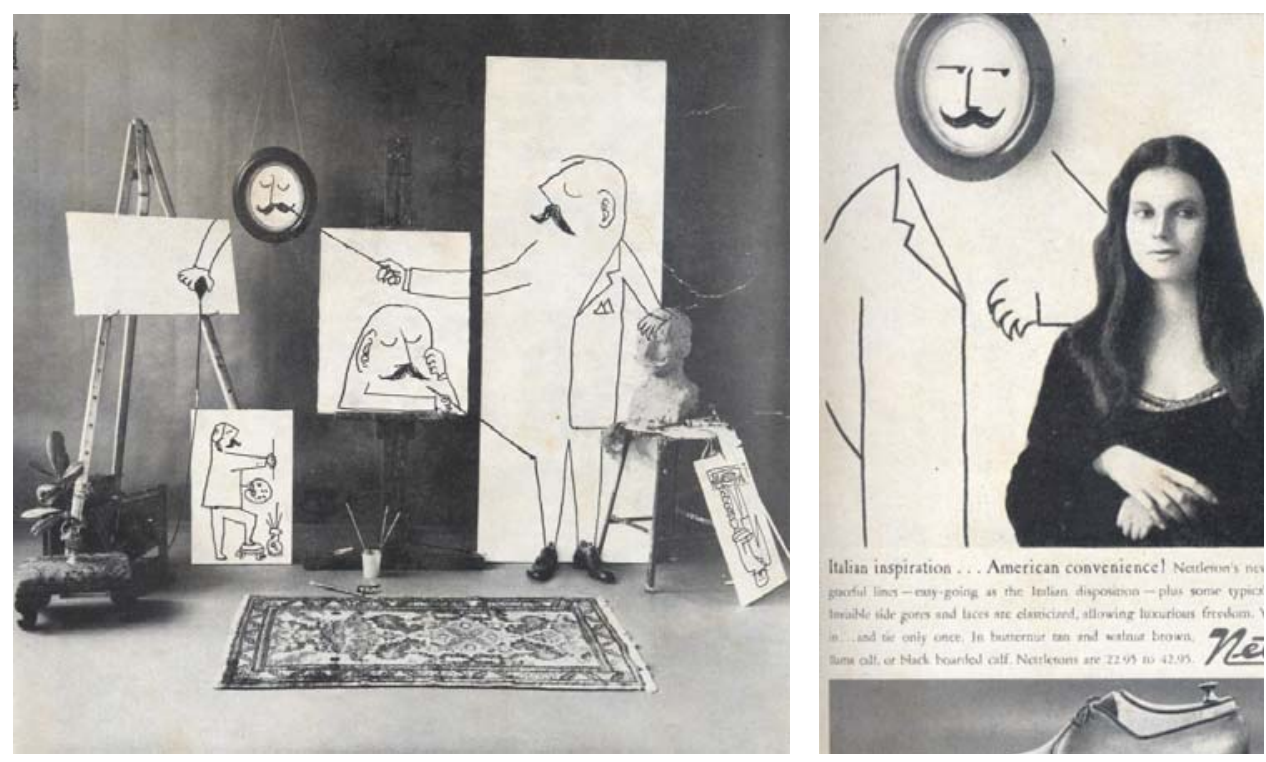

A campanha para sapatos da Nettleton Shoe Company, comentada em artigo na revista Graphis, também deixa claro a influência de Steinberg no meio da propaganda. Mary Gowing observa isso no desenho simples e em traço fino do personagem símbolo da campanha:

$\mathrm{Na}$ América, o cavaleiro bigodudo da propaganda de sapatos Nettleton é afetuosamente conhecido no mercado como Mr. Net (Senhor Lucro). Mr. Net (...) parece ter "crescido". À medida que mais e mais propagandas eram criadas, uma única personalidade parecia ganhar identidade. Um adorável absurdo composto por uma figura com contorno oval e um par de sapatos (...). A influência de Steinberg é óbvia, e penso, bem digerida, certamente bem utilizada (Gowing, 1957, p.80).

Quando Steinberg publicou na Argentina, passou a contracenar com um outro cartunista de estilo semelhante nas páginas das publicações do país. Oski, nascido no mesmo ano que Steinberg, em 1914, se tornou colaborador da Cascabel nos anos 1940. Apesar da semelhança estilística, algumas diferenças evidentes conferiam personalidade própria a seus desenhos, como os olhos circulares, maiores e vazios dos personagens. Estes também apre-
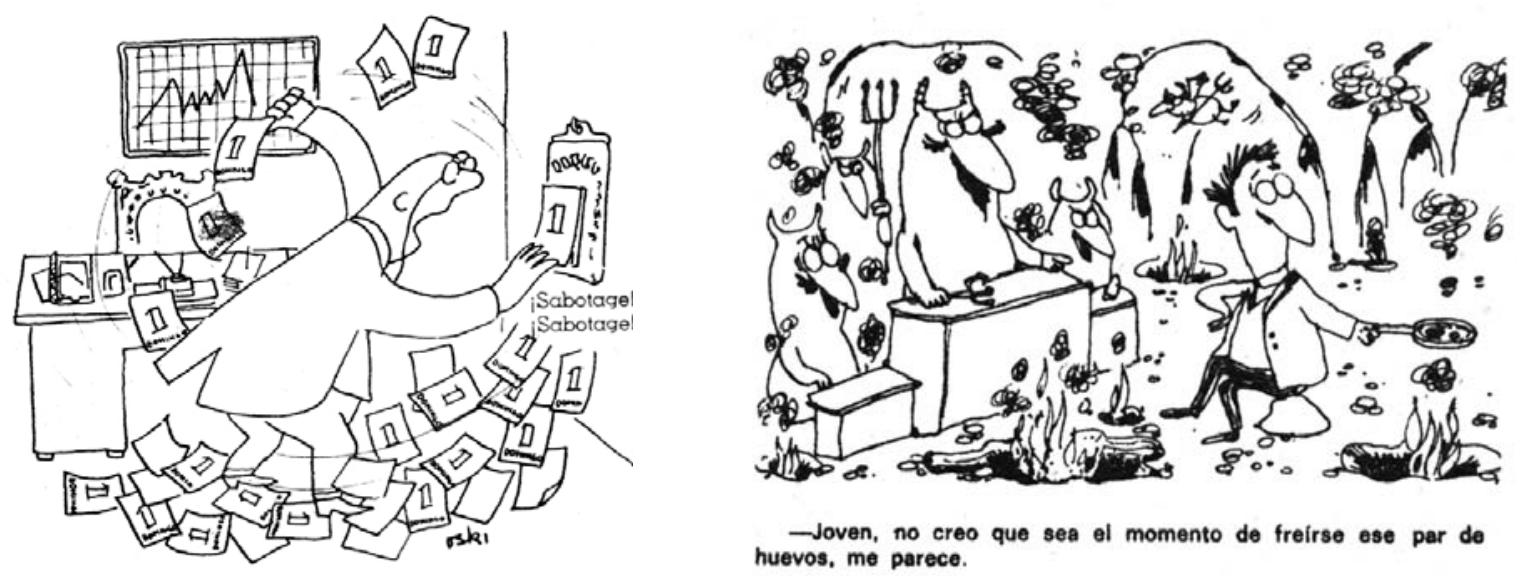

- Joven, no creo que sea el momento de freírse ese par de huevos, me parece. 

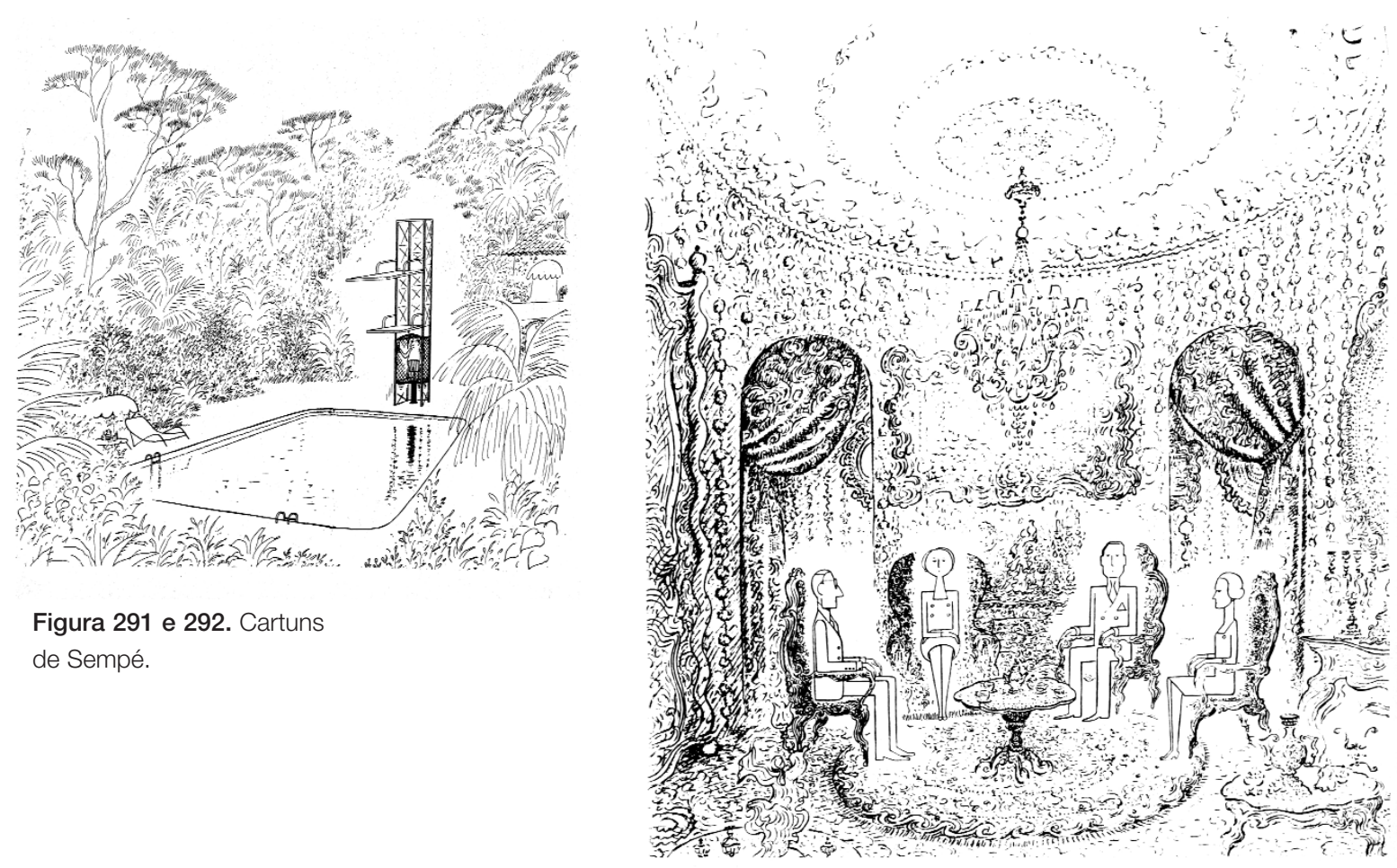

Figura 291 e 292. Cartuns de Sempé.

sentavam nariz de ângulo mais acentuado, semelhante a "bicos". Posteriormente, outros artistas argentinos viriam a fazer uso do humor mudo, como Quino e Mordillo.

O cartunista francês Sempé, nascido em 1932, também viria a se notabilizar pelo humor mudo e desenho simples. Teve sua estréia em 1952, na revista Paris-Match, não demorando para se tornar um dos mais prestigiados humoristas gráficos do mundo (Rius, 1982, p.120). Os cenários cheios de detalhes freqüentemente vistos nos cartuns de Sempé, lembram o excesso de ornamentos dos ambientes rococós e vitorianos de Steinberg. No entanto, o traço de Sempé é mais solto e ágil, conferindo a ele uma expressão própria. É uma característica de seu trabalho as cenas detalhadas vistas de cima ou de uma razoável distância, tornando o personagem pequeno e imerso no ambiente. Esse tratamento de escala acaba conferindo, muitas vezes, grande ênfase ao meio social do personagem, ao modo como ele se relaciona com os vários outros habitantes, assim como com os espaços naturais e construídos.

Outro representante francês do novo cartum moderno é Siné. Como observa a crítica de arte Sheila Leirner, o cartunista, "impressionado pelo grafismo de Steinberg, que os franceses descobriram depois da Segunda Guerra Mundial, explorou (...) as variações mirabolantes que se emancipavam de um simples jogo de palavras à introdução de uma representação insolente, sob um fundo de nonsense" (Leirner, 2003, p.146). Sua atuação política o levou a sofrer processo por "difamar" o exército do país (Rius, 1982, p.125). O nariz mais circular, cujos contornos em inúmeras vezes se sobrepõe ao dos olhos, é um dos detalhes superficiais que diferenciam seu trabalho em relação a Steinberg. Apesar do humor sem falas e legendas, e do traço simples, as piadas tendem a ser mais escrachadas, dada a sua postura crítica e política. 


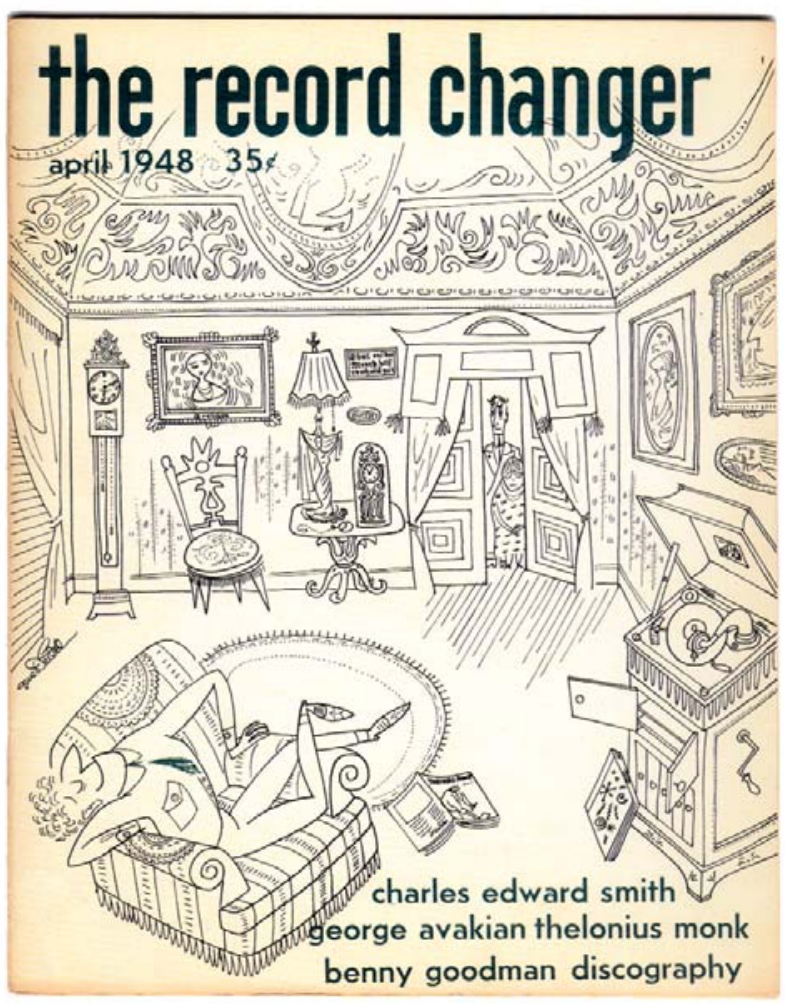

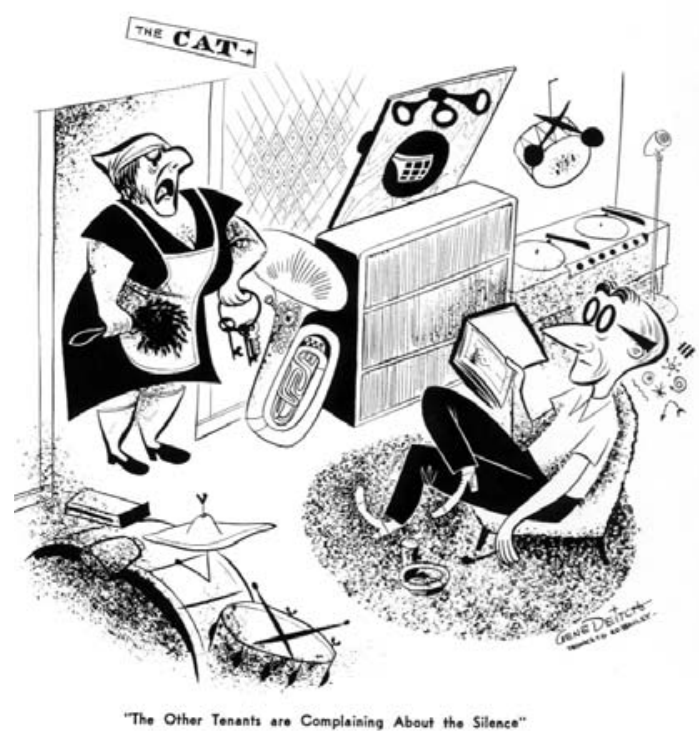

Figura 293. Gene Deitch, capa do The Record Changer, abril de 1948

Figura 294. (acima) Cartum de Gene Deitch, The Record Changer, janeiro de 1949

Steinberg costumava demonstrar desconforto com o decalque direto de seu estilo e soluções. Como comenta Smith, Saul "não ficava lisonjeado ao ver suas inovações se tornarem propriedade pública". Sua transformação gráfica de balões de pensamento e fala em "símbolos" que significavam outros tipos de alusiva forma visual foi consideravelmente imitada por outros artistas (Smith, 2005, p.100). Mas o trabalho mais plagiado parece ter sido a famosa capa e pôster View of the World, que chegou a lhe render uma vitória jurídica contra a Columbia Pictures em 1987 (Smith, 206, p.264), pelo fato da imagem ter sido imitada no cartaz do filme Moscow on the Hudson (Smith, 2006, p.70). Desde cedo, o estilo de Steinberg se tornou referência, servindo de inspiração para o desenvolvimento de trabalhos autorais, mas também sendo objeto de decalque direto. Um exemplo é a capa da revista The Record Changer de abril de 1948, feita por Gene Deitch. Se no miolo da mesma revista Deitch costumava publicar cartuns dentro de um estilo pessoal, inspirado na linguagem das capas de disco de Jazz da época, as inúmeras capas elaboradas por ele para a The Record Changer apresentavam uma grande variação estilística. O trabalho feito para a publicação de abril foi assim descrito pelo artista: "Estou de volta ao trabalho, com uma capa experimentando o estilo de Saul Steinberg. Há aqui um visível garoto rico, passando o tempo na sala de estilo vitoriano decorada por seus pais de gosto retrô" (Deitch, 2003, p.72). A proximidade com o estilo de Saul é enorme, mas alguns detalhes - como no modo como o garoto rico se acomoda na cadeira - deixam transparecer que se trata do trabalho de um imitador.

Com o tempo, a influência de Steinberg passou a se apresentar de modo mais variado, acompanhando o desenvolvimento e as novas fases de seu trabalho. No trabalho do belga Josse Goffin, por exemplo, o trabalho de Saul se faz presente no tom surrealista e na diversi- 


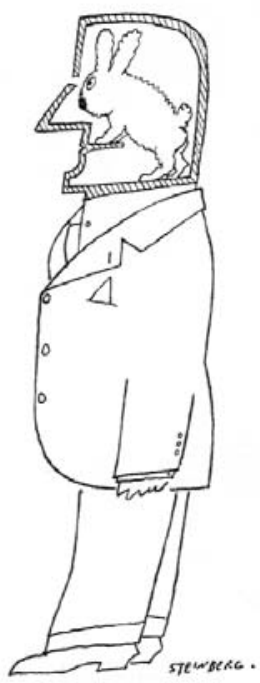

Figura 295. (acima) Steinberg, The New Yorker, novembro de 1958

Figura 296. Goffin, poster, 1981

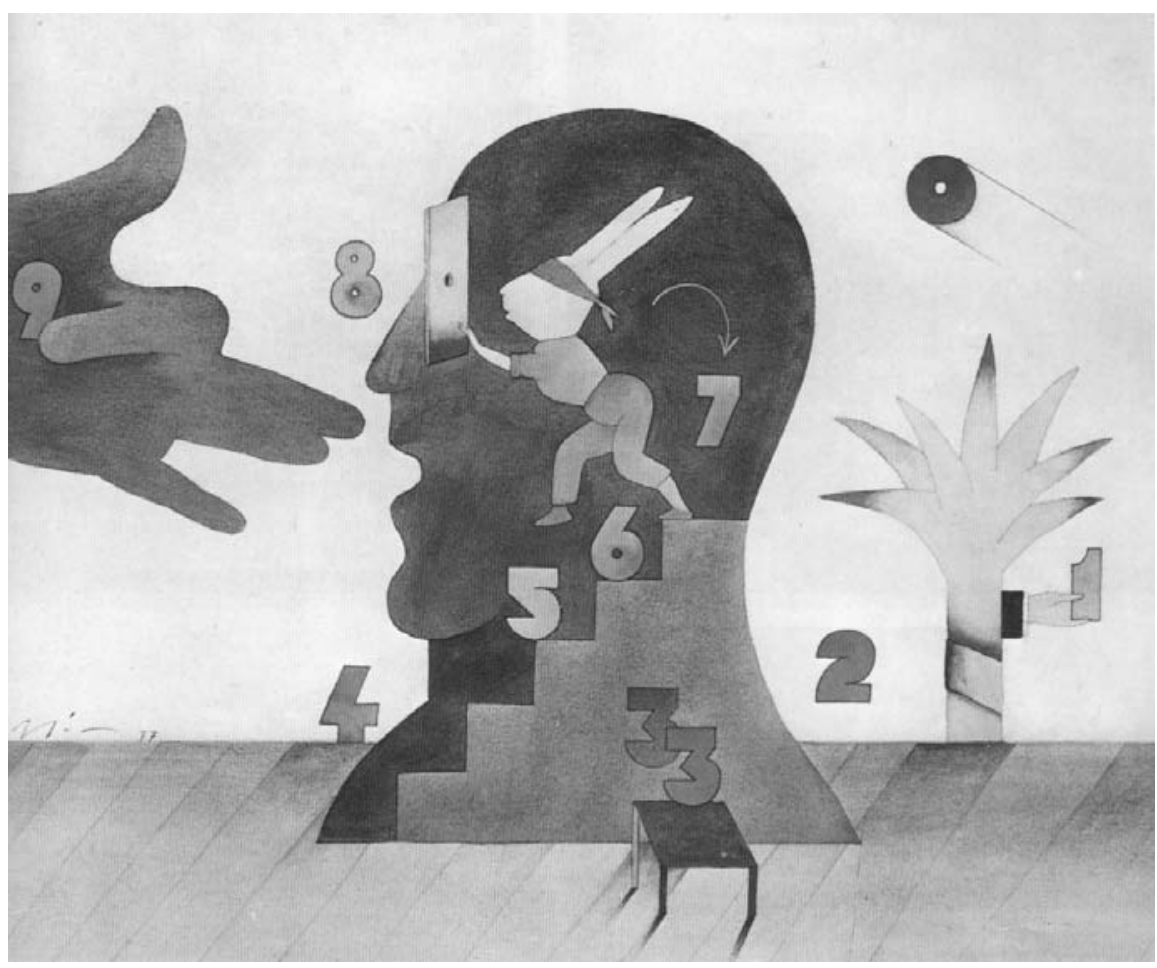

dade de estilos. Ao comentar o trabalho do artista belga, Pierre Baudson diz que "é possível reconhecer algumas poucas relações próximas e várias distantes em: René Magritte, Saul Steinberg, Yves Tanguy, Milton Glaser e outros, todos recebendo sua homenagem através do trabalho de Goffin para o "grande consciente coletivo" que tem produzido o que é hoje uma cultura universal" (Baudson, 1982, p.8). O trabalho de Goffin é apenas um exemplo dentre os diversos que representam a vertente da "ilustração conceitual", com forte influência de Magritte, mas dentro de sua linha mais solta, que priveligia relações desconexas e certo automatismo. Elementos steinbergnianos se sucedem em suas obras, seja nos números dispostos como objetos, seja no caso de um coelho inserido dentro de um crânio humano - uma espécie de self trabalhado antes por Steinberg de modo muito similar.

O belga Folon também apresenta em seu trabalho uma compreensão moderna do desenho, na simplicidade e concisão. $\mathrm{O}$ artista constrói, a partir destes atributos, cenas surreais e enigmáticas. O tom onírico e leve de seus desenhos é reforçado com a técnica da

Figura 297 e 298.

Desenhos de Folon publicados na revista $D u$.
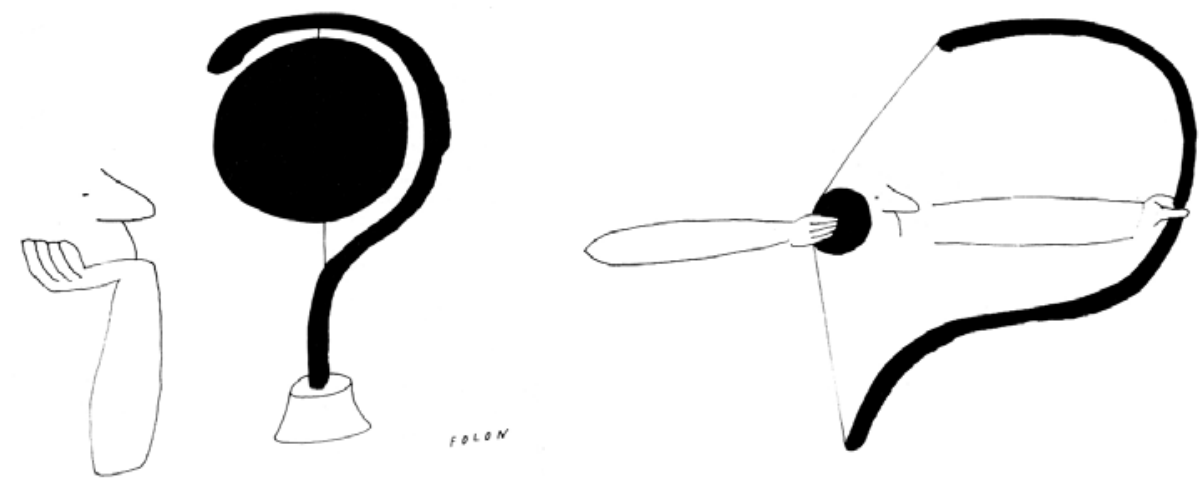
aquarela. Várias obras de Folon recorrem às ambiguidades gráficas, muitas delas em jogos com olhos e bocas. Seus desenhos a traço são muito simples, e em certos casos lembram Steinberg, como nas suas experimentações com pontos de interrogação, publicados na revista $D u$.

O artista Tomi Ungerer, que adquiriu grande prestígio a partir do final dos anos 1950, também assume a influência de Steinberg. Nascido na cidade francesa de Estrasburgo em 1931, foi lá que Ungerer teve contato com a cultura americana e com os desenhos satíricos da famosa revista The New Yorker. O artista chegou aos Estados Unidos em 1956, retornando a Paris logo depois e voltando para ficar na América definitivamente em 1957, publicando seu primeiro livro infantil naquele ano. Com sucesso imediato, colaborou para a Life, Fortune, Harper's Bazaar, Esquire, House \& Garden tão logo chegou à cena da ilustração americana (Pflug, 1959, p.105). Em 1959 já recebia um artigo de destaque na revista Graphis, com trabalhos que sugeriam a proximidade com Steinberg. O recurso da ambigüidade gráfica era amplamente empregado, com a adição de desenho a traço fino em imagens fotográficas de revista, conferindo novo significado a eles. É inevitável comparar estas imagens com algumas propagandas criadas por Steinberg em 1965. O desenho simples e a concisão do resultado final estabeleciam proximidade ainda maior com o artista de origem romena. O trabalho de Ungerer, contudo, não se resumia ao desenho de linha fina, vindo a transitar por caminhos diversos. Como observou Gasser em outro artigo para a Graphis, em 1965, "o primeiro aspecto da oeuvre de Tomi Ungerer que chega aos olhos é a multiplicidade de seus temas e tratamentos técnicos. Enquanto a maioria de seus colegas logo desenvolvem uma linha especial, ou ao menos deixam claro, num relance, o que consideram como sua própria área particular, Ungerer deixa os categorizadores se questionando" (Gasser, 1965, p.274). Ao constatar que a variedade se estende até mesmo à personalidade empregada em seus trabalhos, Gasser sugere que "a conclusão óbvia seria a de que nosso homem é um grande cínico, um satirista resolvido a emitir pequenas confissões mesmo aos mais santificados tabus" (Gasser, 1965, p.274).

A ruptura promovida no humor gráfico, a partir do cartum mudo de desenho simples e conciso, também contou com a contribuição do francês André François. Nascido em 1915 na Romênia - mais precisamente na cidade do então Império Austro-Húngaro Timisoara -, ele e Saul Steinberg, ambos de origem romena, foram provavelmente as grandes referências da arte gráfica humorística nos anos 1950. François teve contato considerável com as artes desde cedo: ele e Raymond Savignac foram assistentes do cartazista francês Cassandre nos anos 30. Em comparação com os cartazes de seu mestre e aqueles das primeiras décadas do século XX, o design que a obra de ambos viria a apresentar era "menos pictórico, lembrando mais cartuns" (Hollis, 2001, p.159). No final dos anos 30, mudou seu nome original André Farkas - para André François, e se tornou cidadão francês, começando a trabalhar para as publicações do país. Ficou primeiro conhecido por seu humor ácido nos periódicos franceses e ingleses, dentre eles a Punch. Como observa Charles Rosner, em artigo escrito em 1952 sobre sua obra, "em seus desenhos mordazes, um senso de humor pode ser detectado 


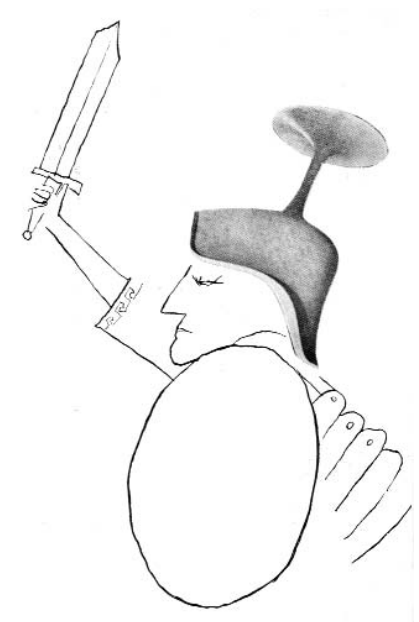

Figura 299-300. Desenhos de Tomi Ungerer publicados na Graphis em 1959
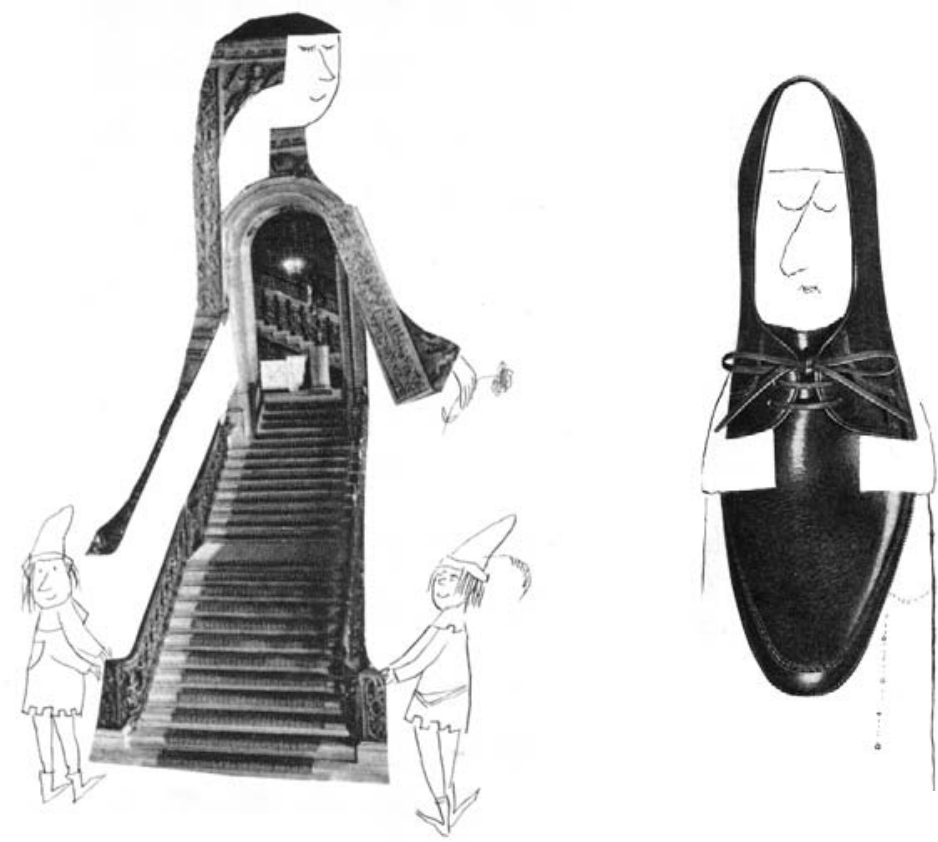

ao mesmo tempo que um senso de tragédia" (Rosner, 1952, p.476). Os cartuns de François criados nesta época seguiam abordagem semelhante à de Steinberg, com desenho a traço, humor mudo, foco definido, concisão e depuração. Evitando comparações, Walt Kelly famoso criador do personagem de quadrinhos Pogo -, assim define o trabalho de François: "Seu estilo é arrojado, honesto, claro, simples, e como nenhum outro - a despeito da rápida e confusa avaliação daqueles que precisam comparar o trabalho de um homem ao de outro para sua orientação pessoal". O desenho rápido e próximo de esboço do cartunista também chamava a atenção de Kelly: "Suas idéias nunca estão mumificadas na técnica, ou empalhadas, ou tostadas e estiradas. Elas não são fósseis de estilo (...)" (Kelly, 1953, p.6). Um artigo de 1954 tomava partido da originalidade de Steinberg, fruto talvez da preocupação em conferir crédito ao novo humor do período aos cartunistas americanos, afirmando: "Os franceses têm estado há muito tempo familiarizados com o trabalho de Steinberg, e muitos

Figura 302 e 303. Cartuns de Andrè François, The Tatooed Sailor, 1953

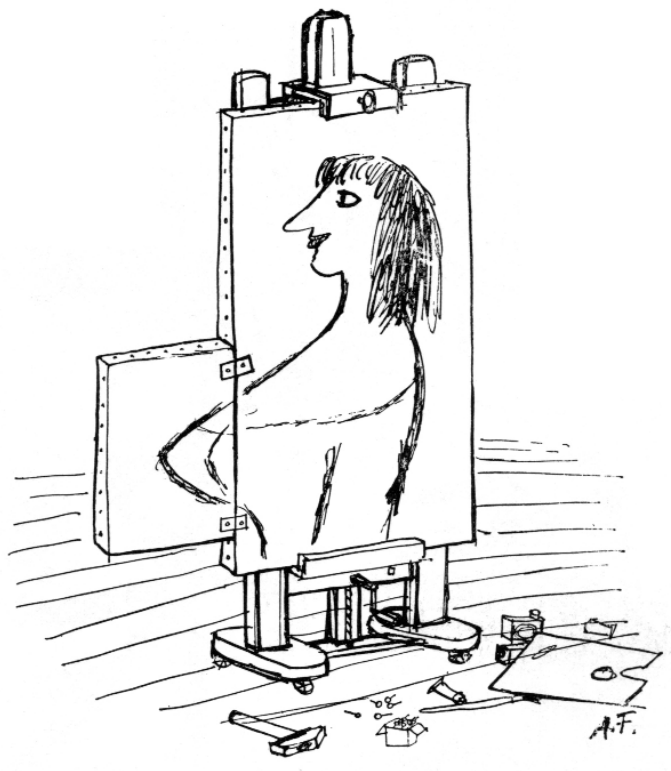




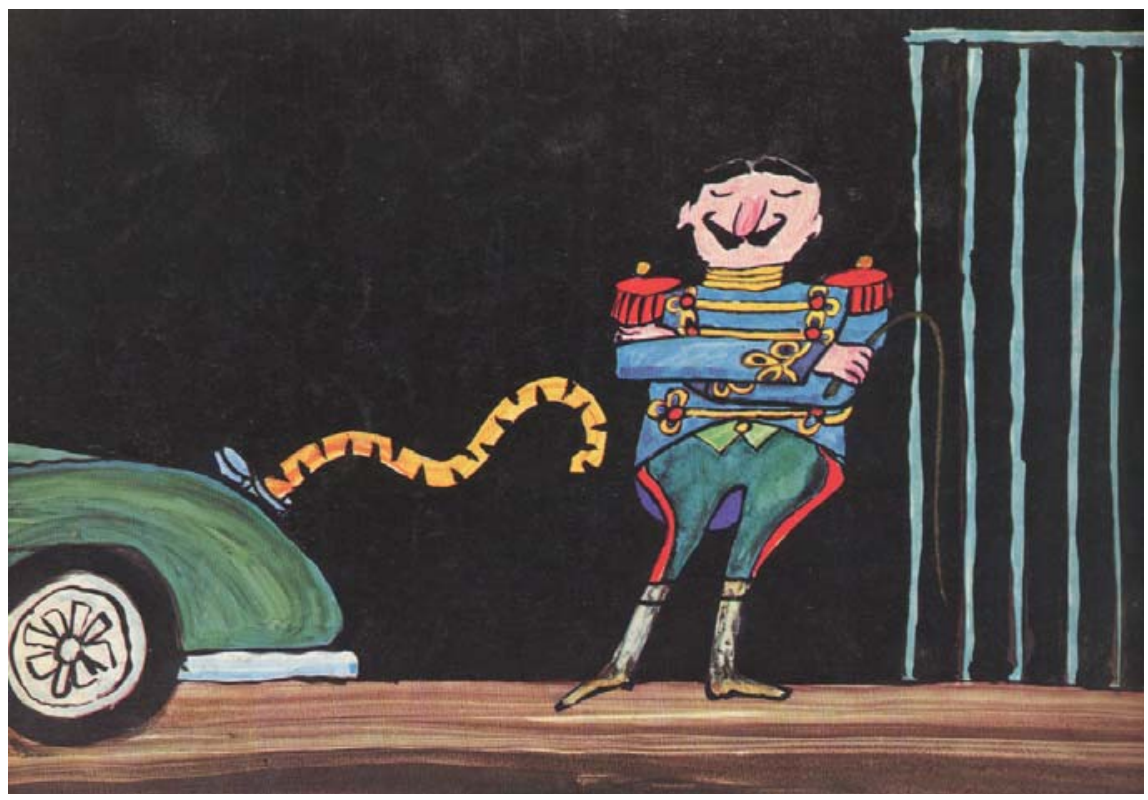

Figura 301. Trabalho de Ungerer publicado na Graphis em 1965

cartunistas franceses têm prestado as mais sinceras homenagens, a da imitação", e acrescenta, The Tatooed Sailor de André François, mostra a sua influência, estilisticamente, e também indica que o humor de "situações extremas" não está restrito a Steinberg, Price, Addams, Thurber" (Constable, 1954, p.24). A frase, ao menos, serve para mostrar que já naquele período a proximidade entre o trabalho de ambos era significativa, seja no humor mudo de traço simples, seja no absurdo de situações e no apelo a recursos de ambigüidade. No entanto, a maior acidez no humor, e uma linha mais "grave", um pouco mais grossa, tensa e irregular, são algumas das características que poderiam ser consideradas na diferenciação dos cartuns de François em relação a Steinberg. O artista francês viria, no entanto, a diversificar suas abordagens, algo que já vinha sendo anunciado no começo de carreira. No artigo de 1952 da Graphis, Rosner percebe a possibilidade de novos caminhos gráficos a serem trilhados: "Ele recebeu uma encomenda da mundialmente famosa loja do extremo oeste de

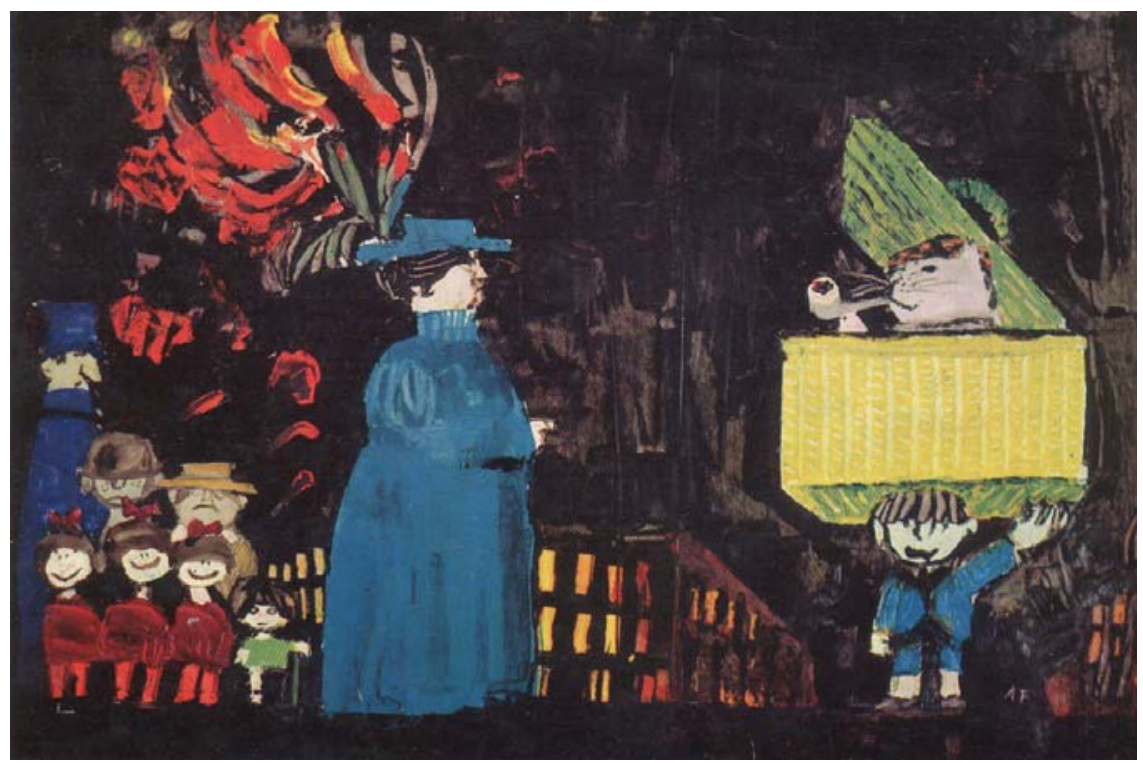

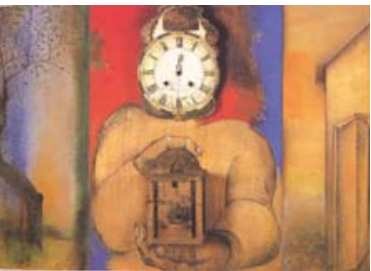

Figura 304. (acima) Trabalho de François, publicado na revista Gráfica.

Figura 305. llustração do livro infantil Tom \& Tabby, publicada em artigo da Graphis em 1963. 


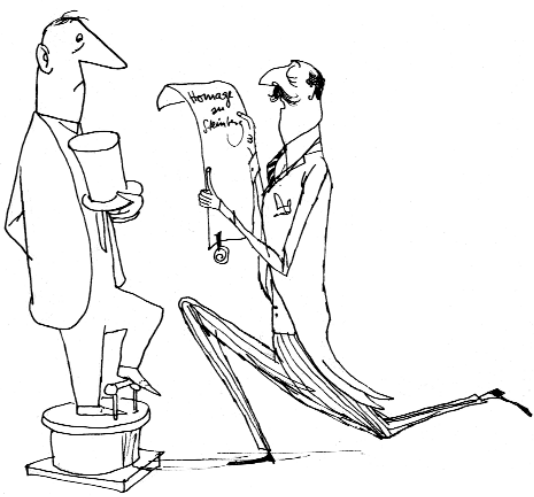

Figura 306. Searle, 1950. Enviado a Steinberg

Figura 307. Searle, 1952

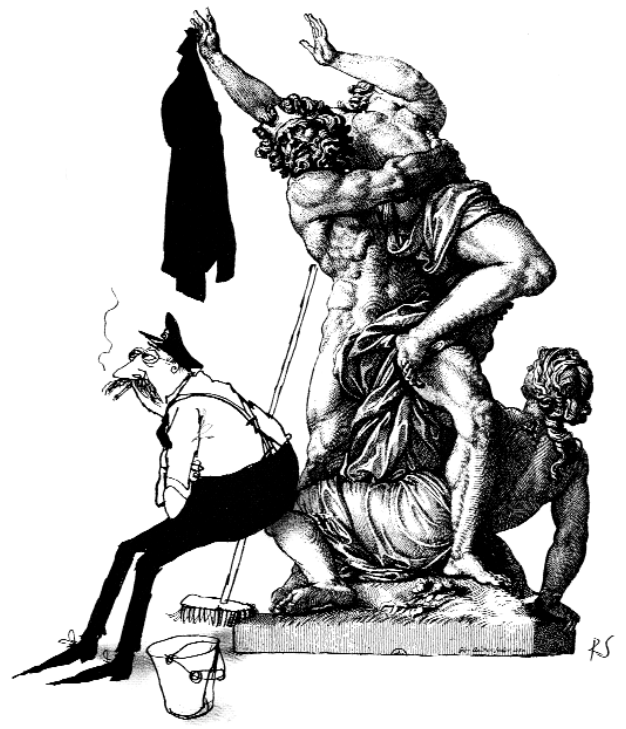

Londres, Simpson's of Piccadilly, para um pacote de baralhos. Eles estão em ativa preparação, e quando aparecerem, nós iremos conhecer pela primeira vez, em aplicação prática, André François, o completo colorista. (...) Ele está ansioso para pintar. É algo que ocorre cedo ou tarde a todo artista do preto-e-branco" (Rosner, 1952, p.476). As abordagens, com o tempo, se tornariam cada vez mais oníricas, fantásticas, de difícil interpretação. Como comenta, nos anos 1980, Gilles de Bure, "suas analogias são ilógicas, suas ilusões são misteriosas, e as conclusões que o observador tenta, em vão, extrair de seu trabalho não o levam muito longe" (de Bure, 1979, p.378). François não restringiu seu trabalho aos cartazes, atuando para as áreas do mercado editorial, publicidade, cenografia, pintura, e trabalhando como ilustrador de revistas, autor de livros infantis, cartazista, cartunista, pintor, escultor. Assim como Steinberg, influenciou uma série de outros artistas gráficos de seu tempo.

Outro importante colaborador da revista Punch é o britânico Ronald Searle. Em contraste com a quietude atemporal e filosófica de Steinberg, seus personagens narigudos se mostram em estilo irascível, carregado de energia. O traço é ágil, expansivo, conferindo
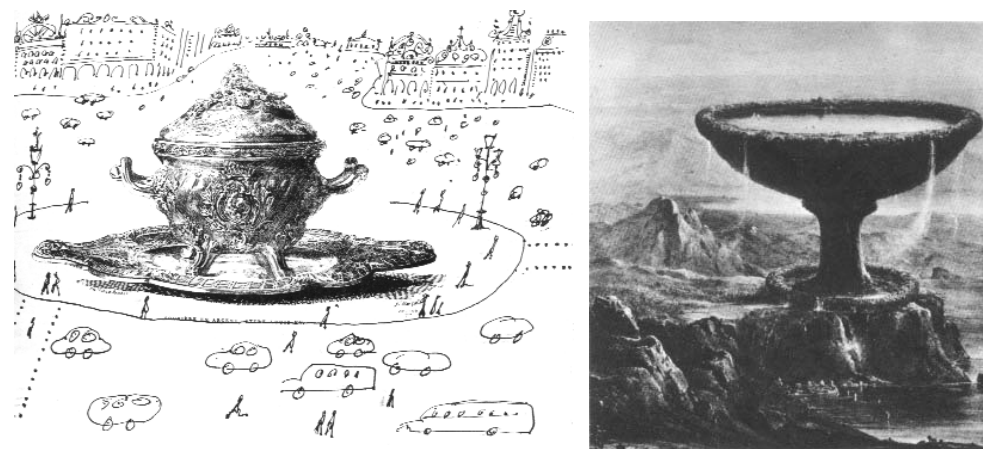

Figura 311. (primeira à esquerda) Steinberg, publicado em Dessins

Figura 312. Pintura de Thomas Cole, mencionada por Glaser

Figura 313. Glaser, ilustração para um conto sobre comidas

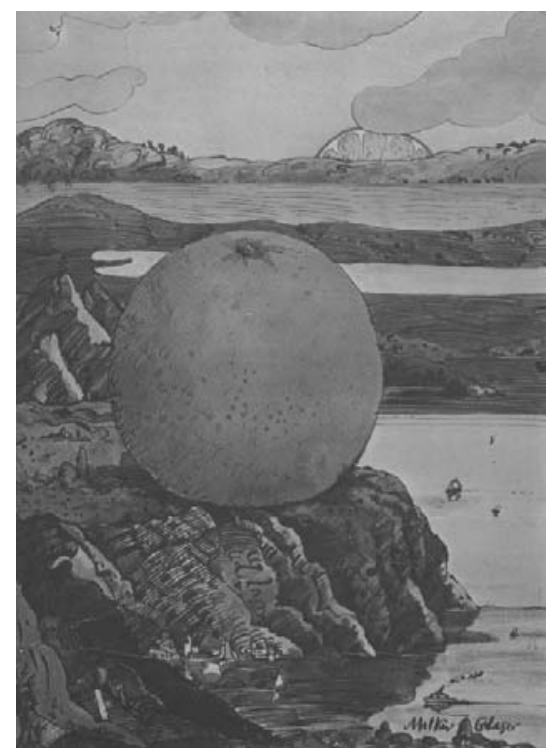



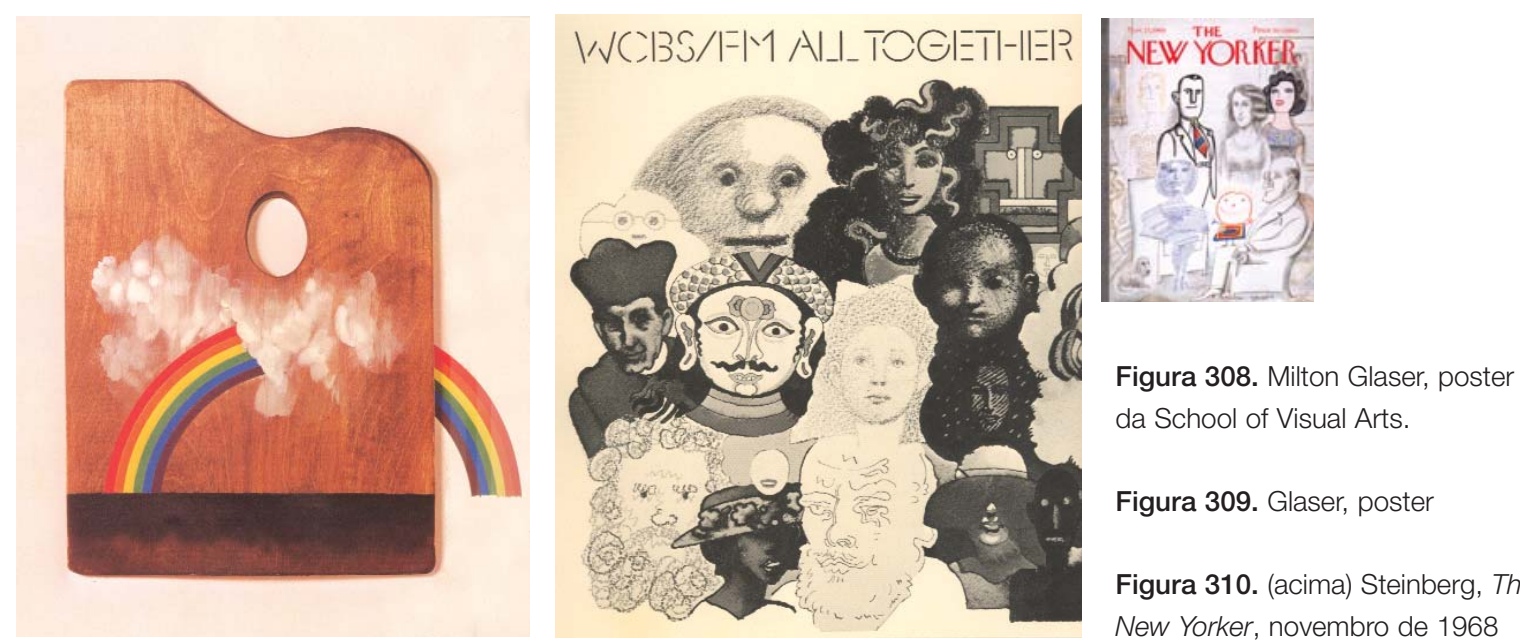

da School of Visual Arts.

Figura 309. Glaser, poster

Figura 310. (acima) Steinberg, The New Yorker, novembro de 1968

movimento às figuras. No entanto, parte de seus cartuns, muitos deles mudos e depurados, sabem conciliar a expressividade peculiar de seu trabalho com um tom mais leve e sutil. Searle brincou com o contraste entre seu estilo caricatural e o de fisionomia impassível de Steinberg, num rascunho de admirador que ele enviou ao cartunista em 1950, em que um personagem de bigodes a la Searle se ajoelha em homenagem a um "embaraçado Homem Steinberg" (Smith, 2005, p.24).

A obra de Steinberg despertou não apenas o interesse dos cartunistas, como chegou ao campo do design gráfico, servindo de referência para vários profissionais da área, que aplicavam seus talentos de ilustração nos trabalhos. Como observa Hollis, ao se referir ao final dos anos 1960, "uma das tendências no design gráfico americano era representada por designers nostálgicos, voltados para a ilustração, como Joseph Low e os profissionais da Push Pin Studios" (Hollis, 2001, p.134). Um trabalho de Milton Glaser, um dos fundadores da Push Pin, para um pôster de uma estação de rádio sugere uma das principais influências de Steinberg em seu trabalho: o uso de variados estilos e técnicas. Na tentativa de expor uma

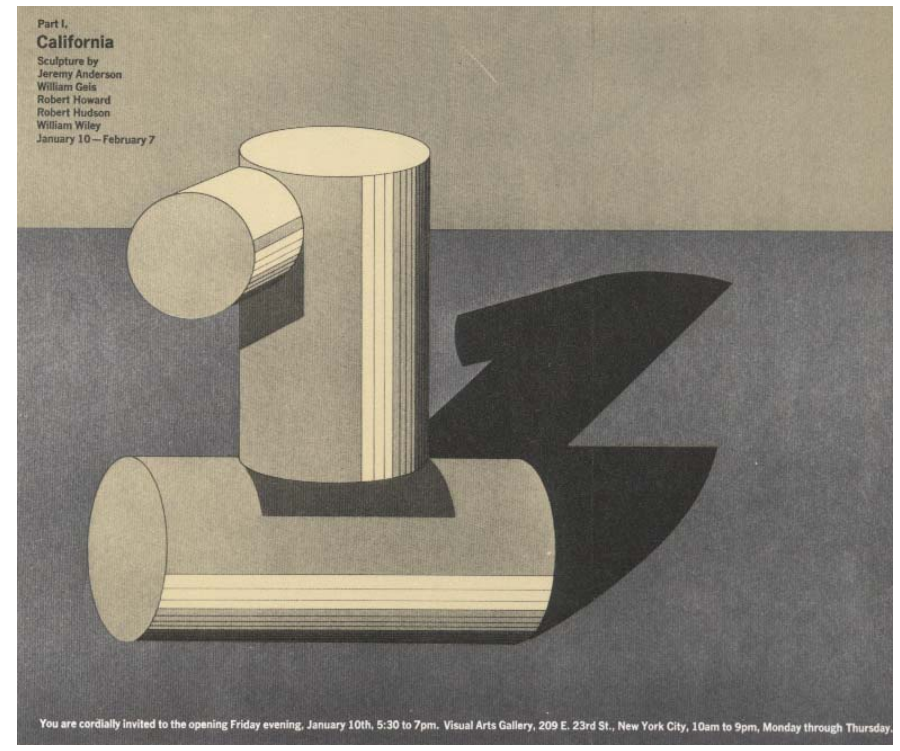

Figura 314. Número-

objeto de Glaser 
amostra da audiência da estação, a imagem remete à capa de Steinberg para a New Yorker, com cada membro de uma família representado por um estilo: pontilhismo, desenho infantil, cubismo, etc. Letras, números e elementos tipográficos apresentados como objetos, como no trabalho para a School of Visual Arts Gallery, também lembram o artista romeno. Apesar da inspiração de seu desenho para um conto sobre comidas - publicado originalmente na revista Look - ser a paisagem de Thomas Cole, segundo o próprio Glaser, a solução lembra também as colagens de Steinberg com elementos fora de escala em ambientes urbanos. Os arco-íris de Milton Glaser, assumidos clichês trabalhados pelo designer, atuam de modo semelhante nos desenhos de Steinberg. Em todos estes trabalhos, está expressa a possibilidade de transformação do sentido original de qualquer elemento gráfico em outra coisa, recurso caro a Saul. De qualquer modo, Steinberg era importante referência, mas estava longe de ser a única. Milton Glaser por vezes flertava com o surrealismo, em certas ocasiões se inspirava na arte japonesa, em outros momentos recorria ao que havia aprendido como discípulo de Morandi. Apesar de semelhanças, os trabalhos da Push Pin apresentavam grande originalidade e, dentre visíveis diferenças, um estilo de época, com influências da arte psicodélica e dos movimentos dos anos 1960. Steven Heller comenta a importância que Steinberg teve no trabalho dos artistas da Push Pin:

No começo dos anos 1950, Chwast comprou uma edição da obra-prima de Steinberg, All in Line, "que mudou minha vida" [diz Chwast], porque despertou um interesse na arte vitoriana e déco. Steinberg, que amava o ornamento futurista, muitas vezes desenhava exagerados edifícios em estilo arte déco em seus irônicos quadros, incluindo o Empire State e o Chrysler. Chwast prestou homenagem ao passé de um modo diferente, através do que ele chamou de "Roxy Style", um pastiche de arte moderne conjugado ao seu estilo contemporâneo, sendo o mais vívido exemplo a capa do gráfico da Push Pin The Meaning of Dreams. [Milton] Glaser também adotou uma variante de arte déco, enquanto outros membros da Push Pin, especialmente Barry Zaid, construiu estilos de ilustração inteiros a partir de uma base moderna (Heller, 2004, p.5).

O trabalho do designer Paul Rand, muito influenciado pelos artistas modernos, também utilizava a linha fina com freqüência, lembrando Steinberg. Ambos se conheciam (Smith, 2006, p.240), mas não há menção clara de influência direta. Por outro lado, Rand, por vezes, contratava ilustradores como Ludwig Bemelmans ou William Steig - outro desenhista de linha fina - para trabalhar com ele (Heller, 1999, p.140). Visivelmente influenciado pelos cartazistas europeus, e talvez por Steinberg, o designer também recorria em inúmeras ocasiões a recursos de ambigüidade.

Dentro de um contexto geral, Steinberg desempenhou papel importante no desenvolvimento daquilo que se convencionou chamar de "ilustração conceitual". Como observa Heller, "a ilustração se desenvolveu do "o-que-você-vê-é-o-que-é" do realismo para o sim- 

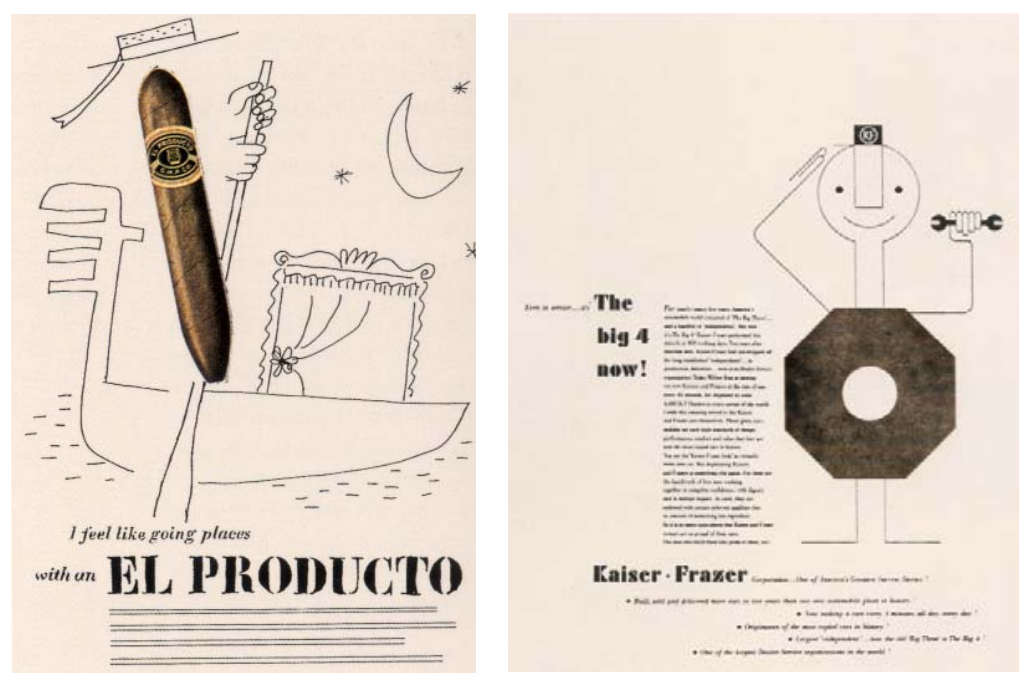

Figura 315. Paul Rand,

El Producto, 1953-7

Figura 316. Paul Rand, propaganda pra Kaiser-Frazer, 1949

bolismo conceitual porque os assuntos e temas cobertos pelas revistas estavam se tornando mais complexos, mais críticos. Apesar das ilustrações da tradição do realismo rockwelliano serem fundamentadas em amplas idéias, os ilustradores rejeitavam ilusão, metáforas, e simbolismo a favor de vinhetas explícitas" (Heller, 2006, p.87). Nos anos 50, a superfície das coisas vinha sendo capturada amplamente pelos fotógrafos, deixando o universo interior aberto à exploração pelos artistas gráficos. Artistas jovens dos anos 50 como Robert Weaver passaram a criar imagens para serem deconstruídas, como na poesia. Mudanças na relação de trabalho, com uma parceria sem precedentes entre o ilustrador e o diretor de arte, foram decorrência de uma nova visão da ilustração, entendida agora como elemento do design e trabalhada para criar mensagens. Heller aponta a importância de novos desenhistas neste processo:

A obsolescência Neo-Rockwelliana ajudou a semear a Ilustração conceitual, mas houve também uma evolução natural feita por artistas iconoclastas que instintivamente apostavam em tendências e modas. Dentre os inovadores, Saul Steinberg, Boris Artzybasheff, e Robert Osborn vestiram a ilustração com inteligência e sátira, expressionismo e surrealismo. Eles rejeitaram o realismo túrgido a favor da ilusão" (Heller, 2006, p.88).).

Outro campo profundamente influenciado por Steinberg foi o da animação. Como observa Amid Amidi, os animadores visuais dos anos 1950 "conceberam um arrojado estilo visual que era derivado das artes modernas, assimilando e adaptando os princípios do cubismo, surrealismo, e expressionismo na esfera da animação (Amidi, 2006, p.9). A lista de influências modernas nos artistas de animação era diversa, podendo constar nomes como Picasso, Matisse, Miró, Jim Flora. O designer-animador Fred Crippen amava o trabalho de Steinberg, por exemplo. Saul ajudava a compor, ao lado de Ben Shahn, Robert Osborn, Ronald Searle, Raoul Dufy, Stuart Davis, Martin e Alice Provensen, dentre outros, um universo visual de referências para estes animadores modernos. Leonard Glasser, um dos grandes 

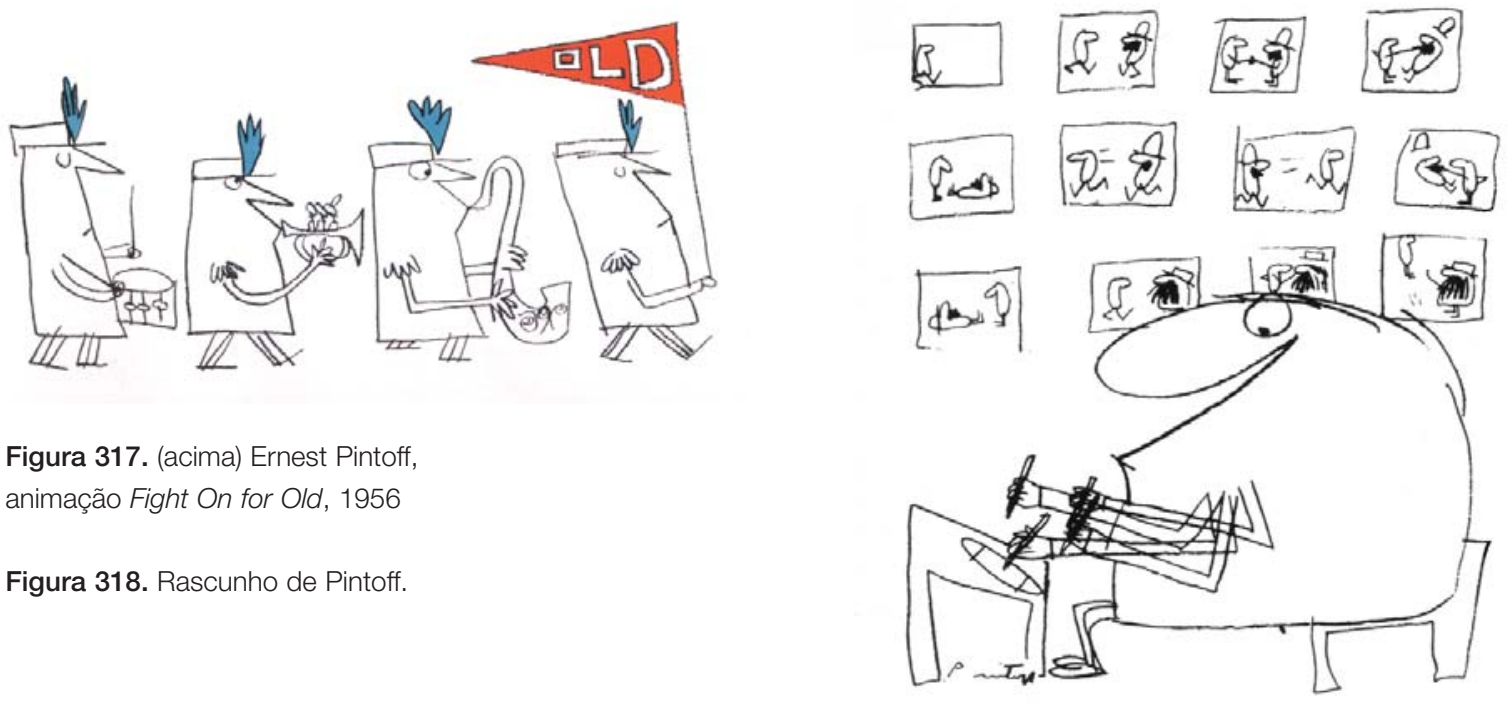

Figura 317. (acima) Ernest Pintoff, animação Fight On for Old, 1956

Figura 318. Rascunho de Pintoff.

colaboradores do estúdio comercial de animação Pintoff Productions, recorda: "Naquela época, era louco com dois cartunistas que havia tomado conhecimento na escola de arte Saul Steinberg e André François. Aquele era o estilo que eu estava tentando acompanhar, e então vi o estilo de Ernie [Pintoff], que era ainda mais simplificado e direto", diz, ao recordar sua aproximação com o fundador da Pintoff (cit. por Amidi, 2006, p.64). John Hubley, importante animador da UPA (United Productions of America), teve seu desenho linear utilizado no filme Brotherhood of Man derivado do pintor modernista Ad Reinhardt, com uma leve "dose do cartunista da New Yorker Saul Steinberg" (Amid, 2006, p.115). Já o animador Oscar Grillo, quando ainda era uma criança em seu país natal, a Argentina, ficou enormemente impressionado com Rooty Toot Toot de John Hubley, pinturas cubistas de Picasso e os cartuns de Steinberg (Amidi, 2006, p.188).

\section{STEINBERG E OS CARTUNISTAS BRASILEIROS}

Nos anos 1960 também já se faz notar a influência direta de Steinberg na nova geração de cartunistas brasileiros, notadamente Ziraldo, Millôr, Borjalo, Fortuna, Jaguar, Claudius. Steinberg é assumido como referência de primeiro escalão por todos eles. Exemplo disso foi a homenagem prestada por alguns - Ziraldo, Jaguar, Fortuna - na edição 12 da revista Bundas de 1999, em que um grupo de cartunistas escolheram suas imagens preferidas de Steinberg para ilustrar um ensaio de Updike. Logicamente, as influências no trabalho destes cartunistas são variadas, não se resumindo ao artista de origem romena: o trabalho de Ziraldo, por exemplo, tem muito de Tomi Ungerer e Savignac. Cada qual desenvolveu um caminho próprio, uma linguagem própria. Pedro Corrêa do Lago comenta a presença de Steinberg na obra destes artistas, no livro Caricaturistas Brasileiros, ao contextualizar o momento do cartum mundial com a cena brasileira: 
O pós-guerra é dominado pela descoberta da arte de cartunistas americanos e franceses, sobretudo Saul Steinberg e André François, e por um grupo de desenhistas liderado por Millôr Fernandes. Esses artistas têm importância determinante para orientar o estilo do cartum brasileiro nos anos 1950 e 60, que tem sua expressão mais acabada, ainda que tardia, nos melhores momentos do Pasquim. Somente a partir de 1970 a caricatura evolui para um novo pólo de atração, influenciado pelo inglês Gerald Scarfe (...). (Lago, 2001, p.15).

Esses cartunistas foram importantes não apenas pelos cartuns em si, como também pelos veículos criados e desenvolvidos por eles. Jaguar foi um dos fundadores da sofisticada revista de cultura Senhor, cuja primeira edição foi lançada em março de 1959, trabalhando como assistente de arte de Carlos Scliar. Millôr foi o "idealizador de uma revista efêmera que a censura fechou em 1964 após apenas oito números, o Pif Paf (Lago, 2001, p.148). Em 1969 a jornal O Pasquim foi fundado pelos cartunistas Jaguar e Claudius - além de Sérgio Cabral, Tarso de Castro e Prósperi - e contou com Ziraldo, Fortuna, Millôr como co-fundadores. Millôr viria a ser um dos "pilares da segunda fase do Pasquim, iniciada em 1971, quando o jornal ganhou mais alento na sua luta contra a censura e a repressão" (Lago, 2001, p.148). As iniciativas editoriais destes desenhistas não se resumiriam a estes casos; exemplo disto foi o surgimento da revista Bundas, editada por Ziraldo, em 1999.

Dentre estes cartunistas da "geração Pasquim", Borjalo chama a atenção desde cedo, em trabalhos precocemente maduros, que apontavam para os novos caminhos do cartum. Herman Lima assim comenta o trabalho de Borjalo, em seu livro História da Caricatura no Brasil, publicado em 1963:

Traço original, sintético ao extremo, embora muitas vezes esteja num detalhe mínimo justamente a própria chave da composição, nunca usando legenda para os seus bonecos, duma concepção também geralmente imprevista, quando não insólita (...). (Lima, 1963, p.1628).
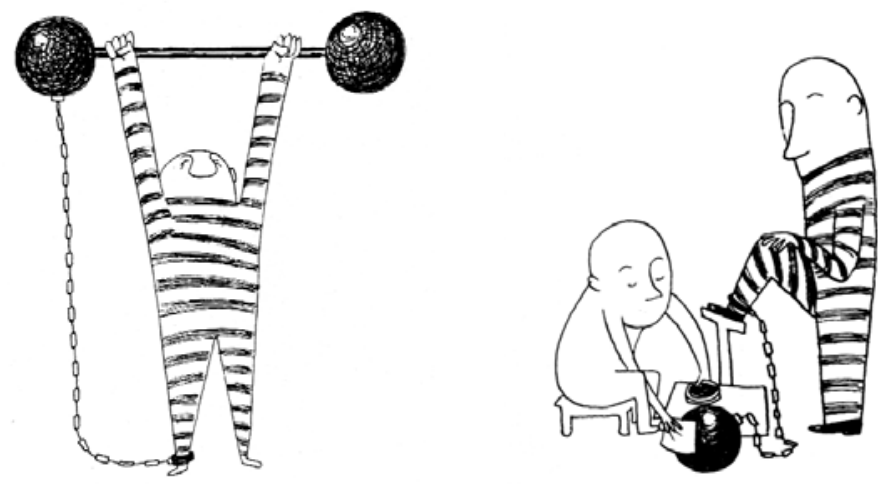

Figura 319 e 320. Cartuns de Borjalo publicados em O Caçador de Borboletas. 
Os cartuns de Borjalo publicados no livro de Herman Lima mostram um domínio daquela inovadora linguagem, conciliando já naquela época o humor mudo e o desenho simples. Seus primeiros trabalhos pareciam já trazer estes elementos, como nota Hélio Pellerino em seu texto Borjalo e a Baleia:

Lembro-me de quando Borjalo apareceu, nas Minas Gerais, como cartunista da Folha de Minas. Seu desenho era novidade integral, pela qualidade do traço, e pelo despojamento da concepção. Não havia nele nenhum excesso ou enxúndia, nada que fosse demasiado - ou dispensável. Artista magro, seu risco tinha a elegância de um toureiro espanhol em plena forma, E casado ao desenho, o humor (Lopes, 1986, p.7).

O trabalho de Borjalo é, dentre os cartunistas brasileiros, um dos que mais se aproxima do "Steinberg cartunista" dos primeiros anos na New Yorker. O livro com coletânea de seus trabalhos, O Caçador de Borboletas, publicado em 1986, é totalmente composto por cartuns de humor mudo, desenho simples, com freqüente apelo ao recurso da transformação e adaptação de objetos. Borjalo, por exemplo, faz explorações semelhantes à de Verner Witting, de novos usos de um peso para prisioneiros: se em Witting a forma circular permitia abordagens ambíguas, transformando o peso em uma bomba, em Borjalo este se transfigura em um peso de halterofilista. Esses novos usos nem sempre eram decorrência da similaridade de forma: em outro cartum, o peso vira um "sapato" a ser engraxado, a partir do cruzamento de duas situações distintas; o engraxate e o pé com peso - e este como extensão do pé. No cartum publicado na revista O Cruzeiro, em 1957, os fios de alta tensão são convertidos em "pautas musicais" a partir da presença e posicionamento musical dos pássaros. Borjalo utiliza, muitas vezes, um outro recurso que é o da contradição que coloca em cheque a atitude do personagem: enquanto um caçador se prepara para atirar em vários pássaros, um pombo correio lhe traz uma carta em outro caso, um caminhão que transportava tron-
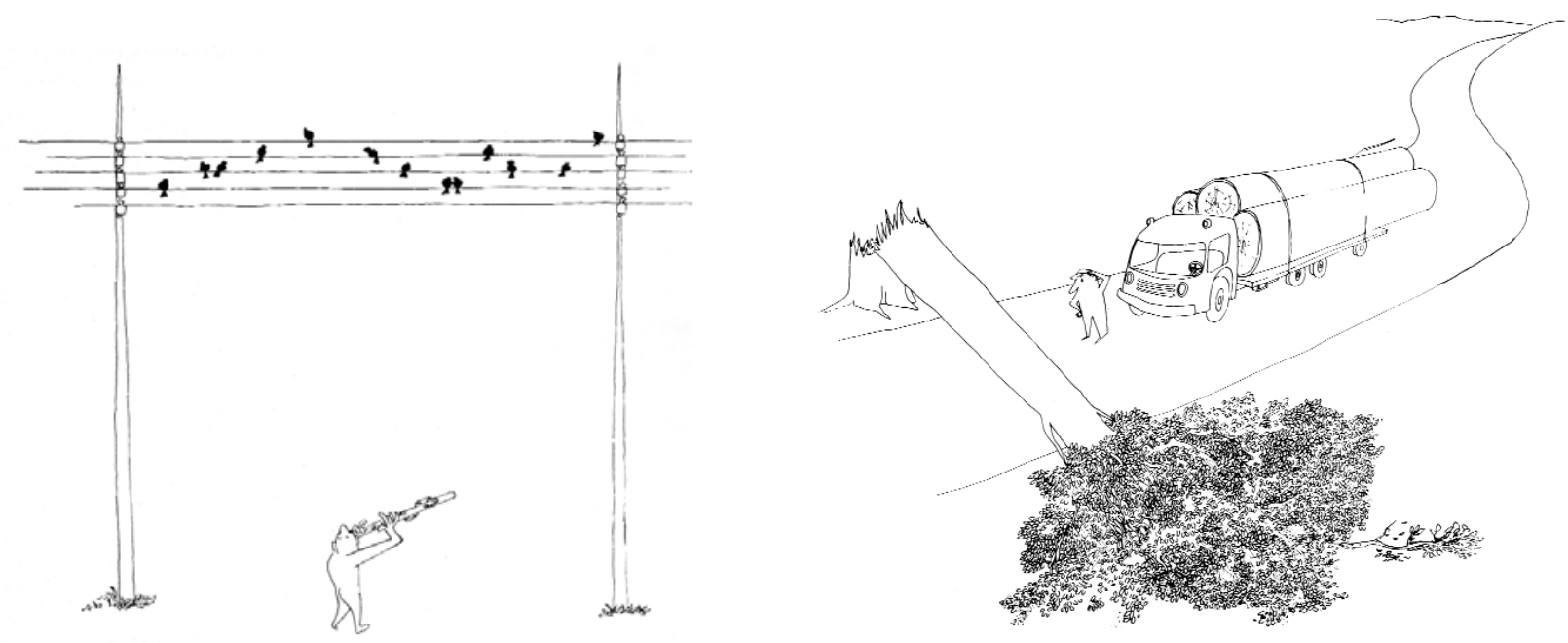


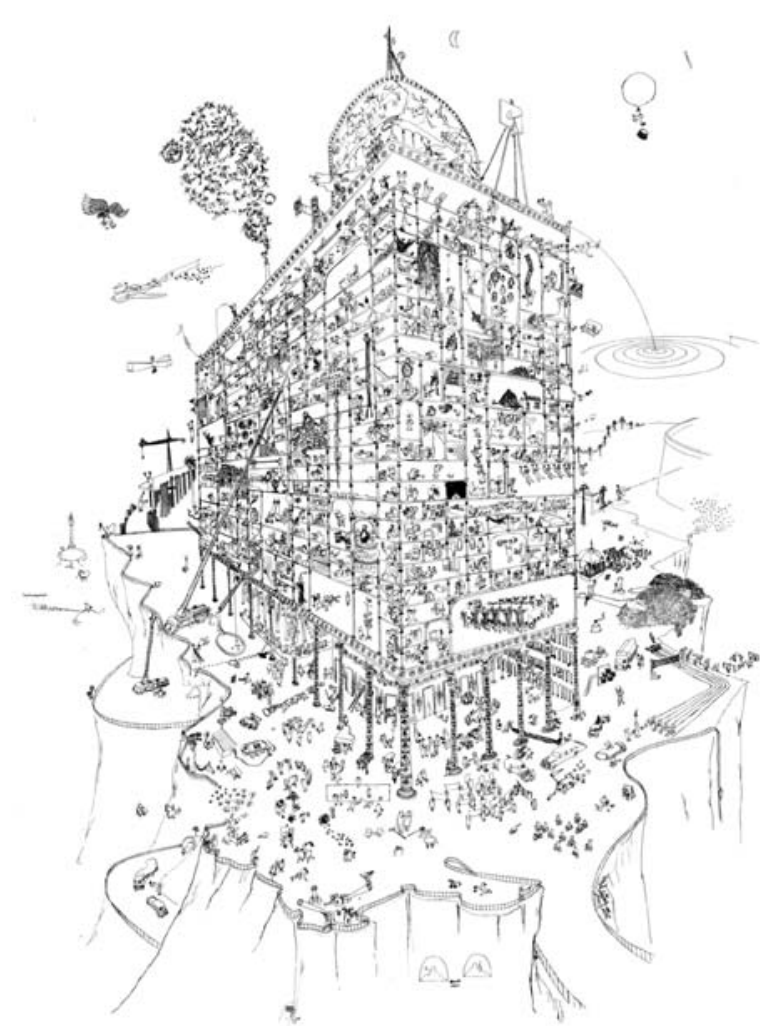

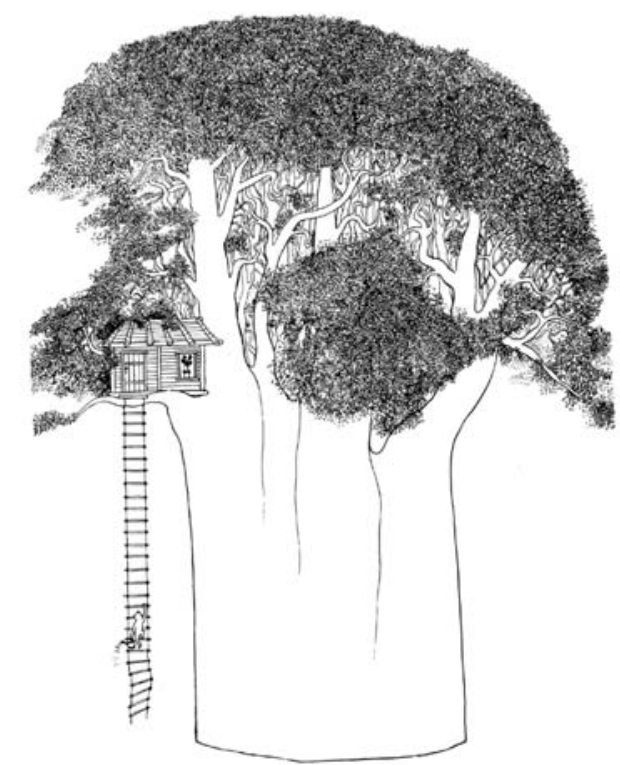

Figura 321-323. Cartuns de Borjalo

Figura 324. (ao lado) Borjalo, O Reencontro Neja com Lupa).

cos de madeira tem seu trajeto interrompido por um outro tronco caído sobre a estrada. Ao contrário de Steinberg, que por vezes conduzia seu desenho simples a cenários com construções e interiores cheios de detalhes, os cartuns de Borjalo seguem a linha depurada, sem conferir atenção às questões do estilo. Dentre as exceções, um cartum publicado na revista Manchete em 1955, que carrega nos detalhes da copa de uma exuberante árvore, em contraste à situação do personagem que se dirige à cabana de madeira para regar uma flor. $\mathrm{Ou}$, em especial, no trabalho O Reencontro - Veja com Lupa, de tamanho 1,5 x 0,75m, com vista panorâmica de uma construção que abriga diversos pequenos cartuns e vinhetas, lembrando um pouco as Panorami de Steinberg publicadas na Itália. O cartunista viria a ingressar em 1966 na Rede Globo, passando a privilegiar a televisão - foi o criador da vinheta que deu origem ao "plim plim", usada na intercalação entre filmes e comerciais.

No livro de Herman Lima, outros dois cartunistas comentados pelo autor poderiam ser citados: Hilde e Fortuna. Hilde Weber, àquela época já com trabalho maduro, dona de um estilo sintético e traço solto, não era do time da "geração Pasquim". No entanto, as características modernas de seus cartuns impelem Herman Lima a fazer comparações com Steinberg, na única citação ao artista da New Yorker nas 1800 páginas do livro:

[Hilde] realizou-se como caricaturista, e dificilmente outro artista terá alcançado as culminâncias a que se alçou, em atmosfera tão ingrata, dando ao gênero uma dignidade que só encontramos em alguns raros, a exemplo de Steinberg, comparação fatal. Seus bonecos da Tribuna da Imprensa, basta dizer que dispensam legenda e tão fabulosamente exprimem sua sátira contundente, para ter dito tudo" (Lima, 1963, p.1605). 
Figura 325. Cartum de Hilde, publicado na Tribuna da Imprensa, 1954

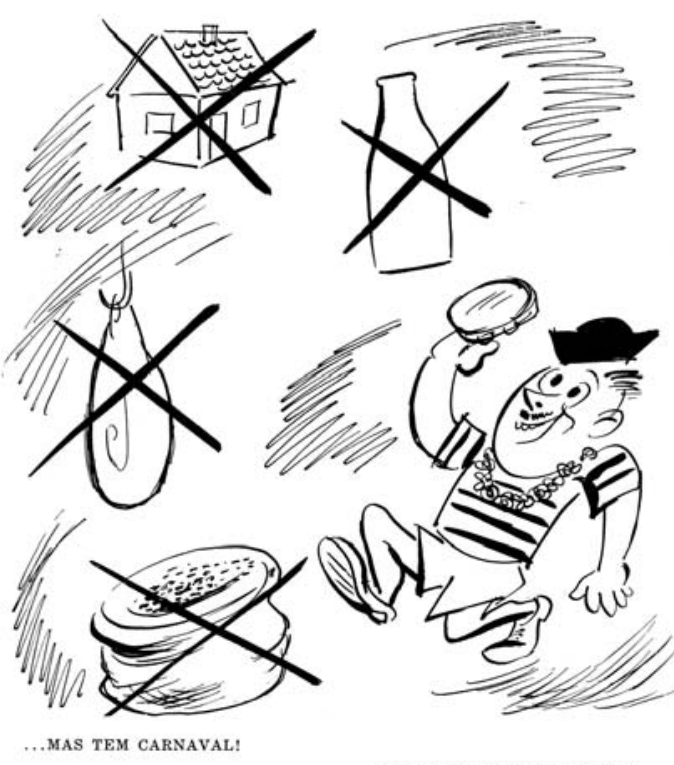

Tribuna da Imprensa (7-2-1954).

Ao comentar o trabalho de Reginaldo José, o Fortuna, Herman Lima enxerga, mais uma vez, sinais das transformações pelas quais o cartum vinha passando: "Como acontece com os humoristas brasileiros atuais, geralmente seus trabalhos não trazem legenda, falando por si, muito embora a linguagem complexa de várias de suas composições. Seu humorismo, porém, é espontâneo, sem prejuízo da dose de leve sarcasmo comum à maior parte dos seus desenhos" (Lima, 1963, p.1607). Fortuna chegou a expressar claramente seu posicionamento moderno, posteriormente: "Eu me identifico com os modernistas, na sua busca pelo apuro formal e na fuga do figurativismo fácil", disse certa vez (cit. por Maringoni, s.p., website). Como observa o cartunista e jornalista Gilberto Maringoni, "o desenho de Fortuna foi também fortemente influenciado pela geração de cartunistas europeus surgidos na esteira do pósguerra, como Saul Steinberg, Sempé, Bosc, André François, dentre outros. O rompimento com a caricatura clássica, quase acadêmica, e a aproximação do desenho de humor com as artes plásticas dessa geração seduziu Millôr Fernandes, Ziraldo, Jaguar, Claudius, Borjalo e evidentemente Fortuna (...)" (Maringoni, s.p., website).

Ainda em relação ao livro de Herman Lima, chama a atenção também o trabalho de outro cartunista que despontava na época de sua publicação: Ziraldo. Ainda em início de carreira, o artista recebe um texto pequeno no livro de Lima, cuja introdução diz: "Ziraldo Alvez Pinto pertence ao grupo de humoristas que vem sucedendo, na imprensa ilustrada do Brasil, os caricaturistas políticos (...), desde que a caricatura política, por força das restrições do D.P.I., no Estado Novo, perdeu definitivamente entre nós o ímpeto de tantos anos" (Lima, 1963, p.1609). O cartum publicado no livro, apesar do tema nacional, curiosamente apresenta uma estilização steinbergniana nos apetrechos da fantasia da carnavalesca. O texto de Lima não cita Steinberg, mas o próprio Ziraldo viria a manifestar sua admiração pelo artista. A filha dele, Daniela Thomas, evidencia tal apreço em um comentário: "(...) para mim e meus irmãos, e todos os que freqüentaram ou ainda freqüentam o estúdio do meu pai, Ziraldo, 

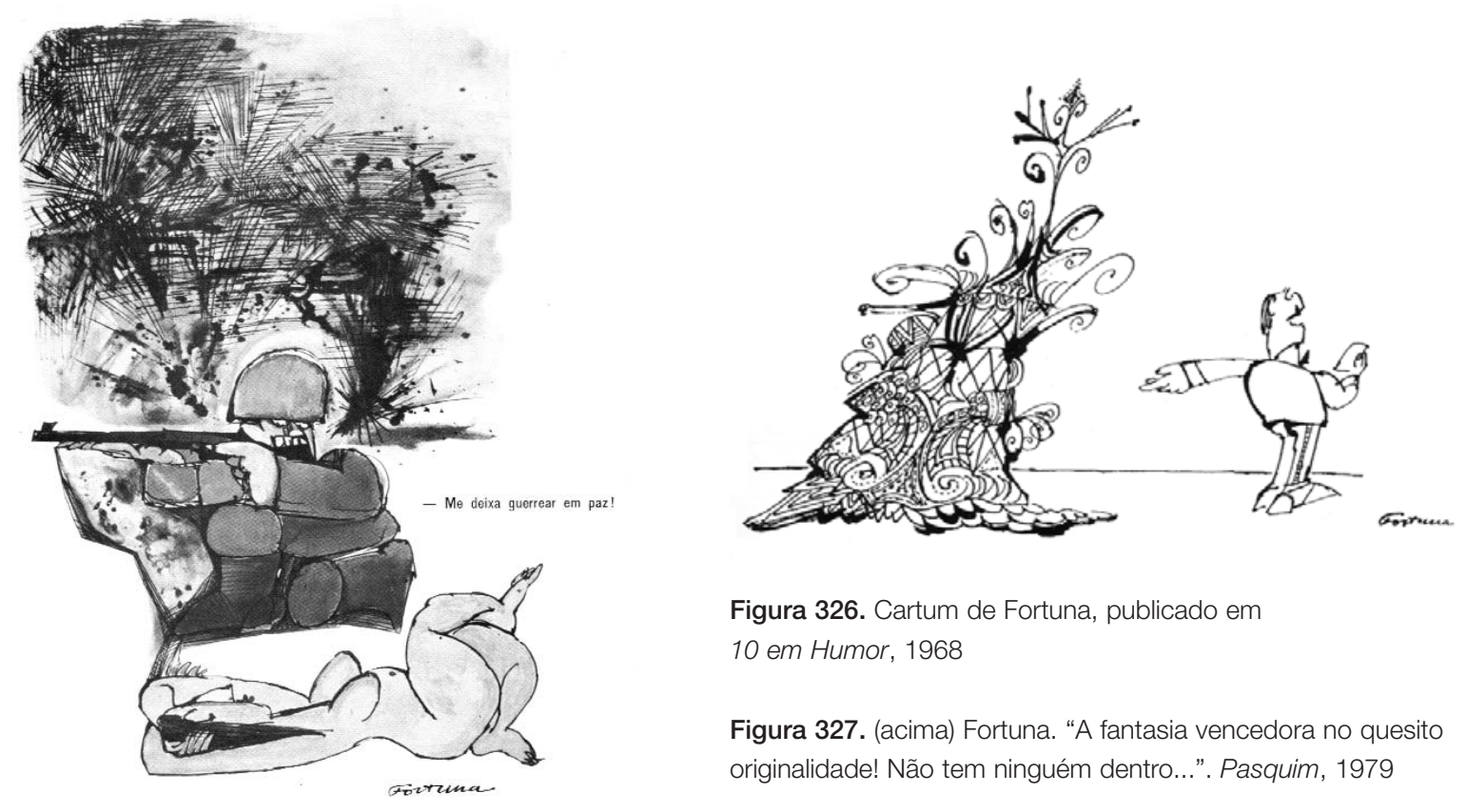

Figura 326. Cartum de Fortuna, publicado em 10 em Humor, 1968

Figura 327. (acima) Fortuna. "A fantasia vencedora no quesito originalidade! Não tem ninguém dentro...”. Pasquim, 1979

Steinberg era e é, o Rei" (Thomas, 1999, p.128). Na análise da extensa obra de Ziraldo - em cartuns, livros infantis, quadrinhos, cartazes, murais, capas de livros -, no entanto, Steinberg assume presença em seus aspectos mais amplos, na compreensão moderna do desenho. Apesar de algumas peculiaridades se apresentarem sutilmente, como na silhueta de homens narigudos, o trabalho de Ziraldo congrega as lições de Steinberg às experiências e referências visuais dos cartazistas e artistas modernos. O extenso mural de 180 metros quadrados A Última Ceia, pintado originalmente no Canecão, no Rio de Janeiro, evidencia essas influências, na mistura de elementos de Picasso - como nos animais da arca -, na costura estilística
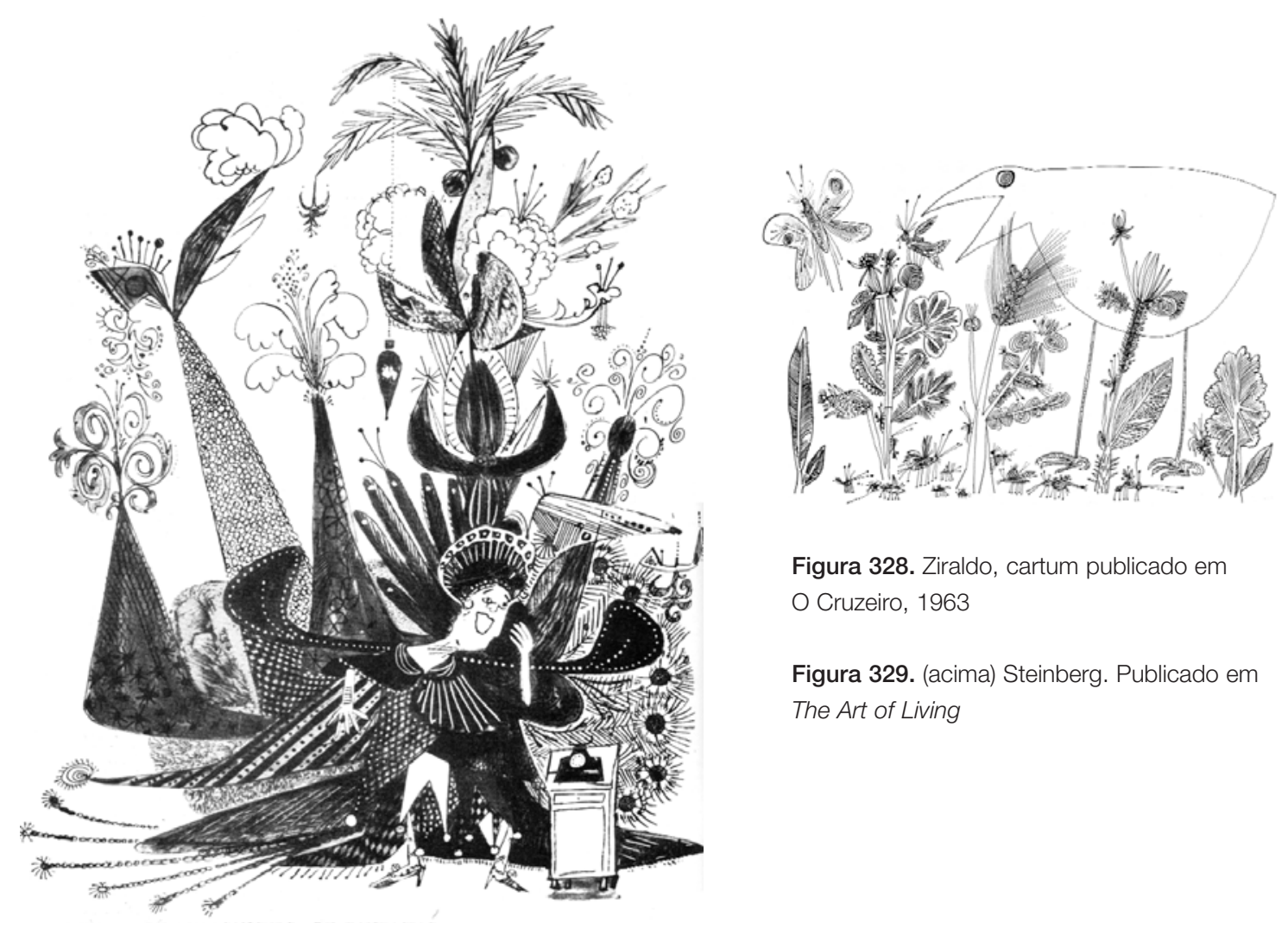

Figura 328. Ziraldo, cartum publicado em O Cruzeiro, 1963

Figura 329. (acima) Steinberg. Publicado em The Art of Living 
Figura 330. Cartum de Ziraldo

Figura 331. (abaixo) Ziraldo, mural A Última Ceia

Figura 332. Cartum de Jaguar, revista Senhor, 1960

Figura 333. Cartum de Jaguar, publicado na coletânia Átila, você é Bárbaro, 1968

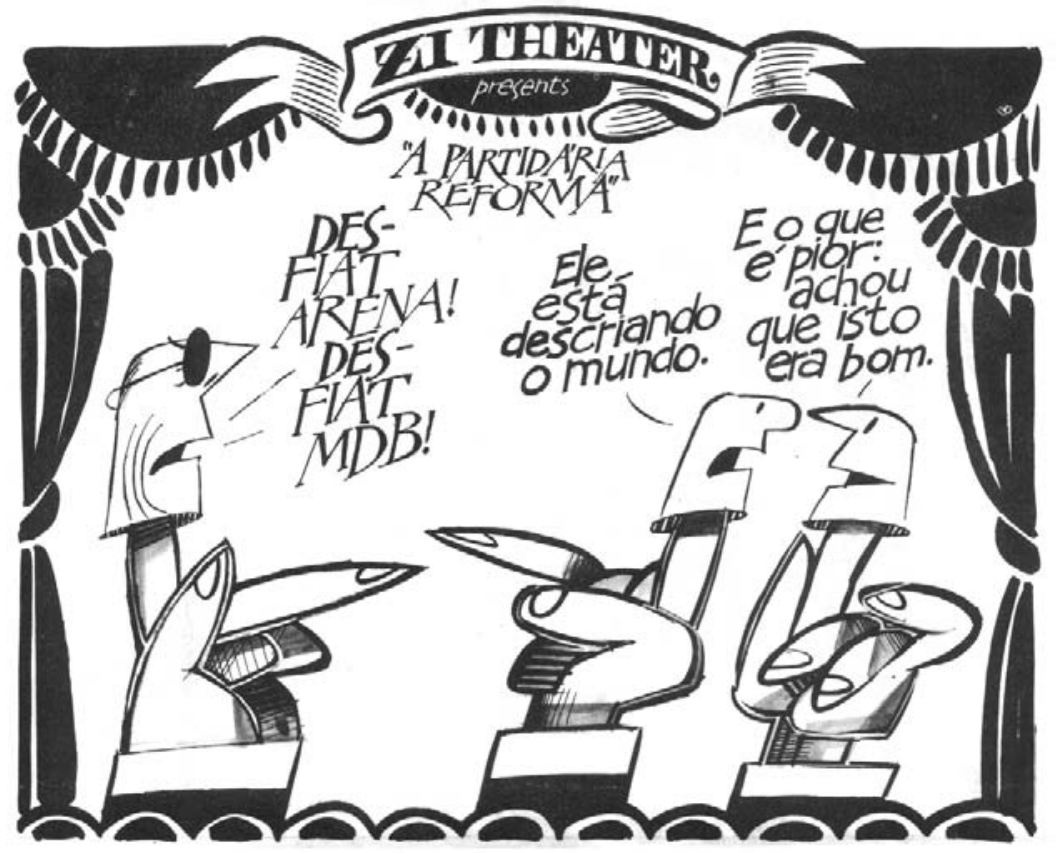

"cubista" que procura conferir unidade ao trabalho, no bebum que mescla o homem narigudo do cartum de Steinberg ao Dubbonet de Cassandre. O Ziraldo cartunista fez muitos trabalhos mudos, que de fato recordam Steinberg, mas são mais frequentes as situações com conversas e comentários, expostos em sua peculiar tipografia. Carlos Castello Branco assim descreve a linguagem de Ziraldo:

Nessa capacidade de aprofundar ambigüidades e analogias, com um nítido espírito político, está a força expressiva de Ziraldo. Sua linguagem, como é da natureza da charge, é o desenho e a palavra rápida, às vezes só o desenho e o título, ou só mesmo o desenho. Ele não é um caricaturista como Lan, mestre do gênero, embora faça também, quando necessário, suas caricaturas, com o melhor traço. (...) caricaturar ele caricatura, mas seus personagens não são específicos, não são pessoas determinadas, são símbolos, homens e objetos representativos de uma situação ou de uma condição, o que lhe permite dimensionar seu riso e sua violência numa escala superior de grandeza (Branco, 1975, p.6).

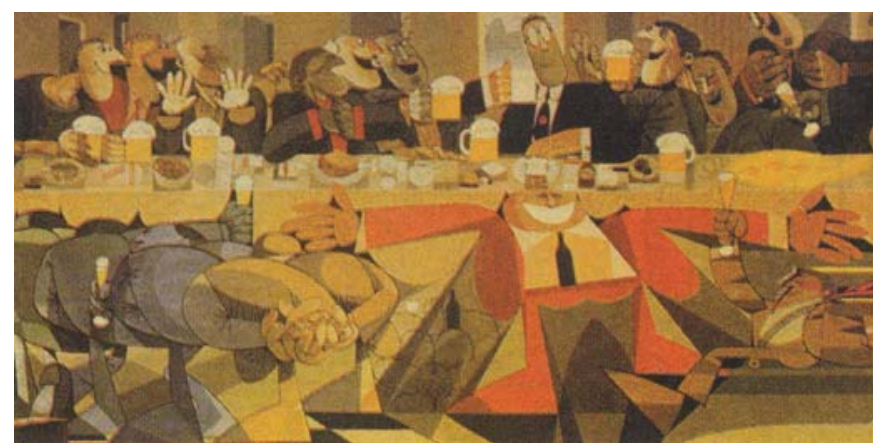




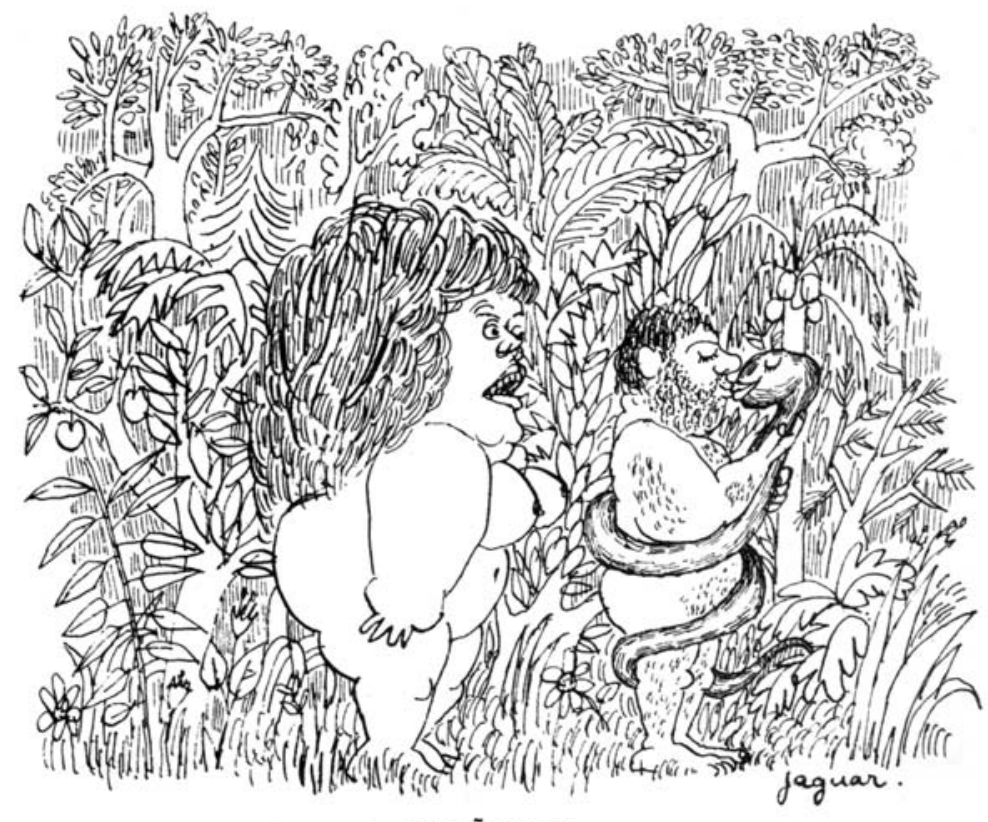

- ADÃO!!!

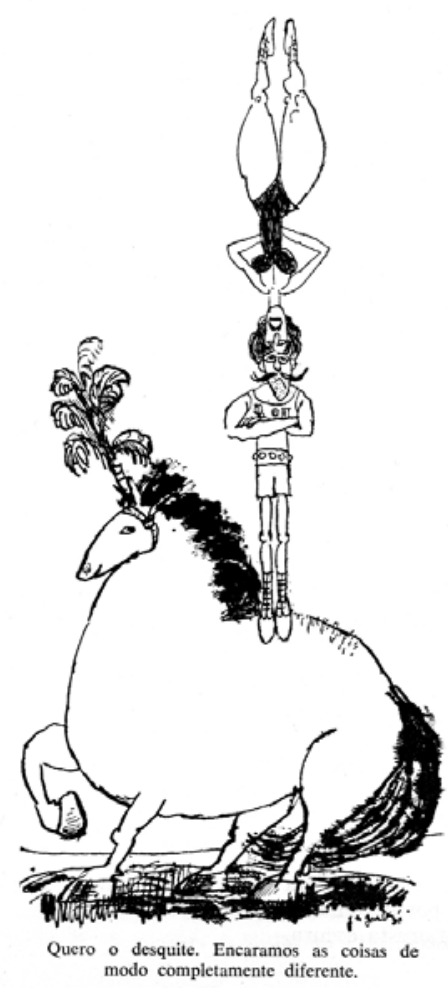

modo completumente diferente.

O caráter universal apontado por Castello Branco reside no personagem narigudo, de desenho sintético, tão ao gosto de Steinberg. Quanto ao desenho dos personagens, Ziraldo tende a buscar contornos mais precisos e geométricos que os de Saul, em um traço forte, rápido, incisivo. Co-fundador do jornal O Pasquim em 1969, e talvez o mais popular dos cartunistas brasileiros desta geração, Ziraldo desenvolveu um trabalho diversificado, de grande alcance e originalidade.

Fundador do Pasquim, Jaguar é, segundo Corrêa do Lago, "o humorista de maior e mais constante presença na imprensa nos últimos 30 anos", ao lado de Millor Fernandes (Lago, 2001, p.156). Dentre os cartunistas da "geração Pasquim", talvez seja ele o que mais demonstra em seu trabalho a influência do André François cartunista, como o de The Tattooed Sailor, pelo traço sujo e humor corrosivo. De qualquer modo, vale lembrar que o próprio André François apresentava nesta fase uma clara abordagem steinbergniana. No trabalho do brasileiro, no entanto, seria mais frequente o humor com legendas, apesar dos vários cartuns mudos criados. Em comparação com Steinberg e François, o traço de Jaguar

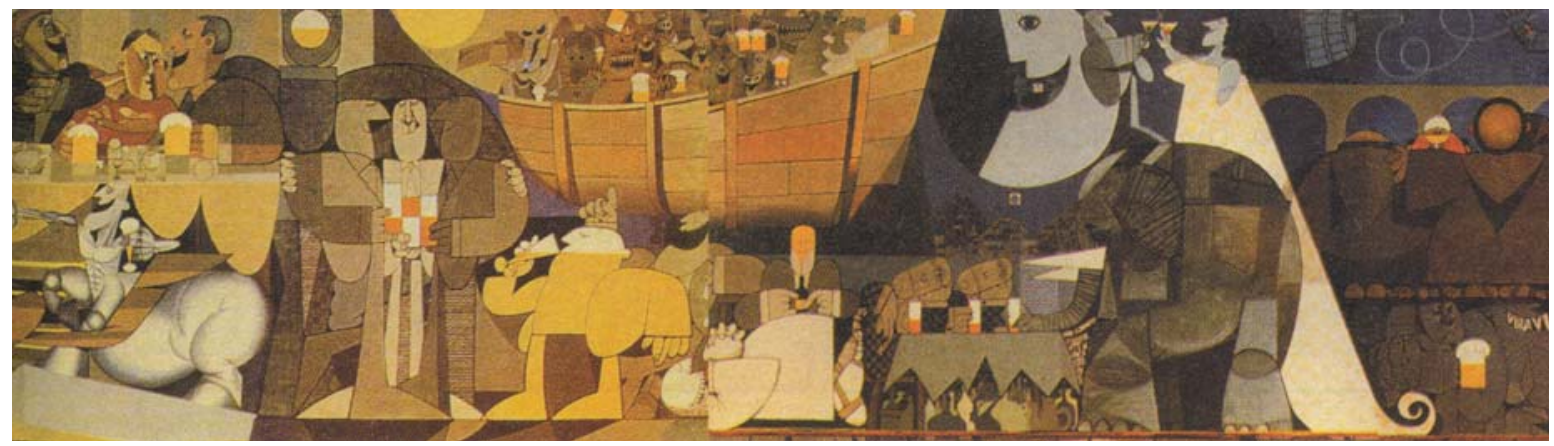




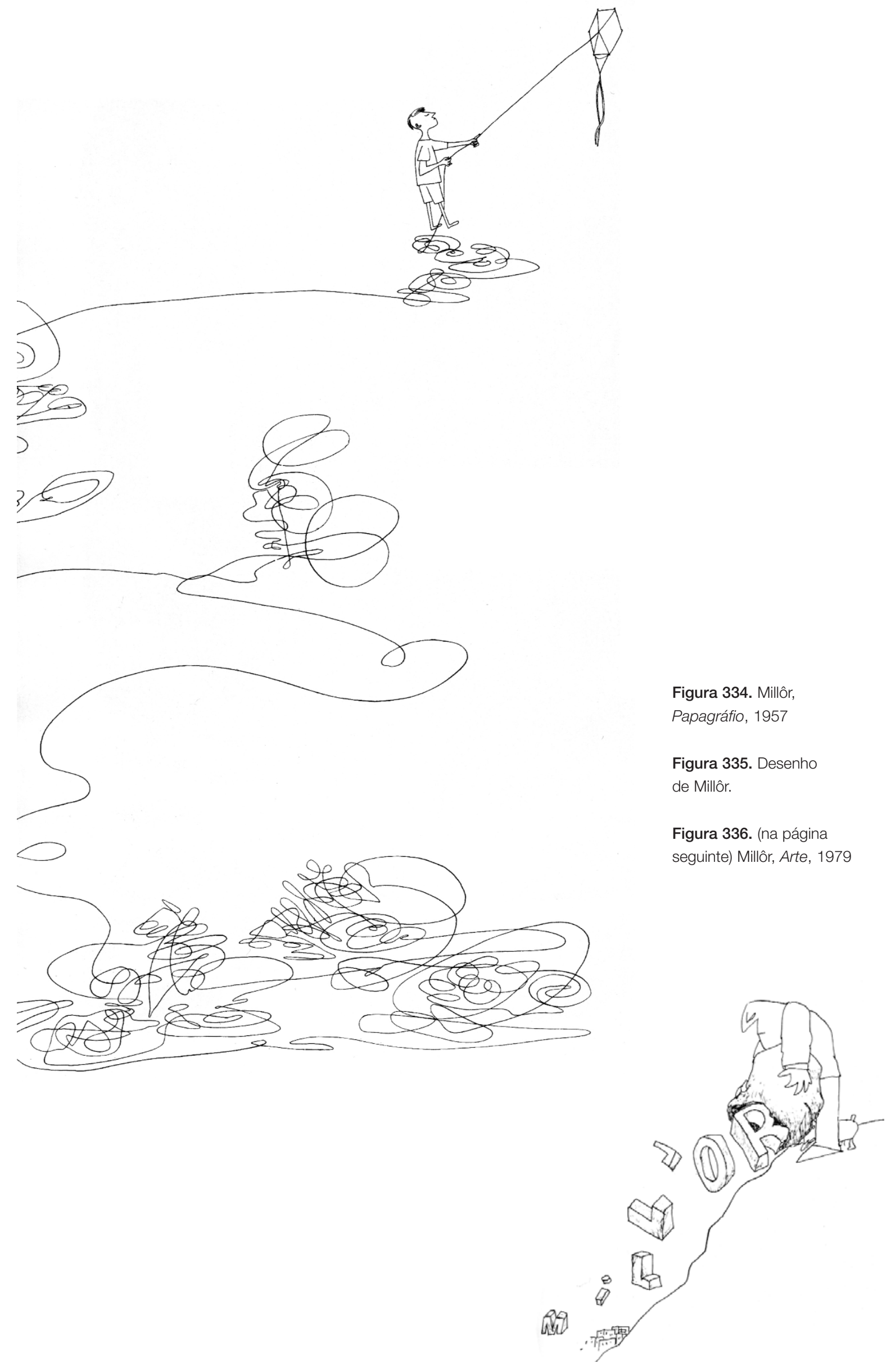


é mais "infantil", trêmulo, ácido; seu desenho é "desleixado, por vezes próximo à garatuja" (Melo, 2006, p.116). A caracterização dos personagens, em muitos casos, procura ressaltar a maldade, insanidade, ironia, ou o cinismo destes. Já o tom de seus cartuns alterna momentos de sutileza com de humor sujo e irreverente, como no cartum que mostra uma Eva traída, publicada na revista Senhor em 1960. Na coletânea Àtila, você é Bárbaro, publicado em 1968, é possível constatar a variedade de abordagens de Jaguar. A ambigüidade gráfica é exposta em um cartum que explora a semelhança de formato entre um tapa-olhos e uma medalha. Mais freqüentes, no entanto, são as contradições, analogias e situações absurdas, acompanhadas por legendas com frases simples. Um exemplo é o cartum de malabaristas de circo, em que uma analogia é feita entre o relacionamento do casal e o modo como se apresentam.

Segundo Pedro Corrêa do Lago, Millôr exerceu "liderança" e foi o "mentor intelectual de um grupo de brilhantes cartunistas que reconheceram sua influência como fundamental (Ziraldo, Fortuna, Claudius, Jaguar)". Também atuou como um dos maiores admiradores e divulgadores do trabalho de Steinberg e André François, "cujas obras apresentou a seus amigos no Brasil" (Lago, 2001, p.148). Um dos maiores expoentes do desenho de humor no Brasil na segunda metade do século XX, autor de livros, peças teatrais, traduções literárias, álbuns de humor, livros ilustrados e de poesia, Millôr assume Steinberg como um dos artistas que mais admira: "Steinberg é um artista da maior importância. Eu não conheço ninguém que tenha tanta criatividade e profundidade" (cit. Rocha, 2000, p.2). Ele chega a dividir um prêmio com Saul em 1955, o primeiro lugar da Exposição Internacional do Museu da Caricatura de Buenos Aires. Muitas vezes comparado a Steinberg, um recente texto de Sheila Leirner sobre Millôr faz o mesmo em várias passagens. A começar pelos parentescos e influências no trabalho do brasileiro; considerado um criador "sem semelhantes em nosso país", Leirner enxerga conexões com artistas da Europa e Estados Unidos:

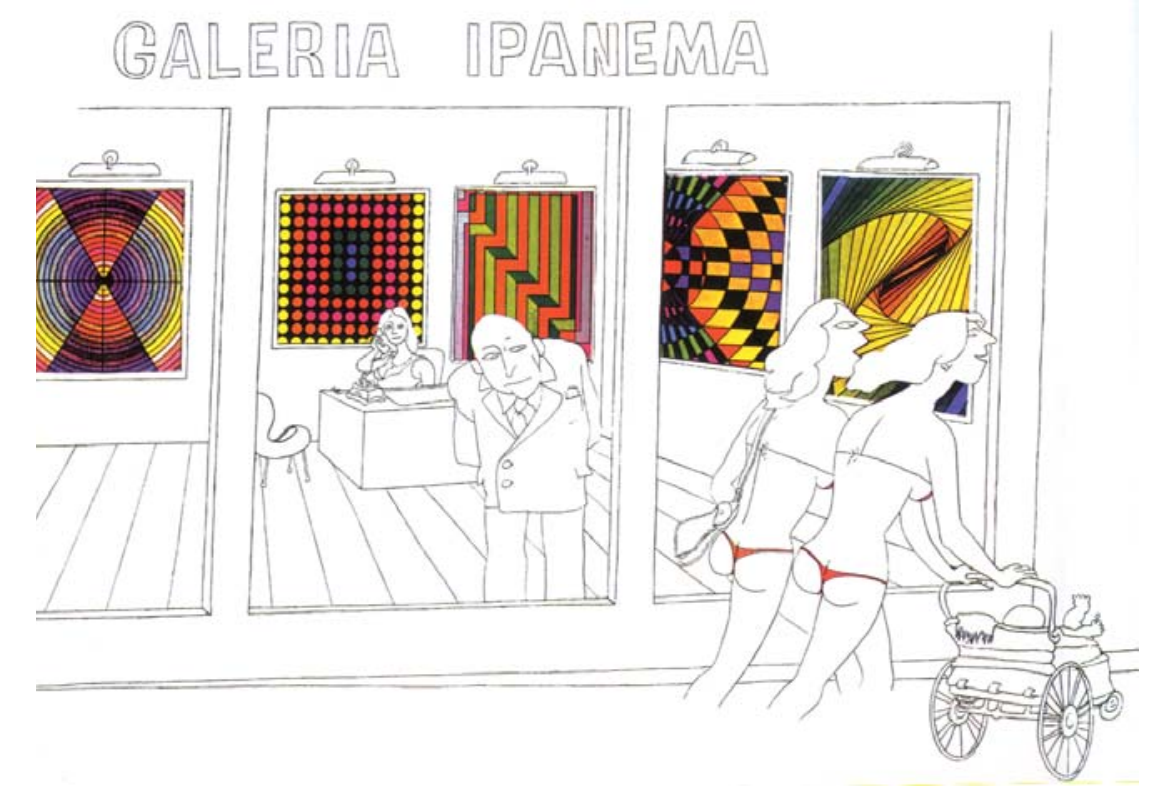


Ali, existem parentescos com os mais radicais, como os ingleses Gerald Scarfe e Ralph Steadman, o alsaciano Tomi Ungerer, os franceses Claude Serre, Bridene, e o alemão Gebhard. Além, é claro, de Siné (Maurice Sinet), Tim, Jean Effel e do eterno Saul Steinberg, tão conhecido dos leitores do New Yorker (Leirner, 2003, p.144).

Um dos aspectos abordados por Leirner é o interesse de ambos os artistas no cruzamento entre as artes, definindo o caráter híbrido de suas obras. Talvez por sua condição única "nessa marginalidade de escritor de quadros e pintor de escrituras, desenhista do pensamento, cartunista do literário, crítico do grafismo e humorista da tragédia", Millôr seria "alguém que está fora de qualquer categoria, livre para pensar, assim como Saul Steinberg (...)" (Leirner, 2003, p.140). A condição de "anomalia nas artes" - de sua não-aceitação no meio artístico - do renomado artista brasileiro é reforçada de modo elogioso por Leirner, ao aplicar a ele uma frase de Rosenberg a propósito de Steinberg: " (...) o fato de que se mantém como um estrangeiro ao "mundo-da-arte" é um problema ao qual o pensamento crítico da arte deve se obrigar a fazer face" (cit. Leirner, 2003, p.144). Ao contrário de Steinberg, no entanto, Millôr não se interessou em expor em galerias e em ser aceito pela área das Arte Plásticas. Além de dizer não pertencer a grupos, tampouco buscou pesquisas, baseadas em preocupações e temas únicos, que pudessem conferir unidade ao conjunto de seu trabalho. Para Leirner, Millôr "não é o "artista sério" da "alta arte", aquela que se baseia em "programas" conceituais e estéticos. Não é o artista "operário", "persistente" de uma "linha pictórica" ou de um "caminho gráfico" (Leirner, 2003, p.140). Nesse aspecto, há certa diferença em relação a Steinberg, que foi desenvolvendo ao longo de sua carreira determinados temas, e estimulando discursos em torno destes. Apesar da influência e de inúmeros pontos em comum, outro aspecto que diferencia Millôr de Steinberg está no desenho. É verdade que em sua fase inicial o brasileiro chegou a fazer desenhos em traço fino, sutis, a la Steinberg. O trabalho Papagráfio, de 1957, é um destes; como observa Corrêa do Lago, o trabalho apresen-
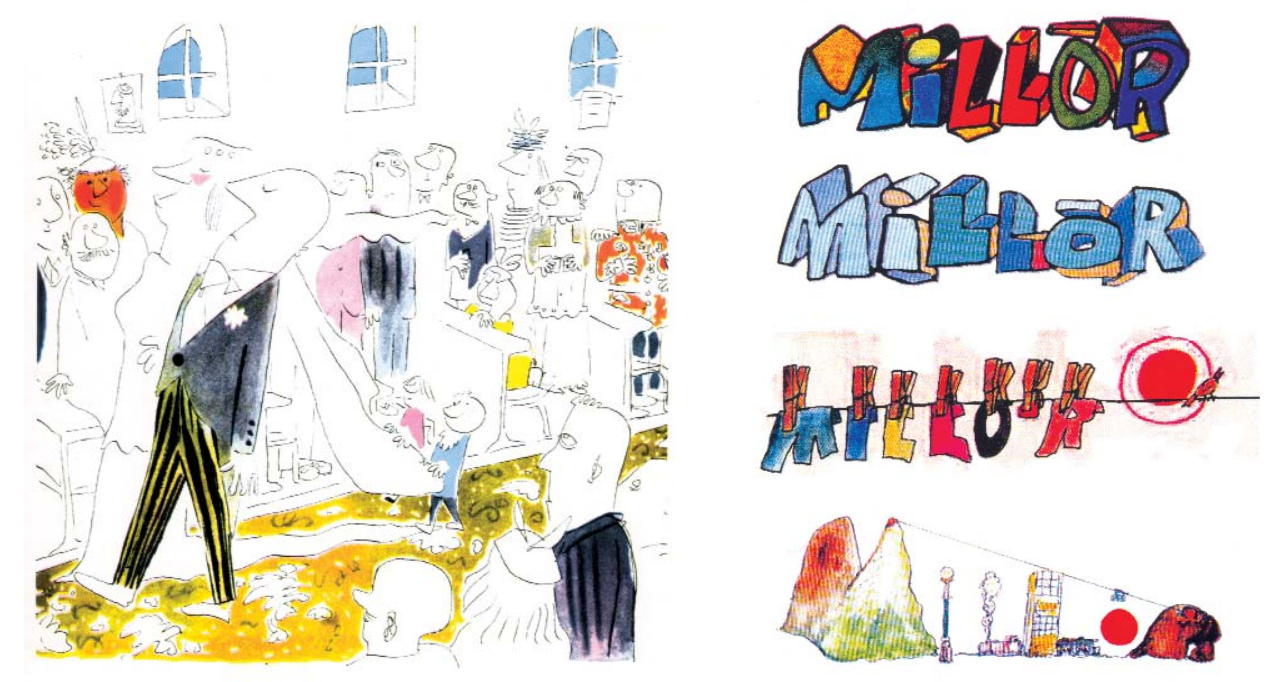
ta "a busca da elegância da linha num desenho claramente inspirado em Saul Steinberg" (Lago, 2001, p.150). Leirner também observa semelhanças em outro trabalho:

(...) O processo da forma, magistralmente domesticado por Steinberg, que desnuda a linha liberando-a de toda confusão com aquilo que ela é levada a representar, é o mesmo de Millôr quando ele desenha a série Pessoas (1975-77). Aqui, o traço se torna o presente insubmisso de todas as formas que, num mesmo movimento, o artista faz e desfaz. Elas prestam contas do vazio e do cheio em todas as suas situações (Leirner, 2003, p.145).

No entanto, seu desenho passaria a apresentar uma linguagem totalmente diversa, com traço grosso. Em comum, ainda, a influência da arte naif, do desenho de criança, que em Millôr ainda lembra Picasso, Dubuffet, o grupo COBRA. Quando questionado sobre referências neste âmbito, no entanto, só menciona um nome: "Miró talvez seja o único que tenha alguma influência no meu trabalho, com aqueles traços grossos", diz. (Cadernos, 2003, p.42). O seu interesse na arte das crianças é tal, que disse em uma entrevista: "Inúmeras vezes eu desenhei com a mão esquerda para recuperar o traço infantil" (Cadernos, 2003, p.42). Em relação ao tratamento dos trabalhos, os cartuns mudos de sua fase inicial não seriam tão freqüentes assim no desenrolar de sua carreira; assim como em Ziraldo, a palavra é elemento marcante nos cartuns dos dois, cada qual com seu peculiar estilo tipográfico.

Outros pontos em comum entre Millôr e Steinberg se fazem presentes, de qualquer modo. Dentre os mais marcantes, o uso de elementos tipográficos que se transformam em "objetos", em "outra coisa". É recorrente o uso destas experiências na própria assinatura do autor, conferindo um novo sentido a cada letra ou brincando com formatos tridimensionais. Neste último aspecto, segundo Millôr, "a inovação foi fazer uma letra com perspectiva errada em relação à outra. Mas a grande invenção foi fazer a perspectiva errada na própria letra, em todas as direções" (cit. por Rocha, 2000, p.4). Os cartuns sobre a arte também marcam

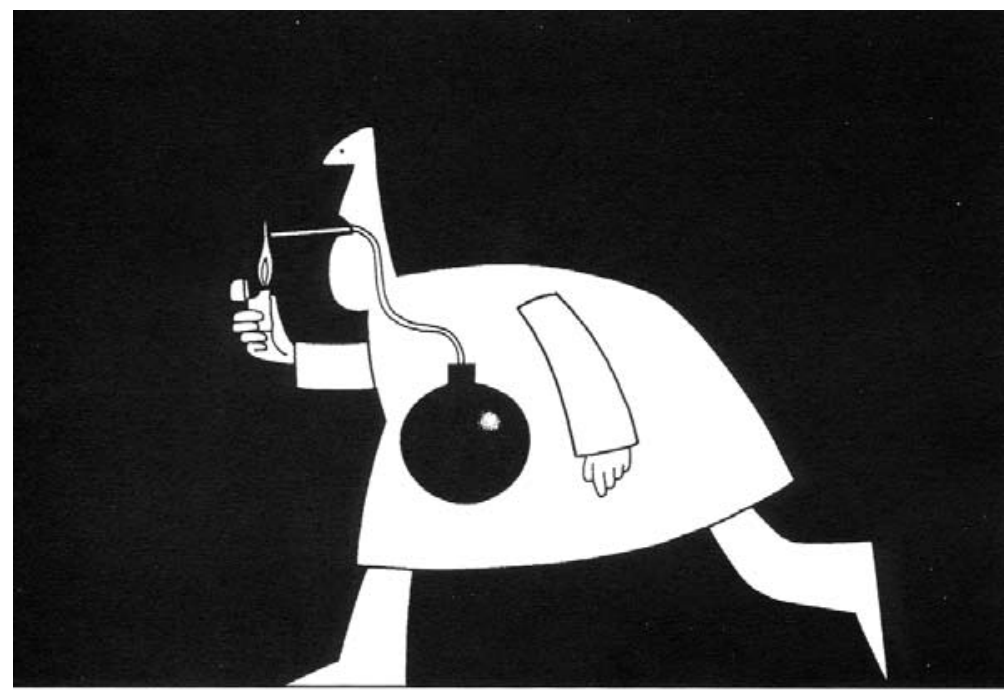

Figura 337. Millôr, 1949

Figura 338. Millôr, letras objetualizadas

Figura 339. Caulos, cartum publicado na coletâna Só Dói Quando Eu Respiro, 2001 


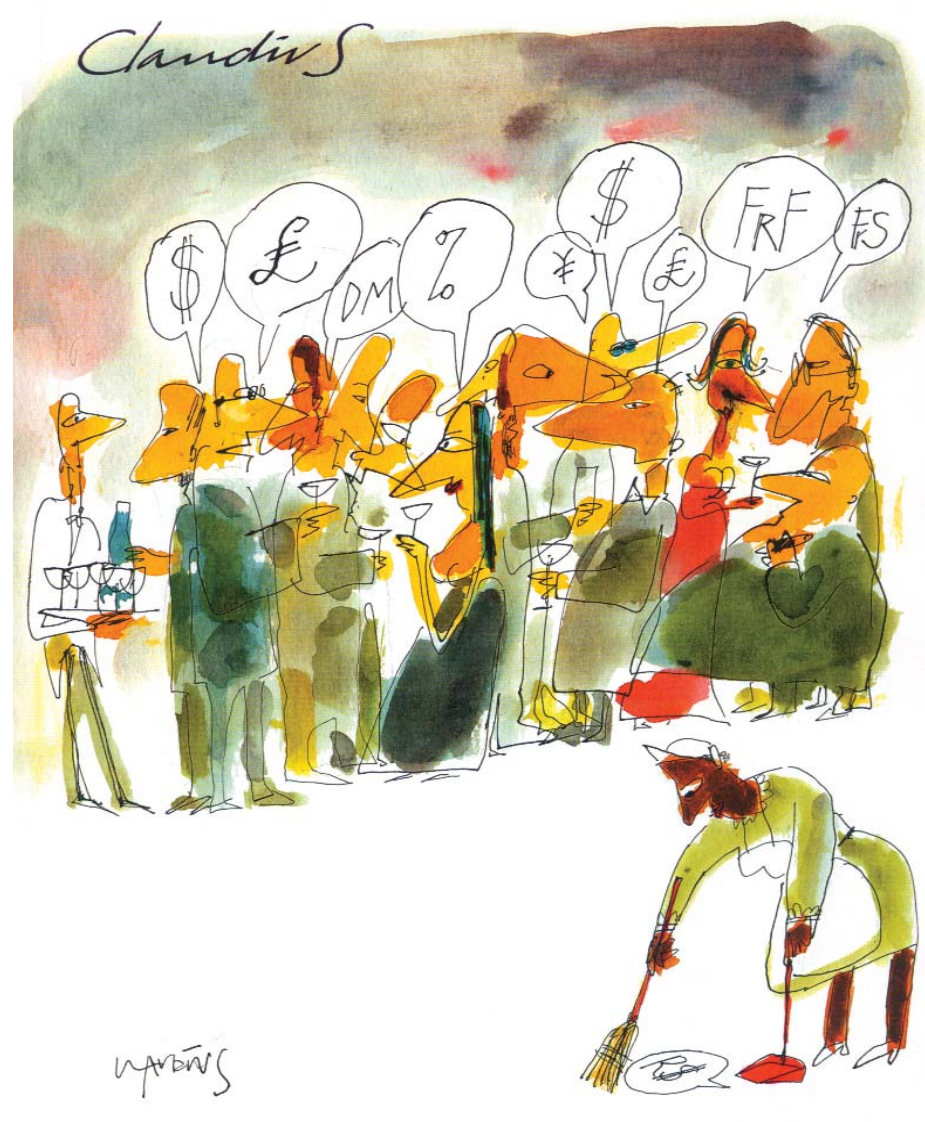

Figura 340. Claudius, cartum publicado na Bundas, 1999

o trabalho dos dois cartunistas. Segundo Leirner, "datam das décadas de 60 e 70 os melhores exemplos da crítica corrosiva exercida por Millôr, quando ele enfoca justamente as artes plásticas, como em O concreto, Estúdio, Exposição(para o famoso O Pif-Paf), Pôr-de-tudo, O ponto de vista do quadro, Enterro de Mondrian, A Abertura, Por do sol acadêmico, Arte (Leirner, 2003, p.142). A proximidade vista no trabalho de ambos influenciou até o modelo de livro escolhido para uma coletânea de Millôr: segundo Leirner, o álbum Desenhos, publicado em 1981 com apresentação de Pietro Maria Bardi e Antônio Houaiss, teve como referência o Saul Steinberg, livro e catálogo da exposição do artista no Museu Whitney (Leirner, 2003, p.140).

Outros cartunistas do Pasquim que expõem lições de Steinberg em seus cartuns são Claudius e Caulos. No trabalho de Claudius, influenciado por Steinberg e Millôr, a linha é o elemento mais marcante, mesmo com a aplicação de cores. $\mathrm{O}$ traço é fino, feito como esboço, quase contínuo. Já Caulos é o cartunista brasileiro que parece mais fazer uso da "imagem dupla" e de recursos de ambigüidade. Seus personagens narigudos são delineados em contornos firmes, seguros, em desenho bem acabado. A maior parte dos trabalhos são mudos e "gráficos", Como, por exemplo, o desenho que aproveita o formato de um cigarro para estendê-lo até o interior de um personagem, transformando-o na extremidade visível de uma bomba. Já outro mestre da linha, Henfil, não aparenta ter recebido influências de Steinberg, mas do francês Reiser, na semelhança do traço solto e cheio de movimento, e na agressividade do humor. 


\section{NAS CAPAS DA NEW YORKER: \\ OS CARTUNS FILOSÓFICOS E ALEGÓRICOS DE STEINBERG}

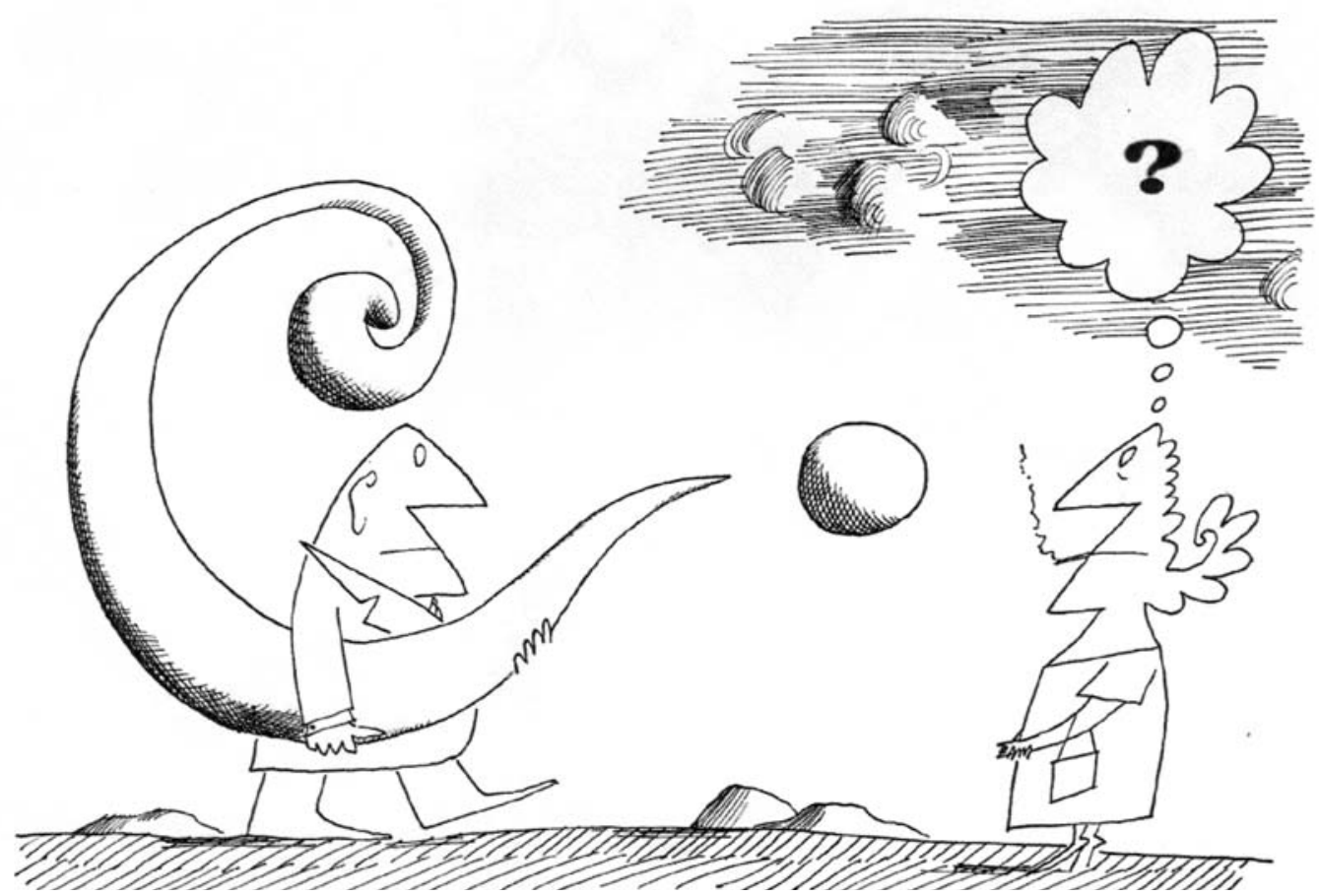

Figura 341. Steinberg, The New Yorker, 29 de julho de 1961

Por volta de 1960, não apenas a vida, mas a própria arte de Steinberg passou por grandes mudanças. Algumas destas transformações se deram, antes de qualquer coisa, geograficamente: em 1959, comprou uma "pequena, aconchegante casa" (Gill, 1978, p.72) em Springs, East Hampton (Rosenberg, 1978, p.243), localidade situada na ponta de Long Island, próxima a Amagansett (Smith, 2006, p.52). Como nota Smith, "para o resto de sua vida, 'o campo' iria enriquecer profundamente seus temas e o repertório sensitivo de sua arte" (Smith, 2006, p.52). Em junho de 1960, outra mudança: no mês em que fez 46 anos, Steinberg se separa de Hedda Sterne (Smith, 2006, p.53). Ele e Hedda, vale frisar, permaneceriam grandes amigos para o resto de suas vidas (Smith, 2006, p.259). O artista deixa o duplex situado em Upper East Side e se muda para o décimo quinto andar de um apartamento localizado no centro da cidade, parte do complexo de construções denominado Washington Square Village, segundo ele uma "utopia à la Ville Radieuse" A localização próxima a Greenwich Village o atraía, por estar sempre lotada de pessoas e turistas, um local aberto e povoado que parecia, segundo Saul, como Veneza à noite. Com os rendimentos de seu mural de Bruxelas, o cartunista compra um Jaguar 1958 índigo, e o envia para Nova York. 
Figura 342. Steinberg e Sigrid em East Hampton, 1959-60

Figura 343. Steinberg, Abstractionist, 1960. Caderno de desenhos.

Figura 344. Abstract comics, 1960

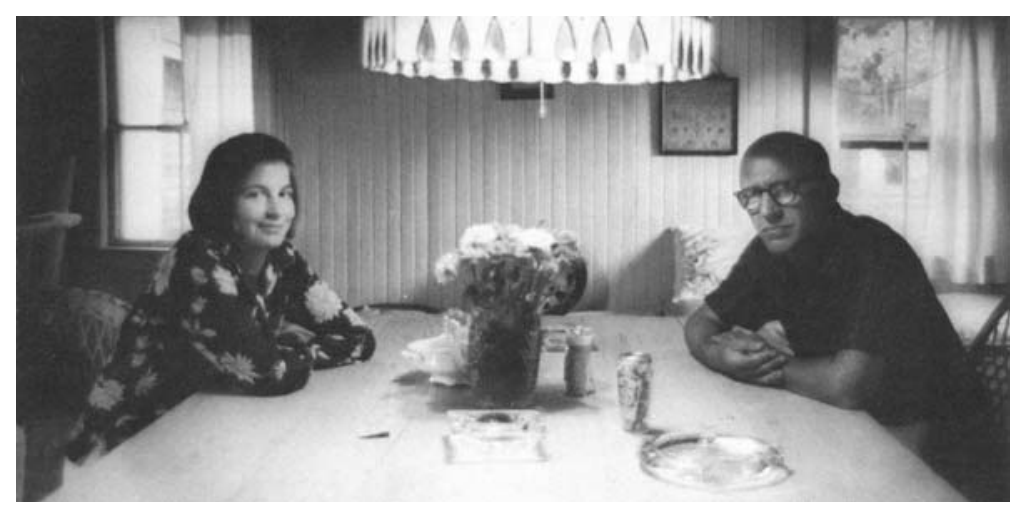

Perdas e novos relacionamentos viriam a acontecer naqueles anos. Em agosto de 1960 morre o pai de Steinberg, e em outubro de 1961, sua mãe - ambos na França, onde viviam (Smith, 2006, p.53). Em 1960 Steinberg conhece e se envolve com Sigrid Spaech, uma fotógrafa alemã e estudante de design que estava trabalhando em Nova York. Spaech nasceu em 1936, o mesmo ano em que Steinberg publicou seus primeiros cartuns na Bertoldo (Smith, 2006, p.259). Como comenta Smith, "o relacionamento, apesar de se tornar profundamente infeliz em boa parte dos 36 anos que ainda estavam por vir, foi fruto de prazer em suas primeiras estações" (Smith, 206, p.53). Steinberg chega a retirar seu bigode, sua "marca" e máscara européia, assumindo agora uma aparência americana que, acreditava, poderia permitir a ele viajar incógnito (Smith, 2006, p.53).

"Porque as pessoas chamam o trabalho de um cartunista de 'coisa'? Eles sempre dizem para mim, 'gosto das suas coisas'" (cit. por Lynes, 1982, p.42). O desconforto de Steinberg, dito por volta dos anos 1970-80, era o de um artista híbrido, que transitava por diversos campos das artes. É no começo dos anos 60 que seu trabalho começa a assumir novas direções, se tornando cada vez mais freqüente e conceitual na The New Yorker. Saul passa a privilegiar a revista, deixando em segundo plano colaborações para outras publicações. Steinberg também começa, aos poucos, a conferir nova ênfase à arte para venda em galerias, trabalhando regularmente com cores e séries temáticas. Como observa Smith, "sustentando todos essas linhas de auto-invenção está uma mudança de temperamento que divide a carreira de Steinberg em duas fases de sensibilidade, a grosso modo antes e depois e 1960" (Smith, 2006, p.54). Ao mesmo tempo, Smith já havia apontado que a imagem de Steinberg aos olhos do público, como cartunista da New Yorker, se estenderia até a metade dos anos 1960, sendo desenvolvida a partir de então sua "terceira carreira", a de artista de galerias (Smith, 2006, p.36). Deste modo, o período entre 1959 e 1966 se caracteriza por grandes mudanças no trabalho do Steinberg da New Yorker, como inovador desenhista do meio editorial. A tensão presente nestas mudanças é comentada por Joel Smith:

A profundidade da mudança se esconde debaixo das consistências superficiais de seu trabalho - mais notadamente, seu continuado uso da linguagem visual do cartum. Se no começo o cartum havia sido a linguagem nativa de suas mãos, o molde no qual ele havia encaixado de 

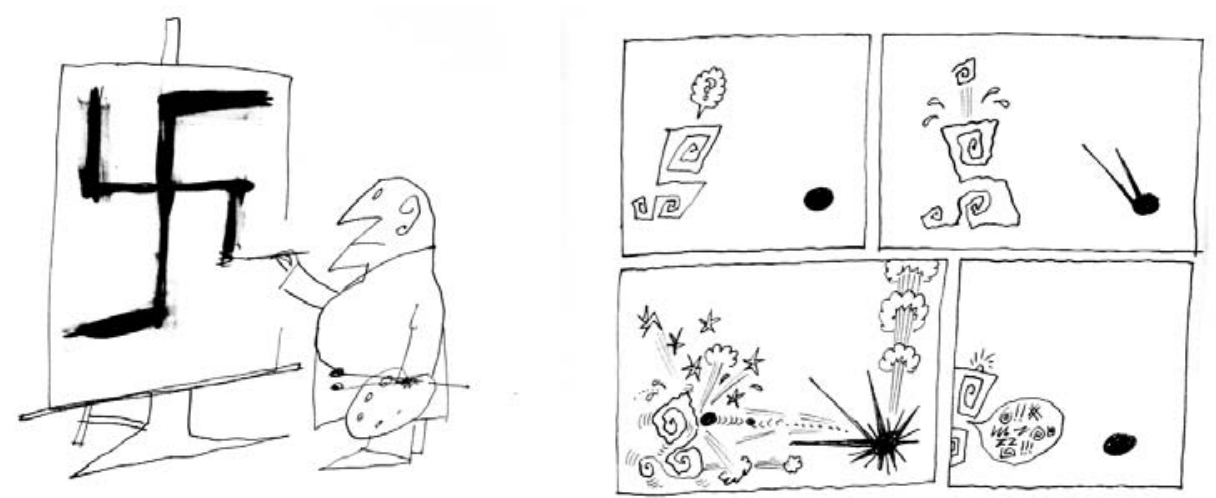

modo reflexivo todas as suas idéias, por volta de 1960 ele existia em sua mente, e na mesa de desenho, em tensão com outras possibilidades. Ele passa a se engajar na abstração, por exemplo, em um (provavelmente não publicado) cartum de 1960 que retrata um pintor gestual cuja espontaneidade ao modo de Franz Kline rende alguns resultados surpreendentes. Outro desenho do mesmo caderno de esboços mostra que mesmo quando um cartunista retira a figuração inteiramente, um cartum conduz ação narrativa (...). Os quadrinhos, com seu rico e hermético sistema de sinais, se caracteriza como uma escola de arte abstrata - apesar de ser uma facilmente compreendida por todos (Smith, 2006, p.54).

Enquanto promovia pesquisas em seus cartuns, Steinberg também foi alvo de experiências, sendo o foco de um episódio do programa de televisão Camera Three, da CBS, em 1960. Cenas que mostravam desenhos em seus livros eram acompanhadas de gravações distorcidas de música e recitais dramáticos ao modo de Ionesco, dentre outras situações. O filme é exibido no MoMA logo depois de sua transmissão na tv. O programa Camera Three viria a ser cancelado pouco tempo depois (Smith, 2006, p.259).

No final de 1960, próximo do Natal, Steinberg lança The Labyrinth. A publicação trazia à tona um de seus trabalhos mais desafiadores, em "primoroso design" (Smith, 2006, p.56). Dentre os assuntos abordados, a ilusão, arte, música, palavras, conversas, geometria, o cubo, gatos, cães, pássaros, o crocodilo, o museu, Moscou e a Samarcanda, outros países do leste, os Estados Unidos, motéis, o beisebol, cavalos de corrida, touradas, heróis, harpas, dentre outros (Rosenberg, 1978, p.243). No entanto, Steinberg experimenta, pela primeira vez, o sabor amargo das baixas vendas e resenhas de teor negativo. "Estou tão lisonjeado quanto Stendhal", contou uma vez a um amigo (cit. por Smith, 2006, p.56). Àquela altura, já estava assinalada a transição do humor popular ao trabalho "difícil". Com o tempo, a crítica passou a compreender melhor suas experiências. "A trivialidade urbana e burguesa do cartum da New Yorker assume a condição de modesta embalagem de um artista particularmente bizantino que tem algo mais substancial para nos contar", escreveu Max Kozloff no The Nation em 1966 (Smith, 2006, p.56).

Em 1961, o Journal of the American Institute of Planners dedica a parte 2 de sua edição ao artista: um especial de título Steinberg on the City, com inúmeros desenhos com 


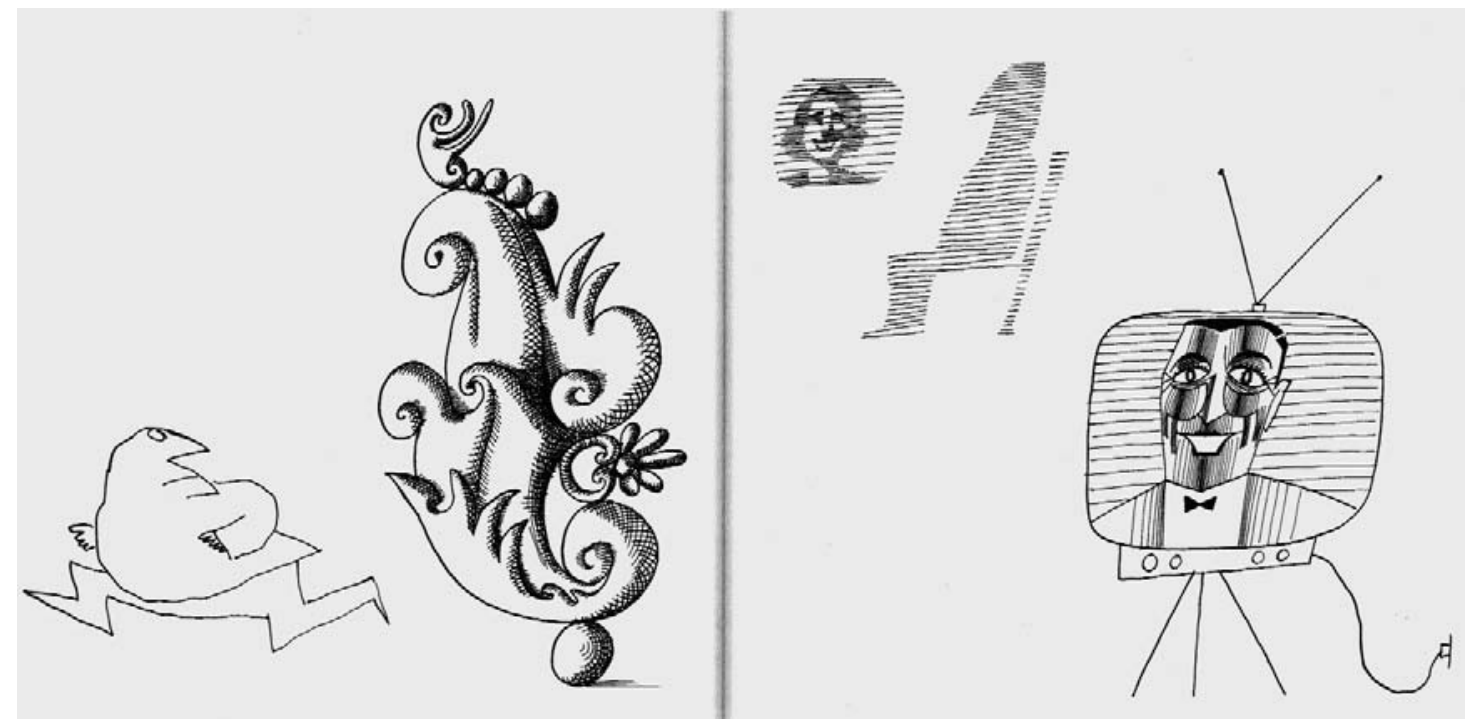

comentários sobre a arquitetura e o urbano. Os trabalhos mostram o Steinbeg cartunista, do desenho simples em linha fina - menos experimental -, dos tempos anteriores. Ainda naquele ano, o cartunista vai para a Itália, em Milão, executar um mural em sgraffitto, na entrada da Palazzina Mayer, que viria a ser destruído em 1997 (Smith, 2006, p.259). Um ano depois, um outro trabalho do gênero seria motivo para uma viagem a Israel, em outubro: o teor do convite era a execução de um mural em um navio. Steinberg foi tomado por um inesperado sentimento de afinidade e apego emocional com a nação de judeus. No final de 1962, em novembro e dezembro, ocorre a exposição Saul Steinberg and Paul Klee, realizada na The Art Gallery da Universidade da Califórnia, em Santa Bárbara, sugerindo proximidades entre os trabalhos dos dois artistas. Saul, apesar de privilegiar cada vez mais seu trabalho na revista The New Yorker, continuou trabalhando também para a Hallmark Cards até 1969, após renegociações com a empresa. Ao invés dos cartões, passa a fazer calendários de mesa coloridos chamados Sketchbooks, que ele havia começado a criar em 1960 (Smith, 2006, p.259).

Naqueles anos, Steinberg dividia suas reflexões com duas figuras importantes em sua vida e obra: o italiano Aldo Buzzi, colega dos tempos da Facoltà di Architettura, e o crítico de arte Harold Rosenberg. A amizade com Buzzi havia sido retomada, após o turbulento período de guerra, em 1945. Naquele ano, Saul chegou a enviar dinheiro e ajuda para o amigo, em Milão, assim como para Ada Ongari, namorada dos tempos na Itália. Buzzi, depois de dividir seu tempo entre o trabalho como escritor e designer de filmagens para diretores como Alberto Lattuada e Federico Fellini, passa a se dedicar totalmente à carreira de autor literário, com o apoio e encorajamento do amigo cartunista (Smith, 2006, p.254). De muitas das conversas e cartas trocadas com Buzzi, ficam registros da vida e do modo de pensar de Steinberg. Em 1962, escreve ao amigo: "Admiro mais e mais a qualidade literária das pessoas, quero dizer, a possibilidade de recontar um fato ou fazer uma observação verdadeira e apropriada. A maioria das pessoas transforma as coisas que acontecem a elas em coisas lidas no jornal. Aquelas que não sabem como contar as coisas me dão medo" (cit. por Smith, 

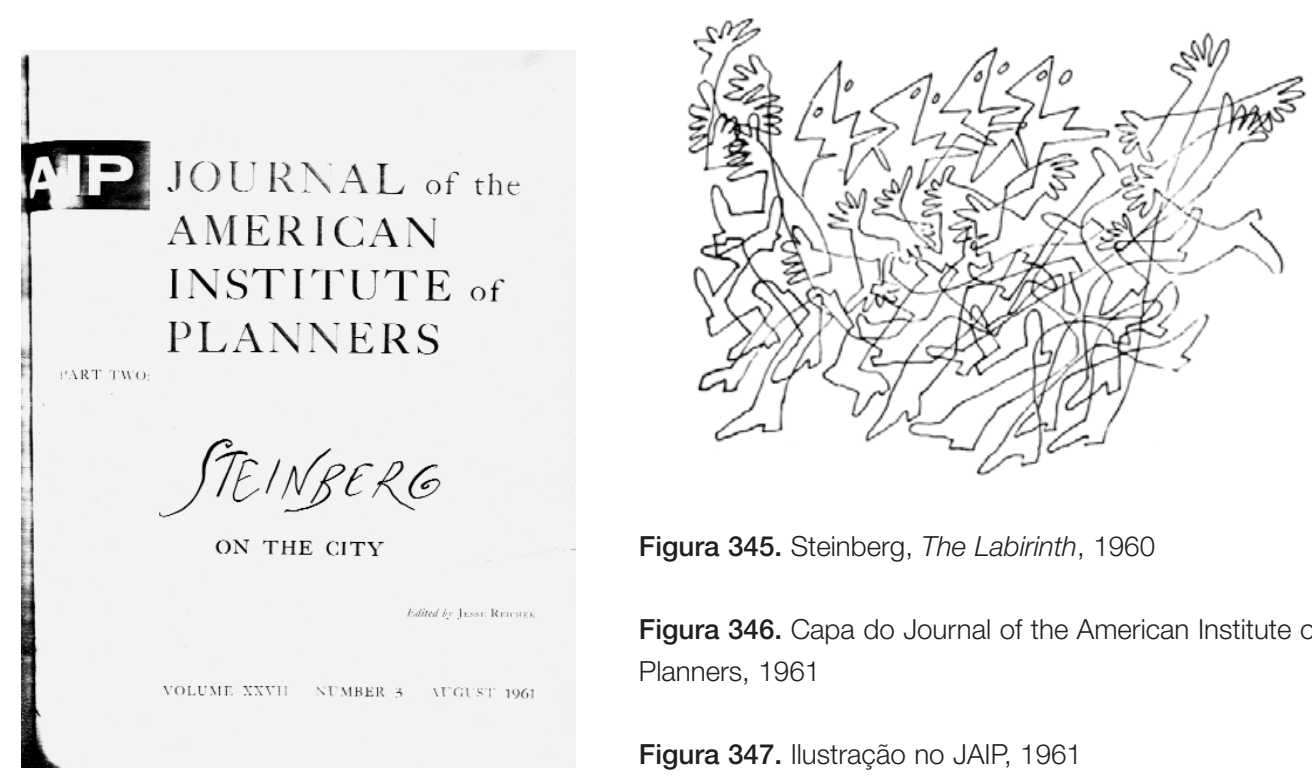

Figura 345. Steinberg, The Labirinth, 1960

Figura 346. Capa do Journal of the American Institute of Planners, 1961

Figura 347. Ilustração no JAIP, 1961

2006, p.259). Em janeiro de 1963, em outra carta, analisa o papel autobiográfico de seus desenhos: "Trabalho minhas 2-3 horas por dia, e ao olhar para o que fiz, posso perceber que me livro de terrores, etc, ao desenhá-los de uma maneira cômica - à maneira dos savages - e portanto, o que desenho é parte de um diário" (cit. por Smith, 2006, p.259). Alguns anos depois, em 1965, divide com o amigo suas impressões sobre o LSD que havia tomado: "Passei um dia de tamanha felicidade que a memória desta possibilidade existir em mim faz todo o resto ficar sem importância, reduz as misérias à sua escala apropriada. É algo muito importante que pode mudar o significado da vida". De fato, era um período de transformações, que em seu desencadeamento faziam o artista ficar imerso em dúvidas. Uma vez, indeciso sobre para onde ir ao se mudar de Greenwich Village, expõe conflitos existenciais e de identidade ao italiano: "Não tenho uma idéia clara do que eu sou ou do que quero ser. Marido? Pintor? Velho, jovem, suburbano, urbano, homem de vida social agitada, ermitão? Também: rico ou pobre?".

Já a amizade com o crítico de renome dos anos do expressionismo abstrato, Harold Rosenberg, se tornou maior e mais próxima a partir de 1963, quando este passou a escrever para a New Yorker. Rosenberg tentaria gravar as longas e discursivas conversas travadas entre ambos, mas a "autoconsciência (ou as dificuldades técnicas)" sempre acabavam com o experimento (Smith, 2006, p.259). É interessante observar como a "guinada" dada por Steinberg em seu trabalho coincide, aproximadamente, com o maior envolvimento com Rosenberg, que desempenharia papel importante na reflexão sobre sua obra.

A década de 1960 foi a que mais presenciou lançamentos de novos livros de Steinberg. Três anos após a publicação do polêmico The Labyrinth, chega às livrarias dos Estados Unidos o livro The Catalogue, uma compilação americana de material dos livros anteriores que não eram mais reimpressos em novas tiragens. Outra compilação é publicada na Alemanha em 1964: Steinberg's Paperback. Um ano depois, em 1965, Saul lança The New World, título decidido na última hora, substituto do previamente escolhido Confessions. O 

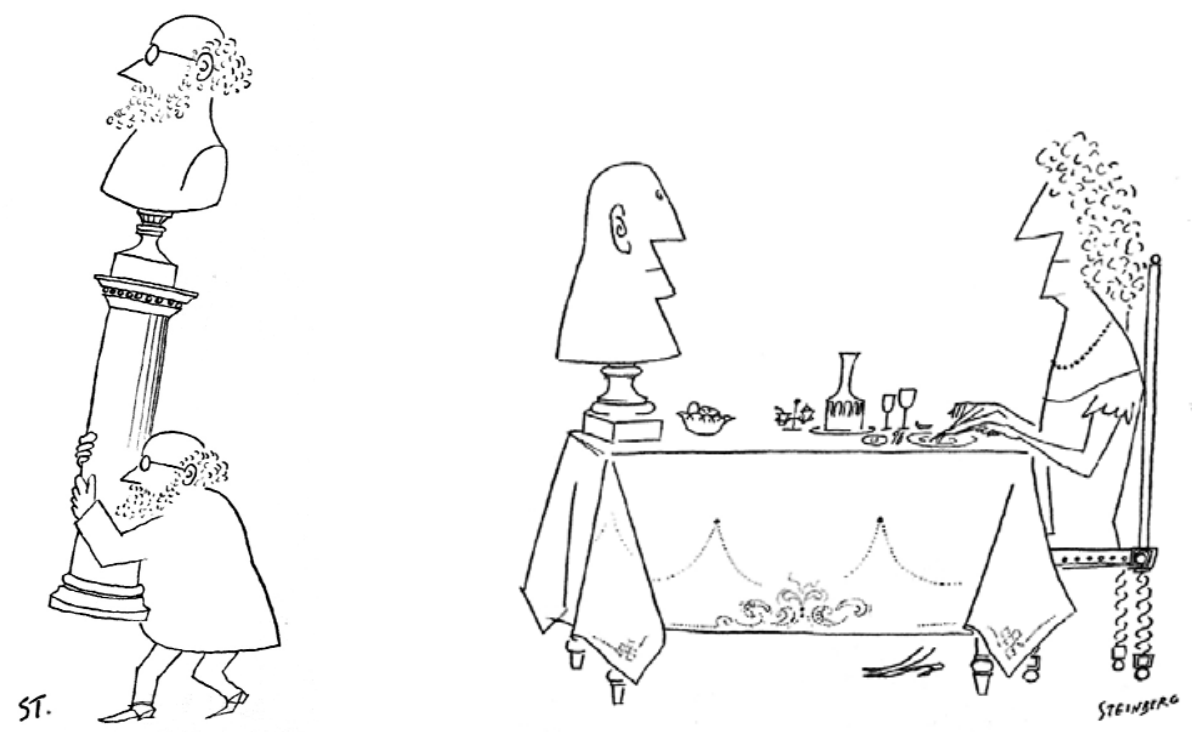

livro apresentou trabalhos que expunham, em seu conjunto, o momento mais filosófico de Steinberg, com números, círculos concêntricos, falas, geometrias, paródias de paródias, Descartes, Newton, pontos de interrogação, Giuseppe Verdi, mesas de desenhar, os desastres da fama, marcas e alegorias (Rosenberg, 1978, p.244). Por fim, em 1966, é publicada Le Masque.

As viagens, obviamente, continuaram, não apenas para a Europa e pelos Estados Unidos. Em 1963, depois de passar por Paris e Itália, segue para Atenas, Asmara e Cairo, Gondar e Addis Abeba, Bombaim. Iria retornar à África, com Sigrid ou sozinho, várias vezes ao longo dos primeiros anos da década de 1970. Sua esposa fotógrafa continuaria a visitar o continente até os anos 1980. Em 1964, Steinberg realiza novas viagens, desta vez para o Oriente: conhece Bangkok, Hong Kong, Kowloon. Passa duas semanas no Japão, em Tókio, Osaka, Nagasaki, Beppu, Kobe, Kyoto Em continente americano, merece destaque a viagem ao Wyoming, com Sigrid, e a visita a Cape Kennedy, como convidado oficial da NASA. Ali, ao assistir ao lançamento do foguete Gemini, compara sua lenta subida à levitação de figuras nas pinturas de Chagall (Smith, 2006, p.260).

\section{STEINberg E OS CARTUNS FILOSÓficos}

Uma abordagem mais filosófica já se esboçava no trabalho de Steinberg desde o começo dos anos 1950. As primeiras esfinges datam de 1953, na New Yorker. O homem que carrega seu próprio busto, e o personagem que desenha sua face com uma assinatura, insinuações de suas preocupações com a identidade, apareciam em 1954. O aspecto cômico tradicional das piadas cedia espaço, aos poucos, a desenhos de conteúdos simbólicos mais misteriosos, em interpretação menos direta. Os assuntos, de algum modo, adquiriam feições existenciais. Às esfinges e monumentos se mesclariam novos personagens. O primeiro dragão é publicado na revista em 1958. Não demoraria a receber a companhia do cavaleiro, um ano depois, em um 

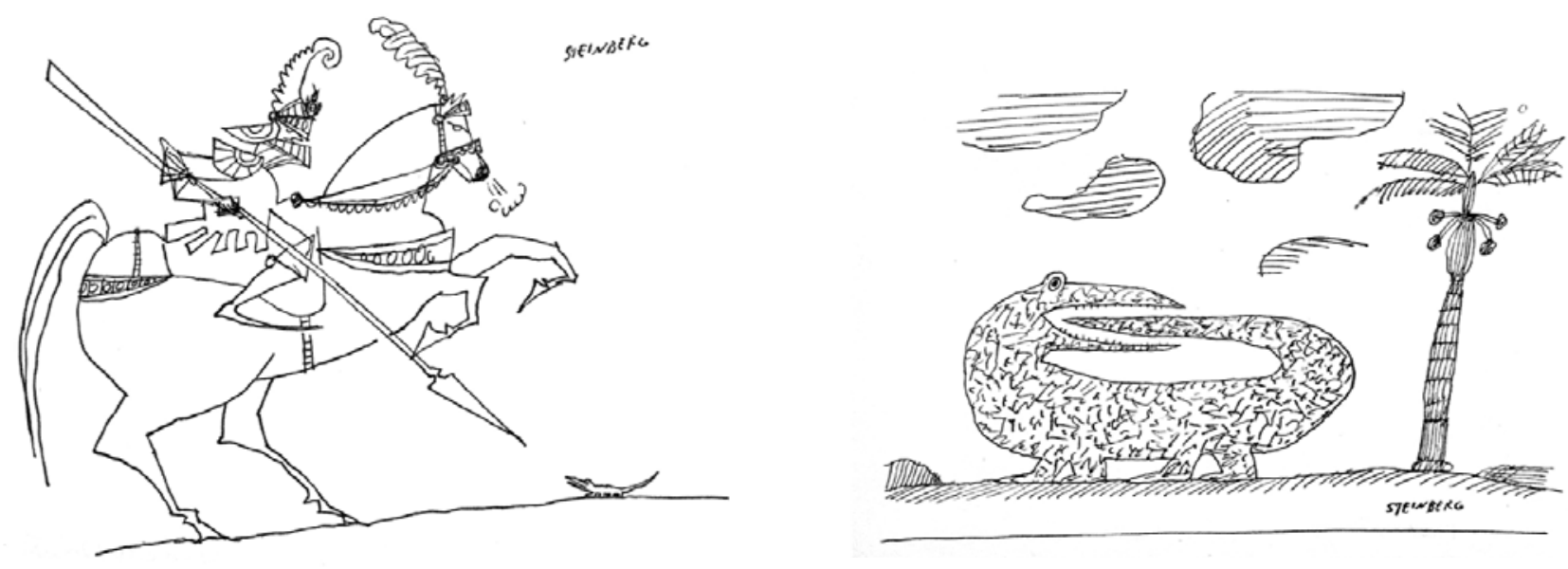

primeiro confronto desproporcional. Estas figuras tão presentes nos anos seguintes colocavam em cheque o conceito de "herói" na contemporaneidade. Como observa Smith, "em um mundo mais jovem e simples, o herói vencia seu encomendado dragão e recebia uma imortalidade terrestre como um monumento público. Os monumentos de papel de Steinberg satisfazem uma era ricamente regada por medo e ambição mas pobre em dragões conquistáveis" (Smith, 2005, p.136). Steinberg generosamente conferiu estatura heróica a executivos, estudantes liberados e outras figuras de nossos tempos. Nem sempre estes trabalhos com heróis ou monumentos eram de fácil assimilação, estabelecendo metáforas difíceis. Uma vez, a propósito de um desenho que mostrava o embate entre o cavaleiro e um abacaxi, Steinberg escreveu a um amigo: "O emplumado chapéu do abacaxi prova minha teoria de que o dragão e o herói são um só" (cit. por Smith, 2005, p.136), sugerindo que a fruta não era de modo algum inofensiva.

Outros personagens também viriam a participar destes jogos cheios de metáforas e alegorias. O mais velho e tradicional de seus "animais", o gato, já havia marcado presença na New Yorker desde 1945, aparecendo esporadicamente de modos diversos. Em 1954, em
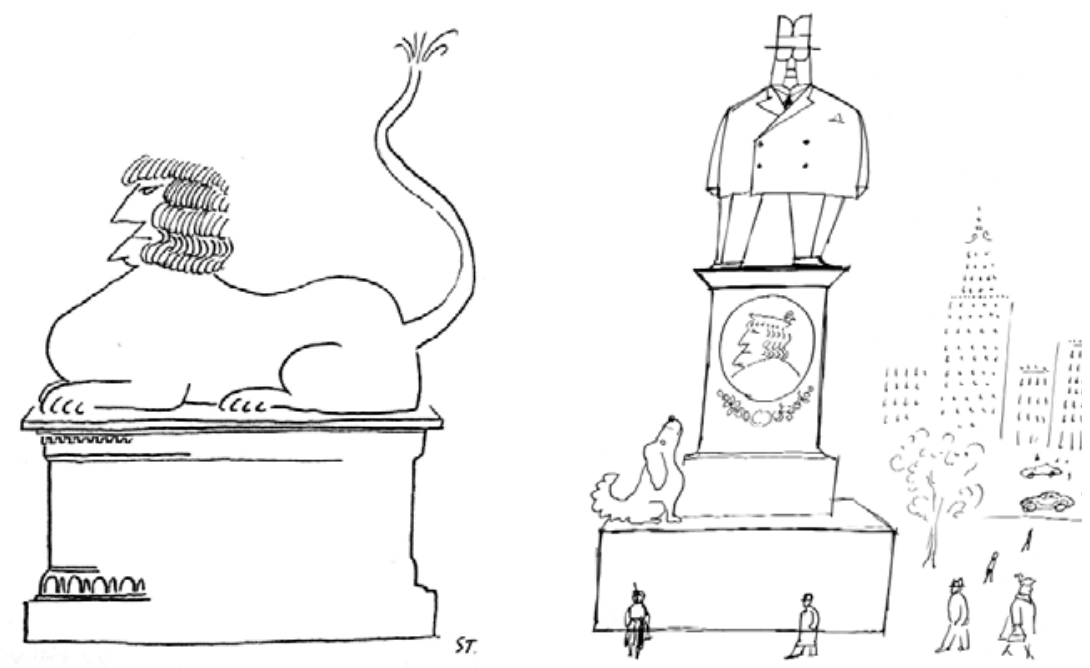

Figura 348. The New Yorker, 1954

Figura 349. The New Yorker, 1953

Figura 350. The New Yorker, 1959

Figura 351. The New Yorker, 1958

Figura 352. The New Yorker, 1953

Figura 353. The New Yorker, 1959 
sua segunda capa, uma família de gatos aparecia humanizada, algo que viria a ser freqüente não só com os felinos, mas também com outros animais. Já um cartum de 1957 conferia ao gato o mesmo peso que sua vítima, o peixe, levantando uma questão existencial ao felino. Em sua fase mais filosófica, viriam a ser comuns as cenas com animais humanizados, como cães, pássaros, peixes e coelhos. Em trabalho de 1959, as aves assumem a feição de pessoas, em diversas situações. "Eu sou um gato", respondia Steinberg às pessoas que perguntavam o porquê do artista criar animais com faces humanas (cit. por Smith, 2005, p.94). Para Smith, o felino na arte de Steinberg "não é o animal, mas a humanidade discretamente vestida com uma máscara, com toda a confidente auto-absorção de espécies dignificadas. (...) O caráter implacável e compenetrado do gato faz dele uma figura adequada ao impulso progressivo do tempo", por exemplo. (Smith, 2005, p.94). Por outro lado, os cães de Steinberg são "a contraparte esforçada ao pouco esforçado gato-artista, gato-meditador, gato-pensador". Os pássaros, para Saul, "eram figuras angelicais da imaginação, mantendo uma chama de fantasia viva no interior da cidade (...). Seus peixes são abobados perseverantes cuja falta de inteligência torna o mundo mecânico (...)". Já os coelhos são vulneráveis, o oposto do crocodilo. Todos estes animais seriam "caricaturas de qualidades humanas" (Smith, 2005, p.164), que levantam questões existenciais, o papel do herói e da vítima, a atuação na sociedade, os diversos temperamentos das pessoas, o modo como se apresentam ao mundo. Neste último aspecto, talvez seja o crocodilo que mais tenha simbolizado esta preocupação de Steinberg. O importante para ele, ao desenhar o animal, era saber "que tipo de técnica o crocodilo emprega para se mostrar" (cit. por Topliss, 2005, p.184).

O crocodilo (...) "se mostra" através de sua mobilidade, seus dentes, e sua escala. O crocodilo de Steinberg anda com duas pernas, o que lhe dá uma liberdade humana de movimento. Ele é selvagelmente agressivo e está com armadura contra o contra-ataque. Desenhado desta maneira, às vezes misturado com um camaleão, o crocodilo se torna o símbolo de Steinberg para o comercialismo e materialismo da civilização americana no meio do século XX (Ele diz que ele [o crocodilo] representa o "poder político" em geral) (Topliss, 2005, p.184).
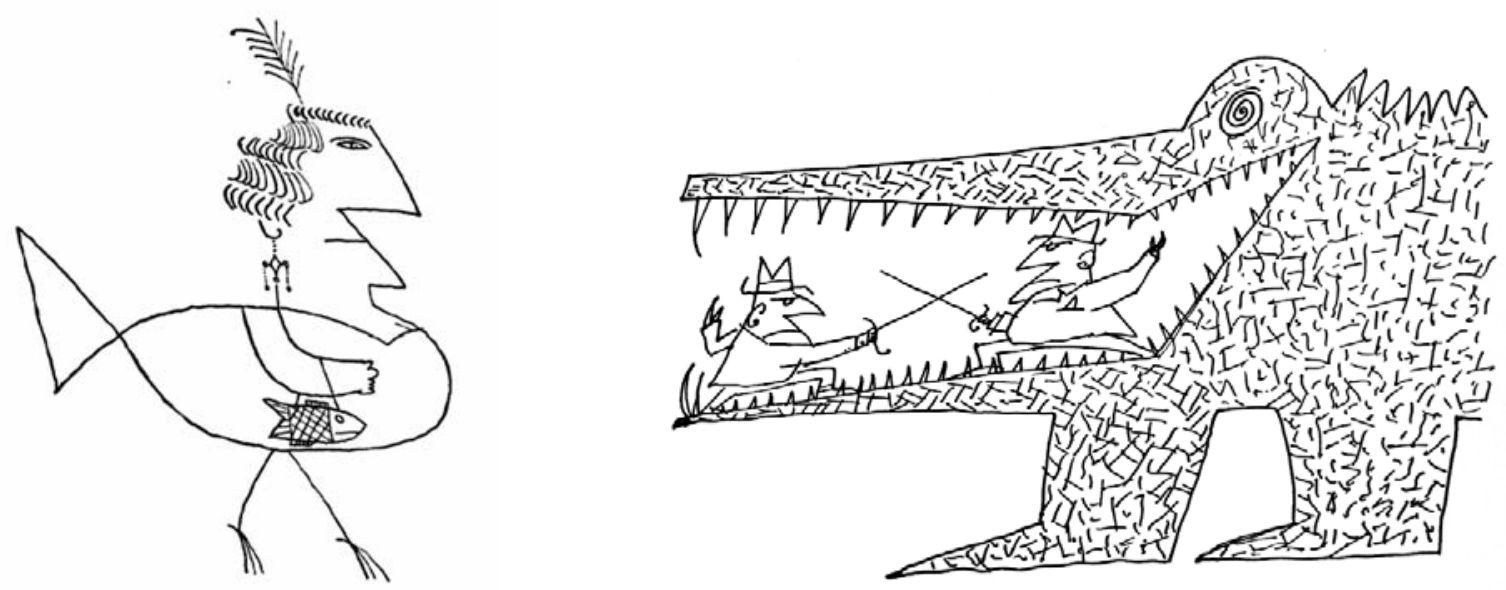
Figura 354. The New Yorker, 1945

Figura 355. The New Yorker, 1957
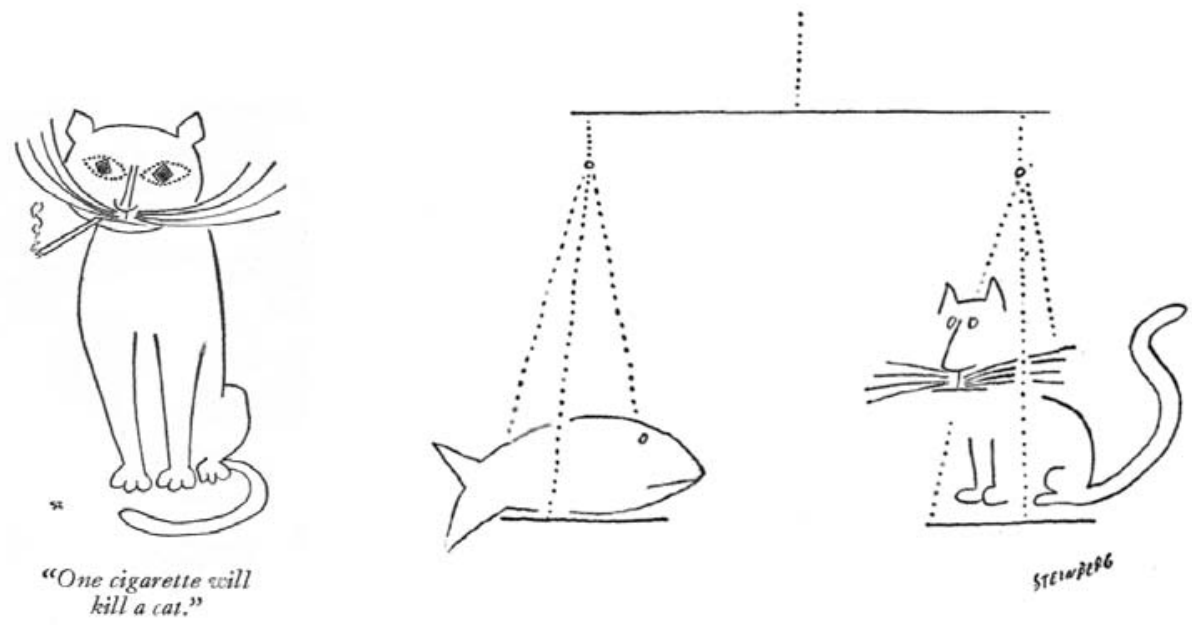

\section{AS ALEGORIAS AMERICANAS}

Esta variedade de novos elementos simbólicos se estende às alegorias americanas. Topliss aponta as americaneries - derivadas das bondieuseries francesas - como uma categoria que Steinberg relaciona aos clichés, uma vez poderosos mas agora desgastados, que muitas vezes simbolizam a vida americana: "Índios, pirâmides, colunas, símbolos, arco-íris, Niagara Falls, a Estátua da Liberdade, Esfinges, todas essas coisas que são parte da mitologia americana" (Gluek, 1970, p.111). Steinberg via humor nestas figuras, "respeitáveis e bonitas, mas cômicas porque são grandes clichês" (cit. por Gluek, 1970, p.112). As bondieuseries constituíam, por outro lado, parte dos primeiros contatos do cartunista com as artes - já transformadas em clichê -, como nos Millets em caixas de chocolate e Madonnas que via na infância (Steinberg, 2002, p.12).

Estas americaneries se sobrepõem à categoria do kitsch, uma palavra essencial à compreensão do trabalho de Steinberg. Para Topliss, o uso que ele faz do kitsch, este caos estético e de mau gosto das sociedades capitalistas modernas, é crítico e construtivo. Ao invés de

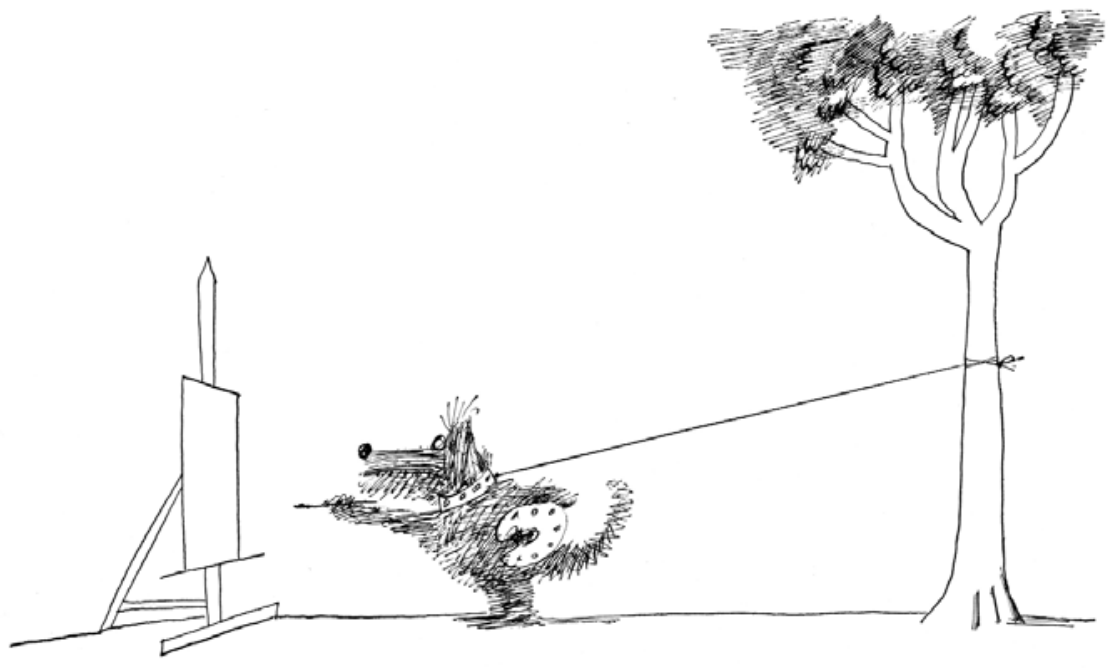

Figura 356. The New Yorker, 1959

Figura 357. The New Yorker, 1960

Figura 358. The New Yorker, 1968 
ser tomado pelos extremos de horror ou sedução, o cartunista estuda estes elementos movido pela busca de entendimento, se mostrando mais interessado na exploração e apropriação destes do que na mera rejeição. Topliss chega a fazer ampla pesquisa movido pela idéia de que esta mitologia foi desenhada a partir dos símbolos da maçonaria, com a intenção de construir uma América a partir de um projeto de vontade racional, desnudando o que ela veio a se tornar (Topliss, 2005, p.219). Seja como for, em muitos de seus desenhos, a América passaria a consistir num um palco de encenações, "tão errática e irreal como o mundo representado em uma nota de dólar" (Smith, 2005, p.64). Americaneries, dragões, leões, jacarés, desenhos geométricos, e outros elementos alegóricos eram dispostos nas mais diversas situações, como em pedestais, sendo comum aparecerem ostentando bandeiras, flâmulas e vestimentas com palavras em latim, algumas como parte do próprio corpo. Cada vez mais distantes das habituais situações de comédia dos cartuns, estes desenhos trafegavam pela "filosofia moral, apresentada (...) em termos gráficos derivados de modelos pré-modernos" (Smith, 2006, p.154). Alguns destes trabalhos com as alegorias anunciam, segundo Smith, sua proximidade com antigas imagens-sermões de famílias hierarquizadas em estilo naive, inseridas em contextos com o inferno e o paraíso. Alguns trabalhos evidenciam um novo modo de construção e organização do desenho, em amplo contraste com os conhecidos cartuns modernistas depurados e com foco definido. Carregado com certo humor, a abordagem de Steinberg nestes trabalhos alegóricos espalha elementos, cada qual com um significado e possibilidade de leitura, criando uma complexa teia de relações. Curioso como o artista que desenvolveu o cartum moderno, em sua síntese e simplicidade, em trabalhos sem necessidade de legenda, resgatava de certo modo a confusão das obras de caricaturistas e ilustradores do final do século XIX, com suas alegorias "tatuadas" e explicativas espalhadas pela página. Obviamente, neste caso cada alegoria mantém um mistério maior, com frases em

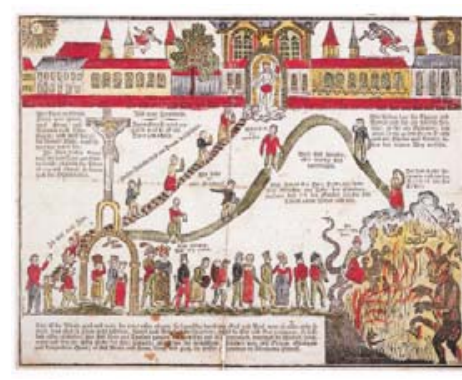

Figura 359. (acima) Das Neue Jerusalem, século XIX

Figura 360. Allegory, 1963

Figura 361. Quadro com símbolos associados à Maçonaria, 1745 (publicado em The Comic Worlds, de Topliss)

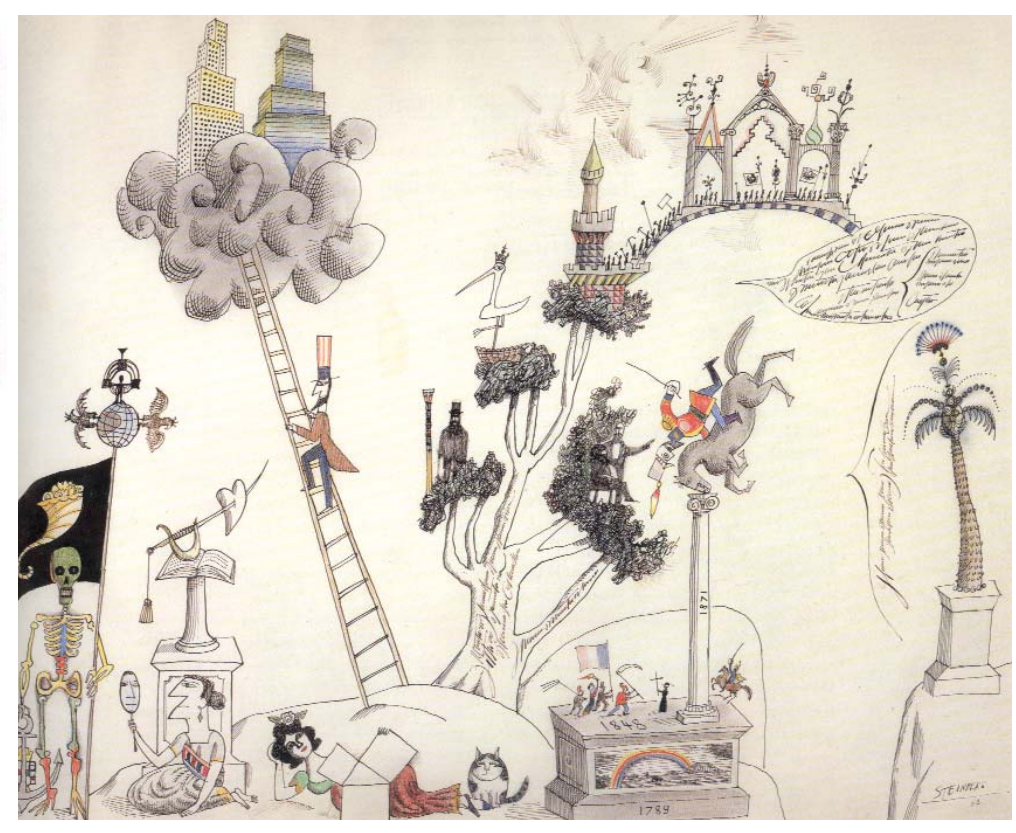


latim e objetos absurdos. Como nota Smith, a propósito da obra Allegory, "a dificuldade aumenta quando você tenta compreender o sentido do conjunto. Tente conectar o macro e o micro (...) e o deliberado absurdo de Allegory fica claro" (Smith, 2005, p.156). Ao se referir ao conjunto de seu trabalho, Steinberg acaba por sugerir pistas: "Essencialmente, estou brincando com a viagem entre percepção e compreensão" (cit. por Smith, 2005, p.156).

\section{A OBJETUALIZAÇÃo DE SignOS}

Ao mesmo tempo em que explorava as americaneries, Steinberg desenvolvia outros gêneros de desenhos filosóficos, utilizando o recurso de objetualização de signos. É bem verdade que neste ponto, já estava claro que mesmo os trabalhos com as alegorias americanas - e outros - envolviam a subversão do sentido de elementos gráficos. Mas a atenção conferida a determinados signos como palavras, letras, elementos tipográficos, e "estilos puros", aproximavam alguns cartuns filosóficos de outros publicados há algum tempo na New Yorker. Os trabalhos com "sons gráficos" e "conversas gráficas", feitos entre 1955 e 1957, abriam caminho para as novas explorações filosóficas. No começo dos anos 1960, certas letras e pontos de interrogação objetualizados são utilizados em situações diversas, como na promoção de reflexões sobre a arte e as galerias, por exemplo. O caráter de "objeto" de alguns destes signos é, em certos casos, realçado pelo degradê que confere sombra a um ponto de interrogação, por exemplo. As interações ocorrem nos modos mais variados: fileiras de números $(1,2,3,4$, etc.) como escadas existenciais, como fila em um guichê. Um casal de letras "A" e "B" apresentam maturidade e austeridade em seus contornos de caixa-alta, em contraste com os adornos curvilíneos das "crianças". Em outro caso, a letra "4" evidencia seus méritos no
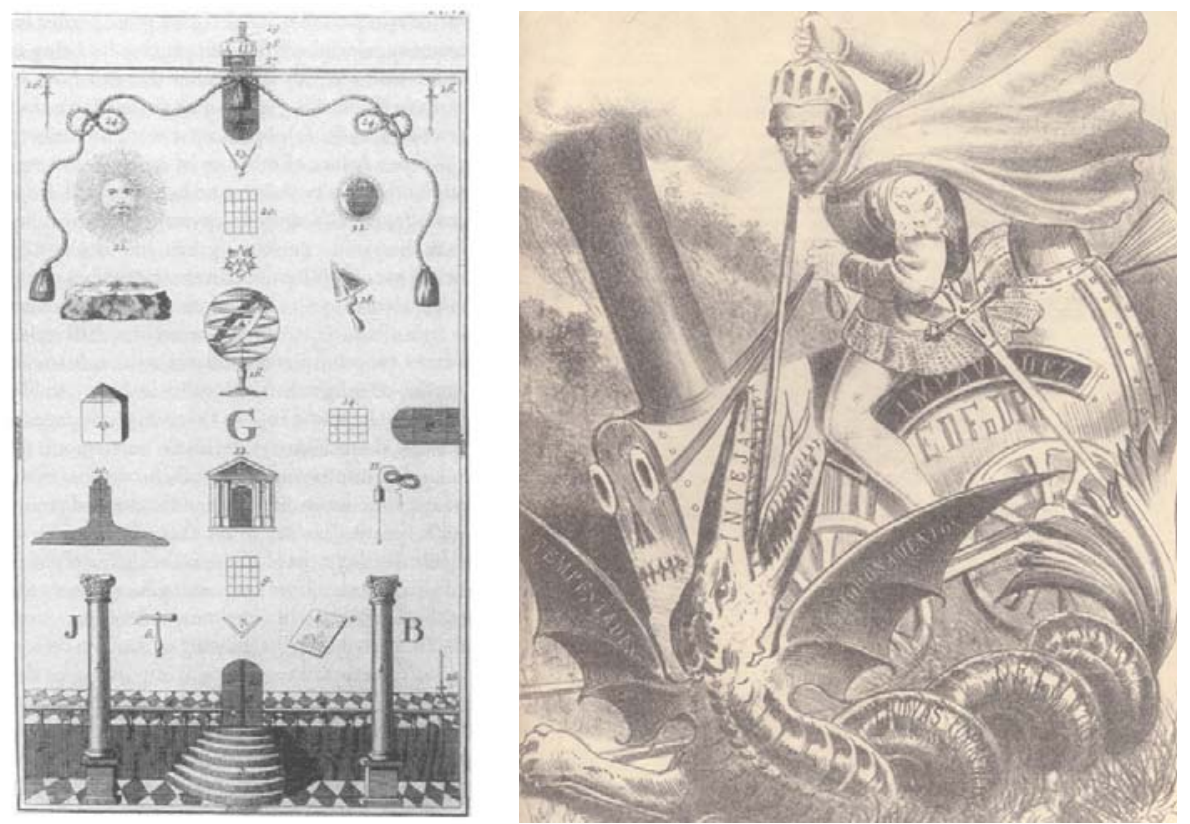

Figura 362.

Henrique Fleiuss, Semana llustrada, 1867. Cada elemento da ilustração tem um significado simbólico, expresso em palavras. Exemplo: "Inveja" na boca do dragão, "Desmoronamento" em uma das asas, "Tempestades" na outra asa, "Impavidez" no trem. 
Figura 363. The New Yorker, 1961

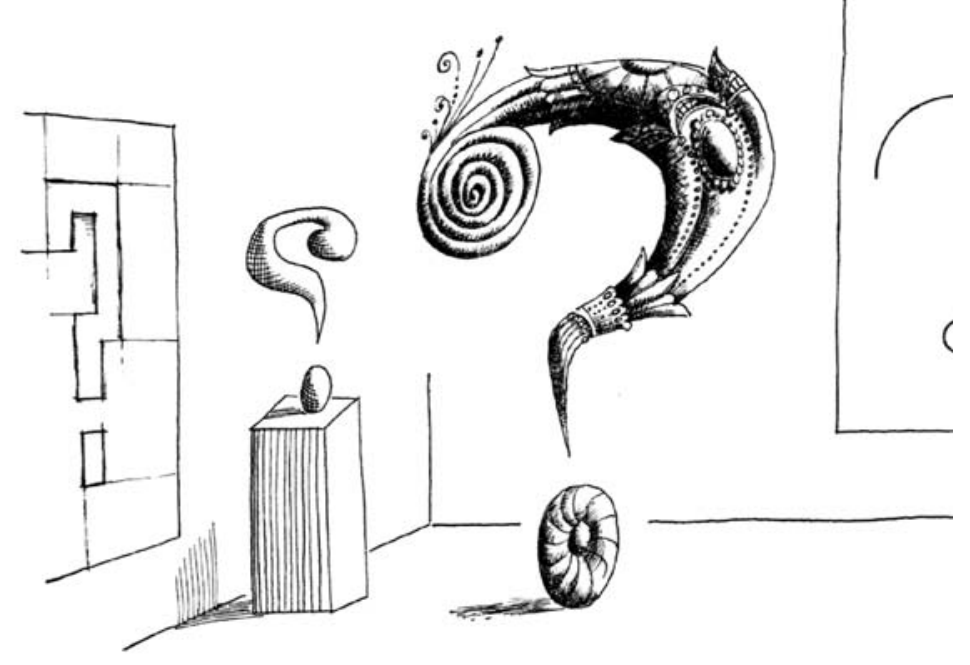

modo como se apresenta ao mundo, com a qualidade anatômica, construtiva e de delimitação de espaço interior e exterior que permite a inspeção de um felino. Para Steinberg, "(...) letras e números são objetos - mas não são apenas objetos, eles têm uma realidade" (cit. por Gluek, 1970, p.112). Como observa Smith, "se as letras significavam um negócio sério para Steinberg, elas também eram 'personagens' no sentido de um cartunista: figuras (...) efetivamente elaboradas para expressarem elas mesmas em pantomine" (Smith, 2005, p.114). Experiências que trabalhavam com o interior dos balões passaram também a ser feitas, deformando seus contornos tradicionais ou inserindo um novo universo de elementos gráficos subvertidos. Em muitas destas situações desenhadas, transparece o caráter filosófico de seu trabalho. "No centro desta comédia sem palavras está uma intimação da solidão de todo ser que fala ou pensa: o E que poderia ser É; um triângulo enfastiado com sua parte no teorema de Pitágoras; um homem sonhando com uma mulher, que sonha com ele" (Smith, 2005, p.100). Uma nova vertente de experimentações viria a aparecer no começo de 1960, com a

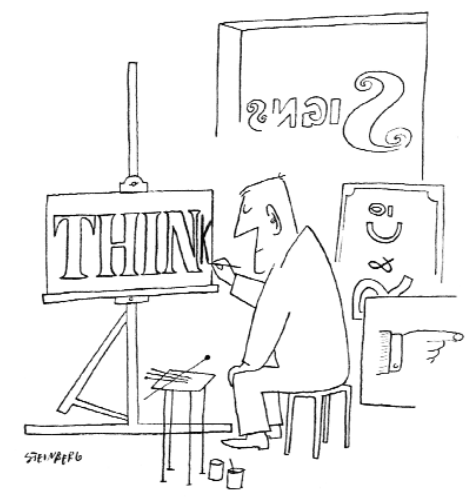

Figura 365. (acima) The New Yorker, 1950

Figura 366. The New Yorker, 1960

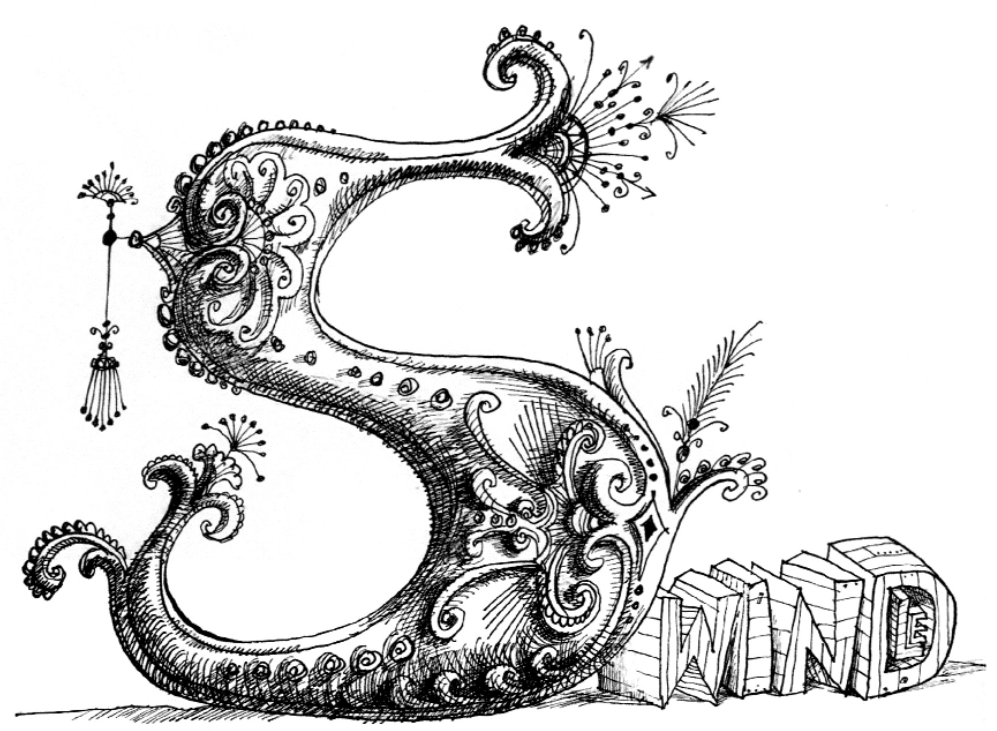



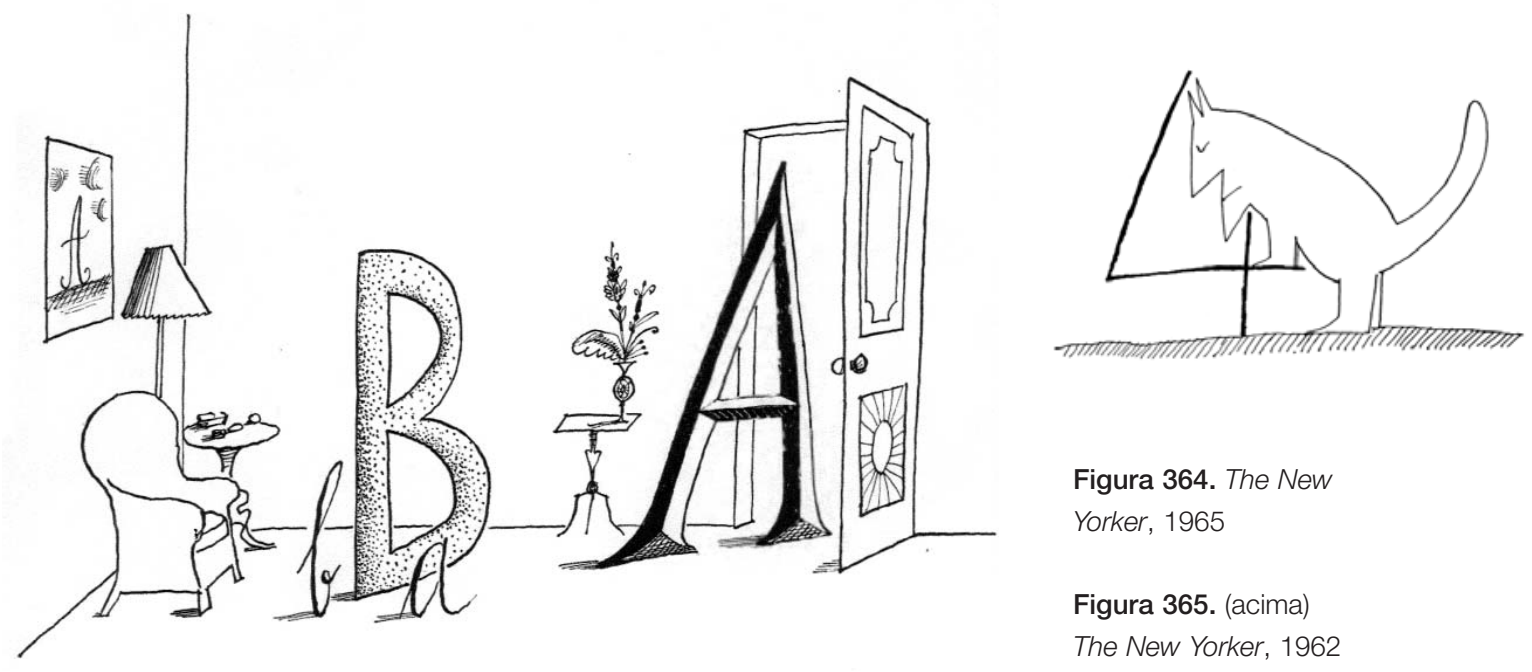

Figura 364. The New

Yorker, 1965

Figura 365. (acima)

The New Yorker, 1962

criação de relações entre o significado de palavras escritas e as deformações promovidas nestas enquanto objetos. Um cartum de 1950 já revelava que Steinberg estava atento a tais possibilidades. $\mathrm{O}$ artista chegou até a fazer propagandas de perfume e jóias utilizando o recurso, como na página dupla publicada na revista Vogue de 1957. Aos poucos, as alegorias, letras e balões objetualizados, estilos subvertidos em personagens de uma nova realidade desenhada, e todo este universo de elementos com lógica gráfica, seriam trabalhados com liberdade, misturados em cenas cada vez mais complexas e misteriosas.

Parte destas novas abordagens, como as transformações gráficas de pensamentos e falas, foram aplicadas posteriormente por outros artistas, sendo "desvalorizadas pela imitação generalizada", segundo Steinberg (Smith, 2005, p.100). Se em certos casos a banalização conduziu ao clichê, foi possível constatar determinados usos de recursos de objetualização que souberam fugir da redundância, como nos trabalhos da Push Pin e de outros artistas inspirados em Steinberg.

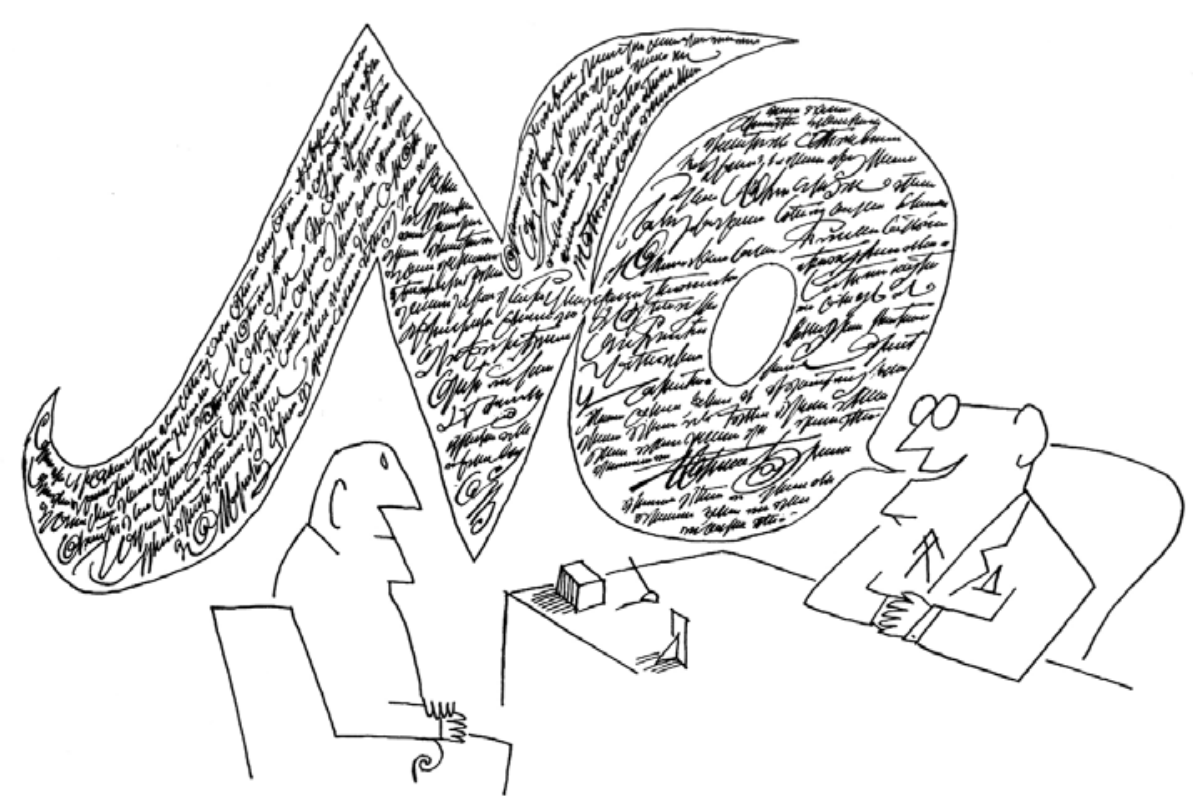

Figura 366. The New Yorker, 1961 


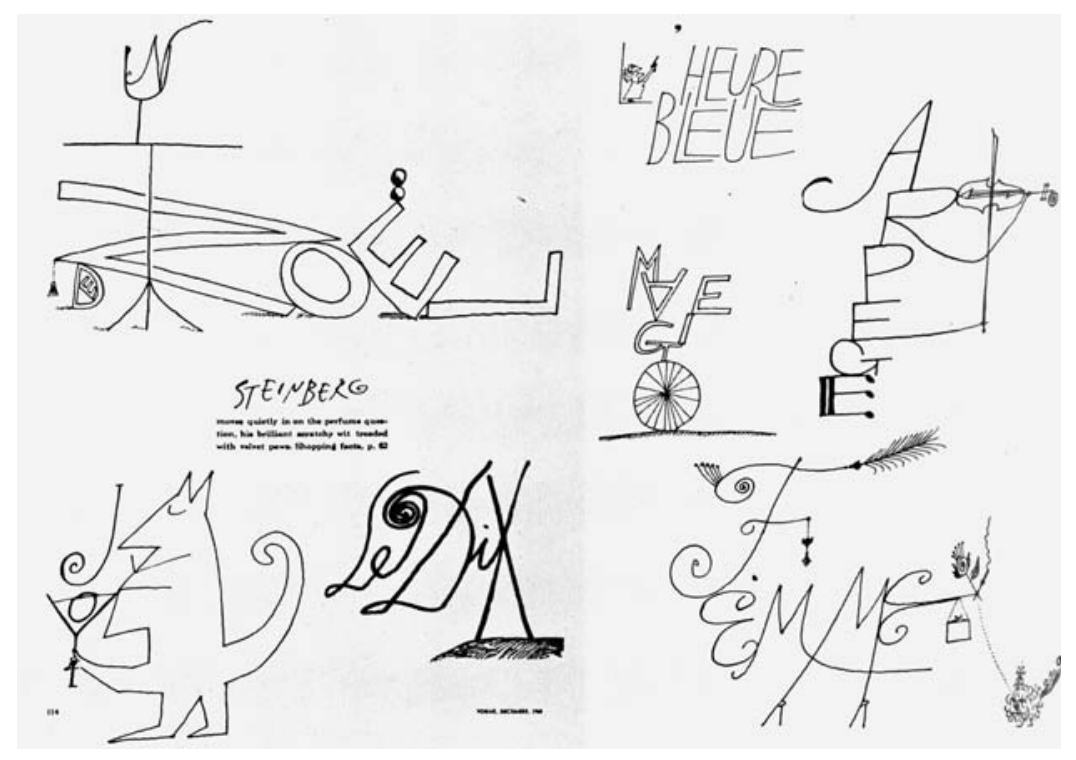

As MÁsCARAS

Além de todos estes trabalhos mais complexos, Steinberg viria a desenvolver uma nova abordagem, importante para o desenrolar de sua carreira, a partir de 1959: as máscaras. Para criálas, o artista apelou ao papel marrom de algumas obras anteriores, como no "casal" de 1955 ou no mural The Americans. Até o final de 1965, ele viria a criar seis máscaras, utilizando estilos diversos, que sugeriam personalidades distintas ao objeto e também a quem as utilizasse. O material empregado, um simples papel de sacolas, era associado ao Halloween nos Estados Unidos e ao festival Lenten na Europa (Smith, 2006, p.148). Estes trabalhos se tornaram conhecidos através das fotografias de Inge Morath, que mostravam ela, Saul e convidados vestidos nas masquerades - bailes de máscaras - na casa de amigos. Corpos seriam acrescentados a algumas máscaras posteriormente, como na Summer Mask, finalizada em 1966 a partir de uma "face" de 1961. Para Steinberg, as máscaras lidavam com as questões da personalidade e o modo como as pessoas se mostram ao mundo.

A máscara é uma proteção contra revelação...Apenas o primitivo e o poeta tem a possibilidade de revelar suas emoções e a verdade em suas próprias faces. As emoções são de uma natureza anti-social em uma sociedade organizada [e são] atribuídas a várias formas de insanidade. Apenas as formas mais seguras são permitidas. A máscara de felicidade perpétua é a mais comum - tristeza é encorajada na doença e em funerais, apenas (Smith, 2006, p.150).

Estas máscaras, de algum modo, funcinavam como exorcismos, transformando algo "incompreensível e assustador em algo claro e visível", segundo Steinberg (cit. por Smith, 2006, p.150). Para ele, as pessoas da sociedade se exorcizam umas às outras, como ocorre com as mulheres, que passaram a ser "transformadas em máscaras" de imagens divinas, de modo a exorcizar sua condição inicial de presença rara e preciosa no começo da colonização. 

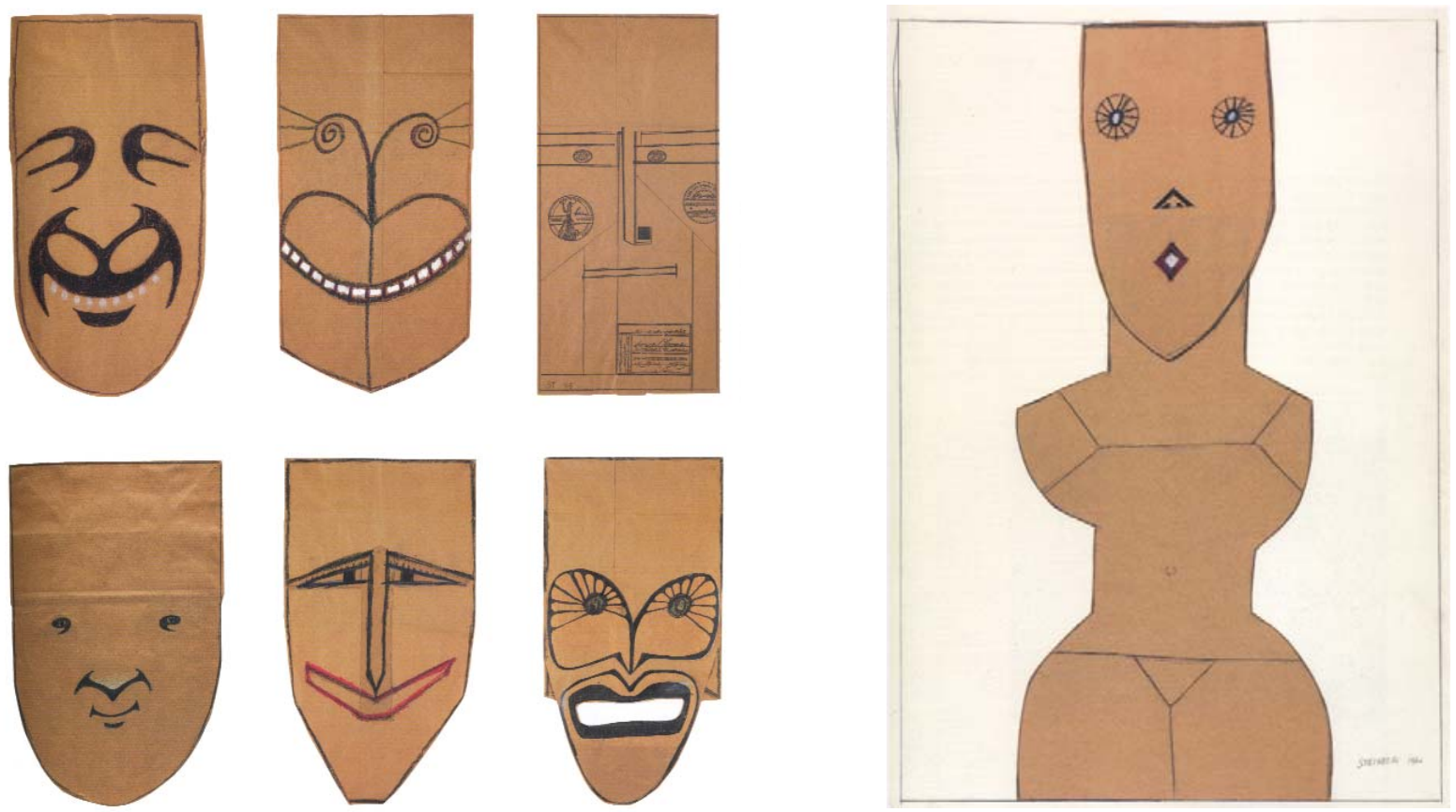

"E as mulheres têm cooperado com o homem, elas inventaram essas qualidades estáticas...Agora, coletes e espartilhos e todas essas coisas são escultura, são estáticas. Mas a coisa mais extraordinária é quando transformam suas faces em elementos estáticos que não irão expressar emoções" (cit. por Smith, 2006, p.150).

\section{STEINBERG CAPISTA}

As mudanças na vida e no trabalho de Steinberg se estenderam à sua atuação como capista. "Depois de oito anos e apenas duas capas para a New Yorker, a partir de 1959 Steinberg contribuiu com capas regularmente, publicando aproximadamente noventa durante as próximas quatro décadas" (Smith, 2006, p.53). Ao longo dos anos, Steinberg se configurou no

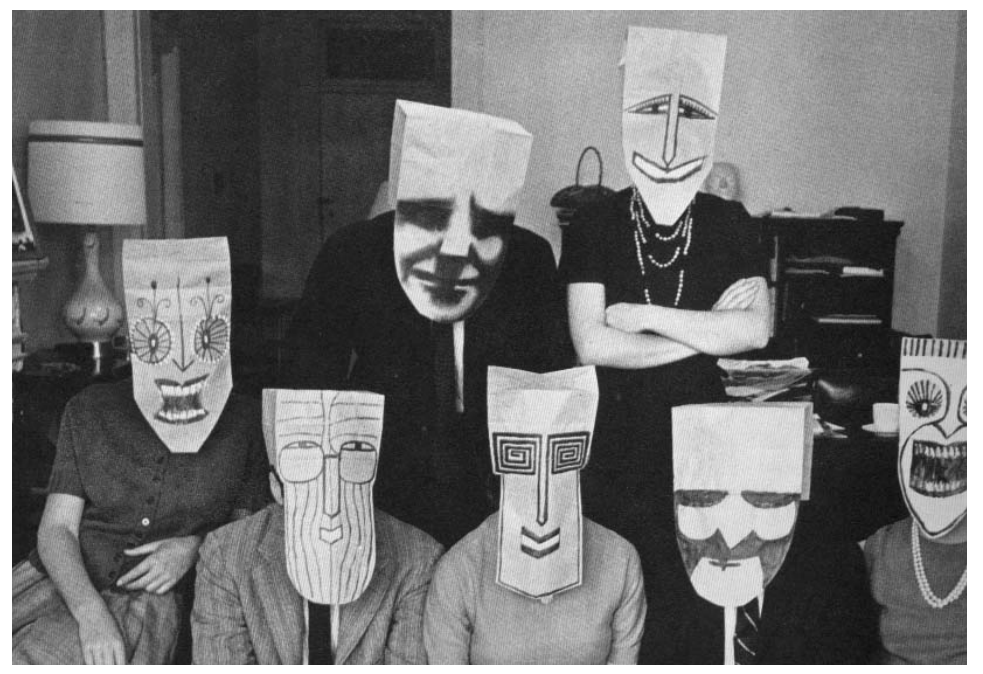

Figura 367. Propaganda de perfume, anos 1950

Figura 368. Steinberg, Six Masks, 1959-65

Figura 369. Foto de Inge Morath, anos 1960 

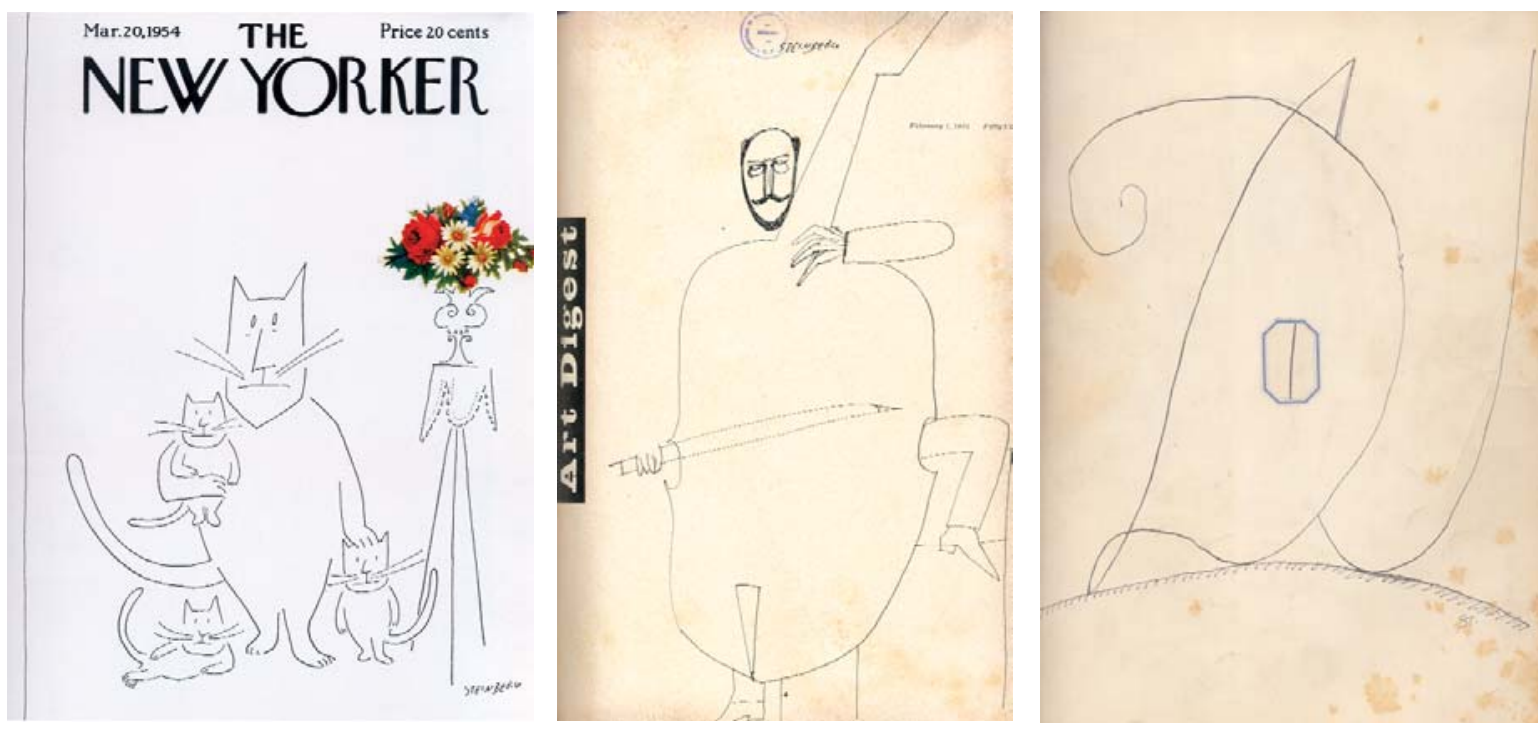

"artista supremo da revista, o ilustrador que tornou toda capa que tocava em um ressonante, inspirado trabalho", nos dizeres da editora de arte da revista, Françoise Mouly (Mouly, 2005, p.26). Várias destas capas seriam caracterizadas pela ousadia no encontro do Steinberg cartunista com o "artista" de trabalhos mais experimentais. Sua primeira capa para a revista, publicada em janeiro de 1945, era produto do trabalho como comentarista da guerra. Mostrava uma situação com soldados na China, em desenho simples e documental, sobre fundo de cor ocre homogênea. Sua segunda capa para a New Yorker só viria a ser feita nove anos depois, em março de 1954. Era uma criação de um Steinberg modernista por excelência: desenho simples, em capa quase branca, exceto pelo detalhe de um buquê de flores, representado por uma foto colorida colada sobre a imagem. Já a capa de janeiro de 1959, sua terceira, trazia o Steinberg dos trabalhos alegóricos. Nos anos seguintes, elas iriam explorar os temas do período, como as alegorias e as experiências com números, letras, falas, balões de pensamento, estilos.

A segunda capa para a New Yorker, com seu ousado fundo branco sob linha fina, não era a primeira do gênero feita por Steinberg. Naquela mesma época, um mês antes da capa dos gatos, em fevereiro de 1954 , Steinberg havia feito uma outra, seguindo a abordagem em linha fina, para a Art Digest. Mas muito antes, o cartunista já havia criado a capa para a revista brasileira Sombra - de dezembro de 1940 - em abordagem semelhante, com desenho simples sobre fundo branco. Seu estilo ainda refletia sua fase italiana, evidente no desenho dos olhos do personagem e nos contornos. Apesar de ter sido o destaque da primeira edição da revista, Saul não mais seria publicado na Sombra. As capas seguintes foram assinadas, em sua maior parte, pela ilustradora E. Anahori, em artes pintadas coloridas de sabor surrealista. Seja no trabalho de Steinberg, seja com as capas de Anahori, a revista Sombra confirmava seu refinamento visual, que refletia tendências do design internacional (A Revista no Brasil, 2000, p.28). Na New Yorker, capas em desenho de linha fina sobre fundo opaco claro ou branco haviam sido elaboradas por James Thurber, destacando-se a desenhada por ele em 


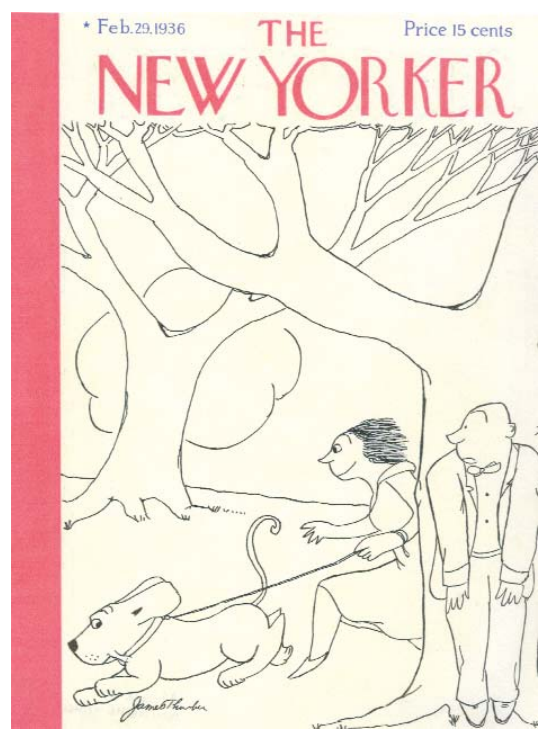

Figura 370. Capa da New

Yorker, 20 de março de 1954

Figura 371. Capa da Art

Digest, fevereiro de 1954

Figura 372. Capa da Du,

agosto de 1966

Figura 372. Capa de James Thurber, fevereiro de 1936.

1936. A revista apresentava capas com desenhos depurados e simples desde os primeiros números, como nos trabalhos de Carl Fornaro, Julian de Miskey, H. O. Hofman, Irvin Rea, mas Thurber foi um inovador da pura linha fina, sem preenchimento, na publicação.

Dez anos depois da capa dos gatos, em 1966, Steinberg fez uma capa em traço fino sobre fundo branco para a revista de cultura $\mathrm{D} u$. O desenho era o próprio título do veículo, feito com a linha de Steinberg e constituindo-se em um enorme "objeto gráfico", assentado sobre uma superfície desenhada com um risco circular. Um pequeno carimbo situado no meio da capa se apresentava como elemento "intruso" e misterioso - o único, também, a abrigar cores. A solução era inusitada pelo modo como foi apresentada, mas a inovação de transformação de títulos em outros objetos já havia sido bastante aplicada nas revistas do começo do século XX, como a publicações da Condé Nest: Vogue e a Vanity Fair. No entanto, o título como elemento desenhado à linha, inserido em um universo steinbergniano em que um carimbo adquire a mesma condição de "personagem", em abordagem ousadamente despojada, confere um toque especial a esta capa da $D u$.

Quando Steinberg passou a investir em sua carreira de capista, a partir de 1959, a ilustração já havia perdido a significativa hegemonia que chegou a ter, em capas de revistas, nas primeiras décadas do século XX. Como observa Steven Heller, "a fotografia era ocasionalmente usada nas capas de revistas antes da inaugural revista Life em 1936, de Henry Luce, mas se passariam décadas até que ultrapassassem a popularidade da ilustração" (Heller, 1996, p.15), apesar de ter sido introduzida em revistas já no final dos anos 1890 (Heller, 1996, p.14). As vantagens da ilustração residiam na sua condição de meio mais controlável, além das enormes possibilidades e facilidades em construir situações complexas e fantásticas. Além disso, como nota Heller, havia a influência da popularidade conquistada pelos pôsteres desde os anos 1890, com as capas sendo consideradas "mini-pôsteres", um culto que continuou durante os anos 1930. Sendo assim, os ilustradores de ponta angariavam grande reputação, responsáveis que eram em definir a personalidade visual das publicações. Heller 

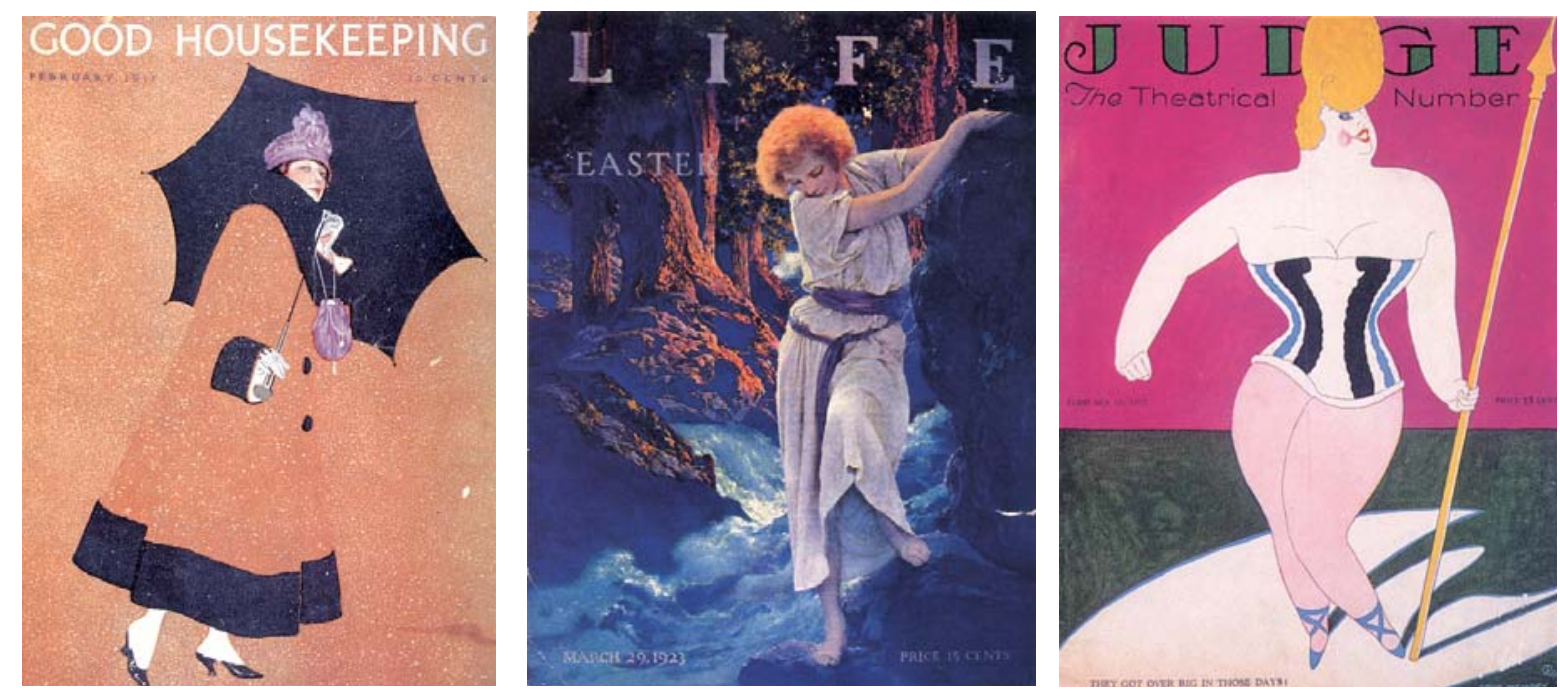

nota que a "Good Housekeeping, por exemplo, era mencionada como 'a revista de Cole Phillips'" (Heller, 1996, p.9), o mesmo acontecendo com Norman Rockwell em relação ao Saturday Evening Post. A Life apresentou capas feitas por grandes ilustradores da Era de Ouro americana, como Maxfield Parrish e James Montgomery Flagg, também publicando as cenas bem-humoradas da Jazz Age de John Held Jr. A Judge apostava no humor, trazendo ao público capas de artistas do cartum como Gardner Rea e Otto Soglow. Na década de 1920 e 1930 a ilustração era indispensável, e dentre as diversas abordagens chamava a atenção o ornamentalismo e formas em estilo art moderne presente em várias revistas. A chegada de importante diretores de arte também contribuiu para enriquecer o cenário das publicações. A partir de 1928, M. F. Agha, imigrante vindo de Berlin, assume a direção de arte de ambas as revistas, revolucionando o design de revistas e contratando os melhores artistas europeus para a Vanity Fair (Weill, 2003, p.80). Esta sofisticada revista cosmopolita deu considerável espaço para artistas como Miguel Covarrubias, William Cotton e Paolo Garreto, "que criaram arte para capas em uma grande variedade de temas sociais, culturais, e políticos" (Heller, 1996, p.10), e "eram as maiores referências da ilustração satírica e do comentário gráfico" (Heller, 1996, p.43). As revistas culturais como a Vanity Fair conferiam maior liberdade que outros gêneros "e introduziram os avant-guardismos que eram adotados em outros lugares" (Heller, 1996, p.43). Em 1934, a Harper's Bazaar trouxe Alexey Brodovitch de Paris, que encomendou capas para Cassandre, André Derain, Marcel Vertes. Em 1938, a Fortune substituiu o ultra tradicionalista e anti-modernista Thomas Cleland por John Brennan, que publicou trabalhos de Matter, Sutnar, Bayer e Cassandre (Weill, 2003, p.80). A ousadia dos trabalhos modernos coexistiu, a partir do final dos anos 1930, com uma tendência de ilustração mais realista, influenciada pelas propagandas, decorrência das transformações da década: uma visão pragmática, atenta à necessidade de vendas, imersa na dura realidade da Grande Depressão e na superioridade das revistas ameaçada por outras mídias 

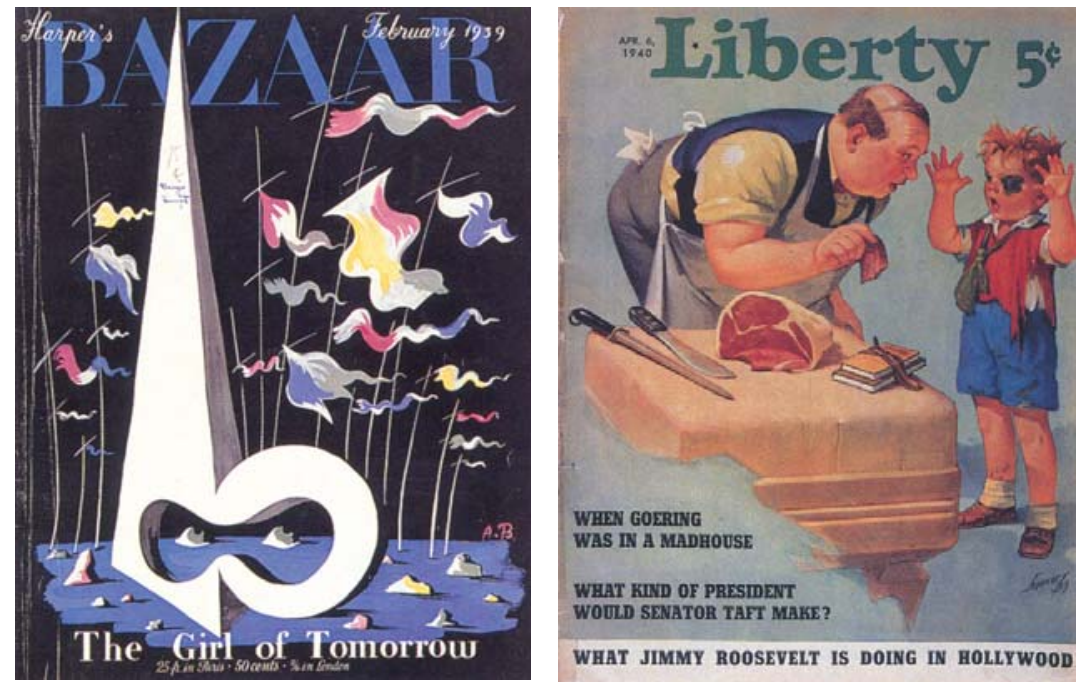

Figura 373. Coles Phillips, Good Housekeeping, 1917

Figura 374. Maxfield Parrish, Life, 1923

Figura 375. Gardner Rea, Judge, 1927

Figura 376. Alexey Brodovitch, Harper's Bazaar, 1939

Figura 376. Capa de Stuart, revista Liberty, abril de 1940.

e pelos jornais (Heller, 1996, p.15). Como observa Heller, "do final dos anos 1930 até os anos 1950, as revistas de conteúdos gerais - incluindo a Liberty, a American, e Pictorial Review, que imitavam o Saturday Evening Post e a Collier - alimentou seus leitores com uma clara dieta regular de ilustração realista" (Heller, 1996, p.16).

Nos anos 1950, apenas três revistas ainda mantinham religiosamente a tradição da capa ilustrada: Saturday Evening Post, Collier's e a The New Yorker. A ilustração ainda aparecia nas pulp magazines e esporadicamente em outras publicações, mas se tornavam cada vez mais de mau gosto. Em 1938, Paul Rand introduziu as capas com colagens nas revistas Apparel Arts e Directions, uma abordagem fotográfica única que ajudou a mudar a aparência do design de capas nas décadas seguintes (Heller, 1996, p.73), aplicando as idéias visuais da Bauhaus. Estas abordagens, com expressiva tipografia, colagens e métodos gráficos modernos "mudaram o foco do cartum para o design gráfico" (Heller, 1996, p.99). Os cartuns e caricaturas da Jazz Age haviam desaparecido com o fim da Vanity Fair, após ser encartada na Vogue, em 1936. Na década de 1940 a Vogue começou a privilegiar a fotografia, e a

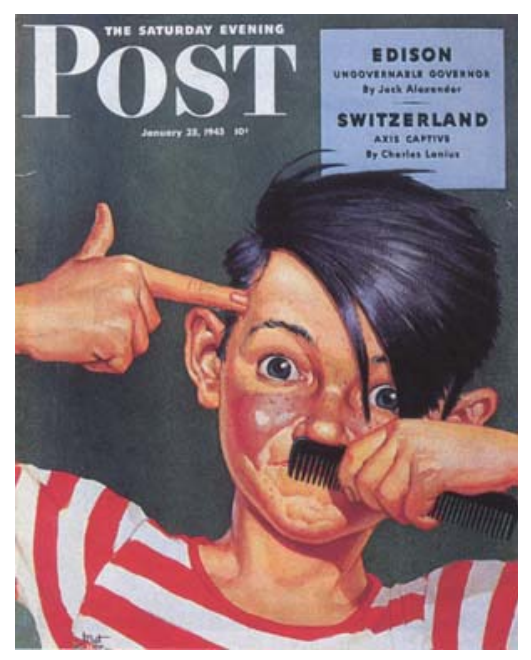

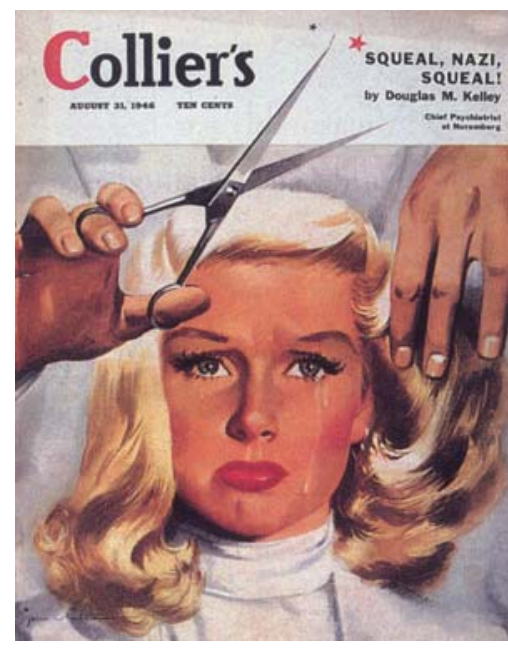

Figura 377. Mat Kunten, The Saturday Evening Post, 1938

Figura 378. Jon Whitcomb, Collier's, 1946 

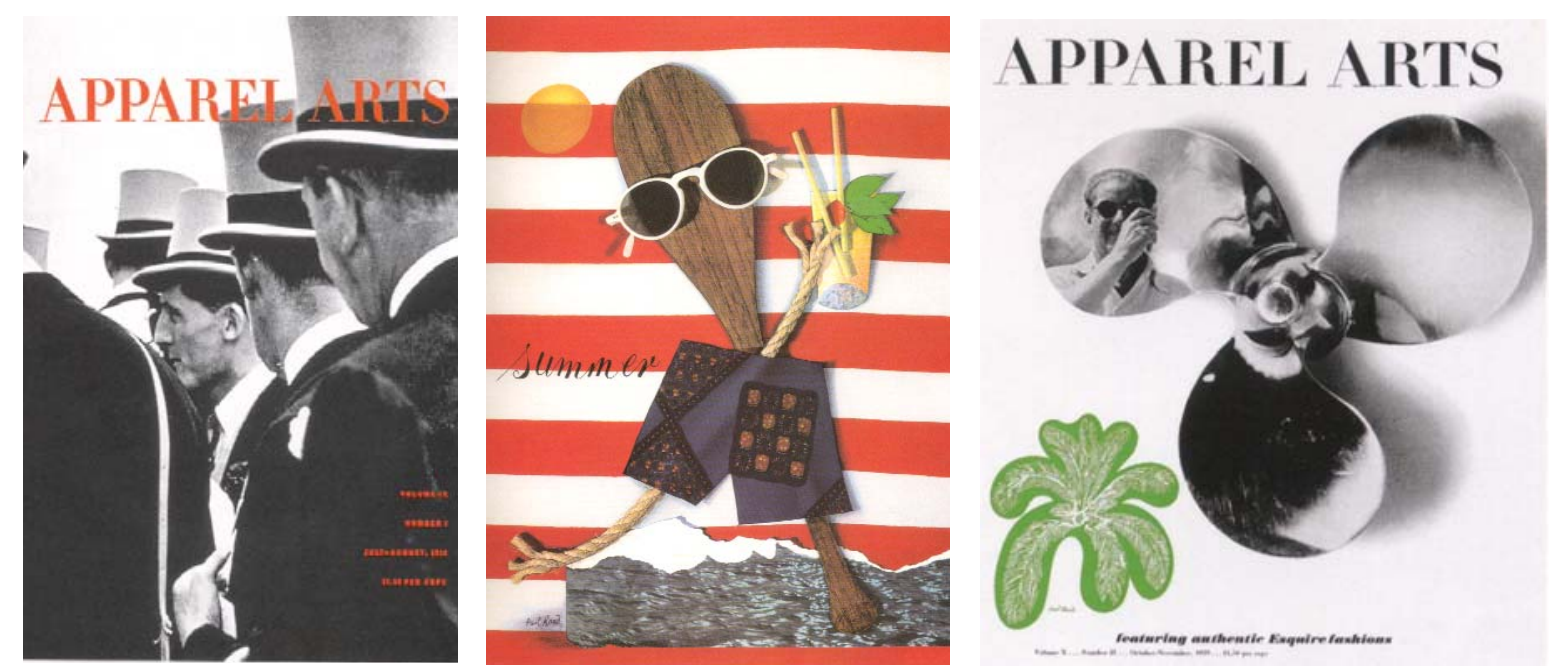

Harper's Bazaar e outras publicações seguiram a mesma tendência. Heller confirma que "nos anos 1960 a fotografia tinha quase totalmente sobrepujado a ilustração nas artes de capa. (...)" (Heller, 1996, p.17). A ressalva deve ser feita às revistas de humor, e algumas culturais e de design, que continuaram a publicar trabalhos de cartunistas e ilustradores nas capas. Steinberg aparece, portanto, como um dos maiores capistas de uma das raras revistas que só publicavam ilustrações nas capas nos anos 1960, exercendo um papel de destaque no ramo, não apenas pela inovação das idéias, mas também pelo simples fato de ser um capista ilustrador naquele período.

Se as capas depuradas de Steinberg - feitas para a Sombra, Du e New Yorker - contrastavam com as capas de outras publicações, os trabalhos criados para a New Yorker nos anos 1960 eram também extremamente originais pela junção da linguagem do cartum com experimentações "artísticas" e semióticas feitas de modo pessoal, autoral e único. A capa The Pursuit of Happiness, debut de sua nova fase como capista em 1959, expõe o vigor de suas abordagens, em uma solução recheada de alegorias. Como observa Topliss, a capa apre-

Figura 379 . Paul Rand, Apparel Arts, 1938

Figura 380. Paul Rand, Apparel Arts, 1939

Figura 381. Paul Rand, Apparel Arts, 1939

Figura 382. Paul Rand, Direction, 1942

Figura 383. Paul Rand, Direction, 1943
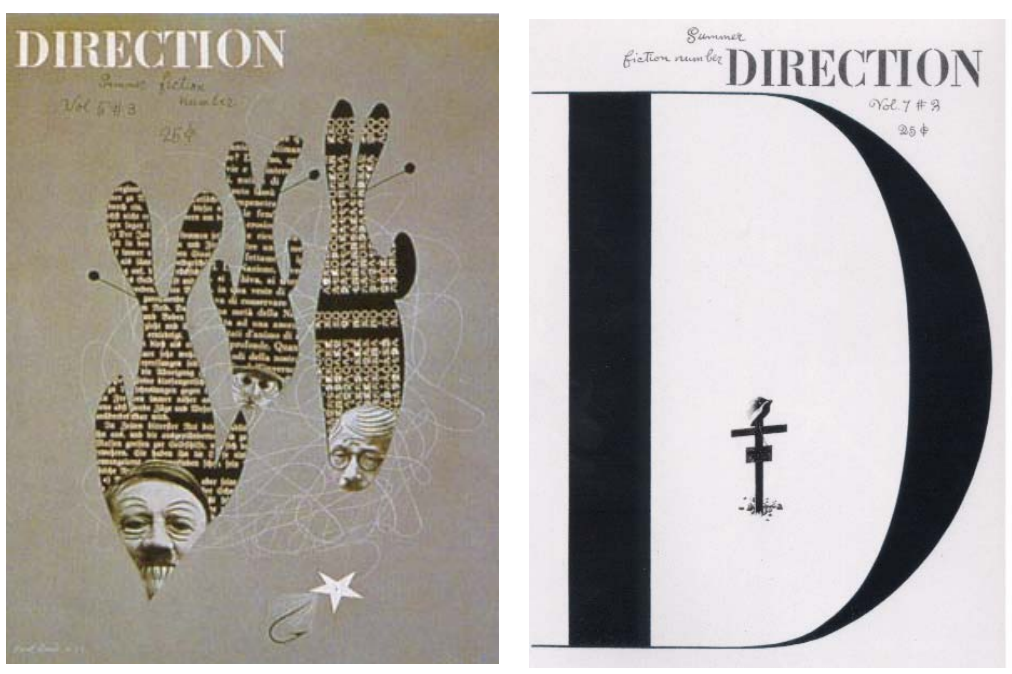


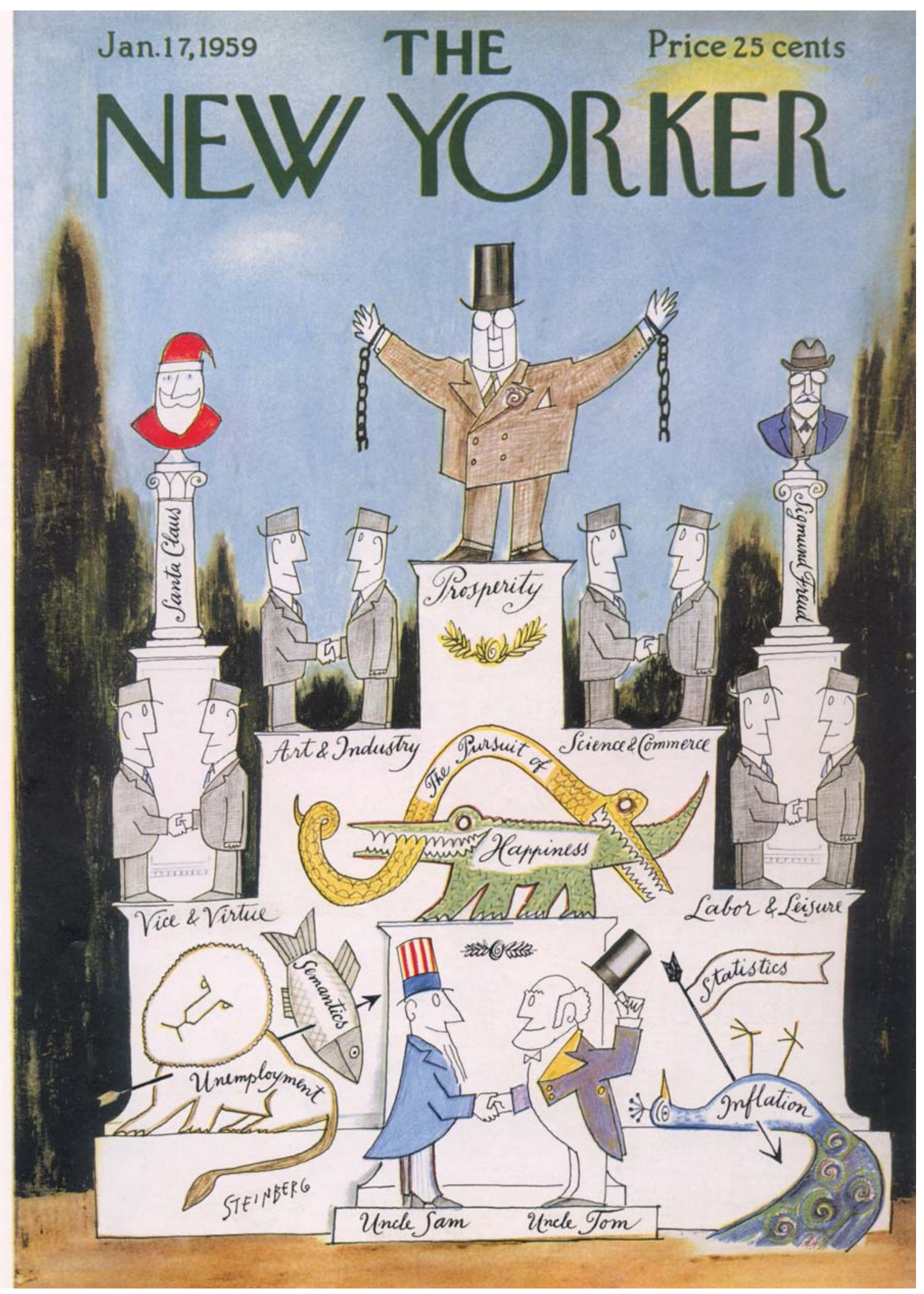

Figura 384. Saul Steinberg, The New Yorker, 17 de janeiro de 1959 

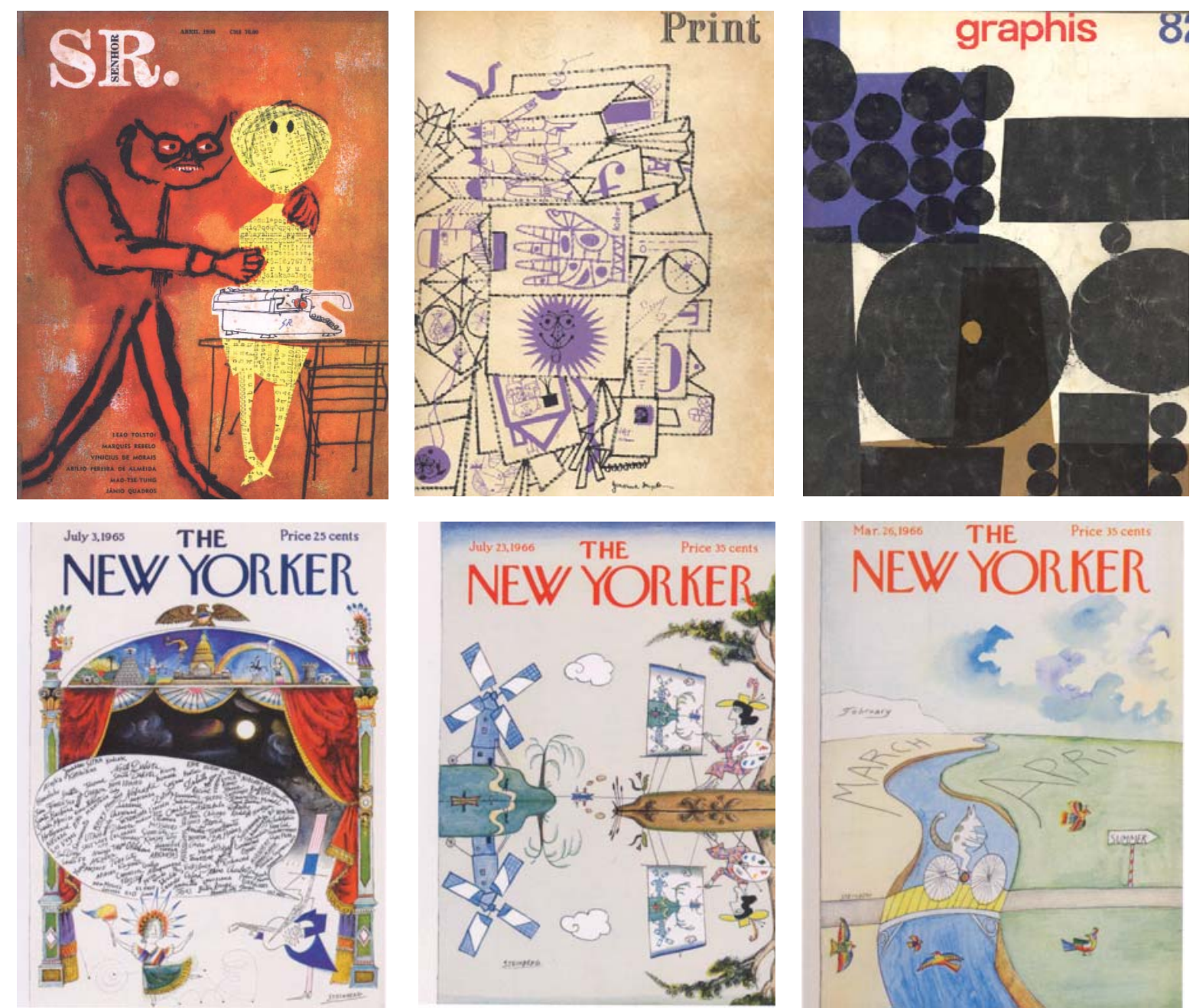

\section{EAquire}
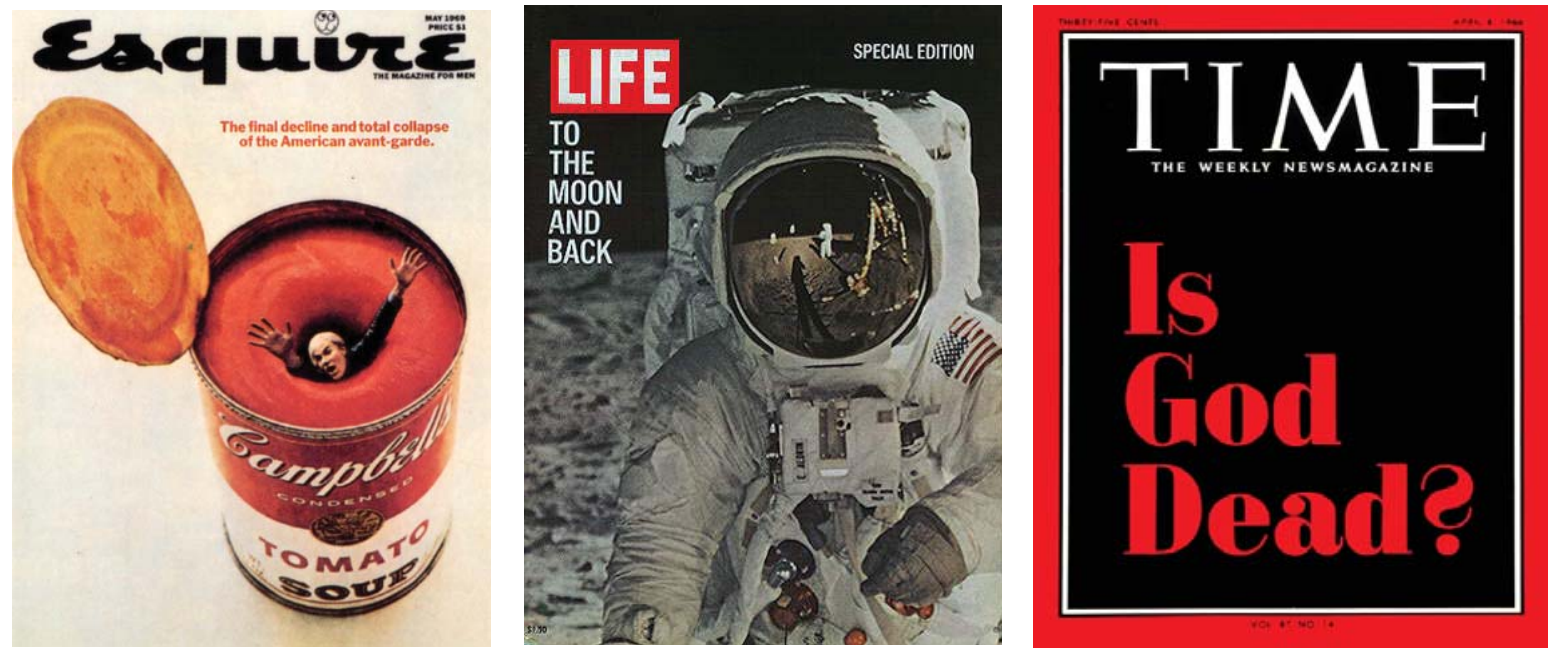

Figura 393. Esquire, 1969

Figura 394. Life, 1969

Figura 395. Time, 1966 


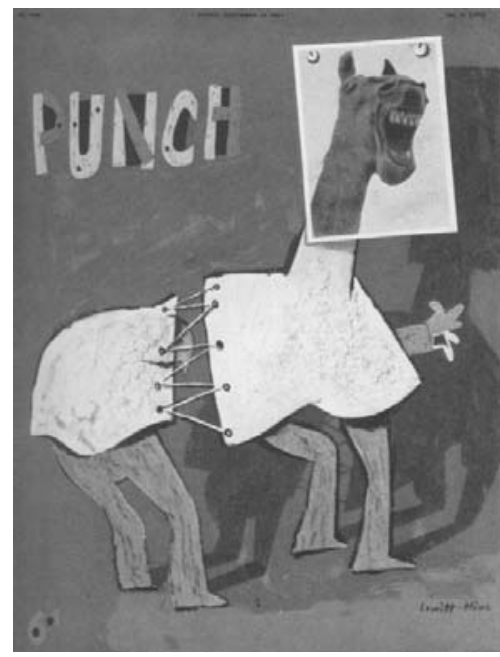

Figura 385. Glauco Rodrigues e Jaguar, Senhor, abril de 1959

Figura 386. Jerome Snyder, Print, 1955

Figura 387. Graphis, 1959

Figura 388. Steinberg, The New Yorker, julho de 1965

Figura 389. Steinberg, The New Yorker, julho de 1966

Figura 390. Steinberg, The New Yorker, março de 1966

Figura 391. Steinberg, The New Yorker, março de 1966

Figura 392. Lewitt-Him, Punch, 1954

senta "o triunfo do American way of life", com o homem de negócios perdendo suas correntes na realização de seu coroamento. O desenho mostra o irônico mas construtivo uso que Steinberg fez do imaginário da Maçonaria, no qual o edifício é o símbolo de uma sociedade perfeitamente projetada" (Topliss, 2005, p.224). Steinberg mais tarde comentou que até os anos 1960, quando ele encontrou uma expressão adequada às capas e portifólios temáticos, seus desenhos para a revista haviam sido "realmente um modo de sustentar-se. Não pensava [neles] como Arte, ou relacionados à autobiografia ou com meus reais impulsos. Eles eram controlados pela censura de mim mesmo como editor, como alguém que faz alguma arte para um certo público e tem que fazer isso ser entendido, lentamente" (cit. por Smith, 2006, p.58). Por fim, o uso deste privilegiado espaço de experimentação, além de inovador, se mostrava adequado à linha editorial e ao público da New Yorker, como analisa Smith:

Ao conferir experiência contemporânea ao mesmo tempo que evitava a última novidade do momento, as capas expressavam, à beira da perfeição, o tom de refinamento pseudo-intelectual que distinguia a The New Yorker de seus vizinhos pseudo-intelectuais (Time), cujas imagens de capas eram relacionadas aos conteúdos da hora; a revistas de baixo pseudo-intelectualismo (The Saturday Evening Post) que propunham uma capa propagandística de trivialidade barata; e dos jornais eruditos (Partisan Review e outros), que evitavam totalmente a arte na capa" (Smith, 2006, p.58).

\section{STEINBERG CARTAZISTA}

A independência temática que Steinberg conferia às suas capas, desprovidas da necessidade de relacioná-las aos assuntos das publicações e abertas às mais diversas pesquisas gráficas, se refletia também na sua produção para cartazes. Apesar de não ser reconhecido pelo imaginário popular como um cartazista, Steinberg fez pôsteres ao longo de sua carreira, como alguns de motivação política, elaborados para levantar fundos, durante a Guerra do Vietnã, no final dos anos 1960 (Smith, 2006, p.261). Em grande parte, no entanto, estes trabalhos 
Figura 396. Poster de teatro de Saul Steinberg

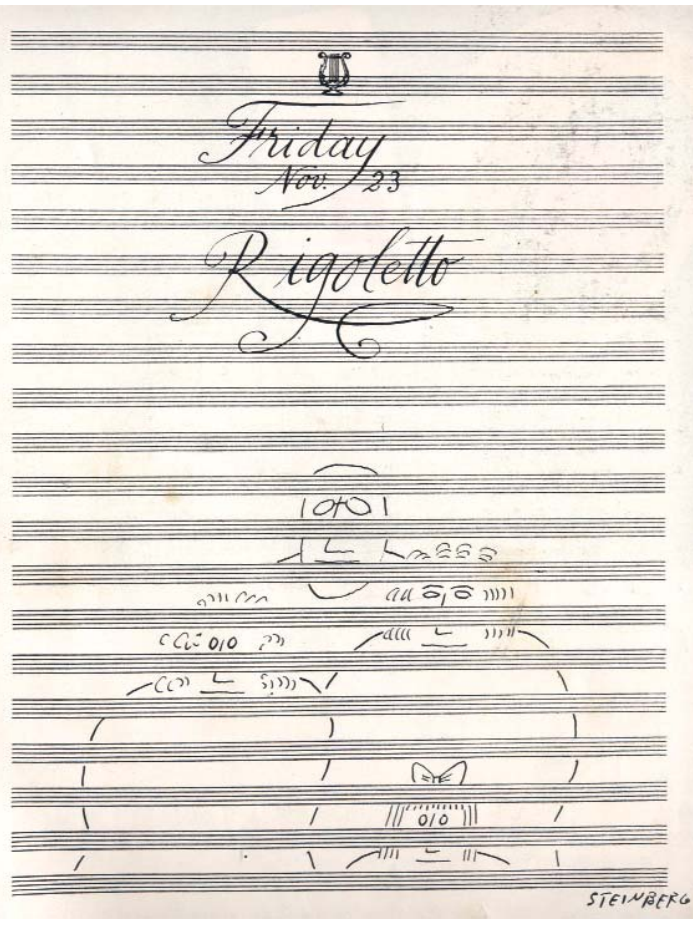

eram pôsteres de suas próprias exposições. Daí, talvez, sua posição sobre os cartazes, nunca vistos como uma forma de arte específica, com "ciência" própria. Steinberg acreditava que qualquer bom desenho serviria para um pôster, se exposto em grande escala - qualquer coisa grande chama a atenção. Reticente, o cartunista talvez não tenha se dedicado a esta arte por acreditar que os cartazes vinham perdendo sua força, em grande parte à pintura fluorescente e às luzes de néon da cidade moderna. Diante destes competidores luminosos e coloridos, o cartunista sentia que o público havia se tornado blasé em relação ao poder da cor, ao menos na mídia cartazística. Alguns de seus cartazes eram totalmente brancos, como o elaborado para a Rigolleto.

Um pôster na América tem que competir com cores brilhantes em todos os lugares. Tudo é constantemente pintado há pouco tempo, mesmo um borrão de ferro, vermelho com ferrugem de uma pintura de prevenção, irá sempre roubar o show. Isto, por sinal, é um problema que confronta pintores igualmente. Se você pinta uma casa que foi pintada recentemente, você mesmo se torna um pintor de casas. Na Europa este problema não existe, não há muita tinta fresca por lá. $\mathrm{O}$ artista precisa se concentrar na qualidade do desenho. Mesmo um pequeno desenho com muito espaço branco em volta dele irá fazer dele um melhor cartaz que a maioria dos outros.

$\mathrm{O}$ artista deve seguir as regras da arte apenas, e não deve se tornar subserviente ao comércio. O comércio irá vencer em seu contato com a arte (...). Nos lembramos dos atores que Toulouse Lautrec pintou apenas por causa de Loutrec. As pessoas que encomendam pôsteres são pessoas simples, elas precisam ser ajudadas, enganadas se necessário, mas nunca temidas (cit. por Allner, 1952, p.104). 


\section{AS PARÓDIAS DE ESTILO}

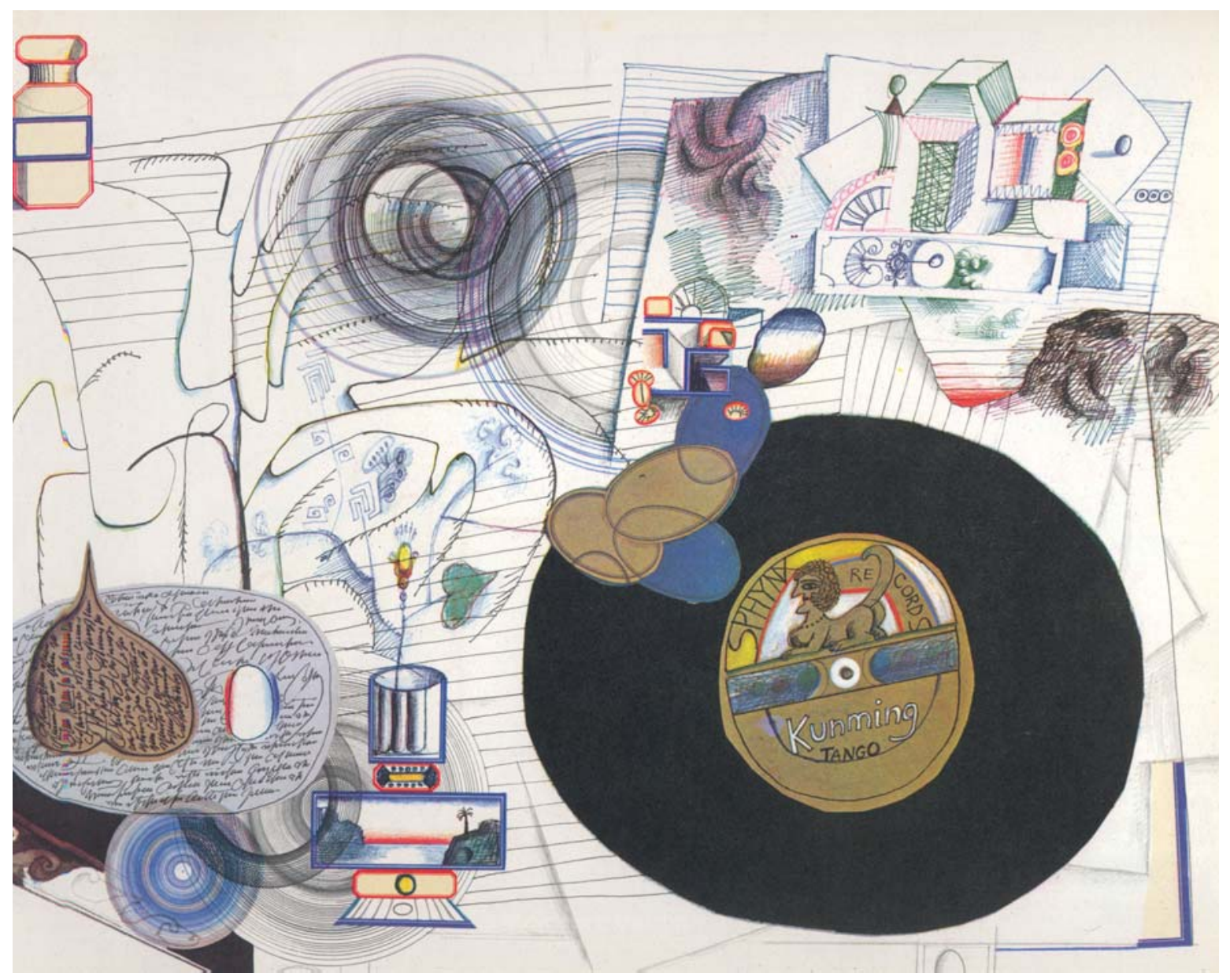

Figura 397. Trabalho publicado em Le Masque, 1966

Em 1965, chama a atenção uma capa que Steinberg faz para a edição de março da New Yorker, uma colagem-paródia com balão, disco de vinil e outros elementos estilizados sobre uma mesa desenhada, sem personagens do cartum. No ano seguinte, este gênero de trabalho seria um dos atrativos de uma mostra realizada na França. Em 1966 é realizada a exposição individual Steinberg: Le Masque, na Galerie Maeght, em Paris, assim como na Fundação Maeght, em Saint-Paul-de Vence. O livro Le Masque também é lançado, em edição colorida e bem produzida, pela refinada galeria e editora francesa. A publicação trazia em suas páginas vários dos trabalhos com alegorias, expondo esfinges, rapinas, índios navajos. Muito fre- 

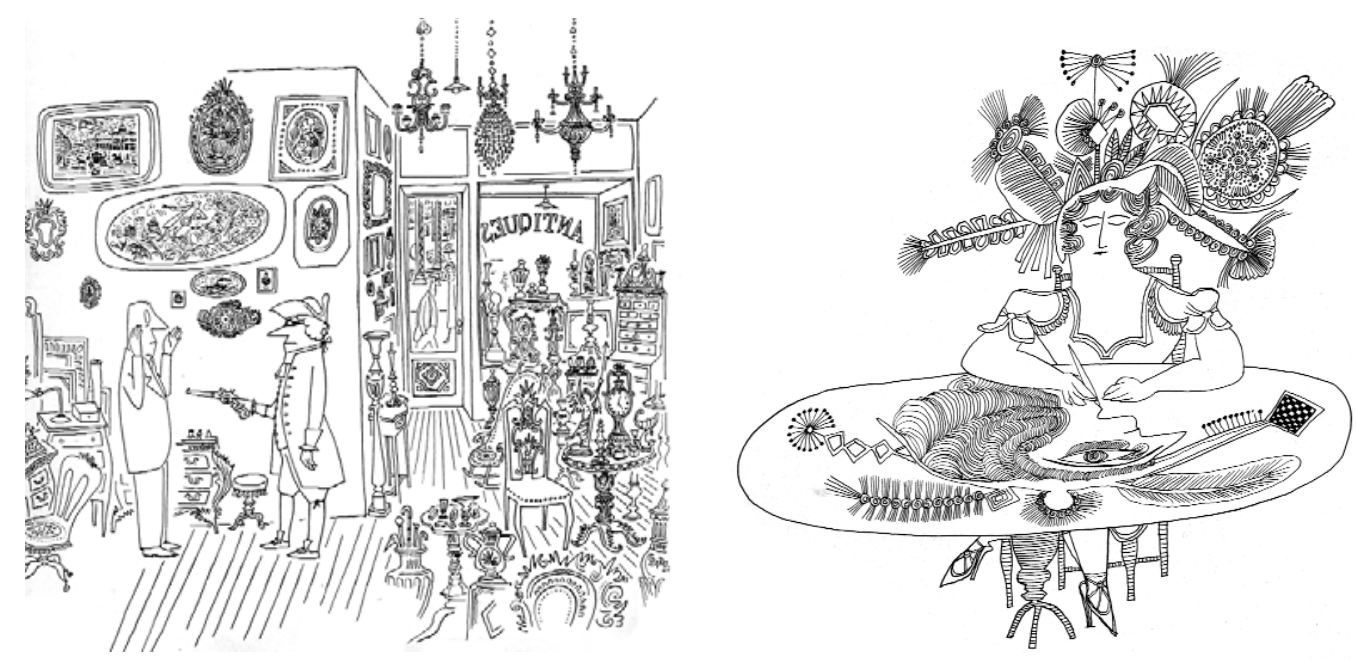

quentes, também, eram as abordagens relacionadas à arte, com artistas que se desenham, paisagens anacrônicas, amantes da arte, naturezas mortas de ilusões. Outras pesquisas da época, como as máscaras, foram apresentadas em todas as suas variações e aplicações, configurando-se em uma das atrações do livro. No entanto, o que mais parece ter marcado este novo conjunto de trabalhos foram as inúmeras colagens e desenhos com paródias de estilo, em variações de cartas de correio, colagens com rótulos, representações de discos de vinil. "Paródia é o espírito de Le Masque", analisa Manuel Gasser (Gasser, 1966, p.8), que escreveu na revista Graphis, a propósito da exposição e do livro:

A passagem o desenho de humor para a fine art, empreendida sem muito sucesso por muitos nos últimos anos, tem sido realizada com confiança por Saul Steinberg. Este sucesso pôde ser comprovado há poucas semanas atrás na Galeria Maeght, uma das principais galerias de arte de Paris, que exibiu os desenhos de Steinberg em salas que habitualmente expõem os mais respeitados pintores europeus, e que agora são publicados em Le Masque, um livro impresso com não menos carinho do que aquele conferido a outras obras primas gráficas de artistas consagrados.

Na verdade, Steinberg tem progredido há algum tempo do desenho de humor tradicional para a livre expressão gráfica aqui exemplificada em Le Masque. Ela começou quando ele primeiro abandonou o modo de desenhar que meramente ilustrava um jogo com palavras e começou seus jogos sem palavras. O próximo passo (com Steinberg na cabeça do movimento) foi o desenho abstrato, não contendo nenhuma anedota do gênero, que obviamente não podia ser "contada", e que o público, de maneira surpreendente, aceitou rapidamente (novamente, em especial, devido à personalidade de Steinberg).

O passo final agora se mantém: persuadir o amante da arte que as formas que um cartunista confere ao papel podem ser mais que mera cópia, e é possível que sejam, de fato, tão valiosas quanto os padrões criados pelos artistas consagrados. (Gasser, 1966, p.8) 

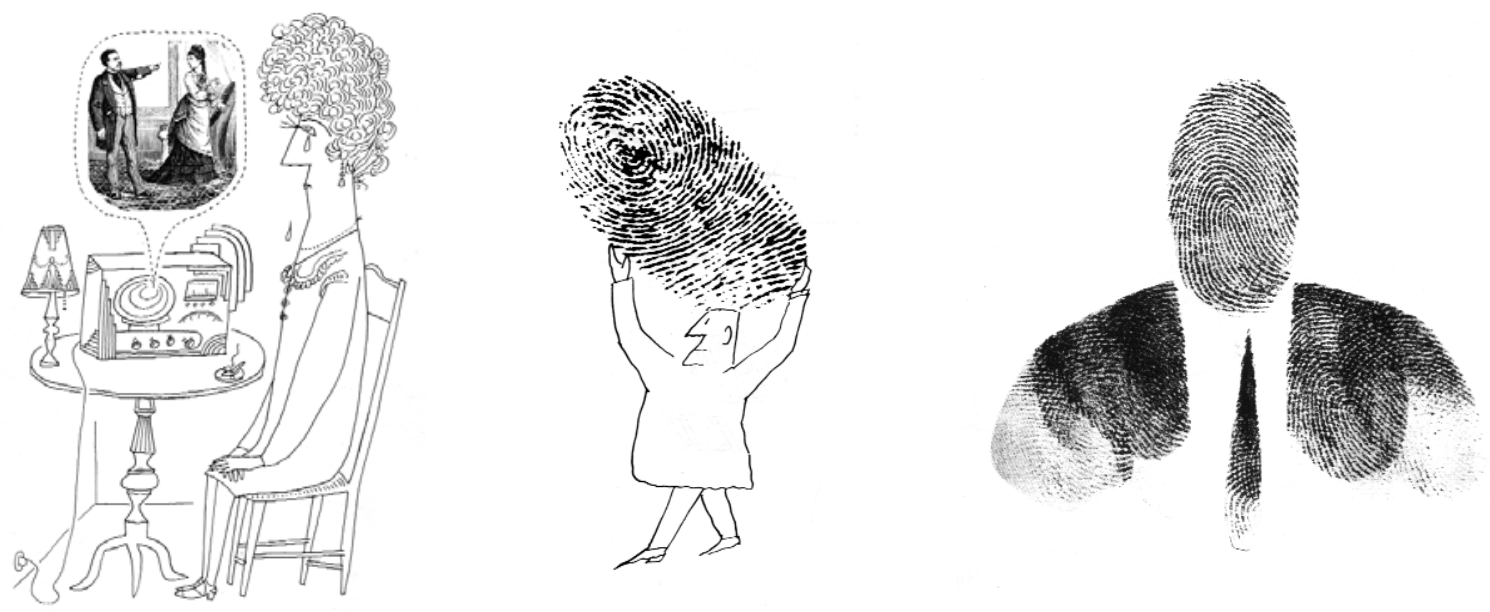

Do "estilo" nos cartuns Às Paródias Gráficas

Como comenta Rosenberg em seu longo texto sobre o artista, "além da história de sua vida, o mais fundamental tema de Steinberg é o estilo - a forma que coisas, lugares, pessoas assumiram através das maneiras da natureza, através a cópia e da invenção humana" (Rosenberg, 1978, p.25). Steinberg levava adiante de modo incisivo, na metade dos anos 1960, um gênero de pesquisa com estilos que começava a ganhar maturidade já no começo dos anos 1950, seja com os documentos e assinaturas, seja em algumas obras específicas como Vichy Water Still Life, de 1953. É fato que o uso de estilos chamava a atenção de Steinberg desde cedo, como nos desenhos dos anos 1940 publicados em All in Line. O excesso de adornos de arquiteturas e espaços interiores presente nestes trabalhos iniciais pertencia, no entanto, à mesma linguagem do conjunto do desenho; ou seja, o traço fino que definia as formas de um capitel era o mesmo que delineava os contornos de um personagem. Eram situações com as típicas figuras de cartum, ambientadas em cenários elaborados que, por vezes, assumiam a condição de "personagens principais". Com o tempo, Steinberg passa a contrapor, cada vez mais, estilos de modo mais evidente, inserindo objetos "alienígenas" em seus habituais desenhos de

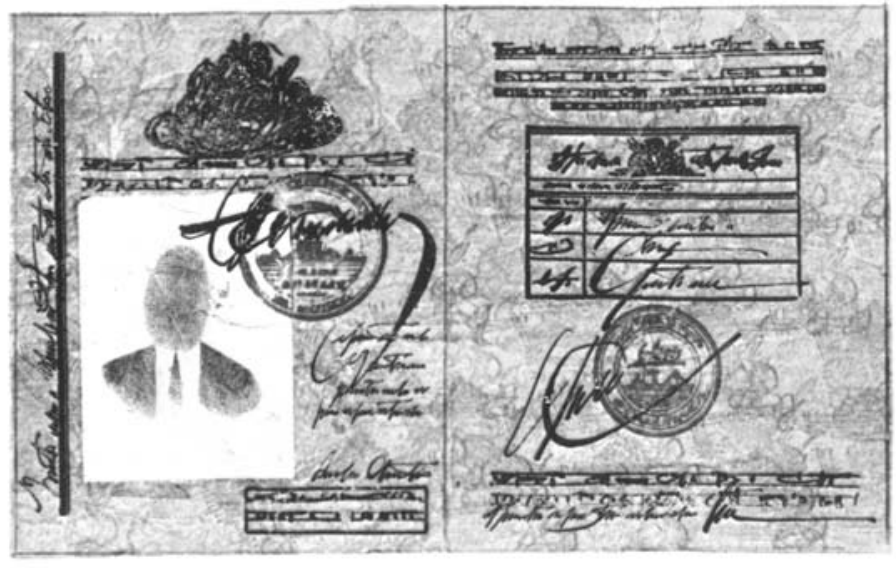

Figura 398-400. Trabalhos

publicados em The Art of Living

Figura 401-402. Trabalhos publicados em Dessins

Figura 403. Um passaporte de Steinberg. 


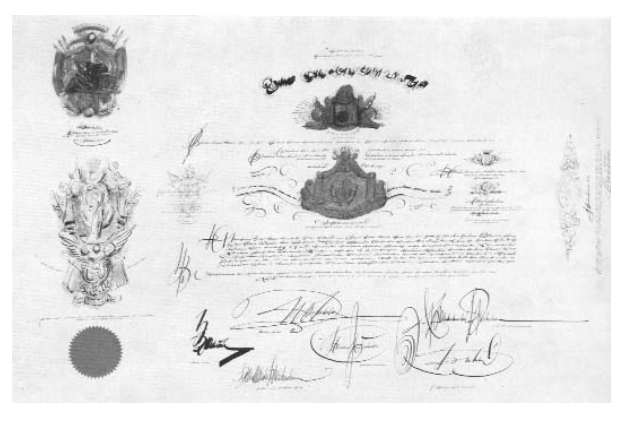

Figura 404. Um dos Documentos de Steinberg

Figura 405. Vichy Water Still Life, 1953

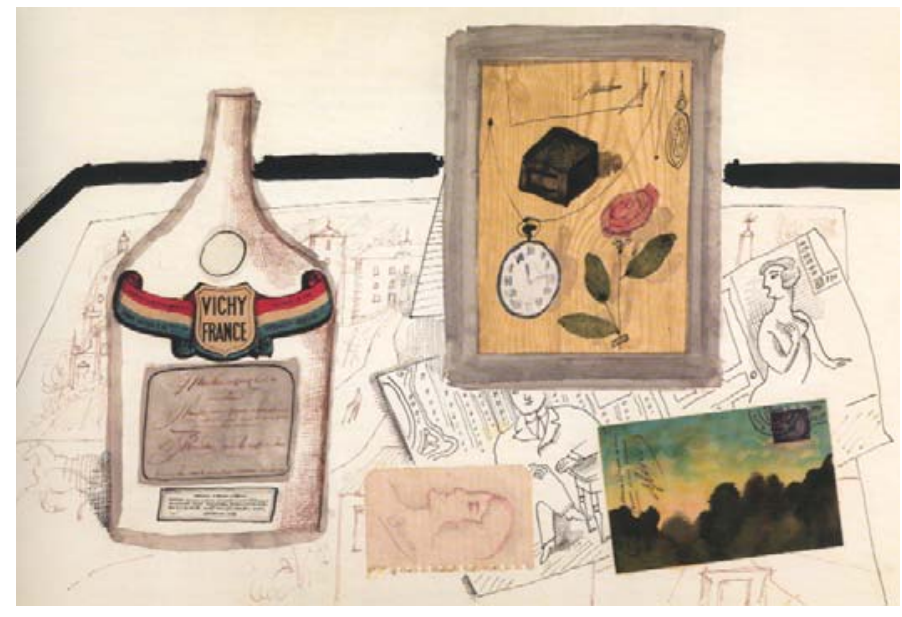

linha, como na inserção pontual de colagens em trabalhos de 1951, no uso de caligrafias e impressões digitais feitas em 1954, ou nos sons gráficos de 1955. À medida que refletia sobre a atuação destes estilos em ambientes de traço steinbergniano, o cartunista também começava a criar, paralelamente, universos compostos apenas por estes elementos gráficos. Nos passaportes e documentos, já não era necessário que um homenzinho narigudo de linha fina aparecesse carregando uma assinatura para sugerir a condição de paródia do elemento gráfico. De algum modo, o conjunto dos trabalhos de Steinberg era suficiente para insinuar o tom de paródia dessas obras, onde cada elemento utilizado parecia assumir uma nova e misteriosa condição como personagem. A natureza-morta Vichy Water, de 1953, segue esta lógica, ao criar um ambiente em que elementos de estilos diversos convivem entre si, espalhados pela imagem. Ao invés de recorrer a poucas técnicas, como as assinaturas dos Documentos, a composição é constituída por cartões-postais, "rascunhos", garrafas de vinho, quadros feitos em aquarela, tinta, lápis, colagem, entalhe. Como contraponto à escassez de figuras cartunescas, uma "personagem" em linha fina parece olhar para um quadro pintado em aquarela; no entanto, ela mesma é um estilo, um dos inúmeros esboços dispostos sobre a mesa. Rosenberg observa que, "como Joyce, Steinberg se apropria de estilos em qualquer lugar que os encontre, seja no meio do caminho ou em um museu, e os reutiliza através de paródias como expressões da experiência contemporânea" (Rosenberg, 1978, p.25). A habilidade de Steinberg não reside apenas na imitação destes estilos. Ele promove uma "reductio ad absurdum ao usar a técnica "certa" com o objeto errado" (Gasser, 1996, p.8).

Manuel Gasser, ao dizer que estes trabalhos de Le Masque não passam por "uma mudança de tema ou estilo", e que "a única diferença entre os desenhos em preto-e-branco do cartunista e o trabalho (...) em Le Masque é de execução técnica" (Gasser, 1996, p.8), procura estabelecer uma justa conexão com as preocupações anteriores de Steinberg. Por outro lado, incorre no risco de minimizar a amplitude de algumas inovações. Além das mudanças de técnicas empregadas, Steinberg surpreende no modo como realiza as composições, seleciona e distribui os elementos gráficos, gerando universos de inusitado grau de abstração. 


\section{O ESTILO COMO PROBLEMA DE IDENTIDADE}

A preocupação com as questões do estilo pode ser relacionada a desenhos que exibem "problemas de identidade", como um cartum metalingüístico publicado em 1945 na New Yorker: são desenhos que se desenham, "desenhos um pouco preocupados em encontrarem a si mesmos em um desenho", como nota Steinberg (cit. por Smith, 2006, p.124). O trabalho de 1945 logo receberia novos desdobramentos em 1953 na própria revista, como no cartum em que o personagem desenha a própria face como uma assinatura, expondo algumas de suas "máscaras"; ou no homem feito de impressão digital, elemento que é uma "assinatura orgânica" (Rosenberg, 1978, p.16), segundo Steinberg a essência de um auto-retrato. Mesmo os documentos, tão produzidos no começo dos anos 1950, sugeriam questões de identidade, num ambiente cenográfico em que formalismos diversos desfilavam suas personalidades e faziam pose, com certa sugestão autobiográfica. Estava aberta a possibilidade, portanto, ao personagem steinbergniano, de fazer uso do melhor elemento gráfico e técnica para se mostrar e se disfarçar, seja em assinaturas, impressões digitais, ou qualquer estilo. Como comenta Smith sobre Steinberg, "a premissa à qual ele havia chegado - fazer suas figuras conscientes de seu status de (auto) representações, como "problemas de identidade" - abriu um rico caminho, que começou com duas séries que ele tomou para si no próximo ano: as tipologias de coquetéis e os perfis de Homens de Impressão Digital. Em cada caso, o casamento de tema e técnica é tão intuitivo que é fácil esquecer que houve a necessidade de invenção" (Smith, 2006, p.124). Na festa Techniques at a Party de Steinberg, posteriormente publicada no livro

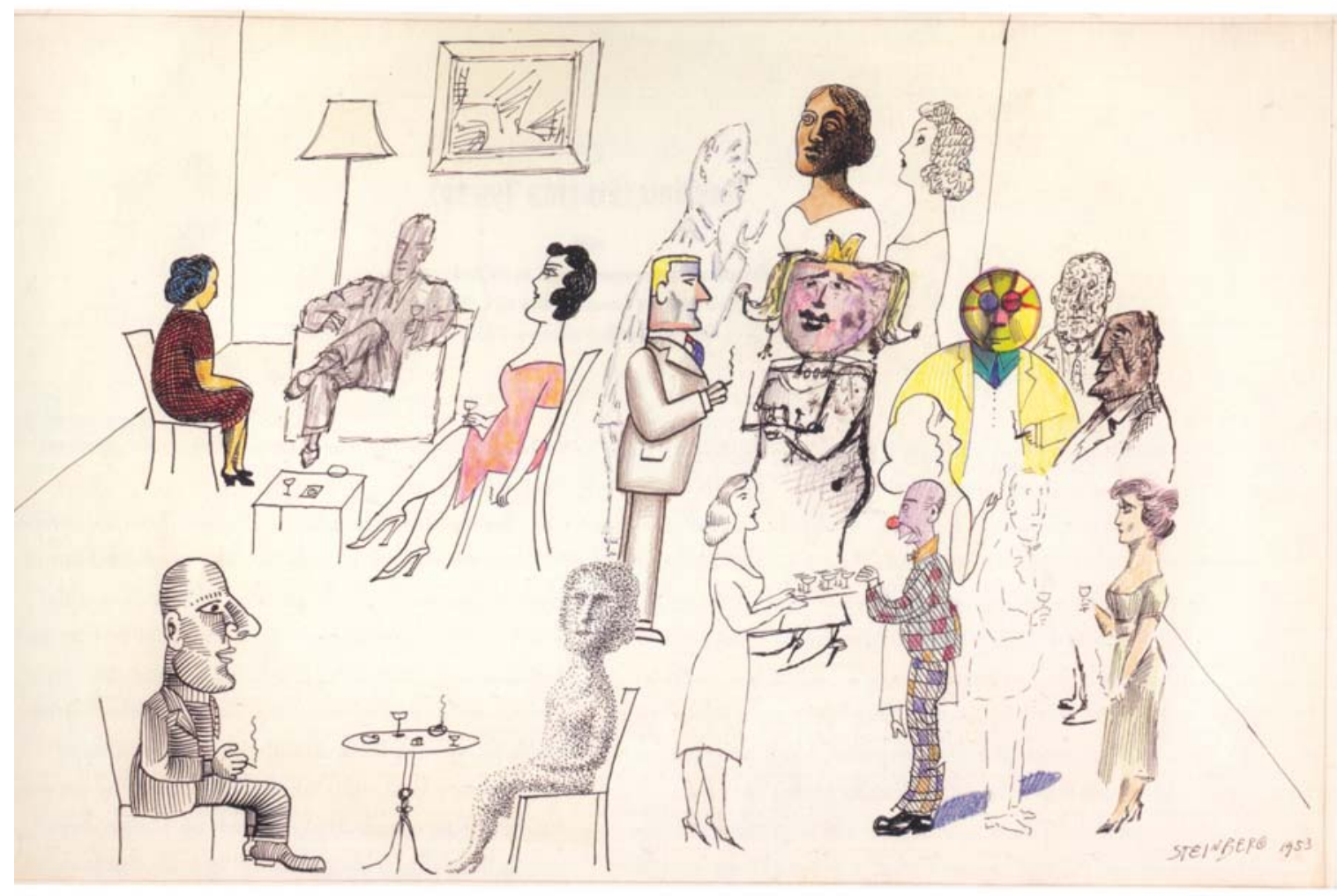

Figura 406. Techniques at a Party, 1953 

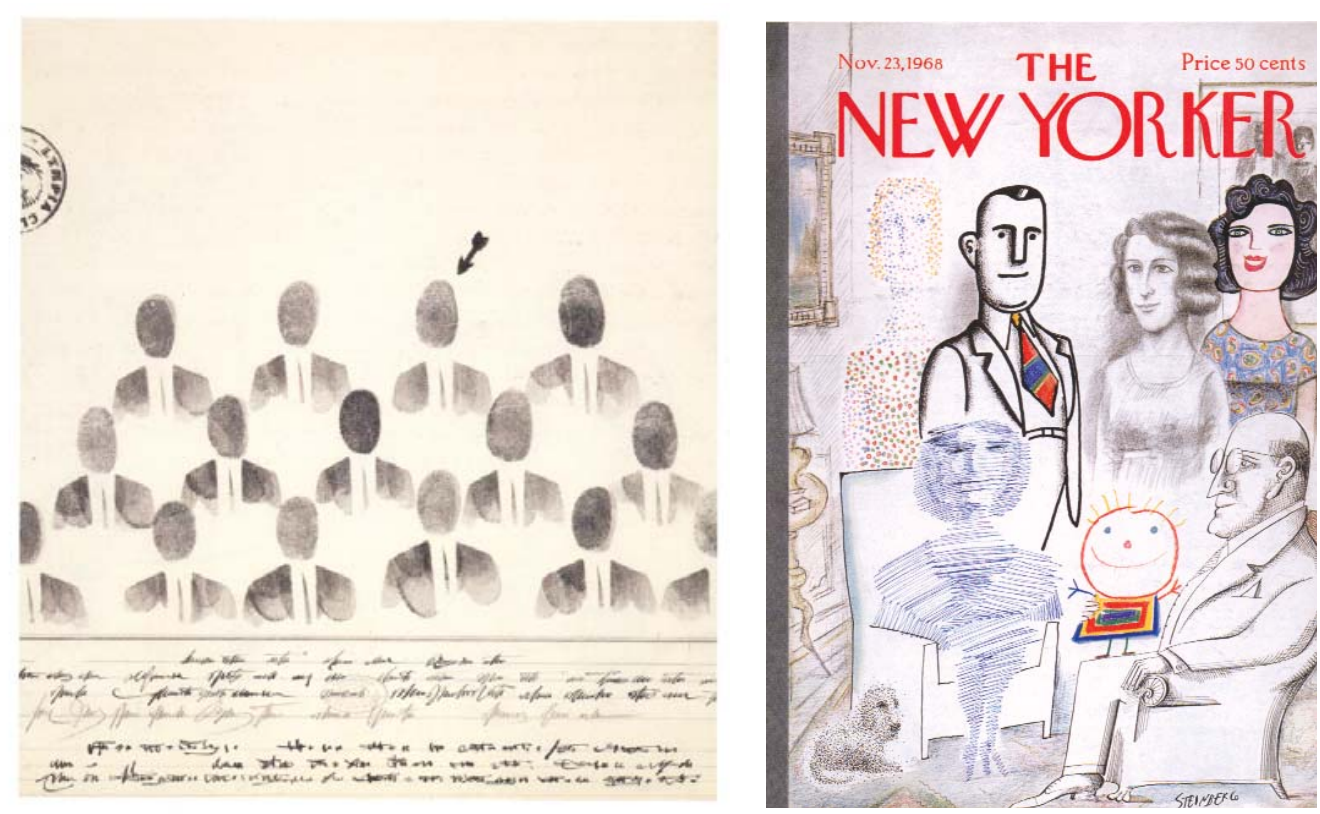

The Discovery of America, personagens postos em conversa numa festa exibem, cada qual, um estilo e uma técnica diferente. Já em Group Photo, Saul mescla uma série de personagens feitos de impressões digitais, desta vez sem olhos e bocas, em um ambiente que lembra os documentos, com seus carimbos e assinaturas. "Na festa de Steinberg, todo mundo é um autoretrato vivo, e o personagem é o estilo (...). Group Photo apresenta a situação contrária - a completa imagem, literalmente, da identidade coletiva". Smith percebe que a questão da identidade individual e coletiva, da diferenciação de um grupo e de sua identificação, era um problema que se fazia muito presente na mente da classe gerencial que constituía o público leitor da New Yorker, e que tinha seus pontos de contato com o contexto político daqueles anos de Guerra Fria:

A Segunda Guerra Mundial havia sido vencida com base na força da conformidade corporativa em uma escala nacional e vasta, e agora a Guerra Fria havia sido assumida no mesmo fundamento. E no entanto, teoricamente, o herói do Sonho americano era o Indivíduo, e o a coletivização à moda soviética, o inimigo (Smith, 2006, p.124).

O indivíduo estilizado viria a ser empregado com freqüência, como nos portifólios de casais e pessoas publicados na New Yorker em 1962, e no emblemático trabalho, feito no mesmo ano para a revista, em uma leitura mais abstrata de trabalhos como Techniques at a Party; ou no Family Group da capa da New Yorker de 1968, criada em 1965. Family Group, para Smith, evidenciaria no retrato de família a mescla de dois conceitos: a orgia do individualismo e a pose em grupo (Smith, 2006, p.124), estabelecendo algo de comum entre os estilos diversos. Estes trabalhos com Indivíduos também podem ser encarados como parentes dos cartuns com sons gráficos e falas gráficas, onde o estilo não está propriamente na face dos personagens, mas na extensão de seus corpos, saindo de suas bocas ou de seus instrumentos. 


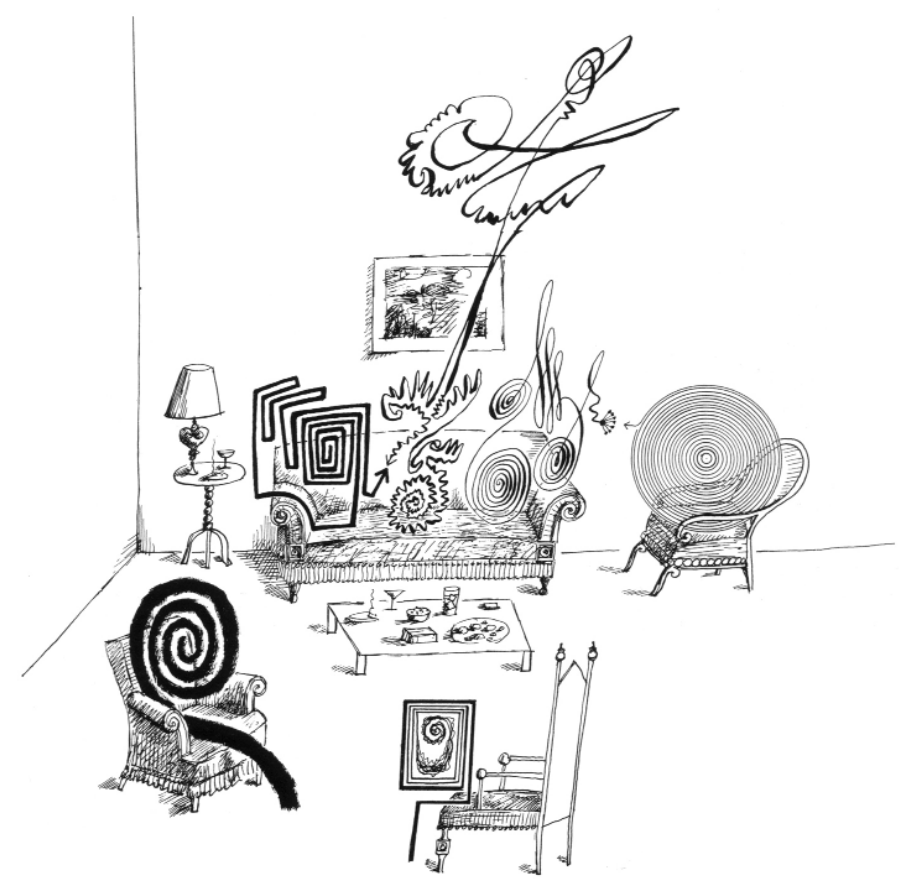

Figura 407. Group Photo,

1953

Figura 408. Untitled (Family Group), The New Yorker, 23 de novembro de 1968

Figura 409. The New Yorker, 1962

Steinberg chega a dizer a seu amigo Buzzi, em 1964: "Gosto de velhos desenhos no qual combino técnicas para explicar as grandes diferenças das pessoas em idéias", notando que "Collete, ao falar de cachorros, explica que o que consideramos raça é na verdade estilo ou personagem" (cit. por Smith, 2006, p.124).

O crítico Harold Rosenberg, em textos publicados nos catálogos Le Masque e Saul Steinberg, vê a questão do individuo como tema central em Steinberg, recorrendo em seus comentários ao self: "Steinberg emergiu entre os artistas americanos que no imediato pósguerra revolucionaram a pintura e a escultura introduzindo nelas um novo tema: o mistério da identidade individual" (Rosenberg, 1978, p.10). Ao colocar o self como aspecto elementar, consegue inserir o cartunista no contexto artístico do período, relacionando-o aos expressionistas abstratos. Em seu trabalho, o tema do self é acompanhado pelo da autobiografia. "De trás para frente, ele é lido como um diário (...). Ele reflete o que li, o meu envolvimento com as pessoas, lugares, temperamentos; várias formas de esquizofrenia que todos nós temos e que seria estúpido ocultar", refletiu Saul em 1970 (cit. por Gluek, 1970, p.110). Este aspecto também emerge como um ponto de contato, explorado por Rosenberg, entre trabalhos tão díspares como o de Steinberg e pintores como Pollock e de Kooning:

Como eles, Steinberg concebeu a arte como autobiografia. Mas autobiografia de quem? O escondido self metafísico. O homem de hoje? O imigrante? O estranho? $\mathrm{Na}$ segunda metade do século, o artista é obrigado a inventar o self que irá pintar seus quadros - e que será o tema de suas pinturas (Rosenberg, 1978, p.10).

Procurando explorar e se aprofundar cada vez mais na questão, talvez fruto das diversas conversas que estabelecia com o cartunista, o crítico não deixa de apontar diferenças entre Steinberg e os expressionistas. Estas residiam, segundo ele, no modo de abordar o self: 
"Ao invés de procurar 'contato' (nos termos de Pollock) com o singular, Steinberg concebeu o teatro do Homem Abstrato, o 'Sr. Qualquer-Um'" (Rosenberg, 1978, p.11). As peculiaridades deste Homem Abstrato são comentadas por ele:

Ao invés de apresentar-se como protagonista, Steinberg projeta um alter-ego que é desapegado, curioso, passivo e medroso - uma de suas mais memoráveis marcas registradas é o cavalheiro que apresenta no interior de sua cabeça um coelho espreitando pelos olhos do homem, uma criatura amedrontada, ao mesmo tempo engaiolada e protegida (The Rabbit). Acessível apenas através de suas metáforas, Steinberg se torna "alguém" em suas demonstrações de como seu ser interior anônimo está constantemente se representando a si mesmo (Rosenberg, 1978, p.12).

Gasser confirma a visão de Rosenberg, ao afirmar que "este anonimato, ou particularmente, esta negação da identidade, é de fato - além do elemento de paródia - uma das principais características da arte de Steinberg" (Gasser, 1966, p.8). É dentro desta lógica de um personagem anônimo, que fala da questão da identidade vestindo diferentes roupagens e máscaras, que transparece o uso que Steinberg faz da paródia de estilos. Muitas vezes configurados em linguagens consagradas pela História da Arte, Saul entende que estes estilos escondem, por debaixo de suas causas puras, um personagem trabalhando suas aparências. Nos trabalhos com paródias, portanto, o foco deixa de ser a obra, para se centrar no personagem por detrás dela. Desse raciocínio pode-se extrair a já citada idéia de disfarce e de "máscara" do estilo. No seu modo de ver o mundo, todas as pessoas vestem máscaras, sejam reais ou metafóricas, inventando personas através de roupas, cortes de cabelo, móveis e postura. As cidades, portanto, definem-se a si mesmas pela arquitetura, e as nações por seus ícones (Rosenberg, 1978, p.14).

Se nos reportarmos novamente a Le Masque, é possível interpretar seu título não apenas pelas máscaras desenhadas por Steinberg e expostas nas fotos de Inge Morath, como também nos demais trabalhos com paródia. Como observa Gasser, "muitas outras figuras são mostradas de modo a sugerirem a máscara, por elas apresentarem evidentemente uma face falsa ao mundo, uma que não reflete sua verdadeira personalidade, ou porque o artista tira as suas máscaras usando uma técnica exatamente adaptada aos seus eu-interiores para apresentá-las" (Gasser, 1966, p.8).

As QUeSTÕES DA ARTE E DO ARTISTA

Relacionadas às paródias, ao estilo e aos problemas de identidade estão as questões da Arte e do Artista. O assunto vem à tona no trabalho de Steinberg desde muito cedo, como por exemplo no trabalho Arte, publicado na italiana Bertoldo em 1937, com seis piadas leg- 

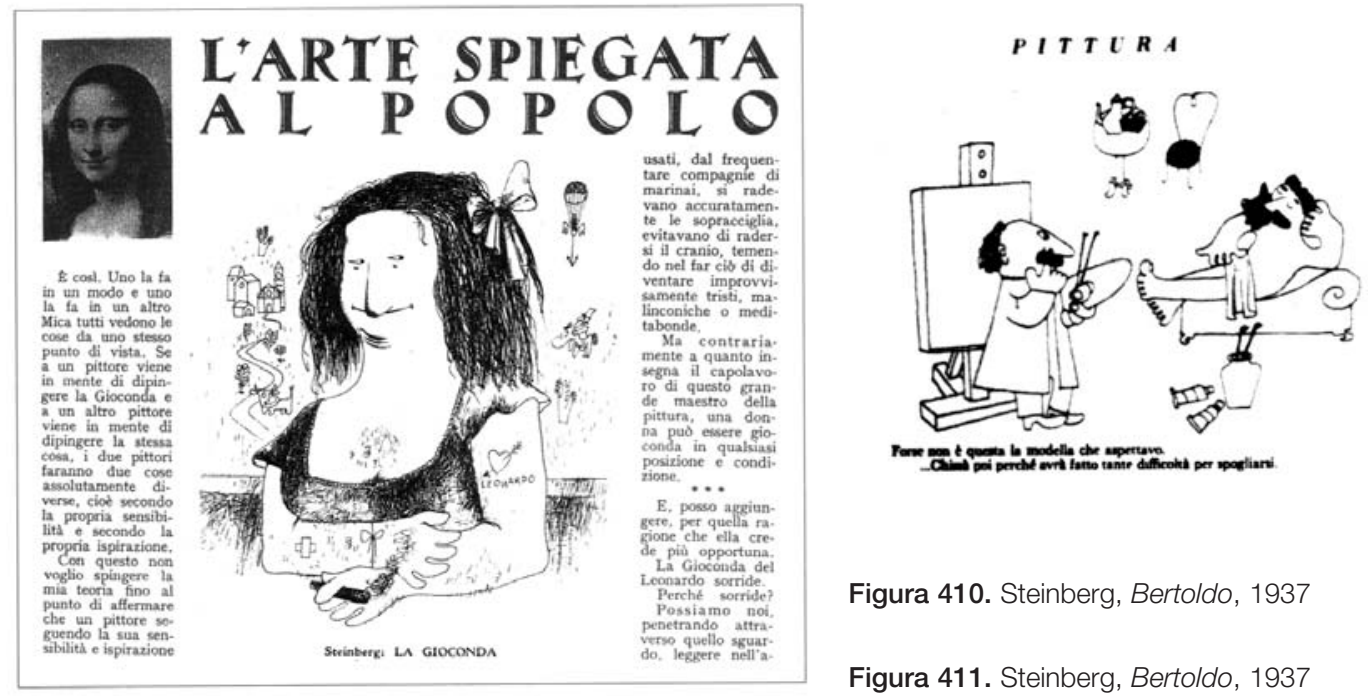

Figura 410. Steinberg, Bertoldo, 1937

Figura 411. Steinberg, Bertoldo, 1937

endadas, ou na ousada versão da Gioconda feita no mesmo ano sob o título L'are spiegata al popolo. Seu cartum de estréia na New Yorker, publicado em 1941, coincidentemente traz uma situação com pintores, na típica solução com legendas do período italiano. Se os artistas profissionais só viriam a aparecer esporadicamente em seus cartuns para a New Yorker, o "olhar de artista" de Steinberg - interessado em encontrar o inusitado no ato de desenhar e no manuseio de objetos - seria incorporado por vários de seus personagens nos anos 1940. Em sua primeira década na revista americana, chama a atenção o cartum de um pintor de casco de tartaruga, feito em 1947, que evidencia uma precoce exploração da presença da arte e do estilo nas coisas, como na proximidade entre os desenhos do casco e uma paisagem pintada. Já a relação entre arte e identidade é sugerida de modo sutil em outro trabalho para a New Yorker, de 1949. A surpresa do desenho reside na não-correspondência à expectativa inicial, que seria uma simples pintura da moça que posa. Ao contrário, o pintor inclui na obra todo o entorno, com outros quadros da mulher pendurados na parede. Os elementos que embelezam o espaço - uma peculiaridade estilística -, ao serem retratados na nova pintura, conferem à moça uma personalidade que não seria a mesma caso o pintor se concentrasse

Figura 412. The

New Yorker, 1943
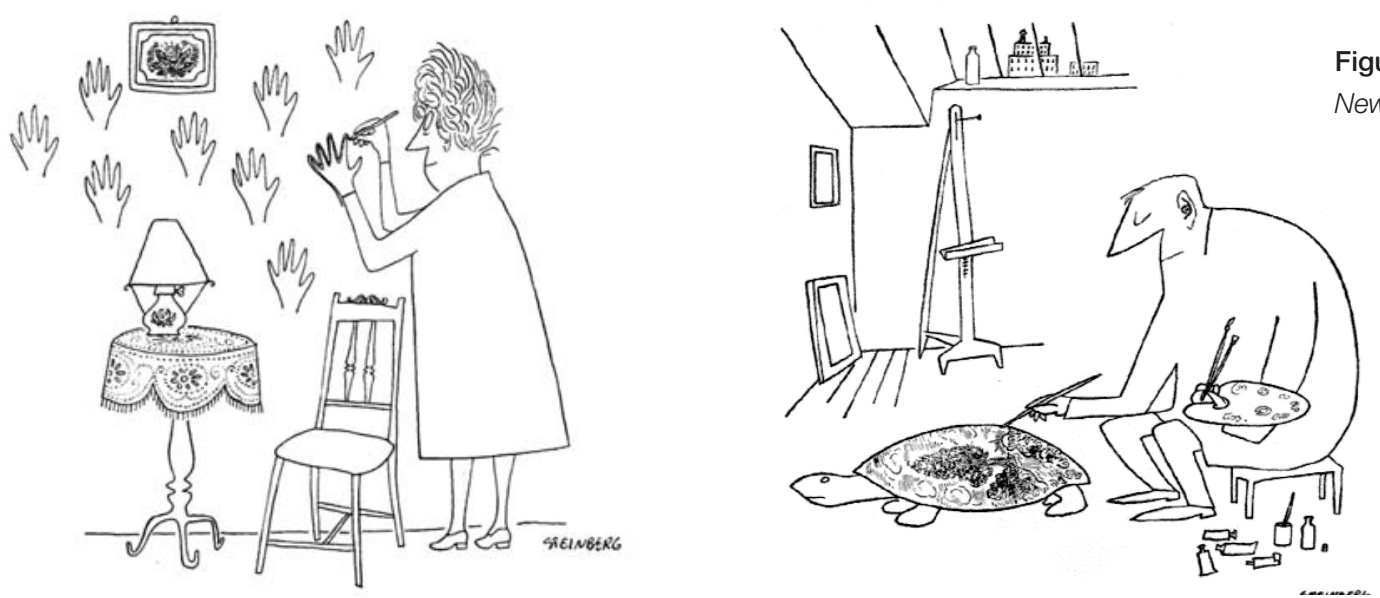

Figura 413. The

New Yorker, 1947 

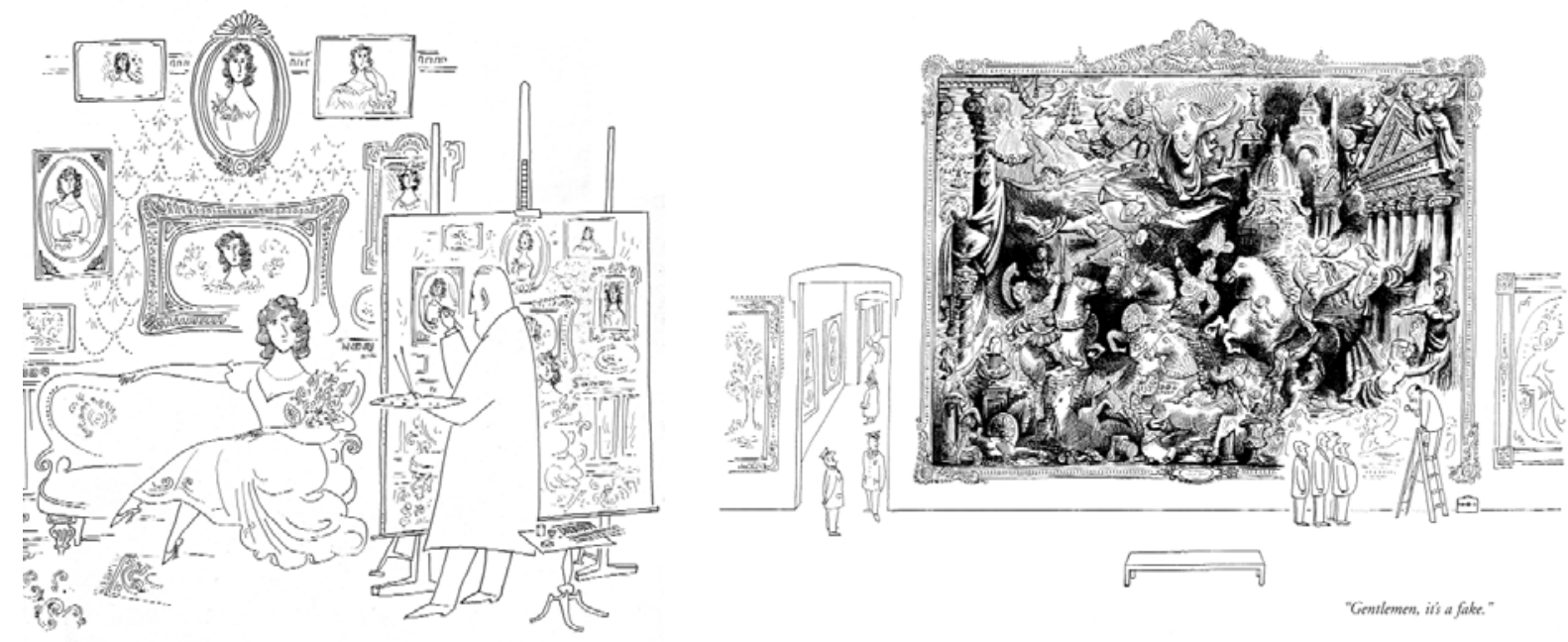

apenas nela, à sua frente. Um ano depois, em um cartum de 1950, é o artista o foco dos comentários: transparece a atenção de Steinberg ao exibicionismo performático do pintor, algo que diz respeito também à sua identidade. $\mathrm{O}$ quadro pintado é de tal modo detalhado que este se configura em um estilo alienígena, um forasteiro naquele mundo de linhas como os carimbos e impressões digitais. Outro trabalho, feito em 1952 e contemporâneo dos documentos e dos primeiros personagens-estilo, salienta a preocupação com o estilo na oposição entre as linhas a la Mondrian da pintura e a decoração do espaço. O comentário de Harold Rosenberg sobre Techniques at a Party serve também para este cartum com estilizações contrastantes: o "estilo é um modo de organizar as coisas culturalmente, e Steinberg justapõe estilos de tempos diferentes para criar uma consciência da constante proliferação de anacronismos" (Rosenberg, 1978, p.25).

No uso dos estilos, Steinberg pretendia refletir sobre o modo como estes elementos atuavam na sociedade: "Meus desenhos contém muitas vezes paródias do desenho. É uma forma de crítica de arte" (cit. por Rosenberg, 1978, p.26). Seu interesse estava voltado ao artefato, às criações do homem. "Apenas objetos uma vez transformados pela invenção humana são assuntos apropriados para Steinberg", comenta Rosenberg. Uma conseqüência foi o alargamento considerável do leque de possibilidades, uma vez que "todas as coisas têm origem na arte" (Rosenberg, 1978, p.19). Para Rosenberg, Saul reverteu a prática de Duchamp e superou o esteticismo do pop, ao incorporar as formas encontradas nos museus à sua própria arte popular - o cartum (Rosenberg, 1978, p.23): "Suas composições cruzam as fronteiras entre arte e caricatura, ilustração, desenho infantil, art brut, sátira, ao mesmo transmitindo reminiscências de estilos da Grécia e Oriente ao cubismo e construtivismo" (Rosenberg, 1978, p.10). O próprio Steinberg chega a abordar a questão: "Você aprende todos os clichês de seu tempo. O meu tempo foi o do cubismo tardio, pela Bauhaus; nossas nuvens vieram direto de Arp (...); mesmo nossas árvores foram influenciadas por uma mania pelo contorno infantil" (cit. por Hughes, 1978, p.51). Seus desenhos, deste modo, acabam representando "em certo sentido, antologias da história da arte", analisa Hilton Kramer 


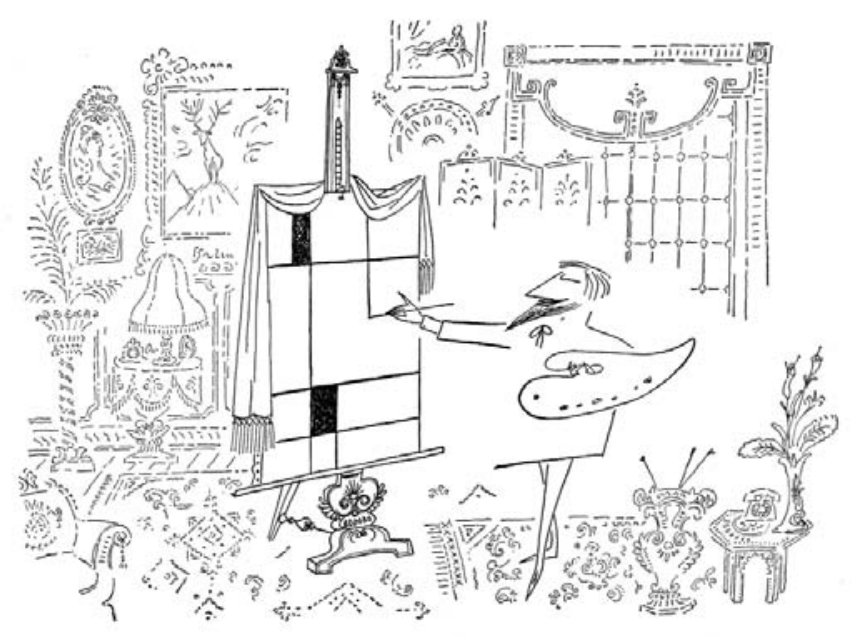

Figura 414. The New Yorker, 1949

Figura 415. The New Yorker, 1950

Figura 416. The New Yorker, 1952

(Boxer, 1999, s.p). Saul chega comentar que criar, em seu tempo, consistia em "artistas historiadores da arte pintando a história da arte para historiadores da arte" (cit. por Rosenberg, 1963, p.142). Para Gasser, os trabalhos com paródias de Steinberg contém as raízes de nossa cultura e civilização, alusões a milhares de anos de evolução artística, que resultam, no entanto, em formas inespecíficas e anônimas: "Tudo o que ele desenha tem suas implicações e referências secretas, uma certa riqueza de associação reflexiva" (Gasser, 1966, p.88). Toda essa ampla variedade de elementos estava disponível para as criações de Steinberg porque o cartunista via estilos em tudo, até mesmo na natureza. De algum modo, a natureza existia enquanto tal a partir do olhar do homem: "O material na arte de Steinberg não são nem coisas como elas são, nem a aparência de coisas, mas a arte nas coisas, seu estilo" (Rosenberg, 1978, p.19). Steinberg chega a observar: "Quando admiro uma cena no campo, procuro por uma assinatura no canto inferior direito" (cit. por Rosenberg, 1978, p.19). Rosenberg conclui que "perceber a realidade como a arte nas coisas é um dos princípios básicos da estética de Steinberg" (Rosenberg, 1978, p.23).

O desenhista com problema de identidade de 1945, que de certo modo estimulou uma sucessão de pesquisas gráficas que transitaram por variações em linha e passaram pelas paródias gráficas dos anos 1960, reaparece incorporando as recentes abordagens ao ponto de partida: em certas obras de Le Masque, o artista cria complexas imagens em vários estilos que são, ao mesmo tempo, parte de si mesmo: elementos gráficos como os "homens" uma vez desenhados, que enfatizam sua condição de representação. Há também versões mais simples, que mantêm a relação gráfica entre o artista e o universo criado por ele, deformando coisas em traços de desenho livre. Em uma variação do tema, uma série foi feita envolvendo a obra de arte e o receptor, em aproximação gráfica com peculiar uso de ambigüidade, lembrando que "o tema de sua arte é o artifício, o modo como pessoas e coisas se caracterizam, ou são inventadas, ao se apresentarem para o mundo". Desta lógica não escapa sequer o desenhista: "O artista é, também, "criação do homem", mais um objeto que sujeito" (Rosenberg, 2006, p.20). 
Figura 417-419. Trabalhos publicados em Le Masque

Figura 420. Desenho da espiral, Steinberg

Figura 421. The New Yorker, 1969

Figura 422. The New Yorker, 1965

Figura 423. Trabalho publicado em Le Masque

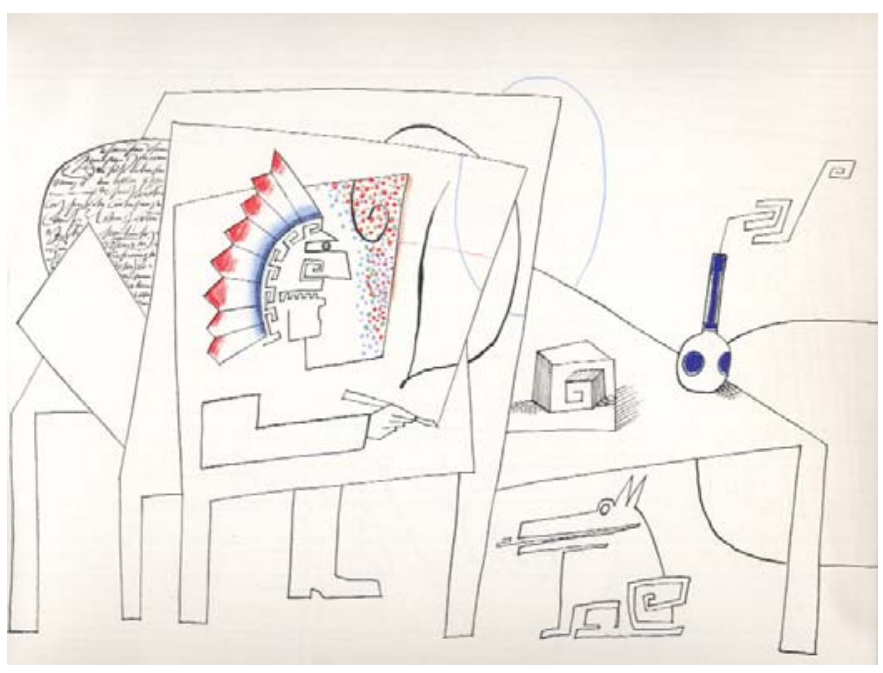

No caso do artista, no entanto, nem sempre este se mostra totalmente mesclado ao estilo que desenha. Também são comuns os trabalhos do criador que delineia, contempla ou está posicionado a uma certa distância dos estilos desenhados, como se estes fossem paisagens. Como comenta Rosenberg, para Steinberg "a paisagem é uma emanação do artista" (Rosenberg, 2006, p.17). Em alguns destes trabalhos, os elementos gráficos pairam sobre sua cabeça; em outros, surgem abordagens existenciais que mostram desenhista imerso em sua própria espiral. "Uma vez que para esse artista a natureza era, em primeiro lugar, sua própria criação, ele é conduzido à ficção e o pequeno homem de Steinberg fica no ar. Por outro lado, o mundo visível é, culturalmente e psicologicamente, uma criação de arte, e ser um artista significa que alguém tem o privilégio de mudá-lo e genuinamente se apropriar dele", já escrevia Rosenberg, em 1963 (Rosenberg, 1963, p.156). Para o crítico, Steinberg faz a relação entre a criação de artefatos e os problemas de identidades, numa situação em que "o artista está rodeado pelo sinal físico de sua identidade", em "um mundo emanando do self" (Rosenberg,
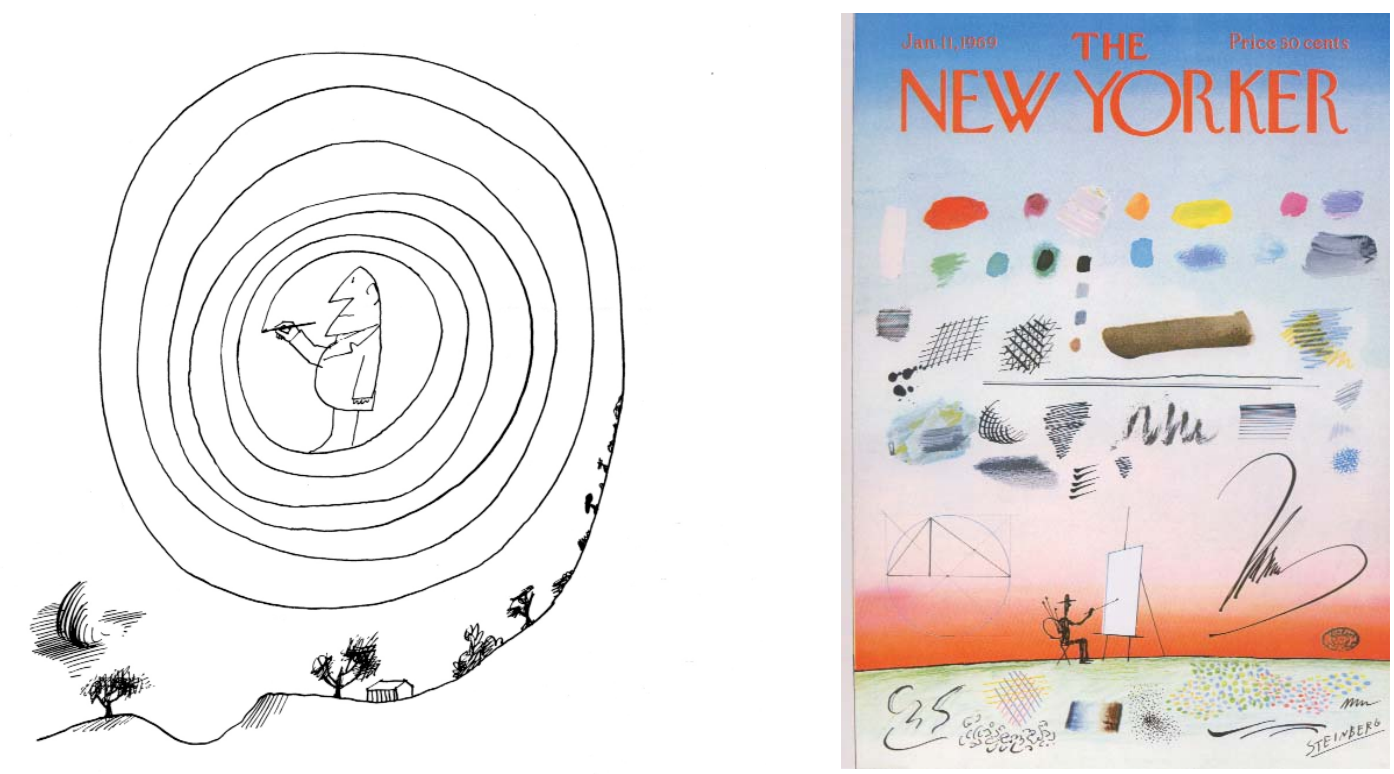

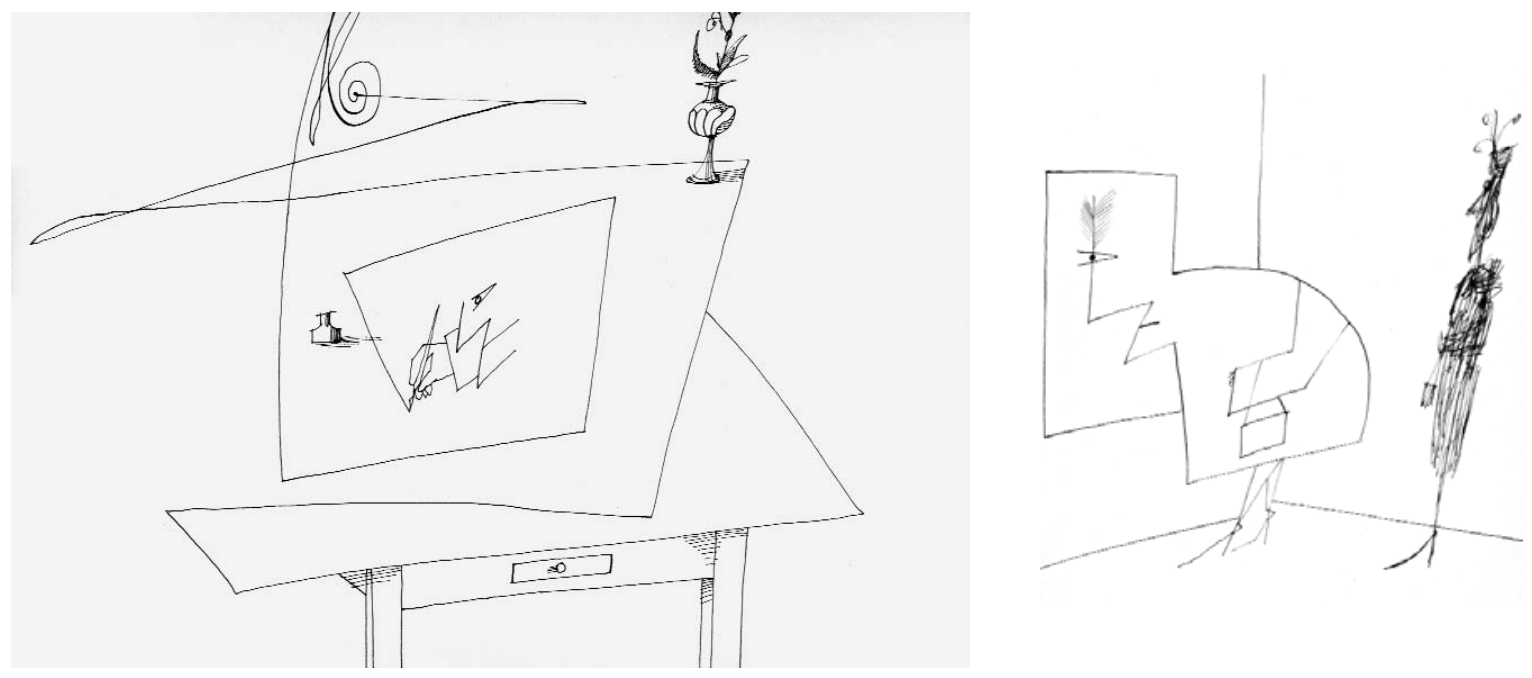

1978, p.17). "Ela fica cada vez mais estreita", comenta Steinberg sobre o desenho. "Este é um desenho amedrontador. Poderia ser a vida de um artista que vive por sua própria essência. Ele se torna a própria linha e finalmente, quando a espiral está fechada, ele se torna a natureza", conclui (cit. por Rosenberg, 1978, p.19).

\section{OS CARIMBOS E POSTCARDS}

Os temas do trabalho de Steinberg abriam margem para a exploração de outras técnicas além do desenho. Steinberg "desenhava" - ou "escrevia" - no sentido amplo do termo. Para além das colagens e diversos recursos empregados, freqüentes em suas obras no período, os carimbos passaram a ser amplamente utilizados. "Eles me ajudam a evitar o prazer narcisístico do trabalho manual. Trabalho é uma armadilha que mantém as pessoas sem pensar - é terapia.
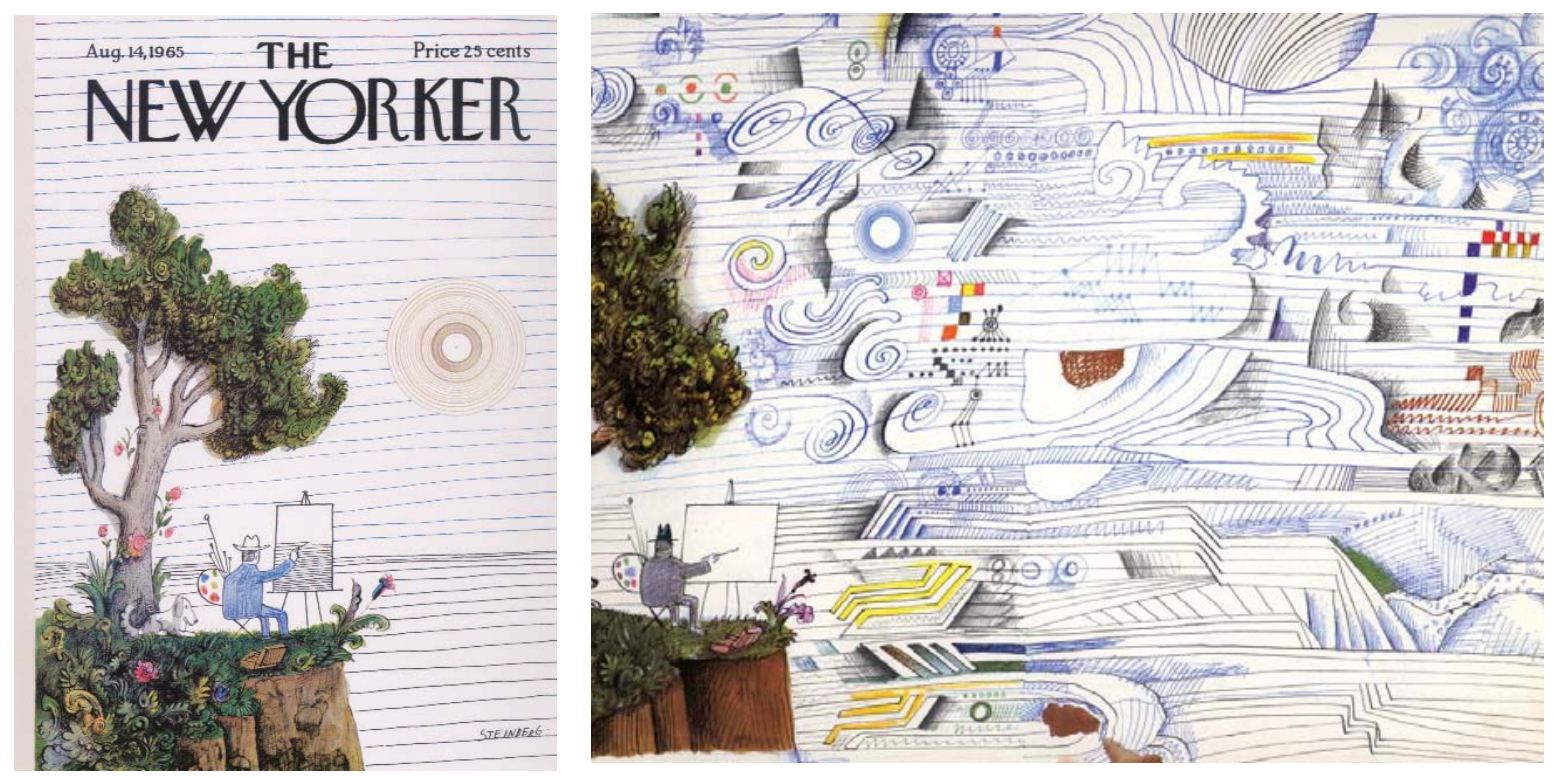
Eu evito fazendo estes simples elementos e então organizando-os (...) É uma forma de arte computadorizada" (cit. por Gluek, 1970, p.112). Parte da "família" de suas pesquisas com estilos e clichês, estes trabalhos também se destacam na produção de Steinberg do final dos anos 1960. A capa de outubro de 1966 para a New Yorker é um dos exemplos de aplicação do recurso, com carimbos ao mesmo tempo "alienígenas" - sobre um fundo de aquarela - e também como personagens principais da cena. Alguns trabalhos sobre ambientes urbanos também foram publicados no miolo da revista, no mesmo ano, com carros, pessoas e decorações repetidas. A técnica, no entanto, já havia sido usada em outras ocasiões, de modo diferente. Como nota Smith, "tão cedo quanto 1951, Steinberg havia começado a acumular carimbos de papelaria para usar em seus desenhos ("RUSH", "ORIGINAL", uma mão que aponta, uma tigela de frutas, uma coroa de flores, bordas folheadas, um brasão de hotel)" (Smith, 2006, p.170), talvez inspirados em seus problemas com vistos e documentos quando tentou ingressar nos Estados Unidos. Mas é em 1966 que o cartunista começa a fazer seus próprios carimbos, desenhados por ele mesmo. Ele inaugura essa nova fase com os selos oficiais falsos - alegorias reais, hexágonos de censores -, e ciclistas, índios, pintores. "Agora, ele poderia compor cenas inteiras no que chamou de 'forma de arte computadorizada'" (Smith, 2006, p.170), ou seja, em obras pautadas na repetição e sem a performance da técnica do desenho. Joel Smith acredita que estes trabalhos com carimbos que tomaram conta da exposição nas galeiras Parsons-Janis 1969, tinham pouca relação com os carimbos das décadas anteriores, e maior proximidade com algumas colagens praticadas pelo jovem cartunista dos tempos da Bertoldo, de recontextualização de certos clichês:

Steinberg havia reavivado seus cartuns ao colar pedaços de gráficos despregados de lixo vitoriano (...). Como veio a acontecer, qualquer pedaço de temas impressos velhos, uma vez transplantados para o novo contexto do cartum, parecia tanto corrupto quanto ridículo - como um velho tentando se misturar a um lúcido grupo jovem (Smith, 2006, p.170).

Figura 424. The New Yorker, outubro de 1966

Figura 425. The New Yorker, dezembro de 1966

Figura 426. Artists and War, 1969

Figura 427. Car, 1953
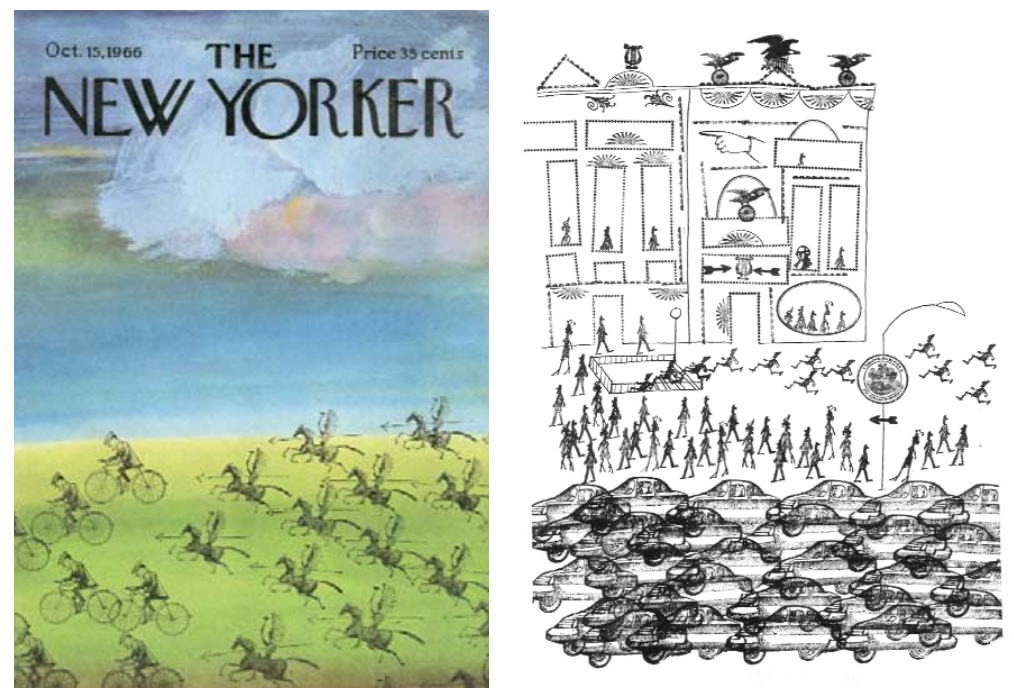
O estranhamento provocado por estas inserções pontuais se manifestava em cartuns como "In posa" e "A scuola", ambas publicadas na Bertoldo em 1937 e 1938, respectivamente. Steinberg também fez uso deste efeito em certos trabalhos dos tempos de guerra publicados no jornal PM: em uma situação com Hitler, por exemplo, coloca o cotovelo do ditador em uma imagem de escarreira. No entanto, o cartunista passa a elaborar colagens mais sutis no pós-guerra, como em Car, de 1953, e Graph Paper Architecture, de 1954. Muitos dos amigos de Steinberg, dentre eles Ad Reinhardt, concluíram que a Guerra no Vietnã devolveu o sentimento de revolta a Steinberg, expressa em determinadas ocasiões pelos carimbos, como em Artists and War, de 1969. "O clichê, o carimbo, tem um significado político", Saul mais tarde comentou, recordando com orgulho que na Primavera de 1968 de Praga, "quando a Tchecoslováquia tinha sua temporada de liberdade,...eles publicaram minhas imagens com carimbo como símbolos de escravidão e tédio imposto pelo Estado" (cit. por Smith, 2006, p.170).

No mesmo período em que retoma os carimbos, Steinberg se volta à criação de cartões-postais, silenciosas paisagens suspensas no tempo, feitas em aquarela. Para Rosenberg, estas obras remetem ao sentimento de nostalgia, "através de toques de anacronismo estilístico e visões de solidão" (Rosenberg, 1978, p.33). "Eles diferem dos desenhos de viagem anteriores de Steinberg no sentido de que não fazem esforço para dominar a essência de um determinado lugar", observa (Rosenberg, 1978, p.33). Vários dos postcards se referem a lugares misteriosos, aludindo, pelo título, a viagens para destinos distantes: Anatolia; Kisumu (Lago Victoria, no Quênia); Kumming (lugar que conheceu na China, durante a guerra). Smith, de qualquer forma, enxerga a menção a um aspecto importante do território americano: "Em um nível literal, os horizontes vazios (...) se referem ao vasto espaço inexplorado que ele primeiro viu no Novo Mundo" (Smith, 2006, p.190). Alguns destes trabalhos, ao apresentarem várias cenas separadas, sugerem "fotografias tiradas em tempos difer-
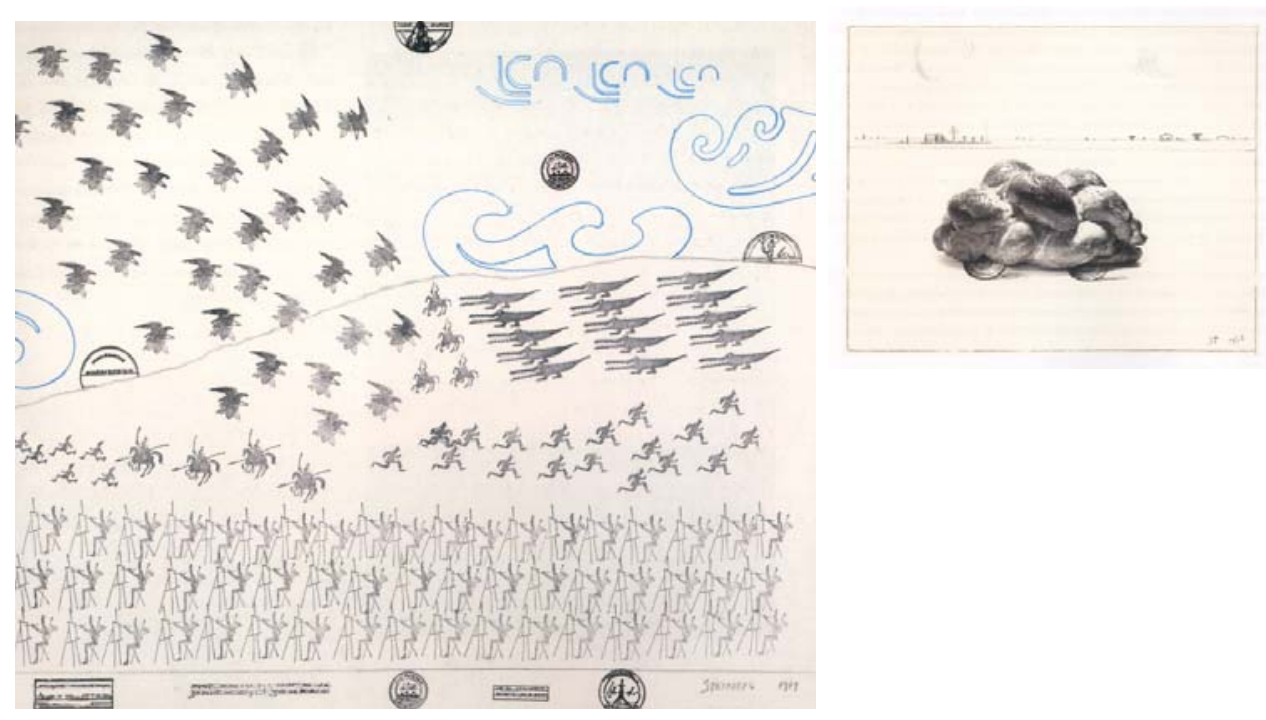
Figura 428. Certified landscapes, 1968

Figura 429. The New Yorker, 1971

Figura 430. November 26, 1965 de 1965.

Figura 431. 12 Variations, 1982

Figura 432. The New Yorker, 1964

Figura 433. Inventory, 1967
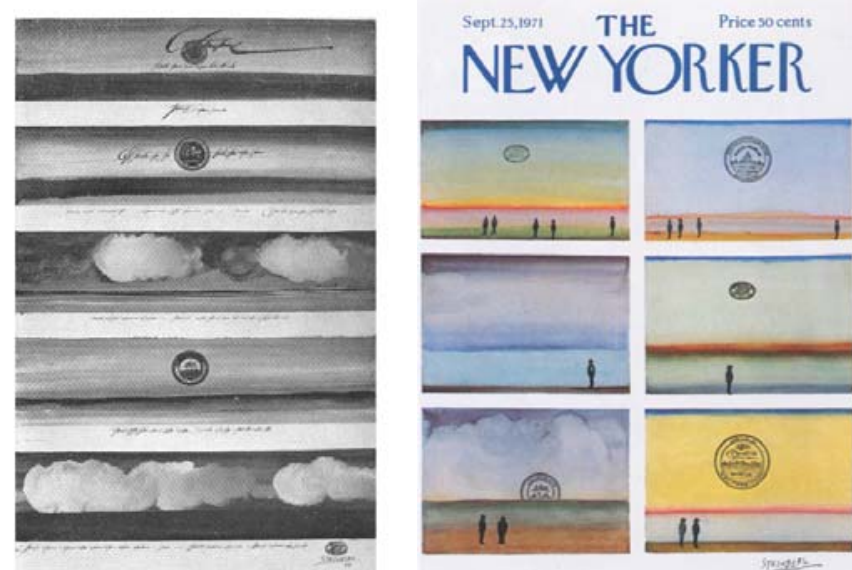

entes" (Rosenberg, 1978, p.33). Em Certified Landscapes, de 1968, os selos oficiais e assinaturas emprestam sua presença a "séries de esguias paisagens horizontais, com nuvens em delicadas cores berrantes que sugerem as esparsas costa do mar de Coubert" (Ashbery, 1969, p.45). Vários dos cartões-postais recebem carimbos, como na capa da edição de setembro de 1971 da New Yorker.

\section{Mistura DE ABORDAGENS}

Algumas das abordagens mais comuns sobre o tema do estilo e do indivíduo no período são: os estilos individualizados em personagens e objetos; as impressões digitais, carimbos e elementos repetitivos dispostos em série; e as colagens-paródias estilísticas, tão encontradas em Le Masque. Muitas vezes, elas aparecem mescladas entre si, ou relacionadas às americaneries, alegorias, autobiografia, às questões do artista, aos jogos com palavras. Inventory, de 1967, é um exemplo de emprego de um recurso que lembra o desenho de personagens-estilos de 1962, mas que aprofunda sua complexidade. Vai além dos estilos puros e insere as alegorias americanas, balões e representações - já subvertidas, com inserção de números e palavras que alteram seu significado - das coisas mais variadas. Um dos recursos de trabalhos como Inventory é alterar o significado de elementos desenhados a partir da inserção de números ou palavras. Steinberg, muitas vezes, estava dando forma ao tempo, como em November 26, 1965, de 1965, feita um ano antes da exposição Le Masque. Nesta obra, "o artista propõe que a mistura de eventos, projeções e memórias de uma agenda, na zona entre forma e falta de forma, é o que se parece com o tempo" (Smith, 2006, p.162). A capacidade de estabelecer correlações aparentemente absurdas, transformando qualquer coisa em outra coisa, evidenciava um gosto que o artista tinha pela metáfora. "Muitas vezes, e de modo considerável, ele desenhou associações indeléveis entre coisas totalmente diferentes", observa Smith, que exemplifica, ao citar os trabalhos 12 Variations, de 1982, e Country Notes, de 1979: 

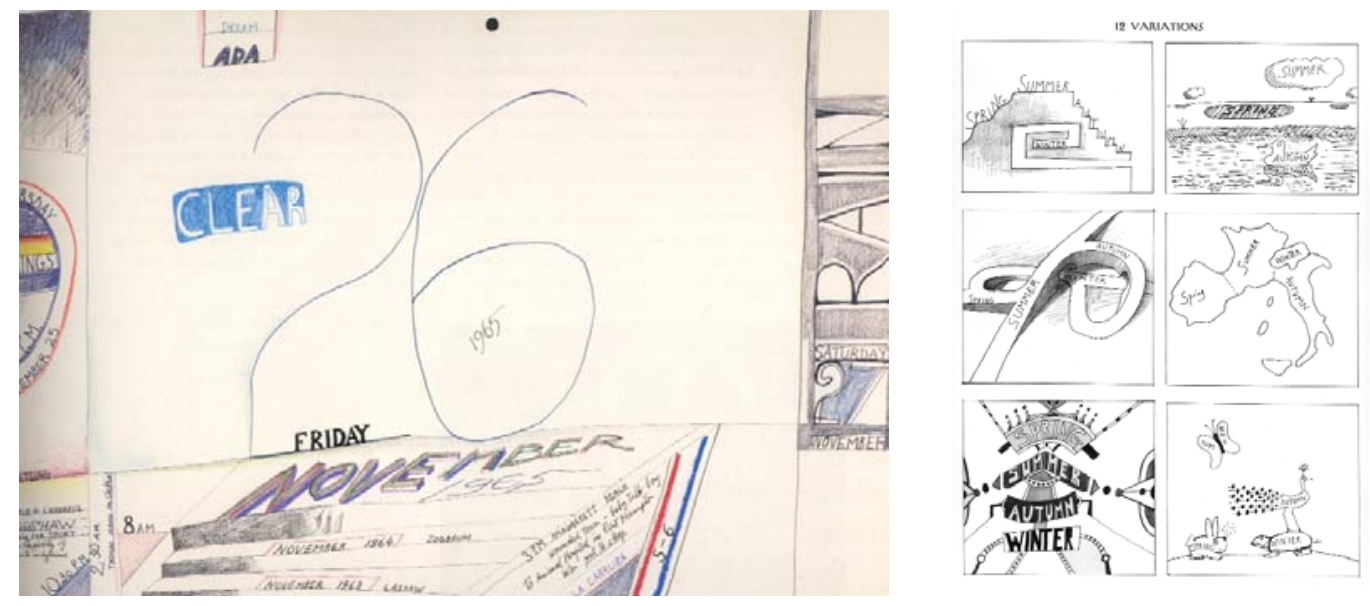

Ele diagramou as estações do ano como (dentre outras coisas) uma tumba piramidal, as nações da Europa Mediterrânea, e um cruzamento de auto-estradas; converteu uma página de amostras de bordas tipográficas em um campo de barulhos ouvidos em sua casa de campo (Smith, 2005, p.172).

Um exemplo da mescla de pesquisas de Steinberg é a capa da New Yorker de dezembro de 1964, que mostra um cruzamento de americaneries, jogos com palavras e estilos dispersos no ar. Já o recurso empregado na capa de outubro de 1963, com mescla da experimentação com balões de fala e papel marrom, incorpora uma radical aplicação de carimbos na colagem Perry in Japan, de 1969. Uma outra obra, a Pineapple de 1970, também é uma boa referência dessa possibilidade de misturas. $\mathrm{O}$ tradicional personagem quixotesco aparece se confrontando com uma figura de composição complexa, formada por um desenho geométrico, um selo, um carimbo e um enorme abacaxi. Os elementos dos cartões-postais que o artista viria desenvolver no final dos anos 1960 também estão presentes, no céu pintado com aquarela, nos carimbos soltos no céu, na tarja disposta na base. As figuras anônimas
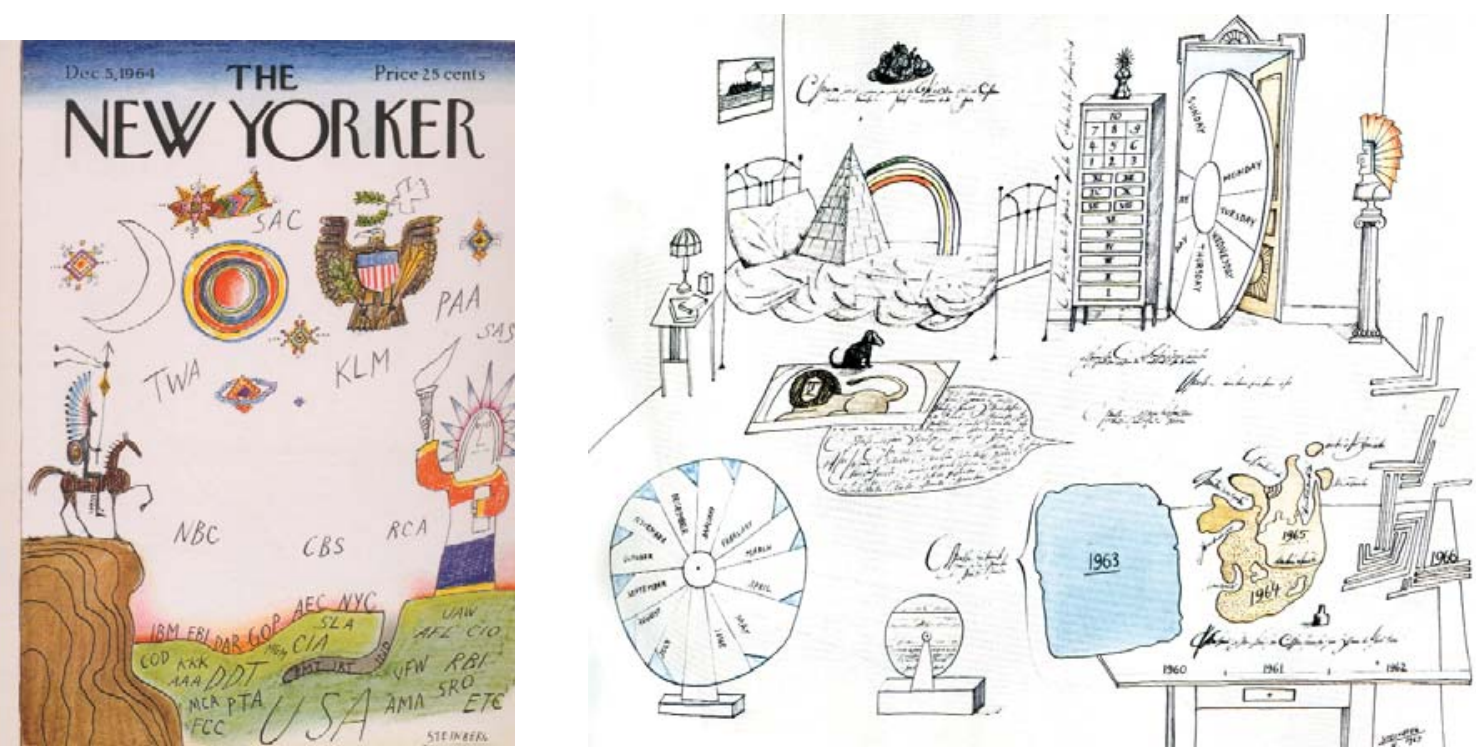
e os contornos de régua de desenho, presentes em cartões-postais ou trabalhos com carimbos do período, também marcam presença. A miscelânea de estilos e abordagens, tão comuns em Steinberg, se apresenta também nos retoques das nuvens e no relevo. O cruzamento de universos steinbergnianos diversos se faz evidente no próprio processo de criação: uma litografia original, com a imagem absurda e simples de um Dom Quixote contra o abacaxi, recebeu intervenções que transformaram seu significado. Por vezes, a miscelânea de abordagens é tal - como em alguns desenhos de Le Masque - que estes trabalhos se tornam enormemente enigmáticos. "Ele tem produzido trabalhos que não podem ser compreendidos a fundo nem por ele mesmo. (...) Seus trabalhos publicados incluem alguns que, de fato, são impenetráveis" (Rosenberg, 2006, p.22), reflete Rosenberg. De qualquer modo, o crítico salienta que "Steinberg insiste que suas próprias interpretações de seus desenhos não são as únicas possíveis. (...) Ele considera o espectador seu colaborador" (Rosenberg, 2006, p.30). Afeito ao mistério, Steinberg não via com bons olhos a explicação da arte pela escrita:

A arte é um tipo de metáfora; a escrita é de um gênero diferente. Um tipo de símbolo não pode explicar outro tipo de símbolo. A escrita pode ser uma metáfora para a História, não para a arte. A pior coisa que um escritor pode fazer é descrevê-la, explicá-la, adulá-la (cit. por Lynes, 1982, p.48).

\section{VIAGENS, EXPOSIÇÕES E UM ASSISTENTE}

Nos idos dos anos 1960, Steinberg começava a ficar cada vez mais em Amangansett. Mais freqüentes também, suas viagens anuais para a Europa seguiam o rotineiro esquema de exibições na Maeght e visitas à sua irmã em Paris ou a Buzzi em Milão. Além das exibições, recebe um prêmio em setembro que sinaliza a sua proximidade com a França: a medalha do Chevalier de L'Ordre des Arts et Lettres do governo francês. Mas as exposições e acontecimentos não ficariam relegados àquele país europeu. Em dezembro de 1966, expõe nas galerias novaiorquinas Betty Parsons e Sidney Janis, com a mostra Steinberg: Recent Works. No ano seguinte, de março a abril, é a vez da Bélgica receber seus trabalhos (Smith, 2006, p.260)

Em 1966, Steinberg passa alguns meses em Washington, como um artista-residente da Smithsonian Institution. "Passei, talvez, os três meses mais estranhos da minha vida", recorda. "Era como se tivesse emigrado para um lugar onde normalmente ninguém emigra Noruega, vamos dizer, ou Albânia" (Steinberg, 2002, p.45). Em Washington, o artista passa a se encontrar, diferentemente de Nova York, com figuras políticas como oficiais de escritório, secretários de Estado, famosos jornalistas, embaixadores. "E suas mulheres", observa, "todas perfeitamente treinadas para a vida da sala de visitas, como receber, como fazer conversas educadas, como serem atraentes. (...) Elas sabem exatamente como serem polidas, como divertir, como deixar as pessoas relaxadas, mas também sabem como se livrar 

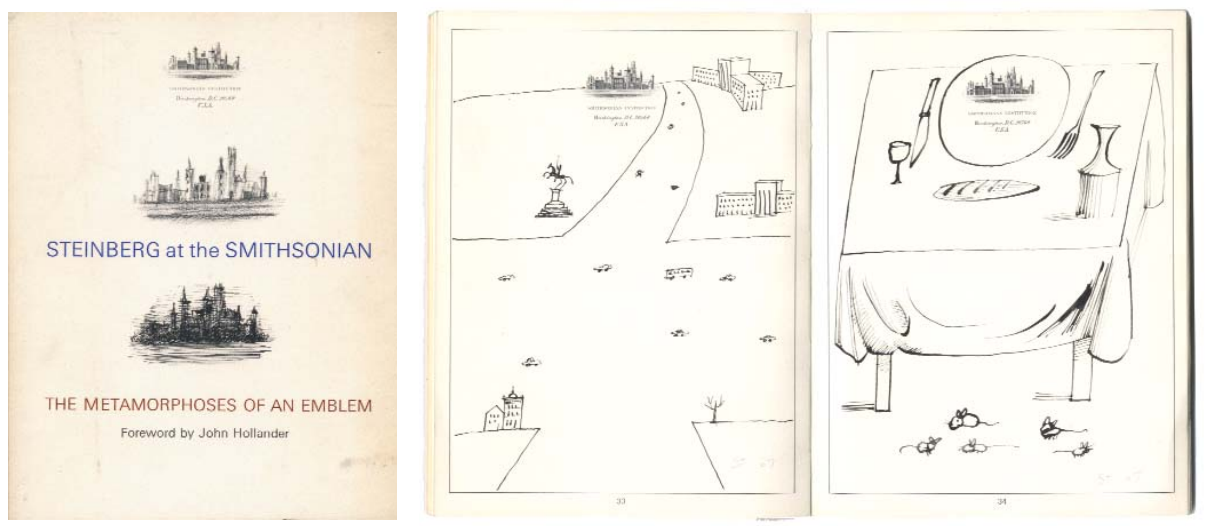

Figura 434-437.

Steinberg at the

Smithsonian, 1973

de pessoas que podem não ser necessariamente tediosas mas estão tediosas no momento, pessoas que não pertencem ao grupo, ou precisam ser dispensadas mais cedo". Contrariado com a vida superficial que observa neste meio, "como em um filme B", Steinberg conclui que "foi contra este mundo que a revolução hippie de nudez, e especialmente, de violência, aconteceu" (Steinberg, 2002, p.46).

Durante sua estadia na capital, Steinberg mora em Georgetown, em uma casa "magnífica, que mais se parecia com um palácio dinamarquês" (Steinberg, 2002, p.47). Ela pertencia a um zoologista especializado em grandes macacos antropóides, e conseqüentemente Steinberg aprende "muito sobre gorilas" em sua biblioteca. Haviam quatro empregados, todos chineses: pai, mãe, e duas filhas. A casa, com quatro pavimentos, precisava de muita atenção: eram centenas de cadeiras, talheres, objetos chineses (Steinberg, 2002). Saul vê Washington como um transatlântico, "o Queen Mary ou o Queen Elizabeth", e ao morar em Georgetown, deduz que está na primeira classe; na segunda classe estariam os empregados dos governantes, a classe turística ficaria com os turistas, e obviamente, os negros seriam o pessoal de bordo que toma conta de tudo para os passageiros" (Steinberg, 2002, p.50).

Todo anoitecer, Steinberg era convidado para sair, tendo que recusar muitos passeios atraentes com importantes senadores e congressistas inteligentes para honrar outros convites. Naquela época, Washington era um lugar consideravelmente sombrio devido à guerra do Vietnã. O presidente Lyndon Johnson tinha baixa aprovação. "Nos encontrávamos em casas tão incômodas quanto os abrigos de ataque aéreo da guerra", recorda (Steinberg, 2002, p.48).
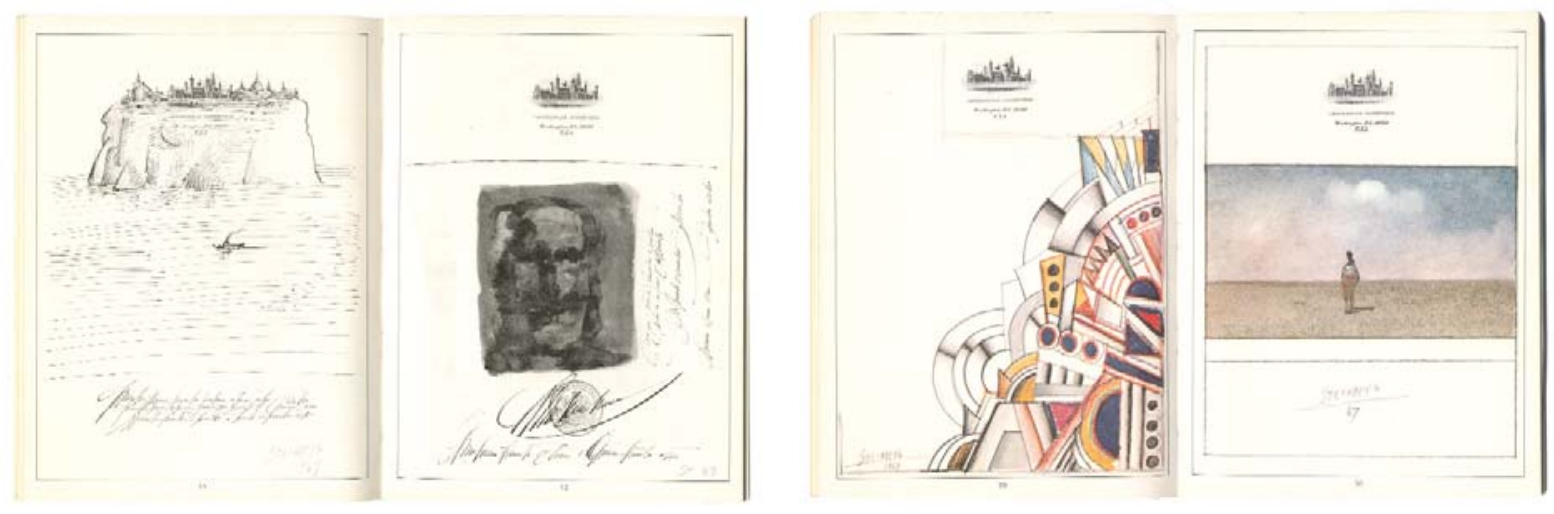
"O papel timbrado da Smithsonian Institution era muito bonito", comenta Steinberg, "com gravuras de metal perfeitas em papéis de vários tipos, um mais luxuoso que o outro. Fiz vários desenhos nestes papéis, usando o cabeçalho de modos diversos" (Steinberg, 2002, p.49). O cartunista resolve recontextualizar o emblema do edifício original de James Renwich, que aparece no papel timbrado da instituição. Mediante uma série de trabalhos com lápis, pincel, selos e fotografia, transforma a vista arquitetônica da Smithsonian Institution em novos contextos, tais como a pintura de uma paisagem sobre uma chaleira chinesa para exportação; uma cidade assentada sobre uma ilha que surge do mar; a decoração pintada no encosto de uma cadeira onde há um gato de pêlo encaracolado (Helkenen, 1980, s.p). Estes trabalhos compuseram um livro: Steinberg at the Smithsonian - The Metamorphosis of na Emblem, publicado em 1973 (Steinberg, 2002, p.49). Como observa Hollander em texto deste livro, esta abordagem "representa um dos gêneros pictóricos mais característicos do artista, a metamorfose de uma dada imagem" (Hollander, 1973, p.4). A partir do mesmo princípio de transformar o significado do carimbo da instituição por meio de intervenções desenhadas, Steinberg expõe nestes trabalhos muito do que vinha fazendo na época, como em Le Masque. Não por acaso, alguns desenhos são extremamente simples, outros lembram os documentos, e por fim, encontramos o edifício imerso em devaneios estilísticos légernianos, cubistas ou do art eéco. Saul também fez, durante sua estadia, trabalhos com outras abordagens inusitadas:

A arte é um tipo de metáfora; a escrita é de um gênero diferente. Um tipo de símbolo não pode explicar outro tipo de símbolo. A escrita pode ser uma metáfora para a História, não para a arte. A pior coisa que um escritor pode fazer é descrevê-la, explicá-la, adulá-la (cit. por Lynes, 1982, p.48).

Em 1968, novas viagens e exposições. Vai com Sigrid para o México, em fevereiro, e ambos visitam a cidade alemã Trier - onde ela nasceu - e Paris em abril. Na capital francesa começavam as manifestações estudantis e dos trabalhadores que eclodiriam em maio, "em um época para uma dose de gás lacrimejante", diz ao amigo Buzzi (cit. Smith, 2006, p.261). A guinada no trabalho e vida de Steinberg também se faria no âmbito dos meios para mostrar seu trabalho: o artista passaria a expor cada vez mais em galerias. De 1968 a 1969, expõe na Venezuela, em Detroid, e tem mais uma mostra individual, desta vez nas galerias Betty Parsons e Sidney Janis, em Nova York. Em 1970, realiza exposição individual em Houston, exibe pinturas a óleo em Pittsburgh, e recebe outra individual em Los Angeles. Steinberg não se acomodou, no entanto, às exibições cada vez mais freqüentes para galerias. Em 1969 e 1970, doou obras e desenhou pôsteres para leilões, galerias e mostras coletivas motivadas politicamente, para levantar fundos para as campanhas contra a guerra do Vietnã (Smith, 2006, p.261). Sua arte de galerias - ao menos parte dela - era razoavelmente acessível naqueles anos. Um artigo da Art in America denominado "Art under \$500,00", de 1970, chama- 


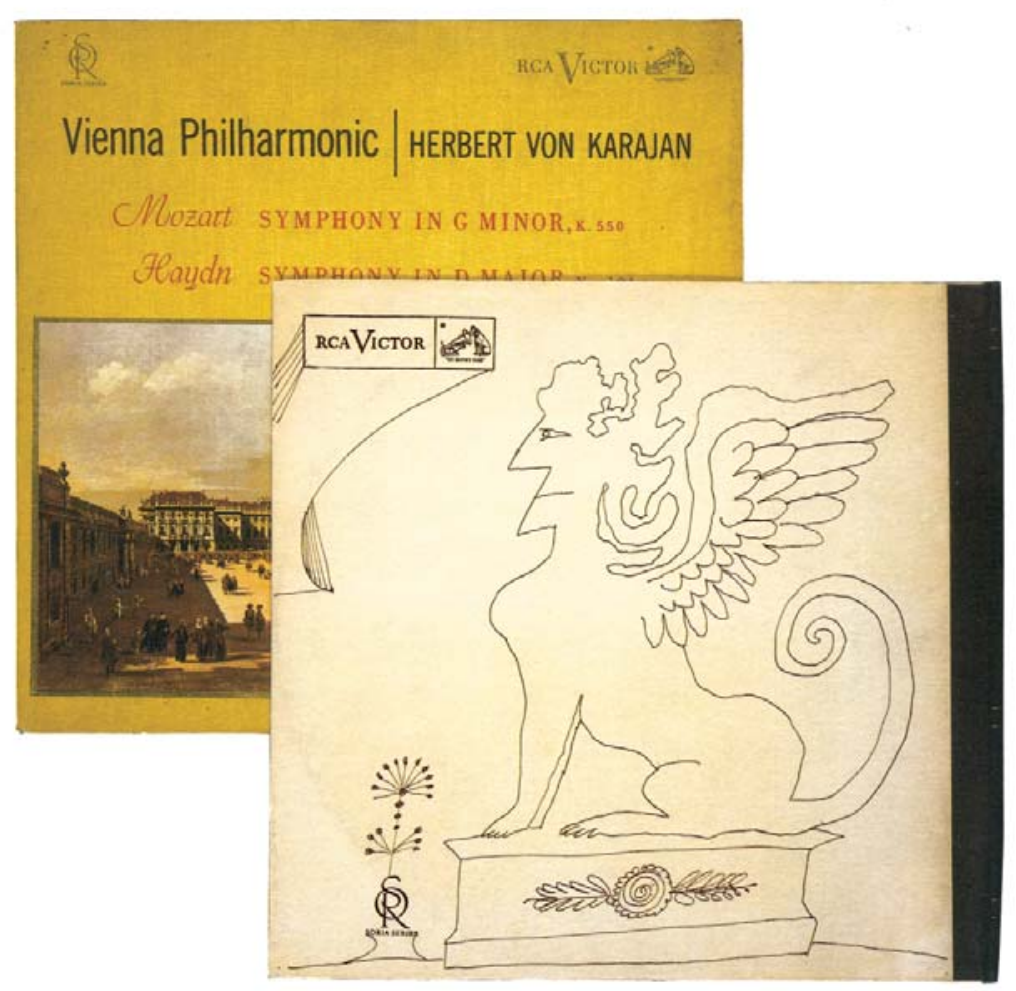

Figura 438.

Presente de

Steinberg a

Van Dalen

va atenção para obras de arte que podiam ser compradas por preços que não eram exorbitantes, e a litografia com carimbos Certified Landscape de Steinberg é citada em meio a um pôster de Roy Lichstenstein, a uma foto de Brassai, ao Snail Cup de Kenneth Price, dentre outras obras. Uma das explicações encontradas pela revista para explicar o fenômeno do baixo preço de determinadas obras de arte residia no fato dos artistas parecerem "querer se comunicar com uma grande audiência" (Piene, 1970, p.95).

Em 1969, Steinberg emprega o imigrante holandês Anton van Dalen, estabelecido desde 1966 em Nova York, como seu assistente. Para Dalen, havia dois artistas na cidade que, segundo ele, "melhor exemplificavam a raíz da beleza" (Dalen, 2004, p.1): o fotógrafo de rua Weegee e Saul Steinberg. Após se encontrar com Weegee por uma hora, certa vez, simplesmente tocando a campainha de sua casa e sendo convidado a entrar, Dalen ligou para Steinberg - após consultar a lista telefônica -, sendo chamado para visitá-lo em seu apartamento em Washington Square Village, e despendendo ali algumas horas também. "Depois, corri com ele para a 57th Street, onde me convidou para a abertura de uma mostra dele na Sidney Janis Gallery. Foi ali que me perguntou se eu sabia de alguém que poderia trabalhar para ele", conta Dalen. O holandês não hesitou: "Deixe comigo. Farei qualquer coisa" (Dalen, 2004, p.1). Steinberg aceitou, e assim seu assistente passou a trabalhar em seu estúdio na 33 Union Square West (Dalen, 2004, p.1). Em setembro de 1968, Saul havia alugado o décimo primeiro andar inteiro do prédio - o mais alto -, três andares acima da Factory de Andy Warhol (Smith, 2006, p.261). Como observa Smith, "até o final de sua vida, 'Saint Anthony' irá fazer tudo, desde empacotar trabalhos para viagem até colar assemblages esculturais,ou mesmo tirar várias fotos para pesquisas de táxis ou das estátuas da Union Square" 
(Smith, 2006, p.261). Em respeito à privacidade de Steinberg, o trabalho de Dalen como assistente do artista por 30 anos só viria a ser comentado publicamente após a morte de Saul (Dalen, 2004, p.1).

Em 1970, dando seqüência às viagens para os lugares mais diversos, Steinberg visita - além de Paris e Milão - Jerusalém, Tel Aviv; na África, conhece Nairóbi, no Quênia, Ghana e Addis Abeba, capital da Etiópia. Em janeiro de 1971 faz sua primeira visita à "amável prisão" de Bircher-Benner, uma clínica privada situada em Uberlingen, na Suíça. O cartunista viria a retornar em seguidos invernos para realizar jejuns de vários dias. Saul pára de fumar em seu primeiro retorno à clínica, no ano seguinte. Em fevereiro de 1971, vai a Oaxaca, no México, e às ilhas caribenhas de St. Martin com Sigrid; em fevereiro de 1972, foi a vez de visitar o Cairo, Luxor, o Quênia, Uganda, e Tanzânia (Smith, 2006, p.261).

Entre junho e julho de 1971, Steinberg faria mais uma exposição individual na Galeria Maeght, de Paris. Dentre os trabalhos expostos, várias de suas abordagens elaboradas na época, como os amplos trabalhos com carimbos de borracha, pinturas a óleo, cartões-postais em aquarelas e uma galeria de trompe-l'oeil com pinturas em falsas perspectivas. A mostra viajou para a Galeria Maeght de Zurique, no outono. Saul acabou comparecendo à abertura em Zurique, não escondendo sua preferência à cidade suíça, uma vez que Paris havia se tornado, segundo ele, uma "garagem" mais adequada ao tráfico do que às pessoas (Smith, 2006, p.261). 


\section{STEINBERG: \\ CRÍTICO DA CIDADE, ARQUITETURA E ESTILOS}

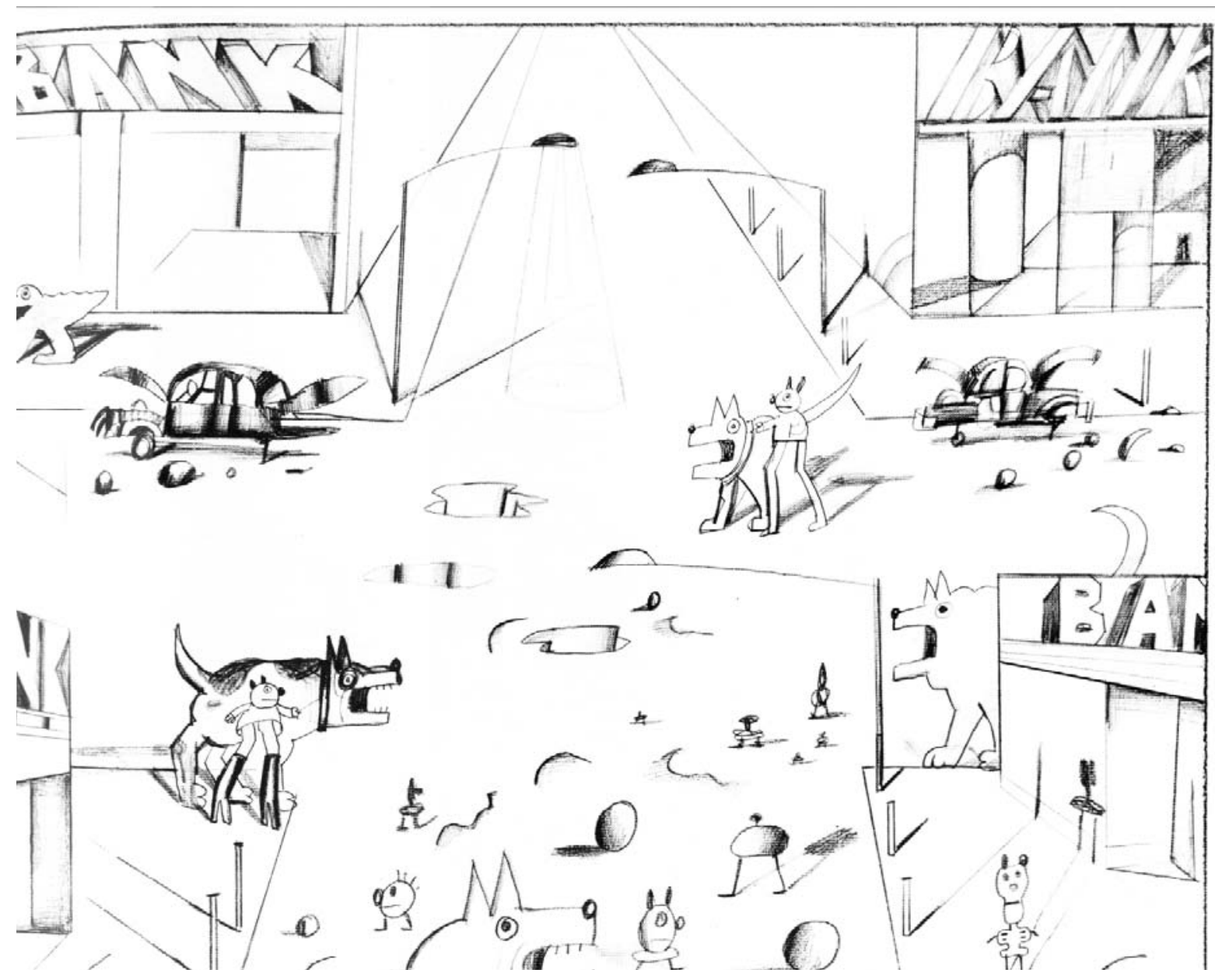

Figura 439. Four Banks, 1974

Os trabalhos com paródias, máscaras, carimbos e autobiografia viriam a fazer parte do próximo livro de Steinberg, The Inspector. Lançado em 1973, a publicação abordou também suas novas pesquisas com o espaço urbano, em desenhos de paradas e desfiles, ruas e avenidas, arquiteturas e sociedade, a guerra urbana. Obras filosóficas sobre o tempo e o espaço, e crocodilos, também marcaram presença no livro. O artista expôs toda a sua maestria como ilusionista nos trabalhos com pautas musicais. Como não poderia deixar de ser, os caubóis, as garotas e vagões-restaurantes da América também figuraram nas páginas do livro (Smith, 2006, p.262).

$\mathrm{Na}$ década de 1970, as galerias com as quais Steinberg mantinha relação promoveram diversas exposições e catálogos. Entre 1973 e 1977, o artista teve duas exposições nas galerias Betty Parsons e Sidney Janis, e outras duas na Galerie Maeght. Já as obras de sua 
estadia em Washington são finalmente expostas, de dezembro de 1973 a fevereiro de 1974, na mostra "Steinberg at the Smithsonian", na própria instituição. Exibições individuais também ocorreram em Milão e Roma, em 1973 e 1974, respectivamente. Em 1977, finalmente acontece a retrospectiva Saul Steinberg, organizada pelo Whitney Museum of American Art (Smith, 2006, p.262). Exposta ao público de abril a julho de 1978, e sob curadoria do crítico de arte Harold Rosenberg, tratava-se de uma mostra ampla, com 258 desenhos, aquarelas, pinturas, esculturas de madeira talhada e colagens, abrangendo um período da carreira do artista que se estende de 1945 a 1975 . Do Whitney, a mostra iria ser exposta posteriormente em Washington, Londres e Saint-Paul de Vence, na França (Helkenen, 1980, s.p). Ao mesmo tempo, foi lançado o livro Saul Steinberg, com texto de Rosenberg, em ampla análise de seu trabalho. O crítico já havia escrito o texto de Le Masque, e levava adiante as reflexões sobre a obra do cartunista, muitas delas decorrentes das conversas que compartilhava com Steinberg, em um texto de 26 páginas.

No mesmo ano em que seu trabalho recebia grande atenção e reconhecimento, a revista Time conferiu matéria sobre sua história, trazendo a público velhos amigos e parentes (Smith, 2006, p.263). O reconhecimento por sua obra, Steinberg admite em texto de Hughes, "é um das maiores satisfações de minha vida" (cit. por Hughes, 1978, p.52). Brendan Gill nota, em artigo publicado no ano da exposição, que "a fama não incomoda Steinberg; ele tem escolhido com sagacidade suas poucas vantagens e conseguido evitar suas inúmeras desvantagens, permanecendo, como pessoa, tão felizmente desconhecido dos programas de talk show do rádio e televisão e colunas de jornais de fofoca quanto qualquer John Doe" (Gill, 1978, p.67). Apesar do grande significado da mostra, Saul procurava manter sua integridade artística. "Nada mudará para mim com o resultado dessa exposição", afirmava em relação à exposição no Whitney. Manifestava, por vezes, o desconforto e os conflitos de sua condição híbrida, aspecto muito discutido no texto de Rosenberg:

\footnotetext{
Algumas vezes, convido a mim mesmo para um pouco de meditação talmúdica e dela emerge a esperança de que se é exibida uma parte tão considerável de minha obra em apenas um lugar, me perdoarão pelo humor contido nela. As pessoas suspeitam que há algo de vergonhosos no humor; erroneamente imaginam o defeito de que carece de seriedade. De qualquer modo, continuo trabalhando. (cit. por Gill, p.7)
}

A década de 1970 também foi um período de mudanças na vida de Steinberg. Foi no ano de 1973 que Steinberg fez sua última mudança de endereço: entre agosto e setembro, deixou seu apartamento na Washington Square Village, se movendo para um duplex na 103 East 75th Street. Seu estúdio, situado no mesmo prédio da Factory de Andy Warhol desde 1968, acabou sendo transferido em 1975 para lá também (Smith, 2006, p.262). Long Island também viria a ser abrigo para parte de suas obras (Hughes, 1978, p.52). Nesta época, seu gato preto Papoose, cujo comportamento Steinberg gostava de observar minuciosamente, 

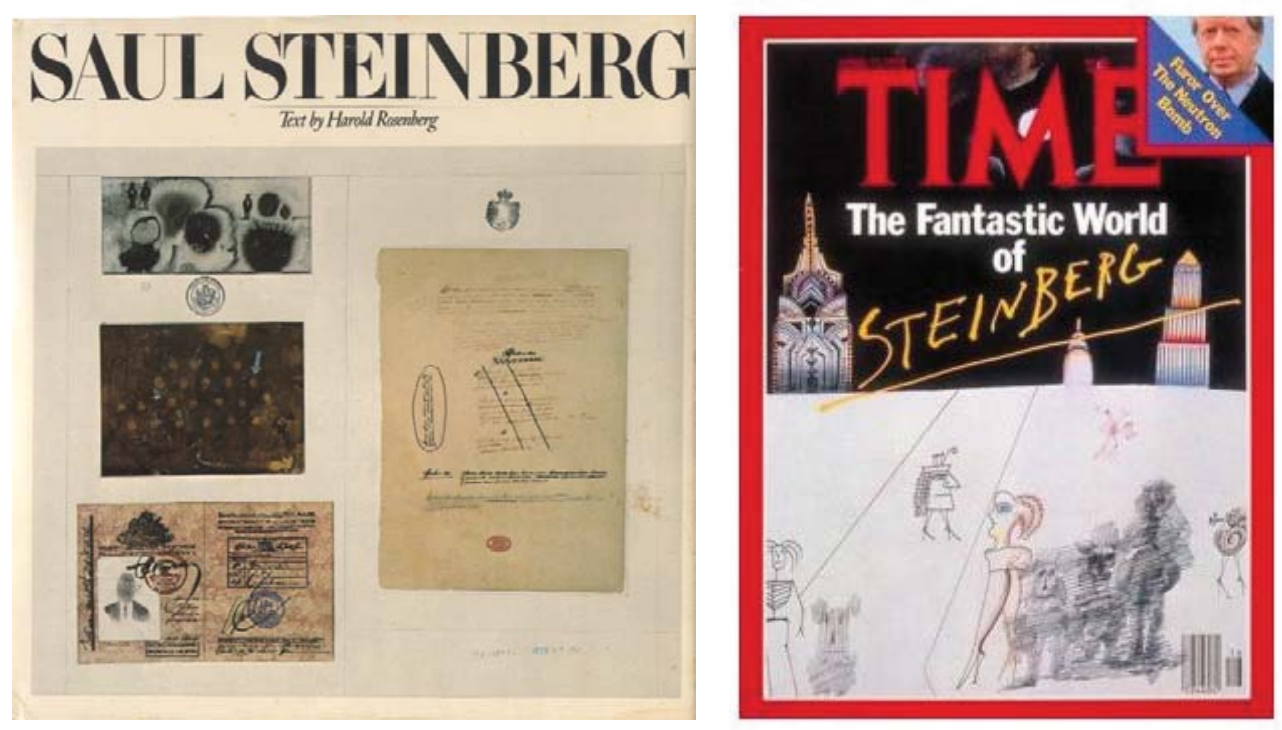

Figura 440.

Capa de Saul

Steinberg, 1978

Figura 441.

Steinberg na

Time, 1978

Figura 442. Foto de Steinberg,

1978

passou a ser uma agradável companhia (Smith, 2006, p.262). Segundo descrição de Brendan Gill, Steinberg era, aos 64 anos, "um homem troncudo, severo, aparentando ser mais novo que sua idade (...). Ele é careca, com um nariz grande, um bigode aparado, e uma voz gentil, agradavelmente grave; as lentes grossas dos óculos que ele costuma usar sem dúvida pretendem corrigir sua visão, mas elas também parecem atuar como uma espécie de disfarce permanente", considerando-o extremamente evasivo mesmo quando procurava ser hospitaleiro (Gill, 1978, p.71). O "estilo de vida steinbergniano" pode ser conferido em artigo de 1978, escrito por Adam Hughes. Segundo ele, os hábitos do Steinberg da década de 1970 estavam definidos, e eram suficientemente confortáveis para que permanecessem sem mudanças. Steinberg dividia seu tempo entre o duplex em Upper East Side, em Manhattan, envolvido com seus próprios objetos e imerso em uma coleção de desenhos de artistas americanos amigos - como de Kooning, Arshile Gorky -, e um estúdio modesto em Long Island (Hughes,

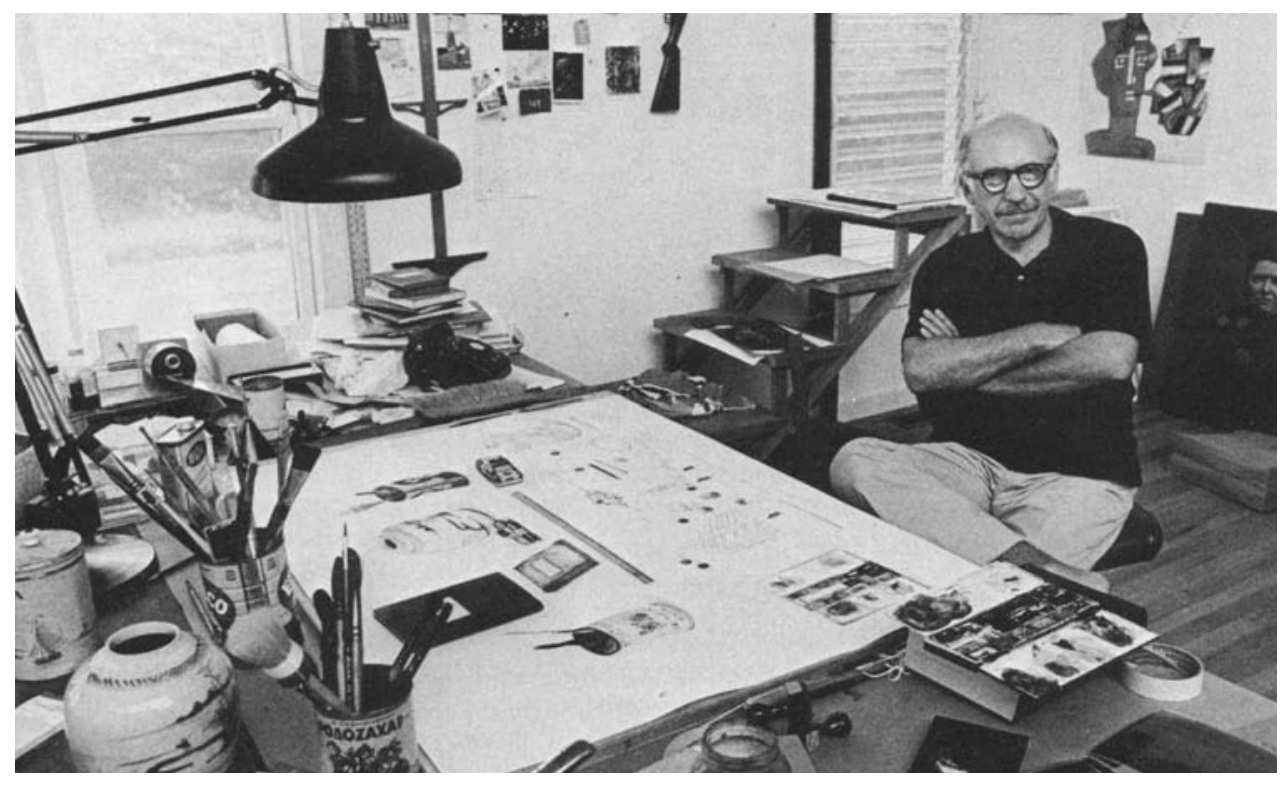


1978, p.52). A coleção pessoal do cartunista abarcava obras de artistas do século XX tais como de sua mulher Hedda Stern, Giacometti, Richard Lindner, Sigrid Spaeth, Josef Albers, Picasso, de Kooning, Klee e Calder (Helkenen, 1980, s.p), chegando a ser citada em 1958, na matéria The Artist as Collector, publicada na revista Art in America. Na casa de campo de Steinberg estavam suas construções de madeira: mesas espalhadas com livros retalhados, canetas criadas, lápis artificiais. Por fim, Hughes conclui que Saul se portava como um homem disciplinado, com muitos amigos e sem inimigos, apreciador do que denominava "o teatro Kabuki da noite" - os rituais de sociabilidade e longas conversas de jantar (Hughes, 1978, p.52). O próprio artista comentou sua rotina em 1978: " De manhã, invento - isto é, tenho uma idéia, - e talvez à tarde a execute no papel. Execução é um ato de narcisismo e, portanto, muito prazeroso. À noite, vejo amigos, vou a festas. Não procuro incitar a fama através do isolamento" (cit. por Gill, 1978, p.73). Para além deste dia-a-dia, as viagens também continuariam a ocorrer, apesar de menos freqüentes que nas décadas anteriores. Ainda assim, foram muitos os lugares visitados por Steinberg, em grande parte para acompanhar suas exposições. O descanso seria o motivo de outras visitas a países, como as viagens para Guadalupe, feitas com Sigrid em 1980, 1986 e 1989 (Smith, 2006, p.263).

No entanto, nem tudo era tão tranqüilo e aprazível. Foi também na década que faleceram alguns entes queridos do cartunista. Em novembro de 1974, Steinberg visitou sua adoentada irmã Lica em Paris, que também viria a ficar durante um mês na casa em Amangansett, em maio de 1975. Lica, no entanto, não resistiu a uma operação no pulmão em julho daquele ano, em Paris. Entre 1976 e 1981 faleceram amigos como Alexandre Calder, Vladimir Nabokov (Smith, 2006, p.262), Richard Lindner, Harold Rosenberg, o escritor da New Yorker S. J. Perelman, e o arquiteto Marcel Breuer. Perelman era um amigo dos primeiros tempos na América, cujo uso meticuloso da linguagem, em estremecedor efeito, foi uma grande inspiração para Steinberg. (Smith, 2006, p.263). O cartunista chega a prestar homenagens a alguns amigos, como no discurso feito na ocasião da morte de Calder. Também escreveu e leu tributos, em 1979, para Lindner e Rosenberg. Não é possível mensurar com exatidão em que grau a seqüência de perdas afetavam o estado de espírito de Steinberg, mas é fato que desde a morte de Calder, há o registro de um Steinberg "cada vez mais inclinado à depressão" (Smith, 2006, p.262). As últimas décadas de seu casamento com Sigrid parecem também não terem sido tomadas pelos momentos mais felizes, como atestam comentários sobre o período. Sinal disso seria a busca de Steinberg por maior paz interior, se retirando por três dias para meditação Zen na região do Vale de Hudson, no estado de Nova York, em 1983. A intenção era amenizar desconfortos causados, dentre outras coisas, pela "saúde mental instável de Sigrid e pela pressão para prosseguir em mais projetos retrospectivos" (Smith, 2006, p.264). Em 1985, mais um exemplo dos sentimentos de Steinberg, quando se reportou ao amigo Aldo Buzzi para contar sobre uma visita ao artista de Kooning: "Uma [visita] triste, porque ele não mais parece estar presente (sorriso permanente e voz sussurrante - ele parece estar surdo, mas não está). Estava rodeado por 3-4 viúvas brigando 


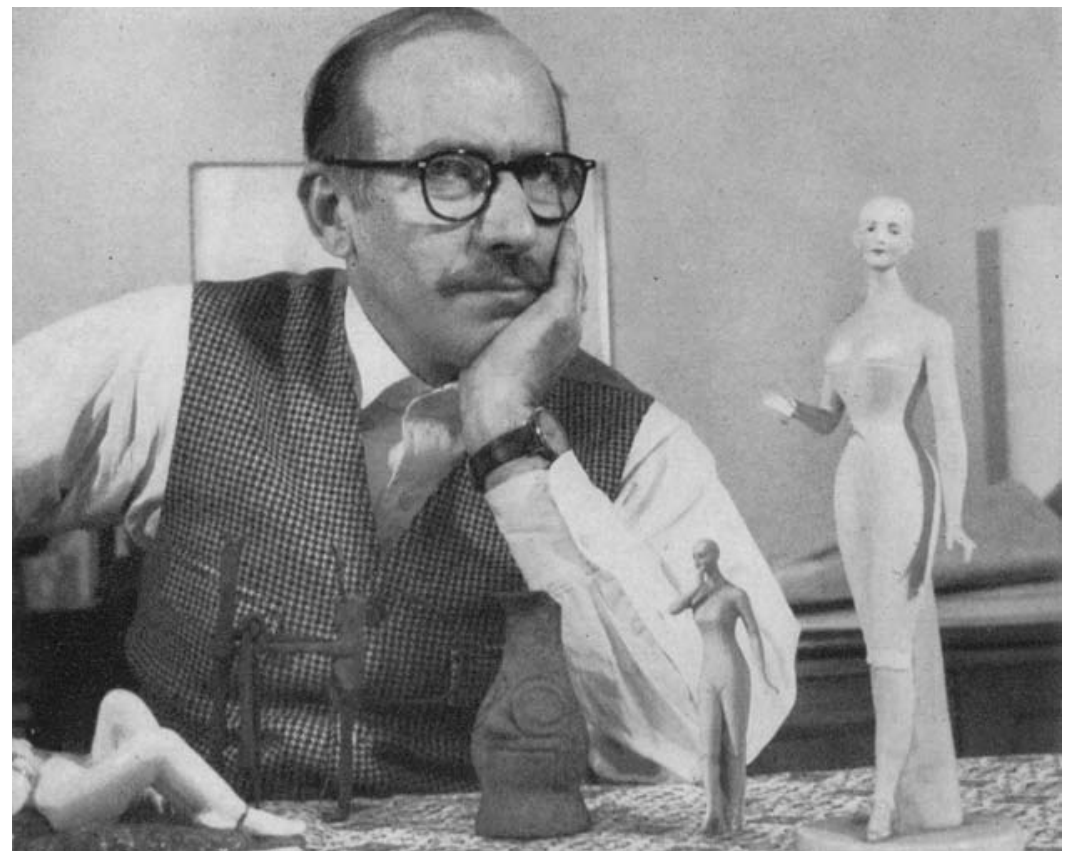

Figura 443. Steinberg posa com algumas peças de sua coleção, no artigo The Artist as Collector, publicado na Art in America, 1958.

sobre o futuro" (cit. por Smith, 2006, p.264). Por outro lado, o cartunista também fez novos relacionamentos. Dentre os novos amigos conquistados no período estavam Ian Frazier, em 1978 com apenas vinte e sete anos, e o novelista de texto difícil e inclassificável William Gaddis, que conheceu em 1982 (Smith, 2006, p.263).

Em 1982, Steinberg terminou seu acordo de representação, que já durava trinta anos, com as galerias Betty Parsons e Sidney Janis para se juntar à Pace Gallery, onde estreou com a mostra Steinberg: Still Life and Architecture (Smith, 2006, p.264). O título da mostra era sugestivo, se referindo às pesquisas que o artista vinha desenvolvendo desde o começo dos anos 1970. As novas abordagens de Steinberg viriam a ser o foco de suas exposições no período. Naquele mesmo ano, outra vertente foi considerada na exposição Saul Steinberg: Mixed Media Works on Paper and Wood, realizada em Chicago. No ano seguinte, em Londres, aconteceria Saul Steinberg: An Exhibition of Sculptures, Collages, and Drawings, 1970-1982, também levando ao público seus trabalhos tridimensionais e experimentações em diversas mídias. Outras mostras do gênero, com títulos que mencionavam objetos e mesas ou enfatizavam os "trabalhos recentes", ocorreriam em Paris (pela Galeria Maeght) em 1986, em Nova York (pela Pace Gallery) em 1987, em São Francisco em 1990; todas elas, em seu conjunto, confirmavam sua fase de artista de galerias.

\section{STEINBERG: A INFLUÊNCIA DO COMIX UNDERGROUND NOS DESENHOS URBANOS}

A partir dos anos 1970, Steinberg passa a dar ênfase a uma série de abordagens, com destaque para as cenas urbanas; a natureza morta e os desenhos de observação; e trabalhos em mídias diferentes, como as mesas e objetos replicados em trompe-l'oeil. 


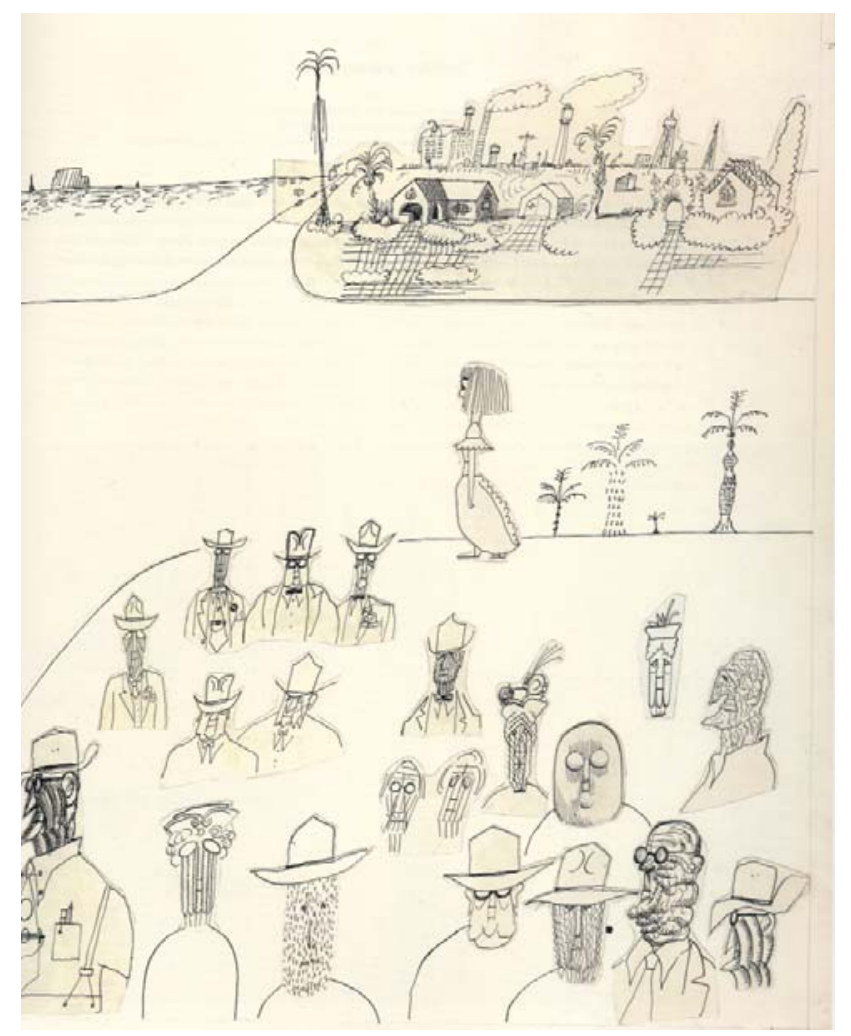

A capa para a edição de janeiro de 1971 da New Yorker expunha um desenho da nova temática urbana de Steinberg, que vinha sendo desenvolvida desde meados dos anos 1960, muito diferente daqueles feitos em linha fina nos anos 1950. Este trabalho, feito em 1970 e apelidado Bleecker Street (a rua principal de Greenwich Village), chocava pela variedade de personagens-estilos, não mais habitués de festas e coquetéis ou de complexos ambientes alegóricos, mas habitantes de um cenário urbano de tom paranóico e violento. É bem verdade que o cartunista já havia feito cenários urbanos compostos por variados personagens estilizados. Em 1964, o desenho Joe Gould's Secret mostrava considerável variedade estilística, onde o hippie, o mendigo, edifícios de habitação modernos e o lixo nas calçadas faziam

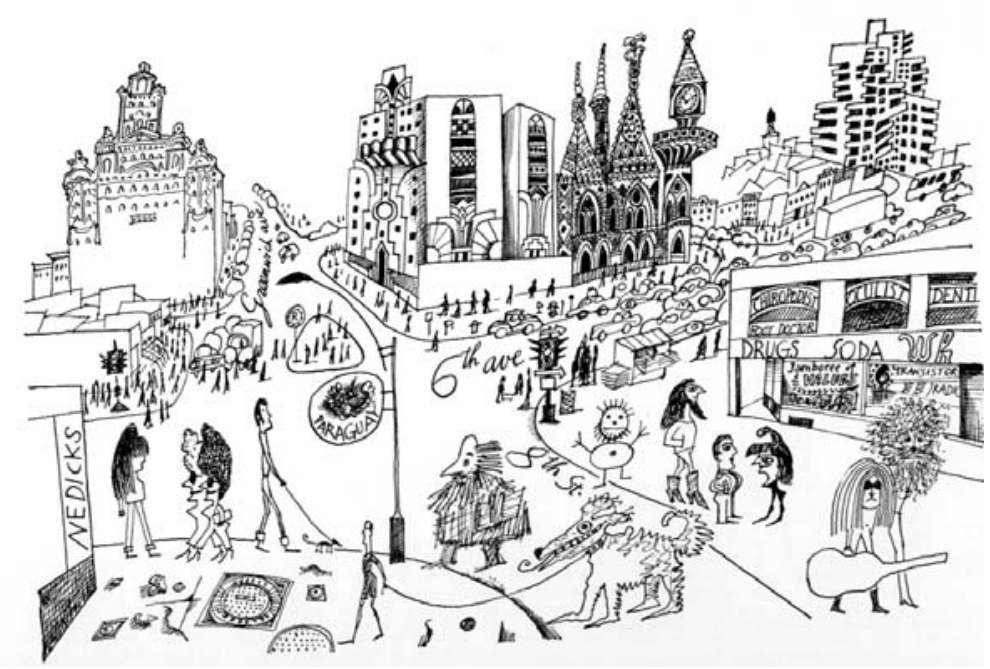



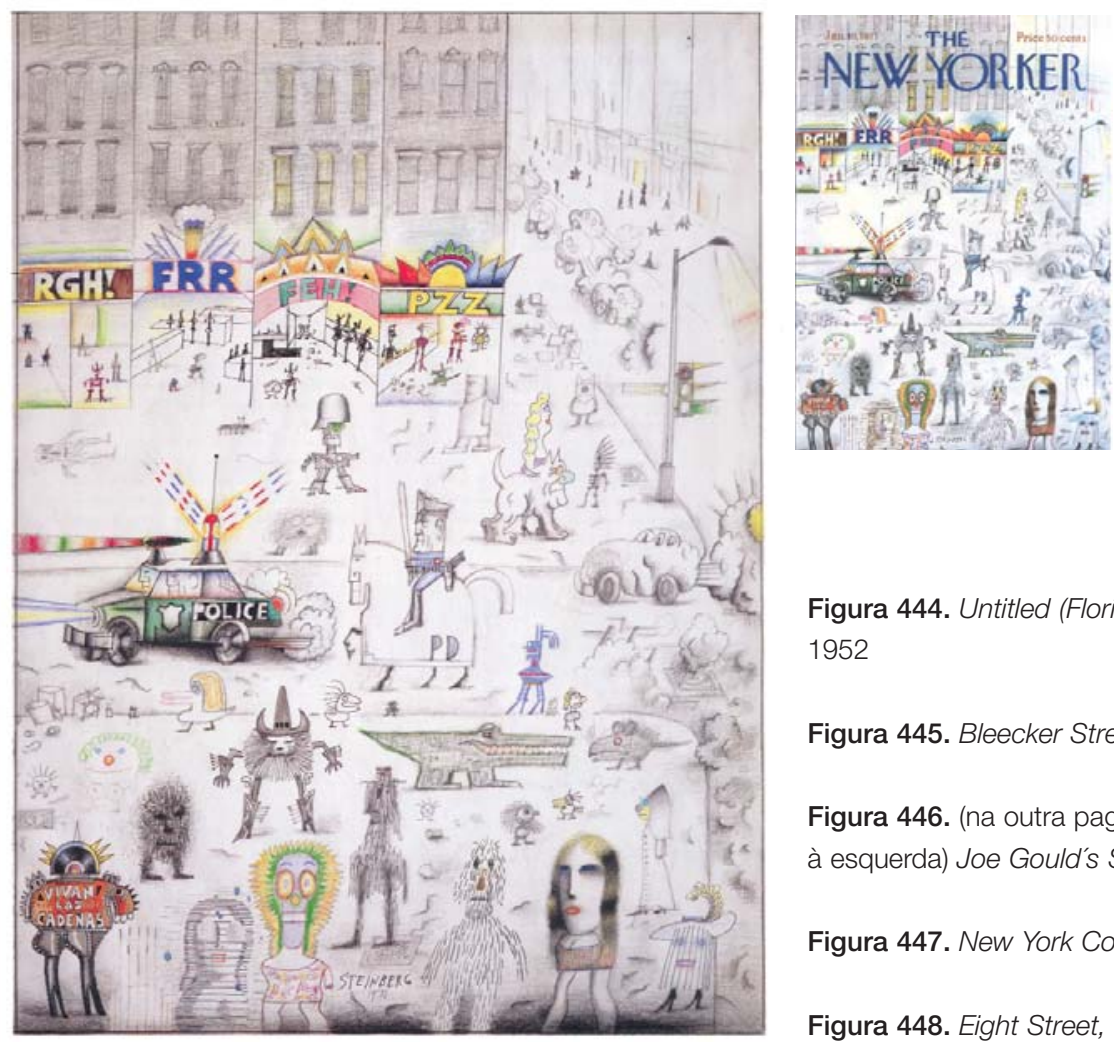

Figura 444. Untitled (Florida Types),

1952

Figura 445. Bleecker Street, 1970

Figura 446. (na outra pagina, abaixo, à esquerda) Joe Gould's Secret, 1964

Figura 447. New York Cops, 1966

Figura 448. Eight Street, 1966

menção aos novos tempos. Em 1966, trabalhos como New York Cops, com as luzes de sirenes de carros e policias, e Eight Street, com personagens representados nos estilos mais inusitados vagando por um espaço urbano de tom surrealista, já sugeriam que a elegância e o otimismo da década passada estava com os dias contados. Em 1969, cenas semelhantes passariam a incorporar facetas nada amistosas, com armas em punho. Mas as experimentações estilísticas com habitantes em ruas da cidade já haviam sido feitas mesmo antes. No desenho urbano de linha fina de 1952, apelidado Florida Types, idosos - na sua maior parte usando chapéus - são desenhados de formas diferentes, em risquinhos pontilhados e econômicos traços verticais a contornos mais delineados. Apesar do claro interesse de Steinberg em estudar o modo
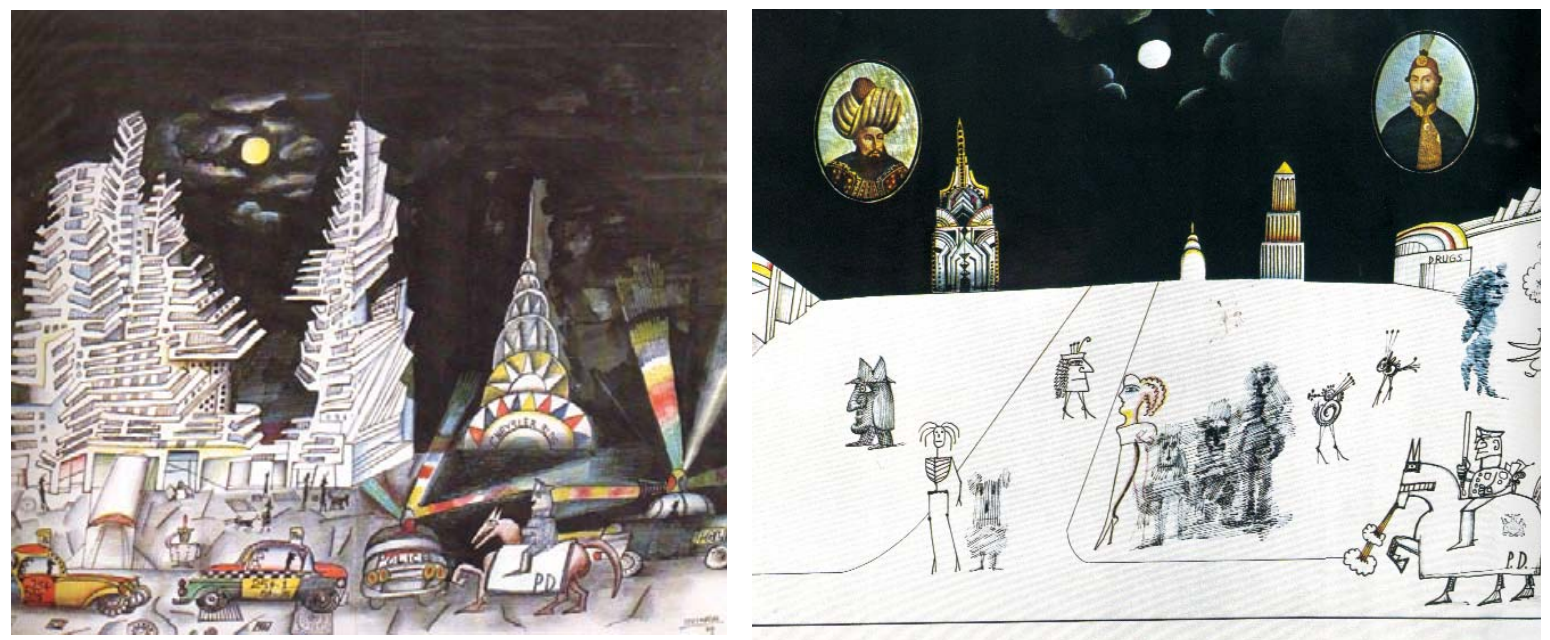

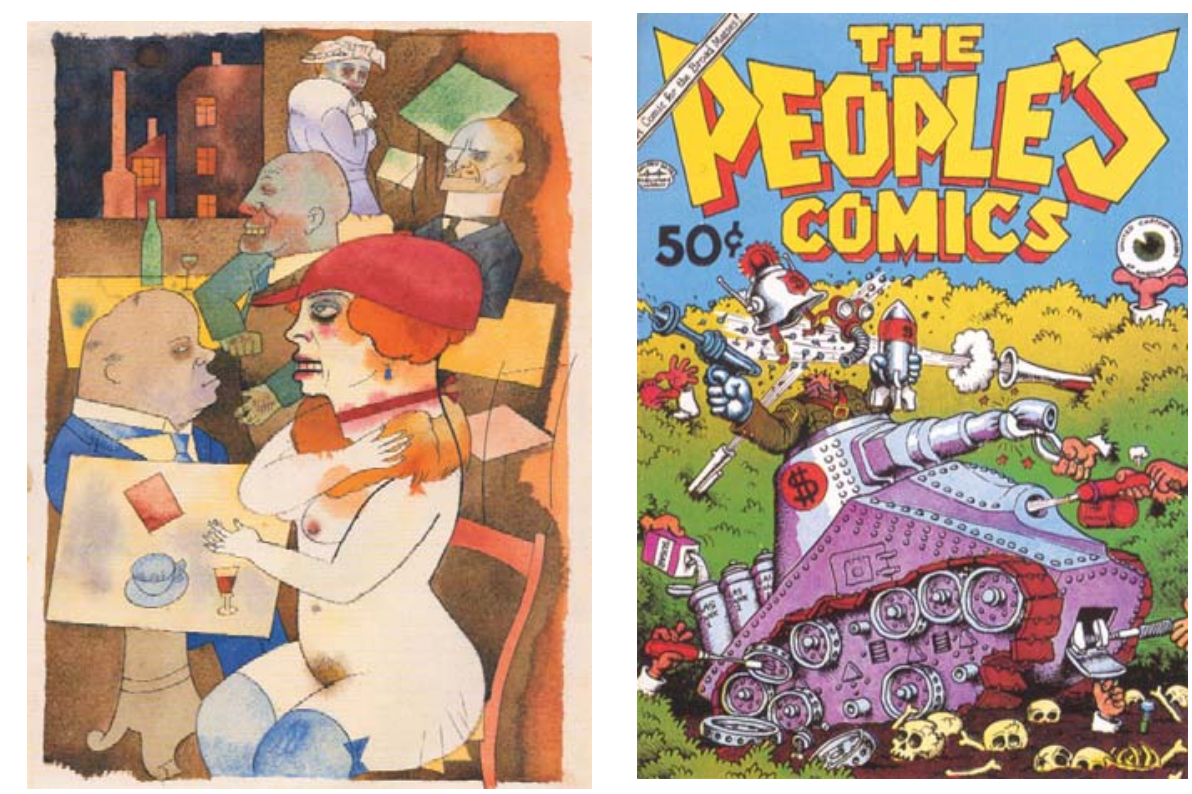

como cada personagem utilizava uma diferente técnica para se apresentar, não há o enorme contraste estilístico encontrado em Techniques at a Party, feito um ano depois. Todas as figuras de Florida Types são feitas a traço, sem cores, do mesmo jeito que o cenário. Já o mural da exposição de Bruxelas de 1958 insere na cidade de linhas, feita em 1952, personagens que contrastam com o fundo. Estes, de fato, também se mostram em inúmeros estilos, integrados com o uso comum do papel marrom. O tom leve do desenho do cenário, com traço dos anos 1950, no entanto, aproximam este trabalho daqueles de temática urbana feitos naquela década. Em Bleecker Street, por outro lado, a diversidade de personagens-estilo é enorme, e a integração destes com o fundo é maior. O cenário urbano de traço steinbergniano dos anos 1950 cede espaço a construções e elementos urbanos feitos a lápis, com estilos espalhados em luminosos e luzes de sirene. Chama a atenção a degradação do ambiente, nas tribos, nos policiais, na sujeira das ruas, na poluição visual. Para Smith, o desenho desta rua "apresenta o retrato em microcosmo de uma nação girando em espiral rumo a uma inarticulada infância", onde a Lei caminha em direção a uma "crise invisível" (Smith, 2006, p.186).

Cabe refletir sobre o que teria acontecido entre a visão otimista dos anos 1950 e o caos do começo dos anos 1970. É fato que Nova York e outras metrópoles do mundo haviam passado por grandes transformações neste curto espaço de tempo, em um mundo imerso em mudanças econômicas e sociais que abriram as portas ao consumismo, à fast-food, à alternância frenética de modismos. Bleecker Street e tantos outros trabalhos do gênero parecem incorporar esses fatores às questões já trabalhadas por Steinberg. Para Joel Smith, por exemplo, mais do que críticas morais ou políticas no sentido habitual, prevalecem temas anteriormente abordados por Steinberg: o estilo e o individualismo. Smith chega a levantar referências de trabalhos com alguma semelhança, no intuito de apontar diferenças. Seriam eles: as cenas de rua de George Grosz, imersas na decadência moral da Berlin da era Weimar; a corrupção política como maior vilã na cidade americana dos quadrinhos alternativos do final 


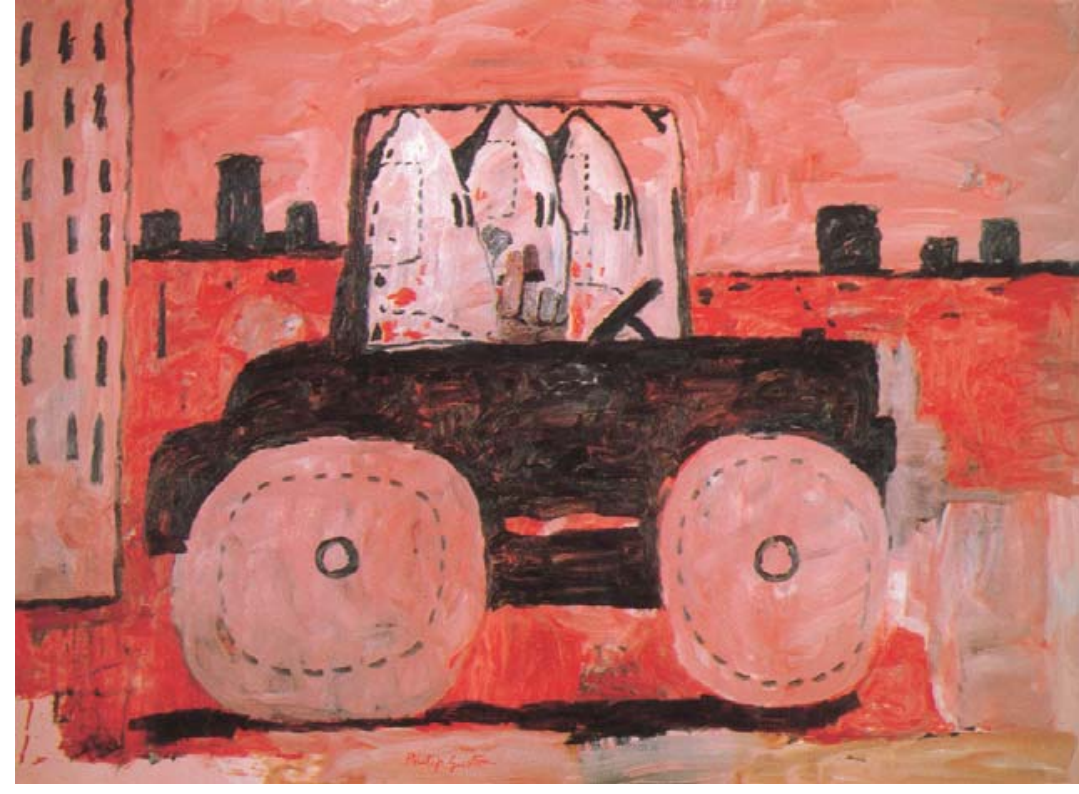

Figura 449. Beauty, I wish to praise thee!, Grosz, 1919

Figura 450. Capa de Robert Crumb, 1972

Figura 451. Philip Guston, City Limits, 1969

dos anos 1960; e por fim, o mal-estar de um "mundo-que-deu-errado" das pinturas figurativas de Philip Guston, "exibidas pela primeira vez nas Galerias Marlborough um mês antes de Steinberg enviar este desenho de capa para a New Yorker" (Smith, 2006, p.186). Estas pinturas do - até então - expressionista abstrato Guston, exibidas em outubro de 1970, não eram nem abstratas, nem "expressionistas", sendo habitadas por "figuras encapadas que se encontravam em noites conspiratórias em quartos baratos ou perambulavam pelas ruas de cidades desertas em calhambeques". Eram trabalhos que descreviam "uma fantástica mas remota visão de um mundo ameaçado pela violência sem motivo", segundo Robert Storr (Storr, 1986, p.49). Apesar da aparente proximidade, Smith enfatiza a diferença de abordagem de Steinberg em relação a estes trabalhos citados, defendendo a idéia de que, para o cartunista da New Yorker, "seu fundamental ponto de referência para o verdadeiro, o bom e o razoável (...) era o estilo":

Sua idéia de Pandemonia, vista aqui [no desenho], é a extinção de estilo de época - a perda daquela integridade social e visual que havia criado uma fábrica inteligível de espaço público (...). A Bleecker Street de Steinberg é o inferno porque é uma Babel de mal-planejados individualismos, onde a "liberdade" encerrou cada figura em um roteiro de vida solitário, conduzindo todos a lugar nenhum (Smith, 2006, p.186).

Deste modo, a passagem para estes trabalhos que expunham "visões do pesadelo" não significava uma conversão ao simples cartum para chocar. Depois de 1960, a arte de Steinberg passa a ser mais bem compreendida como caricatura - com aspectos bastante peculiares (Smith, 2006, p.60). O artista, cada vez mais, recorria aos efeitos amplos da metáfora, intensificação e epítome gráficos - "não em ordem para reduzir a realidade ao nível de um cartum, 

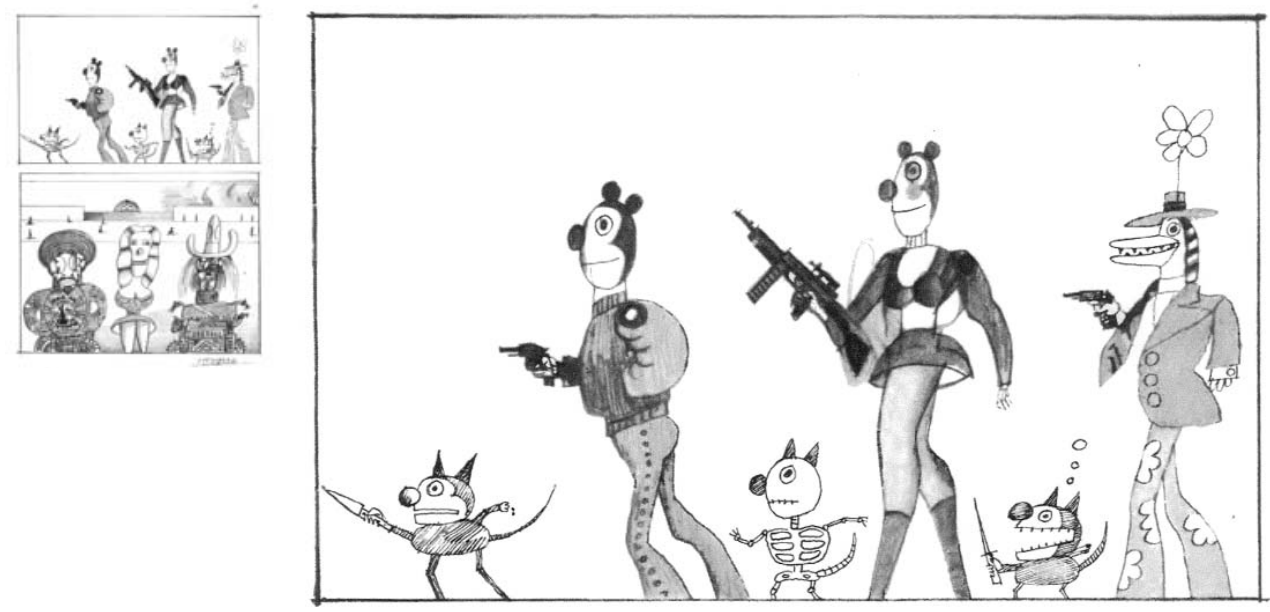

mas para sugerir que a mente assim faz" (Smith, 2006, p.63). De qualquer forma, a violência presente nestes trabalhos traz - congregada ao estilo - novas informações para o trabalho de Steinberg, atento ao comportamento humano. Aos poucos, explode a quantidade de desenhos ácidos das ruas de Nova York, carregadas de um novo imaginário: porteiros como soldados, fachadas de prédios como labirintos assustadores. Dentre seus motivos mais conhecidos estão "as cenas apocalípticas de motins de rua e colapsos urbanos; ou a ocupação dos bizarros lugares-comuns da vida americana em uma matriz cosmopolita" (Hughes, 1978, p. 48). Os Estados Unidos que surgem de alguns de seus desenhos nesta época é um "lugar inquieto e repugnante, um teatro de desastres ocupado por seres grotescos". Como nota Hughes, "em Six Terrorists", de 1971, Steinberg desenha um grupo de guerrilha urbana com faces de Mickey Mouse que representam a geração junk-food: sem sexo, raça, personalidade ou idade".(Hughes, 1978, p. 50). Para Smith, o mundo apresentado nestes trabalhos "estava passando para as mãos daqueles a quem podiam confiar - os astutos, os radicais, e os ferozes" (Smith, 2006, p.192). O próprio Steinberg chegaria a fazer parte da tribo, ao vestir um uniforme de camuflagem pintada e uma máscara militar desenhada por ele. A atenção que o artista dava aos conflitos, como em Street War, era também sugerida nos diversos recortes e fotografias colecionados por ele no período, como por exemplo materiais de tumultos póscoloniais do Oriente Médio e África (Smith, 2006, p.192). Apesar da capa de 1971, é apenas em fevereiro de 1973 que este tipo de trabalho aparece na New Yorker. No entanto, isso ocorre em grande estilo, em portifólio de seis páginas. Algumas destas páginas são divididas em dois grandes desenhos, evidenciando um recurso que Steinberg vinha empregando:

Visões de sua velha vizinhança [de Washington Square Village] - da vida nas calçadas e da revolução das ruas proposta pela contracultura - enchiam seus cadernos de desenhos. Ele destacava várias dúzias de folhas e as pregava nas (...) paredes de seu novo e expandido estúdio em Amagansett. Deste catálogo de personagens à procura de um cenário, ele colou desenhos selecionados aos pares, como Street War, que dão a aparência de episódios narrativos desarticulados (Smith, 2006, p.192). 
A chegada de Steinberg ao grotesco é contemporânea da psicodelia do final dos anos 1960, mas seus trabalhos não eram produto do uso de drogas. Steinberg tomava alucinógenos esporadicamente desde meados dos anos 1950 (Smith, 2006, p.63). Steinberg considerava os alucinógenos "o contrário da arte", elevando as pessoas à condição de ótimos espectadores, ao invés de ótimos artistas (Smith, 2006, p.260). O imaginário alucinatório composto por personagens de olhar violento, psicótico e suspeito também não representava, necessariamente, o medo perante as tribos nova-iorquinas. Saul definia os grupos do Village como "atores vestidos imitando a tradução hollywoodiana da ferocidade e dissolução" (cit. por Smith, 2006, p.63). Para Smith, o que permanecia era o velho modus operandi: "usar a escrita do tema para representar o próprio tema" (Smith, 2006, p.63).

Naquele período, grande parte da expressão visual da cultura hippie estava fundada nos quadrinhos underground, e são nas revistas do gênero que Steinberg irá pesquisar estilos e novos modos de representar os assuntos de sua época. Em 1968, Saul passa a ler os comix, que iriam exercer grande influência sobre seu trabalho a partir de então (Smith, 2006, p.261). Trata-se de aspecto que merece atenção, pois até então são raras as menções do cartunista Steinberg - como pudemos notar até em suas recordações da infância - a referências dos quadrinhos e cartuns.

Mesmo após de mudar de Washington Square Village, Steinberg permaneceu envolvido com o imaginário daquela região de intensa vida urbana. Quando morava lá, andava todo dia até 33 Union Square, no estúdio em que era vizinho de Andy Warhol. A cena jovem do bairro encontrava reflexo nas páginas do jornal underground East Village Other, lido regularmente por Steinberg em 1969. Apesar dos artigos da EVO serem voltados a ataques contra a polícia e a guerra do Vietnã, os quadrinistas de seu suplemento de Gothic Blimp Works pareciam estar centrados na batalha contra o conformismo e a ética protestante de trabalho. R. Crumb, Gilbert Shelton, Vaughn Bodé e Spain Rodriguez, dentre outros, elaboravam fan-

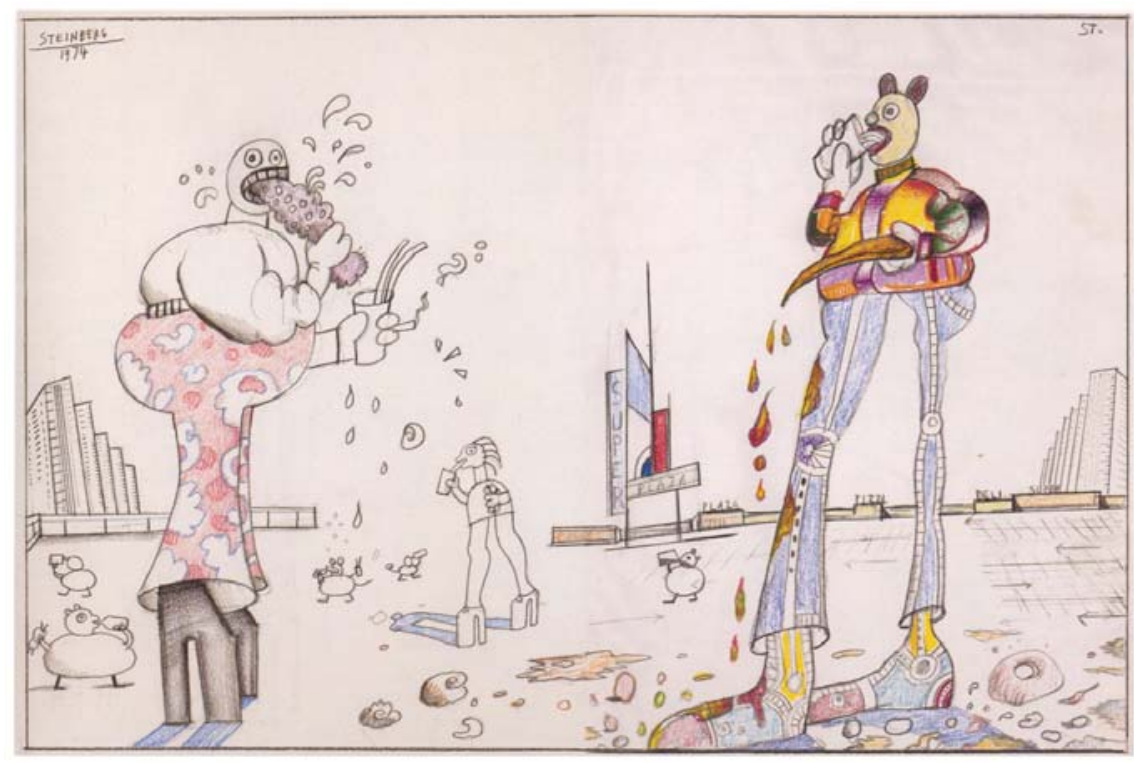

Figura 452. The New Yorker, fevereiro de 1973

Figura 453. Steinberg, Fast Food, The New Yorker, 1976 

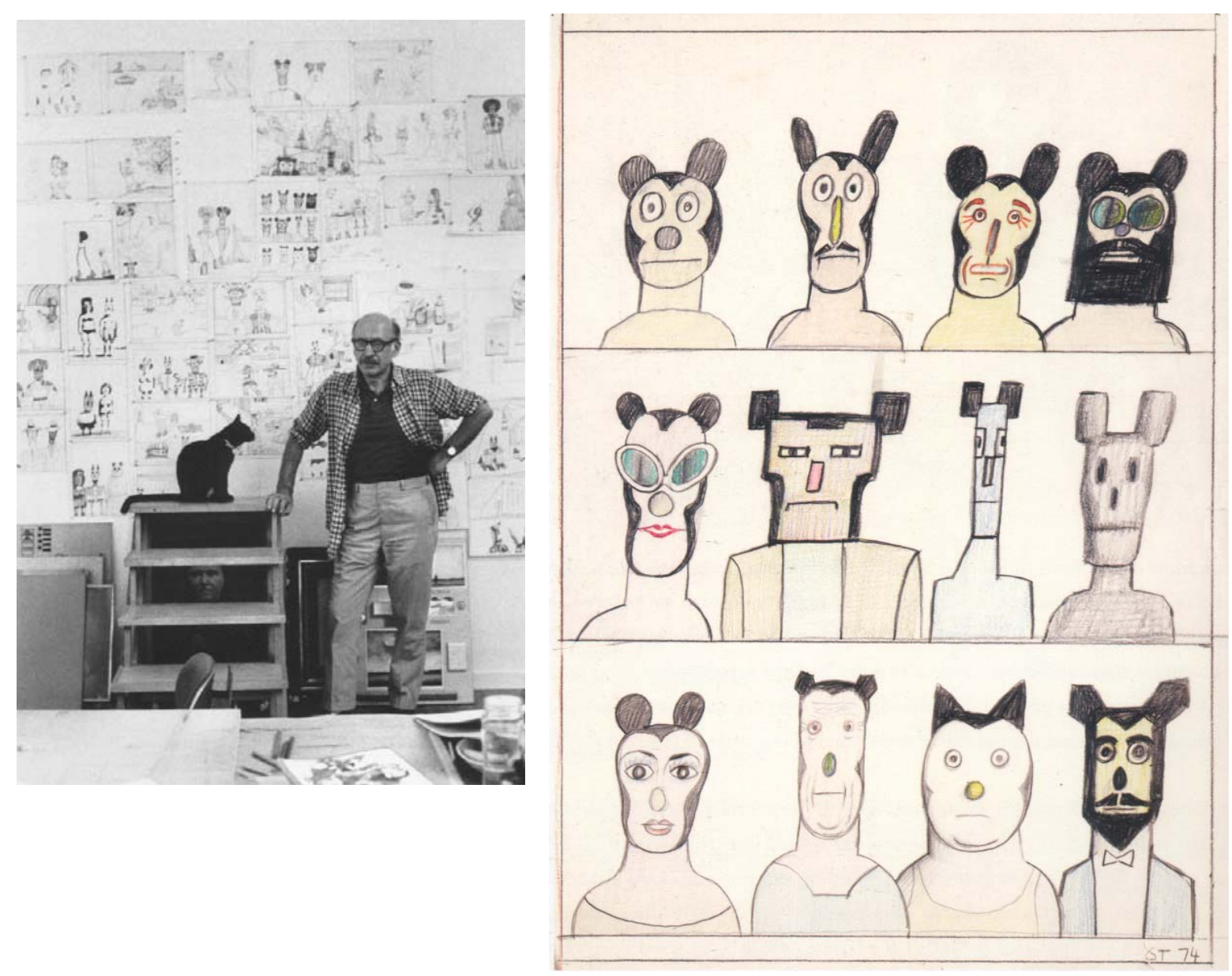

tasias lisérgicas cuja regressão intencional à loucura subpolítica "poderia parecer familiar a um veterano da Bertoldo" (Smith, 2006, p.63). Para Smith, os gatos urbanóides de Steinberg teriam como referência o personagem Waldo, criado por Kim Deitch e publicado na EVO e $G B W$. O felino de Deitch, quadrinista underground de grande presença na imprensa novaiorquina em 1969, "era um gato preto nos moldes do cartum dos anos 1920 - um Félix que caiu em tempos difíceis, e assim um símbolo conciso, talvez, para os problemas contemporâneos que afligem o sonho americano" (Smith, 2006, p.64). Alguns quadrinhos de Deitch, como Karla in Kommieland, deixam claro o recurso de confrontar o universo ingênuo do desenho animado no estilo de Ub Iwerks, do final dos anos 1920 e começo dos 1930, com a malícia, violência e cinismo dos novos tempos. A degradação moral dos toons - ou, por outro lado, a perda da inocência e puritanismo que muitas vezes os caracterizava - não se restringe ao trabalho de Deitch, sendo uma característica geral do comix. A paródia vinha sendo utilizada, em ampla escala, há tempos: "A Mad de Kurtzman foi a primeira iniciativa dos quadrinhos que conseguiu seus efeitos quase que totalmente parodiando outros tipos de cultura popular. (...) Kurtzman percebeu que as convenções da cultura pop circulavam de modo tão profundo na imaginação de sua audiência (...) que poderia ser criado um novo tipo de sátira simplesmente relacionando-as" (Gopnik, 1993, p.75). Gopnik recorda que o "(...) Kurtzman logo voltou sua atenção para um mundo inteiro em explosão da mídia americana 

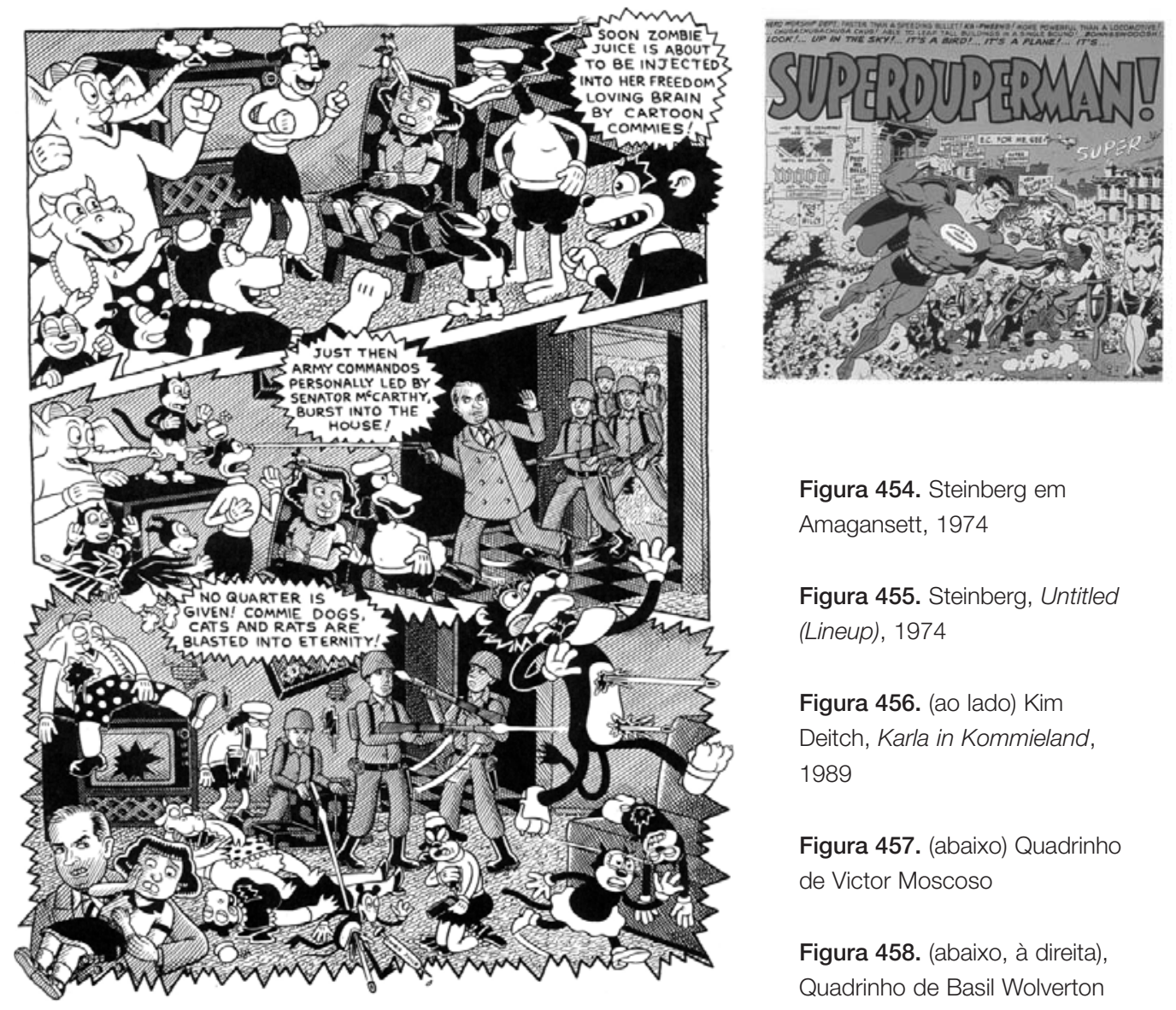

Figura 454. Steinberg em

Amagansett, 1974

Figura 455. Steinberg, Untitled

(Lineup), 1974

Figura 456. (ao lado) Kim

Deitch, Karla in Kommieland,

1989

Figura 457. (abaixo) Quadrinho de Victor Moscoso

Figura 458. (abaixo, à direita), Quadrinho de Basil Wolverton

- de Howdy Doody e o Western e os novos filmes jovens, e até para os desenhos animados clássicos da Disney" (Gopnik, 1993, p.75). Nos quadrinhos underground, a "mistura de Mad (Basil Wolverton especialmente), Disney e o estilo "pé-grande" das tiras de jornal americanas", que geravam "um estilo antigo, de efeito quase "adocicado" (Sabin, 1996, p.94), se fazia presente em muitas das hqs de Crumb, Victor Moscoso, dentre outros. Já os cenários surreais com seres espalhados em amplos espaços, envoltos por nuvens densas ou lisérgicas, com construções ao fundo como pirâmides ou castelos, lembram os trabalhos de Moscoso. O céu escuro, com elementos soltos no espaço, chegam a lembrar o universo de Cococino World, de Krazy Kat. O que Saul não incorpora do underground, sequer como paródia, são as cenas de sexo explícito tão presentes nestes quadrinhos. De qualquer modo, à maneira sutil de Saul, o cartunista explora as pernas - em especial, das mulheres - nas cenas urbanas,
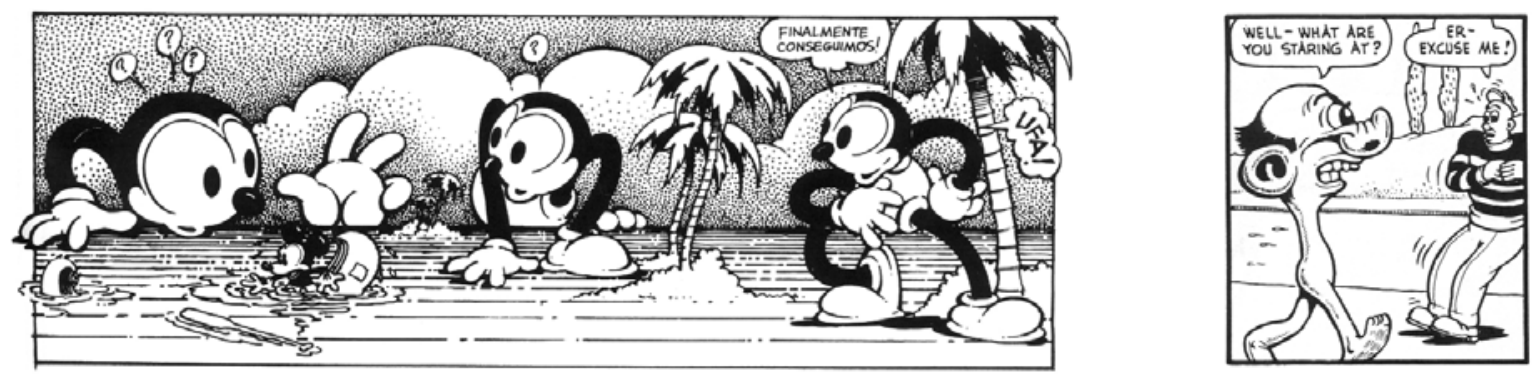

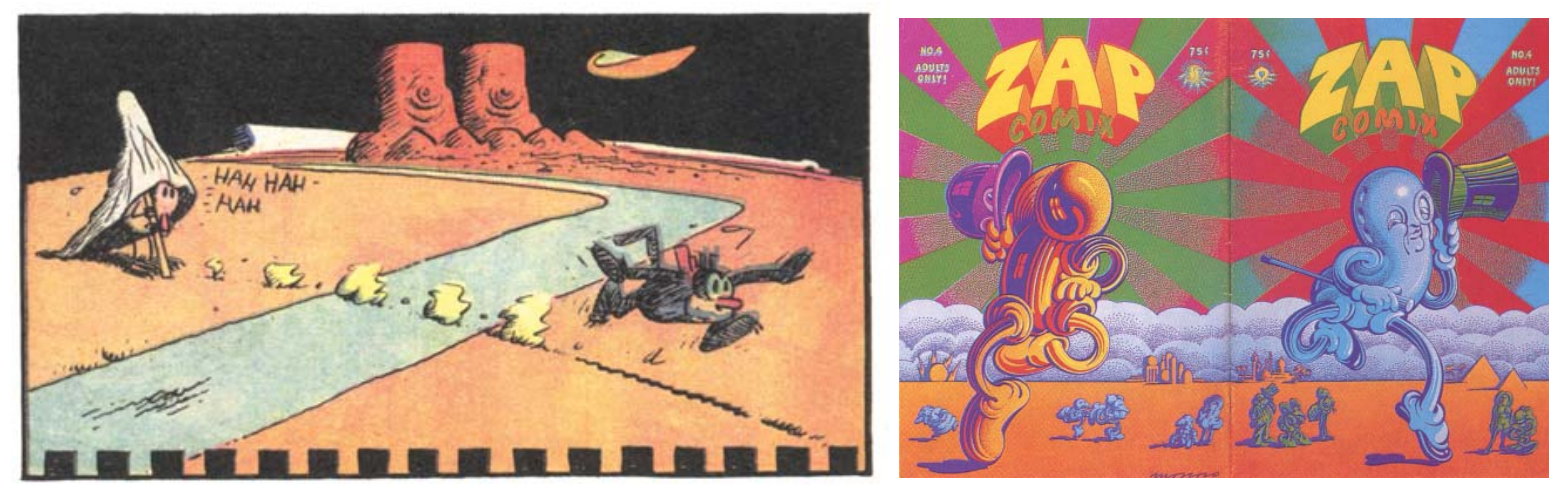

muitas das quais foram criadas para ilustrar o livro de Ian Frazier, Canal Street, de 1990.

Curiosamente, outro expoente da New York School também se aproximava dos quadrinhos, mas vindo de um outro extremo. Philip Guston, na mesma época, surpreendia o meio artístico ao se mover do expressionismo abstrato, com o qual tinha obtido reconhecimento, para pinturas baseadas na figuração. Como comenta Storr, "alguns observadores (...) perguntavam a si mesmos se Guston havia sido influenciado pelo Robert Crumb da Zap Comix" (Storr, 1986, p.50). Guston, no entanto, não tinha ciência do trabalho de Crumb, nem estava procurando grandes conexões com artistas contemporâneos como Peter Saul ou Oyvind Fahlstrom, mas retornava aos seus entusiasmos mais antigos. Além do pólo dominante de referências representado por Piero e Rembrandt - assim como Mondrian, de Chirico, Picasso e Beckmann - ele se mantinha "um fã ávido de filmes e quadrinhos como Mutt and Jeff, Barney Google e Krazy Kat, que havia inspirado ele quando criança" (Storr, 1986, p.51).

Guston e Steinberg não haviam sido os únicos a utilizar as histórias em quadrinhos como referência ou material para seus trabalhos a partir da década de 1960. Uma vez que naquela época imperava a Arte Pop, a cultura de massas era empregada sistematicamente nas obras. São famosos os quadros de Roy Lichtenstein, feitos no começo dos anos 1960, com a ampliação desmesurada de cenas dos quadrinhos mais populares. Andy Warhol utilizou a silhueta de Popeye em uma obra, e Mel Ramos recorreu a outro gênero de personagem de hq em seu Señorita Rio. Hervé Télémaque chegou a um evidente idioma Pop em trabalhos como Pastolare, de 1965, no qual imagens familiares de personagens como Piu-Piu, Pateta e Frajola são configuradas em contornos limpos e áreas de cor chapada, mantendo-se, acima de tudo, interessado nas misteriosas conjunções de motivos fragmentados, numa espécie de "surrealismo tardio" (Livingstone, 1990, p.146). As primeiras obras do italiano Valerio Adami, como L'ora del sandwice, de 1963, empregaram uma técnica de quadrinhos fraturada e expressionista similar à de Télémaque (Livingstone, 1990, p.147). Exibições temáticas chegaram a ser feitas na Europa entre 1964 e 1970, com títulos como La Figuration narrative dans l'art contemporain, de 1965, e Bande dessinée et figuration narrative, de 1967. A própria linguagem seqüencial viria a ser empregada em algumas obras. Os artistas europeus usavam imagens contemporâneas "como pontos de partida para formas de pinturas narrati- 

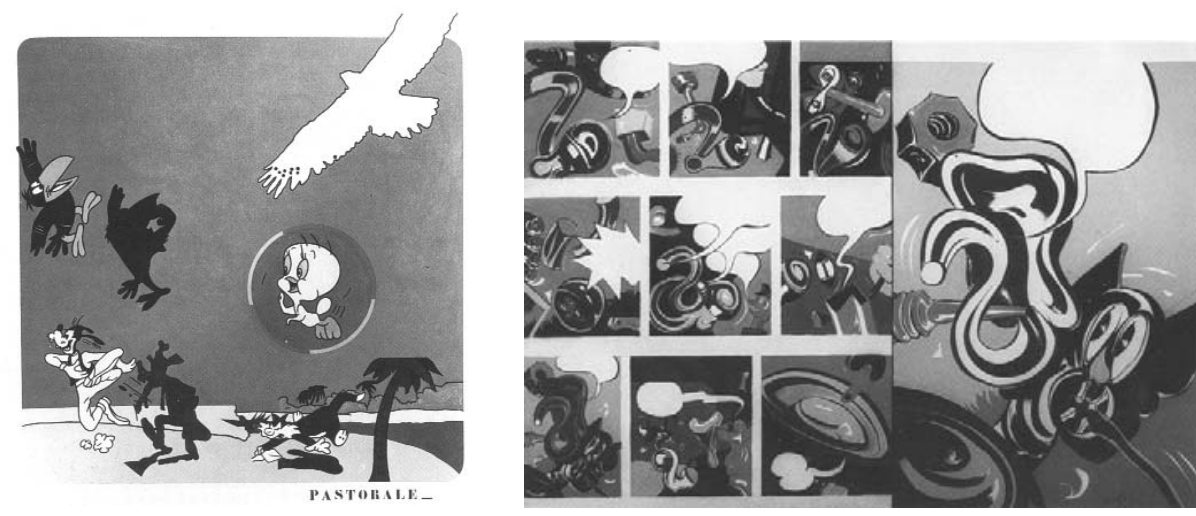

Figura 459. Krazy Kat

Figura 460. Capa da Zap!, arte de Vicotr Moscoso, 1969

Figura 461. Hervé Télémaque

Figura 462. Bernard Rancillac

vas que estavam, em muitos casos, em divergência com a qualidade essencialmente estática e emblemática do mainstream do Pop nos Estados Unidos e na Inglaterra" (Livingstone, 1990, p.146). Dentro desta linha estão os primeiros trabalhos do francês Bernard Rancillac, que usavam as hqs como referência, especificamente no uso da narrativa, como na pintura Private Diary of a Foot, onde explora as possibilidades do formato (Livingstone, 1990, p.146). O suíço Oyvind Fahlstrom também empregou constantemente em suas obras complexas fragmentações de formas e imagens. Os personagens de HQ se fazem presentes em várias de suas obras, como Performing K. K. No. 2 (Sunday Edition), de 1963-64, um de seus muitos trabalhos baseados em Krazy Kat. Apesar destas referências, o artista nunca se encaixou confortavelmente no mainstream do Pop. Fahlstrom - como Télémaque e Rancillac -, não parecia muito interessado no potencial estilístico destas referências dos quadrinhos, tampouco em sua
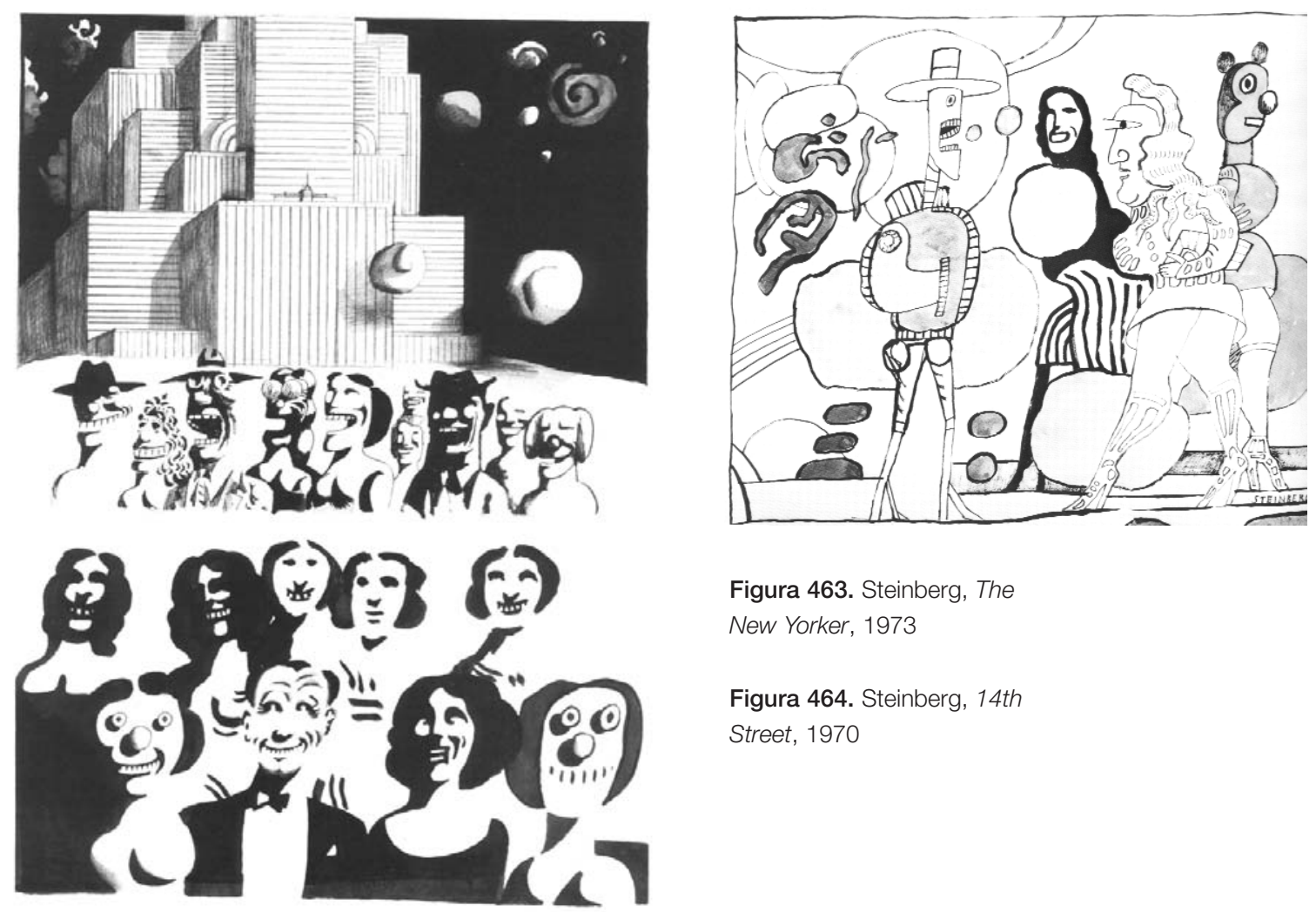

Figura 463. Steinberg, The New Yorker, 1973

Figura 464. Steinberg, 14th Street, 1970 
identidade como signos da cultura contemporânea, mas no seu potencial narrativo (Livingstone, 1990, p.155). Steinberg e Guston, de algum modo, diferem da maior parte destes artistas no envolvimento e proximidade que mantém com o universo dos quadrinhos. Para Saul, "não se pode parodiar algo que você não ame" (Hughes, 1978, p.48).

\section{STEINBerg: OS PORTIFólios NA New Yorker}

Os desenhos urbanos, que estréiam na New Yorker em 1973, coincidem com uma forte retomada dos portifólios. O agrupamento de desenhos, publicados em seqüências de páginas totalmente dedicadas ao artista, haviam sido comuns em seu começo de carreira na New Yorker, como os relatórios de guerra. Depois de 1945, tornaram-se esporádicos, como nos trabalhos The Coast, de 1952. Os ensaios com sons gráficos, publicados em fevereiro de 1955, e o portifólio sobre a viagem à Samarcanda, de 1956, rompem um longo período em que os desenhos de Steinberg ficaram confinados quase que estritamente ao espaço para vinhetas. A partir de então, estes portifólios viriam a ser mais freqüentes, como as seqüências com interrogações objetualizadas de 1961, os números como objetos de 1962, as seis páginas com carimbos de 1966, a personificação das ruas de Nova York de 1968, as brincadeiras com o significado de palavras-objeto de 1969, a montagem de quebra-cabeças sob forma abstrata de 1970, dentre outras. A partir de 1973, duas guinadas consideráveis em sua atuação na New Yorker: praticamente todos os seus trabalhos viriam a ser publicados no formato portifólio, com exceção de ilustrações para artigos. Seriam privilegiados, em significativa parcela, os desenhos sobre a cidade, a arquitetura, e aspectos urbanos. Algumas interrupções ocorreriam, uma delas significativa, entre 1985 e 1990.
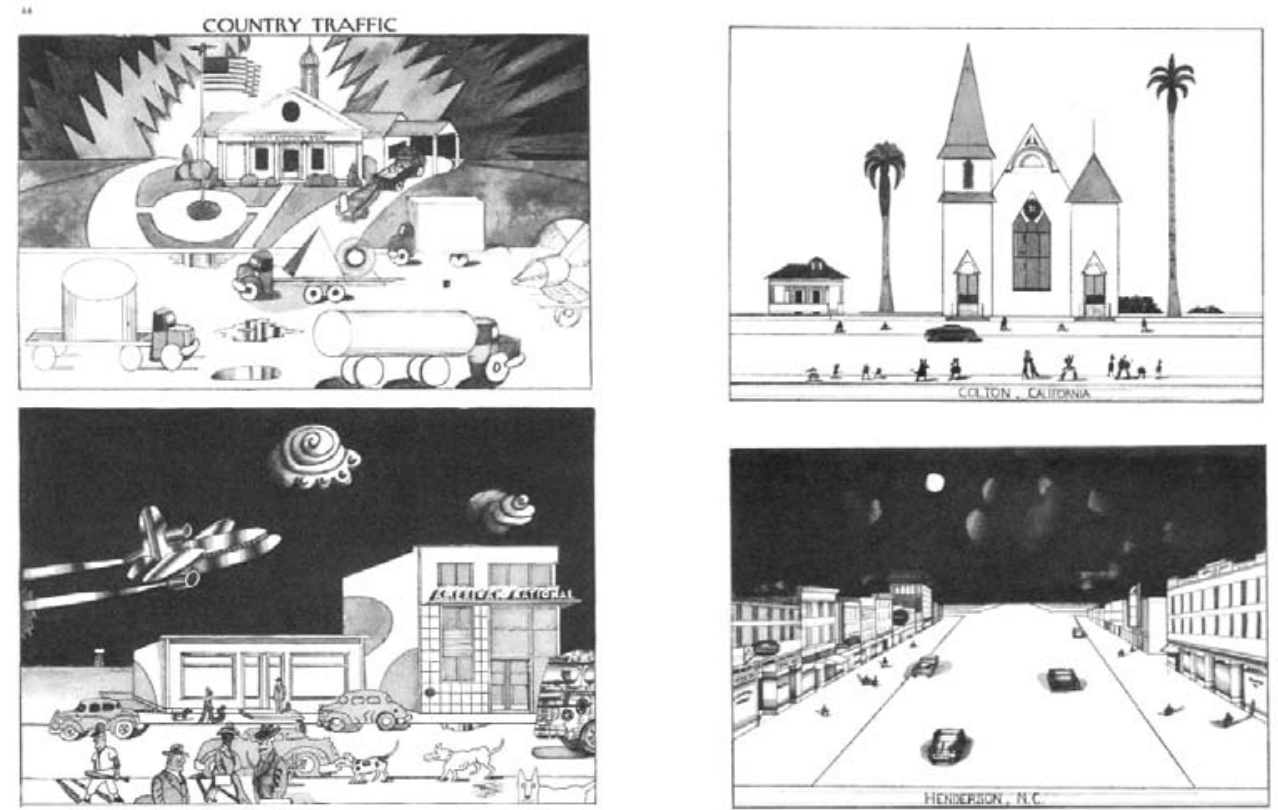
De modo geral, os portifólios apresentavam uma subdivisão de cada página em duas partes, talvez seguindo o procedimento de escolher desenhos pregados na parede, aos pares. Estes trabalhos sobre cidades mostravam vertentes e pesquisas diversas, e eram todos feitos originalmente a cores, mesmo que "as figuras nas páginas internas da revista fossem continuar a ser impressas em preto e branco até 1989" (Smith, 2006, p.206). Dentre as obras semelhantes a The City estava a seqüência de título sugestivo Fast Food, de 1976. Já em City Dogs, de 1977, e Domestic Animals, de 1983, são os animais os personagens principais destes ambientes urbanos, cada qual agindo ao seu modo. Portifólios como Italy - 1938, de 1974, e Cousins, publicado em 1979, promoviam uma volta ao passado imersa em lembranças remotas, referências estilísticas e elementos surreais que remetiam, talvez, ao modo como as recordações envolvem sempre uma dose considerável de fantasia, mistificação e evocações sentimentais. Nas cenas italianas, soldados desfilam tendo ao fundo pesadas construções fascistas e obras cubistas valorizadas pela Regio Politecnico. Na primeira página deste portifólio, o Bar Grillo aparece solitário; em outra imagem, sobressai o interesse estilístico mesclado às influências dos quadrinhos, ainda assim mostrando construções de Milão. Em Cousins, Steinberg tira proveito de seu olhar atento dos tempos da infância, para mesclar suas lembranças da Romênia às experiências com estilos. E a fantasia que percorre estes desenhos adquire novo status e dimensão nas situações desconexas de Dreams, publicada em 1988.

Também são muito freqüentes os postcards, portifólios com dois cartões-postais por página, cada qual referente a um lugar, como Amarillo, Texas. Começam a ser feitos na New Yorker após um período de esforço denominado Batalha de Austerlitz, em que o cartunista ficou cuidando da montagem da exposição de 1978, na retrospectiva do Whitney, e deixou as contribuições para a revista um pouco de lado (Smith, 2006, p.206). São obras que exibem um desenho mais preciso no delineamento retilíneo de ruas e construções, e no sombreamen-
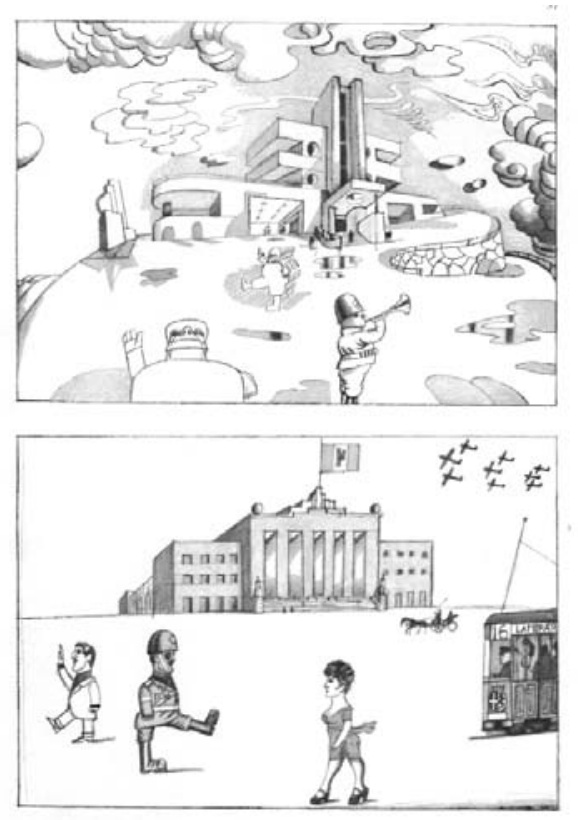
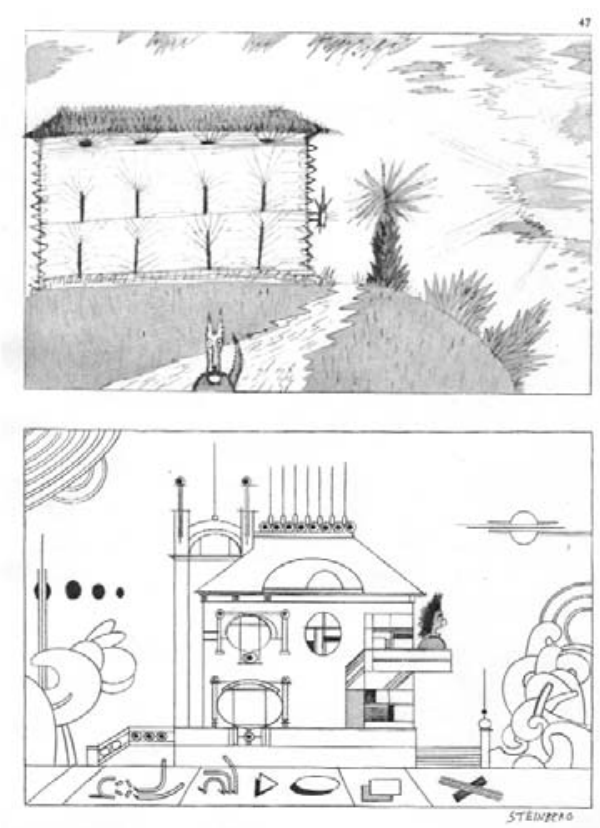

Figura 465468. Portifólios publicados na New Yorker 
to que os aproxima da realidade. De aparência fria, séria, se aproximam - em muitos casos da visão oficialesca e mistificada da cidade. No entanto, em alguns detalhes, transparece o humor do cartunista. No cartão da cidade de Colton, presente na série publicada em 1978, um olhar atento pode perceber que as pequenas silhuetas que caminham pela cidade são de seres cartunizados, de ratos, pássaros. O céu escuro, de lua cheia, de Henderson se apresenta no tom surreal de obras anteriores. Em outros "postcards" fica patente o interesse de Steinberg em confrontar lugares diferentes, cada qual com um modo particular de se mostrar. Feitos ao longo da vida cheia de viagens de Steinberg, as imagens lidam com a sensibilidade seletiva do artista. Ao enaltecer a condição única de viajante do cartunista, conhecedor como poucos dos Estados Unidos, Brendan Gill comenta que estes cartões-postais poderiam igualmente ser chamados, "sem ironia ou sentimentalismo, de democratic vistas" (Gill, 1978, p.73).

As tomadas de lugares das cidades, semelhantes aos cartões-postais, seguiriam sendo produzidas na revista. Em Country Traffic, de 1980, é potencializada a exploração de estilos e clichês, que passam a povoar o que seriam visões austeras e sóbrias de construções e ruas. Em outras vertentes, a atenção à arquitetura fica explícita nos títulos: Architecture - Housing, de 1983, Architecture - Villas, de 1983. Nesta última, a peculiaridade de cada diferente construção é evidenciada pelo próprio estilo empregado para desenhá-la. Já em Housing, aglomerados de habitação, cujos habitantes minúsculos conferem ao ambiente a impressão de lugares desabitados, traduzem a visão esquemática subjacente na construção da cidade. Trabalhos com anotações e legendas também viriam a compor os portifólios sobre a cidade, como em The War with New Jersey, de 1987, e Manhattan, publicado em 1994. As frases reforçam, em muitos casos, o humor de Steinberg e o absurdo captado na reflexão daquilo que observa. Algumas de suas anotações seriam agrupadas em certos momentos, com a arquitetura sendo deixada de lado: em Notebook, sua experiência com o zen budismo, uma conversa sobre arte e carpintaria, ou mesmo o comportamento de um gato passam a ser o foco para divagações, que levam muitas vezes seu pensamento de volta aos temas de sua obra.
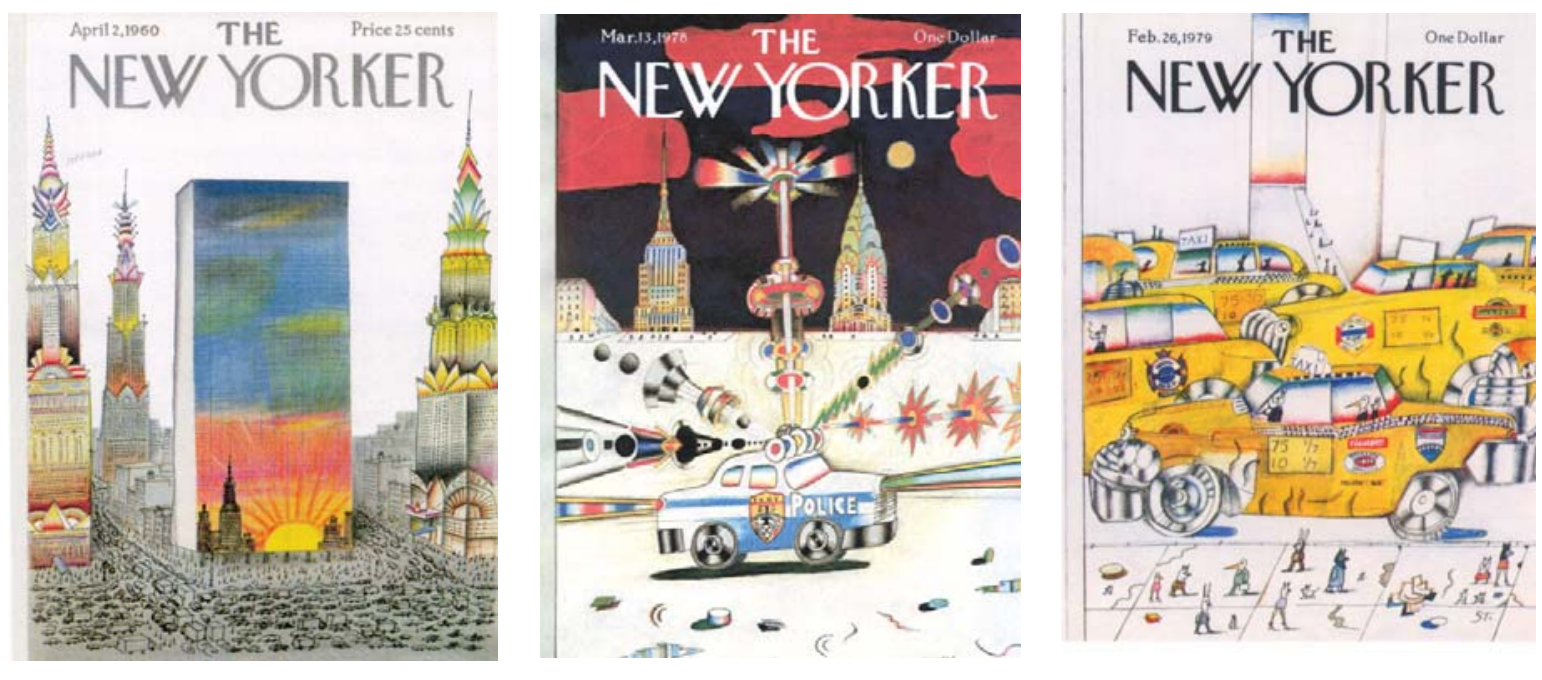
Nesta fase, além dos postcards e trabalhos sobre a cidade, os portifólios também se voltariam algumas vezes para outras explorações, nos jogos entre palavras e expressões gráficas de Body English, Directions, e Inventory, criadas nos anos 1980. A divisão das páginas destes trabalhos em quadrinhos, com legendas em espaço definido, mostrava que Steinberg continuava atento ao modo como a estruturação da página também desempenhava um papel no "modo como as coisas se mostram".

A atenção à cidade não ficaria relegada apenas às páginas internas da New Yorker. Antes da capa de 1971, Steinberg já havia feito uma outra, em abril de 1960, em que comenta de modo otimista o aparecimento de edifícios modernistas na cidade - na cidade, desde o começo dos anos 1950 - entre torres de estilo déco. Naquele caso, o vidro que cobre a superfície homogênea e plana do prédio recebe a paisagem refletida como estilo, evidenciando a percepção da "arte nas coisas" e na própria natureza recriada pela percepção humana. Se neste desenho a inovação ainda estabelece uma relação harmônica com a tradição, os desenhos da Nova York estridente no amálgama de informações, estilos, novidades e individualidades, apareceriam não apenas na capa de 1971, mas também em diversas variações ao longo dos anos. A massa de edifícios deformados que surge, desde o começo dos anos 1960, da aparente interpretação da arquitetura moderna de grandes habitações - cujos ângulos contorcidos poderiam sugerir um caminho rumo ao pós-modernismo -, é potencializada na mescla orgânica de estilos da capa de 1994, lembrando a complexidade de Frank Gehry, pós-modernos e deconstrutivistas.

As capas de temática urbana não se restringiram ao cenário tenso da explosão de estilos e olhares psicóticos. No trabalho de 1987 é o olhar solitário da casa-pato de subúrbio, um clichê envolto pela natureza e à beira de uma auto-estrada, que se faz presente. A construção é uma clara menção ao Patinho de Long Island. Segundo os escritores do livro Aprendendo em Las Vegas (1977), trata-se de um "símbolo escultural e abrigo arquitetônico", onde "a própria construção é um anúncio" (Venturi; Brown; Izenour, 2003, p.40). Já a frieza esquemática da capa de junho de 1992 comenta a simplificadora compreensão da
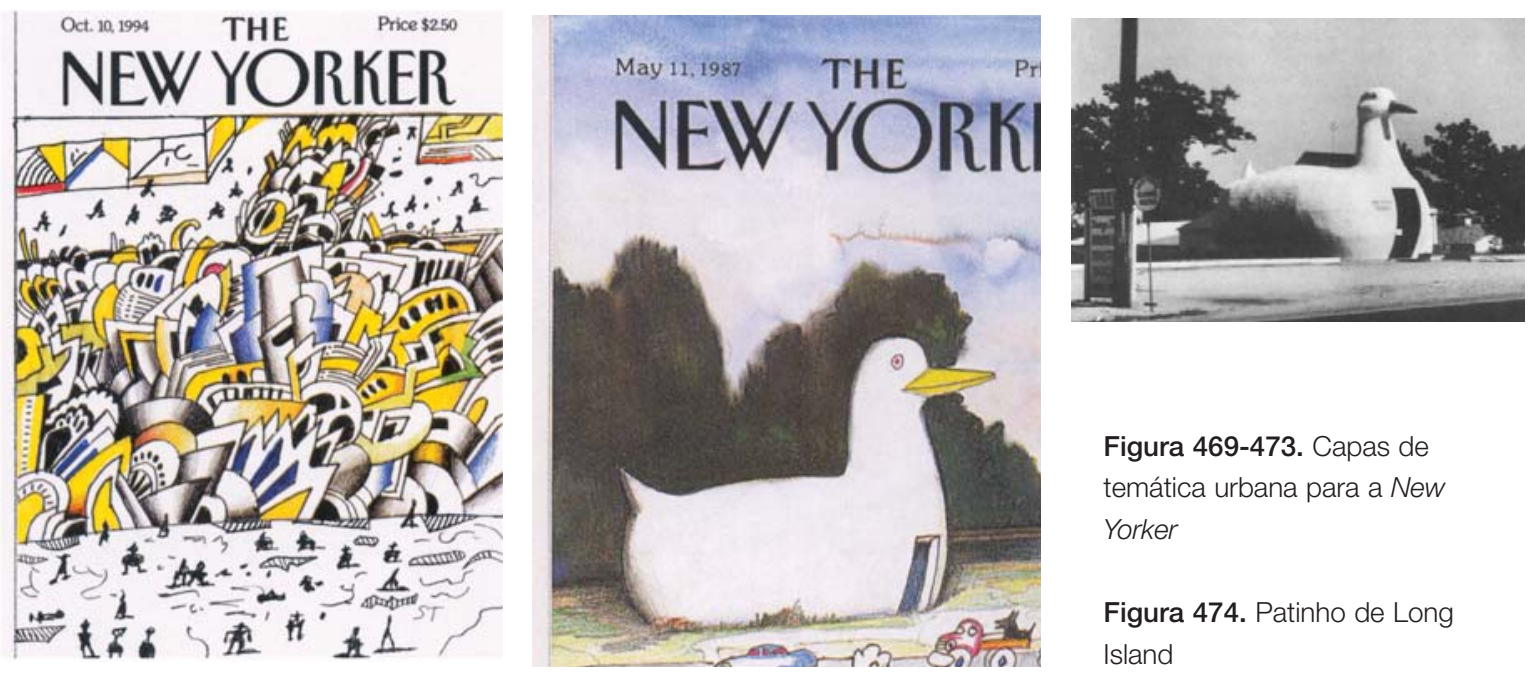

Figura 469-473. Capas de temática urbana para a New Yorker

Figura 474. Patinho de Long Island 


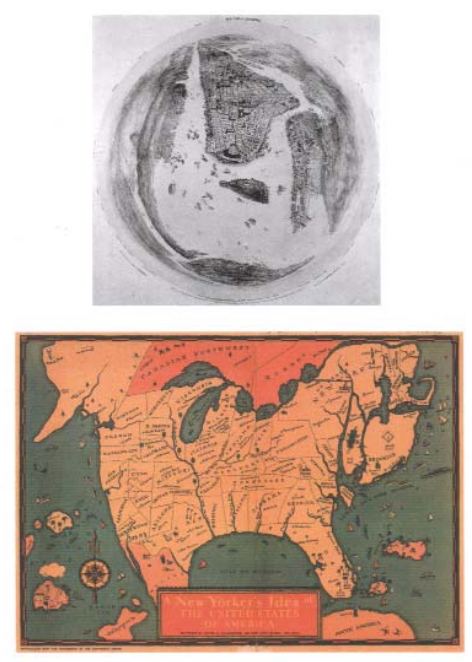

Figura 475. New York \& Environs, 1859

Figura 476. Daniel Wallingford, 1939

Figura 477. Steinberg, View of the World from 9th avenue, 1976

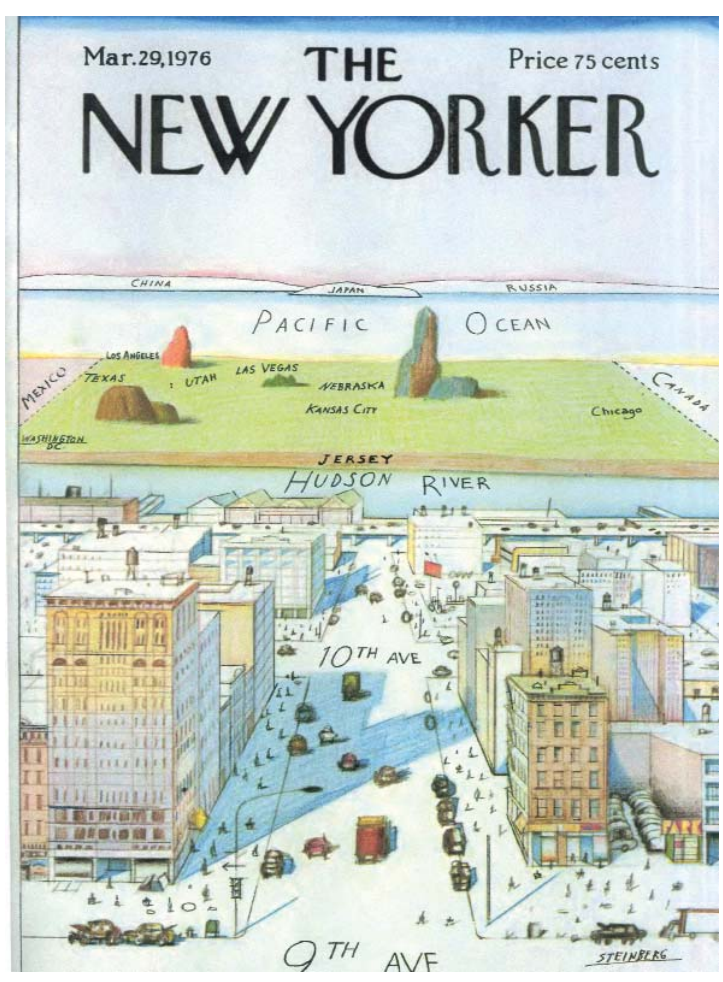

cidade como via de trânsito, em contraponto a uma paisagem natural que sutilmente aparece no horizonte.

Seria, no entanto, uma capa criada em março de 1976 que iria se destacar na carreira de Steinberg. Na opinião de Topliss, este trabalho representa, ironicamente (levando em conta o medo da fama de Steinberg), "a capa de revista mais famosa do século vinte, a imagem mais plagiada imagem de uma cidade, e uma das invenções mais características de Steinberg" (Topliss, 2005, p.188). Em View of the World from 9th Avenue, uma New York vista da 9th Avenue, sem seus símbolos mais marcantes, vê o mundo diminuir no horizonte. Para Lee Lorenz, trata-se "do mundo percebido pelo americano médio" (cit. por Topliss, 2005, p.190). A imagem parte do alto de um prédio, de um "ponto de vista elevado, no sentido de que a altura torna você mestre do universo". Para Topliss, é "o desenho do mais profundo mito de Nova York, a altura de seus edifícios" (Topliss, 2005, p.188). Já Smith chama a atenção para algumas das duradouras marcas de Steinberg, presentes na obra: "(...) mapas mentais de tempo e espaço, a decadência material de Manhattan, e a completa beleza de cor desenvolvida de forma econômica" (Smith, 2005, p.41). O trabalho é uma invenção de duas partes, dividida no meio pelo rio Hudson, cada qual com uma específica linguagem gráfica. A aparência naturalística de Manhattan contrasta com o mapa esquemático a partir de Nova Jersey, "vista como se estivesse sobre uma mesa, da perspectiva de alguém olhando através dela" (Smith, 2006, p.202), em um espaço cartográfico abstrato. O humor de View of the World se faz presente quando a mente imediatamente percebe "a desconexão lógica entre visão e mapa, e a relação mental dual que representam - uma consciência física aguçada do 
ambiente imediato de alguém e a abstração vaga sobre o mundo esquematizado" (Smith, 2006, p.202). Em sua função como capa, o design incorpora o título da revista ao dispor um leve degradê do céu no alto da imagem. Deste modo, a sátira sugere que ali está uma "visão do mundo do nova-iorquino - mas (...) não a visão da New Yorker, nem a de você, leitor". Um certo desconforto com a abordagem é evidente, uma vez que seu tema, segundo Steinberg, "era a vista do mundo das 'pessoas débeis'" (cit. por Smith, 2005, p.43). View of the World tinha precedentes nos desenhos de Los Angeles e da Costa Oeste feitos em 1966, e mais precisamente no trabalho West Side, de 1973. É também possível recorrer a comparações com outros velhos precedentes: a vista aérea deformada de John Bachman (1859), ou o mapa inventado A New Yorker's Idea of the United States of America, de Daniel Wallingford, publicado nos anos 1930 (Smith, 2006, p.204).

\section{O CRÍTICO DE ARQUITETURA E URBANISMO}

Apesar de ter dado significativa ênfase aos desenhos urbanos a partir dos anos 1970, Steinberg era observador da cidade e da arquitetura desde o início de carreira, como atestam seus primeiros portifólios para a New Yorker. Os desenhos de Steinberg, como nota Robert Hughes, começaram a apresentar a partir de determinado momento "uma percepção extremamente refinada da convenção arquitetural: as sombras pontiagudas e as complexas e irracionais fachadas de seus edifícios de sonhos no horizonte americano só poderiam ter sido desenhadas por um ex-estudante de arquitetura olhando fixamente com ironia para seu passado." (Hughes, 1978, p.51). Não foi por acaso, portanto, que o crítico de arquitetura Peter Blake (Blake, 1978, p.106) chegou a dizer, em seu texto Cartoon Critic - para uma matéria de capa da revista americana Architecture -, que "quase tudo o que já foi dito e escrito sobre arquitetura durante os últimos quarenta anos foi expresso de forma muito melhor, mais clara, de modo mais divertido e incisivo, e muito antes, por este extraordinário artista... e sem o uso de uma só palavra (...)." Blake ainda foi mais longe, ao afirmar que "Saul foi, sem dúvida, o mais brilhante crítico de arquitetura nos Estados Unidos na última metade do século". Segundo ele, os desenhos de Steinberg anteciparam, em várias ocasiões por décadas, muito daquilo que mais tarde se traduziria em edifícios e construções reais. Sendo assim, seus desenhos teriam previsto o minimalismo, e os prédios altos totalmente recobertos de vidro, por vinte anos; assim como teriam antecipado os falsos frontões e as coberturas decoradas muito antes que Robert Venturi aparecesse; dentre vários outros exemplos.

É difícil precisar até que ponto as afirmações de Blake são corretas quando ele se refere ao poder premonitório de Steinberg. Quando menciona os "prédios altos totalmente cobertos de vidro" e o "minimalismo", não há maiores especificidades para saber ao certo se Blake se refere aos prédios minimalistas de Mies ou aos "cristais" de vidro espelhado de 
edificações posteriores. Graph Paper Buildings, uma importante referência, foi feito em 1950, sendo contemporâneo do edifício de apartamentos de Chicago Lake Shore Drive de Mies van der Rohe, construído entre 1948 e 1951. O Lever Brithers Company, projeto pelo escritório Skidmore, Owings \& Merril foi levantado em Nova York também naquela época, entre 1951 e 1952. A construção do Seagram de Mies van der Rohe e Philip Johnson data de 1954 e 1956. Se há premonição, ela seria de um ano ao invés de duas décadas. Mas os prédios altos, a idéia da fachada limpa de vidro e de estrutura independente, já eram fatores discutidos há tempos pelos arquitetos. Muitos anos antes, em 1922, os desenhos dos planos visionários de Le Corbusier para "cidades de três milhões de habitantes" cobriam o centro da Cité com altos prédios minimalistas. Steinberg, formado em arquitetura, teve acesso ao ideário moderno em ebulição, numa faculdade onde "o trabalho de Le Corbusier era o que mais interessava os estudantes" (Smith, 2006, p.252). O artista havia chegado a Milão na mesma época que os nazistas fechavam a Bauhaus, o que evidencia a maturidade das questões modernistas àquela altura (Smith, 2006, p.73). Natural, portanto, a familiaridade do cartunista com as questões da arquitetura debatidas desde os tempos da faculdade, às quais ele provavelmente - devido ao seu meio - continuava a acompanhar. De qualquer modo, Blake talvez se refira aos prédios de vidro espelhado, que de fato foram feitos depois. Neste caso, se desconsiderarmos a simplificação habitual do desenho de Steinberg, há algo de premonitório na capa de 1960 da New Yorker, mesmo que as fachadas de prédios como o Seagram já fossem suficientemente envidraçadas para proporcionar a idéia de reflexo da paisagem exterior. Mas se pensarmos que os prédios de vidro espelhado foram apenas uma radicalização daquilo que já era significativamente novo para levantar as questões e impressões essenciais nos anos 1950, o caráter premonitório do desenho de Steinberg passa a ser um detalhe menor. Mais pertinente parece ser a sua compreensão dos valores modernistas de simplicidade que vinham sendo discutidos há décadas, do que a casual semelhança com prédios construídos posteriormente. O que Graph Paper Buildings transmite, acima de tudo, é o modo como Steinberg estava a par das transformações de sua época, acompanhando de modo crítico as mudanças da sociedade, as novas formas e estilos. Acima de tudo, o aspecto mais importante do artigo de Blake reside no modo como o cartunista, de fato, consegue levantar aspectos críticos sobre a cidade e a arquitetura em seus desenhos.

Desde muito cedo, Steinberg chamava a atenção por sua condição - e visão - de arquiteto. Em 1946 a revista Architectural Forum também publica, entre fevereiro e maio, desenhos em linha fina de página inteira: as detalhistas Drug Store, Movie Palace, Doubling Up e Underground, verdadeiras crônicas sobre a energia de uma cidade que deixava para trás a rotina dos tempos de guerra (Smith, 2006, p.92). Naquele mesmo ano, a revista italiana de arquitetura Domus também publicava um artigo intitulado l'architetto Steinberg, escrito por Aldo Buzzi. O amigo italiano de Steinberg, ao falar da formação de arquiteto do cartunista, chega a comentar os desenhos feitos para a Architectural Forum, impressionado, por exemplo, com o uso da "perspectiva, que Steinberg tem usado no limite do possível" (Buzzi, 1946, 


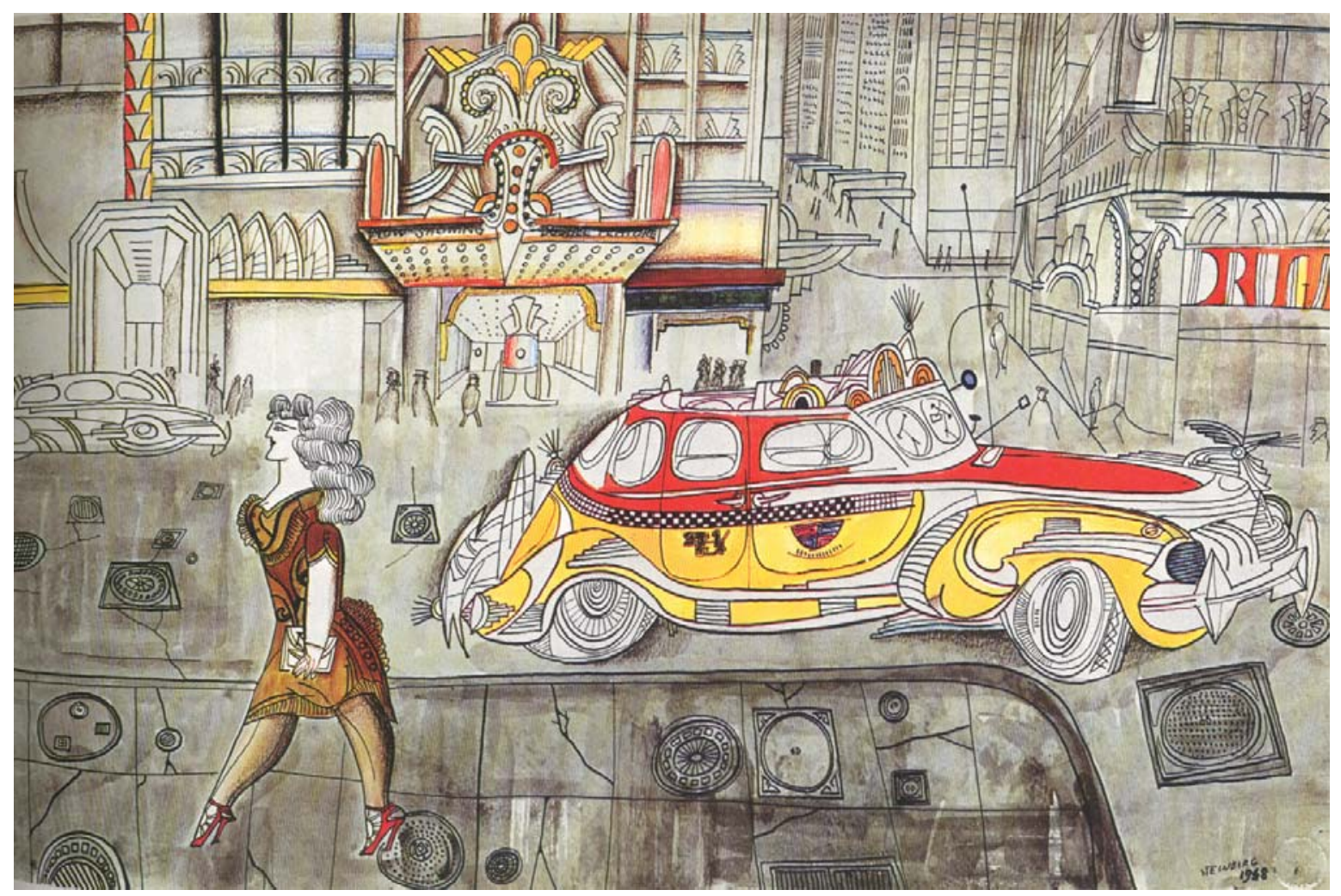

Figura 478. Steinberg, New York taxi and girl, 1948

p.20). Mais contundente, uma referência clara da amplitude de seus desenhos urbanos foi a publicação de um especial sobre Steinberg na parte dois do Journal of the American Institute of Planners, em 1961. Intitulada Steinberg on the City, essa revista de aspecto formal, tradicionalmente voltada para textos, abre o especial com um prefácio de uma página, dedicando todo o restante de seu conteúdo unicamente aos desenhos sobre arquitetura e cidades de Steinberg. Um texto aparece apenas no prefácio da primeira página: "Poucos comentaristas da cena contemporânea têm falado com maior lucidez e clareza que Saul Steinberg. Impaciente com a fraudulência, ele tem lembrado todos nós do fingimento que marca nosso design urbano e pompa cerimonial" (Reichek, 1961, p.3). Os desenhos publicados refletem o momento da carreira de Steinberg. Naquela época, o artista ainda estava começando a desenvolver seus trabalhos mais alegóricos, e o exagero paródico de Le Masque só viria a aparecer cinco anos depois. Isso mostra que naquela altura já era considerável a atuação de Steinberg como observador das questões urbanas, décadas antes das terror cities. A seleção dos trabalhos publicados no Journal of the AIP ignora também os trabalhos dos portifólios de guerra, recheados de observações das cidades visitadas. Confere atenção, portanto, aos outros desenhos das cidades feitos nos anos 1940 e 1950, muitos deles publicados no The Passport e The Labirinth. Estão lá, em traço fino, The Coast, as construções seriadas, detalhes de janelas, interiores ricamente detalhados, o metrô, passageiros, lanchonetes, pontes, as formas luxuriantes e luminosas do estilo déco, a presença maciça de carros nas ruas, nas regiões de planejamento modernista ou em subúrbios espalhados e de baixa densidade. 
Steinberg também teve o mérito de viajar consideravelmente pelo mundo, em especial pelos Estados Unidos, transferindo para suas obras uma rara consciência do país. Brendan Gill, em 1978, chamou a atenção para o fato, indagando: "(...) quantos de nossos artistas viajaram extensivamente por todos os cinqüenta de nossos estados, têm cruzado o país por trem e avião e automóvel, e que visitaram incontáveis centenas de nossas cidades? A que artista, exceto Steinberg, irão os historiadores ter acesso a uma visão única da América de costa a costa?" (Gill, 1978, p.73). The Coast, publicada em 1951 na New Yorker, foi o primeiro portifólio sem relação com a guerra, e mostrava em suas cinco páginas, dentre outras coisas, a diversidade estilística das residências da costa oeste, fruto da viagem feita por Saul a Hollywood no verão de 1950. Como nota Smith, "a Califórnia do Sul era descrita como o paraíso da mistura, onde pamonhas mexicanas podiam ser adquiridas de pagodes chineses, e igrejas eram cobertas por cabanas no estilo colonial-espanhol de Quonset" (Smith, 2005, p.76). Topliss chama a atenção para The Coast, que cogita ser um dos primeiros trabalhos em que Steinberg se pergunta "Como a América se mostra?". "'Se mostrar' - há aí uma ênfase (...) na fachada do país: sua arquitetura, (...) o saqueamento de um dramático relevo de canyons e montanhas pelo desenvolvimento predatório, a exploração comercial, e acima de tudo a propaganda", observa (Topliss, 2005, p.194). Um outro desenho, que a New Yorker costumava usar para ilustrar o Profile de Chicago de A. J. Liebling em 1952, retratava esta cidade como um vilarejo de pioneiros montados a cavalo, com fachadas cenográficas falsas de grandes edifícios. Em viagem feita para Chicago em 1952, para cobrir as convenções dos Partidos Republicanos e Democratas para a New Yorker, o artista havia de fato feito várias anotações, da janela do trem, da América que crescia e se espalhava; dentre os aspectos que mais chamaram sua atenção estavam os frontões falsos da pós-Guerra Civil, "ainda a forma dominante de arquitetura vista nas Main Streets da América das ferrovias", tão bem documentada pelo fotógrafo Walker Evans (Smith, 2006, p.120). Já em Nova York, o que havia era uma sucessão de arranha-céus - dentre eles o art déco Chrysler, que tanto desenhou nos anos 1960 - que estabeleciam uma conversa estilística entre eles (Smith, 2005, p.58). Nova York alimentava o jovem artista com uma infindável quantidade de materiais não-explorados para seus cartuns, tanto de espaços exteriores como interiores. Em um destes trabalhos, de um típico bar nova-iorquino da época, Topliss enxerga uma das primeiras tentativas do artista em desenhar a aparência da América e ao mesmo tempo ir além dela. O desenho não se contenta e atingir a aura do lugar, tecendo um comentário sobre a democracia de massas ao enfatizar a repetição dos personagens enfileirados (Topliss, 2005, p.195). Em alguns destes espaços cheios de detalhes, um destes pormenores poderia ser a válvula para ativar sutilmente o humor, como na drugstore - típica da época - que oferece, em meio aos diversos serviços, momentos de psicanálise. Interiores vistos de fora também são objeto de observação, ao utilizar os batentes das janelas de Manhattan como molduras de imagens através das quais ele espreita os interiores de "apartamentos severamente guarnecidos do pós-guerra" (Smith, 2006, p.58). As Parades também foram responsáveis por diversos desenhos nos anos 1950, 


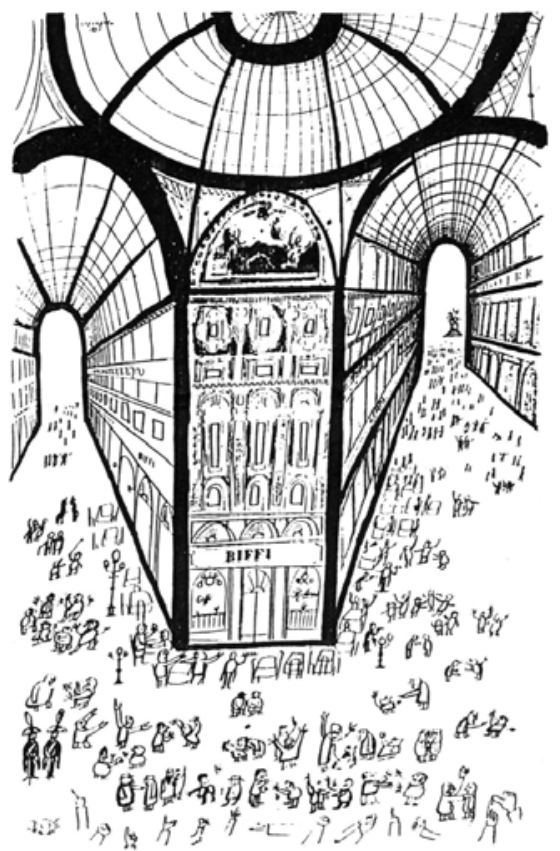

Figura 479. Galleria di Milano, 1951

Figura 480. Underground, 1946

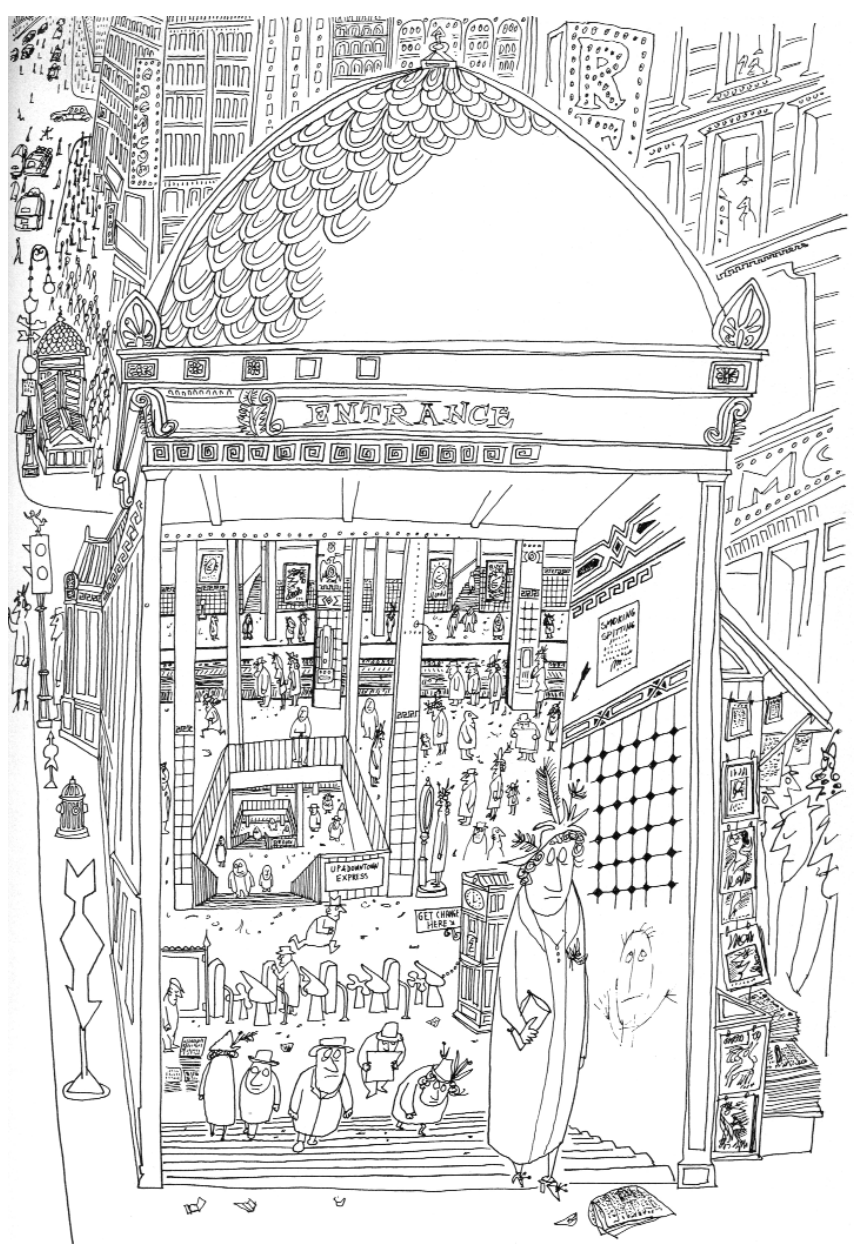

desenvolvendo-se "numa metáfora central de Steinberg para a pompa da identidade social" (Smith, 2006, p.106). Uma de suas primeiras paradas foi publicada na revista Life em 1951, numa longa seqüência posteriormente adquirida pelo Metropolitan Museum of Art em 1952. Estes trabalhos foram expostos em suas inúmeras abordagens no The Passport, The Inspector e no The Discovery of America. Promoviam um formato panorâmico congelado, apresentando ao espectador uma infinidade de "variações no tema da autocelebração como uma autoexposição inconsciente" (Smith, 2006, p.104). Um outro tipo de "parada" era constituído pelas mulheres dos anos 1950, que desfilavam pelas ruas da cidade cheias de aparatos, com presentes, chapéus e roupas volumosas. Interessante observar um recorte destacado por Steinberg de uma seção de cartas de um jornal, que dizia o seguinte sobre essas mulheres: "A mulher média, velha ou nova, parece caminhar por Nova York com sua cabeça inclinada para o alto, mandíbulas firmemente postas, olhos queimando e narinas alargadas. Seus punhos estão usualmente fechados, e ela parece estar procurando por uma briga com membros de qualquer sexo. Porquê isso? (...)" (cit. por Smith, 2006, p.104). No desenho New York Taxi and Girl, de 1948, a pompa da mulher se mescla estilisticamente aos coloridos detalhes art déco dos táxis e luminosos. Mas as mulheres, mesmo em tais vestimentas, apareceriam também de modo mais singelo, como a senhora que sai do metrô em Subway, de 1946. O traba- 
lho mostra também o grande prazer que Saul tinha em explorar as diferenças de pisos e plataformas, algo que já podia ser visto em um cartum da Bertoldo, de 1941, ou em rascunhos (Smith, 2006, p.92).

No entanto, não é apenas Nova York e as cidades americanas que servem de inspiração para este atento viajante que foi Steinberg. São famosas as versões que fez da Piazza de San Marco, uma delas publicada no The Passport, em que mesclava algumas preocupações-chave: "(...) a arquitetura icônica; o espaço público aberto, seu caráter definido pelo hábito das pessoas, mais do que pela lei ou os negócios; a unificação dos regimes e o completo contraste entre a linguagem corporal eloqüente do sul da Europa e o coma afetivo dos americanos" (Smith, 2006, p.116). Muitas outras localidades européias foram também exploradas. Há, por exemplo, o sugestivo delineamento em traço grosso das galerias de Nápoles e Milão, feitos em 1951; já as estações de trem, feitas na mesma época, se apresentam no contraste entre a linguagem gráfica carregada do trem e o emaranhado de linhas finas de coberturas e pontes. Steinberg também efetuou aplicações de clichés, fora de proporção, sobre cenários parisiences feitos a traço, semelhantes aos que havia feito sobre Nova York.

Nova York foi a cidade americana mais desenhada por Steinberg, mas o cartunista também abordou a outra metrópole americana. Saul viveu em Los Angeles durante dois meses nos anos 1950. Ao retornar para a cidade nos anos 1980 para desenvolver trabalhos em gravura, a convite da Gemini Graphic Editions, o artista percebeu que LA - que já o incomodava antes - não era mais familiar (Webb, 1999, p.103). Naquela altura, Steinberg estava habituado, é verdade, à depredação promovida nas cidades. Quando visitou a Flórida em 1962, conheceu "lugares maravilhosos e quentes quase arruinados pela arquitetura sem valor e entretenimentos dos ricos, como na Riviera" (cit. por Smith, 2005, p.76). Na tradução visual destas impressões foram empregadas, muitas vezes, palmeiras em estilo fin-de-siécle, entre o vitoriano e a Jazz Age, e luares característicos dos cartões postais cromolitográficos dos

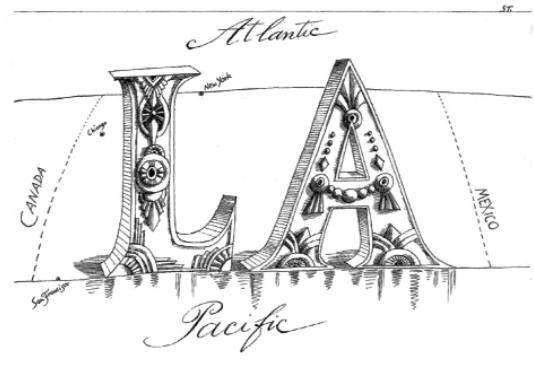

Figura 482. Desenho sobre Los Angeles

Figura 483. Untitled (Streetscape), final dos anos 1980

Figura 484. The New Yorker, 1965

Figura 485. Florida, 1966

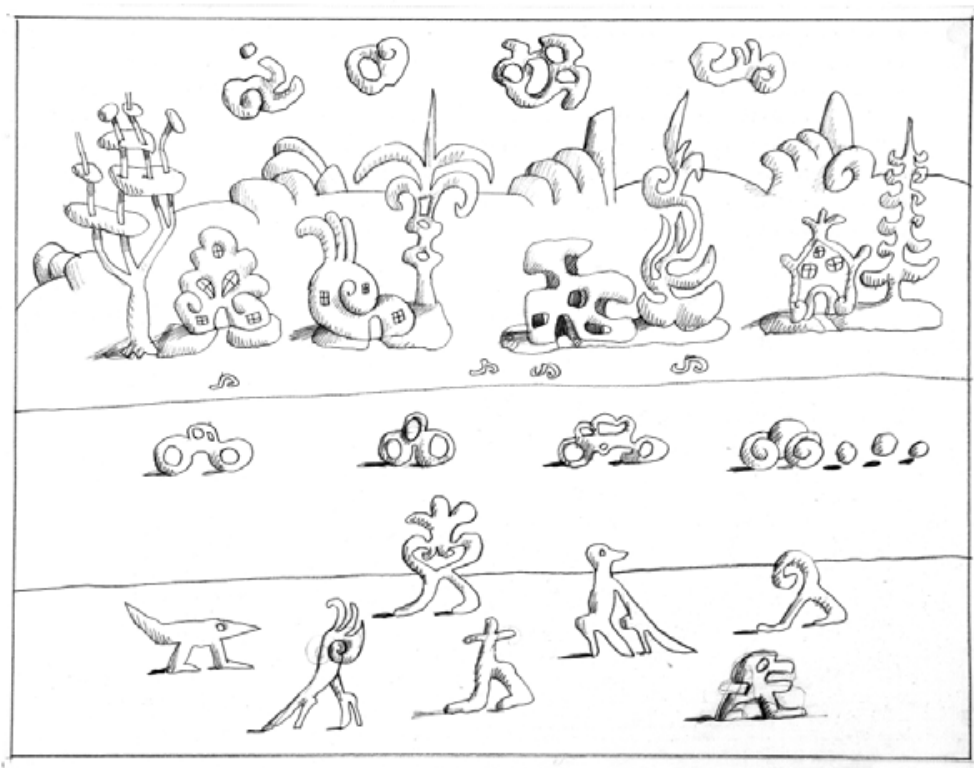




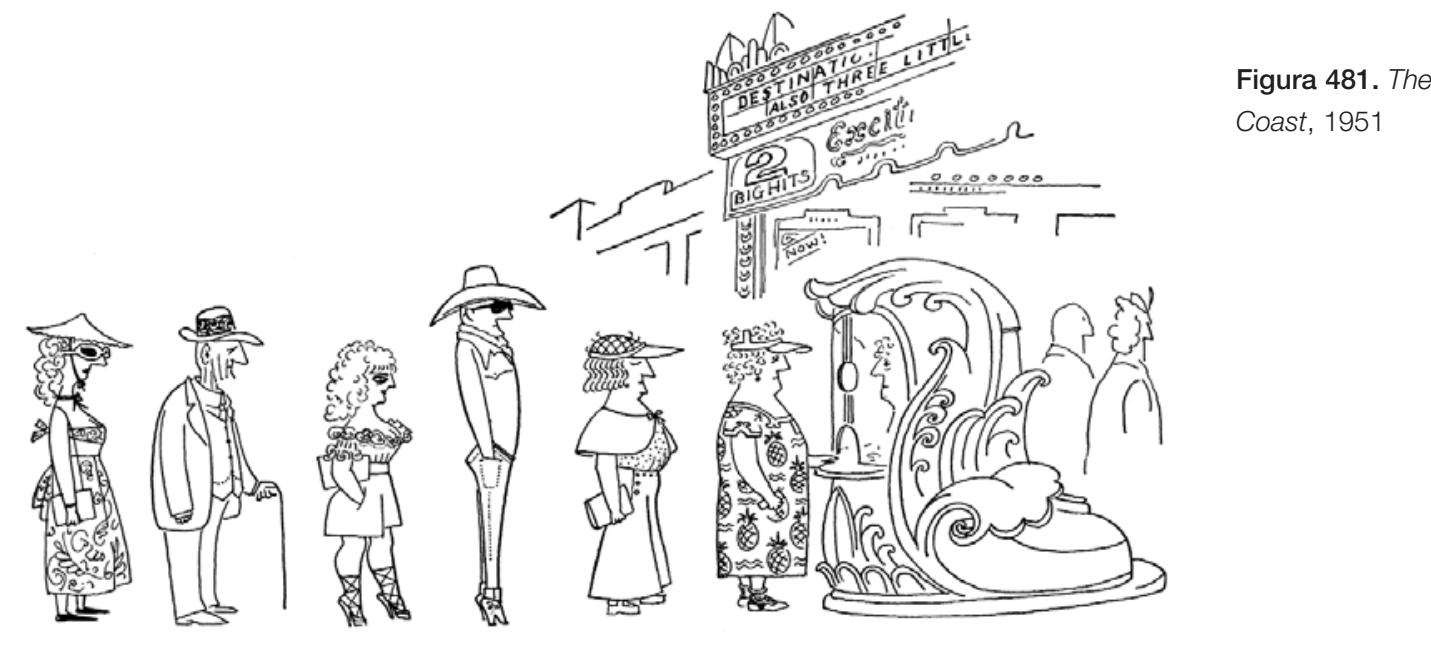

anos 1920, quando a especulação imobiliária inventou Miami (Smith, 2005, p.76). Na capa da New Yorker de 1965, estes clichês adquirem maior dramaticidade ao servirem de cenário para o passeio de um casal cuja vulgaridade Steinberg procurou obter a partir da lógica do "modo como as coisas se mostram". O estilo retrô também aparece nas iniciais utilizadas para retratar Los Angeles em 1966. Mas a miscelânea, inadequação e desproporção entre as construções e elementos urbanos também foram usadas para expor o incômodo de Steinberg. "Los Angeles é uma cidade avant-garde de paródia em arquitetura, e até na natureza (os canyons e palmeiras). (...) Difícil de desenhar, um retalho, como retratar palhaços", disse certa vez (cit. por Rosenberg, 1978, p.238). Após sua volta à cidade, Saul elaboraria a Los Angeles da década de 1980 como uma "paródia assustadoramente sedutora, em tons pastéis, de sua contraparte do leste, Nova York", como na idílica Moonlight in Brentwood (Smith, 2006, p.220). Em alguns destes desenhos, se a disposição espacial dos elementos lembra a Los Angeles desenhada nos anos 1950, como nas suas díspares construções enfileiradas, o estilo empregado
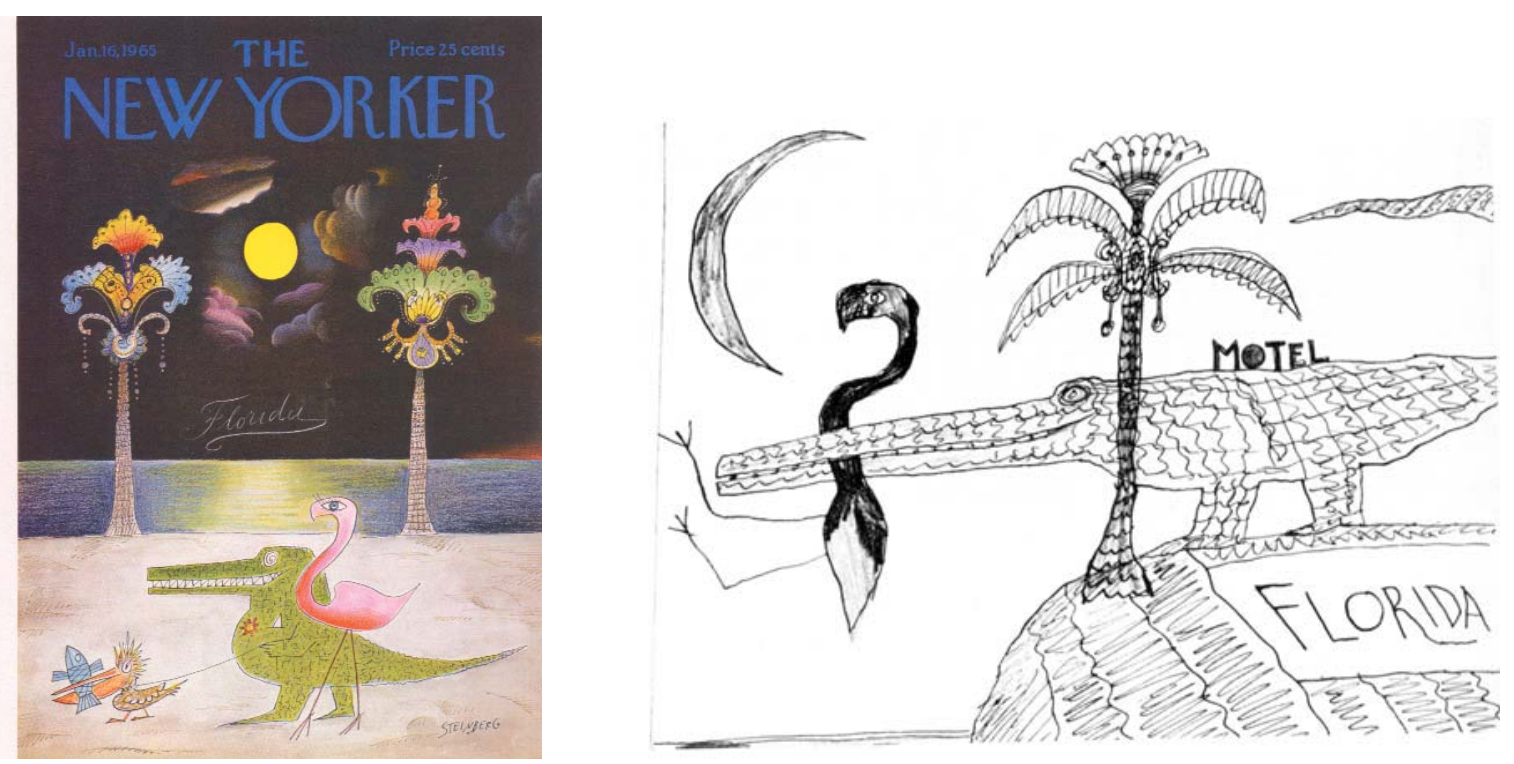


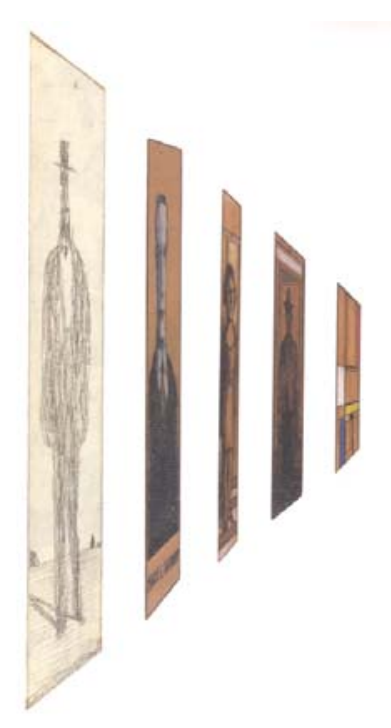

Figura 486. Five False Paintings, 1971

Figura 487. The Politecnico Table, 1974

Figura 488. Library, 1987

Figura 489. Steinberg's

Umgang mit Menschen, 1954

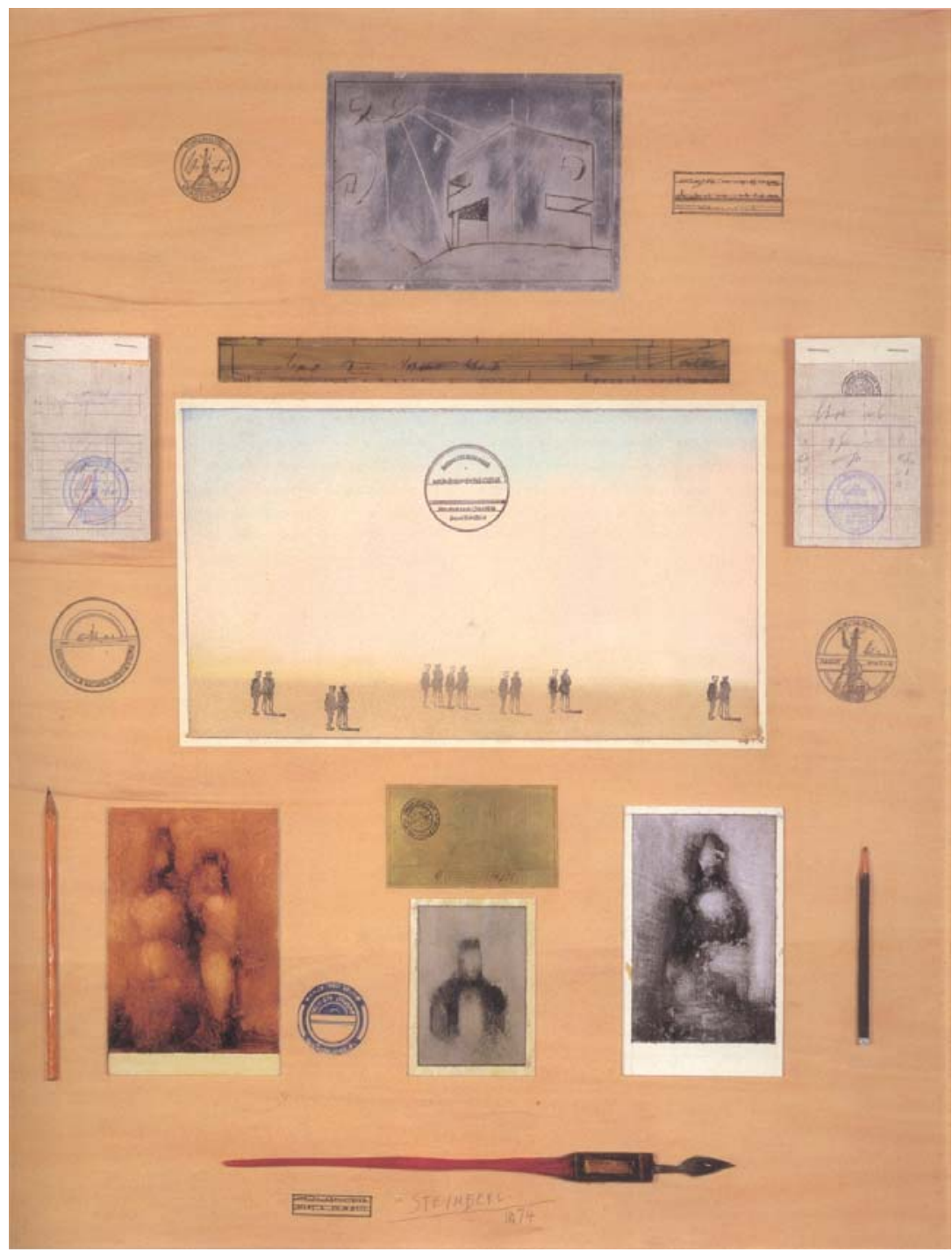

incorpora as experimentações da época, com arquiteturas, palmeiras, carros e habitantes dentro do repertório gráfico da arte psicodélica e underground. A crítica feita de modo sutil e elegante em Beverly Hills é renovada sob uma roupagem ácida, alucinante e vertiginosa.

\section{TRIDIMENSIONALIDADE E MISTURA DE Mídias NAS MESAS, TROMPE-L'́OEIL E ASSEMBLAGES}

A exploração das mais diversas técnicas e o interesse na ambigüidade e em diferentes graus de realidade, presente em intervenções sobre fotos como Excavation (1951), na mistura de Vichy Water (1953), nos passaportes (1951), nas colagens simples de Couple (1955) ou complexas de Konak (1970), em carimbos como Artista at War (1969), nos postcards (1969), dentre outras experimentações, conduziram naturalmente a trabalhos que escapavam do suporte tradicional e plano representado pela folha de papel. O interesse veio cedo, mas como observa Smith, "Steinberg era um perturbado residente do Mundo Plano": "Ele gostava de 
fazer alardes sobre emigrar para a terceira dimensão algum dia, mas estava tendo muita diversão alterando as leis locais da gramática para se mudar" (Smith, 2006, p.174). Duas páginas de seu livro Umgang mit Menschen, de 1954, por exemplo, combinavam desenhos que brincavam com as convenções de figuras de aspecto alterado, segundo a perspectiva. Os personagens, vistos de ângulos excêntricos, foram rotacionados vários graus do plano do papel e se revelaram (como desenhos, obviamente) finos como o papel (Smith, 2006, p.174). A reflexão sobre o mundo da terceira dimensão, de qualquer modo, já vinha sendo esboçada em outros trabalhos. Os documentos, apesar de feitos em folhas planas, representavam uma sutil subversão pelo modo como era usado: ele tinha uma atuação cênica, agia como um documento fake que era enviado pelo correio. Mas são os desenhos feitos em objetos - cadeiras, ba-nheiras, parede, etc -, como Woman in a Tube, de 1949, que simbolizam de modo claro a utilização e uso diferenciado de outros suportes, apesar do resultado final ser considerado a foto impressa. Como Steinberg disse em uma entrevista em 1970, ao valorizar a "idéia" de uma obra:

Não penso em fazer uma escultura, um objeto, realmente. Sou contra esse tipo de coisa. Não quero fazer comércio. (...). Agora, escultura é um desastre, deste ponto de vista. Certamente não faria uma como um objeto. Penso em fazê-la fora do papel, tirando uma fotografia e a destruindo depois. Não há razão para ter um objeto - um documento é suficiente" (Gluek, 1970, p.111).

As máscaras são um marco por serem efetivamente usadas e vestidas por Steinberg e amigos. Mas a foto impressa destas experiências permanece sendo o objetivo final. De qualquer modo, com o tempo Saul cederia na contrariedade à criação e exposição de objetos. Em 1971, Steinberg prossegue em seu interesse com ambigüidades e terceira dimensão em Five False Paintings, feita para o Carnegie International Exhibition of Painting and Sculpture em 1970.
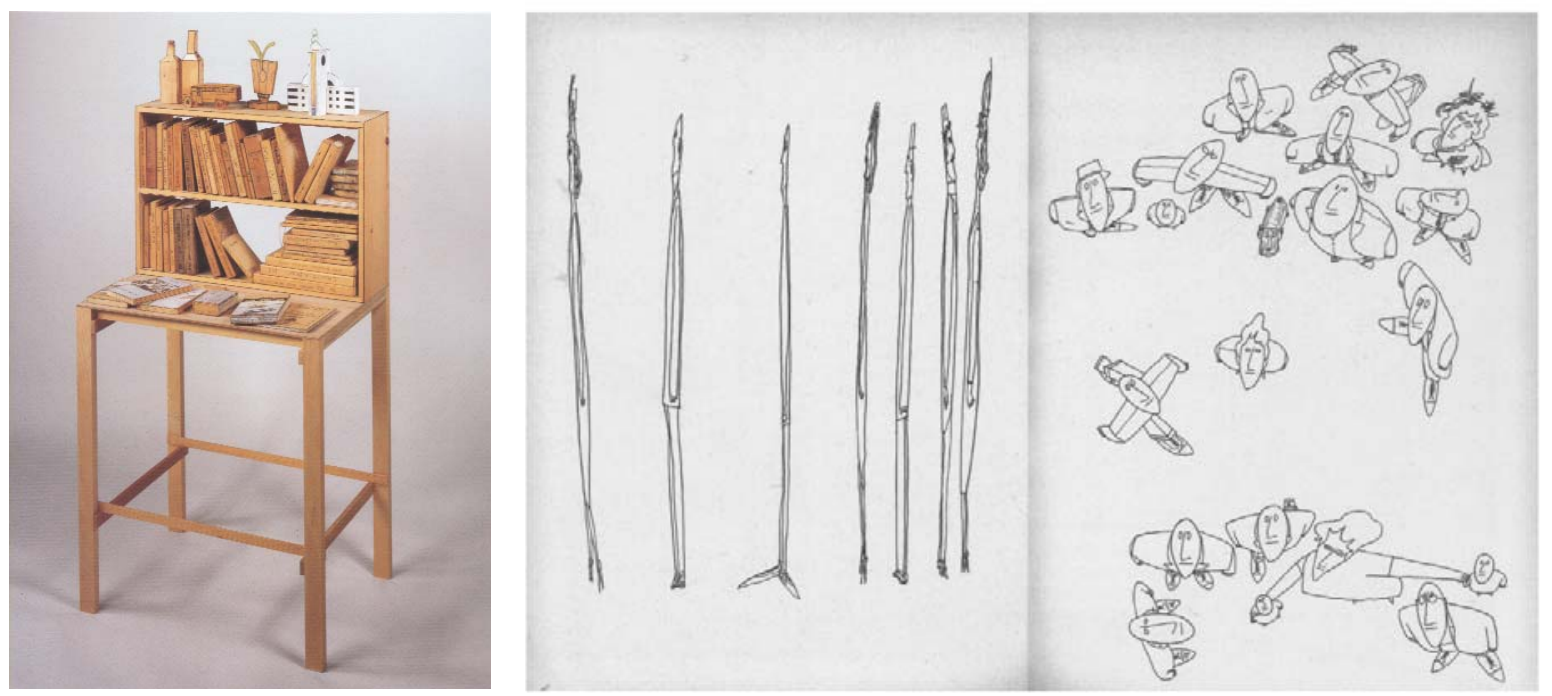


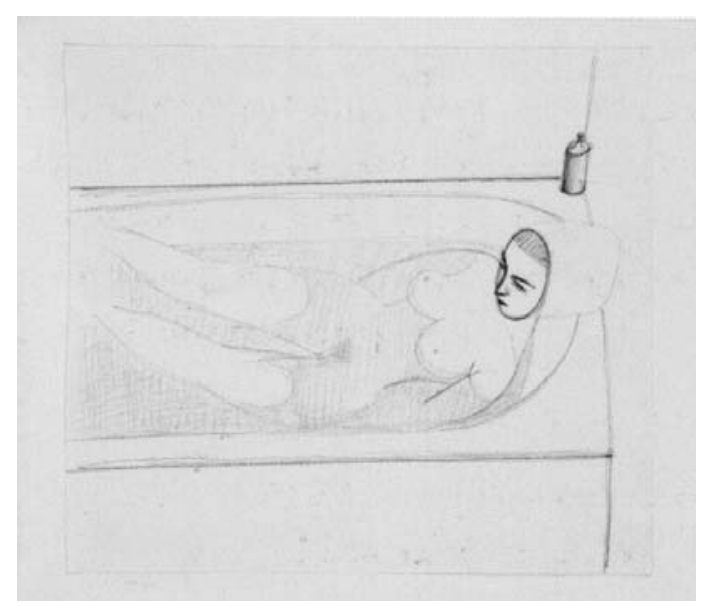

Figura 490. Sigrid

Spaech, 1963

Figura 491. Breakfest Still Life, 1974

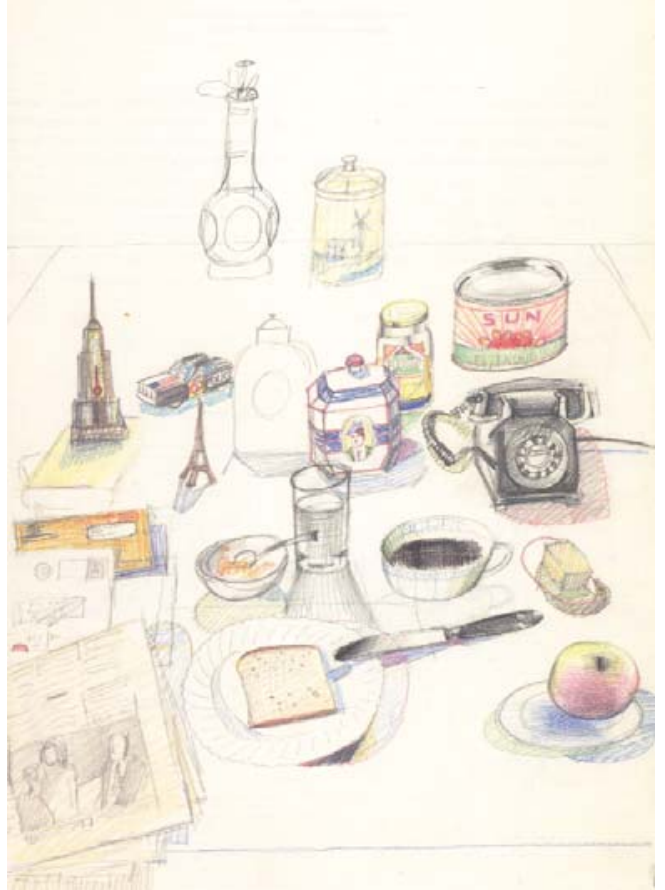

Um verão atrás, ele havia começado a fazer suas pinturas faix como Louse Point, encarando a técnica dentro da lógica de seu trabalho: "Meu trabalho é sobre minha evolução...Quando faço uma paisagem, uso ela da minha forma. Não penso nela como uma paisagem verdadeira, como parte da natureza. É mais como uma colagem da natureza. Ela tem que ser feita em óleo porque se encaixa na minha proposta. Uso carimbos e desenho e qualquer coisa vem logicamente" (cit. por Smith, 2006, p.176). As falsas pinturas criadas em 1971 - cada uma executada em um pedaço de madeira trapezoidal - joga a pintura mais profundamente no jogo de representar a representação. Para Smith, "essas esculturas e baixo-relevo representam pinturas no espaço que, por sua vez, representam cenas além da vida e da arte, exemplificando a preocupação de Steinberg com 'diferentes graus de realidade'" (Smith, 2006, p.176).

O jogo com a aparência das coisas - com a realidade - levou Steinberg a criar réplicas de objetos comuns em seu estúdio na escala 1:1, e em três dimensões, que resultavam em esculturas trompe-l'oeil. Uma metralhadora, inventada por Steinberg em 1974, serviu posteriormente de brinquedo quando o artista resolveu vestir sua roupa de camuflagem de guerra e uma máscara em 1981. Estes objetos eram usados, muitas vezes, em assemblages sobre mesas de madeira, dispostos ao lado de fotos falsas, carimbos e blocos de anotações criados pelo artista, dentre outras experiências miméticas. A documentação de sua vida - a compreensão de um homem através de seu inventário de efeitos físicos - também era um tema que permeava vários destes trabalhos, como em Furniture as Biography e Library, ambos de 1986. O jogo efetuado por estes objetos, representantes do "Steinberg das galerias", lida com a representação visual em si, onde o olho do observador é convencido a acompanhar o artista e simula que uma coisa (um pedaço de papel ou um bloco de madeira) é algo mais" (Smith, 2006, p.69). 


\section{Desenhos DE OBSERVAÇÃo}

Com um trabalho marcado pela abordagem abstrata, intelectual, filosófica, Steinberg também fez inúmeros desenhos de observação, que estabeleciam elo com sua preocupações em entender a verdade das coisas. Saul desenhava desde objetos dispostos sobre sua mesa, como em Breakfest Still Life, de 1974, a retratos do que via na sua casa, como no desenho de 1979 em que mostra Sigrid à mesa e o gato Papoose. Algumas criações do gênero viraram capas da New Yorker, como a da edição de janeiro de 1980. Estes desenhos, feitos periodicamente, combinavam a pura pesquisa com a recreação sensitiva, "um intervalo daquilo que ele chamava de 'ginástica' - o trabalho com cartuns ou idéias desenhadas" (Smith, 2006, p.198). Em 1978, após a famosa exposição retrospectiva, o cartunista comentou: "Hoje em dia, desenho from life. Como os velhos mestres, à medida que envelheço, me torno mais interessado no que está lá fora, e não aqui [na cabeça]" (cit. por Gill, 1978, p.68). Seu envolvimento com tipo de abordagem, no entanto, aparece desde cedo. Como estudante, Saul fez uma "excelente viagem de estudos com minha escola, (...) para Ferrara e Roma". Nesta viagem, Steinberg realiza pela primeira vez desenhos a partir da observação da vida.

Eu, que não havia tido nenhum treinamento artístico profissional e aprendi a desenhar desenhando, tinha até então pensado principalmente em desenhos imaginários, coisas inventadas. Durante a viagem, percebi como é difícil fazer um desenho a partir da vida, e como é importante entender a natureza, a verdade da realidade. Entender a verdade do conteúdo presente no assunto de um desenho - pessoas, arquitetura, ou paisagens - é algo complexo por não ser uma verdade visível, superficial (Steinberg, 2002, p.69).

Como método, era preciso atingir cumplicidade com o objeto: "Você não desenha bem se estiver contando uma mentira" (Steinberg, 2002, p.70). A busca por respostas a questões que ainda não foram levantadas previamente também era, para ele, uma das características deste processo de trabalho. Desenhar a partir da realidade era um desafio a Saul, que mesmo nestas ocasiões mantinha seu preceito de dizer algo além do que os olhos vêem (Steinberg, 2002, p.71). Na criação destes trabalhos, Steinberg não é mais o protagonista, se tornando um "servo de segunda classe" (Steinberg, 2002, p.72), desprotegido em sua busca:

Sou tão impelido pela realidade em minha frente que me esqueço de mim mesmo e trabalho como se estivesse em transe, tentando decifrar a realidade, fazendo o desenho sem me dar conta de que estou fazendo ele. Também temo que o desenho revele certas partes de mim mesmo, áreas de vulgaridade onde não conto a verdade, fazendo uso do que já sei, lugarescomuns, e me vejo - quero dizer, no desenho que fiz - em algumas de minhas falhas regulares: parando sem terminar, ficando cansado em certo momento e falhando ao insistir em algum ponto que deveria ser essencial (Steinberg, 2002, p.72). 
O viajante Steinberg tinha atração por fronteiras: "Parece que passei a vida atravessando de uma fronteira à próxima, algumas delas reais, algumas imaginárias. No meu tempo, era um viajante por necessidade, e agora sou um viajante por escolha. Fronteiras e a exibição de passaportes são coisas tão naturais para mim quanto uma morada fixa é para a maioria das pessoas" (cit. por Gill, 1978, p.68). Ao mesmo tempo, Saul parecia ter encontrado um lar nos Estados Unidos, no modo como foi acolhido e se estabeleceu por lá. "O mundo inteiro é um jardim. Usufruímos dele em certos momentos, mas voltamos para casa quando é noite ou chove", disse numa ocasião (cit. por Pitz, 1951, p.41). Apesar do artista chegar a incluir Râmnicul Sarat no aprazível jardim constituído pelos lugares que conheceu, em Autogrography de 1966, Steinberg demonstrava ter resistências em relação à sua terra natal, como comentou seu ex-assistente van Dalen:

Ele muitas vezes expressava embaraço pela cultura de sua terra natal, para a qual nunca retornou para visitar sequer uma vez, desde que chegou à América em 1942. Quando perguntei a ele porquê nunca havia voltado, me disse que voltaria caso um agente de viagem lhe vendesse um bilhete de 1922. Foi apenas recentemente que fez desenhos tocantes que falam da vida de seu lar na infância e dos membros de sua família. Devido a seu interesse por cartões postais, ele me encarregou de procurar cartões de ruas de Bucareste e prédios dos anos $20 \mathrm{e}$ 30, os quais ele então estudou com prazer (...). Bem no final de sua vida, um amigo deu a ele um grande mapa de Bucareste da Biblioteca Pública de Nova York, a partir do qual me incumbiu de ampliar o bairro de sua infância. Tendo-a como referência, desenhou a lápis seu último mapa (um tema de toda sua vida), um de seus últimos desenhos. (Dalen, 2004, p.4)

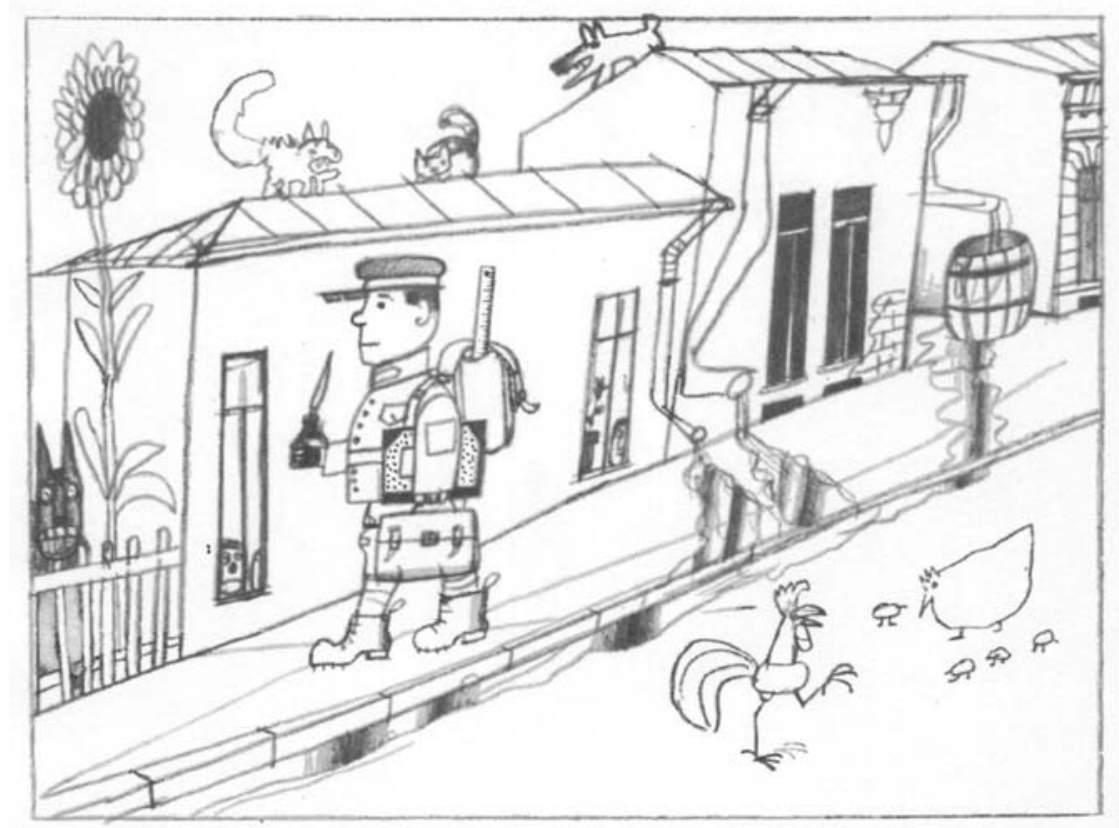




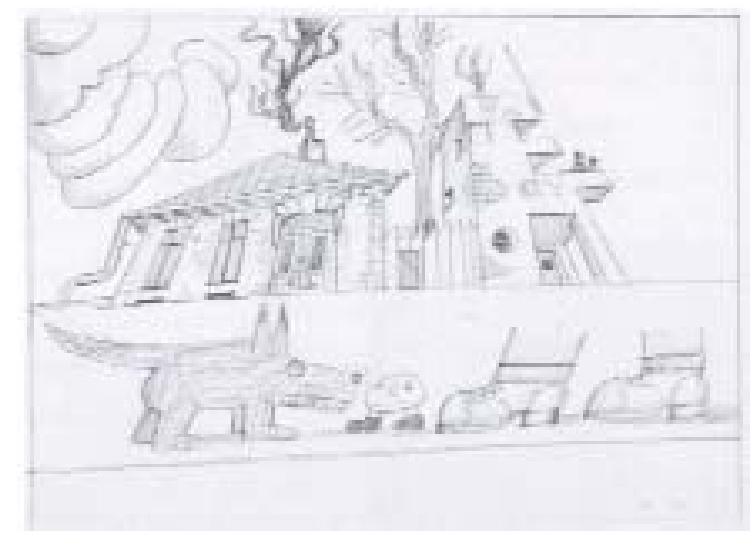

Figura 492. Desenho de memória de Strada Palas, 1978

Figura 493. The New Yorker, 1978

Em outro momento, Steinberg deu diretrizes para a localização da rua onde morou a um amigo que estava indo para a Romênia. Chamava-se rua Palas, era estreita e totalmente sem tráfego. $\mathrm{Na}$ volta, o amigo trouxe não apenas fotos coloridas, mas também slides para projetar na parede em cores e quase no tamanho real, que emocionaram Saul:

Elas mexeram comigo profundamente, especialmente pelo fato de nada ter mudado, a não ser algumas árvores, que ficaram mais altas, e um muro que agora coberto com hera. Fiquei horrorizado ao ver um automóvel estacionado no pátio de minha casa. A rua parece menos elegante porque no lugar das lâmpadas de gás estão grandes postes de madeira. Além disso, eles fizeram algo completamente supérfluo: em uma pequena rua de no máximo oito ou nove metros de largura, eles pintaram linhas brancas no calçamento do cruzamento de pedestres. (Steinberg, 2002, p.42)

Steinberg, ao ver as imagens, se sentiu como se estivesse "olhando para uma tumba, suspendendo o lençol de um cadáver": "Me senti nervoso e ao mesmo tempo curioso para ver, e então nervoso novamente por ter visto - como se tivesse perdido algo". Mais tarde, mais calmo, o artista envia outros dois amigos para tirar fotos, com o propósito de "se curar desta doença". Ao ver as imagens, a impressão é de um lugar parado no tempo: "tudo do mesmo jeito de sempre, tudo igual, exceto pelo fato de cinqüenta anos terem se passado" (Steinberg, 2002, p.42). Saul não consegue esconder o desconforto em lidar com seu passado romeno, em se confrontar diretamente com seu país natal.

A memória destes lugares de tristeza, de sofrimento, e acima de tudo, de grandes emoções, é comprometida quando estes são visitados novamente. É melhor deixar certas coisas em paz, do jeito que estão na memória: com o passar do tempo, elas se tornam as mitologias de nossas vidas. (Steinberg, 2002, p.41) 


\section{Últimos TRABALHOS, REFLEX̃̃ES E OBRAS}

Entre 1985 e 1990, Steinberg não colaborou para New Yorker. A razão disso havia sido a substituição de Shawn por um novo editor, Robert Gottlieb, dois anos depois da revista ter sido comprada pela S. I. Newshouse. Nesse meio tempo, usufrui dos prazeres da yoga e da meditação Zen, praticada há tempos por Sterne, que servem de consolo e alívio (Smith, 2006, p.73). Hedda, desde os anos 1960, conversava pelo telefone com Saul quase todo dia. O bom relacionamento mantido entre ambos é exemplificado em uma passagem do diário de Steinberg: "Perguntei a Hedda - Como tenho esta vontade de ligar para você - Ela diz: porque temos algo em comum - O que é? Eu digo. Nós dois te amamos, ela responde" (Smith, 2006, p.265).

Neste hiato de tempo, Steinberg também encontrou outros escapes para seus desenhos: colaborou com o escritor Ian Frazier no livro Canal Street, em 1990; imprimiu dois portifólios, em 1990 e 1994, no jornal literário Grand Street; e entregou uma série de desenhos feitos em caneta de sinalização para serem usados no New Yorker Review of Books, entre 1994 e 1996. Na época, empreende viagens pela literatura fazendo retratos de fotografias históricas de personalidades como Delacroix (1994), dentre outros escritores e pintores (Smith, 2006, p.74). É em 1992 que Steinberg lança o último de seus livros enquanto vivo, The Discovery of America, com introdução de Arthur C. Danto. O artista envia uma cópia assinada para William Shawn, com uma nota dizendo que ele está pensando em voltar a contribuir para a New Yorker novamente. O adoentado Shawn escreve uma resposta encorajadora no mesmo dia em que vem a falecer (Smith, 2006, p.265). No final de 1991, Saul já havia dado sinal verde para a publicação de cinco desenhos para capas, aprovadas por Shawn em seus últimos anos como editor. Em 1993, após estes trabalhos terem sido utilizados, o cartunista sentiu que era chegado o momento de reconciliação. No final daquele ano, a nova editora Tina Brown e sua editora de arte Françoise Mouly haviam o persuadido a retomar suas contribuições. Tratado como um convidado de honra, ele passou a enviar apenas capas e portifólios, impressos a cores depois da mudança de padrão promovida por Brown nas páginas internas da revista (Smith, 2006, p.74).

A partir de 1995, no entanto, os problemas de ordem pessoal começariam a se acumular. Naquele ano, Sigrid Spaeth, sob tratamento para depressão há tempos, sofre uma severa crise mental durante uma viagem de inverno para St. Bart, e Steinberg a leva de volta para Nova York, hospitalizando-a. O próprio cartunista, cada vez mais desesperado, começou a tomar Librium para ansiedade (Smith, 2006, p.75). Ainda naquele ano, o cartunista é diagnosticado com câncer de tireóide, não sendo recomendada, no entanto, nenhuma intervenção. Saul começou a organizar seu trabalho pensando no uso póstumo de sua obra. Em 1996, uma tragédia: Sigrid comete suicídio, e Steinberg busca suporte e apoio de amigos. O artista passa, então, a ficar boa parte de seu tempo em Amagansett, conversando pelo telefone (Smith, 2006, p.266). As exposições continuariam a acontecer, de qualquer modo, em 
galerias de Nova York e Munique. Em 1998, começa um mês de terapia de choque para depressão, mas Saul fica devastado, no entanto, quando descobre que William Gaddis tinha falecido. Em maio, o artista é diagnosticado com avançado câncer no pâncreas, vindo a falecer em 12 de maio de 1999, aos 84 anos, em sua casa em Manhattan. Inúmeros artigos, textos e reportagens são publicados em sua lembrança e exposições são realizadas ainda naquele ano. A New Yorker permanece publicando alguns de seus cartuns e mesmo capas. A iniciativa de Steinberg proporcionou, também, a criação da The Saul Steinberg Foundation, em 1999, e a herança de seus papéis para a Beinecke Rare Book and Manuscript Library, da Yale University. O livro Saul Steinberg Masquerade é lançado em 2000, e Reflections and Shadows, fruto de conversas com Buzzi, em 2002. Além das exposições, que continuariam sendo feitas ao longo dos anos, importantes publicações sobre sua obra viriam a ser concretizadas, como Steinberg at the New Yorker, de 2005, e Saul Steinberg: Illuminations, em 2006, demonstrando um esforço recente em documentar e expor sua obra. 


\section{CONCLUSÃO}

O conjunto do trabalho de Steinberg, visto em retrospectiva, evidencia um desenhista que soube aliar produtividade a uma significativa variedade de abordagens e experimentações. Trata-se de uma obra densa, na diversidade formal, nos temas e reflexões. Steinberg está muito distante dos artistas gráficos de um estilo - conhecidos por uma "marca", que vem à mente de forma imediata. No caso de Saul, apontar sua maior contribuição às artes gráficas é tarefa árdua. Há diferenças enormes entre os trabalhos dos dez primeiros anos na New Yorker e dos dez últimos. Se o anônimo homenzinho narigudo "Senhor Ninguém" parece ter sido um personagem representativo de Steinberg no seu começo de carreira, a partir da década de 1970 ele praticamente desaparece da New Yorker.

O modo como Steinberg influenciou os cartunistas de seu tempo, responsáveis por rupturas no cartum, aponta para uma de suas características mais importantes: um modo de desenhar moderno. Esse novo cartum que começou a despontar por volta da década de 1930, em sua depuração e tratamento simples, tinha por vocação conferir grande ênfase à idéia. Steinberg soube tirar proveito de sua compreensão gráfica do desenho para desenvolver cartuns que não eram apenas situações sem legendas, mas experimentações de síntese formal, explorações dos atributos da linha para conferir novos significados, com subtextos filosóficos. Sua postura moderna era evidente na busca pelo essencial e necessário, no desconforto com a execução "narcisista". Ao se considerar um escritor, pretendia valorizar o lado intelectual de seu trabalho, pensado enquanto é feito. Dessa valorização da idéia, e com sua compreensão moderna do desenho, Steinberg desenvolveu um interesse cada vez maior pela 
abstração e por abordagens de fundo filosófico. Este é um dos aspectos que o diferem de muitos dos cartunistas de traço fino.

O desenvolvimento de um estilo "não-estilo" steinbergniano, fruto de uma busca moderna pela concisão e simplicidade, the proporcionou um universo depurado a partir do qual qualquer elemento externo inserido se tornaria um "visitante". Nessa situação diferenciada, fruto da intenção do artista, o estilo se torna o foco das atenções, a ser comentado em suas peculiaridades. Estava adquirida a liberdade para emprestar estilos e elementos gráficos de toda a história da arte, da cultura popular, pop, do design e artes gráficas. Ao se servir deste método, e ao desenvolver experimentações de modo gradativo, mesmo trabalhos com miscelânea de estilos e sem qualquer linha fina faziam o observador recordar o universo steinbergniano seco e depurado, mantido como referência. Do Steinberg cartunista permanecia uma certa dose de humor e sua predisposição a configurar situações com o elemento humano, tão bem representado em parte de sua obra pelo Senhor Ninguém. Nos trabalhos mais abstratos, torna-se difícil não entender os variados elementos gráficos como "personagens", atuantes em um espaço delineado. É este método de Steinberg, fruto de seu desenho moderno, que conduz toda a sua obra, permeando as diferentes fases. Se não era único no meio do cartum e das artes gráficas na utilização de tal recurso, é na insistência e no desenvolvimento permanente e gradativo de suas inúmeras possibilidades que conferem à sua obra um papel singular no contexto das artes gráficas do século XX.

$\mathrm{O}$ interesse nas questões do estilo, tão evidente em sua fase final, apareceu de modo precoce, e pode ser apontado como um aspecto de primeira grandeza em sua obra. Voltando no tempo, é possível constatar que determinados cartuns da Bertoldo eram claramente direcionados à arte e arquitetura, e algumas aplicações com colagem abriam espaço à paródia, mesmo que não fossem o foco das piadas. O tratamento dos cenários, carregados de lirismo na disposição de pontuais elementos arquitetônicos fora de escala e com adornos peculiares, também sugeria explorações com estilos, ainda coadjuvantes. A documentação dos espaços em All in Line foi sucedida por experimentações mais explícitas em The Art of Living, ambos livros representativos do Steinberg cartunista. O cartunista estava, aos poucos, construindo uma ponte entre seu universo seco steingberniano e todo um mundo de imagens e artefatos e criados e recriados pelo homem.

No entanto, há uma determinada linha de cartuns, muito feita nos primeiros anos de New Yorker, que influenciou significativa parcela dos artistas steinbergnianos - simbolizando, em parte, o "cartum de Steinberg" - e que não se dirige necessariamente aos estilos. A transformação de objetos em "outra coisa", feita no caso de Steinberg a partir de seu desenho moderno, pode ser apontada também como aspecto de primeira relevância. Considerado de modo amplo, dos cartuns com alterações e objetos dos anos 1940 à efetiva "objetualização" de elementos gráficos, Steinberg influenciou desde desenhistas de linha fina depurada como Tomi Ungerer, a artistas gráficos com interesse em paródias e experimentações estilísticas como Milton Glaser. A objetualização de elementos gráficos e as paródias de estilos se 
apresentam intimamente relacionadas, mas o papel desempenhado pelo recurso da transformação das coisas desenhadas se mostrou fundamental como referência no cenário das artes gráficas. A incorporação e o uso permanente deste procedimento em cartuns é, de fato, uma das grandes contribuições de Steinberg a esta área específica.

Deste modo, Steinberg foi também um grande ilusionista. Se a ambigüidade gráfica, caracterizada pelas imagens duplas e subversões do significado da linha, aparece com força em uma de suas primeiras fases na New Yorker, em um sentido amplo as paródias gráficas que permeiam considerável parte de sua obra são também fruto dos recursos de ilusão. Do interesse em lembrar que seus desenhos são feitos de tinta, transparece a compreensão de seu meio de criação, de sua "realidade" específica, do desenho que fala de desenho. Steinberg trabalhava constantemente com as aparências, e são freqüentes as subversões das subversões das subversões de seus sentidos.

O trabalho de Steinberg evidencia-se, portanto, pela compreensão moderna do desenho, pelo valor atribuído à idéia e à elaboração intelectual, pela abstração e ilusão, pelo interesse em conferir novos significados aos elementos desenhados; as importantes questões do estilo, da arte nas coisas, da autobiografia, da "máscara", aparecem inseridas nesse conjunto de premissas de seu trabalho. No entanto, é difícil falar de Steinberg sem pensar no humor do cartum e no estilo steinbergniano seco e de linha fina, representado pelo homenzinho narigudo. Se Otto Soglow, Thurber, de Miskey e alguns outros desenhistas já vinham elaborando personagens simples anônimos, Steinberg foi importante em seu desenvolvimento e popularização. A amplitude do papel exercido por Mr. Anybody pode ser constatada na quantidade de cartunistas influenciados por Steinberg, assim como na disseminação de suas características nos personagens de animações e propagandas dos anos 1950.

Muitas das experimentações de Steinberg foram inovadoras no meio do cartum, dentre elas as misturas de abordagens com alegorias, objetualização de balões de falas, tipografias, e outros elementos. A aplicação de desenhos do gênero nas capas da New Yorker conferiu a Steinberg uma condição única como capista; em um período cada vez mais escasso de ilustrações em capas, os trabalhos de Steinberg, de grande independência em relação aos temas das revistas, não apenas diferiam das capas fotográficas mas também daquelas com ilustração. 


\section{REFERÊNCIAS}

Livros

ALLNER, W. H. Posters. Nova York: Reinhold Publishing Corporation, 1952.

AMIDI, Amid. Cartoon Modern. São Francisco: Chronicle Books, 2006.

A Revista no Brasil. São Paulo: Editora Abril, 2000.

ARGAN, Giulio Carlo. Arte Moderna. São Paulo: Companhia das Letras, 1993.

ARMITAGE, Shelley. John Held. Jr. - illustrator of the jazz age. Syracuse: Syracuse University Press, 1987.

ARNHEIM, Rudolf. Arte e Percepção Visual - uma psicologia da visão criadora. São Paulo: Enio Matheus Guazzelli \& Cia. Ltda., 1991.

BARDI, Lina Bo. Contribuição Propedeutica ao Ensino da Teoria da Arquitetura. São Paulo: Instituto Lina Bo Bardi, 2002.

BARNICOAT, John. Posters: A Concise History. Londres: Thames \& Hudson, 2003. 
BLANCHARD, Gérard. La Bande Dessinée. Verviers: Marabout Université - Editions Gérard \& C., 1969.

BORJALO. Prefácio de Otto Lara Resende. Texto de Hélio Pellegrino. O Caçador de Borboletas. Rio De janeiro: Editora Globo S.A., 1986.

BRANCO, Carlos Castello. A Linguagem de Ziraldo. A Última do Brasileiro. Rio de Janeiro: Editora Codecri, 1975, pp3-5.

Cadernos de Literatura Brasileira. Millôr Fernandes. n.15. São Paulo: Instituto Moreira Salles, 2003.

CANEMAKER, John. Prefácio de Roy. E. Disney. The Art and Flair of Mary Blair - an appreciation. Nova York: Disney Editions, 2003.

CARUSO, Paulo. Tegey: Uma Descontraída História da Linguagem dos Quadrinhos. Trabalho de Graduação Interdisciplinar, Faculdade de Arquitetura e Urbanismo, Universidade de São Paulo 1977.

CARDOSO, Rafael (org.). O Design Brasileiro antes do desig:aspectos da história gráfica, 1970-1960. São Paulo: Cosac Naify, 2005.

CARLOS, J. Texto de Álvaro Cotrim (Álvarus). J. Carlos. Rio de Janeiro: Editora Nova Fronteira, 1985.

CARLOS, J. Texto de Arthur Dapieve. Organização de Cássio Loredano. J. Carlos Contra a Guerra. Rio de Janeiro: Casa da Palavra, 2000.

CARLOS, J. Organização Cássio Loredano. Texto de Luciano Trigo. Lábaro Estrelado. Rio de Janeiro: Casa da Palavra, 2000.

CAULOS. Só Dói Quando Eu Respiro. Porto Alegre: L\&PM, 2001.

DALEN, Anton van. Steinberg - An Intimate View of His Art and World. Visual Arts Museum at the School of Visual Arts. Nova York: Visual Art Press, 2004.

DAPIEVE, Arthur. "Guerras Cobertas a Nanquim". In: CARLOS, J. Texto de Arthur 
Dapieve. Organização de Cássio Loredano. J. Carlos contra a Guerra. Rio de Janeiro: Casa da Palavra, 2000, pp. 9-35.

DEITCH, Gene. The CAT on a hot thin groove. Seattle: Fantagraphics books, 2003.

ESCHER, M. C. M. C. Escher - L'oevre Graphique. Köln: Taschen, 1993.

FERNANDES, Millôr. Desenhos. Prefácio de Pietro Maria Bardi; Apresentação de Antônio Houaiss. São Paulo: Editora Raízes Artes Gráficas, 1981.

FERNANDES, Millôr et al. 10 em Humor. Rio de Janeiro: ditora Expressão Cultural, 1968.

FERNANDES, Millôr. Produção de Eliana Caruso e Z'AS Produções Culturais. PIF PAF Quarenta Anos Depois. 8 edições da revista PIF-PAF. Rio de Janeiro: Editora Argumento, 2005.

FERNANDES, Millôr. Tempo e Contratempo - Millôr revisita Vão Gôgo. São Paulo: Beca Produções Ltda., 1998.

FIELD, Albert. Transformation Playing Cards. Stamford: U.S. Games Systems, 1987.

FLAGG, James Montgomery et al. Editado por Herb Galewitz. Organizado por Carol Belanger Grafton. Classic Spot Illustrations from the twenties and thirties - by James Montgomery Flagg, Gluyas Williams, John Held, Jr. and others. Nova York: Dover Publications, 2000.

FRANÇOIS, André. Introdução por Walt Kelly. The Tattooed Sailor. Nova York: Alfred A. Knopf, 1953.

GIBBS, Wolcott. "Foreword". In: STEIG, William. Introdução de William Saronyan. Prefácio de Wolcott Gibbs. The Lonely Ones - with 25 new lonely ones. Nova York: Windmill Books, 1970, pp.8-10.

GLASER, Milton. Prefácio de Jean Michel Folon. Milton Glaser - Graphic Design. Nova York: The Overlook Press, 1973.

GOMBRICH, E. H. A História da Arte. Rio de Janeiro: Editora Guanabara, 1988. 
GOMBRICH, E. H. Arte e Ilusão: Um Estudo da Psicologia da Representação Pictórica. São Paulo: Editora Martins Fontes, 1986.

GRONMANN, Will. Klee. Nova York: Harper \& Brothers Publishers, 1985.

GUARESCHI, Alberto; GUARESCHI, Carlotta (cur.). Prefácio de Rossana Bossaglia. Ensaio crítico de Paola Pallotino. Milano 1936-1943: Guareschi e il Bertoldo. Milão: Rizzoli, 1994.

GUPTILL, Arthur L. Prefácio de Dorothy Canfield Fisher. Introdução biográfica de Jack Alexander. Norman Rockwell Illustrator. Nova York: Watson-Gupkill Publications, 1971.

HELLER, Steven. Merz to Emigre and Beyond: avant-garde magazine design of the twentieth century. Londres: Phaidon Press Limited, 2003.

HELLER, Steven. Paul Rand. Londres: Phaidon Press Limited, 1999.

HELLER, Steven; PETTIT, Elinor. Graphic design time line: a century of design milestones. Nova York: Allworth Pres, 2000.

HELLER, Steven; FILI, Louise. Cover History: the art of american magazine covers 19001950. São Francisco: Chronicle Books, 1996.

HELLER, Steven; FILI, Louise. Orelhas por Dan Nadel. Stylepedia - a guide to graphic design mannerisms, quirks, and conceits. São Francisco: Chronicle Books, 2006.

HERDES, Walter; PASCAL, David. The Art of the Comics Strips. Zurique: The Graphic Press, 1972.

HOGARTH, Paul. The Artist as Reporter. Nova York: Reinhold Publishing Corporation, 1967.

HOLLANDER, John. "The Metamorphoses of an Emblem". In: STEINBERG, Saul. Steinberg at the Smithsonian - the metamorphosis of an emblem. Washington: National Collection of Fine Arts by the Smithsonian Institution press, 1973, pp.3-6.

HOLLIS, Richard. Design Gráfico - Uma História Concisa. São Paulo: Martins Fontes, 2001.

INGE, M. Thomas. Comics as Culture. Jackson: University Press of Mississippi, 1990. 
JAGUAR. Prefácio de Paulo Mendes Campos. Átila, Você é Bárbaro. Rio de Janeiro: Civilização Brasileira, 1968.

JAGUAR. É Pau Puro! São Paulo: Círculo do Livro, 1982.

JAGUAR; AUGUSTO, Sérgio. O Melhor do Pasquim. O Pasquim: antologia - volume I 1969-1971. Rio de Janeiro: Desiderata, 2006.

JR., HELD, John. The Works of John Held Jr. Nova York: Ives Washburn, 1931.

LEINER, Sheila. "Raciocínio sobre Papel". In: Cadernos de Literatura Brasileira. Millôr Fernandes. n.15. São Paulo: Instituto Moreira Salles, 2003, pp. 139-148.

LIVINGSTONE, Marco. Pop art - a continuing history. Londres; Thames \& Hudson, 2000.

LLOBERA, Joseph; OLTRA, Romain. La Bande Dessinée.Paris: Éditions AFHA, 1968.

KELLNER, Bruce. Prefácio de John Updike. The Last Dandy Ralph Barton - american artist, 1891-1931. Columbia e Londres: University of Missouri Press, 1991.

KELLY, Walt. "Introdução". In: FRANÇOIS, André. Introdução por Walt Kelly. The Tattooed Sailor. Nova York: Alfred A. Knopf, 1953, pp. 5-7.

KLEE, Paul. Diários. São Paulo: Editora Martins Fontes, 2000.

KLEE, Paul. On Modern Art. Londres: Faber and Faber, 1985.

KLEE, Paul. Sobre a Arte Moderna e outros ensaios. Rio de Janeiro: Jorge Zahar Editor, 2001.

KOHLER, Eric. Prefácio de Tony Bennett. In the Groove - vintage record graphics 19401960. São Francisco: Chronicle Books, 1999.

LIMA, Herman. História da Caricatura no Brasil. 4 vols. Rio de Janeiro: José Olympio Editora, 1963.

LOREDANO, Cássio. Guevara e Figueroa: Caricatura no Brasil nos Anos 20. Rio de Janeiro: Funarte-Instituto de Artes Gráficas, 1988. 
MANGINI, Cinzia; PALlOTINO, Paola. Prefácio de Rossana Bossaglia. Bertoldo e i suoi illustratori. Nuoro: Ilisso Edizioni, 1994.

MANKOFF, Robert. Prefácio de David Remnick. Ensaios de Roger Angell, Nancy Franklin, Lillian Ross, John Updike, Calvin Trillin, Ian Frazier, Mark Singer, Rebecca Mead. The Complete Cartoons of the New Yorker. 2 DVDs. Nova York: Black Dog \&Leventhal Publishers, 2004.

MARTINS, Sergio R. M. A invenção do Humor no Espaço Gráfico. São Paulo: Tese de Doutorado, orientação de Lucrécia D'Alessio Ferrara, FAU-USP, 1993.

MAYNARD, Patrick. Drawing Distinctions - the varieties of graphic expression. Ithaca e Londres: Cornell University Press.

MEGGS, Philip B.; PURVIS, Alston W. Meggs'History of Graphic Design. New Jersey: John Wiley \& Sons, 2006.

MELO, Francisco Homem de. Cidade, Fotografia, Tipografia. Tese de Doutorado Faculdade de Arquitetura e Urbanismo, Universidade de São Paulo, 1994.

MELO, Francisco Homem de (org.). O Design Gráfico Brasileiro: Anos 60. São Paulo: Cosac Naify, 2006.

MONTANER, Josep Maria. A Modernidade Superada - arquitetura, arte e pensamento do século XX. Barcelona: Editorial Gustavo Gili, 2001.

MOYA, Álvaro de. História da História em Quadrinhos. Porto Alegre: L\&PM, 1986.

MÜLLER-BROCKMANN, Josef; MÜLLER-BROCKMANN Shizuko. History of the Poster. Londres: Phaidon Pres Limited, 2004.

MUNARI, Bruno. Fantasia. Barcarena: Editora Presença, 1987.

MUNARI, Bruno. Das Coisas Nascem Coisas. São Paulo: Martins Fontes, 1998.

MUNARI, Luiz. O Costume da Arte. São Paulo: Editora Fupam, 2002. 
NADEL, Dan. Art of Our Time - unknown comics visionaries, 1900-1969. Nova York: Harry N. Abrams, 2006.

NÁSSARA. Organizado por Cássio Loredano. Nássara Desenhista. Rio de Janeiro: FUNARTE/ Instituto Nacional de Artes Plásticas, 1985.

PACKER, William. Introdução de Lady Diana Cooper. The Art of Vogue Covers 1909-1940. Londres: Octopus Books Liited, 1983.

PATATI, Carlos; BRAGA, Flávio. Almanaque dos Quadrinhos - 100 anos de uma mídia popular. Rio de janeiro: Ediouro, 2006.

PELLEGRINO, Hélio. "Borjalo e a Baleia". In: BORJALO. Prefácio de Otto Lara Resende. Texto de Hélio Pellegrino. O Caçador de Borboletas. Rio De janeiro: Editora Globo S.A., 1986, pp.7.

PULVER, Max. The Symbolism of Handwriting. Londres: Scriptor Books, 1931.

RAW Books \& Graphics. Editado por Art Spiegelman e Françoise Mouly. HQs de Kim Deitch, Basil Wolverton, dentre outros. RAW - open wounds from the cutting edge of comix. Nova York: Penguin Books, 1989.

READ, Herbert. Uma História da Pintura Moderna. São Paulo: Editora Martins Fontes, 2001.

REED, Walt; REED, Roger. The Illustrator in America 1880-1980: a century of illustration. Nova York: The Society of Illustration of New York, 1984.

REMINGTON, R. Roger. American Modernism - graphic design, 1920 to 1960. New Haven: Yale University Press, 2003.

REMNICK, David. The Complete New Yorker. Livro Highlights from the New Yorker. 8 DVDs. Nova York: The New Yorker, 2005.

RUIS. La Vida de Cuadritos. México: Editorial Grijalbo, 1983.

RIUS. Santoral de la Caricatura. México: Editorial Posada, 1984. 
ROSENBERG, Harold. Objeto Ansioso. Tradução Vera Pereira. São Paulo: Cosac Naify, 2004.

ROSENBERG, Harold. In: STEINBERG, Saul. Saul Steinberg. Nova York: Whitney Museum of American Art, 1978, pp. 10-36.

ROSS, Lillian. In: STEIG, William. Introdução de Lillian Ross. William Steig Drawings. Nova York: Farrar, Straus \& Giroux, 1979, pp.5-7.

SABIN, Roger. Comics, Comix \& Graphic Novels - A History of Comic Art. Londres: Phaidon Press Limited, 1996.

SARMENTO, Fernanda. Design Editorial no Brasil: Revista Senhor. Dissertação de Mestrado, Faculdade de Arquitetura e Urbanismo, Universidade de São Paulo, São Paulo, 2000.

SAVIGNAC. Savignac: L'Affiche da A à Z. Paris: Editions Hoebeke, 1987.

SEARLE, Ronald. Ronald Searle's Golden Oldies 1941-1961. Londres: Pavilion Books Limited, 1985.

SHAHN, Ben. The Shape of Content. Cambridge e Londres: Harvard University Press, 1957.

SMITH, Joel. Introdução de Charles Simic. Saul Steinberg: Illuminations. New Haven e Londres: Yale University Press, 2006.

SMITH, Joel. Introdução de Ian Frazier. Steinberg na New Yorker. Nova York: Harry N. Abrams, 2005.

SOBRAL, Julieta Costa. "J. Carlos, designer". In: CARDOSO, Rafael (org.). O Design Brasileiro antes do desig:aspectos da história gráfica, 1970-1960. São Paulo: Cosac Naify, 2005, pp. 124-157.

Society of Illustrators. 46th Annual of American Illustration. Hall of Fame 2004 - Saul Steinberg. Nova York: Harper Collins Publishes, 2004.

STEIG, William. Introdução de William Saronyan. Prefácio de Wolcott Gibbs. The Lonely Ones - with 25 new lonely ones. Nova York: Windmill Books, 1970. 
STEIG, William. Introdução de Lillian Ross. William Steig Drawings. Nova York: Farrar, Straus \& Giroux, 1979.

STEINBERG, Saul. All in Line - cartoons by Steinberg. Nova York: Penguin Books, 1947.

STEINBERG, Saul. Dessins. Paris: Gallimard, 1956.

STEINBERG, Saul. Il Labirinto. Milão: Feltrini Editore, 1961.

STEINBERG, Saul (texts by Michel Butor and Harold Rosenberg). Le Masque. Paris: Maeght Editeur, 1966.

STEINBERG, Saul. L'Inspecteur. Paris: Societé Nouvelle des Éditions du Chêne, 1973.

STEINBERG, Saul (with Aldo Buzzi). Reflections and Shadows. Nova York: Random House, 2002.

STEINBERG, Saul (text by Harold Rosenberg). Saul Steinberg. Nova York: Whitney Museum of American Art, 1978.

STEINBERG, Saul. Prefácio de John Hollander. Steinberg at the Smithsonian - the metamorphosis of an emblem. Washington: National Collection of Fine Arts by the Smithsonian Institution Press, 1973.

STEINBERG, Saul. The Art of Living. Nova York: Harper \& Brothers Publishers, 1949.

STEINBERG, Saul. The Catalogue. Cleveland e Nova York: The World Publishing Company, 1962.

STEINBERG, Saul. The Passport. Nova York: Harper \& Brothers Publishers, 1949.

STORR, Robert. Philip Guston. Nova York: Abbeville Press, 1986.

TOPLISS, Iain. The Comics Worlds of Peter Arno, William Steig, Charles Addams and Saul Steinberg. Baltimore e Londres: The Johns Hopkins University Press, 2005.

UPDIKE, John. More Matter - essays and criticism. Nova York: Fawcett Books, 1999. 
VENTURI, Robert; BROWN, Denise Scott; IZENOUR, Steven. Aprendendo com Las Vegas. São Paulo: Cosac Naify, 2003.

WEILL, Alain. Graphic Desig: A History. Nova York: Harry N. Abrams, 2004.

WHITFORD, Frank. The Berlin of George Grosz - drawings, watercolours and prints, 19211930. New Haven e Londres: Yale University Press, 1997.

WIRTH, Kurt. Drawing: A Creative Process. Zurique: ABC Edition Zurich, 1976.

ZIRALDO. 20 Anos de Prontidão. Rio de Janeiro: Record, 1984.

ZIRALDO. Jeremias, o Bom Rio de Janeiro: Editora Expressão e Cultura, 1969.

ZIRALDO. A Última do Brasileiro. Rio de Janeiro: Editora Codecri, 1975.

ReVISTAS

ANGELL, Roger. "Congratulations! It's a Baby". The New Yorker. Nova York: Condé Nast Publications, pp.132-139, 15 de dezembro de 1997.

ANGELL, Roger. Postscript - William Steig. The New Yorker. Nova York: Condé Nast Publications, pp.69-72, 20 de outubro de 2003.

ANGELL, Roger.Uniform Bliss. The New Yorker. Nova York: Condé Nast Publications, pp.90-95, 12 de novembro de 2001.

ASHBERY, John. The Stamp of a Genius. Art News. Nova York: Newsweek, v.68, n.7, p.45;72;74, novembro de 1969 .

BAUDSON, Pierre. Josse Goffin. In: Graphis. n.219. Zurique: Walter Herdeg - The Graphis Press, p.8-17, 1982.

BARDI, Pietro. Steinberg no Brasil. Habitat. Edição 6. São Paulo, p.15, 1952. 
BARTHES, Roland. Defenser D’Afficher: Savignac. In: Graphis. Zurique: Walter Herdeg The Graphis Press, v.29, n.169, p.442-445, 1973.

BAUDSON, Pierre. Goffin. In: Graphis. Zurique: Walter Herdeg - The Graphis Press, n.219, p.8-17, 1982.

BAUR, John I. H. A B C for Collectors of American Contemporary Art. Art in America. Nova York: Art in America, p.45-48, verão de 1958.

B.B.P.R. Il Labirinto dei Ragazzi. Casabella. Milão: Editoriale Domus, n.203, p. 50-54, novembro/dezembro de 1954.

BLAKE, Peter. Cartoon Critic. Architecture, Nova York, p.106-109, setembro de 1999.

BOXER, Sarah. Saul Steinberg, Epic Doodler, Dies at 84. The New York Times, Nova York, s.p, 1999.

BRAUN, Mario. Leo Longanesi. In: Graphis. Zurique: Walter Herdeg - The Graphis Press, v.12, n.64, p.100-113, 1959.

BRYSON, Bernarda. Ben Shahn. In: Graphis. Zurique: Walter Herdeg - The Graphis Press, n.169, p.458-465, 1973.

BUNDAS. Texto de John Updike. Desenhos de Steinberg escolhidos por Chico Caruso, Nani, Fortuna, Miguel Paiva, Jaguar, Ziraldo. Saul Steinberg (1914-1999). Bundas. Rio De Janeiro: Editora Pererê Ltda., n.12, pp. 14-17, agosto/setembro de 1999.

BURE, Gilles de. André François. In: Graphis. Zurique: Walter Herdeg - The Graphis Press, v.35, n.205, p.378-399, 1979.

BUZZI, Aldo. L' architetto Steinberg. Domus. Milão: Editoriale Domus, n.214, p.19-22, outubro de 1946.

C., L. Hedda Sterne e suas máquinas. Habitat. São Paulo, n.9, p.21-25, 1952.

CARUSO, Paulo; JAGUAR. O Enterro de Steinberg. Bundas. Rio de Janeiro: Editora Pererê Ltda., n.2, pp.4, junho de 1999. 
CAVALLONE, Franco. Il Filosofo Mascherato. Linus. Milão, ano 6, n.65, 1970

COATES, Robert M.. The Art Galleries - Contemporary Americans. The New Yorker. Nova York: The New Yorker Magazine Inc., pp.64-67, 11 de outubro de 1947..

CONSTABLE, Rosalind. Saul Steinberg. Art Digest. Nova York: Art Digest, p.9;24;29, fevereiro de 1954.

DESCARGUES, Pierre. Francis Deransart. In: Graphis. Zurique: Walter Herdeg - The Graphis Press, v.19, n.109, p.416-419, 1963.

DEVREE, Howard. It's Funny - But Is It Art?. The New York Times Magazine. Nova York, pp.20-21, setembro de 1946.

EGLY, Max. Klee, Steinberg, Mac Laren. Image et Son: Revue de Cinéma. Paris, v.182, pp. 58-62, março de 1965.

EMMERICH, Andre. The Artist as Collector. Art in America. Nova York: Art in America, p.23-28, verão de 1958 .

ERDOES, Richard. Nation's Business. In: Graphis. Zurique: Walter Herdeg - The Graphis Press, n.54, p.312-315, 1954.

GABLIK, Suzi. Meta-trmpe-l'oeil. Art News. Nova York: Newsweek, v.64, n.1, p.46-49, março de 1965.

GASCAR, Pierre. 2 x André François. In: Graphis. Zurique: Walter Herdeg - The Graphis Press, v.19, n.106, p.122-127, 1963.

GASSER, Manuel. Herbert Leupin. In: Graphis. Zurique: Walter Herdeg - The Graphis Press, n.118, p.98-101, 1965.

GASSER, Manuel. Five Swiss Cartunists. In: Graphis. Zurique: Walter Herdeg - The Graphis Press, n.72, p.318-329, 1957.

GASSER, Manuel. Graphic Irony. In: Graphis. Zurique: Walter Herdeg - The Graphis Press, v.15, n.86, p.500-509, 1959. 
GASSER, Manuel. Norman Rockwell. In: Graphis. Zurique: Walter Herdeg - The Graphis Press, v.12, n.65, p.206-217, 1956.

GASSER, Manuel. Paul Flora. In: Graphis. Zurique: Walter Herdeg - The Graphis Press, v.11, n.61, p.440-443, 1955.

GASSER, Manuel. Saul Steinberg - Werke und Bildnisse. Du, ano 26, p.595-613, agosto de 1966.

GASSER, Manuel. Steinberg. In: Graphis. Zurique: Walter Herdeg - The Graphis Press, v.21, n.117, p.20-33, 1965.

GASSER, Manuel. Steinberg as an Advertising Artist. In: Graphis. Zurique: Walter Herdeg The Graphis Press, v.12, n.67, p.376-385, 1956.

GASSER, Manuel. Steinberg - Le Masque. In: Graphis. Zurique: Walter Herdeg - The Graphis Press, v.22, n.123, p.8-24, 1966.

GASSER, Manuel. Steinberg takes a new turn. In: Graphis. Zurique: Walter Herdeg - The Graphis Press, v.10, n.53, p.208-211, 1954.

GASSER, Manuel. Tomi Ungerer. In: Graphis. Zurique: Walter Herdeg - The Graphis Press, v.21, n.120, p.274-282, 1965.

GASSER, Manuel. Verner Witting. In: Graphis. Zurique: Walter Herdeg - The Graphis Press, n.49, p.394-397, 1953.

GILL, Brendan. Alfred Frueh. The New Yorker. Nova York: The New Yorker Magazine Inc., pp.184, 28 de setembro de 1968.

GILL, Brendan. Peter Arno. The New Yorker. Nova York: The New Yorker Magazine Inc., pp.156, 9 de março de 1968.

GILL, Brendan. Rea Irvin. The New Yorker. Nova York: The New Yorker Magazine Inc., pp.132, 10 de junho de 1972.

GILL, Brendan. Saul Steinberg's Surprise. Horizon. Nova York: American Heritage Publishing, v.21, n.4, p.66-73, abril de 1978. 
GLUEK, Grace. The Artist Speaks: Saul Steinberg. Nova York: Art in America, p. 110-117, novembro/dezembro 1970.

GOPNIK, Adam.Kurtzman's Mad World. The New Yorker. Nova York: Condé Nast Publications, pp.74-77, 29 de março de 1993.

GOPNIK, Adam. The Great Deflater. The New Yorker. Nova York: The Condé Nast Publications Inc., pp.168-177, 27 de junho de 1994.

GOPNIK, Adam. What Steinberg Saw. In: The New Yorker. Nova York: The Condé Nast Publications Inc., 13 de novembro de 2000.

GOWING, Mary. Nettleton. In: Graphis. Zurique: Walter Herdeg - The Graphis Press, v.13, n.69, p.80-83, 1957.

HARPER'S BAZAAR. Persiflage from Paris. Duas páginas com cartuns de Steinberg. Nova York: Hearst Magazines, p.60-61, 1940.

HIRSCHFELD, Al; SPIEGELMAN, Art. Drawings in the Dark. The Comics Journal - Special Edition. Seattle: Fantagraphics, v.4, pp.14-27, winter 2004.

HOLLANDER, John. Klee and Steinberg. Partisan Review. Boston, pp.422-426, verão de 1955.

HUGHES, Robert. The World of Steinberg. In: Time. Toronto: Time Canada, p.48-52, 1978.

JARMAN, Rufus. Profiles - Norman Rockwell. The New Yorker. Nova York: F-R Publishing Company., pp.34-45, 17 de março de 1945.

JARMAN, Rufus. Profiles - Norman Rockwell II. The New Yorker. Nova York: F-R Publishing Company., pp.36-47, 24 de março de 1945.

JOURNAL OF THE AMERICAN INSTITUTE OF PLANNERS. Steinberg on the City. Edição especial dedicada a Steinberg. Baltimore: American Institute of Planners, v. XXVII, n. 3, p.2, 1961.

KRANER, Florian. Erdoes. In: Graphis Annual. Zurique: Walter Herdeg - The Graphis Press, 
KRAMER, Jane. Portifolio by Steinberg - Mission to China. The New Yorker. Nova York: Condé Nast Publications, pp.58-65, 10 de julho de 2000.

LIFE. Speaking of Pictures... Life in the "Guatavir" Line. Três páginas com cartuns de Steinberg. Nova York: Time Warner, p.14-17, 1940.

LIFE. Steinberg and Sterne - Romenian-born cartonist and artist-wife ambush the world with pen and paintbrush. Nova York: Time Warner, v.11, Jul/dez, 1951.

LIONNI, Leo. Ben Shahn. In: Graphis. Zurique: Walter Herdeg - The Graphis Press, v.11, n.62, p.468-485, 1955.

LORENZ, Lee.Cover Stories. The New Yorker. Nova York: Condé Nast Publications, pp.124-125, 15 de dezembro de 1997.

LORENZ, Lee.Rea Irvin. The New Yorker. Nova York: Condé Nast Publications, pp.70-71, 22 de janeiro de 1996.

LYNES, Russell. A Man Named Steinberg. Harper's Magazine. Nova York: Harper \& Brothers, p.44-52, 1954.

LYNES, Russel. Steinberg's Stuff. Architectural Digest. Los Angeles: Knapp Communicatios Corporation, p.42;48, dezembro de 1982.

NADEL, Dan. Tabula Rasa. Print. Cincinnati: F+W Publications, pp.62-65;126, julho/agosto de 2003.

MADEMOISELLE. Mademoisellés Christmas. Mademoiselle. Duas páginas de cartuns de Steinberg. Nova York: Condé Nast Publications, p.114-115, 1941.

MARTINS, Luiz Geraldo Ferrari. A Escrita Plástica: desenho, pensamento, conhecimento e interdisciplinaridade. Tese de Doutorado, Escola de Comunicação e Artes, Universidade de São Paulo, 2004.

McCALLUM, Ian. Labirinth at Milan. The Architectural Review. Londres: The Architectural Review, v.116, n.696, p.401-403, dezembro de 1954. 
M.M. Baroom Art in the Modern Manner. The Architectural Forum. Nova York: TIME, p.148;150, abril de 1948 .

MIRAN, Osvaldo. Saul Steinberg. Gráfica. Curitiba: Casa de Idéias, p.32-45, 1993.

MOTTA, Flavio. Steinberg no Brasil. Habitat. São Paulo, n.9, p.17-20, 1952.

MOULY, Françoise.Cover Story. The New Yorker. Nova York: Condé Nast Publications, pp.81-84, 21 de fevereiro de 2000.

MOULY, Françoise. Cover Stories - Art Appreciation. The New Yorker. Nova York: Condé Nast Publications, pp.26-32, 14 de fevereiro de 2005.

OERI, Georgine. Leo Lionni. In: Graphis Annual. Zurique: Walter Herdeg - The Graphis Press, p.484-491, 1952-1953.

OERI, Georgine. Painters and Lettersforms. Print. Nova York: William Edwin Rudge Publisher, v.9, n.5, p.10-23, 1955.

PFLUNG, Hans. Tomi Ungerer. In: Graphis. Zurique: Walter Herdeg - The Graphis Press, n.82, p.104-113, 1959.

PIENE, Nam R. Art Under \$500,00. In: Art in America. Nova York: Art in America, maio/junho, p. 95-97, 1970.

PITZ, Henry. Saul Steinberg: Mad, Savage, Enigma? American Artist. Nova York: WatsonGuptill Publications, v.15. n.2. issue 142, p.40;41;72, fevereiro de 1951.

POLANO, Sergio. Ed Fella, Lettere Dall'America - il vernacolo nella tradizione statunitense. Casabella. Milão: Elemond, n.658, pp.50-61, julho/agosto 1998.

PRINT. Figurative Typography. Print. Nova York: William Edwin Rudge Publisher, v.9. n.4, p.10-16, 1955.

ROCHA, Claudio; MARCO, Tony de. Entrevista com Millôr Fernandes. Rôllim. Tupigrafia. São Paulo: Editora Bookmakers, n.2, p.2-11, 2002. 
ROSENBERG, Harold. Saul Steinberg's Art World. Art News. Nova York: Newsweek, v.65, n.1, p.51-54;67-68, março de 1966.

ROSENBERG, Harold. The Art World - Ben Shahn. The New Yorker. Nova York: The New Yorker Magazine Inc., pp.156-161, 13 de dezembro de 1976.

ROSENBERG, Harold. The Art World - The Concept of Action in Painting. The New Yorker. Nova York: The New Yorker Magazine Inc., pp.116-128, 25 de maio de 1968.

ROSNER, Charles. André François. In: Graphis Annual. Zurique: Walter Herdeg - The Graphis Press, p.474-483, 1952-1953.

ROSNER, Charles. A Sort of Glass. Print. Nova York: William Edwin Rudge, v.9, n.5, p.2631, maio/junho 1955.

ROSNER, Charles. The Compleat Imbiber. In: Graphis. Zurique: Walter Herdeg - The Graphis Press, n.73, p.418-427, 1957.

ROTZLER, Willy. Citroen. In: Graphis. Zurique: Walter Herdeg - The Graphis Press, v.21, n.122, p.472-473, 1955.

ROZENDAAL, W. J. Bertram. In: Graphis. Zurique: Walter Herdeg - The Graphis Press, n.54, p.292-301, 1954.

SAVIGNAC, Raymond. Posters that Shock by Savignac. In: Graphis. Zurique: Walter Herdeg - The Graphis Press, v.19, n.109, p.376-385, 1963.

SHNEIDER, Pierre. Steinberg at the Louvre. Art in America. Nova York: Art in America, p.82-91, julho/agosto de 1967.

SINISGALLI, Leonardo. Manzi. In: Graphis. Zurique: Walter Herdeg - The Graphis Press, v.09, n.50, p.454-461, 1953.

SINISGALLI, Leonardo. Ricardo Manzi. In: Graphis. Zurique: Walter Herdeg - The Graphis Press, v.19, n.107, p.202-215, 1963.

SCHAMA, Simon. Portifolio by Steinberg - Maps. The New Yorker. Nova York: Condé Nast Publications, pp.216-223, 21 de fevereiro de 2000. 
SOMBRA. Steinberg. Rio de Janeiro, p.48-50, p.72-73, p.88-89, 1941.

STAHLY, François. Galerie Maeght, Paris: book design and advertising art. In: Graphis. Zurique: Walter Herdeg - The Graphis Press, n.56, p.514-521, 1954.

THE COMICS JOURNAL. Drawing in the Dark. Art Spiegelman entrevista Al Hirschfeld. Seattle: Fantagraphics Books, Edição Especial, v.4, p.14-25, 2004.

THE ARCHITECTURAL REVIEW. Cincinnati's Terrace Plaza Hotel. New York: TIME Incorporated, p. 81-92, dezembro de 1948.

THE NEW YORKER. Caricaturist - Hirschfeld. The New Yorker. Nova York: The New Yorker Magazine Inc., pp.42-44, 6 de dezembro de 1958.

THE NEW YORKER. James Thurber. The New Yorker. Nova York: The New Yorker Magazine Inc., pp.247, 11 de novembro de 1961.

THE NEW YORKER. Otto Soglow. The New Yorker. Nova York: The New Yorker Magazine Inc., pp.140, 28 de abril de 1975.

THOMAS, Daniela. Steinberg Está Morto. Viva Sua Arte. Palavra. Belo Horizonte: Editora da Palavra, n.3, pp.125-130, junho de 1999.

TIME. Steinberg, Satirist. Time. Toronto: Time Canada, p.79, 1943.

TOWN \& COUNTRY. The Shot Heard Round the County. Texto de Oliver Wainwright. Ilustração de Steinberg. Nova York: Hearst, 1940.

TUPIGRAFIA. Steinberg. Editada por Claudio Rocha e Tony de Marco. Tupigrafia. São Paulo: Bookmakers, n.2, p.12-19, 2002.

UPDIKE, John. A Case of Melancholia. The New Yorker. Nova York: The Condé Nast Publications Inc., pp.112-120, 20 de fevereiro de 1989.

UPDIKE, John. Saul Steinberg (1914 - 1999). The New York Review of Books. Nova York: NYRB, 1999. 
VERONESE, Giulia. Munari. In: Graphis. Zurique: Walter Herdeg - The Graphis Press, v.11, n.61, p.400-407, 1955.

WEBB, Michael. Saul Steinberg: Walking a Fine Line. In: Graphis, Zurique: Walter Herdeg The Graphis Press, n.324, p.100-105, 1999.

WEILL, Alain. Transitions in Humorous Visual Images - The Substance of Analog Design. IDEA, Tóquio, v.45, n.265, p.6-64, 1997.

\section{Outros DOCUMENTOS}

BARDI, Pietro. Steinberg no Museu de Arte: Uma Festa da Inteligência. Documento original encontrado no acervo da biblioteca do MASP. São Paulo, 1952 (mimeo.).

BARDI, Pietro. Steinberg, Espírito de Nossa Época. Documento original encontrado no acervo da biblioteca do MASP. São Paulo, 1952 (mimeo.).

BARDI, Pietro. Outros textos. Documentos originais encontrados no acervo da biblioteca do MASP. São Paulo, 1952 (mimeo.).

CIVITA, Victor. Outros textos. Documentos originais encontrados no acervo da biblioteca do MASP. São Paulo, 1950 (mimeo.).

BARRETO, Leda. Borjalo $x$ Appe. O Cruzeiro. Disponível em <http://memoriaviva.digi.com.br/ocruzeiro/17101964/171064_1.htm>

CALVINO, Italo. Steinberg: 4. Internacionale Triennale der Zeichnung. Nuremberg: Kunsthalle Nürnberg, 1988.

CAVAlCANTE, Nathália Sá. J. Carlos e a Poética da Liberdade. Disponível em <http://www.eco.ufrj.br/semiosfera/expressao/txtpens3.htm>

GILL, Brendan. Perfil de Steinberg. Agencia de Comunicacion Internacional de los Estados Unidos de America, sem data.

GIUNTA, Néstor. La Historia del Comic en la Argentina. Disponível em $<$ http://www.todohistorietas.com.ar/historia_argentina_1.htm> 
GOPNIK, Adam. Saul Steinberg: Recent Work. Nova York: The Pace Gallery, 1987.

IMPÉRIO, Flávio. Flávio Motta. São Paulo, novembro de 1977.

KRAMER, Hilton. Farewell, Saul Steinberg, a Mordant, Comic Artist . The New Yorker Observer. Disponível em <http://www.observer.com/pages/story.asp?ID=1205>

MATAllANA, Andrea. El Revés de la Trama de la Política. El imaginario politico argentino atraves del humot politico. Disponível em <http://bv.gva.es/documentos/Matallana.doc>

MOTTA, Flávio L. Saul Steinberg no Brasil. São Paulo: FAU-USP, 1952.

MANNUCCI, Enrico. A Homage to Giaci Mondaini (1902 - 1979). Disponível em <http://www.museosatira.it/2000/mondaini/mondaini.html>

ROSENBERG, Harold. Saul Steinberg. Nova York: Whitney Museum of American Art, 1978.

NASCIMBENI, Giulio. Il Lunario. Disponível em <http:/www.leadershipmedica.com/culturale/culott02/culturaleing/8lunarioe/8luning.htm>

NITZBERG, Kevin. Continuing to find artistic humor and direction in an emerging world. Disponível em <http://www.art-themagazine.com/pages/insite14.htm>

SAUL STEINBERG FOUNDATION. Life and Work. Disponível em <http://www.steinbergfoundation.com. Nova York>

STEINBERG, Saul. El Arte en el Cartel. Prefácio por Patrícia S. Helkenen. Catálogo da Exposição. México: Museu Universitario de Ciencias y Arte/UNAM, 1980.

STEINBERG, Saul. The Americans - Aquarelles, Dessins et Collages 1955-1967. Prefácio por P. Robert-Jones, texto por Pierre Baudson. Catálogo da Exposição Universal de Bruxelas. Organizada pela Embaixada dos Estados Unidos. Bruxelas: Musées Royaux des Beaux-Arts, Musée d’Art Moderne, 1967.

UPDIKE, John (with Jean Leymarie). Saul Steinberg: Fifty Works from the Collection of Jeffrey and Sivia Loria. New York: Jeffrey H. Loria \& C 